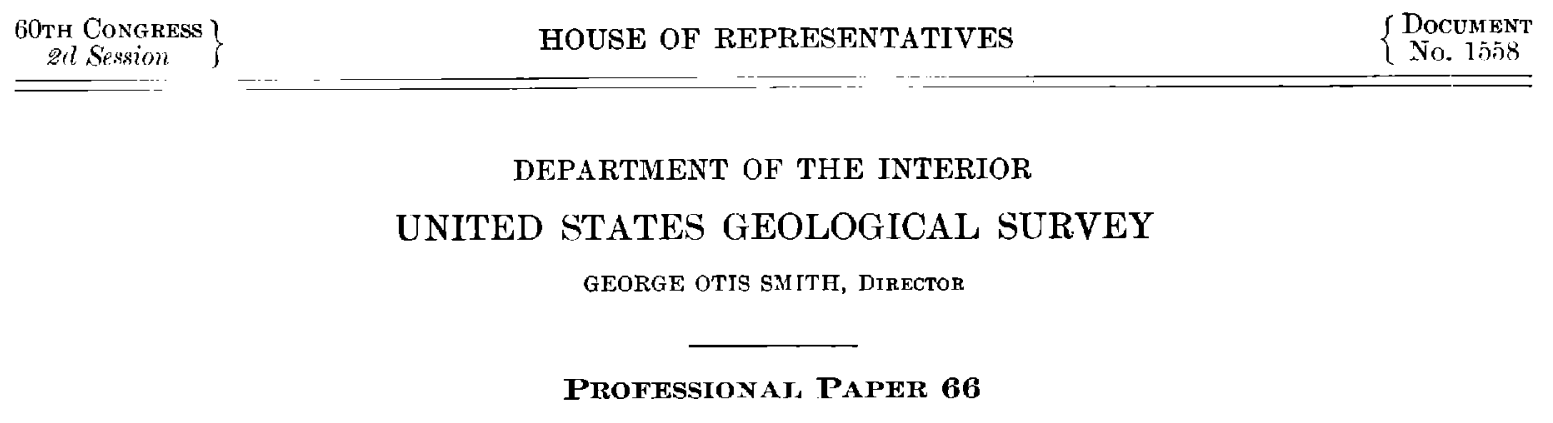

THE

\title{
GEOLOGY AND ORE DEPOSITS OF GOLDFIELD, NEVADA
}

\author{
,BY \\ FREDERICK LESLIE RANSOME
}

ASSISTED IN THE FIELD BY

W. H. EMMONS AND G. H. GARREY

WASHINGTON

GOVFRNMENT PRINTING OFFICE 1909 



\section{CONTENTS.}

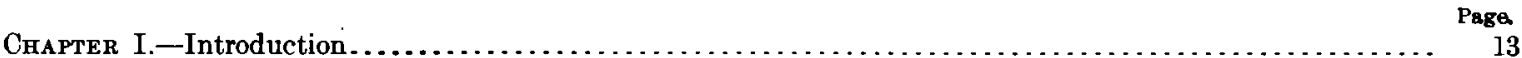

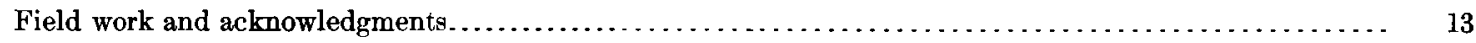

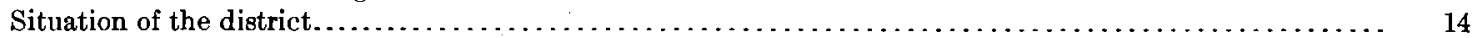

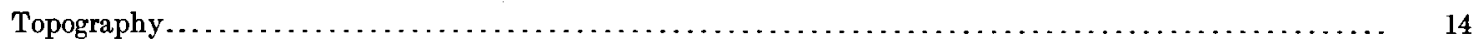

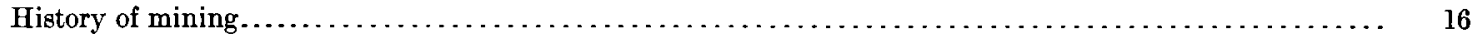

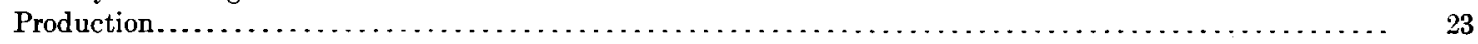

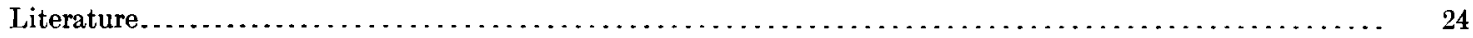

Geographic names. . . . . . . . . . .

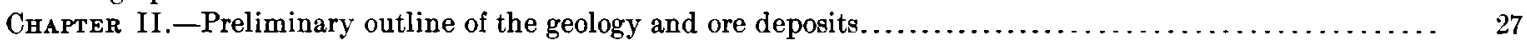

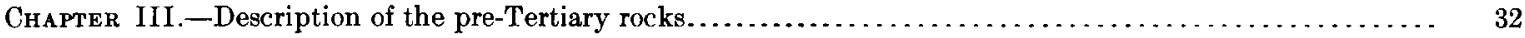

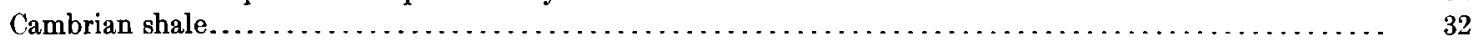

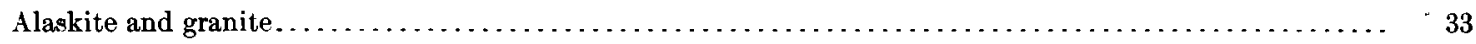

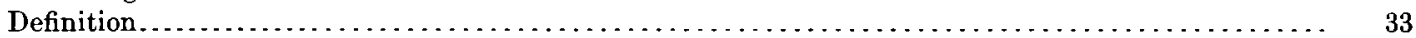

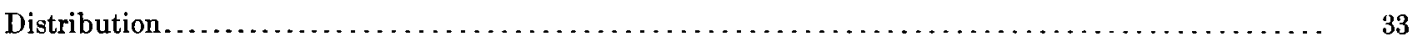

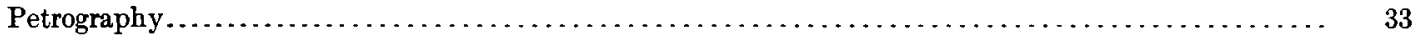

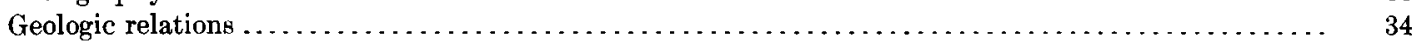

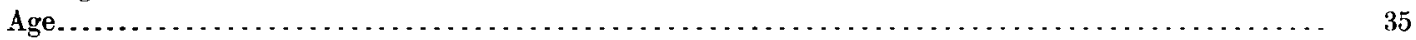

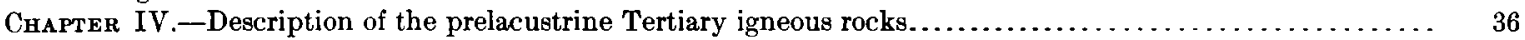

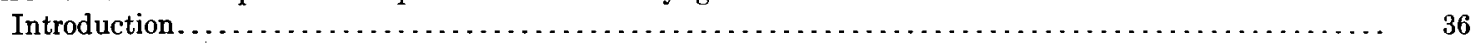

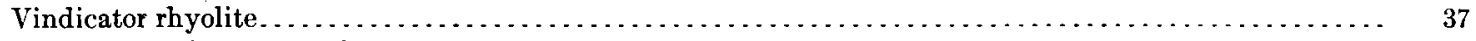

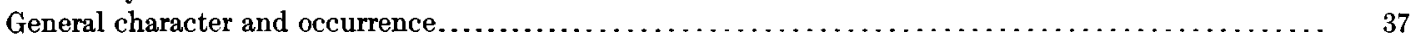

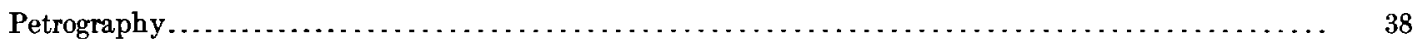

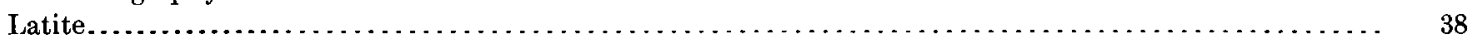

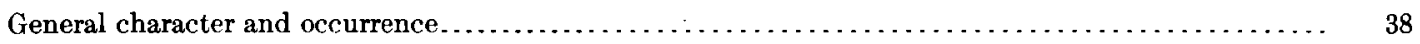

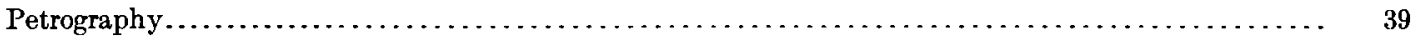

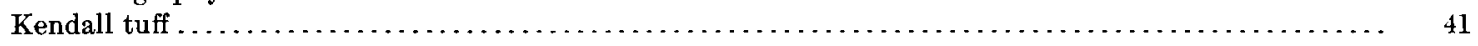

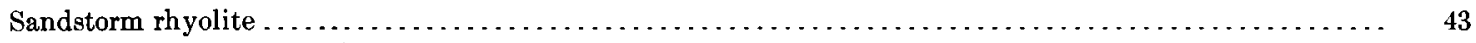

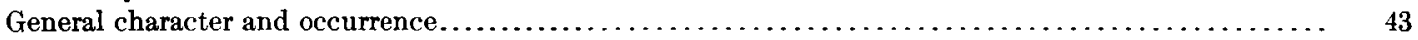

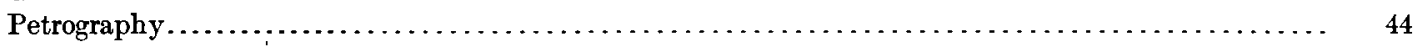

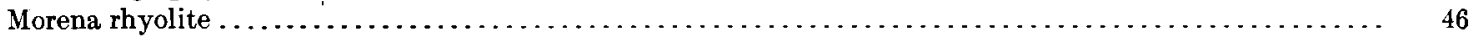

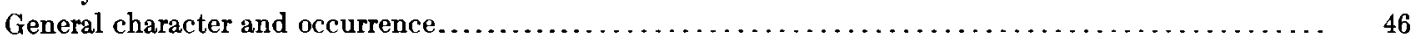

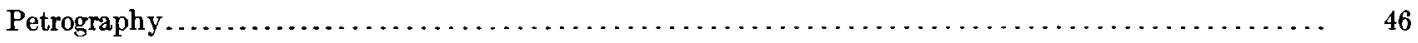

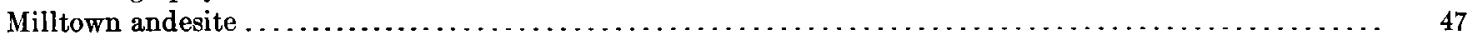

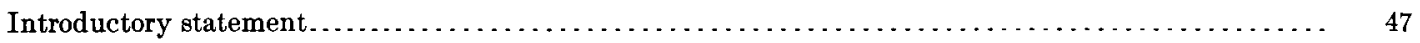

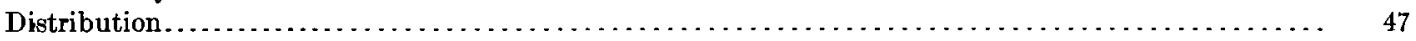

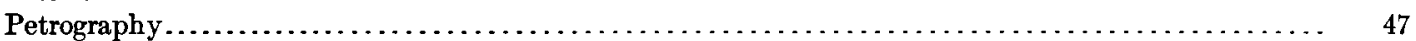

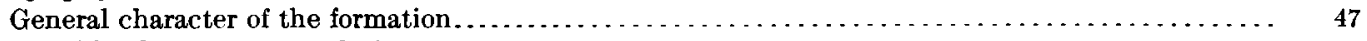

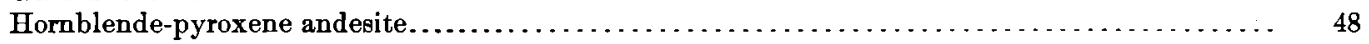

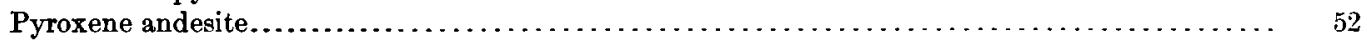

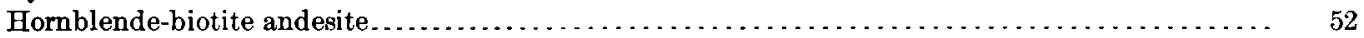

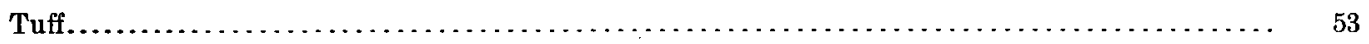

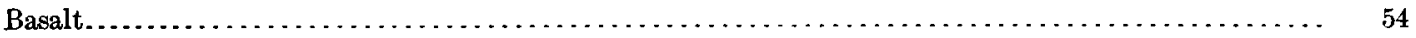

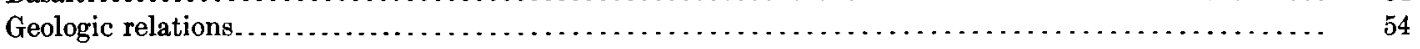

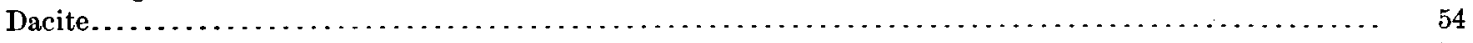

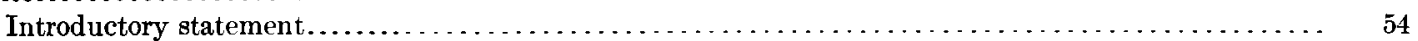

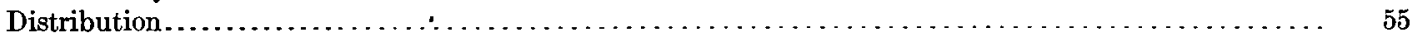

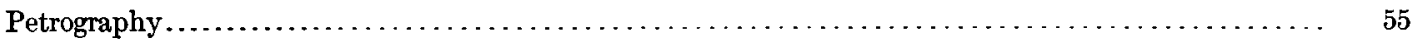

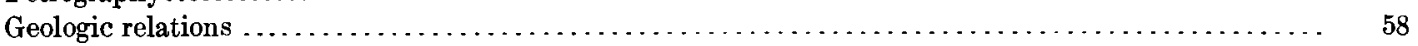

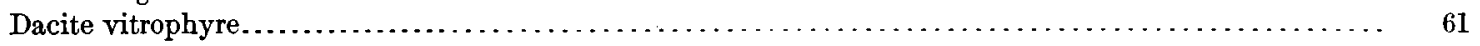

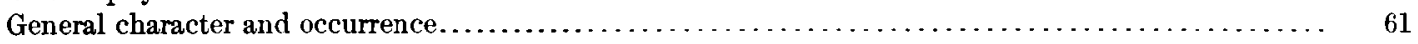

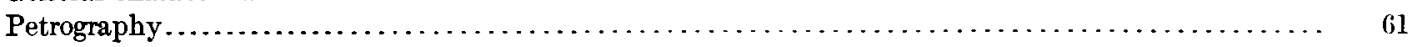

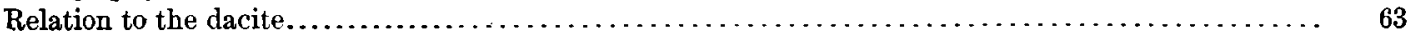


Chapter IV.-Description of the prelacustrine Tertiary igneous rocks-Continued. Page.

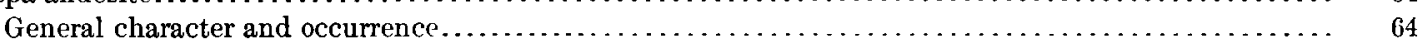

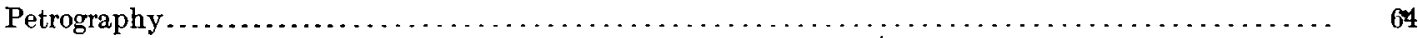

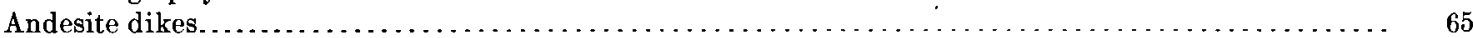

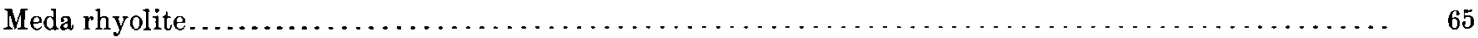

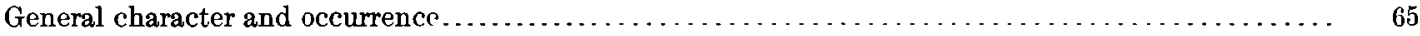

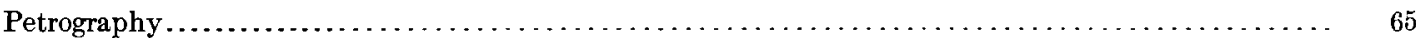

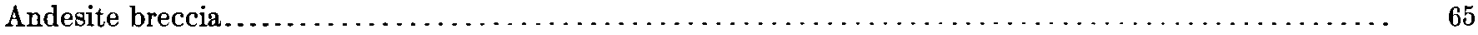

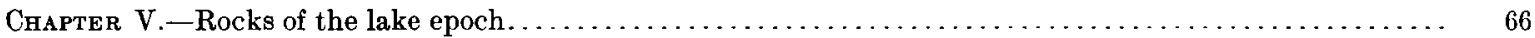

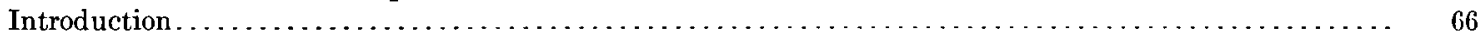

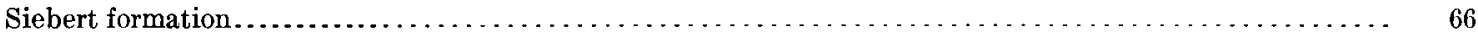

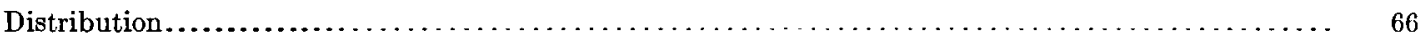

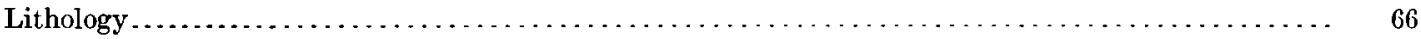

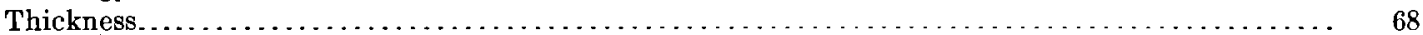

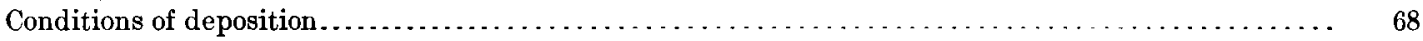

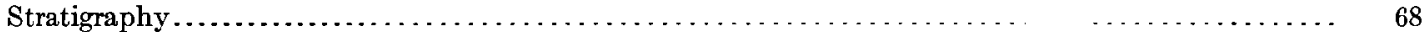

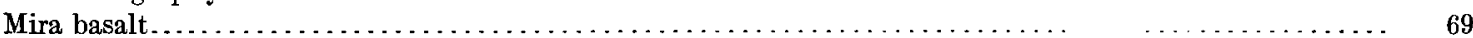

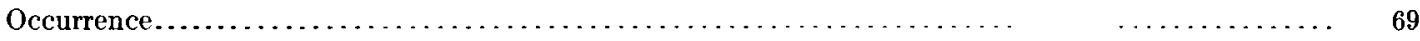

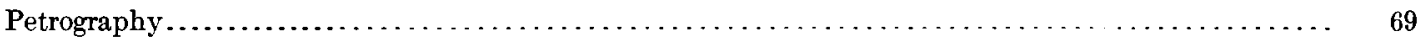

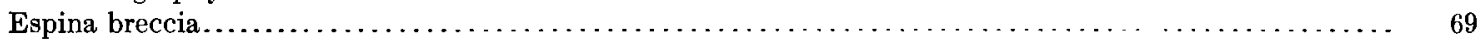

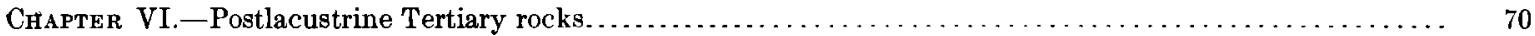

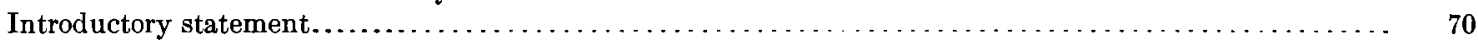

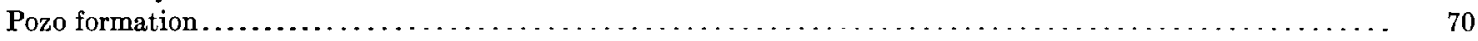

Spearhead rhyolite. . . . . . . . . . . . . . .

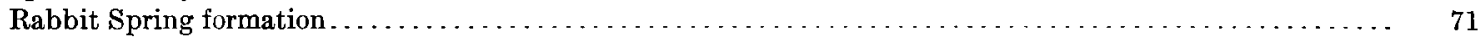

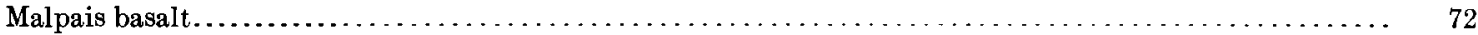

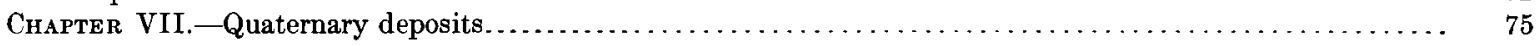

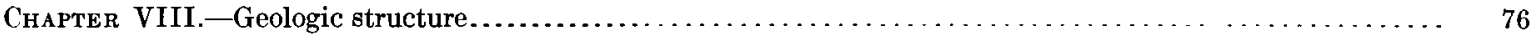

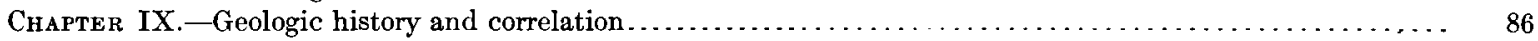

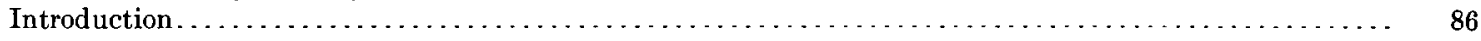

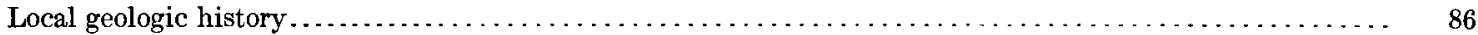

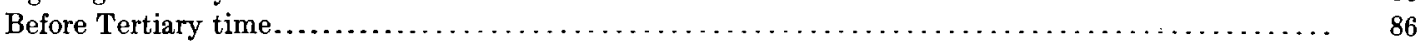

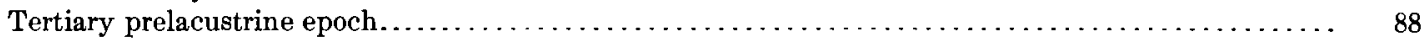

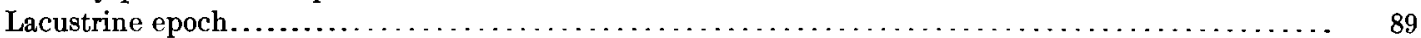

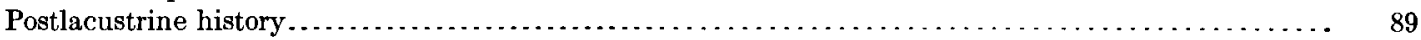

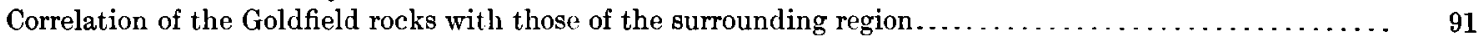

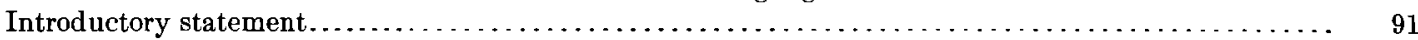

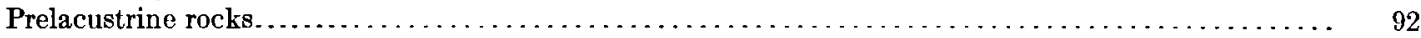

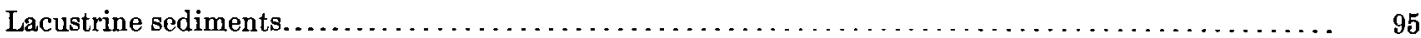

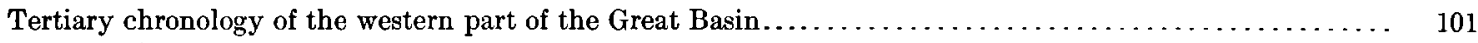

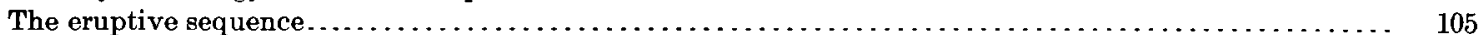

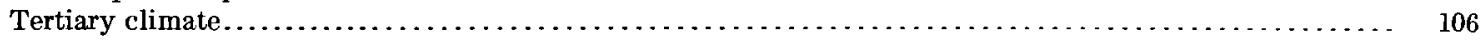

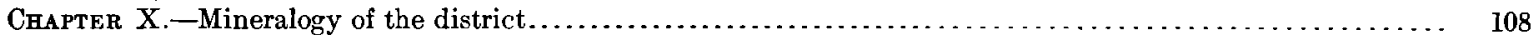

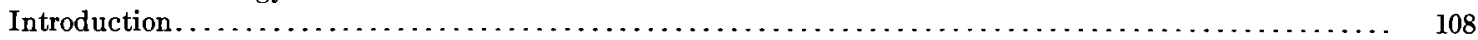

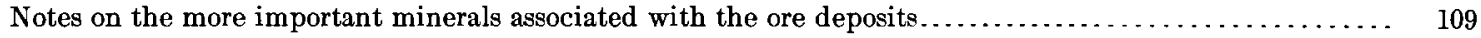

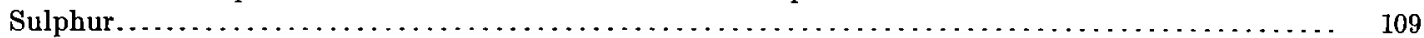

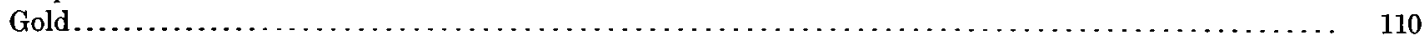

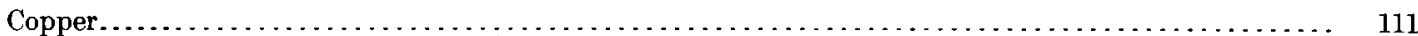

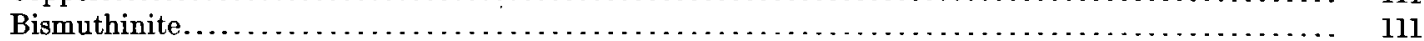

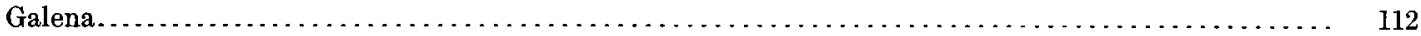

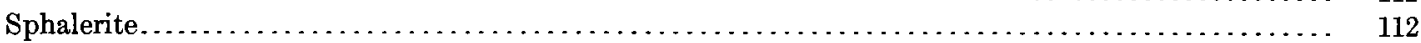

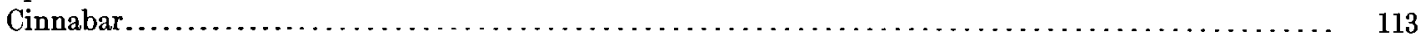

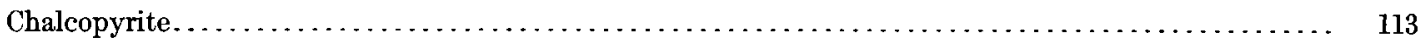

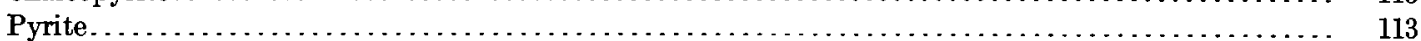

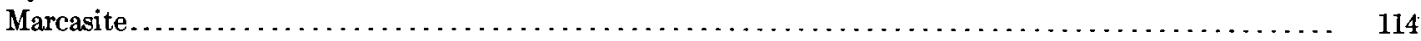

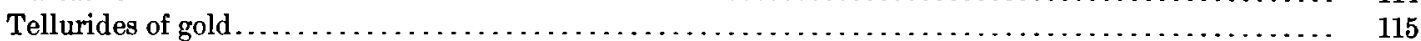

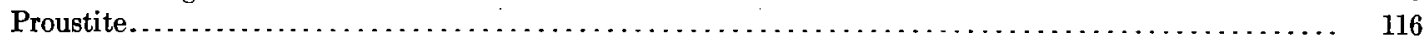

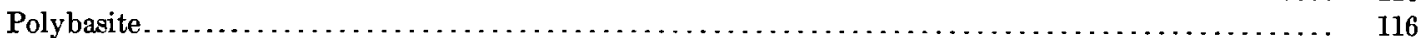

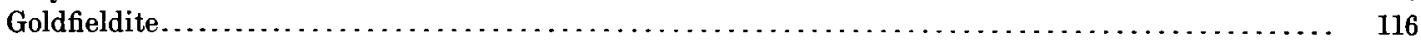

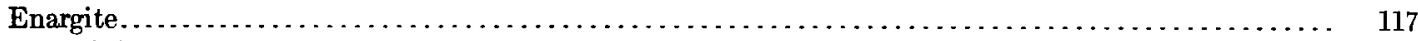

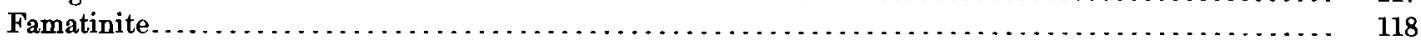

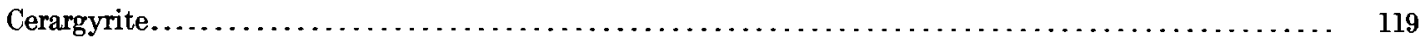


Chapte B X.-Mineralogy of the district-Continued.

Notes on the more important minerals associated with the ore deposits-Continued.

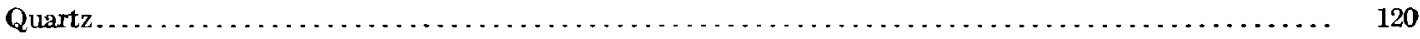

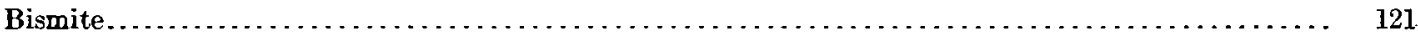

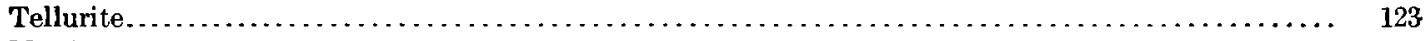

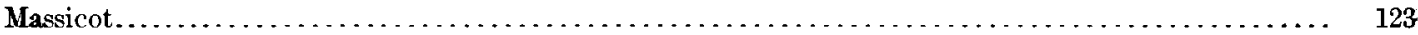

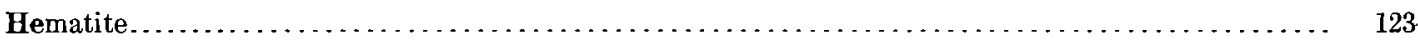

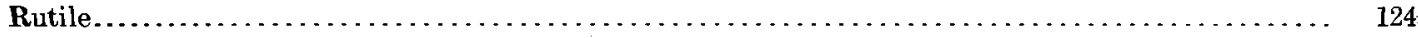

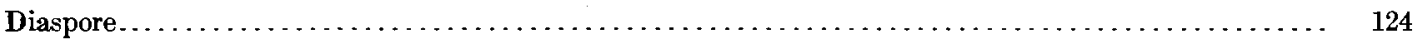

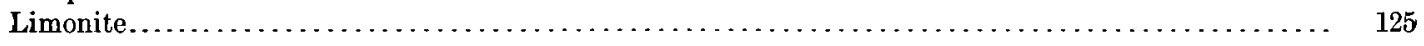

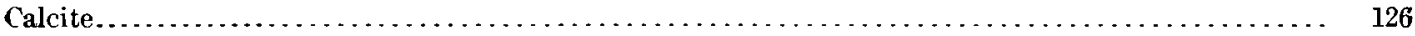

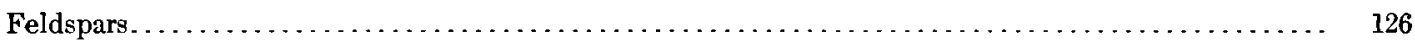

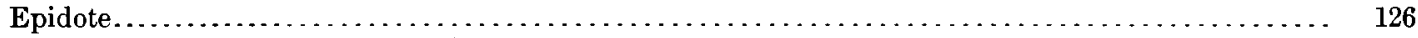

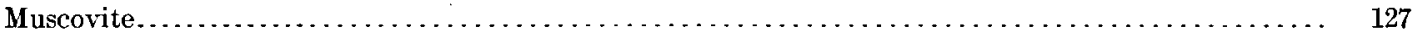

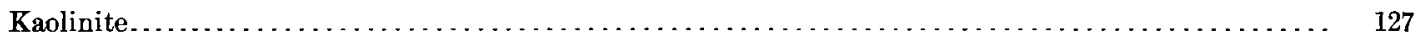

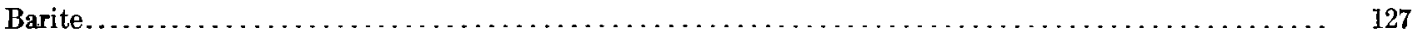

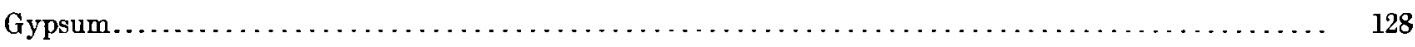

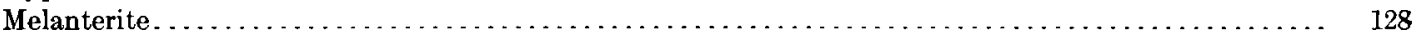

Chalcanthite. . . . . . . . . . . . . .

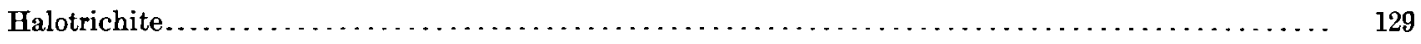

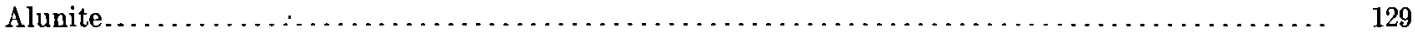

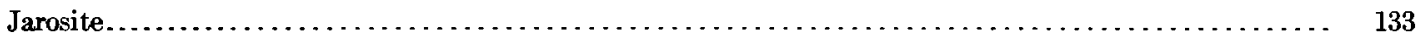

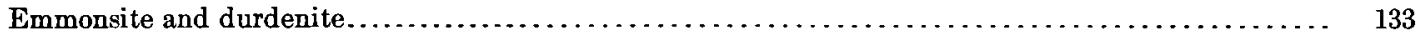

Chapter XI.-The mines; a general account of their distribution, development, and operation, including ore

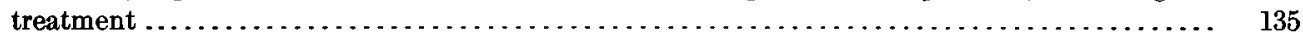

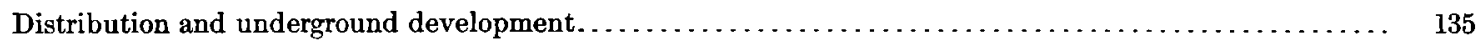

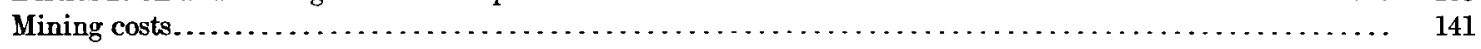

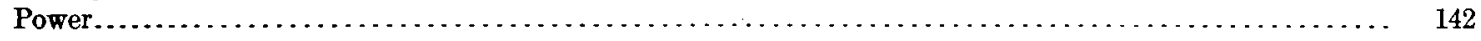

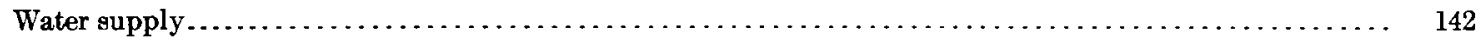

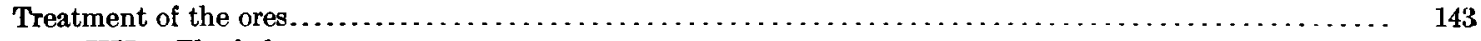

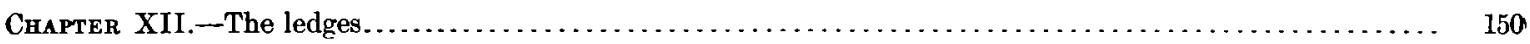

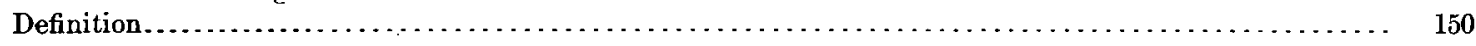

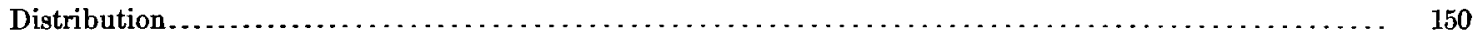

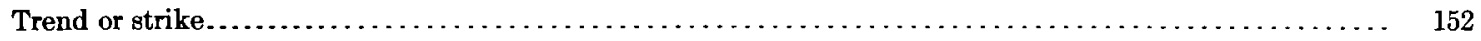

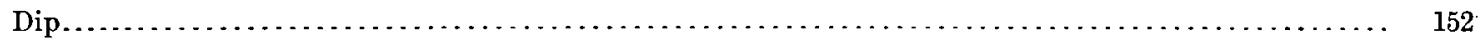

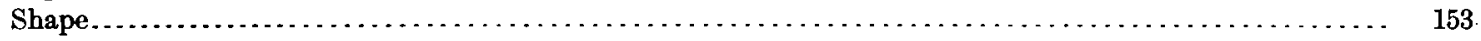

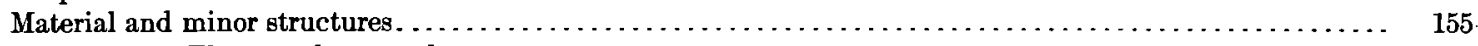

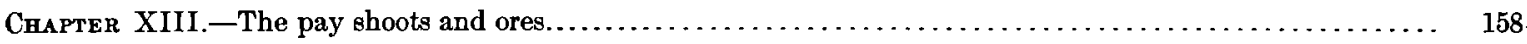

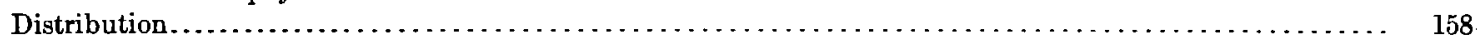

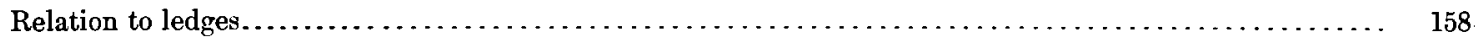

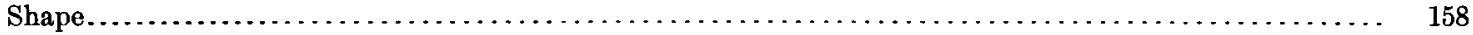

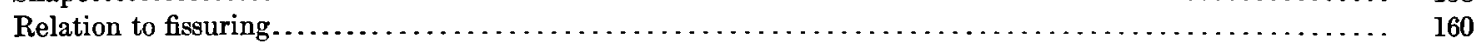

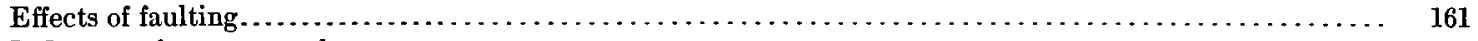

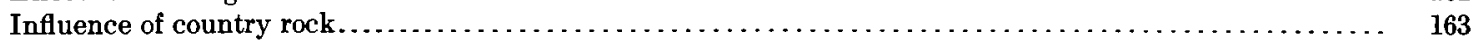

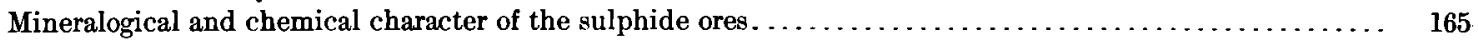

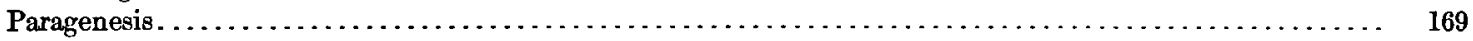

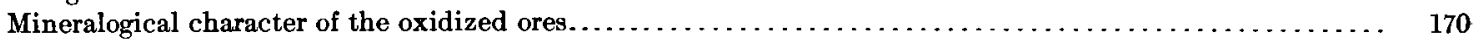

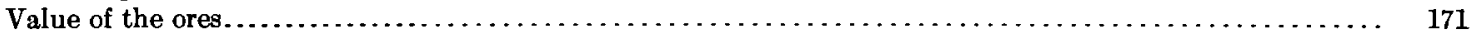

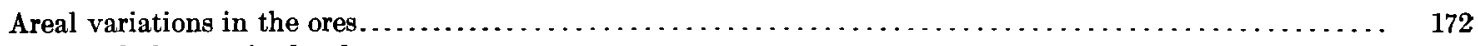

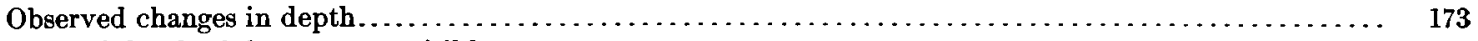

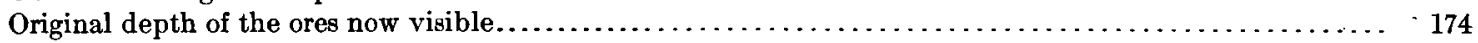

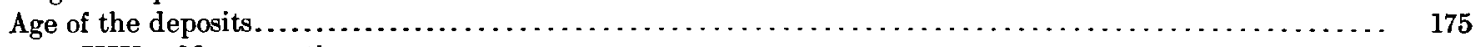

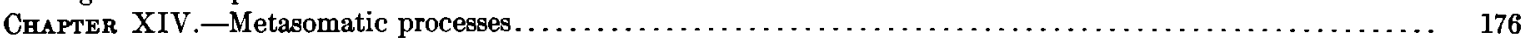

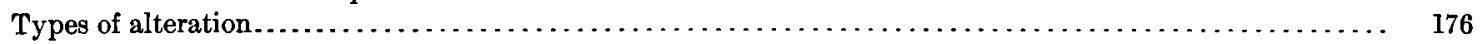

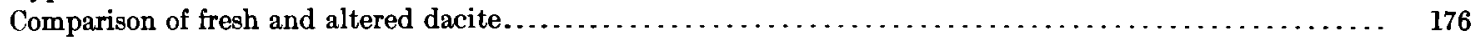

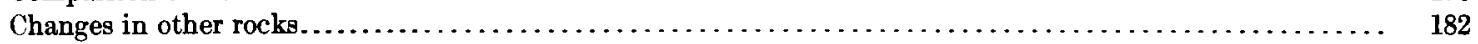

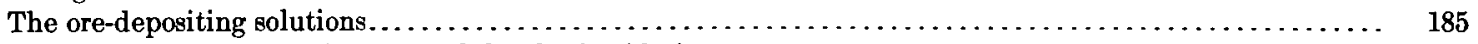

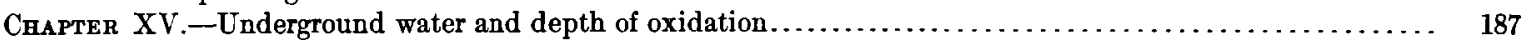

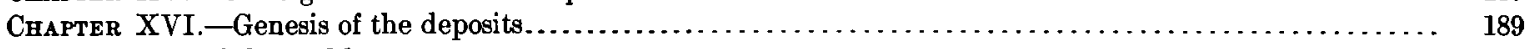

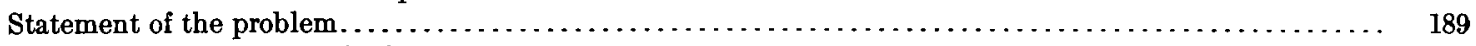

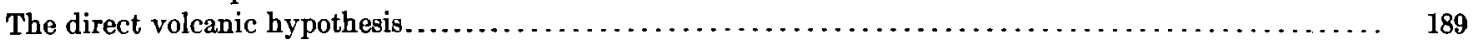

Hypothesis of derivation of the sulphuric acid from the oxidation of pyrite $\ldots \ldots \ldots \ldots \ldots \ldots \ldots \ldots \ldots \ldots 1$

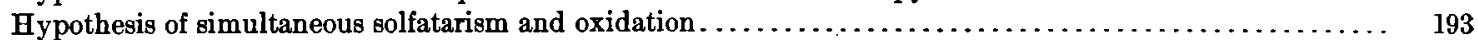


Chapter XVI.-Genesis of the deposits-Continued. Page.

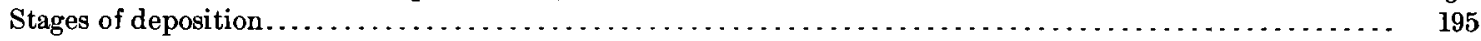

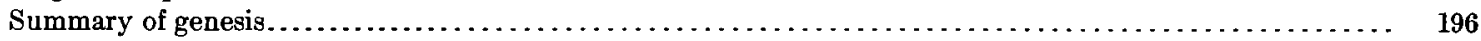

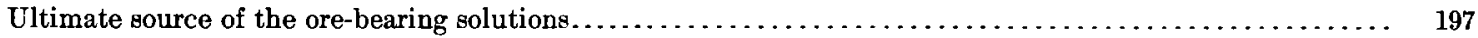

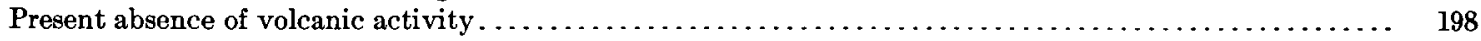

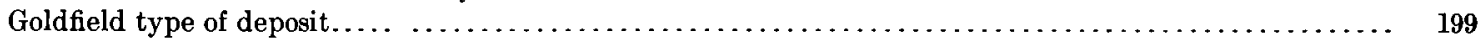

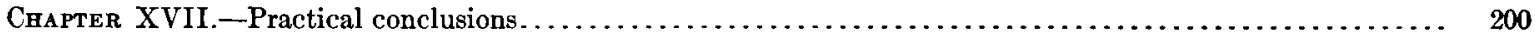

Chapter XVIII._Detailed descriptions of the mines of the Goldfield Consolidated Mines Company ....... 202

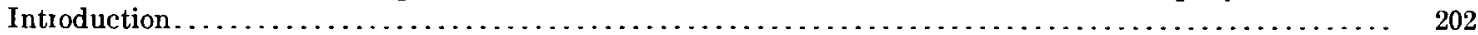

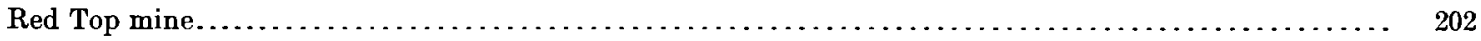

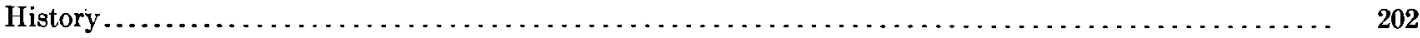

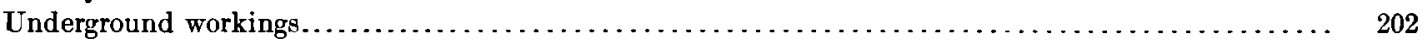

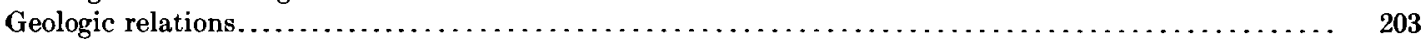

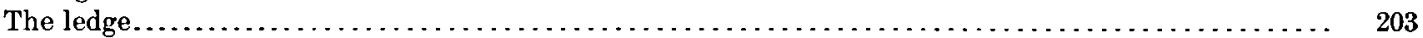

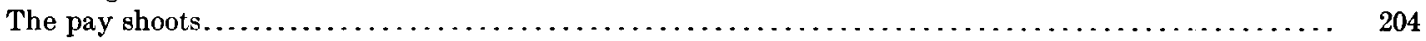

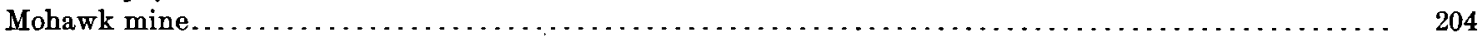

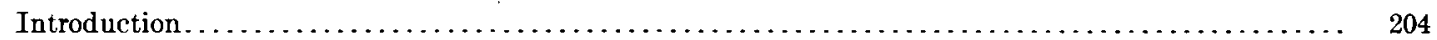

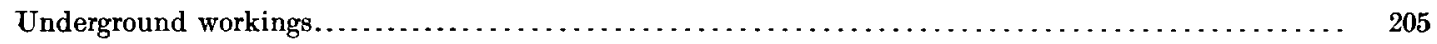

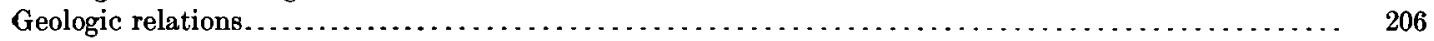

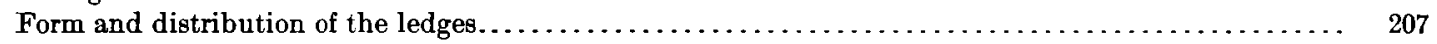

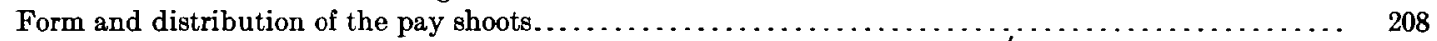

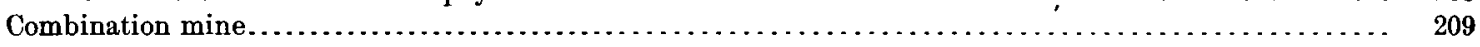

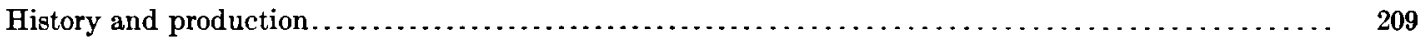

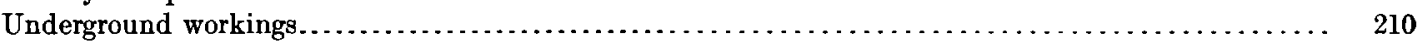

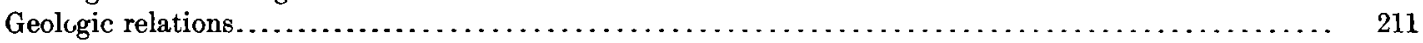

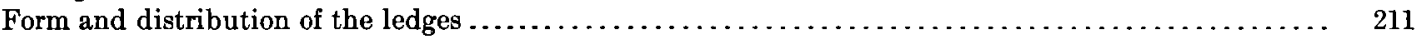

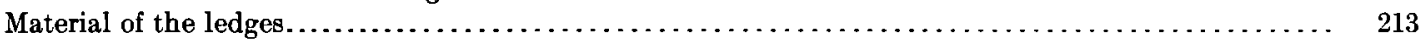

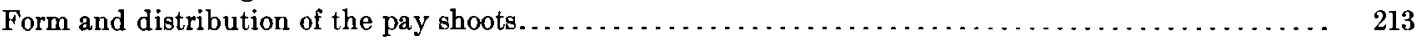

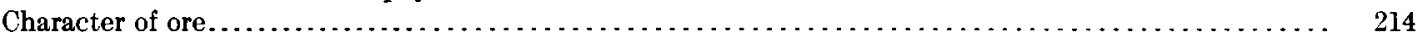

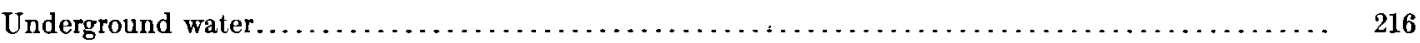

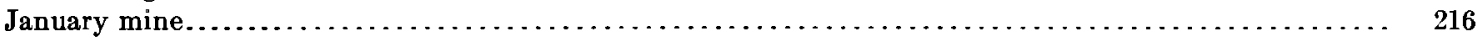

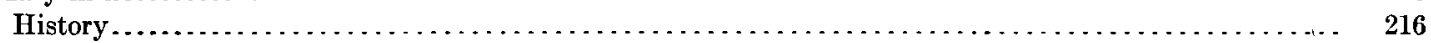

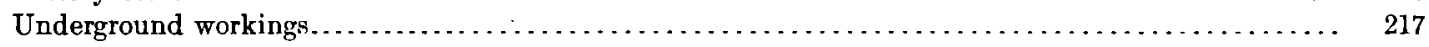

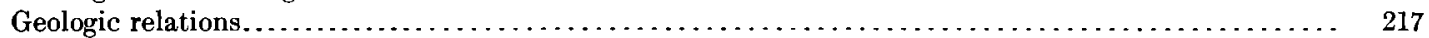

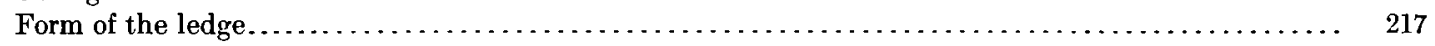

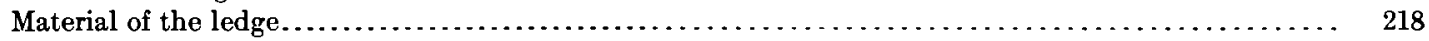

Form and distribution of the ore bodies.........

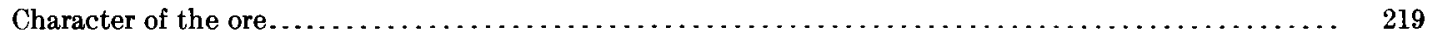

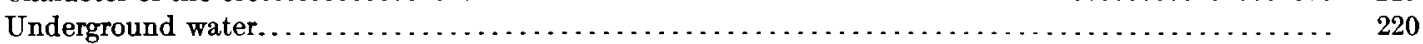

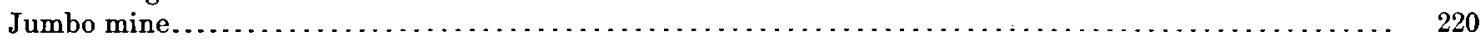

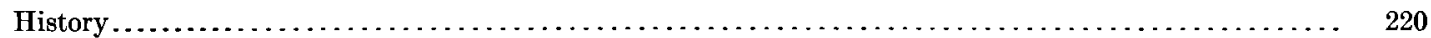

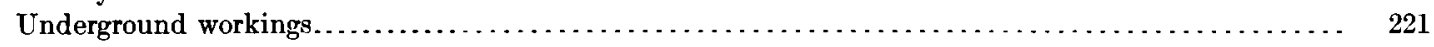

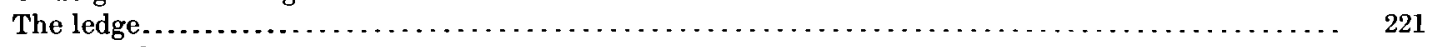

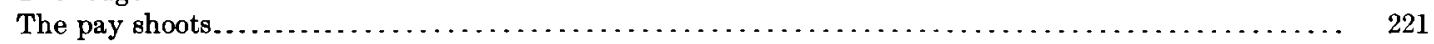

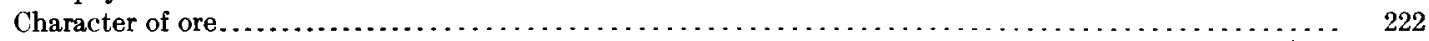

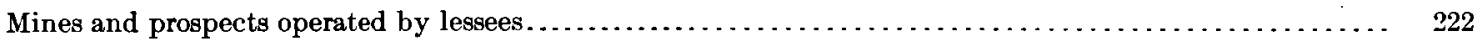

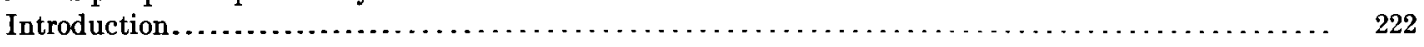

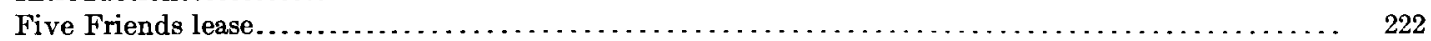

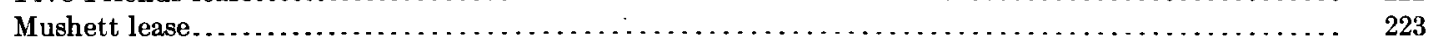

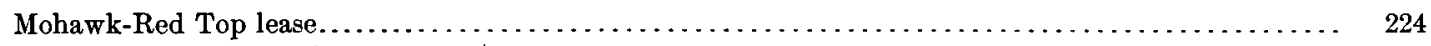

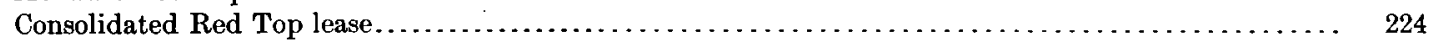

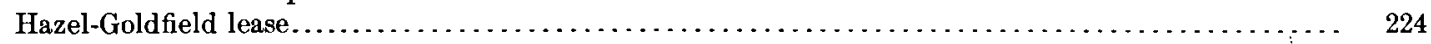

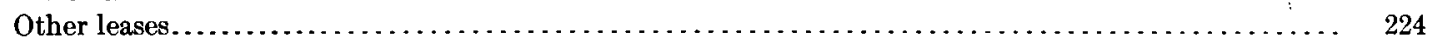

Chapter XIX.-Detailed descriptions of the mines of the Florence-Goldfield Mining Company ........... 225

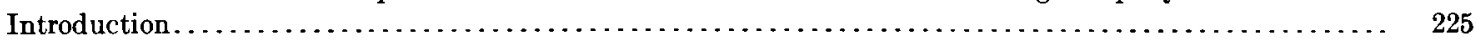

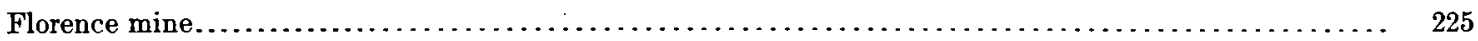

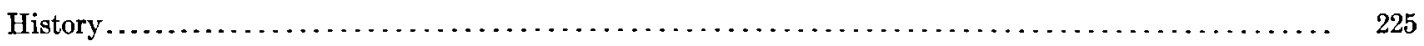

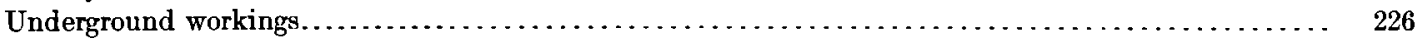

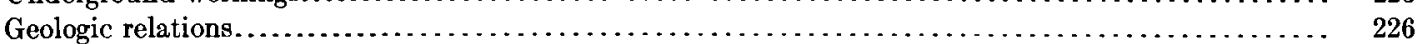

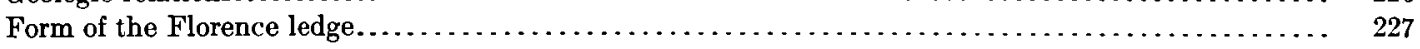

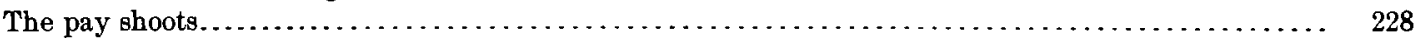

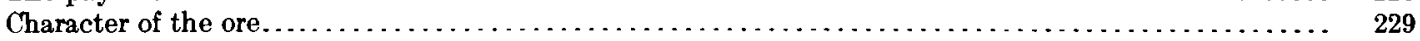

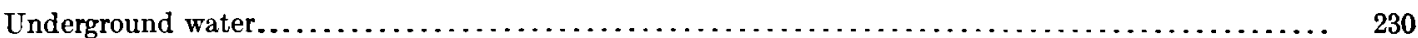


Chapter XIX.-Detailed description of the mines of the Florence-Goldfield Mining Company-Continued. Page.

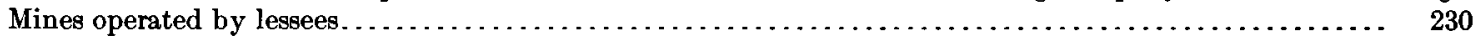

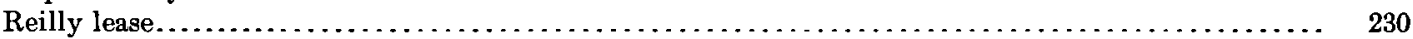

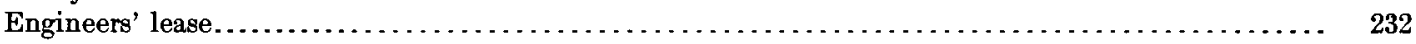

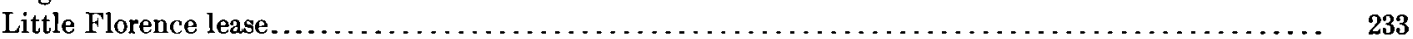

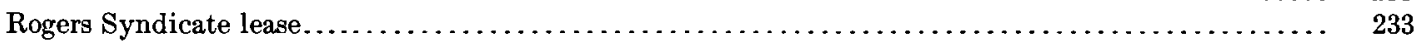

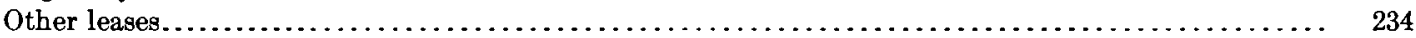

Chapter XX.-Detailed descriptions of the lesser mines and prospects of the Goldfield group............

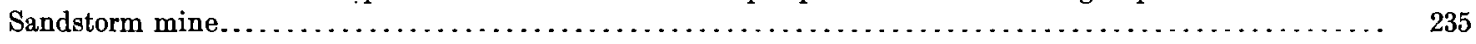

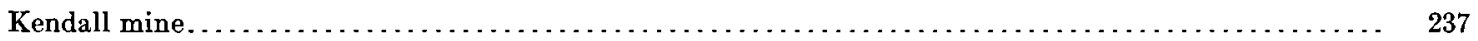

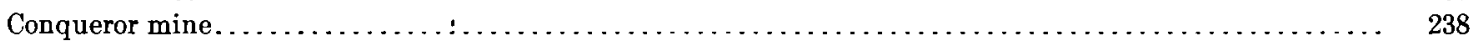

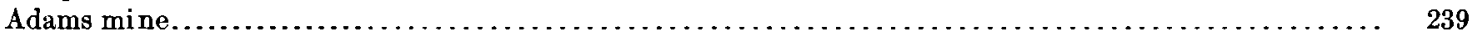

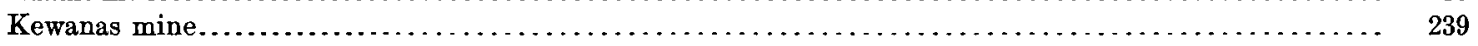

Goldfield Merger Company's mines............................................... 239

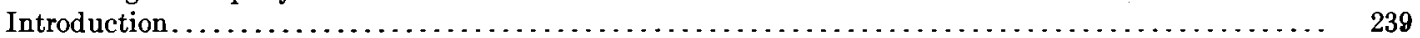

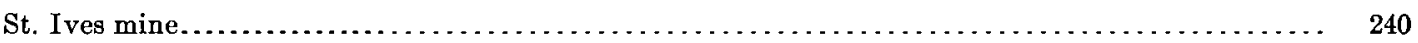

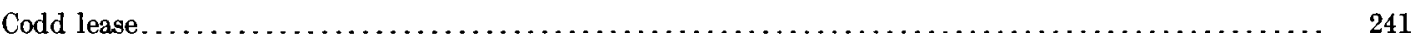

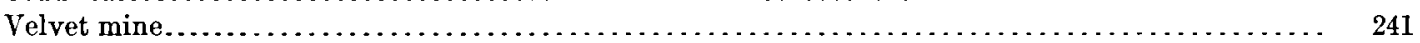

Jumbo-Extension Mining Company's Gold Wedge claim............................... 241

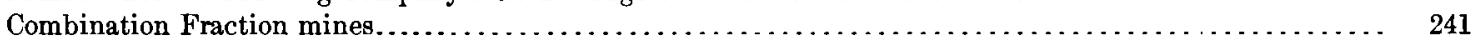

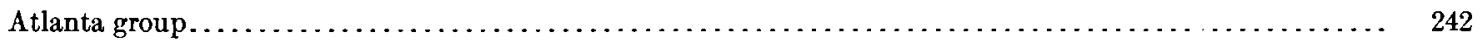

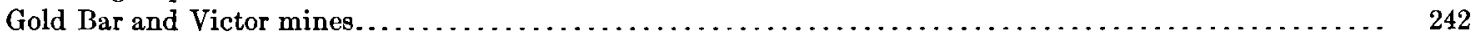

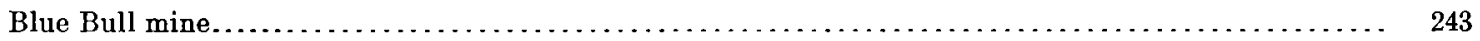

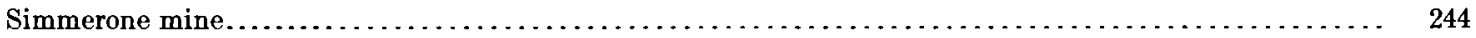

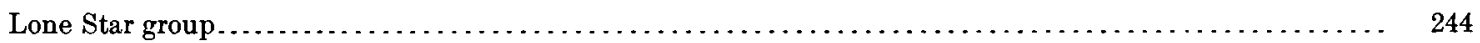

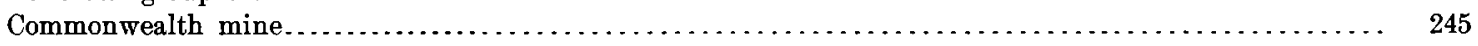

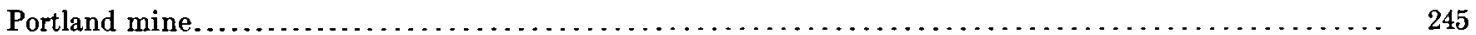

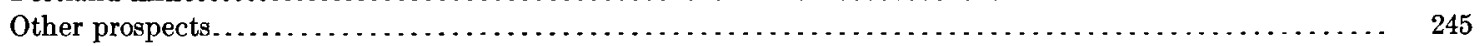

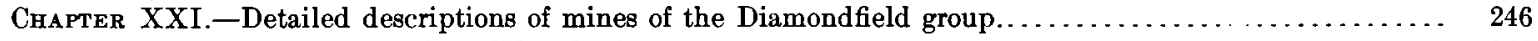

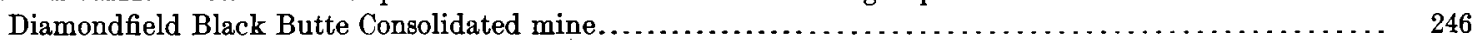

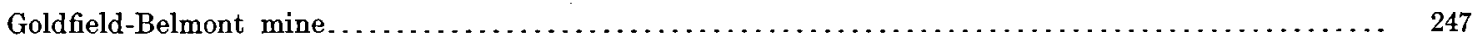

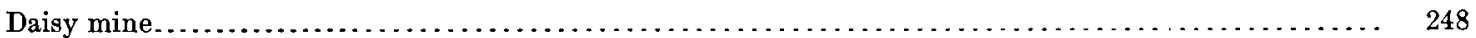

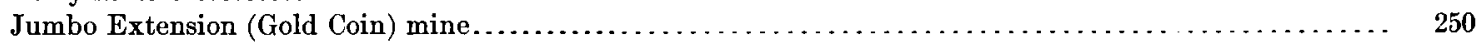

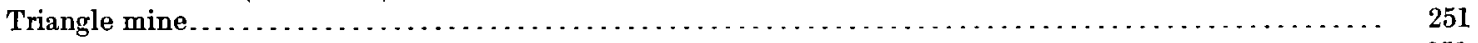

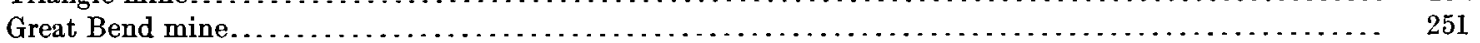

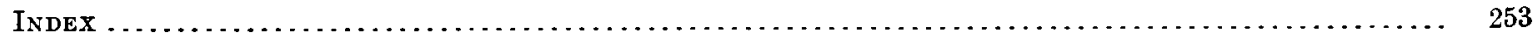





\section{ILLUSTRATIONS.}

PLATES.

Plate I. Topographic map of the Goldfield district. $\ldots \ldots \ldots \ldots \ldots \ldots$ In pocket.

II. Geologic map of the Goldfield district. . . . . . . . . .

III. Goldfield topography: $A$, Goldfield; $B$, Black Butte................................ 16

IV. Geologic reconnaissance map of the region adjacent to Goldfield ............................ 32

V. $A$, Columbia Mountain; $B$, Cambrian shale cut by alaskite, south slope of ('olumbia Mountain..... 34

VI. $A$, Intrusive contact between Morena rhyolite and Cambrian shale, west slope of Columbia Mountain;

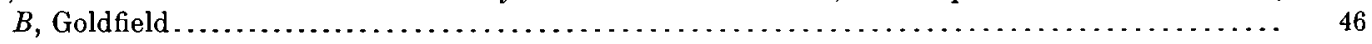

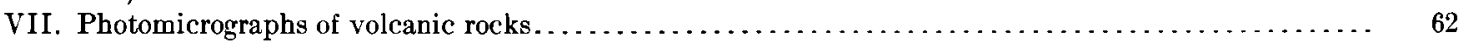

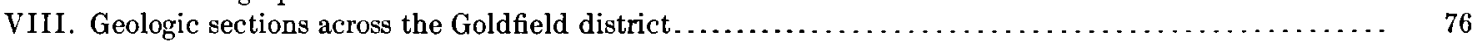

IX. Combined plan of the underground workings of the principal mines near Goldfield............. 136

X. Map showing principal lease blocks in the vicinity of Goldfield $\ldots \ldots \ldots \ldots \ldots \ldots \ldots \ldots \ldots \ldots \ldots \ldots$

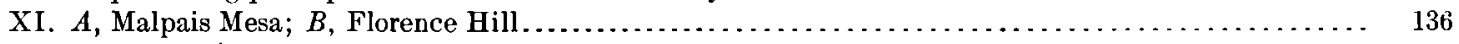

XII. $A$, View northwest from Florence Hill; $B$, View east from Florence Hill ................... 136

XIII. $A$, Sandstorm and Kendall mines; $B$, View from Morena Ridge eastward to Diamondfield and Black

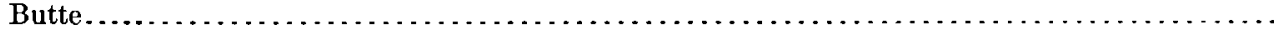

XIV. $A$, Ledge outcrops in Milltown andesite about 2 miles east of Goldfield; $B$, Ledge outcrop in dacite

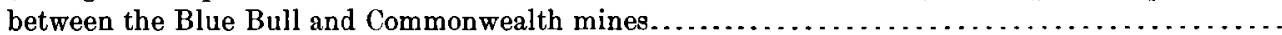

XV. $A$, Ledge outcrops east of Black Cap Mountain; $B$, Ledge outcrops in latite on Banner Mountain....

XVI. Plans of the principal levels of the January mine, with a diagrammatic section showing relations of ore,

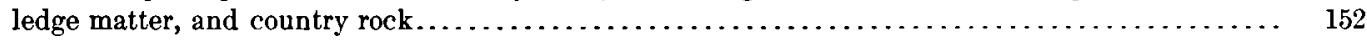

XVII. Sections across the Combination ledge on lines shown on Plate XXXIV $\ldots \ldots \ldots \ldots \ldots \ldots \ldots \ldots \ldots \ldots$

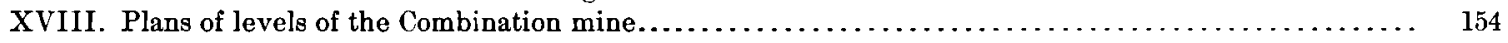

XIX. $A$, Dacitic ledges on ridge near the Commonwealth mine; $B$, Dacitic ledge near the Blue Bull mine. 156

XX. Ledge structure: $A$, Veinlets of compact quartz and kaolinite in altered andesite, Goldfield-Belmont mine; $B$, Sheeted dacite and low-grade ore, Jumbo mine.......................... 156

XXI. $A$, Part of the Sweeney stope in the Florence mine; $B$, The Hayes-Monnette stope in $1906 . \ldots \ldots .160$

XXII. $A$, The "glory hole" of the Combination mine; $B$, Ledge matter on the 150 -foot level of the Florence

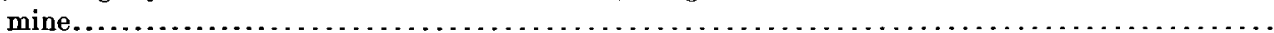

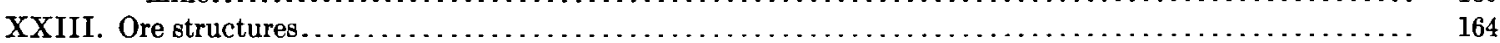

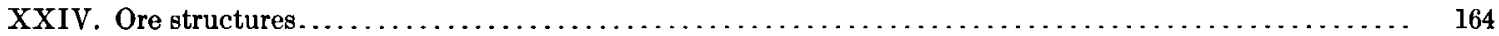

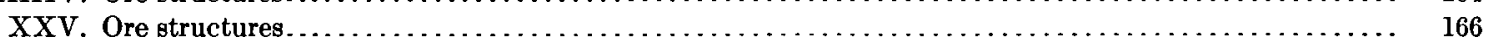

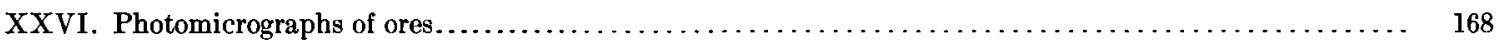

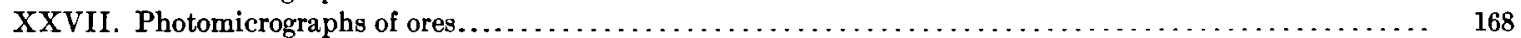

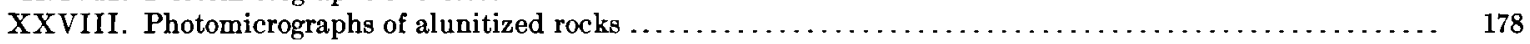

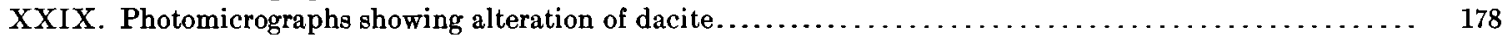

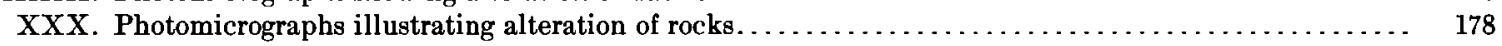

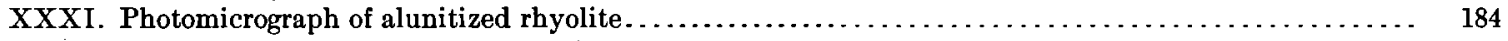

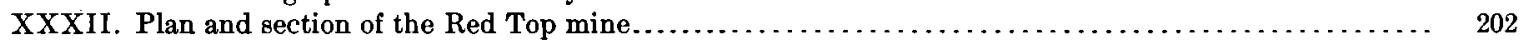

XXXIII. Plan of the Mohawk mine, showing also the workings of lessees on the Gold Wedge claim........ 206

XXXIV. Plan of the Combination mine, including the productive part of the January mine...............

XXXV. Plan of the Florence mine, showing also some of the adjacent workings of lessee companies........ 226 



\section{FIGURES.}

Figure 1. Index map gage.

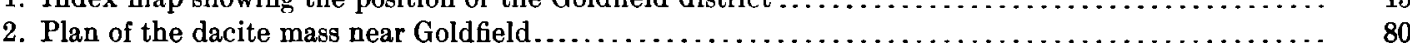

3. Section across the Columbia Mountain fault at the Conqueror mine...................... 82

4. Generalized columnar section of the rocks of the Goldfield district....................... 90

5. Columnar section of rocks of southwestern Nevada and eastern California................ 91

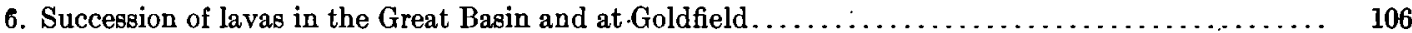

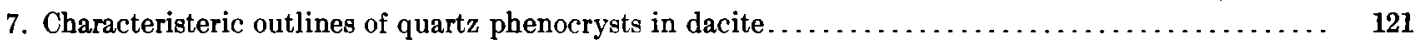

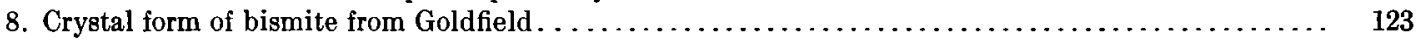

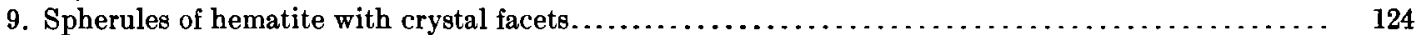

10. Scheme of treatment in the Combination mill.................................... 144

11. Scheme of treatment in the new Goldfield Consolidated mill............................. 147

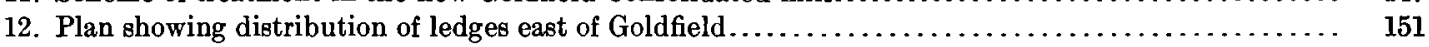

13. Plan of ledge matter and pay shoots on the 100 -foot level of the Florence mine.............. 152

14. Vertical section through an irregular flat ledge in the west wall of the Black Butte tunnel........ 152

15. Sections across the Mohawk ledge on lines shown on Plate XXXIII . . . . . . . . . . . . . . 153

16. Sections across the Reilly pay shoot. . . . . . . . . . . . . . . . . . . . . . . . . . . . 154

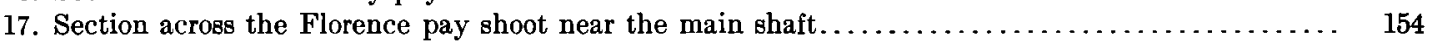

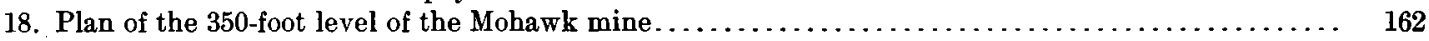

19. Diagram showing the portions of the Goldfield district in which the rocks have undergone extensive alunitic alteration.

20. Diagram illustrating gains and losses of each chemical constituent in terms of percentage of mass of original fresh dacite.

21. Geologic plan of the 600 -foot level of the Mohawk mine $\ldots \ldots \ldots \ldots \ldots \ldots \ldots \ldots \ldots \ldots \ldots \ldots \ldots$

22. Diagram showing relation of the Mohawk ledge to the dacite-latite contact................... 206

23. Plan of part of the 130 -foot level of the Combination mine................................ 211

24. Diagram showing possible plan of the combined January and Combination ledges........... 212

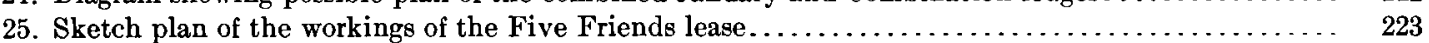

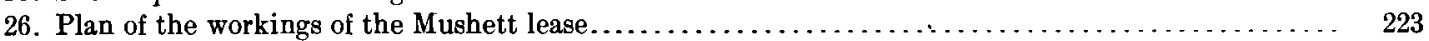

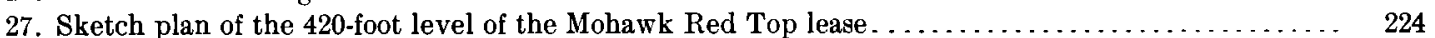

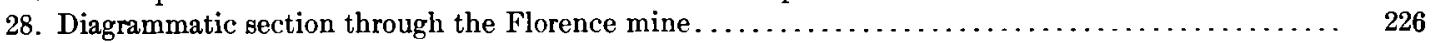

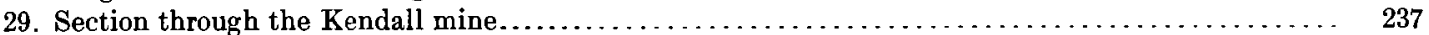

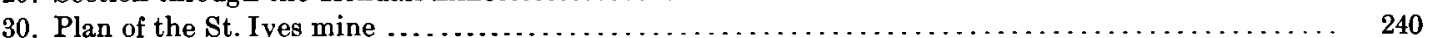

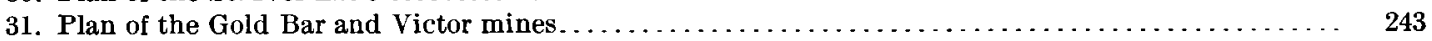

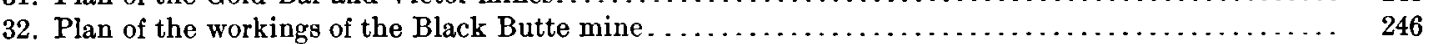

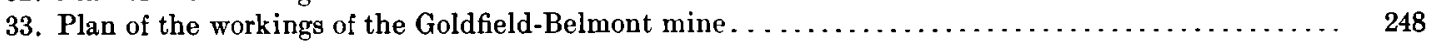

34. Plan and longitudinal projection of the workings on the Daisy group...................... 249 



\title{
THE GEOLOGY AND ORE DEPOSITS OF GOLDFIELD, NEVADA.
}

\author{
By Frederick Leslie Ransome. \\ CHAPTER I.
}

INTRODUCTION.

FIELD WORK AND ACKNOWLEDGMENTS.

During the summer of 1905 a topographic map of the Goldfield district, on a scale of 2,000 feet to the inch ( $1: 24000)$, and covering approximately $31 \frac{1}{2}$ square miles (82 square kilometers), was'made by Mr. William Stranahan, topographer. With this map as a base, detailed geologic work was begun in September of the same year. Messrs. W. H. Emmons and G. H. Garrey assisted in the field work of the first season. In the main, the geologic mapping of that portion of the district lying in Nye County (see PI. II, in pocket) and extending from Blackcap Mountain to Black Butte is the work of Mr. Garrey. The part lying south of a line drawn from Blackcap Mountain to Goldfield and west of the Goldfield-Tonopah freight road (i. e., the southern and western borders of the area) was mapped principally by Mr. Emmons. The field notes of both geologists have been used whenever it was necessary to supplement my own observations with details observed by them in their respective divisions of the field. All the geologic mapping was done with traverse plane tables, each contact being followed and numerous points upon it determined by intersections.

A preliminary report ${ }^{a}$ on the district was issued early in 1907 and the greater part of the final report was finished by the end of the same year. The rapid development of the mines during 1906 and 1907, the large number of new ore bodies found, and the important discoveries made at depths not reached when the first field work was brought to a close, rendered it clear that the disadvantage of a few months delay in the publication of final results would be amply compensated for by a second visit to the field and by a study of underground workings opened since the close of the year 1905. Accordingly a supplementary investigation of the district was carried on from June 11 to July 27, 1908. It was found necessary, moreover, in consequence of the many modifications in the cultural features (changes in roads, additional shafts and buildings, etc.) to thoroughly revise the topographic map published in 1906 . Mr. W. M. Beaman, topographer, was occupied with this revision during September, October, and part of November, 1908.

The assistance rendered us in the course of our investigation by all interested in the development of the district was hearty and general. It is a pleasure to record gratefully the generous cooperation of Mr. H. P. Henderson, geologist for the Goldfield Consolidated Mining Company, and of our professional colleagues, the local mining engineers, particularly Messrs. E. A. Byler, George B. Church, F. A. Lucy, C. D. Wilkinson, A. E. Barnes, W. Stranahan, F. J. Siebert, and Charles J. Moore. Very helpful also was the active interest of the owners and superintendents of mines.

a Ransome, F. I., Preliminary account of Goldfield, Bullfrog, and other mining districts in southern Nevada: Bull. U. S. Geol. Survey No. $303,1907$. 
The various chemical tests and the analyses of minerals and rocks recorded in the following pages were made in the chemical laboratory of the Geological Survey by Messrs. George Steiger, W. T. Schaller, and Chase Palmer.

A full and representative collection of the rocks and ores of the Goldfield district has been deposited in the National Museum, Washington, D. C., where it may be examined by anyone on application to the curator of geology. It is hoped that arrangements may be made whereby a smaller collection illustrative of this report may be placed on exhibition in Goldfield.

All plans of mine workings and all plats of claims accompanying this report have been compiled from the maps of the various companies and are published with their permission. The standard of mine surveying at Goldfield is generally excellent and there is no reason for supposing that any of the maps here utilized are incorrect. The United States Geological Survey does not, however, vouch for their accuracy.

\section{SITUATION OF THE DISTRICT.}

The town of Goldfield, which, with the adjoining settlement of Columbia, has a population estimated at about 15,000, lies near the eastern border of Esmeralda County, in southwestern Nevada. (See fig. 1.) It is about 28 miles (45 kilometers) nearly due south of Tonopah and 7 miles (11 kilometers) a little north of east from the old mining camp of Montezuma. As may be seen from Plate I, the eastern part of the Goldfield district, including Black Butte, lies in Nye County.

Three railroads of standard gage enter the district. A branch of the Southern Pacific leaves the main line at Hazen and connects at Mina with the Tonopah and Goldfield Railroad, which enters Goldfield on the north by way of Tonopah and Tonopah Junction. Through trains are run over this route from San Francisco to Goldfield. The Las Vegas and Tonopah Railroad leaves the San Pedro, Los Angeles and Salt Lake Railroad at Las Vegas, Nev., and passes through the Bullfrog district, 60 miles (96.5 kilometers) south-southeast of Goldfield. The Tonopah and Tidewater Railroad branches from the main line of the Santa Fe system at Ludlow, Cal., and reaches Goldfield by way of Death Valley and the Bullfrog district. The northern route affords communication with San Francisco, and particularly with the works of the Selby Smelting and Lead Company where a large part of the Goldfield ore has been treated. The two southern routes give access to Los Angeles and to the smelters of Utah.

\section{TOPOGRAPHY.}

The hills in the vicinity of Goldfield form an irregular group (see Pl. I, in pocket), having no definite trend and belonging to no recognized mountain range. On the north, east, and south these hills slope down to broad, undrained sterile basins, each with its characteristic central playa-a gleaming level plain incrusted with salts, except when an occasional shower has spread a film of water over its surface. The average altitude of the playa floors above sea level in this region is about 5,000 feet $(1,524$ meters). Such a basin, approximately 10 miles ( 16 kilometers) in width, separates the Goldfield Hills from Stonewall Mountain, a prominent landmark southeast of the district and visible in Plate XIV, $A$. A low, broad pass between this basin and one to the north of it connects the Goldfield Hills with the northwest end of the Cactus Range, Cactus Peak being 20 miles (32 kilometers) east-northeast from Goldfield. A similar inconspicuous divide, about 12 miles (19 kilometers) north-northeast of Goldfield, forms a slight connection between the Goldfield Hills and the hills of the Southern Klondike and Tonopah districts.

West of town a basaltic mesa (see Pl. II), at this latitude about 4 miles (6.4 kilometers) wide, stretches to the eastern base of Montezuma Peak, which is composed in part of rocks similar to those of the Goldfield district. The old mining settlement of Montezuma lies near the summit of the peak, which is 8,426 feet $(2,568$ meters) in height and 7 miles (11 kilometers) a little south of west from Goldfield. 
Goldfield is situated on the southern rim of one of the typical desert basins of the region, which merges through a low pass 22 miles (35.4 kilometers) north of town into the still larger basin west of Tonopah. (See Pl. IV.) This pass, through which the railroad runs from Tonopah to Goldfield, is between the Lone Mountain Range on the west and the Tonopah Hills on the east.

The portion of the Goldfield Hills, which is particularly described in the present paper and which will for convenience be hereafter referred to as the Goldfield district, is shown in the accompanying map (Pl. I). The relief in this area ranges from 5,400 feet (1,646 meters) in its

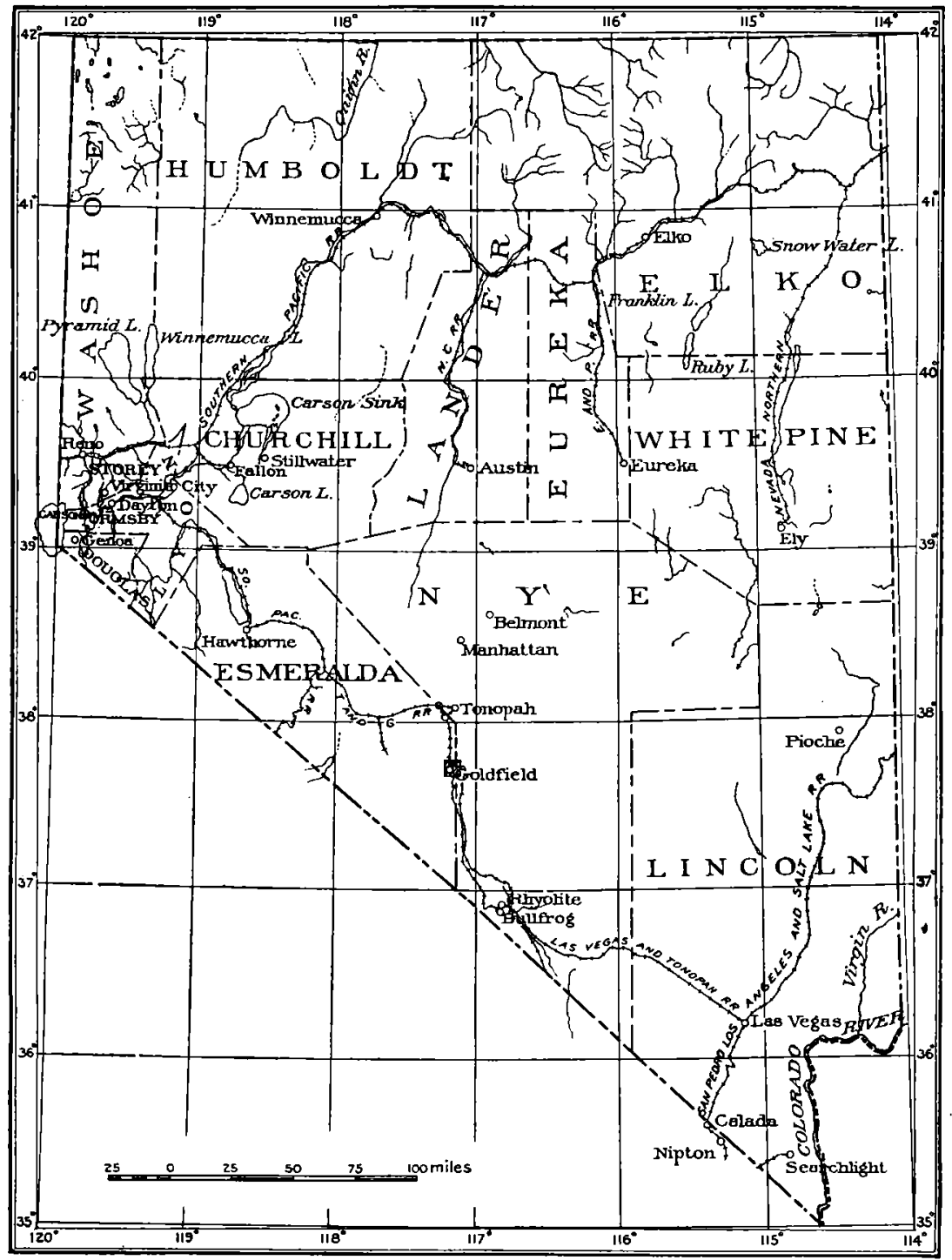

FIGURE 1.-Index map showing the position of the Goldfield distriet.

northwest corner to 6,635 feet $(2,022$ meters) on the summit of Preble Mountain, near the southeast corner. The culminating peak of the Goldfield Hills, however, known as Diamond Peak, is just east of the area represented in the map and attains an elevation of nearly 7,000 feet $(2,133$ meters). A large part of the district may be described as a rolling plateau (see Pls. III and VIII), ranging from 5,700 to 5,800 feet (1,737 to 1,768 meters) in general elevation and surmounted by many irregularly distributed peaks and knobs, of which Preble, Blackcap, Vindicator, Banner, and Columbia mountains are conspicuous examples. Not any of these hills are volcanic craters or local volcanic upheavals, as has been asserted in some descriptions 
of the district. They owe their height above the surrounding country merely to the fact that they are composed of material somewhat harder or more durable than the average rock of the region, and have thus succumbed more slowly to the general erosion that has carved the existing relief from a gently domed volcanic series. The superior resistance of the hills is in some cases due to the original character of the rock of which they are composed; in other cases to a capping of young and fresh lava, but by far the greater number of the smaller knobs that stud the district, of which Black Butte, Plate III, $B$, is an excellent example, are prominent because the rock has been hardened by intense local metamorphism in a manner that will be described in connection with the ore deposits.

The fact that much of the district is a rolling plain diversified by rocky knobs has an important bearing in a region where detritus tends to accumulate on all but the steepest slopes. In the Tonopah district, and especially in the Bullfrog district, there is generally a fairly definite line between steep, bare, rocky hills and the gentle alluvial slopes at their base. At Goldfield, however, the general gradients, as may be seen from Plate VIII, are so slight that detritus accumulates over much of the surface and interferes seriously with attempts to determine the distribution and structure of the underlying rocks.

\section{HISTORY OF MINING.}

At the beginning of the present decade the state of the mining industry in Nevada had so far declined as to appear but a feeble and flickering reminder of past splendor. The output of the great Comstock, a lode which in forty years had yielded about $\$ 400,000,000$ in gold and silver, had dwindled in 1899 to the relatively paltry sum of $\$ 171,677.90$; and the whole State in that year produced only $\$ 3,740,790$ (with silver reckoned at coinage value), nearly half of this coming from Lincoln County, in which the Delamar mine was the only large producer. Eureka, Pioche, Eldorado Canyon, and many places of less note had apparently passed from activity into tradition.

With the opening of the year 1900 , however, there were signs that some of the older camps were preparing to shake off their dusty lethargy. On the Comstock, particularly, some progress was made in freeing the deep levels from water and the production from this famous lode rose to $\$ 700,865$. But the one event which transformed a gradual resuscitation of mining, the natural accompaniment of great national prosperity in all other branches of industry, into a movement almost explosive in its energy and suddenness, and resulted in the development of Goldfield, Bullfrog, Manhattan, Wonder, Fairview, and many other new fields, was the discovery, in 1900, of the Tonopah deposits by James L. Butler. In 1901 ore to the value of $\$ 576,145$ was shipped from the Tonopah district, and prospectors were not slow in acting upon this striking demonstration of the fact that the State of Nevada, owing largely to its uncompromisingly desert character, had hitherto been very inadequately prospected. From Tonopah as a base prospectors scattered over the desert, and as the size and richness of the new bonanzas became known the number of explorers increased. Many of these, as well as prospectors of an earlier generation, must have walked over the low hills which lie east of Montezuma Peak, 24 miles (38.6 kilometers) south of Tonopah. They could scarcely have failed to remark the dark siliceous outcrops, or combs, which are a notable feature of their topography and must have suspected the connection of these with ore deposition. How gold ore of such unprecedented richness, lying so close to the surface in a region of such obvious volcanic and chemical activity, escaped detection when work was in progress at the old camps of Montezuma, Lida, and Silver Peak, is difficult to comprehend. The explanation is probably to be found in the fact that the earlier prospectors were looking for quartz veins of the normal type, particularly for silverbearing veins, and finding nothing of value in the projecting parts of some of these curious rusty "blow outs" concluded that all were barren and passed on to what seemed more promising localities. The gold pan was not at that time a recognized part of the outfit of a Nevada prospector, and the first attempts to use it at Goldfield were not successful because the pioneers panned the hard quartz broken from the croppings instead of the soft disintegrated material which in this district generally contains the gold. 


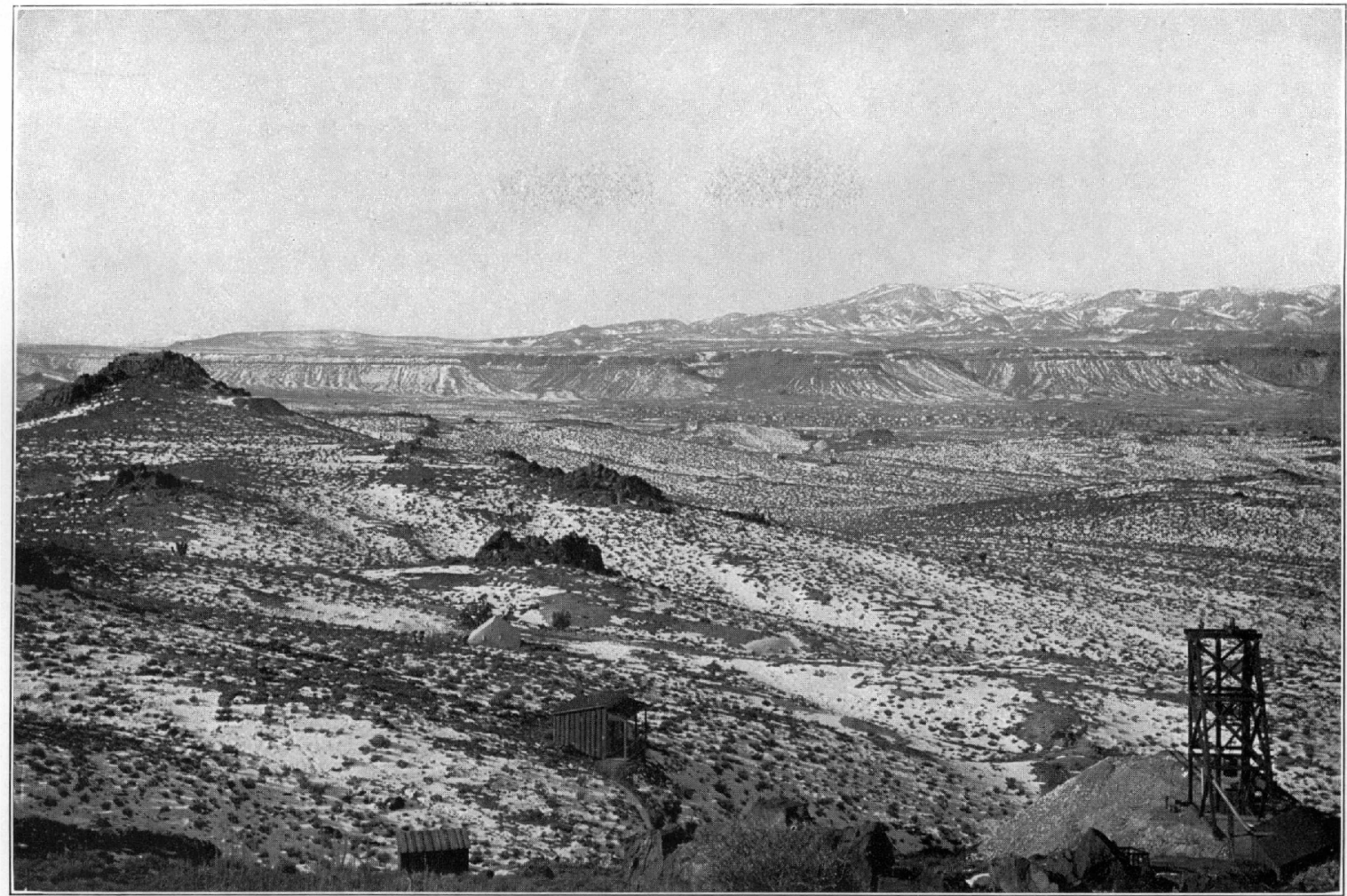

A. GOLDFIELD; FROM POINT NEAR THE OLD BLUE BULL SHAFT.

Characteristic ledge outcrops in foreground; Malpais Mesa behind the town; Montezuma Peak beyond. Looking west.

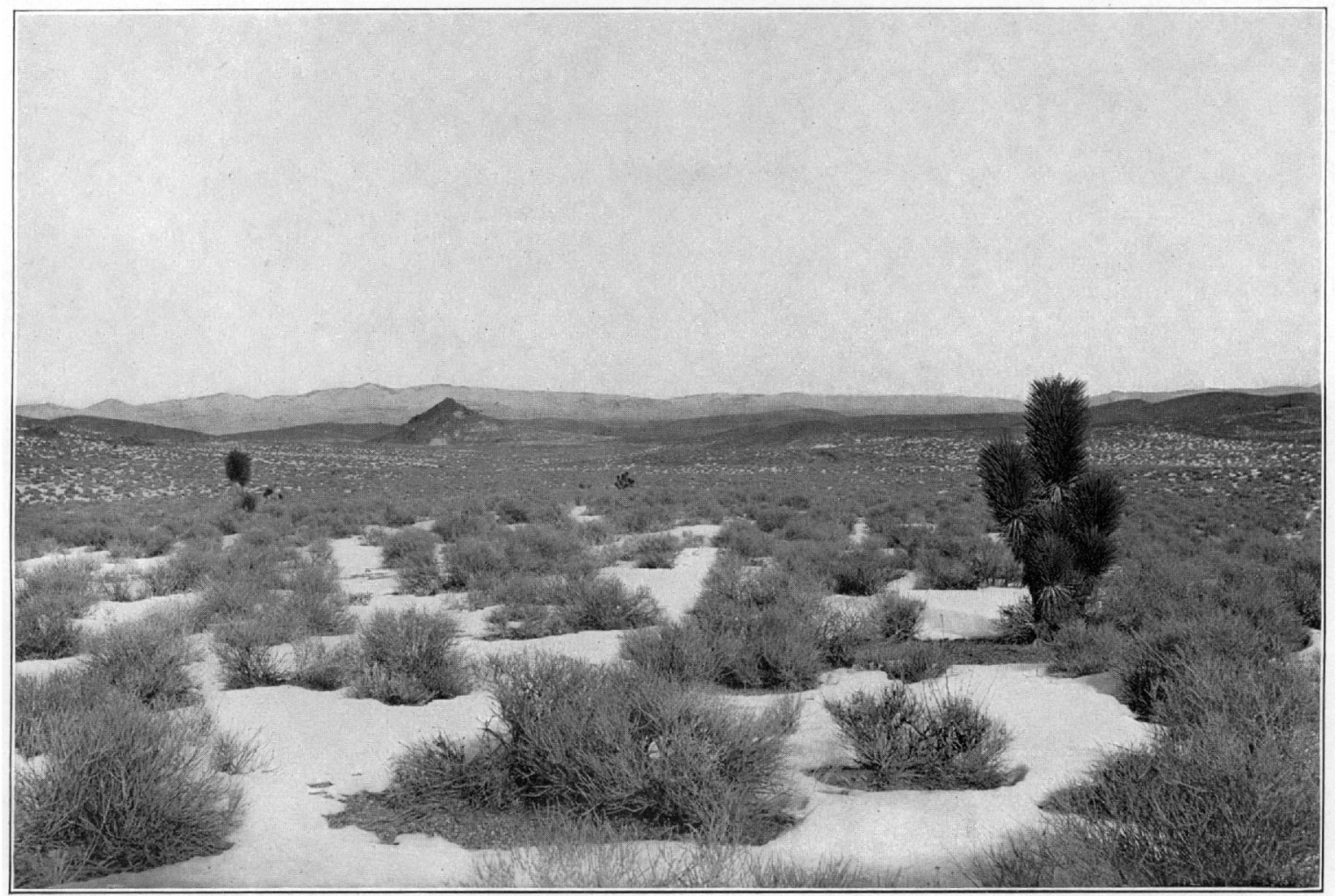

3. BLACK BUTTE; FROM POINT NEAR MCLAUGHLIN'S WELL.

A typical knob of ledge matter rising above the general rolling surface. The white dump at the base of the butte inarks the portal of the main tunnel. To the right of it, extending obliquely up the slope, are the cuts on the Flat vein. 

It was not until late in 1902 that "float" gold was found on Columbia Mountain by Harry Stimler and William Marsh. After seeking in vain for the source of this gold the two prospectors worked northward, and on December 2 of the same year located claims on and near the Sandstorm lode. A brief period of excitement followed their discovery, men thronging into the district on foot and in wagons and automobiles. No important ore bodies were immediately uncovered, however; interest flagged; and all but a few of the more determined or more sanguine prospectors left the district, then known as Grandpa. Stimler and Marsh's original locations appear to have lapsed, the ground being afterwards relocated by others. Among those who remained were A. D. Myers and R. C. Hart, who, on May 24, 1903, located the Combination lode. These two men had been "grubstaked" by eight others and were under contract with their backers to do the assessment work. The early locations south of Columbia Mountain were not based on direct discovery of ore, but were made with the view of securing claims as near as possible to the point at which gold was first found. They were originally speculative holdings merely.

Hart soon sold his interest to T. D. Murphy, who, with Myers, began to develop their property. Their pertinacity was rewarded by the discovery of the Combination ore shoot, and to them and their associates undoubtedly belongs the credit of the real opening of the district. It was at this time (June, 1903) that J. E. Spurr, then studying the geology of Tonopah, paid a hasty visit to the district and published a brief note ${ }^{a}$ on the geology, which was supplemented by a fuller statement ${ }^{b}$ made after a second visit in November, 1904.

In October, 1903, after the existence of ore in the Combination ledge had been proved by a short tunnel, the ground was bonded to the Combination Mines Company for $\$ 5,000$ in cash and $\$ 70,000$ to be paid in later instalments. In the following December this company began the shipment of ore. Prospecting was actively resumed over the district in January and February of 1904, and before midsummer rich ore was being shipped from the Jumbo, Florence, and January mines.

With the exception of the Combination, all the mines which have attained any importance were first opened and developed by the leasing system, and so near the surface and so rich were many of the ore bodies that numbers of the successful lesses made ample fortunes in a few months or even in a few weeks. The royalties exacted usually ranged from 20 to 30 per cent of the net value of the ore extracted. At one time there were six sets of lessees working through as many shafts on the Jumbo lode. The blocks were from 100 to 300 feet (30.5 to 91.4 meters) in length, the most productive and best known being that generally referred to as the BowesKernick lease.

The daily output from all of these workings in August, 1904, was estimated at $\$ 10,000$, and the total to the expiration of the leases, early in 1905, amounted to considerably more than $\$ 1,000,000$. Another famous lease was the Sweeney lease on the Florence mine, which expired on January 15, 1905, after a production amounting to $\$ 650,000$. The Patrick lease on the January mine, probably the first important lease granted in the camp, produced about $\$ 500,000$. Later, and in some respects more sensational than the leases just mentioned, was that granted to B. J. Reilly and associates on No. 1 block of the Florence ground. This lease, after having been successively abandoned by two earlier holders, was taken up by Reilly and his partners in April, 1905. Ore was found in the following June, but it was not until August that the true richness of the body became apparent. In the short time then available before the expiration of the term, on October 19,1905, nearly all of the ore which the lease produced was mined and hoisted to the surface. The royalties paid to the Florence-Goldfield Mining Company represent a total output of $\$ 475,000$. Most accounts, however, give the production as $\$ 750,000$. Some of this ore was of extraordinary richness, a lot of about $4 \frac{1}{2}$ tons, ${ }^{c}$ taken out from the bottom of the workings during the last days of the lease, averaging, according to Mr. Frank Oliver, then superintendent of the Florence mine, between $\$ 6,000$ and $\$ 7,000$ per ton.

a Bull. U. S. Geol. Survey No. 225, 1904, pp. 118-119.

$b$ Bull. U. S. Geol. Survey No. 260, 1905, pp. 132-139.

c The tons referred to in this report are in every case "short tons" of 2,000 pounds. Since the short ton is equivalent to approximately 0.9 me ric ton, conversion to the metric units is in most cases unnecessary. 
Early in 1905 the district probably contained fully 8,000 people, over two-thirds of whom were in the town of Goldfield. Late in the year, owing to the attractions of Manhattan and other recently opened camps and to a decreasing activity in prospecting, in leasing, and in the various more or less speculative transactions so characteristic of a new mining district, the population had somewhat declined.

The completion of a railroad from Tonopah to Goldfield in September, 1905, gave the district a much-needed improvement in transportation, although freight charges were still maintained at unduly high figures. Another important event of the year was the discovery of a large body of rich ore in the Red Top mine, which had not previously been a productive property. On the whole, the year 1905 witnessed a slight ebb in the tide of prosperity, due to many causes. The rapid exhaustion of many of the rich shoots worked by lessees and the failure to immediately find other rich bodies at greater depth aroused forebodings which not even the record of the Reilly lease could allay. The Jumbo mine, after making fortunes for lessees, was involved in litigation and became temporarily unproductive. The bottom level of the Combination mine had been allowed to fill with water and the bottom level of the Florence mine revealed as yet no shipping ore. New camps, particularly Manhattan, were coming into prominence and were drawing men away from Goldfield, which under all these circumstances could not avoid some reaction from the buoyant optimism of the preceding year. The entrance of the Red Top mine into the rank of producers at the close of the year did much to restore confidence, although no one yet realized what extraordinary riches still lay concealed within 250 feet ( 76 meters) of the surface in the little area of about a quarter of a square mile ( 0.6 square kilometer) which contained the Red Top, Combination, January, Jumbo, and Florence mines.

During the first quarter of 1906 no very important changes took place in the general situation at Goldfield. Several new ore bodies were found and the discovery of rich ore in the Sandstorm between the 100 and 150 foot levels proved encouraging in view of the shallow depth to which stoping had hitherto been restricted in this mine. The development of the Laguna mine, east of the Red Top, was begun, and a few tons of low-grade. ore were found by lessees on the Mohawk claim. The various local mills and reduction works were in active operation, including a new Kinkead mill on Columbia Mountain. The Combination mill was working 20 stamps and installing tube mills.

In June differences between the mine owners and the miners' union threatened to become acute, being complicated by the introduction into Goldfield of an organization of labor called the Industrial Workers of the World. The latter had declared a strike against the Western Union Telegraph Company which threatened to involve all the workmen in the district. A visit of Governor Sparks to Goldfield early in June, when he addressed the labor unions, appeared to avert the threatened trouble, but the spirit of unrest still smoldered.

Ore was first discovered on the Hayes-Monnette lease of the Mohawk in April, 1906, at a depth of about 250 feet ( 76 meters). By the end of the first week in June nearly 2,500 tons of sulphide ore averaging 2.7 ounces of gold per ton had been shipped, and in the following month the Mohawk ground began to attract much attention and was actively worked by several sets of lessees. In the early days of the Hayes-Monnette lease considerable fruitless work had been done on the 150-foot level; and there, as later developments showed, the main drift missed the great ore shoot by a few feet only. In September the ore shoot, there very rich, was opened from that level, and this one lease block was soon shipping up to $\$ 60,000$ worth of ore a day from two shafts. The original Hayes-Monnette lease covered an area 700 feet (213 meters) long by 373 feet (113 meters) wide. About two-thirds of this was sold to other lessees who met with less success than did the original holders on the retained third.

On some of the Mohawk leases the miners were paid $\$ 5$ for six-hour shifts. Mere wages in fact counted for little where the prime consideration on the part of the lessee was to raise as much rich ore as possible in a given time and where the obvious aim of many employees and others was to steal the greatest quantity possible. It is reported that miners in some cases refused $\$ 20$ a day on development work in order to accept $\$ 5$ a day with the opportunity 
for illegal perquisites in the Mohawk. The extent to which "highgrading," or the stealing of rich ore, went on in 1906 is almost incredible. Two shipments of stolen ore, valued at $\$ 60,000$ and $\$ 150,000$ were seized on the cars. Scores of so-called assay offices sprang up, the main business of which was the traffic in dishonestly acquired "highgrade." It has been locally estimated that over $\$ 2,000,000$ was stolen from the Mohawk, Red Top, and Jumbo mines alone up to the latter part of 1907 . About $\$ 250,000$ worth of stolen ore is said to have been recovered in 1906. While these figures may be exaggerated they give some idea of the magnitude of the thefts. The report of the Goldfield Consolidated Mines Company for the year ending November 1,1907 , shows that stolen ore to the value of $\$ 30,896.98$ was actually recovered between May 1 and October 31, 1907. T. A. Rickard ${ }^{a}$ states that the total stealings from this one company for the year 1907 were fully $\$ 1,000,000$, and the same conclusion is reached from a comparison of the figures of mine production, with those of the mint for that year. ${ }^{b}$

In October, 1906, the town of Goldfield was in a very flourishing condition. According to the local correspondent of the Engineering and Mining Journal there were at that time over 150 buildings in course of construction. There were 56 mining companies in operation, employing 2,250 men. There were 27 leases on the Mohawk, of which 12 were shipping ore. The population of the district at the close of the year was estimated at 15,000 .

It is not surprising that the remarkable discoveries in the Hayes-Monnette and Little Florence lease blocks, coming at a time when over the country at large a wave of speculation had reached what we now know was nearly breaking height, should have led to overconfidence and inflation. In the prospectuses of promoters and in the minds of eager investors nearly every claim was a potential Mohawk. One mining company, the ground of which, so fair as known, has never produced a pound of ore, is capitalized at 2,000,000 shares with a par value of $\$ 1$. Yet, notwithstanding this obvious overcapitalization these shares were quoted at one time at $\$ 1.80$, corresponding to a total valuation of the property of $\$ 3,600,000$. In October, 1908 , the public, with chastened judgment, valued the same chance for finding an ore body at $\$ 400,000$.

Overcapitalization is not confined to any one company, but is so common as to be generally accepted as a matter of course. Prospects irrespective of all probabilities are generally capitalized at $\$ 1,000,000$ from the start, and it is a fair question whether the mines of one or two of the most important companies, in spite of their past productiveness, great known resources, and reasonable expectations, warrant their very large capitalization. Even at a time of general inflation, such as that at the close of 1906, some of the most valuable of these stocks did not reach par, although others having no basis of value other than expectation were quoted at high premiums. As an investment mining stock during the life of the mine should repay in dividends to its holders the sum invested plus interest calculated at a rate considerably higher than that customary in well-secured loans. The public, however, in buying mining stock is influenced as a rule more by the prospect of immediate high returns than by the real value of the investment. That the speculative side of the transaction should be usually dominant follows naturally from the great extent to which chance enters into mining operations, particularly where, as at Goldfield, the ore bodies are both rich and irregular. The buyer expects to sell at an advance or to dispose of his holdings after the receipt of rich dividends at something near their purchase price.

Friction between miners and operators continued through the latter part of 1906, the wage scale and the problem of preventing ore thefts being prominent subjects of negotiation. In August an eight-hour day was agreed upon for all work with rates of $\$ 4$ and $\$ 4.50$ for ordinary and $\$ 5$ to $\$ 5.50$ for skilled labor. The harmony, however, proved transitory. The attempt of the operators to eliminate stealing by the use of change rooms for the men met with opposition from the miners and the regulation of wages became a recurring point of contention.

a The reat gold mines: Min and Scl. Press, vol. 96, 1908, p. 161.

$b$ Lindgren, W., and MaCaskey, H. D., Production of gold and silver in 1907: Mineral Resources U. S. for 1907, pt. 1, U. S. Geol. Survey, 1908, p. 122. 
On November 20, 1906, occurred the most important consolidation of interests yet effected at Goldfield. The Mohawk, Jumbo, Red Top, and Laguna mines were consolidated under the title of the Goldfield Consolidated Mines Company, incorporated under the laws of Wyoming and capitalized at $\$ 50,000,000$, in $5,000,000$ shares, at $\$ 10$ par value. In this transaction C. D. Taylor received $\$ 1,330,000$ for his shares in the Jumbo and Red Top companies, at a rate of $\$ 2$ a share. Mr. George Wingfield, who became president of the new corporation, with his associates received 250,000 shares as their commission for effecting the amalgamation. The consolidated company also secured options on the Combination and January mines, which they subsequently acquired. The price paid for the Combination mine in March, 1907, was reported to be $\$ 4,000,000$.

The extent and development of the properties in the initial consolidation are shown in the following table issued by the company early in December. 1906:

Acreage and workings of consolidated mines.

\begin{tabular}{|c|c|c|c|c|c|c|c|}
\hline Mine. & & Area. & Shafts. & Drifts. & Crosscuts. & Raises. & Winzes. \\
\hline \multirow[t]{2}{*}{ 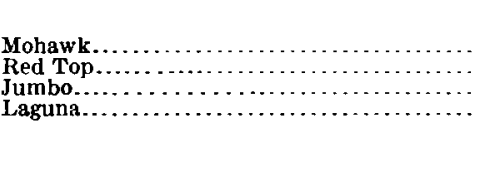 } & 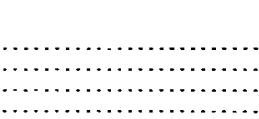 & $\begin{array}{l}\text { Acres. } \\
42.227 \\
62.440 \\
18.690 \\
33.113\end{array}$ & $\begin{array}{r}\text { Feet. } \\
3,140 \\
300 \\
1,350 \\
140\end{array}$ & $\begin{array}{r}\text { Feet. } \\
2,710 \\
1,670 \\
2,020 \\
\ldots \ldots\end{array}$ & $\begin{array}{r}\text { Feet. } \\
3,715 \\
1,545 \\
1,025 \\
360\end{array}$ & \begin{tabular}{r|} 
Feet. \\
1,565 \\
530 \\
645
\end{tabular} & $\begin{array}{r}\text { Feet. } \\
465 \\
35 \\
125 \\
\ldots .\end{array}$ \\
\hline & & 156.470 & 4,930 & 6,400 & 6,645 & 2,740 & 625 \\
\hline
\end{tabular}

To the above were subsequently added over 200 acres embraced in the Combination and January holdings. The production credited to these properties at the time of consolidation is as follows:

Production of consolidated mines.

\begin{tabular}{|c|c|c|c|}
\hline Mine. & Gross value. & Net value. & Royalties. \\
\hline \multirow[t]{2}{*}{$\begin{array}{l}\text { Jumbo.... } \\
\text { Red Top.: } \\
\text { Mohawk.. }\end{array}$} & $\begin{array}{r}\$ 1,607,342 \\
308,515 \\
4,875,519\end{array}$ & $\begin{array}{r}\mathbf{8 8 1 3}, 098 \\
260,177 \\
\mathbf{3}, 135,426\end{array}$ & $\begin{array}{r}\$ 201,771 \\
705,469\end{array}$ \\
\hline & $6,791,776$ & $4,208,701$ & 907,240 \\
\hline
\end{tabular}

The market value of the Consolidated shares at the beginning of 1907 was about $\$ 7$. On November 21,1907 , they were quoted at $\$ 3.95$. The Hayes-Monnette lease, after surpassing all records in the district for the value of ore shipped in less than a year's time, expired on January 11, 1907. According to a statement issued by the Goldfield Consolidated Mines Company, the output of the Mohawk leases was as follows:

Production of Mohauk leases from A pril 18 to November $20,1906$.

\begin{tabular}{|c|c|c|c|c|c|}
\hline Lease. & $\begin{array}{l}\text { Ore in dry } \\
\text { tons. }\end{array}$ & $\begin{array}{l}\text { Gross } \\
\text { value. }\end{array}$ & Net value. & Royalties. & Balances. \\
\hline 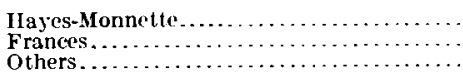 & $\begin{array}{r}20,909 \\
6,422 \\
7,466\end{array}$ & $\begin{array}{r}\$ 2,597,845 \\
993,508 \\
484,566\end{array}$ & $\begin{array}{r}\$ 2,038,398 \\
784,490 \\
312,538\end{array}$ & $\begin{array}{r}8458,640 \\
176,510 \\
70,320\end{array}$ & $\begin{array}{r}\$ 1,579,758 \\
607,980 \\
242,218\end{array}$ \\
\hline & 34,797 & $4,075,919$ & $3,135,426$ & 705,470 & $2,429,956$ \\
\hline
\end{tabular}

The foregoing table is not complete, as most of the leases still had from one to two months to run. The total gross production of the Hayes-Monnette, according to a statement by Mr. II. J. Monnette in the Goldfield News, amounted to $\$ 4,400,000$. The gross output for October alone was approximately $\$ 1,300,000$. Shipments continued to be made from the dump of this lease until late in 1907 . The average freight and treatment rate on ores shipped to smelters in 1906 was about $\$ 23.50$ a ton.

Throughout the year 1907 the free development of the district continued to be hampered by friction between the mine operators and the unions. In April one of the many short-lived 
and partial strikes was settled on the reported basis of recognition by the operators of the Western Federation of Miners and the withdrawal of the organization of the Industrial Workers of the World from the district. In November the miners refused to accept part payment of their wages in checks or exchange drafts-an expedient which the employers had adopted in consequence of the exceptional financial conditions then prevailing throughout the country and the congestion in the smelters of the siliceous Goldfield ores, which prevented prompt settlement with the shippers. Local samplers, who act as middlemen between some of the mines and the smelters, were compelled to refuse the purchase of ore or to accept it only upon the understanding that payment therefor might be subject to delay. Under these unusual circumstances most of the large mines were compelled to store their rich ore or to curtail production.

About 1,900 men struck on November 27. On December 6, at the request of the governor of Nevada, in view of the fact that the State maintains no militia, 9 companies of federal troops were ordered into the district from San Francisco and Monterey. No actual violence appears to have been committed by the strikers prior to the call for troops, but the experience at Cripple Creek and other mining camps in the West was held by the mine owners to justify the conclusion that any attempt to reopen the mines with nonunion men would be followed by bloodshed and by the destruction of property.

On December 9 the Goldfield Mine Operators' Association announced the following changes in the scale of wages:

Wages at Goldfield.

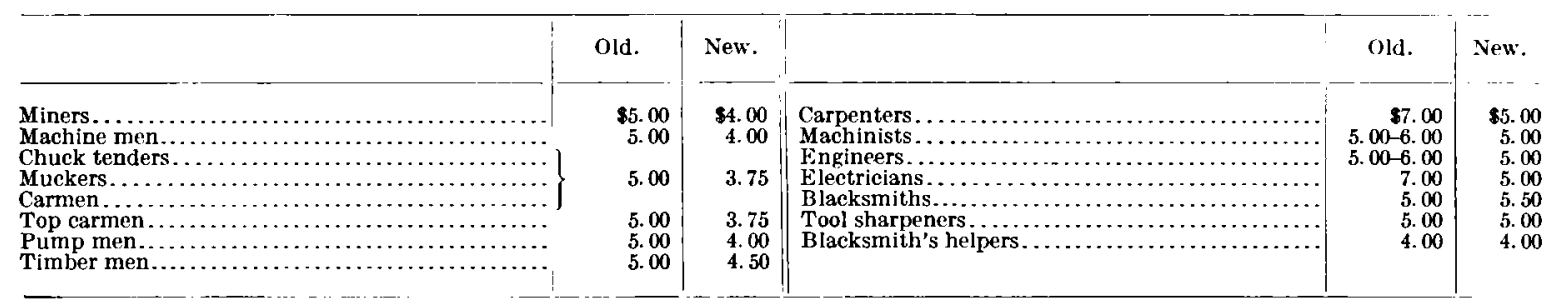

The new scale, however, was not immediately put into effect. Resolutions were passed, also, to the effect that no one affiliated with the Western Federation of Miners should be employed at the mines.

Some correspondence was carried on in December between the governor of Nevada and the President of the United States concerning the propriety of the call for troops and of their continued presence in the district. Governor Sparks was urged to call the legislature together, in order that the State might take steps to maintain order within its boundaries or else formally call upon the Federal Government for assistance. On December 11 a federal commission consisting of Lawrence O. Murray, Assistant Secretary of Commerce and Labor, Charles P. Neill, Commissioner of Labor, and Herbert Knox Smith, Commissioner of Corporations, was sent to the district to investigate the conditions there obtaining. Its members reached Goldfield and began the taking of testimony on December 15,1907 . In the meantime some of the mines were reopening with new men or with old employees who renounced allegiance to the local union.

On December 30 the three commissioners reported their findings to the President. ${ }^{a}$ They concluded that there had been no justification for the calling of federal troops and that the State of Nevada should take upon itself the preservation of order in the district. On January 4 a part of the troops was withdrawn, 2 companies being left at Goldfield. On January 14 the state legislature convened in special session, and on January 16 it passed a resolution asking that the federal troops be allowed to remain until a suitable state organization could be effected to police the district. On January 24 the legislature passed a bill for the creation of a force of state constabulary consisting of a superintendent, an inspector, 25 subordinate officers, and 250 privates, and on the same day it requested the Mine Operators' Association of Goldfield to abolish the card system of employment which discriminated against certain labor organizations. This 
request was acceded to, with the result that competency and good repute became the sole qualifications demanded of the employee. The following rules, copies to be posted at each mine, were promulgated by the mine owners:

This mine is to be worked under the open-shop policy of the Goldfield Mine Operators' Association, hiring and discharging men without regard to whether they do or do not belong to any labor organization, and under the following rules and regulations:

1. The time of each man on every shift belongs to this company and to no one else.

2. No walking delegate or other representative of any labor organization is to be allowed upon these premises at any time or for any purpose.

3. No soliciting of membership in any labor organization is to be allowed upon these premises at any time by an employee of this company or by anyone else.

4. No discussion of labor questions, either for or against unions, or in any way connected therewith, is to be allowed during working hours, or upon these premises at any time or under any circumstances.

5. No employee of this company is to be annoyed or interfered with by any other employee in his work in any way whatsoever because he may or may not belong to any labor organization, or for any other reason, and all employees are to work together harmoniously for the best interests of the company.

6. No employee of this company is to harass, intimidate, or interfere with any working man of the Goldfield mining district because he does or does not belong to any labor organization.

7. All employees are requested to report any violations of these regulations to the management, and any employee found guilty of violating them, or any part of them, will be immediately discharged and be disqualified from any further employment by this company.

8. Any outsider violating any of these rules will be immediately ejected from the premises and prosecuted by law for trespass.

On March 7, 1908, the last of the federal troops were withdrawn, and in April the Goldfield miners' union declared the strike at an end.

Among the notable events of the year 1907 was the discovery of ore by lessees in the Little Florence mine, near Milltown, at a point about 600 feet south of the Florence claim, and in the Rogers lease on the Red King claim. These developments were important in that the new ore bodies occur in andesite, while the mines which had previously proved so productive are in dacite. Ore in andesite was found also in the Daisy mine, near Diamondfield. A promising feature of this year's development was the considerable depth, from 400 to 500 feet, at which some of the newly opened ore bodies were found. The Las Vegas and Tonopah Railroad, connecting Goldfield with the Bullfrog district, was completed in the latter part of October, giving the Goldfield mines an outlet by way of Las Vegas to the smelters of Utah. A few months later the Tonopah and Tidewater Railroad also built into the district. In this year Goldfield became the seat of Esmeralda County.

The year 1908 was mainly a period of slow recovery from the depression of 1907 and of preparation for extensive operations in the future. The Goldfield Consolidated Mines Company confined its work chiefly to the development of the Mohawk and Combination mines and to the construction of its 100-stamp mill, on the west face of Sandstorm Ridge, at a cost of $\$ 750,000$. The 600 -foot level of the Mohawk was opened, and there proved to be a large body of good ore at that depth. The Florence Company did practically no underground work, but completed a pipe line and a 20-stamp mill.

Lessees continued to be fairly active. The Little Florence lease expired on April 26 and the Rogers Syndicate lease on July 11, 1908. Both were highly profitable. The gross production of the Little Florence is estimated at over $\$ 1,500,000(\$ 1,285,000$ net) and of the Rogers Syndicate about $\$ 500,000$. The success of these lessees has led to thorough exploration of the ground on the east, south, and west of Florence Hill and the sinking of more than a score of shafts in this vicinity to depths ranging from 300 to 500 feet. One result was the discovery of a small, although very rich, ore body in the Engineers' lease on the east side of the hill.

On May 1, 1908, the St. Ives, Velvet, Potlatch, and Gold Horn mining companies consolidated as the Goldfield Merger Mines Company, with a nominal capital of $\$ 5,000,000$. Up to the date of consolidation the St. Ives had produced less than $\$ 100,000$ and the Velvet probably less than $\$ 25,000$. 
The character of the Goldfield deposits is such that endless litigation might easily result were the law of the apex invoked with the same ingenuity and contested with the same bitterness as in Butte. Fortunately for the district the mine owners have been wise enough to avoid this danger by compromise or consolidation. A notable example of such foresight was shown in July, 1908, when the Goldfield Consolidated Mines Company and the Jumbo Extension Mining Company reached an agreement regarding the Wedge fractional claim of the latter company, which lies immediately northeast of the Mohawk No. 2 claim. On February 18, 1908, the Jumbo Extension Company and its tenants were enjoined from working the Wedge claim on the ground that the ore in this fraction had its apex in the property of the Consolidated Company. On July 24 the Jumbo Extension Company deeded the Wedge claim to the Goldfield Consolidated Mines Company and relinquished to the latter a one-fourth interest in the Vinegarone fraction, lying immediately northeast of the Red Top claim. On its side the Consolidated Company recognized existing leases on the Wedge claim and agreed not to claim more than one-half of any ore that might in future be mined from veins on the Polverde claim apexing on Consolidated ground. This agreement is creditable to all concerned-to the engineers who established the facts, to the lawyers who interpreted the legal bearing of these, and to the companies who accepted them. Its ratification deserves to rank as one of the important events in the history of the district.

According to the secretary of the Mine Operators' Association, the total number of miners employed in the latter part of June, 1908 , was about 1,800 , the monthly pay roll having a total of $\$ 200,000$.

\section{PRODUCTION.}

The gross production of the Goldfield district from the beginning of mining to the end of 1907 is shown in the following table, the figures being taken from the reports on the production of gold and silver published by the United States Geological Survey. The silver is calculated at the average commercial value at New York for each year. As the figures represent gross output, no deductions have been made for freight, treatment, or loss in smelting.

\section{Production of the Goldfield district.}

\begin{tabular}{|c|c|c|c|c|c|c|c|}
\hline \multirow{2}{*}{ Year. } & \multirow{2}{*}{ Ore. } & \multicolumn{2}{|c|}{ Gold. } & \multicolumn{2}{|c|}{ Silver. } & \multirow{2}{*}{$\begin{array}{l}\text { Total } \\
\text { value. }\end{array}$} & \multirow{2}{*}{$\begin{array}{c}\text { A verage } \\
\text { value } \\
\text { per ton. }\end{array}$} \\
\hline & & Quantity. & Value. & Quantity. & Value. & & \\
\hline \multirow[t]{2}{*}{$\begin{array}{r}1903 \\
1904 \ldots \\
1905, \ldots \ldots \\
1906, \ldots \ldots \\
1907 \ldots \ldots \ldots\end{array}$} & \begin{tabular}{|r} 
Short tons. \\
335 \\
7,433 \\
19,548 \\
59,628 \\
101,136
\end{tabular} & $\begin{array}{r}\text { Fine ounces. } \\
3,412.66 \\
113,293.23 \\
91,087.76 \\
339,890.20 \\
406,756.16\end{array}$ & $\begin{array}{r}\$ 70,670 \\
2,341,979 \\
1,882,951 \\
7,026,154 \\
8,408,396\end{array}$ & $\begin{array}{r}\text { Fine ounces. } \\
287 \\
19,954 \\
8,589 \\
15,648 \\
71,710\end{array}$ & $\begin{array}{r}\$ 155 \\
11,374 \\
5,188 \\
10,484 \\
\mathbf{4 7}, 329\end{array}$ & $\begin{array}{r}\$ 70,825 \\
2,353,353 \\
1,888,139 \\
7,036,638 \\
8,455,725\end{array}$ & $\begin{array}{r}\$ 211.41 \\
316.60 \\
96.58 \\
118.00 \\
83.61\end{array}$ \\
\hline & 188,080 & $954,446.01$ & $19,730,150$ & 116,188 & 74,530 & $19,804,680$ & 105.29 \\
\hline
\end{tabular}

The decrease in 1905 is accounted for mainly by the expiration of many leases at the close of that year, by the necessity of more systematic underground development by the mining companies as a preparation for mining on their own account, by the idleness of the Jumbo mine, which had contributed over $\$ 1,000,000$ to the production of 1904 , and by the tendency of the mine owners to hold their ore until railway transportation and better milling facilities should decrease the cost of treatment. The remarkable revival of successful leasing in 1906, particularly on the Mohawk No. 2 claim, and the improved facilities for shipping and marketing ore are reflected in the greatly increased production for that year. 
The following approximate figures, taken from the current reports of local correspondents to the mining journals, will give some idea of the size, value, and fluctuations of weekly shipments in the latter part of 1907 :

Weekly output from Goldfield, 1907.

\begin{tabular}{|c|c|c|c|c|c|}
\hline Week ending- & $\begin{array}{l}\text { Tons of } \\
\text { ore. }\end{array}$ & $\begin{array}{l}\text { Est: mated } \\
\text { value. }\end{array}$ & Week ending- & $\begin{array}{c}\text { Tons of } \\
\text { ore. }\end{array}$ & $\begin{array}{l}\text { Estimated } \\
\text { value. }\end{array}$ \\
\hline $\begin{array}{l}\text { July } 6 \ldots \ldots \\
\text { July } 13 \ldots \ldots \\
\text { July } 20 \ldots \ldots\end{array}$ & $\begin{array}{l}3,417 \\
3,919\end{array}$ & $\$ 590,000$ & September 20. & $\begin{array}{l}3,492 \\
4,129\end{array}$ & $\begin{array}{r}\$ 400,000 \\
400,000\end{array}$ \\
\hline July $27 \ldots$ & 3,143 & 345,250 & October $12 . .$. & 3,877 & 382,000 \\
\hline August $3 . .$. & 3,930 & 479,400 & October 19. & & \\
\hline August 10.. & 3,709 & 400,000 & October $26 \ldots$ & 5,390 & 508,000 \\
\hline August 17. & 3,810 & 400,000 & November $8 . .$. & 1,950 & 204,850 \\
\hline August 24. & 3,417 & 350,000 & November $15 \ldots$ & 4,939 & 456,450 \\
\hline $\begin{array}{l}\text { August } 31 \\
\text { September } \\
7\end{array}$ & 1,566 & 285,000 & 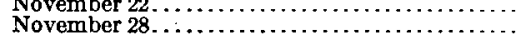 & $\begin{array}{l}5,801 \\
3,570\end{array}$ & $\begin{array}{l}674,200 \\
354,230\end{array}$ \\
\hline September $14 \ldots \ldots \ldots \ldots \ldots \ldots \ldots \ldots \ldots \ldots \ldots$ & 2,466 & 290,000 & & & \\
\hline
\end{tabular}

The following statement from the Mining and Scientific Press of November 9, 1907, shows the sources of the ore treated in the district or shipped from Goldfield during the week ending on November 3:

Output of Goldfield mines for the week ending November 3, 1907.

\begin{tabular}{|c|c|c|c|c|c|}
\hline & Tons. & Value. & & Tons. & Value. \\
\hline 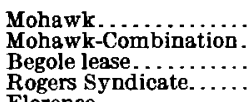 & $\begin{array}{r}834 \\
768 \\
390 \\
90\end{array}$ & $\begin{array}{r}8125,000 \\
53,700 \\
29,000 \\
9,000\end{array}$ & 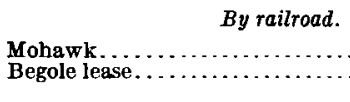 & $\begin{array}{l}698 \\
165\end{array}$ & $\begin{array}{r}\$ 100,000 \\
16,500\end{array}$ \\
\hline 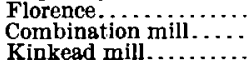 & $\begin{array}{r}46 \\
560 \\
140\end{array}$ & $\begin{array}{r}4,600 \\
39,200 \\
7,000\end{array}$ & & 3,741 & 399,700 \\
\hline
\end{tabular}

Of the 101,136 tons of ore treated in $1907,17,782$ tons, of an average value of $\$ 44.90$ a ton, were milled, yielding 434 tons of concentrates, which contained $\$ 195,231$ in gold and $\$ 2,057$ in silver. The 83,354 tons shipped had an average value of $\$ 91.86$ a ton.

In June and July, 1908, the estimated value of the weekly shipments of ore and concentrates from Goldfield ranged from $\$ 175,000$ to $\$ 200,000$. Owing to causes noted in the preceding historical sketch, the output of the district for 1908 will probably be less than that for 1907 .

\section{LITERATURE.}

The following list aims to include: (1) Publications of value for a general understanding of the geology of southwestern Nevada, particularly those which treat of formations represented in the Goldfield district; (2) publications descriptive of mining districts in the region adjacent to Goldfield; and (3) publications containing original and important contributions to our knowledge of the geology or ores of the Goldfield deposits. Many short papers relating to the district are not included in any of these categories and are therefore intentionally omitted.

\section{(1) WORKS ON THE GENERAL REGION.}

King, Clarence. Systematic geology: U. S. Geol. Expl. 40th Par., vol. 1, 1878.

Contains a wealth of information on the geologic development of the whole region of which the Goldfield district is a part.

Spurr, J. E. Descriptive geology of Nevada south of the fortieth parallel and adjacent portions of California. Bull.

U. S. Geol. Survey No. 208, 1905.

Deals with the general region and may be regarded as supplementary to the work of King.

BALl, S. H. A geologic reconnaissance in southwestern Nevada and eastern California. Bull. U. S. Geol. Survey No. 308, 1907.

A further development and extension of the reconnaissance work begun by Spurr in 1899 (Bull. U. S. Geol. Survey No. 208, 1903).

- The post-Jurassic igneous rocks of southwestern Nevada. Jour. Geology, vol. 16, 1908, pp. 36-45.

Describes the petrography and relationships of the intrusive granular rocks of pre-Tertiary age. 


\section{(2) DESCRIPTIONS OF MINING DISTRICTS IN THE GOLDFIELD REGION.}

Spurr, J. E. Ore deposits of Tonopah and neighboring districts, Nevada. Bull. U. S. Geol. Survey No. 213, 1903, pp. 81-87.

Describes Southern Klondike, Silver Peak, Gold Mountain, and Hennepah districts. The Goldfield deposits were not yet known.

The ore deposits of Tonopah, Nevada. (Preliminary report) Bull. U. S. Geol. Survey No. 219, 1903.

- Preliminary report on the ore deposits of Tonopah, Nevada. Bull. U. S. Geol. Survey No. 225, 1904, pp. 89-110.

Ore deposits of Silver Peak Quadrangle, Nevada. Bull. U. S. Geol. Survey No. 225, 1904, pp. 111-117.

Developments at Tonopah, Nevada, during 1904. Bull. U. S. Geol. Survey No. 260, 1905, pp. 140-149.

Geology of the Tonopah mining district, Nevada. Prof. Paper U. S. Geol. Survey No. 42, 1905.

The ore deposits of the Silver Peak quadrangle. Prof. Paper U. S. Geol. Survey No. 55, 1906.

Ball, S. H. Notes on ore deposits of southwestern Nevada and eastern California. Bull. U. S. Geol. Survey No. 285, 1906, pp. 53-73.

Ransome, F. L. A preliminary account of Goldfield, Bullfrog, and other mining districts in southern Nevada; with notes on the Manhattan district by W. H. Emmons and G. H. Garrey. Bull. U. S. Geol. Survey No. 303, 1906.

TAfт, H. H. Notes on southern Nevada and Inyo County, California. Trans. Am. Inst. Min. Eng., vol. 37, 1907, pp. 178-197.

Chiefly historical and descriptive of mining development and some notes on geology.

\section{(3) PAPERS ON THE GOLDFIELD DISTRICT.}

SPURr, J. E. Notes on the geology of the Goldfield district, Nevada. Bull. U. S. Geol. Survey No. 225, 1904, pp. 118-119.

Notes occurrence of alaskite and rhyolite on Columbia Mountain, and describes their intrusion into dark siliceous sediments. Best assays then obtained (June, 1903) were $\$ 50$ a ton.

The ores of Goldfield, Nevada. Bull. U. S. Geol. Survey No. 260, 1905, pp. 132-139.

Describes conditions in November, 1904. Gives additional notes on geology. The peculiar shape of the deposits and their mineralogical character are described in some detail. The ledges are regarded as products of metamorphism by hot ascending water.

Moore, Charles J. The Goldfield mining district. Goldfield News, April 21, 1905. Of interest as an early effort to interpret the geology of the district.

Winchell, Horace V. Notes on Goldfield, Nevada. Am. Geologist, vol. 35, 1905, pp. 382-385.

Describes the ore deposits as silicified rhyolite dikes. Recognizes the evidence of solfataric action.

Bosqui, Francis L. Ore treatment at the Combination mine, Goldfield, Nevada. Min. and Sci. Press, vol. 93, 1906, pp. 413-415 and 451-454.

An excellent description of processes employed, with results and costs.

TAFт, H. H. Notes on southern Nevada and Inyo County, California. Trans. Am. Inst. Min. Eng., vol. 37, 1907, pp. 178-197.

Chiefly historical and descriptive of mining development with some notes on geology.

Hastings, J. B., and Berkey, C. P. The geology and petrography of the Goldfeld mining district, Nevada. Trans. Am. Inst. Min. Eng., vol. 37, 1907, pp. 140-159.

Presents a good account of the rocks and shows their distribution by a sketch map. The paper errs in citing Columbia, Knickerbocker (Preble), Black Cap, and other hills as volcanic necks or cones, and contains scant information on the age and structural relations of the various rocks.

Ransome, F. L. A preliminary account of Goldfield, Bullfrog, and other mining districts in southern Nevada; with notes on the Manhattan district by W. H. Emmons and G. H. Garrey. Bull. U. S. Geol. Survey No. 303, 1906.

Collins, E. A. The Combination mine. Min. and Sci. Press, vol. 95, 1907, pp. 397-399 and 435-438.

History of mine and methods of mining and treating the ore. Describes general character of the ore bodies.

Ransome, F. L. The association of alunite with gold in the Goldfield district, Nevada. Econ. Geology, vol. 2, 1907, pp. 667-692.

Describes the alteration of the dacite in connection with ore deposition. Establishes the abundant occurrence of alunite as a characteristic mineral of the ores and altered country rock, and discusses the genesis of the deposits.

Sharwood, W. J. Gold tellurides. Min. and Sci. Press, vol. 94, 1907, pp. 731-732.

Drawings of thin sections showing relations of telluride, gold, and quartz.

Browne, R. Stuart. Cyanidation in Nevada. Min. and Sci. Press, vol. 95, 1907, p. 677.

Proposes to treat Goldfield ores by dry crushing, roasting, and final leaching with cyanide solution.

Rickard, T. A. Goldfield, Nevada. Min. and Sci. Press, vol. 96, 1908, pp. 559, 664, 738, 774, 840.

General notes on the district. The articles on the history of the district, on the moral effect of rich ore, and on metallurgical development are particularly good.

Becker, Arnold. Geological possiblities at Goldfield. Min. and Sci. Press, vol. 96, 1908, p. 846.

An attempt to show that there is a second sheet of dacite below the one in which the rich Mohawk ore bodies occur and that this lower sheet may prove productive. The supposed lower dacite does not exist. 
King, Lochiel M. Cyanidation in Nevada. Min. and Sci. Press, vol. 96, 1908, pp. 123-126. Advocates dry crushing, roasting, and cyanidation of crude ore.

KIrby, A. G. Cyanidation in Nevada. Min. and Sci. Press, vol. 96, 1908, pp. 836-839.

Describes mill tests on Combination and Mohawk ores. Believes that ores can be more economically treated by wet crushing, amalgamating, concentrating, and then roasting and cyaniding the concentrates in the district, than by roasting and cyaniding the crude ore.

\section{GEOGRAPHIC NAMES.}

A search for geographic names to distinguish successive eruptions of lava of the same petrographic character (there are in the district, for example, five rhyolites of different age) soon showed how few names in local use were available for this purpose. It became necessary to apply names to certain topographic features in order that the rocks typically developed at these localities might be appropriately designated. The difficulty of finding English names which are appropriate, and which can at the same time be fitly applied to geologic formations, becomes evident on trial. In names chosen from the Spanish the ordinary meaning of the words is less obtrusive, and it is possible to find terms which are appropriate, euphonious, and easily pronounced. The following list shows the new names employed in this report, with their derivation and usage:

Names applied in this report to topographic features.

\begin{tabular}{|c|c|c|}
\hline Name. & Derivation and comment. & Geologic use. \\
\hline Malpais Mesa. . & $\begin{array}{l}\text { Spanish mal pais (mal pah-ees"), bad country. Popularly pronounced mal'-a-pī. } \\
\text { The feature here called Malpais Mesa is locally referred to as "the Malapai" or } \\
\text { "the mesa." }\end{array}$ & Malpais basalt. \\
\hline $\begin{array}{l}\text { Spearhead Point........... } \\
\text { Pozo Canyon............ }\end{array}$ & $\begin{array}{l}\text { Refers to shape of point } \\
\text { Spanish pozo, well. Refers to fact that a well in this ravine was formerly the chief } \\
\text { source of water for Goldfield. }\end{array}$ & $\begin{array}{l}\text { Spearhead rhyolite. } \\
\text { Pozo formation (sedimentary). }\end{array}$ \\
\hline $\begin{array}{l}\text { Mira Mountain ....... } \\
\text { Meda Pass }, \ldots \ldots \ldots \\
\text { Chispa Hills........... }\end{array}$ & $\begin{array}{l}\text { Spanish mira (mea'-ra), look!, behold! Refers to view of Goldfield from the summit. } \\
\text { From Goldfeld Meda Mining Co., whose claims cover the pass................... } \\
\text { Spanish chispa, sparkle. Refers to the sparkling black mica on the surface of the } \\
\text { hills. }\end{array}$ & $\begin{array}{l}\text { Mira basalt. } \\
\text { Meda rhyolite. } \\
\text { Chispa andesite. }\end{array}$ \\
\hline $\begin{array}{l}\text { Espina Hill } \ldots \ldots \ldots \ldots \ldots \\
\text { Morena Ridge. } \ldots \ldots \ldots \ldots\end{array}$ & $\begin{array}{l}\text { Spanish espina (es-pee'na), spine. Refers to shape of bill } \ldots \ldots \ldots \ldots \ldots \ldots \ldots \\
\text { Spanish morena (mo-ray'-na), brown. Refers to color of the rhyolite } \ldots \ldots \ldots \ldots \ldots\end{array}$ & $\begin{array}{l}\text { Espina breccia. } \\
\text { Morena rhyolite. }\end{array}$ \\
\hline
\end{tabular}




\section{CHAPTER II.}

\section{PRELIMINARY OUTLINE OF THE GEOLOGY AND ORE DEPOSITS.}

This chapter is not intended as a complete synopsis of the whole report. Its function is to give the reader such a preliminary and general view of the field as will enable him to follow more readily and, it is hoped, with greater interest, the ampler exposition of the succeeding chapters.

The geologic structure of Goldfield, compared with that of most districts in which deposits of the precious metals are found, is simple. The district is essentially a low, domical ${ }^{a}$ uplift of Tertiary lavas and lake sediments resting upon a foundation of ancient granitic and metamorphic rocks. The erosion of this flat dome has exposed the pre-Tertiary rocks at a number of places in the central part of the district and these outcrops are surrounded by wide concentric zones of successively younger formations. Some of the later lavas were erupted after the dome had been elevated and truncated.

The oldest rocks exposed in the district are found on Columbia and Vindicator mountains, and from Columbia or Goldfield are particularly noticeable as conspicuous dark patches on the southern slope of the former peak. Originally thin-bedded limestones or calcareous shales, with subordinate beds of sandstone, the formation is now much contorted and metamorphosed. The calcareous beds have been changed to compact aggregates of quartz (jasperoid) crowded with microscopic black particles, probably carbonaceous, and the sandstone to hard, vitreous quartzite. These beds are probably Cambrian.

The metamorphism is apparently due to the intrusion into these sediments of masses of a granitic rock composed essentially of quartz and orthoclase, a type for which Spurr has proposed the name alaskite. This rock is well exposed on Columbia Mountain and makes up a large part of Vindicator Mountain. Smaller areas occur in the vicinity of Banner Mountain. Most of the alaskite contains a very little black mica and some plagioclase. In most exposures the mica is decomposed and scarcely noticeable, but northeast of the summit of Vindicator Mountain the alaskite mass grades into a biotite granite.

The alaskite was probably intruded at about the close of Jurassic time. It is certain that this event was followed by a long interval during which the region was eroded to the surface of moderate relief subsequently covered by the irruption of Tertiary lavas.

The sequence of Tertiary eruptions as exemplified by the rocks of the Goldfield district is given in the following list, the oldest rocks being at the bottom. To prevent confusion between rocks of like petrographic character erupted at different periods, recurrent kinds are distinguished by local geographic terms derived from places at or near which the corresponding rocks may be seen.

a The word domal (from the Isatin domus, a house) which means "belonging to a house" was originally an astrological term, but was Iater applied to the roof-like planes of certain crystal forms. It has unfortunately slipped into some currency in geologic literature as a substitute for domical, which is the correct adjective in reference to a dome and is analogous to conical, spherical, and cubical. 


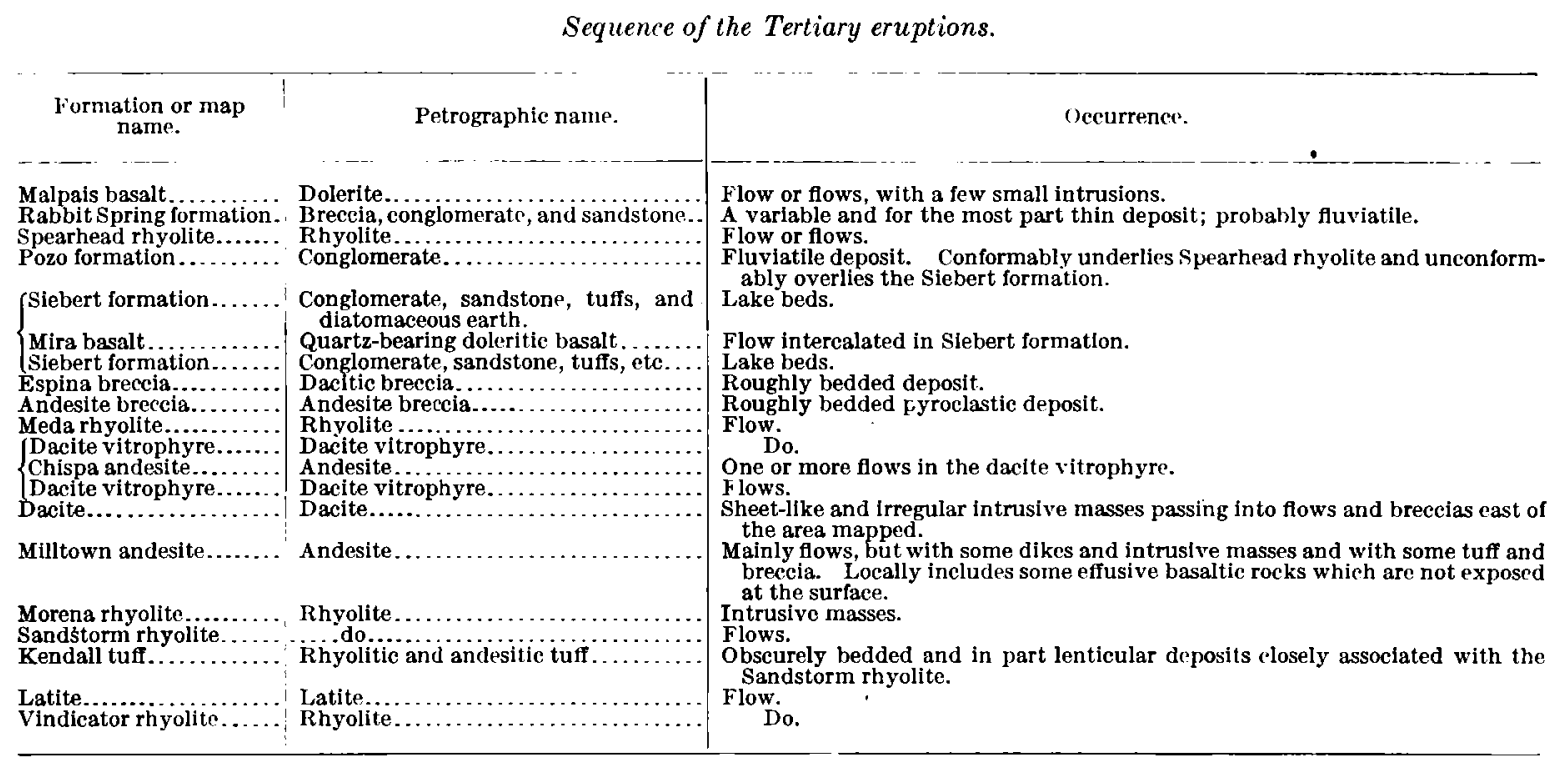

A few dikes of uncertain position in the sequence are not included in the foregoing list.

The Vindicator rhyolite rests on Cambrian sediments and alaskite on the flanks of Vindicator Mountain and on the summit of Columbia Mountain. Much of it is greatly altered and contains abundant alunite.

The latite, as may be seen from Plate II, occupies an area a little over 2 miles (3.2 kilometers) in diameter in the center of the district, and a smaller area south of Columbia. Its characteristic features may be well seen in the vicinity of McLaughlin's well, on Banner Mountain, and on the southern edge of the town of Columbia. The rock, nowhere fresh, is normally dull purplish or greenish gray. A spotted or mottled appearance, due to flow brecciation, is rather characteristic and is well shown on a small hill half a mile north of the summit of Banner Mountain. The freshest obtainable specimens of the latite show phenocrysts of feldspar, hornblende, and mica in a compact, streaky groundmass that was evidently once a glass with wellmarked flowage lines. As a rule, the latite, when it has not been subjected to the intense local alteration connected with ore deposition, may be distinguished from the later andesitic rocks by the absence of fresh phenocrysts and the peculiar streakiness of its groundmass, which resembles the groundmass of a rhyolite rather than that of most andesites.

The rock is a flow resting generally upon a clean and rather uneven surface of alaskite and Paleozoic sediments, although on Vindicator Mountain it rests in part on the oldest rhyolite. Its thickness is not known, but is clearly variable, as on Columbia Mountain the succeeding rhyolite rests directly upon the alaskite. The maximum thickness is tentatively estimated at 300 feet (91 meters); it may be considerably more.

Overlying the latite, or resting on the pre-Tertiary rocks where the latite is absent, is a series of thin, glassy rhyolite flows which is best developed in the rounded white hills northwest of Columbia Mountain. This, the Sandstorm rhyolite, is closely associated with pale greenish tuffs (Kendall tuff) of mingled latitic and rhyolitic character and is cut by masses of intrusive Morena rhyolite. The effusive rhyolite is usually nearly white, has conspicuous flow lamination, and weathers in thin, shelly flakes. This is the rock of the Sandstorm mine and of the hills lying west of the road from the mine to Columbia. It all shows some devitrification and silicification, particularly in the vicinity of the ore deposits. Certain varieties or portions of this rhyolite acquired by flowage a very thin lamination, which gives the rock when somewhat weathered a deceptive resemblance to indurated clay shale. The rhyolite appears to have been thickest in the vicinity of Columbia Mountain and to thin out to the southeast. None of it has been found southeast of McLaughlin's well. 
The Kendall tuff associated with these early rhyolitic eruptions may be best examined along the southwest base of Columbia Mountain and directly west of the Kendall mine. Underground it is exposed in the west workings of the 100-foot level of this mine.

The intrusive or Morena rhyolite that forms Morena Ridge extends north from the summit of Columbia Mountain to the Adams mine and cuts the shaly Sandstorm rhyolite at the Conqueror mine.

After the eruptions of the earlier rhyolites the region was covered with successive flows of andesite, accompanied by subordinate layers of andesitic tuff. The products of these eruptions, the Milltown andesite, constitute the most extensive formation in the district. (See Pl. II.) The total thickness of this deposit, as of most of the other volcanic formations in this district, can not be determined, owing to the slight deformation of the rocks, their poor exposures, the comparatively slight topographic relief, and the absence of persistent datum planes, such as may usually be found in stratified rocks. It probably lies between 600 and 800 feet (183 and 244 meters).

The dacite, whose eruption followed the andesitic period, is in many respects the most interesting rock in the district and is very important from an economic point of view. It occupies, as may be seen by reference to Plate II, a considerable area east of Goldfield and Columbia and is the principal country rock of the larger mines. This mass appears to be an intrusive sheet about 700 feet (213 meters) in maximum thickness, but in most places much thinner.

A larger body of dacite extends southward from Tognoni Springs and forms some of the high hills just east of the mapped portion of the district. This body, as may be seen from Plate II, makes up a large part of Preble Mountain, where it is probably intrusive into the Milltown andesite. East of the area mapped, however, the dacite is undoubtedly effusive and is associated with volcanic breccia. Smaller masses of dacite occur southeast of Black Butte and in the central part of the district.

Mineralogically and chemically the dacite at Goldfield is merely a quartz-bearing andesite and is in no way similar to the more siliceous rocks called dacite by Spurr in his report on the Tonopah district. ${ }^{a}$

Contemporaneously with, or shortly after, the dacite intrusion a rock classed as dacite vitrophyre was erupted as a series of flows and is now extensively exposed in the low hills in the southeast corner of the district. This rock is in most places a porous light-gray or greenish rock with abundant glistening scales of black mica and phenocrysts of fresh plagioclase. The dacite vitrophyre is associated with one or more intercalated flows of andesite (Chispa andesite). The eruption of the dacite vitrophyre was followed by a flow of rhyolite (Meda rhyolite) and by eruptions of andesitic breccia.

After these eruptions the region was covered by an extensive body of fresh water in which were laid down 1,000 feet (305 meters) or more of bedded conglomerates, tuffs, tuffaceous sands, pumiceous ash, and diatomaceous earth. These deposits cover a large part of the district, particularly in its outskirts. They underlie the town of Goldfield and stretch both northward and southward beyond the limits of the area studied. They also extend beneath Malpais Mesa southwest of town and are well exposed in the steep bluffs of Pozo Canyon. The beds here dip generally westward at angles ranging from $25^{\circ}$ to $30^{\circ}$.

As dacite vitrophyre and associated flows are present beneath the lake beds in only a small part of the district, and as the formation of the lake indicates some change in the configuration of the region, there is at least a suggestion of erosion between these eruptions and the lacustrine condition. Volcanism continued active during the existence of the lake, as is shown by the prevailingly volcanic nature of the sediments and the occurrence within them of a thick flow of quartz-bearing basalt (Mira basalt) and thin flows of glassy rhyolite. The Mira basalt, as shown by wells, underlies the southwestern part of Goldfield and is exposed on the automobile road to the Bullfrog district.

a Spurr's reasons for using the name dacite for rocks which strietly should receive other names are given in Geology of Tonopah mining district, Nevala: Prof. Paper (.) S. Geol. Survey No. 42, 1905, p. 59, footnote. 
In the eastern part of the district, northeast of Preble Mountain, are some bedded breccias and tuffs from 200 to 300 feet (61 to 91 meters) in present thickness. They rest upon dacite and andesite and are made up largely of fragments of these rocks, particularly of dacite mingled with abundant fragments of volcanic glass and some sandy tuffs. These beds, the Espina breccia, are possibly of the same age as the lake beds just described.

The dacite vitrophyre is cut by dikes of andesite. Whether these were erupted before, during, or after the lacustrine episode is not determinable.

Lacustrine conditions were ended by uplift of the region, the domical structure being then initiated. After the lake beds had been beveled by erosion and entirely swept away from the central part of the district eruptions of rhyolite lavas again began.

The latest rhyolite, called the Spearhead rhyolite, is a light-pink or pale-green rock, rather porous and containing abundant pumiceous fragments. It comprises two flows about 100 feet (30 meters) in total maximum thickness, which are exposed in the bluffs southwest of Goldfield. It is this rock that is quarried for building stone at Rabbit Spring. The rhyolite is in some places overlain by a few feet of unconsolidated tuffaceous sand and volcanic gravel, called the Rabbit Spring formation.

Finally, the volcanic history of the region was brought to a close by the eruption of one or more flows of olivine basalt. This is the dark rock that is conspicuous as the capping of Malpais Mesa southwest of town, and has accordingly been given the local designation of the Malpais basalt. It also forms the summit of Myers Mountain, Blackcap Mountain, and of several hills south and east of the area mapped. The larger areas of this rock represent remnants of flows which rest upon a nearly horizontal surface of older rocks; but some smaller masses, such as that shown on the east slope of Vindicator Mountain, are intrusive and may fill orifices through which the basalt reached the surface to spread out as flows.

The eruption of the Malpais basalt was followed by a period of erosion which, varied by slight deformations of the rocks, has continued to the present.

There is no paleontological evidence upon which to assign the Tertiary formations at Goldfield to the recognized series of that system. For reasons later presented the prelacustrine volcanic rocks are provisionally regarded as Eocene, the lacustrine formations as Miocene, and the postlacustrine formations as Pliocene.

The sulphide ores of the Goldfield district are of complex mineralogical character, native gold and pyrite being accompanied by minerals containing copper, silver, antimony, arsenic, bismuth, tellurium, and other elements. In some ores the gold occurs free in fine particles, which as a rule are so closely crowded together in the characteristic flinty quartz gangue as to form yellow bands or blotches. The associated minerals are pyrite, marcasite, bismuthinite, a reddish gray cupriferous mineral which appears to correspond more nearly to famatinite than to any other known species, and a new cupric sulphantimonite, which has been named goldfieldite. A concentric crustification is highly characteristic of the richest ores, fragments of silicified, alunitized, and pyritized rock being covered by shells of gold and sulphides.

The most notable features of these ore bodies are their remarkable richness and their equally remarkable irregularity. The ores are almost without exception associated with craggy outcrops of silicified volcanic rock, although only a very small proportion of these outcrops, which are extraordinarily numerous and constitute the most striking superficial features of the district, have been found productive. Associated with the silicification other processes of locally intense alteration, especially the formation of alunite, have also been active, producing in many cases a softening of the rock affected, and thus serving to accentuate the silicified portions under the selective action of erosion. The deposits have formed along izones of fissuring, which for the most part are very irregular in trend, are rarely traceable in any one direction for more than half a mile, and are not planes of notable faulting. Branching and intersection are very common. Many of the outcrops show no linear character, being mere irregular knobs of siliceous and alunitic material. Some of these probably represent intense alteration at the point of intersection of two or more inconspicuous approximately vertical fissures. Others 
are erosion remnants of nearly horizontal silicified zones and, as in the case of Black Butte, merely cap the hills whose summits they form.

The most important ore bodies thus far found are in dacite, although some small, very rich pay shoots have been discovered in the Milltown andesite.

Oxidized ores have supplied a large part of the gold produced during the first two or three years of exploitation, and in some mines, particularly the Sandstorm and Kendall, which are in rhyolite, no sulphide ores are as yet known. As a rule the oxidized ore is a soft, shattered, more or less earthy material, usually stained brown by oxide of iron. Fragments of rusty porous quartz are mingled with kaolin, alunite, gypsum, alum, oxide of iron, and various earthy mixtures of no definite mineral composition. Some of the rich ore, as in the Sandstorm mine, is a nearly white, impure kaolin, gritty from the presence of minute crystals or grains of quartz, and containing all through it abundant specks of free gold. Barite, in crystals up to an inch (25 millimeters) in length, is abundant in this ore. In the January and Combination mines some of the most characteristic rich ore consists of porous rusty quartz (silicified dacite), in which the pores and crevices are partly filled with yellow, earthy limonite and tiny pearly scales of bismite, the oxide of bismuth. In some specimens these scales form pseudomorphs after bismuthinite. They are usually a sign of rich ore, but are occasionally found in lowgrade or barren material. In the mines at Black Butte the richest oxidized ore usually shows little greenish-yellow specks of a ferric tellurite, either emmonsite or durdenite, and tellurite, the oxide of tellurium, was noted in a partly oxidized telluride ore from the Goldfield-Belmont mine near Black Butte. Melanterite (hydrous ferrous sulphate), in some cases mixed with a very little chalcanthite (hydrous copper sulphate), occurs in the partly oxidized ore of the Combination and Florence mines.

The valuable constituent of the oxidized ores is native gold. Native silver or halogen compounds of silver are not common.

The time of deposition of the ores is not definitely known, but was probably Pliocene. They were deposited from acidified solutions and the deposits now exposed are believed to have been at no time covered by more than 1,000 feet (305 meters) of rock. 


\section{CHAPTER III.}

\section{DESCRIPTION OF THE PRE-TERTIARY ROCKS.}

\section{CAMBRIAN SHALE.}

The oldest rocks exposed in the Goldfield district are certain dark, fine-grained, and thinbedded sediments forming parts of Columbia and Vindicator mountains. Those on Columbia Mountain are most conspicuously displayed on the southwest slope, appearing as dark patches which, by their contrast with the light-hued alaskite and rhyolite, constitute a striking feature of the hill as seen from Goldfield or Columbia. In Plate V, $A$, which is a view of Columbia Mountain from a point between the two towns, this difference in shade is much less evident than in the actual view.

The individual beds are thin, most of them less than 4 inches thick. The material is prevailingly aphanitic and of a dense flinty texture. The color is gray, so dark as to appear nearly black when seen in mass. The microscope shows that these beds are now composed of a fine crystalline aggregate of quartz containing abundant opaque black microscopic particles, which are probably carbonaceous, and some minute crystals of pyrite. It is the presence of these inclusions that gives the rock its dark color. Some specimens show tiny grains and veinlets of a colorless anhedral mineral which has not been definitely determined, but which has the general optical characteristics of zoisite.

This is the rock referred to by Spurr ${ }^{a}$ as "jasperoid" and regarded by him as probably a silicified limestone. While such a derivation is not impossible it is thought more probable that the rock was originally a siliceous shale containing considerable organic matter and probably some calcite. On the south slope of Columbia Mountain these dark flinty shales are interbedded with a few thin layers of quartzite.

The shales occur in comparatively small masses which have been intruded by alaskite. The original terrane of which they once formed a part has been greatly disrupted by the act of intrusion, and it is doubtful whether any extensive remnants remain beneath the Tertiary volcanic rocks of the Goldfield district. The visible bodies of shale in Columbia and Vindicator mountains probably rest upon alaskite in intrusive contact. Their internal structure therefore has little bearing upon the present tectonic features of the region. It is sufficient to say that the beds have been greatly disturbed by the alaskite intrusion. Those on the west slope of Vindicator Mountain have a general strike of N. $20^{\circ} \mathrm{W}$. and dip west at an angle of $75^{\circ}$. Whether this attitude represents folding prior to the granitic invasion there is no means of telling.

No fossils have been found in these shales and the only local clue to their age is the fact that they constitute a part of the eroded floor upon which the Tertiary rocks accumulated. The studies of H. W. Turner, ${ }^{b}$ J. E. Spurr, ${ }^{c}$ and S. H. Ball ${ }^{d}$ have shown, however, that north, west, and south of the Goldfield district are extensive areas of sedimentary rocks referable to the Cambrian period. These rocks are represented in the Southern Klondike district, 14 miles (22.5 kilometers) north of Goldfield; in the Silver Peak Range, of which Montezuma Peak, 7 miles (11 kilometers) west of Goldfield, is a spur; and in some hills just east of the halfway station, 6 miles (9.6 kilometers) south of Goldfield, on the stage road to Lida. Cambrian fossils

a Geology of the Goldfield district, Nevada: Bull. U. S. Geol. Survey No. 225, 1904, p. 119. The ores of Goldfield, Nevada: Bull. U. S. Geol. Survey No. 260, 1905, p. 133 .

$b$ Silver Peak folio (unpublished).

c Descriptive geology of Nevada south of the forticth parallel: Bull. L. S. Geol. Survey No. 208, 2d ed., 1905, pp. 184-185.

d A geologic reconnaissance in southwestern Nevada and eastern California: Bull. $\mathcal{L}$. S. Geol. Survey No. 308, 1907. 


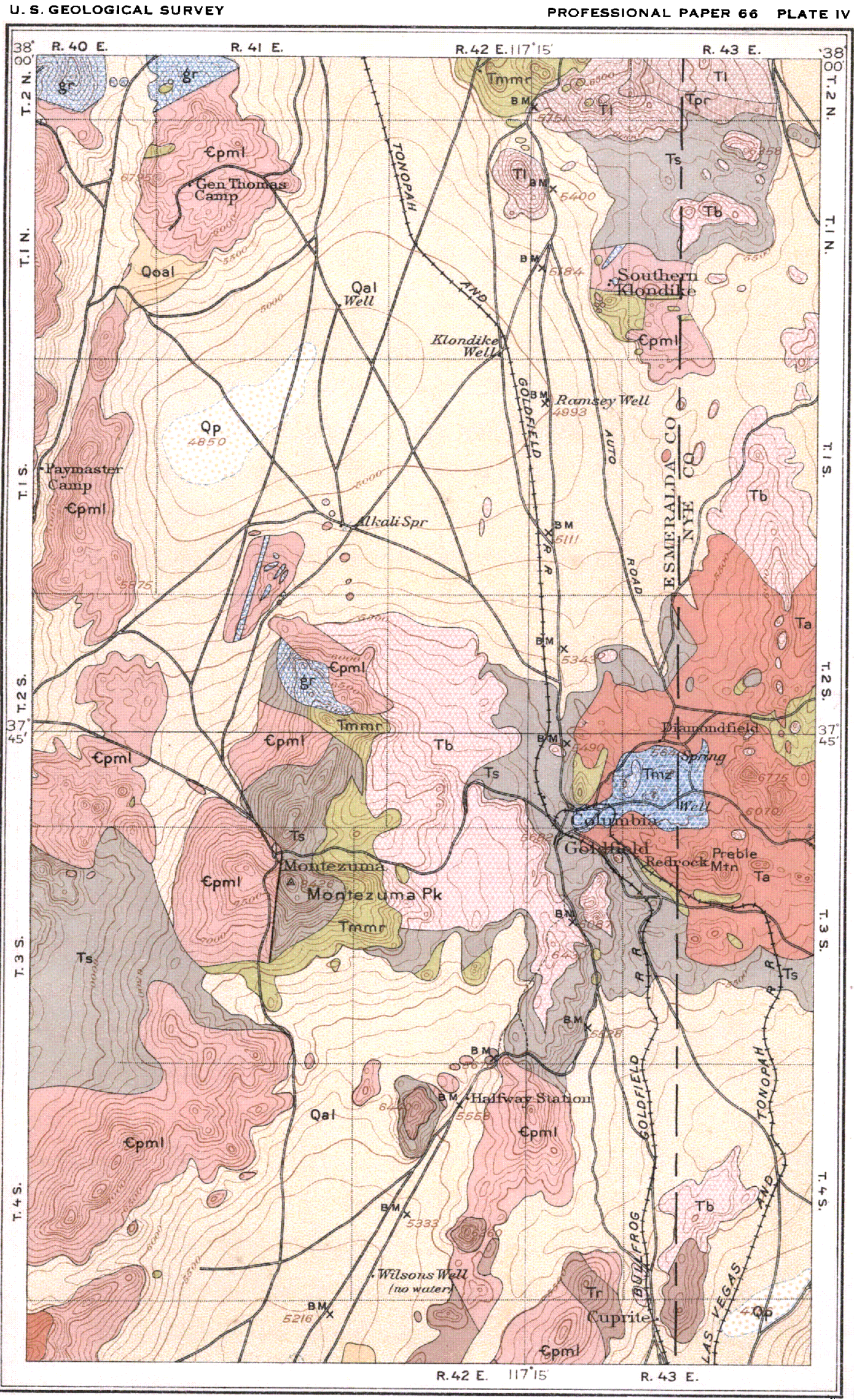

GEOLOGIC RECONNAISSANCE MAP OF THE REGION ADJACENT TO GOLDFIELD After S.HBall

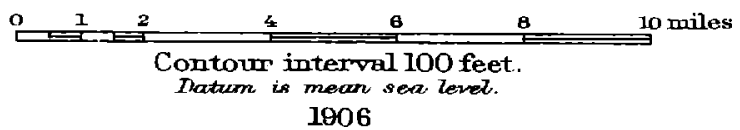

LEGEND SEDIMENTARY ROCKS

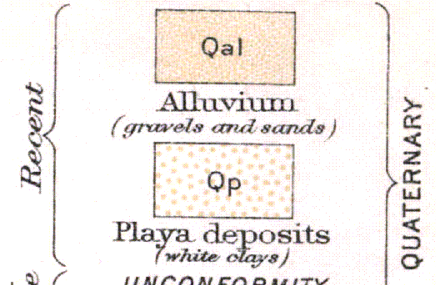

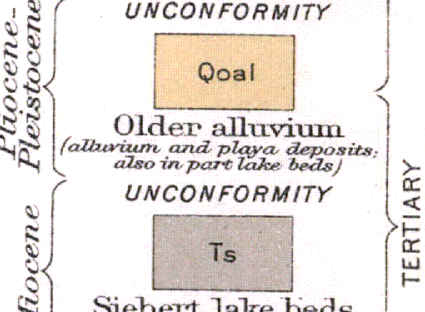

Siebert lake beds glomerate, und orays) UNCONFORMITY

Epml $\frac{z}{\frac{2}{a}}$

- Prospect Mountain Timestone

dark-gray, fine-grained U IGNEOUS ROCKS

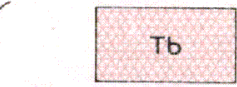

Basalt and basic andesite
(flows, oones, and dikes)

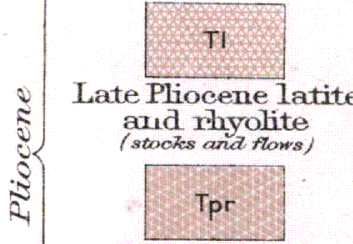

Middle Pliocene rhyolite

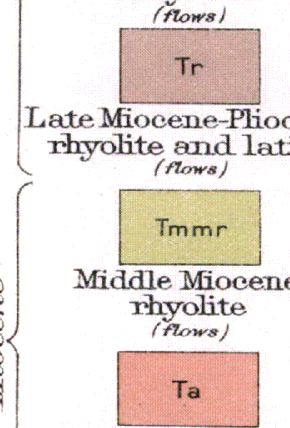

Miocene andesite (intrusive, masses

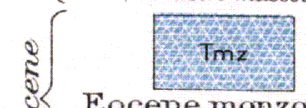

Es Ecene monzonite i porphyry and biotite andesite

$\left.\begin{array}{c}80 \\ \text { Granite,quartz } \\ \text { monzonite, and } \\ \text { syenite } \\ \text { (batholith and athes) }\end{array}\right\}$

\section{Fanlt}



have been found at Silver Peak, ${ }^{a}$ at Lida, ${ }^{b}$ near Cuprite ${ }^{c}$ (about 16 miles (25.5 kilometers) south of Goldfield), and at a locality 4 miles (6.5 kilometers) west-northwest of Montezuma Peak. $^{d}$ These Cambrian rocks comprise, according to Ball, ${ }^{c}$ fine-grained dark limestone, shale, and quartzite, the shale and limestone in the Silver Peak Range being interbedded and grading one into the other. As shown in Plate IV, which is compiled chiefly from the geologic map (Pl. I) accompanying Ball's report, the situation of Goldfield with reference to the areas of Cambrian rocks which partly encircle the district is such as to render it reasonably certain that the metamorphosed beds of Columbia and Vindicator mountains are also Cambrian. They are regarded as probably metamorphosed remnants of the shaly beds belonging to that period as represented in the Silver Peak Range and elsewhere in this general region.

\section{ALASKITE AND GRANITE.}

DEFINITION.

The name alaskite was proposed by Spurr $^{f}$ in 1900 to designate the group of holocrystalline quartz and alkali-feldspar rocks to which the name aplite had previously been rather loosely applied by most petrographers. Aplite, however, had come into wide use as a textural term applied to rocks of many kinds, usually occurring as dikes, and the name no longer had any precise mineralogical significance. Rocks of granitic texture and habit, consisting essentially of quartz with orthoclase or other alkali feldspar, have proved to be so widespread and to constitute such important masses, particularly in Nevada, that Spurr's proposal is amply justified. The name alaskite is already familiar to the mining men of that State.

By the addition of black mica alaskite may grade into biotite granite (granitite), a transition which, as will presently be shown, is exemplified in the Goldfield district. In a simple field classification the alaskite might properly be called granite, this name in such usage designating any quartz-feldspar rock of visible and even grain.

\section{DISTRIBUTION.}

As may be seen from the geologic map (Pl. II) the principal exposures of granitic rocks are in the central part of the district, especially in the vicinity of Columbia, Vindicator, and Banner mountains. Two exceptional occurrences deserve mention, although they are too small to appear on the map. One mass, discovered in a prospect on the north slope of Black Butte, is apparently a block a few feet in diameter, inclosed in andesite. The other mass, the visible portion of which is about 10 feet (3 meters) in diameter, occurs in the northwestern corner of the area mapped in Plate II, close to the small patch of rhyolite crossed by the line of the electric power company in section 15. This also may be a loose block, as it is surrounded by the sedimentary deposits belonging to the Siebert formation, which is probably some hundreds of feet thick at this point. This supposition seems more probable than the alternative one, that the mass is the top of a sharp alaskite hill projecting through the sediments. The transportation of large blocks of pre-Tertiary rock by the lava flows which inundated the district at several periods in its later geological history is not inherently improbable. Underground, alaskite has been cut in the Sandstorm mine on the 400 -foot level, about 290 feet (88 meters) southeast of the shaft.

\section{PETROGRAPIIY.}

The rock of the Columbia Mountain areas is evenly granular, consisting wholly, so far as can be seen without the microscope, of xenomorphic ${ }^{g}$ crystals of quartz and feldspar. The

a Walcott, C. D., Second contribution to the Cambrian faunas of North America: Bull. U. S. Geol. Survey No. 30,1886, p. 38.

b Spurr, J. E., Descriptive geology of Nevada south of the fortieth parallel: Bull. U. S. Geol. Survey No. 208, 2d ed., 1905, p. 185.

$c$ Ball, S. H., A geologic reconnaissance of southwestern Nevada and eastern California: Bull. U. S. Geol. Survey No. 3c8, 1907, p. 66.

$d$ Ball, S. H., op. cit., p. 57 .

e Op. cit., pp. $51,56,66$.

$f$ Classification of igneous rocks according to composition: Am. Geologist, vol. 25, 1900, pp. 229-232.

$a$ So far as practicable the textural terms applied to rocks in this report are those proposed or recommended by Cross, Iddings, Pirsson, and Washington in their paper "The texture of igneous rocks"' (Jour. Geology, vol. 14, 1906, pp. 692-707).

$79145-N o .66-09-3$ 
average diameter of the grains is rather less than 5 millimeters, although some of the feldspar crystals are occasionally larger and show a slight tendency toward porphyritic development. The prevailing color is light reddish, the tint being due to microscopic flecks of hematite in the feldspars. Some of the rock, however, is nearly white.

Thin sections show that over 95 per cent of the rock consists of quartz and microperthitic orthoclase. In addition to these minerals there is a little sodic oligoclase and small scattered plates of what was probably once biotite, but is now an aggregate of a faintly greenish mica with the birefringence of muscovite, and epidote. The feldspars are fairly fresh and the rock has undergone no appreciable dynamometamorphism since its original solidification. It is a typical alaskite.

The alaskite of Columbia Mountain is cut by occasional aplitic dikes of lighter color and finer grain than the mass of the rock. Such of these as were microscopically examined show essentially the same mineralogical composition as the alaskite, although oligoclase is perhaps a little more abundant in them.

The main mass of Vindicator Mountain is composed of a moderately coarse reddish alaskite, closely resembling that of Columbia Mountain and made up chiefly of quartz and orthoclase. In many places the rock is silicified or kaolinized. On the eastern slope of the mountain the alaskite passes gradually into biotite granite. This granite, which is well exposed along the road half a mile $(0.8$ kilometer) northeast of the summit of the mountain, shows a pronounced tendency toward a porphyritic texture, large rounded anhedral crystals of quartz and orthoclase being closely crowded in a rather fine-granular groundmass consisting of the same minerals with oligoclase and biotite. Some of the quartz crystals show the embayed outlines characteristic of granite porphyries. Much of the granite is considerably decomposed, the biotite being altered to chlorite and epidote. The latter mineral has also developed extensively in the feldspars. Titanite and zircon occur as accessory minerals.

A similar porphyritic variety, really a granite porphyry, is exposed in a shaft which goes through Vindicator rhyolite into the granite at a point half a mile (0.8 kilometer) east of the summit of Vindicator Mountain. This facies has a reddish tint from the abundant phenocrysts of red orthoclase. The other visible crystals are quartz and sinall dull greenish specks, evidently in part hornblende. The microsope shows large turbid crystals of microperthitic orthoclase, rounded and embayed ones of quartz, some automorphic green hornblende, abundant pseudomorphs of chlorite and epidote after biotite, some irregular grains of titanite, and a little plagioclase. There is also some pyrite. The orthoclase shows incipient sericitization.

The alaskite of Vindicator Mountain, particularly on the ridge south of the summit, contains numerous small dikelike masses of an aphanitic rock which has a much-altered and bleached appearance. The microscope shows a compact aggregate of quartz and other secondary minerals with no recognizable igneous characteristics. The masses may possibly represent rhyolitic dikes but their original character can only be surmised.

The rock of the various smaller areas shown on the geologic map (Pl. II) is in most cases too decomposed for satisfactory microscopical study. Most of them are composed of typical alaskite, with no mica. Biotitic facies occur, however, in the masses exposed north of Banner Mountain and east of Vindicator Mountain.

\section{GEOLOGIC RELATIONS.}

The alaskite and granite are intrusive into the Cambrian shale. (See Pl. V, B.) The intruding magma appears to have been highly viscous and some of the exposures on Columbia Mountain indicate that the alaskite had in some places solidified in contact with the shale before the general movement of the magma had ceased. In other words, the contact, while clearly of intrusive character, is accompanied by brecciation of both shale and alaskite. Whatever rocks may have overlain the shale at the time of intrusion were removed by erosion prior to the outbreak of Tertiary volcanism. The opening of that epoch found the Goldfield region eroded to a tract of low relief floored with alaskite and granite, within which lay a few residual patches of Cambrian shale. 


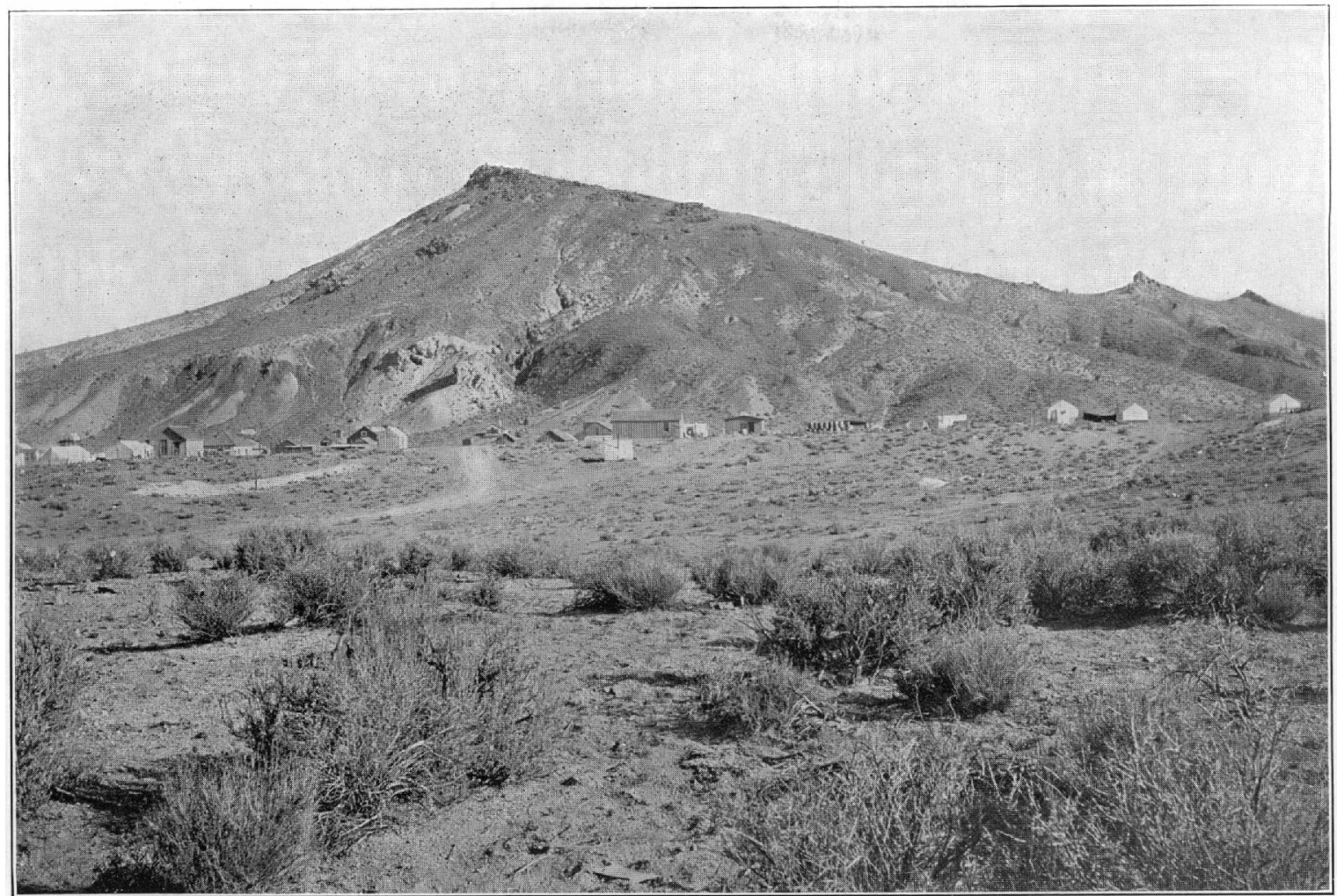

1. COLUMBIA MOUNTAIN; FROM THE SOUTH.

The top of the mountain is Vindicator rhyolite. The two sharp knobs at the right are silicified dacite. Dark areas near the base of the mountain are Cambrian shale.

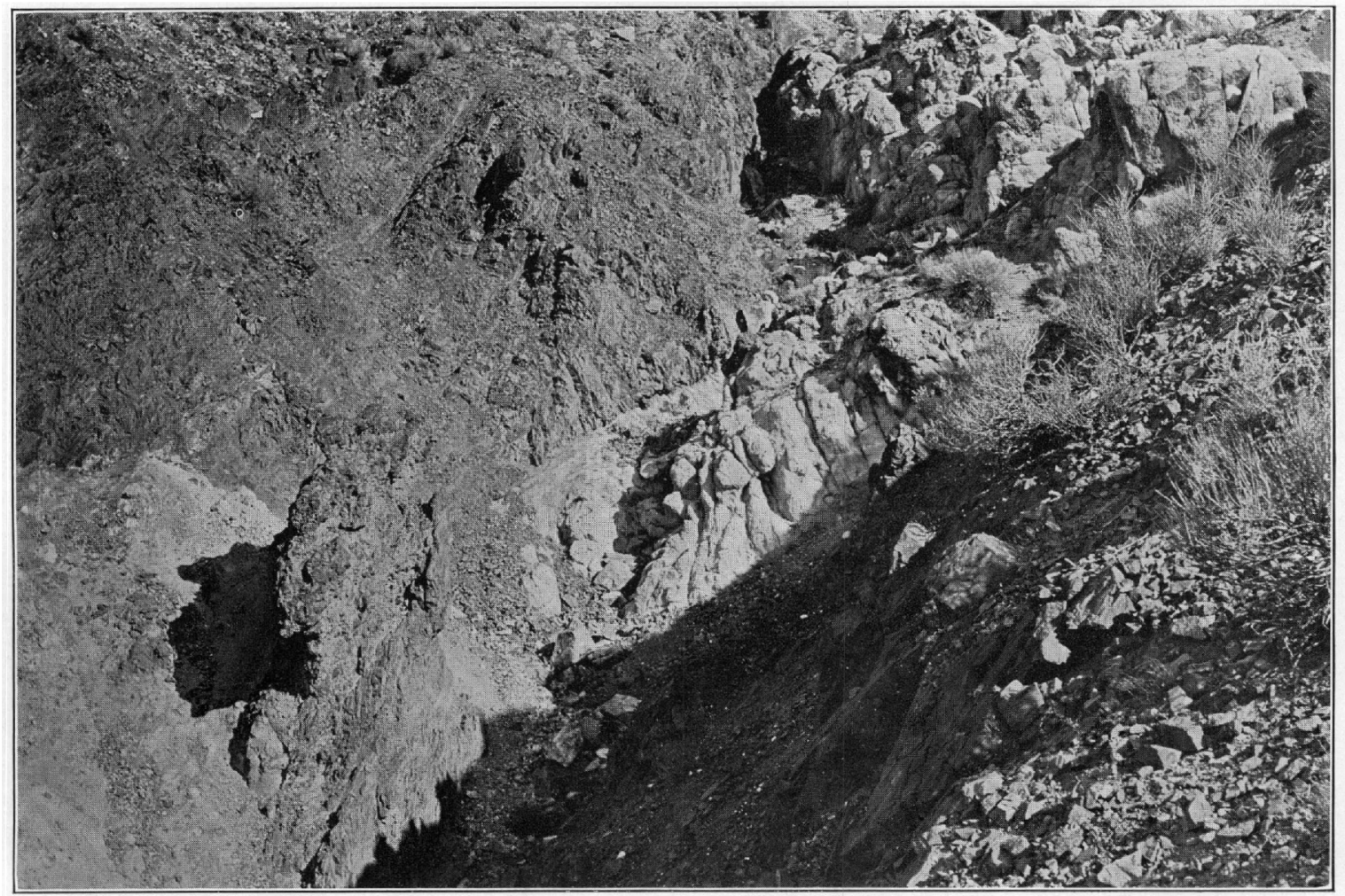

B. CAMBRIAN SHALE (DARK ROCK) CUT BY ALASKITE (LIGHT ROCK).

South slope of Columbia Mountain 

AGE.

The age of the alaskite and granite intrusion is not definitely determinable from local relations. These indicate merely that the rock is post-Cambrian and is older than the Tertiary eruptives. Clarence King ${ }^{a}$ many years ago advanced the opinion that the ranges of western Nevada and the Sierra Nevada are of contemporaneous origin and that their granitic intrusions are of early Cretaceous age. The post-Jurassic age of the Sierra Nevada batholith has long been well established, and the reconnaissances made by J. E. Spurr ${ }^{b}$ and S. H. Ball ${ }^{c}$ with the study of the Humboldt region by G. D. Louderback ${ }^{d}$ all support the view of King as to the contemporaneous age of the principal granitic intrusions of the Nevada ranges. The alaskite of the Goldfield district can therefore be considered with some confidence as belonging to the early Cretaceous period.

a U. S. Geol. Expl. 40th Par., vol. 1, 1878, pp. 733-754.

${ }^{b}$ Descriptive geology of Nevada south of the fortieth parallel: Bull. I. S. Geol. Survey No. 208, 2d ed., 1905 . See also, The ores of Goldfield, Nerada: Bull. U. S. Geol. Survey No. 260, 1905, p. 133.

c A geologic reconnaissance in southwestern Nevada and eastern California: Bull. U. S. Geol. Survey No. $308,1907$.

$d$ Basin Range structure of the Humboldt Region: Bull. Geol. Soc. America, vol. 15, 1904, p. 336. 


\section{CHAPTER IV.}

\section{DESCRIPTION OF THE PRELACUSTRINE TERTIARY IGNEOUS ROCKS.}

\section{INTRODUCTION.}

Definite assignment of all of the various lithologic units composing the volcanic series at Goldfield to the standard divisions of Tertiary time is not yet possible and may never be effected. The general post-Mesozoic age of the volcanic rocks of the Great Basin has, however, been so firmly established by von Richthofen, King, and later investigators as to be generally accepted as one of the basal facts of the geologic history of the region. In the vicinity of the fortieth parallel, King ${ }^{a}$ was able, by reference to the Miocene sediments of Pahute Lake and the Pliocene beds of Shoshone Lake, to determine the divisions of the Tertiary to which many of the lavas belong.

In the Tonopah district Spurr, ${ }^{b}$ by the help of the Siebert sediments, which he tentatively correlated with those of King's extinct Miocene Pahute Lake, was also able to reach some conclusions as to the age of the several eruptions.

The extent to which similar results are attainable in the Goldfield region will be fully discussed in a subsequent chapter. For the present it is enough to keep in mind the fact that a group of lake sediments, equivalent to and very probably once continuous with the Siebert tuff of Tonopah, occurs in the Goldfield district. They record a distinct lacustrine epoch initiated and terminated by deformation and erosion. It is thus possible to divide the Tertiary rocks of the district into three natural groups divided by conspicuous unconformity. These are: (1) the prelacustrine flows and intrusions, (2) the lake beds and associated volcanic rocks, and (3) the postlacustrine volcanic rocks. The correlation of these groups with the rocks of other districts and the discussion of their geologic chronology will be deferred until the rocks themselves have been described.

The prelacustrine rocks in the order of their eruption are: (1) the Vindicator rhyolite, (2) latite, (3) the Kendall tuff, (4) the Sandstorm rhyolite, (5) the Morena rhyolite, (6) the Milltown andesite, (7) dacite, (8) dacite vitrophyre and the Chispa andesite, (9) the Meda rhyolite, and (10) andesite breccia.

In the preliminary report ${ }^{c}$ on the district, written in advance of chemical and full petrographic study, the latite was called the "first or earlier andesite" and was made to include most of the altered rock now called Vindicator rhyolite.

In the present stage of the science of petrology the consistent treatment in an economic report of any varied eruptive series presents peculiar difficulties. The ordinary classification and nomenclature of igneous rocks which has grown up in the half century since Sorby applied the microscope to their study has the recognized defects of most structures built from old materials and added to at various times. It has become unsatisfactory both to the general geologist and to the petrologist. The modern quantitative system of classification, while logical, refined, and accurate, is adapted rather to the needs of the specialist than to those of the field geologist or engineer. On the other hand, simpler schemes for classifying rocks without the use of the microscope, such as that recently presented by Pirsson, ${ }^{d}$ are not adequate to express the facts developed in an investigation like the present, in which field observations have been supplemented by microscopical and chemical work. In view of these considerations the older petrographical classification, exemplified in the Elemente der Gesteinslehre and Mikroskopische

a U. S. Geol. Expl. 40th Par,, vol. 1, 1878

$b$ Geology of the Tonopah mining district, Nevada: Prof. Paper ¿. S. Geol. Survey No. 42, 1905

c Bull. U. S. Geol. Survey No. 303, 1907.

d Pirsson, L. V., Rocks and rock minerals. New York and London, 1908. 
Physiographie of Rosenbusch, has, nothwithstanding its defects, been generally followed in this report. In addition, the position in the quantitative system has been given of such unaltered rocks as have been chemically analyzed.

\section{VINDICATOR RHYOLITE.}

\section{GENERAL CHARACTER AND OCCURRENCE.}

The oldest member of the volcanic series derives its name from Vindicator Mountain and is most extensively exposed on the flanks of that peak. As may be seen from Plate II, the central pre-Tertiary mass of the mountain is surrounded by the rhyolite on all sides except the southeast, the exposure attaining a width of nearly half a mile on the north. A small mass of much-silicified rock, probably a remnant of the rhyolite, rests on the summit of the peak. What is supposed also to be a larger residual of the same flow caps Columbia Mountain.

The rock is nowhere fresh, and as a rule contains abundant alunite, the mineral being in many localities distinctly visible in freshly broken fragments of the rock as small pale-pink crystals. Much of the altered rhyolite is very hard and forms prominent outcrops, often with characteristic pitted surfaces, due to the solution and removal of the pseudomorphs of alunite after feldspar.

As the basal member of the Tertiary volcanic series the Vindicator rhyolite rests upon an undulating surface of alaskite and Cambrian shale. The character of the rock shows it to have been effusive. The base of the flow is well exposed half a mile northeast of the summit of Vindicator Mountain, where a nearly white altered rock may be seen lying upon a slightly rolling surface of biotite granite. The latter shows only slight superficial weathering and appears to have been swept clean of loose detritus before the first Tertiary eruptive. The basal portion of the flow contains many fragments of the underlying granite as well as of the dark Cambrian shale. Considerable alteration has taken place in the volcanic rock near the contact, it being bleached to a delicate pale-green tint and in places intensely silicified. This silicification is related to a fairly regular system of fissures which strike about N. $30^{\circ} \mathrm{W}$. and dip northeast, giving a sheeted structure to the rhyolite. These fissures do not show in the underlying granite. The solutions which effected the silicification probably worked their way along the contact between the two rocks and ascended in the parallel fissures. The most intense alteration borders these cracks, which are in many places very narrow and were not themselves filled with quartz.

The rhyolite on the summit of Columbia Mountain was originally supposed to be part of the intrusive mass of Morena rhyolite which forms the ridge to the north. It is, however, distinctly a capping, and prospect shafts near its edge have shown it to rest on the Cambrian shale. At the north end of the oval cap (Pl. II) a small pit, open in 1905, exposed the base of the rhyolite, which is here separated from the shale by a foot or more of gravelly material containing fragments of alaskite and shale, evidently old surficial detritus. Petrographically the rock of the summit is identical with that on the west slope of Vindicator Mountain, near the Lucky Boys shaft. On the other hand, no very distinct contact has been found between the rhyolite capping Columbia Mountain and the somewhat similar Morena rhyolite to the northwest, which is known to be intrusive. 'The boundary as drawn on the geologic map (Pl. II) corresponds to an obscure line of separation which is admittedly unsatisfactory. Nevertheless the preponderance of evidence favors the view that the capping of the mountain is the Vindicator rhyolite which has been intruded on the west by the younger but locally similar Morena rhyolite. A close, irregular intrusive contact between two similar rhyolites might be difficult to recognize even were the surface swept clean of all detritus.

There are no exposures from which the thickness of the Vindicator rhyolite can be directly

measured. It is evidently far from uniform, as a glance at the map will show. The maximum thickness, as estimated from t'ie general relations and structure illustrated by sections $\mathbf{A}-\boldsymbol{\Lambda}^{\prime}$ and $\mathrm{D}-\mathrm{D}^{\prime}$, Plate VIII, is probably about 200 feet (61 meters). 


\section{PETROGRAPIIY.}

The weathered surfaces of the Vindicator rhyolite are generally some shade of light gray, although in places they are stained buff or brown by iron oxide. A pitted appearance, already referred to, is characteristic of the harder silicified outcrops. On fresh fracture the rock is white or light gray, usually with a faint pink tint due to the abundant alunite. Some varieties northeast of Vindicator Mountain are pale greenish gray. The rock is everywhere much altered, the only primary mineral recognizable, as a rule, being quartz in fairly abundant anhedral phenocrysts up to 5 millimeters in diameter.

Under the microscope the Vindicator rhyolite shows rounded and embayed phenocrysts of quartz and pseudomorphs of alunite after feldspar, presumably orthoclase. Some thin sections show alunite pseudomorphs also after phenocrysts whose outlines are suggestive of mica. The groundmass has the general structure characteristic of rhyolitic glasses, but has undergone complete devitrification and is now a fine-grained aggregate of quartz and alunite, accompanied in some varieties of the rock by smaller quantities of kaolinite. Diaspore has been found in some thin sections, and calcite occurs in a richly alunitic variety of the rhyolite from the east slope of Vindicator Mountain. The general texture of the rock as it appears under the microscope is shown in Plates XXVIII and XXXI.

A good place to study the alunitic alteration of the rhyolite is on the east shoulder of Vindicator Mountain, about a quarter of a mile from the summit. Some of the rock here is nearly white, mottled with spots and rings of pale-pink alunite. Some specimens also show minute, faint-blue specks which have not been identified with any mineral observed in thin section. A chemical analysis of this rhyolite (specimen G. 333) is given on page 183 in connection with a full discussion of the character of its alteration. The rock capping Columbia Mountain also illustrates particularly well the pseudomorphous development of alunite after feldspar. (See Pl. XXVIII.)

In the simple field classification suggested by Pirsson the Vindicator rhyolite would be called a felsite. The rock is too much altered to be assigned a place in the quantitative system.

\section{LATITE. $a$}

GENERAL CHARACTER AND OCCURRENCE.

The latite, as may be seen from Plate II, occupies the greater part of an area a little over 2 miles (3 kilometers) in diameter in the center of the district, and a smaller area south of Columbia. Its characteristic features may be well seen on Banner Mountain, in the vicinity of McLaughlin's well, and on the southern edge of the town of Columbia. This rock has not been found in a fresh condition. Its normal color is dull purplish or greenish gray. A spotted or mottled appearance, due to flow-brecciation, is rather characteristic and is well shown on a small hill half a mile ( 0.8 kilometer) north of the summit of Banner Mountain. The freshest obtainable specimens of the latite show phenocrysts of feldspar, hornblende, and mica in a compact, streaky groundmass that was evidently once a glass with well-marked flowage lines. All the phenocrysts have the dullness that indicates more or less thorough alteration, and the original glassy base is now devitrified. As a rule, the latite, when it has not been subjected to the intense local alteration connected with ore deposition, may be distinguished from the later andesitic rocks by the absence of fresh phenocrysts, and especially by the peculiar streakiness of its groundmass, which resembles the groundmass of a rhyolite rather than that of most andesites. Even intense alteration does not always obliterate this feature. The much-altered latite has frequently been mistaken for dacite, and probably no amount of experience will insure even a keen observer against occasional errors of this kind. The altered latite may contain blebs of secondary quartz, but these are usually of lighter tint and less homogeneous than the primary quartz of the dacite. Little vugs, with projecting quartz crystals, are rather characteristic of the alunitized and pyritized latite. 
The rock is apparently a flow resting upon a rather uneven surface of alaskite, Cambrian sediments, and Vindicator rhyolite. Its thickness is not known, but is probably very variable, as on Columbia Mountain the succeeding rhyolite rests directly upon the alaskite. The maximum thickness is tentatively estimated at 300 feet (91 meters). Although the latite is prevailingly massive or exhibits only moderate flow brecciation, a west crosscut on the 612 -foot level of the Combination-Fraction shaft has exposed some altered pyroclastic rock which appears to belong to this formation.

The latite underlies a large part of the district, but is exposed only where deformation followed by extensive erosion has stripped away the rocks that once covered it. As might be expected from its place in the local geologic column and the general domical structure of the district, the rork occurs in the central part of the area studied, encircling the exposed masses of alaskite, Cambrian shale, and Vindicator rhyolite. Banner Mountain lies almost in the center of the largest expanse of the latite. This tract, while roughly circular, has a very irregular outline expressive not only of the usual inequalities of erosion, but also of the nearly horizontal undulating contact between this rock and those that overlie it.

A smaller area of latite is exposed just south of the town of Columbia, and a very small exposure at the northwest end of the same town is worthy of mention, since it shows the latite overlain by the Sandstorm rhyolite.

When the district was studied in 1905 the presence of latite under the andesite south and southeast of Florence Hill could only be inferred. At present several shafts go through the andesite into the latite. The Yellow Tiger, situated a mile southeast of Milltown, went into latite at a depth of about 510 feet (155 meters), showing that this formation extends southward beneath the andesite for at least three-quarters of a mile (1.2 kilometers) from its nearest surface exposure. The developments of the past three years have proved, moreover, that the latite in general underlies the dacite of the Mohawk, and other important mines near Goldfield at a maximum depth of about 700 feet (213 meters).

The only part of the district where the base of the latite is visible is in the vicinity of Vindicator Mountain. The contact with the underlying rocks, however, is so poorly exposed and so obscured by alteration that no detailed observations on its original character are possible. The fact that the latite in some places, as on Banner Mountain, is in direct contact with the alaskite suggests that there may have been considerable erosion whereby the Vindicator rhyolite was in part removed prior to the latitic eruptions. On the other hand, the Vindicator rhyolite may never have covered all of the old alaskite surface. It is possible, moreover, that the juxtaposition of the latite and alaskite along the south slope of Vindicator Mountain may be due to a fault nearly parallel to and northwest of the one shown (Pl. II) half a mile northwest of Banner Mountain. While the relation of the rocks suggests such a fault the evidence for its existence is hardly sufficient to warrant placing it on the map.

In regard to the relations of the latite south of Columbia to the older rocks little definite information is available. The mass is overlapped on the west, south, and partly on the east by the younger Siebert formation, under which it is known to extend for over half a mile (0.8 kilometers) to the south. On the north it is in contact with Kendall tuff, the contact corresponding to a fault.

\section{PETROGRAPHY.}

The normal tint of the latite is dull gray with a suggestion of lilac or purple. Some varieties, however, are dull mottled green and where local alteration has been intense the rock may be yellow, pale pink, light green, or white. More or less alteration has invariably taken place, and none of the rock has the dark-gray color and glistening phenocrysts characteristic of the later andesitic and basaltic rocks of the region. Surfaces of fresh fracture show numerous small dull-white phenocrysts of feldspar, with much less conspicuous darker phenocrysts representing some altered femic mineral, in a dense finely streaked groundmass, which on close inspection reveals the pasty flow-texture frequently found in rhyolite, but not common in latitic or andesitic rocks. At many localities, particularly in the vicinity of McLaughlin's 
well and north of Banner Mountain, the rock is decidedly mottled, and close examination shows it to be a flow breccia in which the fragments are of the same general character as the matrix, although some slight difference in texture is sufficient to produce delicate color distinctions in weathering. In this respect also the rock resembles rhyolite.

Under the microscope the latite shows a vitrophyric texture, phenocrysts of plagioclase, biotite, and hornblende lying in a glassy groundmass which shows the characteristic wavy and curled flowage lines associated with this textural type. Apatite, magnetite, and zircon are accessory constituents.

The phenocrysts are never quite fresh. The plagioclase, which is andesine-labradorite with approximately the composition $\mathrm{Ab}_{1} \mathrm{An}_{1}$, is changed to quartz, alunite, calcite, sericite, and kaolinite. The relative proportions of these secondary minerals as well as the degree of alteration or replacement varies in different specimens, even in those from the same locality. Quartz is the most abundant mineral formed at the expense of the feldspars, although calcite is scarcely less common. Sericite is decidedly subordinate to quartz and calcite, and kaolinite is rather rare except with alunite in cases of special alteration in the vicinity of ore bodies. It is apt to be more abundant in the altered groundmass than in the phenocrysts. As a rule, the feldspar is only partly altered, a portion of the crystal being replaced by quartz or calcite or both, while another portion remains as limpid and fresh in appearance as in the younger basalts of the region. The replacement is usually sharp and complete, with no intervening stage or zone of turbidity in the feldspar as seen under the microscope. The alteration does not necessarily proceed from the periphery of a crystal toward its center. Many feldspar phenocrysts, especially those which originally contained glass inclusions, are changed to quartz and calcite in their central parts while still retaining an outer shell of fresh andesine.

Only a very few remnants of fresh biotite and no hornblende were found in the 40 to 50 specimens of this rock microscopically examined. The most characteristic change in the biotite is a bleaching, whereby the mineral becomes pale green or colorless and resembles muscovite in birefringence. This form of alteration is associated with the development of particles of magnetite and hematite, which in some pseudomorphs are so thickly crowded as to render them practically opaque and in others are gathered into a dark peripheral shell. This shell, defining the outline of the former phenocryst, is as a rule persistent and may remain when the rock has been wholly altered to a granular aggregate of quartz. The common alteration of biotite into chlorite interlaminated with lenses of epidote is also represented in some specimens.

The former presence of hornblende as an original constituent of the rock is indicated by pseudomorphs of quartz, calcite and iron oxides possessing the characteristic prismatic sections of that mineral. Most of these pseudomorphs, like those after biotite, are enveloped in dark shells of iron oxides. It is possible that some pyroxene may also have been present in the original rock, but no pseudomorphs definitely referable to this mineral have been detected.

The groundmass of the latite was originally glassy, containing only incipient crystal forms. In the rock of the small outcrop at the northwest end of Columbia the groundmass shows a faint spherulitic structure. Elsewhere it exhibits the ordinary flow banding of a pasty microlitic glass. Very little, if any, of this glass now remains. It has not only devitrified, or become crystalline, through lapse of time and through conditions of pressure and temperature favoring such molecular rearrangement, but has also been altered by the same agencies that have changed the phenocrysts to aggregates of secondary minerals. The boundary between endogenous devitrification and the processes that have altered the phenocrysts is not a sharp one. Simple devitrification, however, involves no essential change in the composition of the rock, whereas in the more pronounced phases of general alterations, such as have in some places changed the latite to an aggregate of quartz with very subordinate kaolinite and pyrite, there has been a notable change in the chemical constitution of the rock as well as in its mineralogical character.

The most abundant secondary mineral in the groundmass is quartz. Calcite also is common, while kaolinite and sericite are rather rare. Alunite is abundant in the vicinity of the 
ore deposits. Where the alteration has not been extreme, the groundmass shows little bunches of quartz and calcite interspersed through a faintly crystalline groundmass in which the constituent crystals are too minute for identification. Where alteration has been most thorough, this groundmass is transformed to a distinctly crystalline granular aggregate of quartz.

Owing to its generally altered condition the latite has not been subjected to complete chemical analysis. A partial examination by Dr. F. C. Sullivan, however, of a specimen collected 1 mile northwest of McLaughlin's well affords the following results:

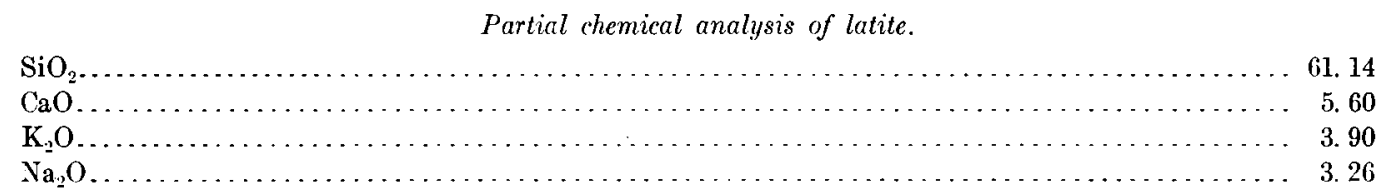

The specimen analyzed (G. 348) has a dull olive-gray tint and is fresher than most of the rock. It contains phenocrysts of andesine or labradorite $\left(A b_{1} A n_{1}\right)$ partly altered to calcite; of biotite changed to chlorite, quartz, epidote, and calcite; and of hornblende (and possibly augite) replaced by pseudomorphs of calcite, quartz, and magnetite. The groundmass is the usual obscurely crystalline aggregate resulting from the devitrification of a glassy base. The rock concains a few minute crystals of pyrite.

The partial analysis shows that it is a latite rather than an ordinary andesite, and the use of the special name is convenient to distinguish the rock from the andesites proper that occur higher in the volcanic series.

The general alteration which the latite has undergone, while probably broadly related to the economic mineralization of the district, is not always intimately associated with individual ore deposits, nor is it confined to those particular parts of the district where ore bodies are known to be present.

On the southern edge of the town of Columbia the latite has been altered to a white, porous chalky rock which has been quarried for building stone. Under the microscope this shows almost no trace of its original igneous texture, but is chiefly a very fine-grained aggregate of kaolin with some quartz, alunite, and sericite.

Certain phases of intense or local alteration of this and other rocks, in the immediate vicinity of the ores, are reserved for fuller treatment in a later chapter in connection with the description of the ore deposits.

\section{KENDALL TUFF.}

The Kendall tuff, which takes its name from the Kendall mine, is of uniform character and as a rule is easily distinguished from the much younger tuffaceous beds of the Siebert formation, with which it is in places in contact. As taken from mine workings where oxidation has not penetrated, the body of the tuff is rather dark gray and has an andesitic appearance. This gray matrix is flecked with irregular pale-green spots, usually less than half an inch in diameter, of a soft waxy material which sometimes contains small scales of biotite. When slightly weathered the tuff is a shade lighter in color and the green spots become yellowish. As exposed and quarried on the north edge of the town of Columbia, the tuff is light gray with a rather faint greenish mottling instead of the more distinct spots seen elsewhere. As a rule the tuff contains few visible rock fragments, but pebbles of alaskite, andesite, and rhyolite have been found in it and in some places are moderately abundant. Well-rounded bowlders of alaskite up to 6 inches ( 15 centimeters) in diameter were observed embedded in the tuff on the dump of the Winston lease shaft, on the Mohawk No. 1 claim, southeast of Columbia. Similar bowlders, as well as fragments of rhyolite, are common also at a depth of 213 feet (65 meters) in the tuff of the Gold Sovereign prospect, half a mile (0.8 kilometer) north of McLaughlin's well.

The largest area of the tuff associated with the Sandstorm rhyolite is that partly underlying the town of Columbia. Another body is inclosed in the rhyolite at the Kendall mine 
and some smaller included masses occur on the lower western slope of Columbia Mountain. Tuffaceous beds or layers are also found in some of the shafts sunk in the Sandstorm rhyolite.

The microscope shows the tuff to be everywhere more or less altered and to consist of fragments of glassy rhyclite and of latite or andesite. The rock is apparently of mixed derivation and can not properly be called either a rhyolite or a latite tuff. On account of the alteration it is not possible to identify the latitic fragments with certainty, but it is probable that they were derived from the latite of the district. The rhyolitic eruptions presumably broke through this rock at certain points with explosive violence and comminuted fragments of the latite were thus mingled with rhyolitic particles. The finding of occasional fragments of alaskite in the tuff lends support to this view. Many of the rhyolite particles in the tuff contain abundant quartz phenocrysts, and as such phenocrysts are not common in the Sandstorm rhyolite these particles may also have been derived from an older rock, probably from the Vindicator rhyolite. On the other hand, the tuff also contains angular fragments and blocks up to a foot ( 0.3 meter) or more in diameter of the Sandstorm rhyolite, as may be seen in the Black Rock shaft about 500 feet (152 meters) west of the Conqueror mine.

The rhyolite-latite tuff is very closely associated with the Sandstorm rhyolite, next to be described, and is to be regarded as a practically contemporaneous deposit. It is apparently not a continuous formation, but probably accumulated in local basins at more than one period during the rhyolitic eruptions. The greater part of the tuff, however, is near or at the base of the rhyolite, and for this reason is first described.

The large area of tuff near Columbia is considered to occupy an approximately basal position with reference to the Sandstorm rhyolite, although were this the only body of the Kendall tuff it would be difficult to say whether it overlies or underlies the rhyolite to the north of it. It is possible that the contact between the two may in part be due to faulting. The two small patches farther north, on the west slope of Columbia Mountain, appear to be small lenticular masses in the rhyolite. The body of tuff at the Kendall mine may also be a lens with Sandstorm rhyolite beneath it as well as above it but the base was not exposed in the mine workings at the time of visit. (See fig. 29, p. 237.) The main Sandstorm shaft, not accessible at the time of visit, is reported to have gone from Sandstorm rhyolite into Kendall tuff at a depth of 200 feet (61 meters) and to have continued in this rock for another 200 feet to the bottom.

A shaft close to the road, about 500 feet (152 meters) east of the Sandstorm shafts, penetrates 100 feet ( 30 meters) of glassy banded rhyolite and exposes 25 feet ( 7.5 meters) of tuff at the bottom. The tuff is overlain nearly horizontally by the rhyolite but its base is not reached by the shaft.

The Black Rock shaft, 500 feet west of the Conqueror mine, exhibits a similar relation of rhyolite to tuff. The bottom of this shaft, which was about 100 feet (30 meters) deep at the time of visit, is in rhyolite-latite tuff, here containing large angular blocks of rhyolite. The tuff is overlain by about 80 feet (24 meters) of glassy spherulitic rhyolite and rhyolite flow breccia, including layers of the shalelike variety of the Sandstorm rhyolite. The rocks are devitrified and altered and the planes separating tuff from flow breccia and volcanic glass are indistinct, much of the glassy rhyolite having a clastic, sedimentary aspect.

At the Gold Sovereign mine, already referred to, the shaft after going through a slight thickness of shaly Sandstorm rhyolite continued for 200 feet (61 meters) in greenish bedded tuffs which on account of their lithologic character and stratigraphic position are correlated with the Kendall tuff. The material here contains abundant fragments of alaskite and rhyolite with small particles of Cambrian shale in its lower part and rests on an uneven surface of granite or alask te. As exposed in a crosscut east of the shaft on the 213-foot level the contact, which apparent $y$ is not a fault, dips to the west at about $45^{\circ}$. The relations of the tuff to the latite and Vin icator rhyolite in this locality are not fully understood. While the oldest rhyolite appear $:$, in this part of the district, to have never covered or to have been eroded away from the granit 3 before the eruption of the latite, it is difficult to account for the local absence of the latter fo mation at the Gold Sovereign mine, particularly as the latite is the prevailing rock for more han a mile (1.6 kilometer) north of McLaughlin's well (see Pl. II) and prior to 
the sinking of the shaft was supposed to continue under the small residual areas of Sandstorm rhyolite. It seems necessary to conclude: (1) That revision of the mapping would show some Kendall tuff outcropping around the edges of the small patches of Sandstorm rhyolite, a fact easy to overlook on account of the poor exposures and the general similarity of the weathered tuff to some varieties of the latite. Such overlooked areas can not be large, inasmuch as typical latite occurs north of McLaughlin's well and both east- and north of Banner Mountain. (2) That the old granitic surface is locally irregular and was in part exposed after the eruption of the latite and before the deposition of the Kendall tuff, the latter being laid down on a surface that was also diversified by hillocks and hollows.

Excellent exposures of the Kendall tuff may be studied in the railway cuts along the south slope of Columbia Mountain. The beds here have a dip of $45^{\circ} \mathrm{SW}$.

\section{SANDSTORM RHYOLITE.}

general Character aNd OCCURRENCE.

Overlying the latite and most of the Kendall tuff or, in places where the earlier volcanics are absent, resting on the pre-Tertiary rocks, are some thin, originally glassy rhyolite flows which attain their greatest development in the rounded white hills northwest of Columbia Mountain. This effusive rhyolite is usually nearly white, shows conspicuous flow lamination, and weathers in thin, shelly flakes. It is the rock of the Sandstorm mine, whence its name, and of the hills lying west of the road from the mine to Columbia. It all shows some devitrification and silicification, particularly in the vicinity of the ore deposits. Certain varieties or portions of this rhyolite acquired by flowage a very thin lamination, causing the rock when somewhat weathered to closely resemble indurated clay shale. This appearance is exceedingly deceptive, as may be seen at the Conqueror (Tonopah Club) mine. The town of Diamondfield is partly underlain by this shalelike rhyolite, and small residual patches of a similar material are scattered over the surface of the latite northeast of Banner Mountain. (See Pl. II.) The rhyolite appears to have been thickest in the vicinity of Columbia Mountain and to thin out to the southeast. None of it has been found southeast of McLaughlin's well.

The largest area of the Sandstorm rhyolite is that extending from the vicinity of the town of Columbia northward to the south base of Kendall Mountain. Another body, probably connected with the Sandstorm mass under the intervening Milltown andesite (see Pl. II), contains the Adams and Tonopah Club mines, southeast of Kendall Mountain. The northwestern half of the roughly circular main area of latite is fringed with small patches of the Sandstorm rhyolite. This is for the most part the shaly variety and its outcrops are inconspicuous, the presence of the rock being indicated in most instances merely by the thin loose flakes, resembling gray shale, into which the rhyolite disintegrates on weathering.

A rather more resistant variety forms some low hills about half a mile southeast of Black Butte, and a few small residual outliers, chiefly of the shaly form, are scattered over the latite north of McLaughlin's well. The area between Diamondfield and Black Butte, on the other hand, is probably an inlier, a small rhyolite hill projecting through the younger Milltown andesite.

That the Sandstorm rhyolite is younger than the latite was a conclusion reached in 1905 from the relative distribution of the two rocks as shown in Plate II. At that time also the dumps of two abandoned shafts-one half a mile S. $5^{\circ}$ E. from the summit of Vindicator Mountain and just south of the road to McLaughlin's well, the other on the west slope of the mountain-indicated that the shaly Sandstorm rhyolite had been penetrated and latite found below. In 1905 a shaft half a mile (0.8 kilometer) southeast of the top of Vindicator, after going through about 50 feet ( 15 meters) of Milltown andesite, had continued for another 50 feet into soft, altered, rhyolitic flow breccia with streaks of dark devitrified glass, the whole looking remarkably like a gray tuffaceous sandstone with thin layers of shale. The bottom at the time of visit was in shaly rhyolite. In 1908 this shaft had been abandoned, but the dump showed that the rhyolite had been penetrated and latite found beneath it. 
The Sandstorm rhyolite north of Columbia probably rests for the most part on Kendall tuff, which in turn appears to occupy one or more depressions in the alaskite. The irregularity of the pre-Kendall surface is well shown at the Mayne shaft, 1,500 feet (457 meters) northwest of the summit of Columbia Mountain, near the eastern edge of the largest area of alaskite. (See PI. II.) Although only about 200 feet (61 meters) from the outcrop of the alaskite, this shaft was sunk 100 feet (30 meters) before reaching that rock. In the southeast crosscut on the 400-foot level of the Sandstorm mine the Kendall tuff, according to Mr. H. C. Cutler, the superintendent, was found resting upon a slope of alaskite, which dipped about $50^{\circ} \mathrm{W}$. To what extent this irregularity is the result of faulting since the eruption of the Sandstorm rhyolite can not be determined from the scanty data available. At the northwest end of Columbia town one small and rather obscure exposure shows rhyolite of the shaly variety dipping west and apparently overlying latite. The relation of these rocks to the Kendall tuff at this place is not clear.

At the Sandstorm shaft the rhyolite has a thickness of 200 feet (61 meters). This is not a maximum, as at least another hundred feet is represented by the hill which rises southwest of the shaft. A single measurement, moreover, owing to the uneven surface upon which the rock rests and the disturbance introduced by the subsequent intrusion of the Morena rhyolite, throws little light upon the average thickness. It is thought probable that the Sandstorm rhyolite may attain a maximum thickness of 300 to 400 feet (91 to 122 meters) northwest of Columbia Mountain. Around Vindicator and Banner mountains it thins to less than 100 feet (30 meters), and southeast of McLaughlin's well disappears, the Milltown andesite resting upon the latite.

Although the Kendall tuff and Sandstorm rhyolite are separately mapped and successively described, their intimate relationship should not be lost sight of. They probably belong to the same eruptive epoch and are to some extent intermingled.

\section{PETROGRAPHY.}

As exposed in the principal area, northwest of Columbia Mountain, the Sandstorm rhyolite is a nearly white rock with fine, often much contorted flow banding. Under the influence of weathering, the rhyolite splits along this flow lamination into thin shelly flakes, somewhat resembling disintegrated shale. Much of the surface of the low, rounded, white hills between Columbia and the Sandstorm mine is covered with this flaky detritus. Locally, as near the Sandstorm and Kendall mines, the rhyolite is intensely silicified and outcrops as cellular masses of nearly pure quartz. Phenocrysts are small and inconspicuous, consisting chiefly of feldspar. The abundant groundmass was once highly glassy, and in some localities still shows small spherulites and lithophyses. The delicate fluxion lines in this groundmass are very characteristic of the Sandstorm rhyolite and, in connection with the paucity of quartz phenocrysts, serve to distinguish the rock from the younger and intrusive Morena rhyolite. The general dull-white appearance of the rhyolite is sufficient to show that the rock no longer retains its original glassy condition, but has crystallized into secondary aggregates. Microscopical investigation confirms this conclusion.

Seen in thin section under the microscope, the Sandstorm rhyolite shows phenocrysts of sanidine in a groundmass which, in addition to the wavy flow lines visible in hand specimens, frequently exhibits delicate reticulating and spiral cracks, the typical perlitic structure of siliceous volcanic glasses. The glass itself, however, as may be seen between crossed nicols, has devitrified and is now represented by an exceedingly fine-grained aggregate, consisting chiefly of quartz, but containing also some chalcedony or opal, kaolin, and probably other minerals not optically determinable. Some specimens show remnants of mica, probably biotite, and occasional altered crystals of sodic plagioclase. Quartz phenocrysts, while not entirely absent, are rare and inconspicuous. Zircon occurs sparingly in the usual small rounded grains and prisms.

A large part of the rhyolite shows more intense alteration than can be ascribed to simple devitrification. Such rock, for example, as that which lies along the ridge between the Sand- 
storm and Kendall mines and forms several craggy points south of the former property, consists for the most part of a crystalline granular aggregate of quartz, which, although aphanitic, is of less fine grain than the usual product of devitrification. With the quartz may occur considerable kaolin, silicification and kaolinization clearly having gone on simultaneously. Alunite is also fairly abundant and in some specimens occurs with quartz as distinct pseudomorphs after sanidine. In the most altered varieties the phenocrysts and some of the glassy bands or streaks in the groundmass have been dissolved and the cavities thus formed lined with druses of quartz. Such rock is rough and cavernous. Being composed of almost pure quartz, it is resistant of decay and forms most of the prominent outcrops in the rhyolitic area.

About 900 feet (275 meters) east of the Sandstorm mine, the rhyolite, near its contact with the overlapping Milltown andesite, has a more regular lamination than is usual in the area just described, and splits, on exposure to the weather, into thin gray flakes which might easily be mistaken for shale. Close observation, however, reveals irregularities in the lamination which show it to be a flowage phenomenon, and microscopical examination renders it certain that the rock is a devitrified glassy rhyolite. A similar shaly facies occurs at the southern end of the main rhyolite area and is exposed in the Columbia Mountain No. 2 Tunnel, near its portal. This variety of the rhyolite, however, is much more abundant in an area of the Sandstorm rhyolite presently to be described, namely, that extending from the Adams mine, about a third of a mile ( 0.5 kilometer) east of the Sandstorm, northeastward past the Conquerer (Tonopah Club) mine.

The rhyolite of the small area shown in Plate II, in the northwest corner of the region, is a partly devitrified spherulitic glass. This rock is fresher than in the other areas and contains some glass as well as a few phenocrysts of sodic plagioclase. The principal secondary minerals are quartz, chalcedony, and opal.

The lithologic character of the shaly facies of the Sandstorm rhyolite is well displayed just north of the Conquerer mine. Much of the material here has the appearance of a white or light-gray shale with a dense porcelain-like texture grading in places into softer chalkylooking varieties. The microscope shows that these are devitrified glasses consisting of very fine grained aggregates of quartz, kaolin, and possibly other minerals. Interlaminated with these aphanitic layers are rhyolite flow breccias containing fragments of white pumice and of devitrified glassy rhyolite. One of the shaly bands, about 1,500 feet east of the summit of Kendall Mountain and close to the contact with the Milltown andesite, contains abundant hollow spherulites or lithophyses up to several inches in diameter.

An unusual variety of the rhyolite outcrops prominently just west of the Adams mine. This is a rough porous rock evidently somewhat altered. The microscope shows it to be a devitrified and partly silicified spherulitic glass. Rock of the same character occurs north of the Conqueror mine, and both are probably alteration products of a variety of the rhyolite resembling that from the western edge of the district, described above.

The rock of the small areas extending from the west side of Vindicator Mountain to Diamondfield is chiefly the gray shaly variety. Just west of Diamondfield, however, are some outcrops of rhyolite flow breccia.

Between Diamondfield and Black Butte is an area of devitrified and silicified glassy rhyolite ranging from white chalky facies to nearly black flinty varieties.

The area mapped as Sandstorm rhyolite between Black Butte and Tognoni Springs is occupied by much altered rock of somewhat doubtful character. Most of the area is littered with the shaly detritus indicative of the presence of the Sandstorm rhyolite and some of the specimens collected are devitrified glassy rhyolite such as is known to occur in that formation. Other specimens, however, contain abundant quartz phenocrysts and resemble the later Morena rhyolite. Still others are undoubtedly much altered latite. It is certain, therefore, that the area as mapped includes rocks of more than one kind, although it is doubtful whether these can be separately mapped, owing to their general alteration and to the unsatisfactory character of the exposures. 
The remaining areas of Sandstorm rhyolite, including the outliers north of McLaughlin's well and the patches south of Vindicator Mountain, are all occupied by the gray shaly variety already described. Many of them, were it not for the relations clearly shown near the Sandstorm and Conqueror mines, would probably, in the absence of microscopical investigation, be taken for sedimentary shales.

\section{MORENA RHYOLITE.}

\section{GENERAI. CHARACTER AND OCCURRENCE.}

The Morena rhyolite is intrusive into the Sandstorm rhyolite and pre-Tertiary rocks, but is older than the Milltown andesite. The presence of this rock on Morena Ridge, the northern spur of Columbia Mountain, has suggested its local name.

The principal area of intrusive rhyolite is that shown on Plate II, as extending from near the top of Columbia Mountain northward to the Adams mine. Smaller masses are exposed on the west slope of the mountain and in the vicinity of the Conqueror mine.

The irregular intrusion of the Morena rhyolite into the shaly Sandstorm rhyolite is well shown in the Adams and Conqueror mines, the intrusive rock close to the contact being crowded with inclusions of the other. The shaft of the Kendall mine, about 200 feet (61 meters) deep at the time of visit late in 1905 , was in the intrusive rhyolite at the bottom, but the contact with the effusive Sandstorm rhyolite was not then visible. A sharp intrusion contact between the Morena rhyolite and Cambrian shale as exposed in a prospect on the west side of Columbia Mountain, near the summit, is shown in Plate VI, $A$.

\section{PETROGRAPHY.}

The Morena rhyolite is somewhat darker than the Sandstorm rhyolite, being generally gray or buff. As a rule it shows no flow lamination or banding, and contains abundant small phenocrysts of quartz, with less conspicuous feldspars, in a compact lithoidal groundmass. Although the rock has in places been subjected to intense local alteration, it is on the whole fresher than the Sandstorm rhyolite, many specimens showing under the microscope abundant glass with only incipient devitrification.

The quartz phenocrysts, most of which are less than 5 millimeters in diameter, show the usual embayed and rounded outlines characteristic of siliceous porphyries in thin section. These phenocrysts as a rule are not affected by alteration, although in a specimen from the area at the Conqueror mine, near the contact with the Sandstorm rhyolite, they are enlarged by secondary quartz, which has replaced the groundmass adjacent to the crystals, in optical continuity with them.

The principal feldspar is orthoclase. In some specimens this is fresh and clear, but more frequently it shows some alteration, either to very fine grained obscure aggregates composed chiefly of kaolin, or, in certain intensely altered facies, to aggregates of alunite and quartz. These latter pseudomorphs are well shown in specimens from the Conqueror mine and doubtless in many other localities where the rhyolite has clearly undergone similar alteration. Most of the fresher varieties contain a few crystals of plagioclase, some of which is sufficiently calcic to be classed as labradorite.

Biotite was originally present as phenocrysts, but appears to be everywhere bleached or chloritized.

In the same altered rock that shows the secondary enlargement of quartz phenocrysts, from near the Conqueror mine (specimen G. 697), there occurs a colorless secondary mineral which closely resembles quartz in refraction and birefringence. The mean refractive index, however, is slightly lower, being less than the Canada balsam of the slide. The mineral, like quartz, is uniaxial, but is optically negative. It forms anhedrons with a suggestion of stout prismatic development, and is probably scapolite.

Although the Morena rhyolite does not exhibit the same conspicuous flow lamination as the Sandstorm rhyolite, the microscope shows marked fluxion in the groundmass, the streaky glass curving around the phenocrysts in the manner typical of siliceous glassy lavas. 
U. S. GEOLOGICAL SURVEY

PROFESSIONAL PAPER 66 PLATE VI

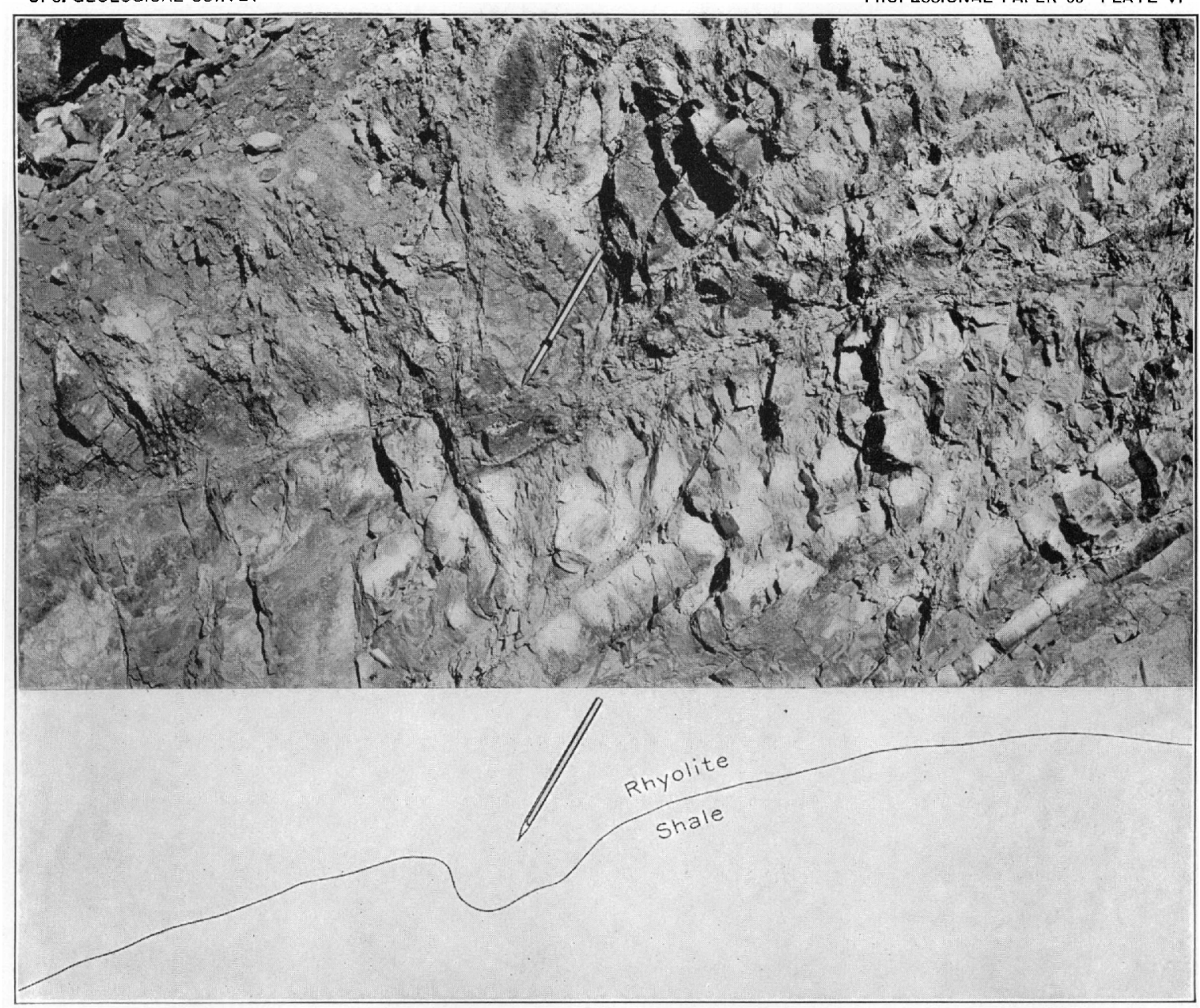

A. INTRUSIVE CONTACT BETWEEN MORENA RHYOLITE AND CAMBRIAN SHALE.

West slope of Colun bia Mountain.

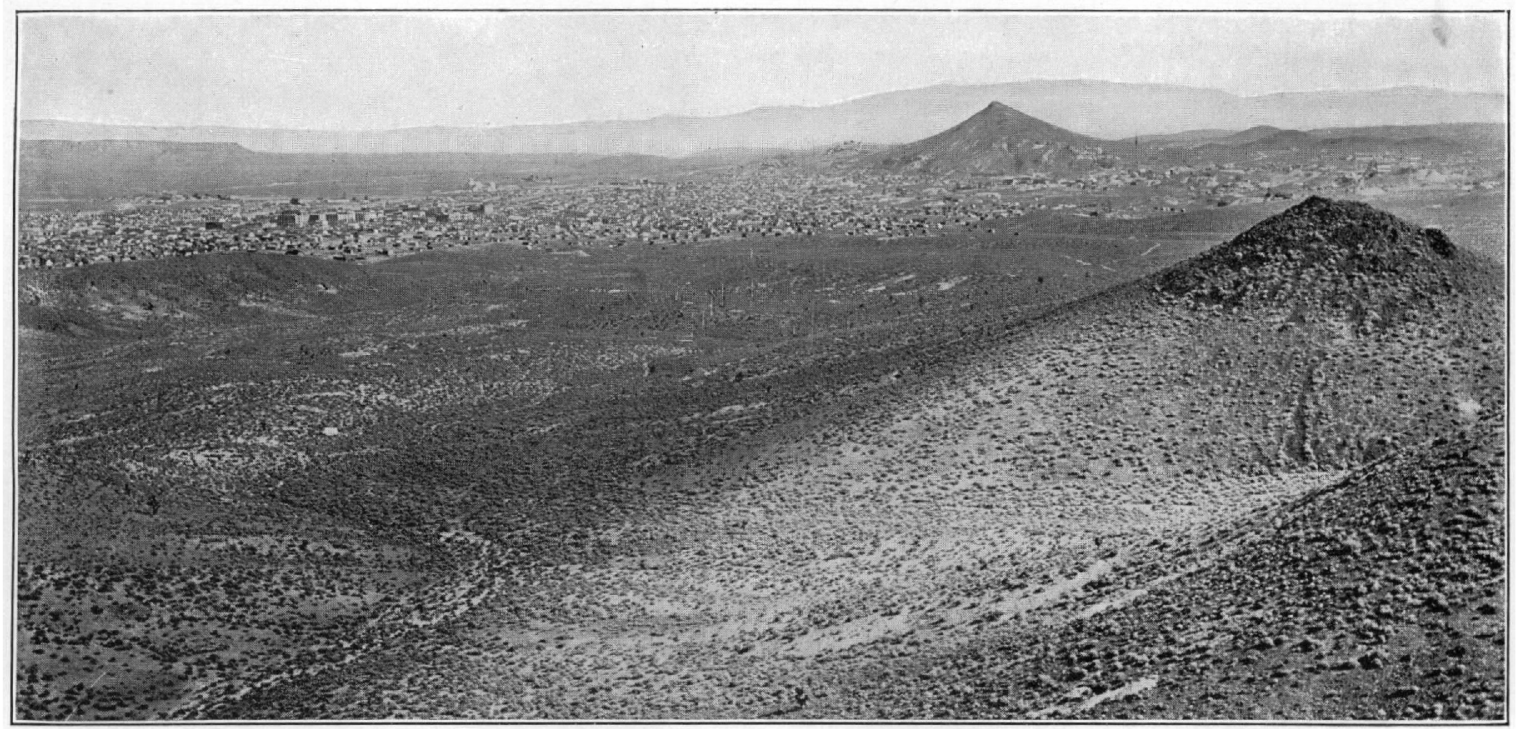

J3. GOLDFIELD; FROM MIRA MOUNTAIN.

The sharp peak is Columbia Mountain. The principal mines lie beyond the basalt-capped hill in the right foreground. 



\section{MILLTOWN ANDESITE.}

INTRODUCTORY STATEMENT.

The intrusion of the Morena rhyolite may have been followed by some erosion. Then came eruptions of andesite, which covered the region with successive flows of this rock, with here and there local and subordinate accumulations of andesitic tuff. The products of these eruptions constitute the most extensive formation in the district. (See Pl. II.) The total thickness of this deposit, as of most of the other volcanic formations in this district, can not be accurately determined, owing to the slight general cleformation of the rocks, their poor exposures, the comparatively low topographic relief, and the absence of persist int datum planes, such as may usually be found in stratified rocks. It probably lies between 600 and 800 feet (183 and 244 meters).

The petrographic study of the andesites shows that they contain phenocrysts of labradorite feldspar, hornblende, augite, orthorhombic pyroxene, and occasionally biotite in groundmasses ranging from hyalepiilitis to vitrophyric in texture. The formation mapped as Milltown andesite undoubtedly includes more than one lava flow, with some pyroclastic and intrusive rocks, but it is quite impracticable in this field to discriminate individual flows in mapping the whole area.

The local name of the formation is derived from the small settlement of Milltown, about a mile east of Goldtield.

\section{DISTRIBCTION.}

As may be seen from Plate II, the andesitic terrane occupies a very large part of the district. One broad, irregular belt stretches easiward from the edge of the main valley north of Goldfield past Diamondficld and beyond the eastern boundary of the area mapped. Another belt extends from near Goldfield eastward beyond Preble and Blackcap mountains. These two belts are prevented from meeting on the west and east sides of the central part of the district by extensive intrusive masses of dacite. Were it not for these intrusions the andesite would undoubtedly form a complete although irregular band around the central latite area, and thus still further accentuate the general concentric and domical structure of the district.

The rounded andesitic hill which emerges from the Siebert formation near the railway, 2 miles (3.2 kilometers) north of Goldfield, is probably an inlier, the andesite being continuous, under the later formation, with the andesite of Kendall Mountain and vicinity. Some small areas of the andesite similarly projecting through the Siebert formation are shown in the northeast corner of the geologic map (Pl. II).

PETROGRAPIIY.

GENERAL CHARACTER OF THE FORMation.

The rocks mapped as the Milltown andesite in Plate II undoubtedly include more than one lava flow and exhibit greater variety in color and texture than any other formation in the district. In a few localities the superposition of one flow upon another can be recognized, as, for example, in the hill two-thirds of a mile (1 kilometer) northeast of Columbia Mountain, in another hill half a mile ( 0.8 kilometer) northeast of Kendall Mountain, and in the extreme northeast part of the district; but after some effort had been made to extend these local distinctions over the district the attempt was abandoned as impracticable. The actual petrographic difference between rocks belonging to successive eruptions is in some cases no greater than between the variations in texture and composition of individual lava flows. Since the exposures over all but a very small part of the district are such that the different flows would have to be discriminated solely by petrographic means, much of the andesite being altered almost beyond recognition, and since it is by no means certain that each flow extended over the whole district, the necessity for treating the andesite as a unit is apparent. With the flows are associated some local deposits of andesite tuff, as already mentioned, and some intrusive bodies of small size, the whole constituting a typical volcanic complex. 
The fresher varieties of the andesite range in color from nearly black to light gray. The altered forms are usually of lighter hue and may be gray, brown, red, yellow, green, or white. The darker fresh kinds are in most places dense ringing rocks with splintery fracture and an almost basaltic aspect. Such a rock, showing small phenocrysts of augite, occurs 1,000 feet (305 meters) northeast of the transformer station east of Columbia Mountain. A similar andesite, but with the megascopic dark phenocrysts of hornblende instead of augite, forms a dike which is crossed by the road south of Vindicator Mountain. As a rule, however, the hornblendic varieties are lighter colored and less dense rocks than the pyroxenic ones, although, as will be shown, the two types are connected by intermediate forms. Andesite with conspicuous phenocrysts of hornblende is particularly abundant in the part of the district lying northeast of Black Butte. A similar hornblendic variety occurs also in a hill 1,000 feet (305 meters) south of Diamondfield. Hornblende is present in many varieties of the andesite in which it is not conspicuous in hand specimens. It has in many such rocks undergone molecular change into aggregates of augite, magnetite, and plagioclase, the abundance of augite being often in rough inverse proportion to the diminution of the hornblende by this process. While it can not be said that all of the pyroxene andesite in the district once contained hornblende or biotite, the evidence is clear that much of it did. The probability of such a derivation of some pyroxene andesites from originally hornblende-bearing magmas was pointed out by Von Lasaulx ${ }^{a}$ some years ago. Later, H. S. Washington, ${ }^{b}$ after showing that hornblende and biotite in molten magmas are stable only under plutonic conditions and undergo a paramorphic change into augite and magnetite in lavas not too quickly cooled, suggested that "some of the augite andesites, especially the more acid ones, may owe their augitic character to the alteration and subsequent disintegration of previously existing hornblendes or biotites, in accordance with the views of Von Lasaulx."

The pyroxenic andesites of the Goldfield district, even those containing enstatite or hypersthene, furnish a good example of such an origin. Not all of the pyroxene in them was formed by the paramorphic change of hornblende and biotite and the subsequent dispersal of the aggregates of augite and magnetite by the movement of the magma, but most of the pyroxene andesites, had they been more quickly cooled and solidified, would probably contain hornblende and perhaps biotite.

The occurrence of plagioclase with augite and magnetite as a result of the molecular disintegration of hornblende is not often mentioned. J. P. Iddings ${ }^{c}$ notes it, however, and states that orthorhombic pyroxene may also be present in such paramorphic aggregates.

In the course of the present investigation over 200 specimens of the Milltown andesite, from all parts of the district, have been microscopically studied. While the andesitic rocks are of too many kinds to be embraced in a single petrographic description, it is impracticable, on the other hand, to describe in detail every one of the many varieties found. Accordingly only certain representative or striking facies, including those of which chemical analyses have been made, will be fully described. Such description will be followed in each case by comments upon the range, transitions, and affiliations of the variety described.

HORNBLENDE-PYROXENE ANDESITE.

By far the most prevalent type of andesite is one in which labradorite, augite, enstatite, and hornblende all occur as phenocrysts in a hyalopilitic or microlitic groundmass. Two fresh specimens of this type, one (G. 316) from the summit of a hill two-thirds of a mile (1 kilometer) northeast of Columbia Mountain, just north of the Goldfield-Diamondfield road, and the other (G. 59) from the area of andesite shown in the northeast corner of the geologic map (Pl. II) about $1 \frac{1}{2}$ miles ( 2.5 kilometers) northeast of Black Butte, were selected for chemical analysis and special description. The latter specimen was collected just outside of the area included in Plate II.

a Ueber Vorkommen und Verbreitung der Augitandesite im Siebengebirge: Sitzungsber. Nieder-rhein. Gesellsch. in Bonn, vol. 41, 1884, p. 155.

$b$ The magmatic alteration of hornblende and biotite: Jour. Geology, vol. 4, 189t, pp. 257-282.

$c$ Rock minerals: New York and London, 1906, p. 341. 
The specimen from the hill near Columbia Mountain is a dark, reddish brown, evidently glassy rock, in which the naked eye can detect minute phenocrysts of plagioclase and black hoinblende.

Under the microscope, phenocrysts of plagioclase up to 3 millimeters in length and smaller crystals of augite, orthorhombic pyroxene, hornblende, magnetite, and apatite appear scattered through an abundant glassy groundmass crowded with minute feldspar microlites. The texture of the groundmass is hyalopilitic. The rock is perfectly fresh.

The feldspar phenocrysts, save for inclusions of glass, are clear, exhibit the usual albite, Carlsbad, and pericline twinning and have an approximate composition of $\mathrm{Ab}_{3} \mathrm{An}_{7}$, corresponding to a rather calcic labradorite. The microlites are too small and are embedded in too much glass for satisfactory optical determination of their place in the isomorphous plagioclase series. In all of the Milltown andesite studied the phenocrysts are labradorite and range in composition from $\mathrm{Ab}_{3} \mathrm{An}_{4}$ to $\mathrm{Ab}_{1} \mathrm{An}_{4}$.

The augite is faintly green in thin section, with a maximum measured extinction angle of $40^{\circ}$. In other specimens of the andesite it is about $45^{\circ}$. The planes of the prism zone are often well developed, but many crystals show only rounded outlines. The augite of the pyroxene-hornblende andesite specimens frequently shows the usual twinning on the plane (100). This mineral decomposes readily, and in many specimens of the andesite in which the labradorite is still fresh the monoclinic pyroxene has been converted to pseudomorphs of calcite. It is probably near diopside in composition.

Orthorhombic pyroxene is rather abundant in small euhedral phenocrysts of prismatic habit with blunt pyramidal terminations. Although nearly colorless, the crystals are faintly pleochroic, rays vibrating parallel to $\mathrm{X}^{a}$ giving a slight reddish tint and those parallel to $\mathrm{Y}$ and $\mathrm{Z}$ being faintly tinged with green. The birefringence is low and the optical character is apparrently positive, although some uncertainty attaches to the latter determination owing to the large optic angle and small size of the prism cross sections. The pyroxene is thus probably enstatite, hypersthene being optically negative and having as a rule stronger pleochroism and birefringence. In many specimens of the pyroxene-hornblende andesite the orthorhombic pyroxene is partly or wholly decomposed to a pale yellowish green mineral of variable birefringence, the interference colors ranging from the usual gray or yellow of ordinary serpentine to those almost as brilliant as in biotite. In some cases the mineral is distinctly an aggregate; but in most specimens it is optically homogeneous, with a fine fibrous structure parallel to the prism axis of the pyroxene. Such pseudomorphs exhibit parallel extinction, and the direction of least elasticity is that of the elongation of the fibers. The mineral, like iddingsite, which it sometimes resembles, is probably closely related to serpentine. The relation to ordinary serpentine of such strongly birefringent minerals as iddingsite and possibly other similar alteration products of the magnesian silicates is still obscure. The orthorhombic pyroxene becomes serpentinized during the early stages of alteration of the andesite, before the augite changes to calcite.

The hornblende occurs in rounded anhedrons with narrow opaque reaction rims. The absence of extensive paramorphic change and the glassy character of the groundmass indicate comparatively quick cooling of the magma. Two varieties of hornblende are present, usually intergrown in the same crystal. One is pleochroic in brown and the other in green tints. Apparently in both, however, the ray vibrating parallel to $\mathrm{X}$ is greenish yellow.

All of the Milltown andesite contains magnetite, probably with some ilmenite, and apatite. The latter occurs in the usual small stout hexagonal prisms, many of which have a fibrous appearance due to lines of small dark inclusions parallel to the prism axis. Such crystals are faintly pleochroic.

The second rock, that from the northeast corner of the district, is dark gray and appears more crystalline. The phenocrysts of feldspar and hornblende are much more abundant.

a Throughout this report the crystallographic directions of greatest, mean, and least elasticity will be designated, respectively, as $X$, $Y$, and $Z$, instead of by the German a, b, and c. frequently used. This usage follows the example set by J. P. Iddings in his "Rock minerals," New $Y$ ork and Iöndon, 1906, and makes for elearness and convenience.

†!)14-Xo. $60-09-4$ 
The microscope shows phenocrysts of the same minerals as occur in the other rock. Determination of some of the feldspars by the Michel Lévy method gives compositions approximating to $\mathrm{Ab}_{1} \mathrm{An}_{4}$, corresponding to a calcic labradorite. The central parts of the crystals are often of spongy texture and full of glass inclusions, these cores usually showing sharp crystallographic outlines and being inclosed in a shell of clear labradorite. The augite is colorless or faintly green and shows a maximum extinction of about $35^{\circ}$. The hornblende is generally brown in thin section, the pleochroism being $\mathrm{X}$ greenish yellow, $\mathrm{Y}$ and $\mathrm{Z}$ yellowish brown. The absorption is $\mathrm{Z}>\mathrm{Y}>\mathrm{X}$. Some of the hornblende shows no reaction rims or paramorphism. Other crystals have been partly or wholly altered, prior to the solidification of the rock, into aggregates of augite, magnetite, and plagioclase. Orthorhombic pyroxene occurs much as in the rock near Columbia Mountain and appears to be enstatite. The groundmass is glassy hyalopilitic.

Chemical analyses of these two rocks were made by George Steiger in the United States Geological Survey laboratory, the results being as follows:

Chemical analyses of pyroxene-hornblende andesite.

\begin{tabular}{|c|c|c|c|c|c|c|c|}
\hline & 1. & 2. & 3. & & 1. & 2. & 3. \\
\hline \multirow[t]{2}{*}{ 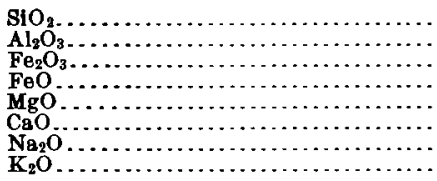 } & \multirow[t]{2}{*}{\begin{tabular}{r|}
58.06 \\
17.43 \\
3.83 \\
1.91 \\
2.60 \\
6.33 \\
3.34 \\
2.61
\end{tabular}} & \multirow[t]{2}{*}{$\begin{aligned} 60.41 \\
16.59 \\
3.18 \\
1.70 \\
2.13 \\
5.26 \\
3.94 \\
1.70\end{aligned}$} & \multirow[t]{2}{*}{$\begin{array}{r}54.66 \\
17.53 \\
3.18 \\
3.52 \\
3.62 \\
7.33 \\
3.56 \\
2.22\end{array}$} & \multirow[t]{2}{*}{ 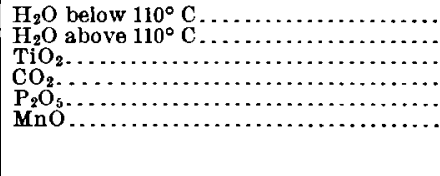 } & $\begin{array}{r}0.97 \\
1.88 \\
.87 \\
\text { None. } \\
.27 \\
.09 \\
\end{array}$ & $\begin{array}{r}1.94 \\
2.64 \\
.62 \\
\text { None. } \\
.31 \\
.07 \\
\end{array}$ & $\begin{array}{r}0.59 \\
.69 \\
.99 \\
1.35 \\
.30 \\
.12 \\
\end{array}$ \\
\hline & & & & & 100.19 & 100.49 & 99.66 \\
\hline
\end{tabular}

1. Pyroxene-hornblende andesite (G. 59), 1 miles (2.5 kilometers) northeast of Black Butte.

2. Pyroxene-hornblende andesite (G.316), two-thirds mile (1 kilometer) northeast of Columbia Mountain.

3. Pyroxene-hornblende andesite, 1 mile (1.6 kilometers) northeast of Columbia Mountain.

The norm of analysis 1, calculated in accordance with the quantitative system of Cross, Iddings, Pirsson, and Washington, ${ }^{a}$ is as follows:

Norm of pyroxene-hornblende andesite $1 \frac{1}{2}$ miles northeast of Black Butte.

\begin{tabular}{|c|c|c|c|}
\hline Quartz..... & 13. 26 & Magnetite........................ & 3. 71 \\
\hline Orthoclase.............. & 15.57 & Hematite........................... & 1. 28 \\
\hline 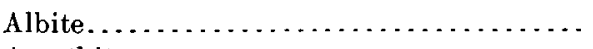 & 27. 77 & Apatite............................. & .67 \\
\hline Anorthite $\ldots \ldots \ldots \ldots \ldots \ldots \ldots \ldots \ldots \ldots \ldots \ldots \ldots$ & 25.02 & & 97.31 \\
\hline Diopside $\left(\mathrm{CaO}, \mathrm{MgO}, \mathrm{SiO}_{2}\right) \ldots \ldots \ldots \ldots \ldots \ldots$ & 3.46 & Water. & 2.75 \\
\hline $\begin{array}{l}\text { Enstatite }\left(\mathrm{MgO}, \mathrm{SiO}_{2}\right) \ldots \ldots \ldots \ldots \ldots \ldots \\
\text { Ilmenite } \ldots \ldots \ldots \ldots \ldots \ldots \ldots \ldots \ldots \ldots\end{array}$ & $\begin{array}{l}4.90 \\
1.67\end{array}$ & & 100.06 \\
\hline
\end{tabular}

This affords 81.62 per cent of salic minerals against 15.69 per cent of femic minerals, and the rock belongs in the dosalane class of that system. It is dosalic, alkalicalcic, quardofelic, and dosodic, thus corresponding to the subrang tonalose. It is accurately described in terms of the quantitative system as a vitriphyro-tonalose.

It may be noted that a very large proportion of the andesites of the western United States ${ }^{b}$ fall in this same subrang, which is very near the hypothetical average igneous rock as calculated by F. W. Clarke, ${ }^{c}$ H. S. Washington, ${ }^{d}$ and Alfred Harker. ${ }^{e}$

The mode of the rock analyzed differs from the calculated norm in the presence of much glass, probably richer in potassium than the crystalline part of the fabric, in the absence of recognizable orthoclase, in the presence of labradorite instead of albite and anorthite, in the absence of free quartz, probably in the occurrence of somewhat aluminous and ferruginous microclinic pyroxene (augite) instead of diopside, and in the actual mineralogical functions of the iron oxides.

a Quantitative classification of igneous rocks, Chicago and London, 1903.

b See Washington, H. S., Chemical analyses of igneous rocks: Prof. Paper U. S. Geol. Survey No. 14, 1903, pp 231-245.

c Bull. U. S. Geol. Survey No. 228, 1904, pp. 14-20.

d Op. cit., pp. 106-117.

e On the average composition of British igneous rocks: Geol. Mag., new ser., 4th decade, vol. 6, 1899, pp. 220-222. 
The norm of rock 2 is as follows:

Norm of pyroxene-hornblende andesite two-thirds mile northeast of Columbia Mountain.

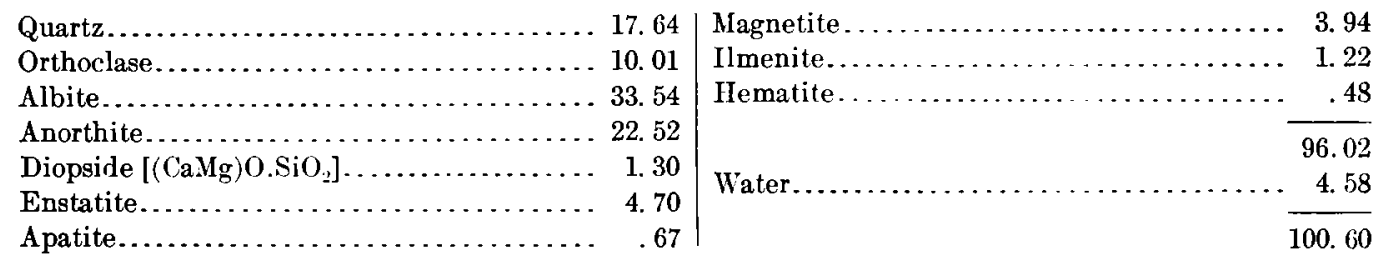

This rock also is a vitriphyro-tonalose, but lies near the line separating this subrang from yellowstonose, the corresponding subrang in the persalane class.

The rock of analysis 3 was collected a few hundred yards east of rock 1 , and may belong to an underlying flow. It shows no hornblende in the thin section studied, and was selected as representative of the pyroxene andesite. Subsequent examination of the hand specimen, however, revealed a single phenocryst of hornblende, and the analysis is accordingly discussed at this place. The rock well illustrates the close relation between the hornblende-pyroxene and pyroxene andesites in this district.

Under the microscope the rock appears perfectly fresh, the carbonate indicated in the analysis evidently occurring in a few small scattered amygdules. The phenocrysts are labradorite $\left(A b_{3} \mathbf{A n}_{4}\right)$, augite, enstatite, magnetite, and apatite. The pyroxenes are more abundant than in the hornblendic varieties of andesite just described. The augite is faintly green, with extinction angles up to $43^{\circ}$. The orthorhombic pyroxene is particularly well developed in the usual stout prisms and is slightly more pleochroic than in the rocks previously described. It is probably near hypersthene in composition. The groundmass is hyalopilitic.

The norm of this rock is as follows:

Worm of pyroxene-hornblende andesite 1 mile northeast of Columbia Mountain.

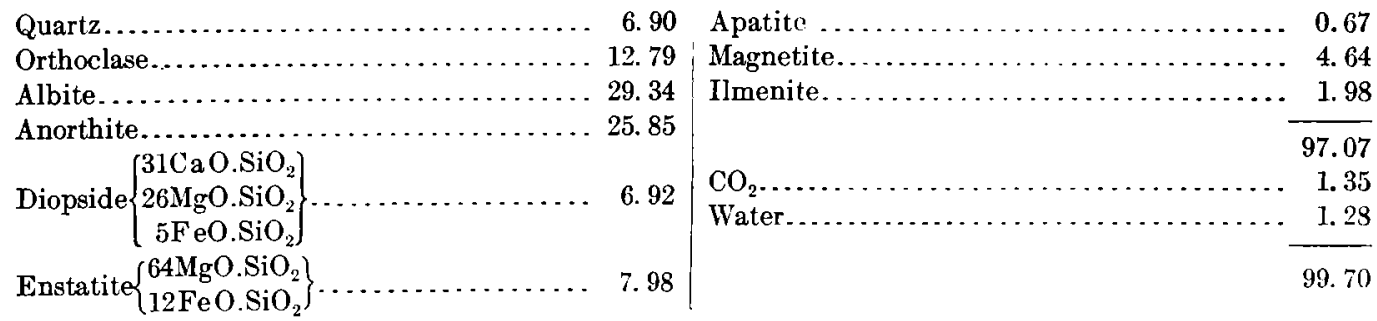

The rock in terms of the quantitative system is dosalic, alkalicalcic, quardofelic, and dosodic, and is therefore, like the other two rocks analyzed, tonalose.

Study of the distribution of the pyroxene-hornblende variety of the Milltown andesite shows that while it is certainly the dominant facies, and although it occurs here and there over the whole andesite area, yet it occupies no well-defined portions of that area to the exclusions of the other varieties presently to be described. In a few places the distinction between the pyroxene-hornblende facies and andesite free from hornblende or containing biotite is sharp enough to indicate a contact between two flows. This, however, is exceptional. As a rule the hornblende andesite grades into pyroxene andesite, and every step in the transition can be studied in thin sections from those in which hornblende is abundant to those in which the mineral has undergone complete magmatic transformation into aggregates of labradorite, augite, and magnetite, or is so rare as not to appear in every thin section of the rock. In some pyroxene andesites these aggregates still preserve the rough outlines of the hornblende; in others the outlines are lost and the aggregate merges with the general fabric of the rock. As already pointed out, most or all of the pyroxene andesite once contained hornblende, the survival or disappearance of this mineral depending upon the rate and conditions of cooling. Furthermore, it is almost certain that hornblende may be present in one part of a flow and absent in another. 
PYROXENE ANDESITE.

In every respect, except the absence of hornblende ana rather more abundant pyroxene, the prroxene andesite is identical with the hornblendic variety just described. Its chemical composition is probably well represented by analysis 3 on page 50, although, as stated, this particular facies contains an occasional phenocryst of hornblende.

A particularly glassy variety is exposed on the hillside just east of Tognoni Springs. This is a dark-gray rock, which on close inspection is seen to be composed chiefly of glass with a characteristic oily luster. The material has a pronounced flow structure, brought out in specimens by the alternation of bands of greenish-gray glass with nearly black layers.

The microscope shows the rock to be a vitrophyre, the glass containing phenocrysts of labradorite and orthorhombic pyroxene as well as tiny microlites of augite and plagioclase. The orthorhombic pyroxene is more strongly pleochroic than in most of the andesites of the district. The acute bisectrix corresponds to the direction of greatest elasticity, $\mathrm{X}$, and sections parallel to the macropinacoid (100) give a biaxial interference figure. The axial angle, also, is smaller than in the enstatite of the other andesites studied and the pyroxene is in this case liypersthene.

HORNBLENDE-BIOTITE ANDESITL.

A specimen from 1 mile (1.6 kilometer) northeast of Black Butte (G. 63) was selected for chemical analysis as representative of the hornblende-biotite andesite. This is a light-gray, somewhat porous rock showing abundant phenocrysts of hornblende, biotite, and feldspar in an aphanitic base. Most of the phenocrysts are less than 5 millimeters in length.

Under the microscope the feldspar proves to be labradorite with the approximate composition $\mathrm{Ab}_{2} \mathrm{An}_{3}$, it being less calcic than in the pyroxenic varieties of the andesite. The hornblende is the common brown variety with narrow dark reaction rims consisting of magnetite, plagioclase, and a colorless isotropic material, probably glass. Similar rims surround the sections of biotite, which has the optical character of meroxene. The rock was evidently cooled too quickly to allow any molecular rearrangement of the hornblende and biotite. Among the smaller phenoerysts are rather abundant prisms of cloudy pleochroic apatite and grains of magnetite. The groundmass is glassy hyalopilitic, the plagioclase microlites being for the most part too minute for satisfactory determination of their precise character. No pyroxene appears in the thin section studied.

The chemical analysis of this rock, by Mr. George Steiger, is as follows:

Chenical analysis of hornblende-biotite andesite.

\begin{tabular}{|c|c|c|c|}
\hline $\mathrm{SiO}_{2}$ & 63. 16 & $\mathrm{H}_{2} \mathrm{O}$ below $110^{\circ} \mathrm{C} \ldots$ & 1. 12 \\
\hline $\mathrm{Al}_{2} \mathrm{O}_{3}$ & 16. 74 & $\mathrm{H}_{2} \mathrm{O}$ above $110^{\circ}\left({ }^{\prime} \ldots \ldots \ldots \ldots \ldots\right.$ & .77 \\
\hline $\mathrm{Fe}_{2} \mathrm{O}_{3}$ & 3.94 & $\mathrm{TiO}_{2} \ldots \ldots \ldots \ldots \ldots \ldots \ldots$ & .61 \\
\hline $\mathrm{FeO}$.. & .47 & $\mathrm{CO}_{2} \cdots \ldots$ & None. \\
\hline $\mathrm{MgO}$. & 1. 12 & $\mathbf{P}_{2} \mathrm{O}_{5} \ldots \ldots \ldots \ldots \ldots \ldots \ldots \ldots$ & .30 \\
\hline $\mathrm{CaO}$ & 4. 07 & $\operatorname{MnO} \ldots \ldots \ldots \ldots \ldots \ldots \ldots \ldots \ldots \ldots \ldots$ & .04 \\
\hline $\mathrm{Na}_{2} \mathrm{O}$ & 3. 88 & & - - - \\
\hline $\mathrm{K}, \mathrm{O}$ & 3. 71 & & 99.93 \\
\hline
\end{tabular}

The analysis, as might have been expected, shows more silica and less iron oxides, magnesia, and lime than those of the prroxenic andesites on page 50.

The norm calculated from this analysis is as follows:

Norm of hornblende-biotite andesite.

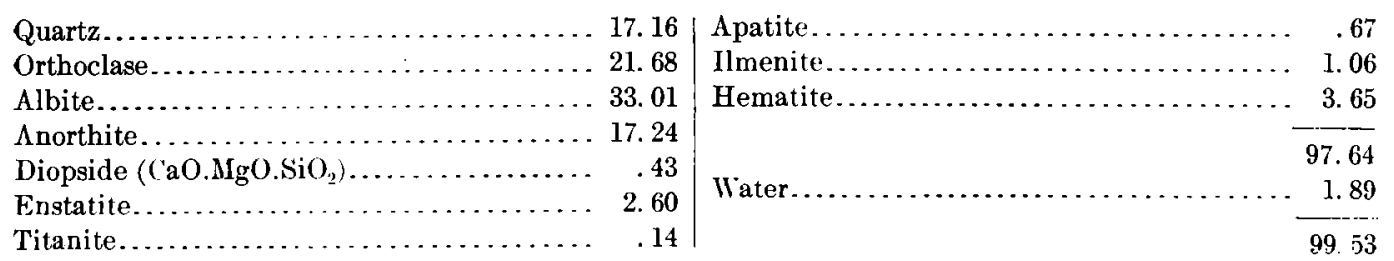


In this norm the proportion of salic to femic minerals is greater than 7 to 1 , and the rock falls in the persalane class. It is quardofelie, alkalicalcic, and sodipotassic, although very near dosodic. The rock is accordingly amiatose but is exceedingly close to yellowstonose.

The chemical analysis of this rock shows that it can not be regarded merely as a quickly cooled part of a magma chemically identical with that which solidified as hornblende-pyroxene and pyroxene andesite. In other words, it indicates clearly that the mineralogical differences in the Milltown andesite can not all be explained as various steps in the change from the complex molecules of biotite and hornblende to the more stable combination of augite, magnetite, and labradorite.

A rather striking variety of hornblende-biotite-augite andesite (G. 47) occurs $1 \frac{1}{2}$ miles (2.5 kilometers) east of Black Butte, just outside of the area included in Plate II. This rock contains abundant small sparkling phenocrysts of hornblende and biotite and subordinate plagioclase in a light-gray aphanitic groundmass. The microscope shows that the majority of the phenocrysts are of sharp euhedral form. The hornblende shows no resorption. Its pleochroism is $\mathrm{X}$ light yellowish green, $\mathrm{Y}$ dark brownish green, and $\mathrm{Z}$ brownish yellow. The absorption is $\mathrm{Y}>\mathrm{Z}>\mathrm{X}$ and the extinction angle $\mathrm{Z} \wedge \mathrm{C}$ is about $11^{\circ}$. Some crystals are twinned repeatedly on the orthopinacoid (100). A colorless augite also occurs as phenocrysts, often intergrown with hornblende and biotite. In this rock there is nothing to indicate that the constituents of the augite have ever crystallized as hornblende. The plagioclase is labradorite. The groundmass is glassy, with microlites of plagioclase. The appearance of this rock in thin section is shown in Plate VII, $A$.

Hornblende-biotite andesite, free from pyroxene, occurs so far as known only in the northeast corner of the district and possibly in the small hill 1,000 feet ( 305 meters) south of Diamondfield, the rock at the latter locality not being sufficiently fresh to permit the positive statement that pyroxene was never present. Biotitic andesite occurs half a mile west of Diamondfielcl, on the southeast slope of Blackcap Mountain, one-half mile (0.8 kilometer) south of Myers Mountain, about a mile (1.6 kilometers) northeast of Kendall Mountain and in a few other places in the district. At all the localities mentioned, however, the rock is pyroxene-bearing or is so decomposed as to leave the question of the possible former presence of pyroxene in doubt. It thus appears that there is scarcely any more ground for a definite division of the Milltown andesite on the basis of the presence or absence of biotite than on the basis of the presence or absence of hornblende. There is a suggestion from the position of the biotitehornblende andesite in the northeast corner of the district that this rock belongs to a late flow in the Milltown andesite. This suggestion is supported moreover by the similarity in mineralogical and chemical composition of the biotite-hornblende andesite with the dacite presently to be described.

Deposits of tuff constitute a wholly subordinate part of the Milltown andesite. A small accumulation occurs near the east base of the hill three-fourths mile (1.2 kilometers) northeast of Columbia Mountain. Tuffaceous rocks are present along the eastern edge of the area, north of Tognoni Springs. These, however, like much of the massive andesite with which they are associated, are so intensely altered to white kaolinic aggregates that little can be determinerl regarding their original character or present boundaries. The hill two-thirds mile (1 kilometer) northeast of Myers Mountain is composed in part of much-altered tuff. In view of the ease with which clastic rocks of this character succumb to chemical attack their general altered condition in this district is not surprising. It is probable that in other parts of the area than those mentioned rocks now bleached and metamorphosed beyond recognition may have been originally tuffaceous.

In underground work andesite tuff and breccia has been found in the Daisy mine as the prevailing rock on the 300 -foot and 400 -foot levels. The Crooks shaft of the Kewana Leasing Company, about half a mile ( 0.8 kilometer) southeast of the summit of Columbia Mountain, went through 140 feet ( 43 meters) of dacite, then through more than 100 feet (30 meters) of andesite into andesitic breccia. The latter continued to a depth of at least 410 feet (125 meters) - the bottom of the shaft at time of visit. 
BASALT:

In the Portland mine, east of Goldfield, a crosscut to the east on the 250-foot level which was accessible in 1905 exposed a series of thin amygdaloidal basalt flows with associated tuffs. Nearly all the rock in this mine is much altered, and the ground in general is so soft and so cut up by gouge-filled fissures that prospecting was carried on with difficulty. Such observations as were possible under these conditions showed that the basalt occurs near the base of the Milltown andesite and just above the latite. The thickness of the basalt and basalt tuff could not be determined. What appears to be the same amygdaloidal basalt has been cut in the Red Hills shaft, 800 feet (244 meters) southeast of the Portland.

The material of the flows is an ordinary olivinite basalt with nothing noteworthy in its sharacter. It is nowhere exposed at the surface, so far as known, and represents a very local rruption at the beginning of the andesite period. The old vent is probably somewhere beneath the Milltown andesite in the vicinity of the Portland mine.

\section{GEOLOGIC RELATIONS.}

The Milltown andesite overlies the Sandstorm and Morena rhyolites, or the latite where ;hese are absent. While probably made up chiefly of gently inclined lava flows, only obscure races of stratiform structure are visible. Here and there a hill rising above the minor unduations of the surface furnishes a suggestion of one nearly horizontal flow capping another. The general topography of the district, however, and the conditions of exposure are such that almost nothing of the internal structure of the andesite complex is revealed.

One of the best places in the district to observe the effusive character of the andesite and to distinguish the superposition of flows is in the steep slope just east of the northernmost of the three Tognoni Springs. The lower part of the slope is occupied by a poorly exposed and rather decomposed andesite. Above this lies about 40 feet (12 meters) of andesitic tuffbreccia, which is overlain by 50 or 60 feet (15 to 18 meters) of brittle, banded volcanic glass, an andesite vitrophyre, which has been described on page 52. This glassy lava is overlain by dacite, which at this place is probably a flow.

Nowhere in the region adjacent to Goldfield is there, so far as known, a single definite and well-exposed contact between the individual flows of the formation. Yet the occurrence of buffaceous and glassy rocks and the variety in the andesites prove that the formation is really complex.

Andesitic dikes within the Milltown andesite may be present at many localities, but can not ordinarily be distinguished from the effusive members of the formation, owing to similarity in petrographic character and obscurity of exposure.

As already stated, no accurate determination of the thickness of the Milltown andesite can be made. The Yellow Tiger shaft (see PI. VIII, section $F-F^{\prime}$ ) goes through 510 feet (155 meters) of this rock, and the total thickness at this locality prior to erosion is estimated at 700 feet (213 meters). Whether this can be regarded as greater or less than the average for the formation is not known.

\section{DACITE.}

\section{INTRODUCTORY STATEMENT.}

The dacite, whose eruption followed the andesitic period, is in many respects the most interesting rock in the district, and is certainly the most important from an economic point of view. It occupies, as may be seen by reference to Plate II, a considerable area east of Goldfield and Columbia and is the principal country rock of the Mohawk, Combination, January, Jumbo, Redtop, and Florence mines. It is, at least in part, intrusive in the andesite.

The dacite, of which typical and fairly fresh specimens can be collected on the little hill 500 feet (152 meters) northeast of the transformer station, has the general appearance of rather dark andesite. It is usually more conspicuously porphyritic than the andesites of the 
district, but its essential distinction from them is the presence of phenocrysts of quartz. All of these are angular fragments or crystals rounded by magmatic corrosion, and as a rule are neither very numerous nor very conspicuous. The rock consists of labradorite feldspar, hornblende, biotite, augite, and quartz in the usual andesitic groundmass. Chemical analysis of the dacite shows that it contains 60 per cent of silica, or only 2 per cent more than a hornblendic andesite from the northeastern part of the district. . Mineralogically and chemically the dacite at Goldfield is merely a quartz-bearing andesite and is in no way similar to the more siliceous rocks called dacite by Spurr in his report on the Tonopah district. ${ }^{a}$

\section{DISTRIBUTION.}

The dacite that lies just east of Goldfield contains the principal mines of the district. (See Pl. II.) Another large mass of dacite extends southward from near Tognoni Springs to Preble Mountain. This body extends for some miles east of the area included in Plate II and forms the high hills east of Tognoni Springs. In this vicinity the rock is fresh but the southern extension of the mass, particularly that forming the greater part of Preble Mountain, is intensely altered, so much so that the dacite is distinguishable with much difficulty from the similarly altered andesite. Smaller masses of dacite occur just east of Black Butte, in the extreme northeast corner of the district, between Diamondfield and McLaughlin's well, and in the vicinity of Preble Mountain.

The distribution of the dacite is much more irregular than that of the Milltown andesite, the irregularity scarcely admitting any other explanation than that of intrusion. The outlines of the dacite areas, moreover, suggest that this rock cuts the andesite, a suggestion in harmony with the clearly effusive character of the Milltown andesite as a whole.

In two places masses of soft altered latite have been observed which appear to be included blocks in the dacite. One of these is in the Mohawk mine (see p. 207), and the other is on the 500 -foot level of the Winston shaft on the Cornishman claim. The latter mass is about 10 feet ( 3 meters) long and is exposed on one side of a drift which it does not cross. The dacite, which is also somewhat altered, shows a platy structure parallel to the surface of the inclusion.

\section{PETROGRAPHY.}

The unaltered and typical dacite is a dark-gray rock in which the most obvious characteristic, as compared with the Milltown andesite, is a more conspicuous porphyritic texture. Phenocrysts of plagioclase from 5 to 10 millimeters in length are abundant, and in contrast with the dark-gray aphanitic groundmass give the dacite a decided speckled appearance, which is of use as a rough means of recognizing exposures of this rock. Even where greatly altered the dacite, as may be seen on the dumps of the Red Top, Mohawk, Combination, and other mines, still retains a spotted appearance-due to the difference in shade between the pseudomorphs after the feldspar phenocrysts and the altered groundmass - which is rarely found in the altered forms of the andesite. Associated with the phenocrysts of plagioclase are less abundant ones of augite, hornblende, and biotite, the proportions and relative prominence of these ferromagnesian or femic minerals varying in different localities. The phenocrysts of quartz, which constitute the most useful and in many places the only petrographic means of distinguishing the dacite from the andesite, are never abundant and seldom conspicuous. Close inspection of hand specimens, however, will usually reveal the rounded outlines and conchoidal fracture of the quartz which is often more noticeable in altered than in fresh varieties of the rock.

The appearance of the fresh dacite can be well studied on the hill immediately northeast of the transformer station east of Columbia, and in the steep hills just east of Tognoni Springs.

A specimen (G. 97) taken half a mile (0.8 kilometer) northeast of Columbia Mountain, near the point where the dacite wedges out against the Columbia Mountain fault (see Pl. II),

Spurr's reasons for using the name dacite for rocks which should strictly receive other names are given in Geology of the Tonopah district, Nevada: Prof. Paper U. S. Geol. Survey No. 42, 1905, p. 59, footnote. 
was selected for chemical analysis as the freshest obtainable representative facies of this particular dacitic body. The rock analyzed is dark gray, with moderately abundant phenocrysts of clear plagioclase, up to a centimeter in length, in a dark aphanitic groundmass. There are present, also, less numerous phenocrysts of augite and biotite with occasional anhedral ${ }^{a}$ grains of quartz. The volumetric ratio of phenocrysts to groundmass is estimated at rather less than 1 to 3 .

Under the microscope the feldspar phenocrysts prove to be labradorite of the approximate composition $A b_{1} A n_{1}$. They are perfectly fresh, with slightly rounded euhedral ${ }^{b}$ outlines. A noticeable feature is the presence in many crystals of closely crowded minute inclusions of glass, which in some cases constitute cloudy cores or kernels, in others sharply bounded shells, the center of the crystal being clear. The augite crystals are roughly euhedral or subhedral, with a maximum measured extinction angle, $\mathrm{Z} \wedge \mathrm{c}$, of about $45^{\circ}$. The biotite occurs in the usual short, rather irregular pseudo-hexagonal prisms. Both biotite and augite are entirely fresh. The quartz phenocrysts are anhedral, with rounded, embayed, or sharply angular outlines.

Hornblende is very abundant, but is confined almost exclusively to the groundmass, most of the crystals being comparable in size rather with the feldspar microlites than with the phenocrysts just described. The general color is yellowish green, the pleochroism being $\mathrm{X}$ yellow, $\mathrm{Y}$ yellow-green, and $\mathrm{Z}$ brownish green, and the absorption $\mathrm{Z}>\mathrm{Y}>\mathrm{X}$. Neither the biotite nor the hornblende shows any magmatic resorption or pseudomorphism. The largest hornblende crystal in the thin section studied is about half a millimeter in length. It should be said, however, that in dacite from other parts of the district the hornblende occurs as phenocrysts.

The feldspar microlites in the groundmass are at least in part labradorite of as calcic composition as the phenocrysts. They, the hornblende, and a little magnetite and apatite are embedded in an abundant glass, which in transmitted light is gray, with incipient crystals (crystallites). There is one crystal of titanite, 0.3 millimeter in length, in the thin section studied.

The chemical analysis, by Mr. George Steiger, is given below, under 1.

Chemical analyses of dacite.

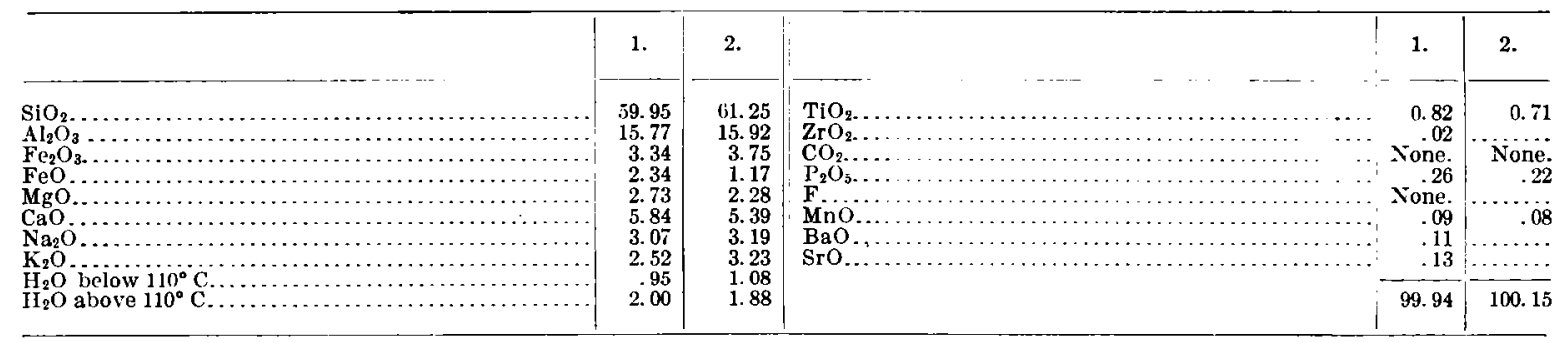

1. Dacite (G. 97), one-half mile ( 0.8 kilometer) northeast of Columbia Mountain. Intrusive.

2. Dacite (G. 83), Diamiond Peak. Effusive.

The norm calculated from analysis 1 is as follows:

Norm of dacite one-half mile northeast of Columbia Mountain.

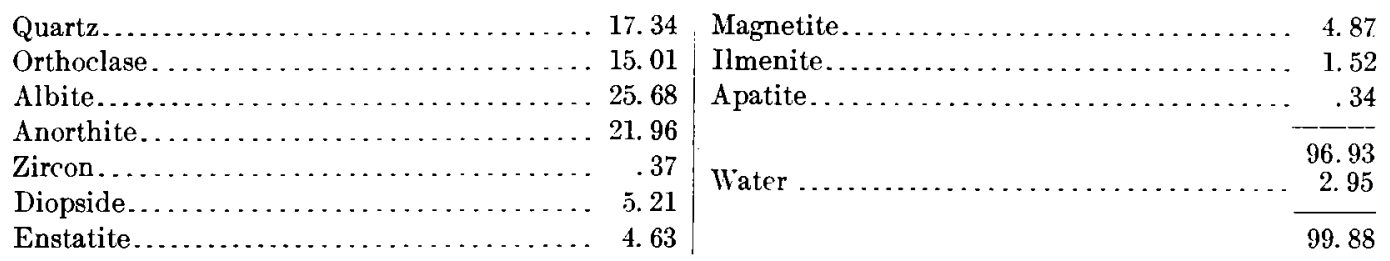

${ }_{a}$ Anhedral $=$ without crystal faces, xenomorphic, allotriomorphic. See Cross, W., Iddings, J. P., P'irsson, I. V., and Washington, H. S., The texture of igneous rocks: Jour. Geology, vol. 14, 1906, p. 698.

$b$ Euhedral = bounded by crystal faces; idiomorphic, automorphic. 
This dacite, like the andesite previously described, is a tonalose in accordance with the nomenclature of the quantitative system. It is, however, close to the sodipotassic subrang harzose in the same quardofelic order, austrare.

Another specimen of dacite (G. 83) selected for analysis comes from Diamond Peak, one-half mile (0.8 kilometer) east-southeast from Tognoni Springs and just outside the area mapped in Plate II. Like most of the dacite in this part of the district, it is more conspicuously porphyritic than the rock just described, the dark-gray groundmass being thickly strewn with crystals of plagioclase up to a centimeter in length, with abundant sparkling phenocrysts of hornblende and biotite. The volumetric ratio of phenocrysts to groundmass is estimated at nearly one to two.

Under the microscope, the rock closely resembles the dacite from near the transformer station. The plagioclase is labradorite ranging from $A b_{1} A_{n}$ to $A_{3} A_{4} n_{4}$. The hornblende is of the same character as in the facies last described, but in addition to occurring in the groundmass it forms phenocrysts up to 2 or 3 millimeters in length. These crystals exhibit no magmatic resorption or paramorphism. The section, however, shows one or two aggregates of hornblende, augite, and magnetite that are suggestive of paramorphic change of an earlier generation of hornblende phenocrysts.

Quartz occurs in the thin section of this specimen in two or three small, rounded, embayed phenocrysts. It is more abundant and conspicuous in other specimens from the same rock mass.

The groundmass is a colorless glass crowded with crystallites and with microlites of p'agioclase and hornblende. No titanite was observed in this rock, the accessory minerals being magnetite and apatite.

The chemical analysis of this rock is given under 2, on page 56. The calculated norm from analysis 2 is as follows:

Norm of dacite from Diamond Peak.

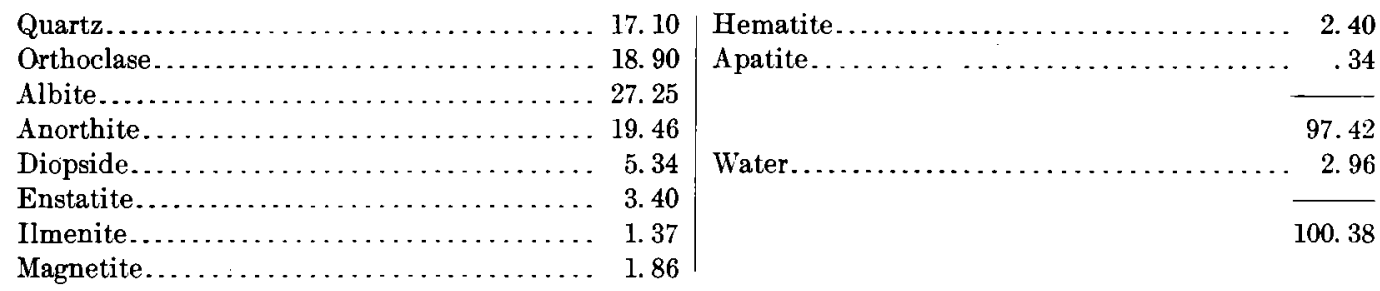

This norm corresponds to a harzose, near tonalose. In the ordinary classification the rock is a dacite, close to quartz latite.

The mass of dacite which is partly mapped in Plate II as a small area in the extreme northeast corner of the district is composed of a very fresh rock of different appearance from the dacite near Goldfield or near Tognoni Springs. This variety is rather light gray with moderately abundant phenocrysts of plagioclase, hornblende, augite, and biotite in a dense aphanitic groundmass.

The microscope shows that this rock, in spite of its different aspect, is practically identical in mineralogical composition and texture with the dacite from Diamond Peak. The quartz phenocrysts are few and small and might easily be overlooked in a casual examination of a thin section. Some of the hornblende and biotite crystals show incipient peripheral change to magnetite and augite.

The groundmass consists of microlites of plagioclase and augite, with grains of magnetite in a pale-brown to colorless glass containing crystallites. The rock is absolutely fresh.

In general the fresh dacite, wherever found, is remarkably uniform in character, as seen under the microscope. The rock, however, has been extensively altered, and even moderately fresh rock is not the most common except in the northeastern part of the district. Much of the dacite is so changed in appearance by this alteration that one unfamiliar with the various stages of the process and unable to resort to petrographical methods would be quite unable to identify it. 
A comparatively inconspicuous mode of alteration consists in the change of the plagioclase and augite to calcite, which may be accompanied by quartz; of the biotite to epidote and chlorite with some form of iron oxide; and of the hornblende to dark aggregates of finely disseminated magnetite and quartz. Such alteration may usually be recognized by the lusterless greenish-gray tint of the rock and the dullness or opacity of the plagioclase phenocrysts.

Another much more intense process of alteration, which is well exemplified in the vicinity of Preble Mountain and in the mines near Goldfield, changes the rock to a light-gray or white mass in which the occasional small phenocrysts of quartz are all that remain of the original minerals of the dacite. The feldspars, most of them still recognizable from their outlines, are no longer clear and vitreous, but are dull and chalky. The microscope shows that the principal constituents of such altered rock are quartz and alunite, the hydrous sulphate of aluminum and potassium. In some varieties kaolinite is present with the alunite; in still others the rock is chiefly quartz and kaolinite. A more detailed account of this alteration and of the further stage of complete silicification will be given in Chapter XIV.

\section{GEOLOGIO RELATIONS.}

Most of the dacite within the area covered by the geologic map (Pl. II) is regarded as intrusive into the Milltown andesite and older rocks. As this important fact is not obvious, and as the dacite is known to occur as an effusive rock associated with dacitic breccia just east of Tognoni Springs, the evidence bearing upon the question whether the dacite of the district is intrusive requires detailed consideration.

At one point only within the district, so far as known, is a contact between unaltered dacite and andesite exposed. This is near the eastern border of the district, 1,300 feet ( 396 meters) in a direction N. $26^{\circ} \mathrm{W}$. from the sharp summit of Espina Hill. At this place a little saddle is occupied by dacite between an isolated area of andesite on the west and volcanic breccia on the east. (See Pl. VIII, section $A-A^{\prime}$.) The andesite is a fine-grained compact variety and looks younger and fresher than the dacite. The latter, however, contains fragments of the andesite and has a noticeably glassy selvage band within half an inch (12 millimeters) or less of the sharp irregular contact. The dacite shows some flow structure near the contact, and the intrusion presumably took place very close to the then existing surface.

The large body of dacite northeast of Goldfield has the general form of an irregular sheet with a present maximum thickness of about 700 feet (213 meters). Its outline is very irregular. Along the east side of Columbia Mountain the dacite ends against the Columbia Mountrin fault. (See Pl. II.) South of the town of Columbia the rock extends westward across the line of the fault and is in part overlapped by the younger Siebert formation. Surface exposures in this vicinity throw no light whatever on the character of the contact between the dacite on the one hand and the latite and Kendall tuff on the other. The artificial exposures underground are scarcely more satisfactory. Some shafts sunk by lessees west of the Red Top mine might at one time have afforded valuable information; but in this district shafts from 200 to 400 feet (61 to 122 meters) deep are often put down and abandoned within a few months. They soon become inaccessible or unsafe, those who sank them disappear, and only the dump is left to perplex and tantalize the geologist.

The workings of the Red Top, Mohawk, Combination, and January mines all show the dacite to be in contact along its western border with latite. On the whole, this contact, as illustrated in Plate VIII, section $\mathrm{C}^{-} \mathrm{C}^{\prime}$, has a general dip east, the average angle being from $30^{\circ}$ to $40^{\circ}$. The rocks in its vicinity are generally altered and soft. Partly in consequence of this condition they are disturbed and are traversed by many seams of muddy gouge. There has been considerable movement along the contact, whatever its original character, and its present appearance in individual exposures is that of a fault plane. Detailed study of the mines shows, however, that these planes are not continuous and that the contact is more irregular than it should be were the dacite here bounded on the west by a fault. On the 450-foot level of the Mohawk mine the main latite-dacite contact is at the Mohawk shaft. From this shaft a west crosscut to the Mackenzie shaft goes through latite for 400 feet (122 meters), then enters dacite and continues 
in this rock for 250 feet ( 76 meters) to the face. (See Pl. VIII, section C-C'.) As usual the contact is disturbed, but this dacite west of the Mackenzie shaft is thought to be a dike which has come up through the latite and connects with the dacite sheet above.

In the lower levels of the Mohawk mine and in parts of the Combination mine ore has been found at the contact, partly in dacite and partly in latite. In such places the contact, much obscured by the mineralization, appears to be of the irregular kind characteristic of igneous intrusion.

On the whole, while much remains to be learned, the evidence relating to the dacite-latite contact west of the Red Top, Mohawk, and Combination mines is thought to indicate that it was originally intrusive and that it has since been modified by many local faults. As will later be shown, the whole body of dacite containing the principal mines has been racked by movements which have transformed joints, contacts, and other planes of weakness into gouge-filled fissures.

On the south the dacite is in contact with the Milltown andesite. When the preliminary report was issued it was thought probable that this contact dipped gently to the south, such a supposition being a reasonable conclusion from the general relation of the geologic boundary between the two rocks to the topography. The Florence was then the only shaft that had penetrated the Milltown andesite in this locality and the exposures it afforded lent some support to such a view. (See Pl. VIII, section $\mathbf{F}-\mathrm{F}^{\prime}$.) It is now known that the contact is in general very steep and that the andesite near Milltown rests not on dacite, but on latite. In the Florence workings the contact is much obscured by the alteration of the rocks. It is apparently close to the shaft on the 150-foot level and only 20 to 30 feet (6 to 9 meters) south of the shaft on the 250-foot level. (See fig. 28). The Little Florence shaft, 500 feet (152 meters) south of the Florence shaft and 500 feet deep, is all in andesite. The Rosebud, Rogers, Florence Annex (Engineer's Lease), Pollard-Florence, and Florence-Extension No. 2 shafts, all 500 feet (152 meters) deep, and all on the southeast slope of Florence Hill, show andesite as the prevalent rock to the bottom. It thus appears that in this locality not only does the dacite abut against the Milltown andesite with a nearly vertical contact, but the latter rock extends to unusual depth (see Pl. VIII, section G-G') and probably occupies one of the fissures or conduits through which the andesitic flows issued. At one place on the 509-foot level of the Ragers lease a narrow slab of mineralized dacite between andesite walls has been drifted on for a short distance. It is probably a small dike.

On the south slope of the little hill north of Milltown the Baltimore Belle shaft, 375 feet (114 meters) deep, is all in andesite. Farther east the Atlanta-Cherokee shaft, 500 feet (152 meters) deep and, as shown on Plate II, very close to the dacite contact, is nearly all in andesite. A little dacite was cut near the bottom, but this, probably an intrusive offshoot from the main body to the north, was penetrated and andesite was found below it. The Garrison shaft, just northeast of the Atlanta-Cherokee, is in dacite at the surface, but the bottom, at 300 feet (91 meters), is in andesite. Both dacite and andesite occur at the 250 -foot level, the relations of the two rocks being suggestive of irregular intrusion of the andesite by the dacite. Alteration and disturbance of the rocks, however, render interpretation of the observed relations uncertain. Near this shaft the contact crosses the ridge and swings north of the line of shafts, which continues southeastward along the crest to the Gold Bar and Victor mines. The Gold Bar workings, 300 feet (91 meters) deep, are mainly in andesite and latite, the latter being the rock of the 300foot level. Considerable dacite is exposed on the 200-foot level, however, where it apparently occurs as irregular masses in the andesite. The rocks in this mine are generally much altered and disturbed so that contacts as a rule are very obscure. At one place, however, on the 200foot level, west of the shaft, a little intrusive tongue of dacite projecting into andesite was plainly discernible in 1908. Although both rocks were soft and altered the sharp irregular contact was distinct, and specimens have since been microscopically identified as andesite and dacite.

Of the contact along the eastern and northern sides of the main dacite sheet little more is known than appears from the map (PI. II) and structure sections (Pl. VIII). It is poorly exposed and has not been much explored underground. The boundary corresponding to the 
contact is sinuous, and in general defines the thin edge of the dacite sheet which rests for the most part on Milltown andesite, but in some places on latite or Sandstorm rhyolite.

Practically nothing is known concerning the detailed character of the contacts of the other bodies of dacite, such as that near Black Butte and those in the vicinity of Preble Mountain. These contacts are either not actually exposed or are so blurred by the intense alteration of the rocks that the only information they furnish is such as is deducible from their courses on the map and from the relation of these to the topography. This information alone, however, is demonstrative of intrusion. If the boundary of the dacite mass of Preble Mountain, for example, be supposed reasonably accurate, if it be carefully considered with reference to the slopes which it traverses (see Pl. II), and if the attempt be made to get from this inspection an idea of the shape of the mass, this shape is found to be consistent only with the hypothesis of irregular intrusion of the dacite into the andesite.

Finally the dacite as a whole does not accord with the general concentric plan which has resulted from the doming and erosion of a series of originally nearly horizontal lava flows. Reference to Plate II shows that it cuts across the annular area of Milltown andesite from west to east.

So far as the mapped area is concerned the evidence for the generally intrusive character of the dacite may be regarded as sufficient. It appears, however, that the intrusion took place under a cover of andesitic rocks which was comparatively thin, and that some of the dacite broke through and was erupted at the surface. The textural uniformity of the dacite and the comparatively slight extent to which the hornblende and biotite have undergone paramorphic change both suggest that the magma solidified under conditions of pressure and temperature such as would be afforded by intrusion under some load. On the other hand, the comparative thinness of the former cover is indicated by the presence of some glass in the groundmass of the dacite and the absence of any recognizable contact metamorphism of the andesite by the invading rock.

Some additional reconnaissance east of the mapped area in 1908 showed that in the neighborhood of Tognoni Springs a transition takes place from intrusive dacite on the west to effusive dacite on the east. A mile or two east of these springs, on the east slope of the first high hill east of Diamond Peak, are exposed the edges of a series of lava flows dipping gently to the west. At the base of the section observed is a flow of rather dense andesite overlain by a dark-gray andesite vitrophyre like that which may be seen on the slope just northeast of Tognoni Springs. (See p. 52.) Resting on this glassy flow is an unstratified dacitic breccia from 200 to 300 feet (61 to 91 meters) thick composed wholly of fragments of dacite and containing angular blocks and bomblike masses up to 6 feet (1.8 meters) in diameter. This deposit is overlain by a flow of massive dacite of approximately equal thickness.

A mile (1.6 kilometers) or less east of the section just described another hillside exposes a flow of dacite resting on glassy andesite without any intervening breccia. Above the typical dacite is a flow of volcanic glass, probably dacitic, and overlying this a flow of rhyolite which is thought to be the Meda rhyolite.

Diamond Peak, which lies just east of the mapped area and is the culminating point of the steep slope east of Tognoni Springs, is composed mainly of dacite. This is apparently a flow, several hundred feet thick, which dips gently westward and passes directly, with no essential change in petrographic character, into the dacite south of the springs. This in turn is directly continuous with the dacite of Preble Mountain, supposed to be intrusive.

It thus appears that in the Goldfield district there is a remarkable transition from an intrusive rock to an effusive one. The imaginary restoration of the conditions under which the eruption took place is somewhat difficult. The familiar conception of narrow vertical dikes connecting with overlying lava flows has no application here and no sharp distinction seems possible between the intruded and extravasated dacite. The magma appears to have irregularly invaded the older rocks, to have lifted these in part as an overlying crust, and to have poured through various ragged rents in this comparatively thin cover. The locus of one such rent is supposed to lie between Preble Mountain and Tognoni Springs, most of the dacite west 
of this line being intrusive and most of that east of it effusive. The breccias to the east of the mapped area prove that the outbreak of dacitic magma was accompanied by explosive activity.

That transitions similar to the one just described must have occurred countless times in the history of the earth is obvious. It is rare, however, that erosion has progressed just far enough to reveal but not obliterate them. It is the realization of these unusual conditions that has led to skeptical scrutiny of the evidence for intrusion in the case of the dacite near Goldfield and to the presentation of that evidence in more detail than would otherwise be necessary.

\section{DACITE VITROPHYRE. $a$}

\section{geNeral CHARACTER AND OCCURRENCE.}

The dacite vitrophyre is a volcanic formation, consisting of thin lava flows with one or more ash beds, which as a whole rests upon an uneven surface of andesite and is overlain by the Meda rhyolite, andesite breccia, and deposits of the lacustrine epoch. Its age, so far as fixed by the general geological succession, is thus the same as that of the dacite. The vitrophyre is limited to the southern part of the district and extends from the vicinity of Myers Mountain southeastward past Blackcap Mountain and beyond the boundary of the area mapped. With some Chispa andesite it forms a series of low, rounded, light-colored hills (Chispa Hills), crosser by the freight road from Goldfield to the Bullfrog district and skirted on the north by the Gold Crater road. The details of distribution may be had from Plate II.

\section{PETROGRAPHY.}

The most abundant and characteristic material of the formation is a very light gray or nearly white rock, often with a faint tinge of green or pink. The texture is apparently porous, although the microscope shows this appearance to be in most cases misleading. The comparative softness of the material and the presence of blotches in the glassy groundmass give it considerable resemblance to a tuff. The rock is, in most places, finely speckled with small scales of biotite and contains less noticeable crystals of feldspar and quartz.

A typical specimen (G. 158) collected alongside of the Gold Crater road, 1 mile (1.6 kilometers) southwest of Blackcap Mountain, was selected for description and chemical analysis.

The rock is light greenish gray with irregular greenish blotches. Flakes of biotite, a millimeter or two in diameter, and larger phenocrysts of quartz and clear feldspar are distributed through a dull aphanitic groundmass. Under the microscope (Pl. VII, $B$ ) the rock shows a typical vitrophyric structure, phenocrysts of vitreous plagioclase, biotite, and quartz being embedded in a eutaxitic glass. The plagioclase is in part labradorite, near $\mathrm{Ab}_{2} \mathrm{An}_{3}$ in composition, but other varieties may also be present. There is, in the section studied, a single phenocryst of hornblende partly changed to an aggregate consisting chiefly of magnetite. The groundmass is almost wholly glass, partly transparent, and partly gray and cloudy, with incipient crystal growths. Streaks of these different varieties of the glassy base, drawn out by flowage, give the rock its blotchy appearance in hand specimens and its eutaxitic structure as seen under the microscope.

A chemical analysis of this rock, made in the Survey laboratory by George Steiger, is as follows:

Chemical analysis of dacite vitrophyre.

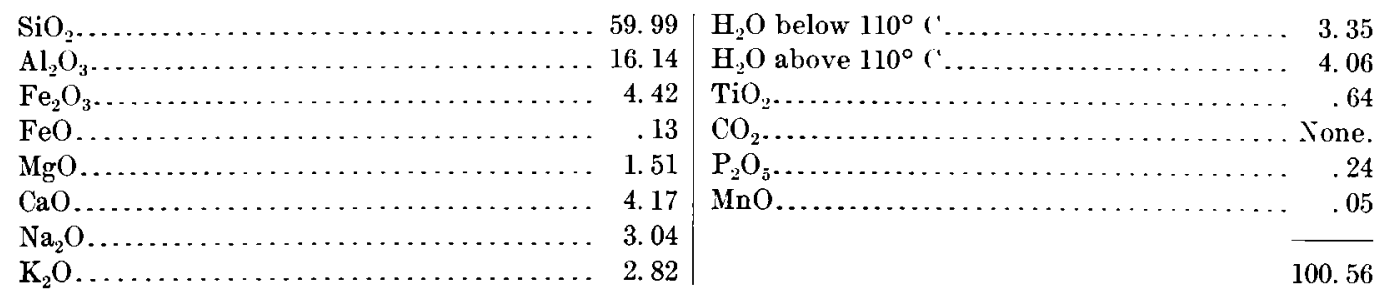

a In the preliminary report (Bull. U. S. Geol. Survey No. 303, 1907, p. 18), written before the rocks had been thoroughly studied, the forma tion here designated dacite vitrophyre was provisionally called quartz-latite. 


\section{PLATE VII.}

\section{Photomicrographs of Volcanic Rocks.}

A. Hornblende-biotite-augite andesite (G. 47). Northeast corner of district, $1 \frac{1}{2}$ miles east of Black Butte. Contains phenocrysts of labradorite (l), hornblende (h), biotite (b), and augite (not shown in section) in a glassy hyalopilitic groundmass $(\mathrm{g})$. Ordinary light. Magnified 40 diameters.

$B$. Dacite vitrophyre (G. 163). Southern edge of district, 13 miles southwest of Preble Mountain. Contains phenocrysts of plagioclase ( $p$ ) near oligoclase in composition, biotite (b), and quartz ( $q$ ), in a eutaxitic brown glass (g) containing shreds of clearer glass $\left(\mathrm{g}^{\prime}\right)$. This variety probably approaches quartz latite or rhyolite in composition. Hole in section (h). Ordinary light. Magnified 35 diameters.

C. Olivine basalt (dolerite) (G. 2). Edge of Malpais Mesa above Rabbit Spring. Contains phenocrysts of anorthite (a), olivine (o) partly altered to red-brown serpentine and an occasional crystal of hornblende (not shown). The holocrystalline groundmass (g) is composed of plagioclase (labradorite or anorthite), augite, olivine, magnetite, a little interstitial calcite, and apatite. Nicols crossed. Magnified 40 diameters.

D. Mica basalt (dolerite) (G. 46). Northeast corner of district, 2 miles east of Black Butte. Contains anorthite (a), a bright chestnut biotite (b), augite (p), olivine (not shown), calcite (c), magnetite and apatite. There is no sharp distinction between phenocrysts and groundmass. The biotite projects into irregular miarolitic cavities, many of which are partly filled with calcite. The minerals are all fresh except the olivine, which is altered to deep red-brown serpentine. Hole in section (h). Nicols crossed. Magnified 40 diameters. 

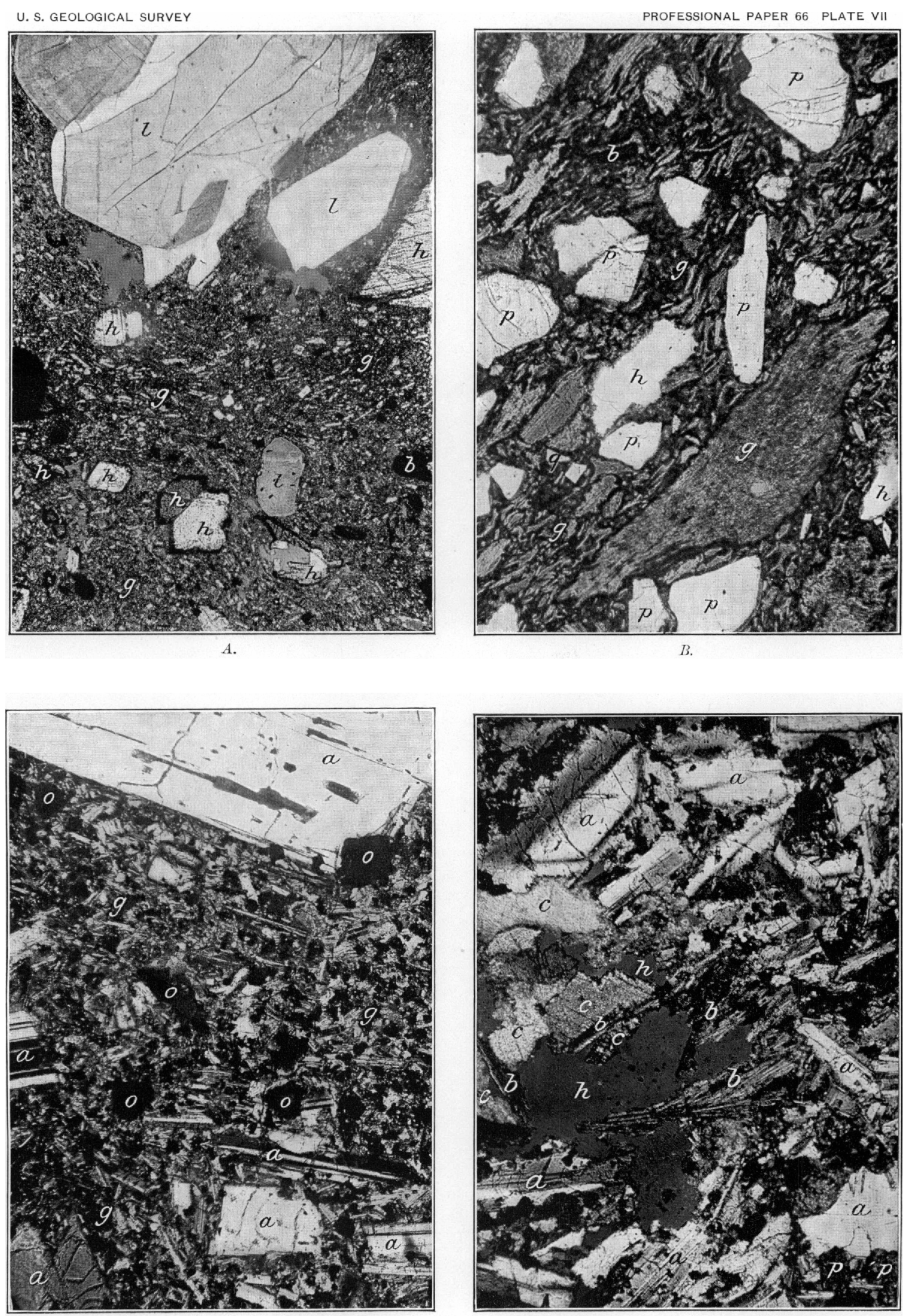

PHOTOMICROGRAPHS OF VOLCANIC ROCKS. 

A remarkable feature of this analysis, and one not easily accounted for, is the unusual ratio between the ferrous and ferric iron. As the rock is perfectly fresh, containing no hematite and very little augite, it would seem that ferrous iron should be much more abundant than the ferric form, inasmuch as in biotite and magnetite the ferric iron is normally combined with respectively greater and equal amounts of the divalent form. Three determinations of the iron were made by Mr. Steiger and two additional determinations, by another method, were carried out by Doctor Hillebrand. All agree so closely as to show that the abnormal ratio is not due to defective analysis. As there is apparently enough magnetite in the rock to account for all the ferrous iron found it seems necessary to conclude that the biotite is of unusual composition and that probably some iron in the ferric state is present in the glass of the groundmass. ${ }^{a}$

The norm calculated from this analysis is as follows:

\begin{tabular}{|c|c|c|c|}
\hline \multicolumn{4}{|c|}{ Norm of dacite vitrophyre. } \\
\hline Quartz...... & 20.76 & Ilmenite.... & .30 \\
\hline Orthoclası............................ & 16. 68 & Titanite......... & 1. 18 \\
\hline Albite....................... & 25.68 & & \\
\hline Anorthitc $\ldots \ldots \ldots \ldots \ldots \ldots \ldots \ldots \ldots \ldots$ & 18.90 & & 92.90 \\
\hline Corundur: $\ldots \ldots \ldots \ldots \ldots \ldots \ldots \ldots$ & 1. 12 & Water... & 7. 41 \\
\hline Enstatite $\ldots \ldots \ldots \ldots \ldots \ldots \ldots \ldots \ldots \ldots \ldots$ & 3.80 & & \\
\hline Hematite.$\ldots \ldots \ldots \ldots \ldots \ldots \ldots \ldots$ & 4. 48 & & 100.31 \\
\hline
\end{tabular}

The rock is amiatose, in the persalane class, britannare crder, alkalicalcic rang and sodipotassic subrang, of the quantitative classiication. It is practically on the line, however, between amiatose and the unnamed dopotassic subrang of the same rang and order.

The only rock falling in this unnamed subrang in H. S. Washington's tables of analyses ${ }^{b}$ is a so-called retinite, described by V. Sabatini and analyzed by G. Aichino. This analysis is here quoted for comparison with the dacite vitrophyre.

Chemical anal:/sis of retinite. $c$

\begin{tabular}{|c|c|}
\hline 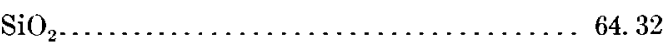 & $\mathrm{NaO} \ldots \ldots \ldots \ldots \ldots \ldots \ldots \ldots \ldots \ldots \ldots \ldots \ldots \ldots \ldots \ldots$ \\
\hline $\mathrm{Al}_{2} \mathrm{O}_{3} \ldots \ldots \ldots \ldots \ldots \ldots \ldots \ldots$ & $\mathrm{K}_{2} \mathrm{O} \ldots \ldots \ldots \ldots \ldots \ldots \ldots \ldots \ldots \ldots \ldots$ \\
\hline $\mathrm{Fe}_{2} \mathrm{O}_{3} \ldots \ldots \ldots \ldots \ldots \ldots \ldots \ldots \ldots \ldots \ldots \ldots \ldots \ldots \ldots \ldots \ldots$ & $\mathrm{H}_{2} \mathrm{O} \ldots \ldots \ldots \ldots \ldots \ldots \ldots \ldots \ldots \ldots \ldots \ldots$ \\
\hline $\begin{array}{l}\mathrm{Fe} O \ldots \\
\mathrm{MgO} \ldots \ldots \ldots \ldots \ldots \ldots \ldots \ldots \ldots\end{array}$ & \\
\hline
\end{tabular}

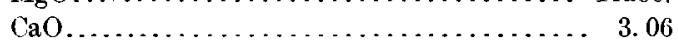

The interesting feature of the comparison is the considerable difference between the analysis here quoted and that of the dacite vitrophyre, which very narrowly escapes falling into the same subrang.

A mile and a half (25 kilometers) south of Preble Mountain (one-fourth mile outside of the area mapped) a quarry has been opened in a bed of white volcanis ash, and the material, although very soft, has been used for buildings in Goldfield. It is composed almost entirely of small particles of volcanic glass with a few crystals or fragments of biotite, feldspar, and quartz. No chemical analysis has been made of this tuff, but it probabiy corresponds in composition to the dacite vitrophyre with which it is associated.

\section{RELATION TO THE DACITE.}

As the dacite vitrophyre has not the slightest physical resemblance to the dacite, it was at first supposed that the vitrophyre was the younger rock-the product of eruptions, that may have been separated from the dacite by a considerable interval of deformation and erosion. This

a Since this was written the Swedish chemist Robert Mauzelius has found that the ferrous iron of minerals may be partly oxidized during the grinding preparatory to analysis. W. F. Hillebrand (Jour. Am. Chem. Soc., vol. 30, 1908, pp. 1120-1131), in whose paper may be found references to earlier work, has recently confirmed and extended the experiments of Mauzelius and others. This discovery may account in part for the unexpected ratio of ferrous and ferric iron in the dacite vitrophyre, but there has been no opportunity to test this before the report goes to press.

b Prof. Paper U. S. Geol. Survey No. 14, 1903, p. 183.

c Sabatini, V., Descrizione geologica delle Isole I’ontine: Boll. R. Comitato geol. ital., vol. 24, 1893, p. 252. 
was the view expressed in the preliminary report. ${ }^{a}$ Subsequent petrographic study, however has shown that the vitrophyric dacite has some mineralogical features in common with the intrusive dacite, and chemical analyses prove that the two rocks are nearly identical in chemical composition. In order to illustrate this chemical likeness, the analyses of the dacite rocks are here given side by side.

Chemical analyses of dacite and dacite vitrophyre.

[George Steiger, analyst.]

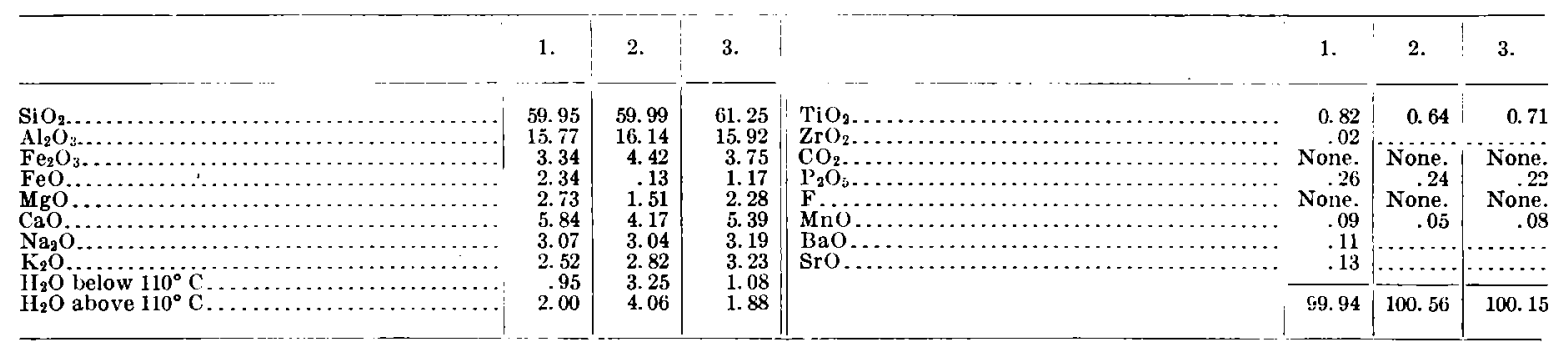

1. Dacite, one-half mile ( 0.8 kilometer) northeast of Columbia Mountain.

2. Dacite vitrophyre, 1 mile (1.6 kilometers) southwest of Blackcap Mountain.

3. Dacite, Diamond Peak, one-half mile (0.8 kilometer) east-southeast of Tognoni Springs.

The vitrophyre, owing to the abundance of glass, contains a larger quantity of water than the more crystalline rocks. It has somewhat less iron, calcium, and magnesium, but the chemical difference is no greater than may obtain in rocks known to be the products of a single eruption. The vitrophyre, as has been shown, falls into the persalane class of the quantitative classification, while the dacite is in the dosalane class. Both rocks, however, are near the border line between the two arbitrary classes, and any such definite scheme of artificial grouping necessarily separates many rocks which are chemically very close together.

Were the dacite and dacite vitrophyre separated in geologic time by an interval of erosion or by the eruption of some other lava, the resemblance would be regarded as a rather remarkable coincidence. As it is, the two rocks are known to be of nearly the same age. Whether they were simultaneously erupted, the vitrophyre as an effusive equivalent of the dacite, can not be determined from the data available. The fact that dacite known to be effusive east of Tognoni Springs has the same general habit as the intrusive dacite near Goldfield, whereas the dacite vitrophyre is a rock of wholly different aspect, suggests that the eruptions of the dacite and dacite vitrophyre were not strictly contemporaneous. The vitrophyre is probably slightly younger.

\section{CHISPA ANDESITE.}

\section{GENERAL CHARACTER AND OCCURRENCE.}

The Chispa andesite occurs as flows intercalated in the dacite vitrophyre. A traverse of the Chispa Hills shows five of these flows, of which the northern ends of two only come into the area mapped (PI. II). They dip to the southwest with the dacite vitrophyre at angles up to $50^{\circ}$. There is evidently some faulting in this vicinity, and it is possible that some of the apparently distinct flows may be repeated exposures of the same lava sheet in successive fault blocks. All the dark andesite bands, which contrast in color with the light dacite vitrophyre, end rather abruptly on the northwest in a manner suggestive of faulting. The larger of the two areas shown in Plate II is in contact along its northern border with the Milltown andesite. This contact is covered by soil and wash and is further obscured by the deep decomposition of the rocks. Its position is uncertain and nothing is known of its characte:. It may correspond to a fault.

\section{PETROGRAPHY.}

The Chispa andesite is generally a brownish-gray porous rock. The most abundant of the small phenocrysts are augite, and, with less conspicuous feldspars, are embedded in a brown aphanitic vesicular groundmass. The microscope shows the rock to be an ordinary fresh 
glassy augite andesite with no special features. The phenocrysts of augite, plagioclase, and magnetite lie in a turbid microlitic glass. A few aggregates of smaller individuals of these minerals appear to represent resorbed hornblende.

\section{ANDESITE DIKES.}

Cutting the Milltown andesite, dacite vitrophyre, and Chispa andesite in the southeastern corner of the district are a few dikes of a still younger andesite. Possibly similar dikes occur elsewhere, but in most places it would be impossible to distinguish them if present from the mass of the Milltown andesite. Many exposures originally supposed to be dikes were found afterwards to be merely unaltered parts of the andesite, which in some localities outcrop from the softer disintegrated material around them in a manner strongly suggestive of younger intrusions.

The dike andesites are as a rule not particularly fresh, and no special petrographic study was made of them. Some show phenocrysts of hornblende, but the microscope proves them to be for the most part rather feldspathic rocks with subordinate femic constituents. The groundmass ccntains considerable glass, and a vesicular texture is not uncommon. It appears therefore that the parts of the dikes now visible were never far from the surface.

\section{MEDA RHYOLITE.}

\section{GENERAL CHARACTER AND OCCURRENCE.}

The Meda rhyolite, which takes its local name from Meda Pass, is exposed in the vicinity of the pass and close to the road south of Myers Mountain. Two small areas of rhyolite in the northeast corner of the district, parts of a much larger area to the east, are supposed to represent the same epoch of eruption and are mapped as Meda rhyolite, although it is not certain that they were ever continuous with the rhyolite near Meda Pass. The rock is a flow which northeast of Tognoni Springs rests on Milltown andesite and dacite and in the southern part of the district on clacite vitrophyre. It probably varies much in thickness.

PETROGRAPIIY.

The rhyolite of the type locality near Meda Pass varies in color from light gray to pink. Some of it has a well-marked flow structure which is accentuated by many narrow lenticular streaks of obsidian. Small phenocrysts of feldspar and quartz are abundant although not conspicuous. The microscope shows the rock to be a fresh glassy rhyolite vitrophyre in which the phenocrysts of quartz and orthoclase are accompanied by less abundant crystals of plagioclase and biotite. The plagioclase is mostly oligoclase. Some of the rock northeast of Meda Pass is a little more crystalline than the variety just described and contains more abundant scales of biotite. It is this latter facies that is exposed south of Myers Mountain.

The rhyolite mapped in the northeastern corner of the district is a light reddish-gray variety with abundant small phenocrysts of quartz which, with crystals of orthoclase and biotite, are embedded in a eutaxitic groundmass. East of the area mapped this rock grades into more crystalline varieties.

\section{ANDESITE BRECCIA.}

About half a mile ( 0.8 kilometer) southeast of Meda Pass the northern end of a body of andesite breccia barely comes into the area mapped. This is a bedded deposit and consists of fragments of andesite, mostly scoriaceous and more or less decomposed, firmly cemented in a matrix of andesitic tuff. The fragments are rarely over 6 inches (15 centimeters) in diameter. The breccia rests upon the Meda rhyolite, or where this is absent on the dacite vitrophyre. It dips gently to the southwest and is overlain by tuffs supposed to be part of the Siebert formation. It is probable that this breccia was laid down contemporaneously with the intrusion of the andesite dikes noted above. 


\title{
CHAPTER V.
}

\section{ROCKS OF THE LAKE EPOCH.}

\section{INTRODUCTION.}

In the Tertiary lake that probably covered much of the district after the eruption of the dacite, dacite vitrophyre, Meda rhyolite, and andesite breccia, there were laid down over 500 feet (152 meters) of bedded tuffs, tuffaceous sands, pumiceous ash, conglomerates, and diatomaceous earth. These are the deposits known to the miners as "cement rock." Volcanism continued during the existence of the lake, as shown by the prevailingly volcanic character of the sediments and the occurrence within them of a thick flow of quartz-bearing basalt (Mira basalt) and a few thin flows of glassy rhyolite. The Mira basalt, as shown by wells, underlies the southwestern part of Goldfield and it is exposed on the automobile road to Bullfrog. Lacustrine conditions were ended by deformation of the region, the domical structure probably being initiated by this uplift.

The sedimentary deposits of the lake epoch will in this report be called the Siebert formation, being regarded as the equivalent of the Siebert tuff of the Tonopah district, described and named by Spurr. ${ }^{a}$

\section{SIEBERT FORMATION.}

\author{
DISTRIBUTION.
}

The beds of the Siebert formation are prevailingly rather soft and disintegrate readily. Consequently they do not as a rule give rise to prominent outcrops. They underlie the town of Goldfield and occupy the valley to the north through which passes the railway to Tonopah. South of Goldfield they cover a large area, Myers Mountain and similar eminences in that direction being made up of these beds capped by basalt. They also underlie much of the basaltic mesa southwest of Goldfield and some of the best exposures of them are in the steep sides of the mesa near Pozo Canyon. (See Pl. II.) Other areas extend into the northern part of the district and deposits belonging to this formation undoubtedly underlie a large part of the desert plains which surround the Goldfield Hills.

\section{LITHOLOGY.}

The sediments of the Siebert formation exhibit a wide range of character, although they consist almost entirely of volcanic and diatomaceous material, the former greatly predominating.

Most of the material exposed or penetrated in wells near Goldfield consists of soft, sandy tuffs alternating with beds of volcanic conglomerate or gravel. The bedding is in most places fairly regular, but in small exposures is not always clearly distinguishable from cross-bedding. In the 100-foot well of the Columbia Ice and Cold Storage Company the gravel or conglomerate beds are said to occur every 20 to 30 feet ( 6 to 9 meters) and to be from 1 to 2 feet ( 0.3 to 0.6 meter) thick.

The soft, light-gray, sandy beds which constitute most of the formation as exposed near Goldfield and in the valley to the north are composed almost entirely of volcanic ash. The constituent particles, as seen under the microscope, are chiefly angular bits of transparent

a Spurr, J. E., Geology of the Tonopah mining district, Nevada: P’of. Paper C. s. Geol. Survey No. 42, 1905, pp. 51-55. 
glass. These show so little rounding as to indicate that the material either was transported only for very short distances by streams or else fell directly as ash showers into the waters of Siebert Lake. In some beds the minute size of the particles suggests that the material was blown from some vent as fine dust, such as might be carried for many miles by winds.

With the tuffs are associated some thin beds of diatomaceous earth, distinguishable from the ash beds by their whiteness and lightness. There is in some places, however, a gradation from tuff into the organic deposit. The purest form of diatomaceous earth was found in the northwest corner of the area mapped, near the point where the electric-power line enters the district. The material is cream color, exceedingly light, and splits into paper-thin leaves. A little of the powder when covered with a drop of water and examined under a high power of the microscope is seen to be made up entirely of the whole and broken cells, or frustules, of diatoms. The species of these tiny plants are probably the same as those identified by Dr. R. M. Bagg from the Siebert tuff at Tonopah. ${ }^{a}$ Inasmuch as these low organisms, owing to their wide range through geologic time, are of little value in determining the age of the rocks with which they are associated, it seemed scarcely worth while to have specific determinations made on the Goldfield material. An impure and less thinly laminated diatomaceous earth occurs just east of the railway, near the crossing of the electric-power line, and similar material, associated with soft, light-gray, pumiceous tuffs, underlies much of the low ground between Myers Mountain and Meda Pass.

The conglomerates associated with the fine tuffs and infusorial earth contain pebbles of most of the prelacustrine rocks of the district, those of rhyolite being probably most abundant. The material of the conglomerates, however, varies from place to place. Some of the shafts sunk near the eastern side of the town of Goldfield show the Siebert formation to contain many fragments of dacite up to a foot ( 0.3 meter) or more in diameter. Still larger fragments of the same rock are abundant in the Siebert beds about a mile southeast of Myers Mountain. The dump of an abandoned shaft, a few yards northeast of the railway station in Columbia, shows that the basal part of the Siebert (which here rests on the Kendall tuff) is a breccia containing fragments of dacite up to 18 inches $(0.5$ meter) in diameter. The matrix in which these blocks are embedded is composed of particles of volcanic rocks of various kinds, those of andesite predominating. Small pebbles of quartz also were noted in some of the conglomerates of the Siebert.

The flow of Mira basalt, shown south of Goldfield in Plate II, is overlain by beds of lightcolored tuff which contain, near their base, vesicular blocks of the basalt. This phase of the Siebert is well exposed on the north slope of Spearhead Point, south of Goldfield. The beds, which dip $25^{\circ} \mathrm{S}$., have in general a pale greenish yellow tint and are rather soft. They comprise fine-grained tuffaceous sandstones and small-pebbled conglomerates or grits, the latter showing cross-bedding.

In the northeastern part of the district much of the Siebert formation is a soft, brown, sandy tuff, composed chiefly of particles of feldspar, hornblende, and other minerals found in the massive lavas. This material in places overlies a deposit made up of fragments of light vesicular glass, or pumice.

At Meda Pass the Meda rhyolite is overlain by a bed of white pumiceous tuff probably from 20 to 30 feet ( 6 to 9 meters) thick. The upper surface of this tuff is very uneven, the inequalities being apparently due in part to erosion and in part to subsequent minor faulting. Upon it rest dark friable sandy tuffs, which in the limited exposures available show very irregular lamination with diverse dips, but no true bedding. This material is really a basaltic or andesitic sand in which the partially rounded grains of plagioclase, augite, magnetite, and brown glass have been cemented by calcite. It is closely associated with, and probably grades into, or is overlain by, coarser tuffs in which the cementing material of the basaltic fragments is also mainly crystalline calcite. The exposures in this part of the district are very unsatisfactory, but the tuffs just lescribed are probably part of the Siebert. The beds which appar-

a Spurr, J. E., Geology of the Tonopah mining district, Nevada: Prof. Paper U. S. Geol. Survey No. 42, 1905, pp. 69-70. 
ently overlie them and form the ridge between Meda Pass and Mira Mountain are exposed only in a few prospect pits. One such pit between bench mark 5813 and Mira Mountain shows soft gray tuffs with layers of coarse angular conglomerate. The material is partly andesitic, but is of mixed derivation. Similar soft tuffs dip $35^{\circ}$ to $40^{\circ} \mathrm{W}$. under the basalt cap of the mountain.

\section{THICKNESS.}

The thickness of the Siebert formation has previously been given (p. 29) as "1,000 feet or more." This, however, may be under the mark. It is difficult to draw sections to scale, and in accordance with known surface relations, that do not give a thickness of over 2,000 feet (610 meters) for the lake sediments in the vicinity of Goldfield. Exposures are far too poor to permit of any satisfactory measurement of thickness, and consequently we are forced to be content with estimates. The beds are certainly over 500 feet (152 meters) in thickness. Part of the apparent 2,000 feet, however, is probably due to faults and minor folds not visible at the surface. On the whole, 1,000 feet ( 305 meters) is probably as fair an estimate as can be made at present of the maximum thickness of the Siebert formation at Goldfield. Ball's map ${ }^{a}$ indicates that the nearly horizontal Siebert beds which constitute the upper part of Montezuma Peak have a thickness of at least 1,000 feet, and the formation exhibits similar development in the Monitor Hills, ${ }^{b} 25$ miles (40 kilometers) northeast of Goldfield, and at the southern end of the Belted Range, ${ }^{c} 60$ miles (96.5 kilometers) to the southeast.

CONDITIONS OF DEPOSITION,

The variations in the Siebert formation from pure diatomaceous earth and fine volcanic ash to coarse accumulations of large angular rock fragments indicate that the Tertiary lake was of variable depth, and that parts of the district rose above its waters. On the other hand, the Siebert lake beds, as shown by the work of Ball ${ }^{d}$ and of Spurr, ${ }^{e}$ and as indicated by the probable correlation of them with the Pahute lake beds of King, have a wide distribution over western Nevada, so that the lake, in spite of the evidence of the existence of near-by land, can have been no local feature. It was probably an exceedingly irregular body of water, comparable in shape with the labyrinthine inland sea which would arise were the present desert valleys to receive a rainfall persistently in excess of evaporation. That the bottom of the lake was exceedingly uneven is shown not only by the relation of the beds to the present topography of the district, but by the reconnaissance work of $\mathrm{S}$. H. Ball $f$ over a much larger area. Above the waters of the Tertiary Siebert or Pahute Lake rose not only mountains of older rocks, but volcanoes in active eruption, which hurled angular blocks of lava into the water, and must at times have covered parts of the lake with floating pumice and volcanic dust. Torrential rains probably aided in transferring the detrital products of eruption to their final resting place at the bottom of the lake, while in the intervals of quiet between eruptions, or in sheltered spots, diatoms found in the temperature of the water and in its silica contents conditions favorable to their abundant development.

\section{STRATIGRAPHY.}

The stratigraphy of the Siebert rocks, owing to their prevalent softness, is very unsatisfactorily revealed. In general the beds dip away from the center of the district at low angles. Exposures in the bluffs southwest of Goldfield indicate a dip of about $18^{\circ} \mathrm{W}$. in that part of the field. This, however, is probably steeper than obtains north of Goldfield and in the northern part of the district.

The beds have been subjected to some faulting, as may be seen along the edge of the mesa, southwest of town. This disturbance will be described in a subsequent chapter.

\footnotetext{
a Ball, S. H., A geologic reconnaissance in southwestern Nevada and eastern California: Bull. U. S. Geol. Survey No. 308, 1907, Pl. I

b Op. cit., p. 97 .

c Op. cit., p. 143

d $\mathrm{A}$ geologic reconnaissance in south western Nevada and eastern California: Bull. U. S. Geol. Survey No. $308,1907$.

$e$ Geology of the Tonopah mining district, Nevada: Prof. Paper U. S. Geol. Survey No. 42, 1905.

$f$ Op. eit., Pl. I, figs. 7 and 13.
} 


\section{MIRA BASALT.}

\section{OCCURRENCE.}

The Mira basalt occurs as a flow, apparently about 100 feet (30 meters) in greatest thickness (see also geologic sections, Pl. VIII), intercalated in the Siebert sediments. This rock underlies the southern part of the town of Goldfield. The flow rises gently toward the south, capping Mira Mountain and some smaller hills in its neighborhood. (See Pl. II.) North of Goldfield the Mira basalt is partly concealed by the Siebert formation, a few small areas only having been uncovered by erosion in the vicinity of the railroad station.

\section{PETROGRAPIYY.}

The basalt as exposed at the surface is prevailingly vesicular and is characterized megascopically by the presence of rather large phenocrysts, up to three-fourths of an inch $(1.8$ centimeters) in length, of vitreous feldspar, which are disseminated sparingly through the rock. Although these feldspars are often bright and fresh, the rock as a whole presents a somewhat more weathered appearance than the later olivine basalt which caps the large mesa southwest of Goldfield. Denser and fresher varieties are obtained, however, in some of the wells near the town.

Under the microscope the rock appears as an ordinary olivinitic basalt, save for the rather sporadic occurrence of quartz phenocrysts. The plagioclase is labradorite. The olivine is in some facies completely serpentinized, in others only initially attacked. The quartz occurs in rounded or embayed anhedrons, which, in some specimens, are surrounded by narrow rims of augite. Not every thin section contains quartz, and where this mineral is absent there is little to distinguish this rock from the later basalt. This similarity is particularly marked in the case of specimens of the older basalt taken from wells in the southern part of town. The rock from some of these wells is a doleritic variety with much olivine and no quartz. In spite of its resemblance to the basalt of the neighboring mesa ( $\mathrm{Pl}$. II), this doleritic facies is apparently part of the same flow as the vesicular quartz-bearing variety, and is so mapped. It must be said, however, that the geologic relations of the rocks in the valley around Goldfield are very obscure. There may be unrecognized faults concealed beneath the loose detritus which covers most of the surface.

\section{ESPINA BRECCIA.}

In the eastern part of the district, northeast of Preble Mountain, is a deposit of breccia and tuff which shows a rough nearly horizontal bedding, and is about 200 feet (61 meters) in thickness. The material is for the most part greatly altered so that its original character is in part doubtful. Fragments of dacite are abundant, particularly in the lower beds, while the upper beds contain much volcanic glass in bomb like masses up to a foot ( 0.3 meter) in diameter, mingled with fragments of glassy rhyolite.

The breccia records explosive volcanic eruptions of rhyolitic material which has since been extensively altered to opal, secondary quartz, kaolinite, and perhaps alunite. Whether the stratification was effected beneath the waters of Siebert Lake or is the result of successive showers of volcanic detritus upon a land surface is a question to which the character of the material affords no decisive answer.

The Espina breccia may be part of the Siebert formation, but definite correlation is not at present possible and the deposit, therefore, has been given a local name. 


\section{CHAPTER VI.}

\section{POSTLACUSTRINE TERTIARY ROCKS.}

\section{INTRODUCTORY STATEMENT.}

With the close of the lake epoch the rocks of the district underwent deformation, followed by erosion. Consequently the postlacustrine rocks rest unconformably upon the older formations, as may be well seen in the cliffs bounding the mesa southwest of Goldfield, particularly in the vicinity of Pozo Canyon. Here the Siebert sediments are in some places tilted to angles up to $30^{\circ}$, with the practically horizontal lavas which cap the mesa lying upon their eroded edges. The postlacustrine rocks comprise four distinct formations, which, from the base up, are (1) the Pozo formation, consisting of beds of rolcanic conglomerate and sandstone; (2) two flows of rhyolite, which may conveniently be called the Spearhead rhyolite; (3) a thin layer of sandstone and conglomerate, here named the Rabbit Spring formation; and (4) one or more flows of olivine basalt (Malpais basalt), with some biotitic and hornblendic facies.

\section{POZO FORMATION.}

The Pozo formation is named from Pozo Canyon, where may be seen the only satisfactory exposure of these rocks in the district. At the bend in the ravine (see Pl. II), about threequarters of a mile (1.2 kilometers) southwest of the center of Goldfield, some 50 feet (15 meters) of the Pozo formation is exposed in a cliff section, capped with the Spearhead rhyolite, which in turn is overlain by the Malpais basalt. The Pozo consists of roughly bedded, imperfectly assorted conglomerates associated with some soft sandstone. The material is mainly of volcanic derivation, andesitic, basaltic, and pumiceous fragments being abundant. The pebbles, which are not well rounded, range in size from sand grains to blocks a foot or two (0.3 to 0.6 meter) in diameter. The larger blocks are not confined to any one part of the deposit and some are embedded in the fine sandy layers. The general bedding of the deposit is nearly horizontal, but in detail the stratification is irregular and as exposed in the cliff shows small local unconformities. It is evident that after some of the sands were laid down currents changed, channels were scoured, and were later filled with gravel. The whole deposit is clearly of fluviatile origin.

The base of the formation is not visible in the section just described. On the opposite side of the ravine, however, the conglomerate may be seen resting upon an uneven erosion surface of the soft yellowish Siebert beds. The Pozo formation thins rapidly to the north, and at Spearhead Point the rhyolite rests directly upon the eroded edges of the Siebert strata.

Partly consolidated gravels and sands referable to the Pozo formation are exposed in the railway cut a short distance south of Meda Pass. They conformably underlie the Spearhead rhyolite and doubtless rest uncomformably upon the tuffaceous Siebert beds, although this contact is not exposed. The pebbles are subangular, ill-assorted, and of many kinds. A few are of dacite which had undergone the characteristic alunitic alteration prior to the erosion that furnished the materials of the conglomerate. The total thickness of the deposit, which contains some sandy and tuffaceous layers, is probably between 50 and 100 feet (15 and 30 meters).

A little less than a mile (1.6 kilometers) north of Black Butte is a ridge capped with roughly bedded conglomerate with some fine tuff near the base of the deposit. The conglomerate contains fragments of andesite and dacite cemented by calcite. In its upper part the deposit contains many blocks, some as much as 6 feet ( 2 meters) across, of vesicular basalt of the same kind as that of the postlacustrine flows. 
The correlation of this material is somewhat in doubt, but it is provisionally mapped with the Pozo formation. It is possible, also, that a small part of what has been mapped as Siebert in the northeast corner of the district may really belong with the Pozo, as the latter formation had not been recognized when this part of the field was studied. It is questionable, however, whether the Pozo, if present northeast of Black Butte, could be there satisfactorily separated from the dominant and poorly exposed Siebert.

\section{SPEARHEAD RHYOLITE.}

The rhyolitic flows are well exposed at Rabbit Spring, west of Goldfield, and in Pozo Canyon. At Rabbit Spring they have a thickness of about 80 feet (24 meters), while at the southern boundary of the district mapped they are altogether only about 20 feet ( 6 meters) thick. In most places two distinct subdivisions are recognizable-an upper, thicker, pinkish member, and a lower, thinner, brown member. These are thought to be distinct flows, but the rock of both members is essentially the same and no evidence of any erosion or deposition between the eruption of the two varieties has been found.

At Rabbit Spring, where the upper rhyolite has been quarried for building stone, the rock is a rather soft, porous, pinkish-gray rhyolite, containing so many fragments of pumice as to warrant the name of "flow breccia." These pumiceous fragments are everywhere present in the Spearhead rhyolite, but they vary in abundance from place to place. In some localities they are so numerous as to give the rhyolite the aspect of a tuff; in others the flow is comparatively compact and massive.

Under the microscope the rhyolite shows phenocrysts of quartz and orthoclase and a curly eutaxitic glass, which, in some specimens, shows incipient devitrifaction. Among the rarer phenocrysts are biotite, hornblende, and green pyroxene. These seldom occur as more than one or two imperfect crystals in any single section and may be entirely absent.

The Spearhead rhyolite has been extensively used as a building stone in Goldfield and is the material of the court-house and of the town fire station.

\section{RABBIT SPRING FORMATION.}

The Rabbit Spring formation is exposed in the bluffs above the spring whence it derives its name and in other places along the edge of Malpais Mesa. A deposit correlated with it occurs also beneath the basalt of Blackcap Mountain.

As exposed near Rabbit Spring, the formation is from 10 to 15 feet (3 to 4.5 meters) thick, and is consequently exaggerated as shown on the geologic map (Pl. II). It consists here of sandstone, apparently derived from the underlying rhyolite, with lenses of conglomerate, of which the pebbles are all of volcanic rocks. In its upper part the formation merges with the brecciated vesicular base of the overlying olivine basalt. The occurrence of this bedded sandstone and conglomerate indicates fluviatile action or a very brief recurrence of at least local lacustrine conditions just prior to the basaltic eruptions.

At Blackcap Mountain the basalt cap rests in part upon a wedge of volcanic sandstone and conglomerate, the pebbles of the latter being mostly andesite and basalt. This wedge is about 25 feet (7.6 meters) thick on the west face of the mountain, but thins to the east, and has not been seen on that side of the summit. (See Pl. II.) The lower 7 feet ( 2 meters) of the basalt is exceedingly vesicular and much brecciated by the movement of the flow. These sediments are correlated with those above Rabbit Spring, although it is by no means certain that they were laid down in one continuous body of water. The Siebert formation, if it ever covered this part of the district, was eroded away before the Rabbit Spring formation was laid down. The Spearhead rhyolite is also missing at Blackcap Mountain. 


\section{MALPAIS BASALT.}

The youngest volcanic rock in the district is the dark olivinitic basalt which caps the mesa southwest of Goldfield, Myers, and Blackcap mountains, and many of the hills along the eastern border of the area studied. The same rock occurs also as small intrusive masses, such as that on the east slope of Vindicator Mountain and the small bodies mapped about a mile (1.6 kilometers) northeast of Preble Mountain (Pl. II).

The basalt appears to have flowed over a somewhat diversified topography, covering considerable areas of plain and enveloping the bases of hills which rose above the general level of the country. As shown by sections $\mathrm{D}^{-\mathrm{D}^{\prime}}$ and $\mathrm{E}-\mathrm{E}^{\prime}$, Plate VIII, there is nothing improbable in the supposition that most of the central part of the district, including Vindicator Mountain, was once covered by basalt, although erosion has left no remnants to testify directly to this extensive volcanic inundation. On the other hand, some of the high dacite hills just east of the area mapped and Montezuma Peak, west of Goldfield, appear to rise above the level of the former lava flood.

Whatever its former extent, the basalt has been much reauced by erosion and is represented to-day by a series of dissevered remnants. Of these the largest forms Malpais Mesa, near Goldfield, a desolate somber plateau some 4 miles (6.5 kilometers) in width and 12 miles (19 kilometers) in length from north to south. ${ }^{a}$ A small part only of this basaltic table or mesa comes within the area represented in Plate II. The cliffs which bound the mesa on the east continue for several miles north of Goldfield to form the western wall of the valley in which the town lies, until finally the escarpment turns to the west and the valley opens into the desert plain north of the Goldfield Hills.

The basalt cap of the mesa is apout 100 feet (30 meters) thick as exposed in the cliffs near Goldfield. On top of Myers Mountain is 200 feet ( 61 meters) of basalt and on Blackcap about 100 feet.

It is by no means certain that all of the olivine basalt belongs to a single flow or issued from one vent. The rock exhibits sufficient lithological variety to suggest that the lava may have come from more than one orifice and may not have been of entirely simultaneous eruption. Ball, ${ }^{b}$ moreover, has shown that basalt was the last rock erupted over a wide region circumjacent to Goldfield, such as could have hardly been covered by a single flow. Within this region are basaltic cones, some of which are visible northeast of the railroad about 15 miles (24 kilometers) southeast of Beatty, indicating that the basaltic magma reached the surface through several conduits.

The basalt of Malpais Mesa is a holocrystalline variety such as is properly designated dolerite. (See Pl. VII, C.) Vesicular facies, containing more or less glass, occur, however, at the base of the flow. The rock contains abundant phenocrysts of calcic labradorite $\left(A b_{1} A n_{2}\right)$ and olivine in a crystalline groundmass of the same minerals, with much augite and magnetite, a little biotite, and many small prisms of apatite. Filling the interstices between some of the subhedral labradorite crystals of the groundmass is a clear untwinned feldspar of distinctly lower index of refraction and weak birefringence. This is probably orthoclase. It is not conspicuous in the thin section and was evidently the last mineral to crystallize. It usually incloses delicate prisms of apatite. The minerals are all perfectly fresh except the olivine, which is partly altered to a red-brown serpentinous mineral (iddingsite). It is questionable, however, whether this alteration comes under the head of ordinary weathering. Its frequent occurrence in basalts exhibiting no signs of general decomposition suggests that this change in the olivine may in some cases follow very closely upon the solidification of the magma. A chemical analysis of this olivine dolerite is given under 1 in the following table. The small quantity of carbon dioxide there shown comes from a little calcite which occupies some small interstitial spaces between the crystals of the groundmass and is not obviously a decomposition product of any particular mineral. 
Chemical analyses of basalts.

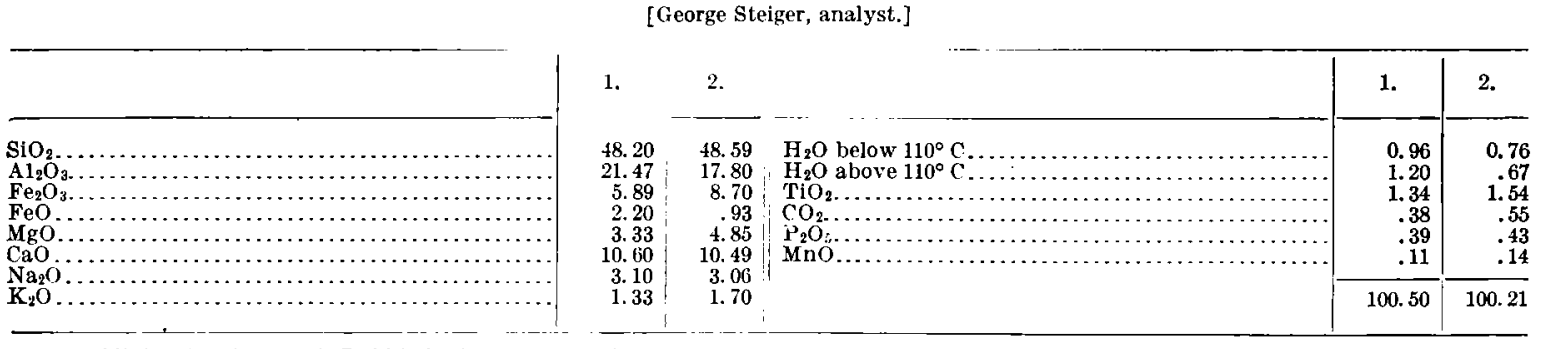

1. Olivine dolerite (G. 2), Rabbit Spring, near Goldrield.

2. Mica dolerite (G. $\mathbf{4}$ ), 2 miles ( 3.2 kilometers) east of Black Butte.

The norm of the olivine dolerite, calculated from analysis 1 , is as follows:

Norm of olivine dolerite.

\begin{tabular}{|c|c|c|c|}
\hline Anorthite...$\ldots \ldots \ldots \ldots \ldots$ & 40.87 & Magnetite... & 3.48 \\
\hline Albite.............................. & 26.20 & Ilmenite................. & 2. 43 \\
\hline Orthoclase $\ldots \ldots \ldots \ldots \ldots \ldots \ldots \ldots \ldots \ldots$ & 7.78 & & 96.95 \\
\hline Quartz $\ldots \ldots \ldots \ldots \ldots \ldots$ & .54 & (Calcite. & $.90)$ \\
\hline $\begin{array}{l}\text { Diopside } \ldots \ldots \ldots \ldots \\
\text { Enstatite } \ldots \ldots \ldots \ldots \ldots\end{array}$ & $\begin{array}{l}7.13 \\
5.00\end{array}$ & Water ......... & 2.16 \\
\hline Hematite. & 3.52 & & 100.01 \\
\hline
\end{tabular}

The rock is a hessose in terms of the quantitative classification.

The basalt of Myers Mountain, which is vertically columnar, contains phenocrysts of augite as well as of labradorite and olivine. The rock is a holocrystalline doleritic variety and is almost ideally fresh, the olivine showing only traces of serpentinization along irregular microscopic cracks. This serpentine is of the ordinary greenish yellow kind. Many of the olivine phenocrysts are magmatically embayed, much as are quartz phenocrysts in rhyolite. In the area of basalt just east of Myers Mountain the olivine is nearly all altered to the same orangecolored, strongly birefringent, serpentinous mineral as is found in the basalt of the large mesa to the west.

Most of the cap of Blackcap Mountain is a fine-grained, even-textured basalt, which the microscope shows to be of the holocrystalline doleritic type. The olivine is all changed to serpentinous pseudomorphs of fibrous structure and deep reddish-orange color in transmitted light. The labradorite and augite are fresh, although the rock contains a little interstitial calcite. The dolerite contains also a little orthoclase as the final product of crystallization. Some specimens contain biotite. Whether these belong to a distinct flow or are merely facies of one thick lava sheet was not determined. The biotite is a light-colored variety, the pleochroism being $\mathrm{X}$ pale buff, $\mathrm{Y}$ and $\mathrm{Z}$ yellowish chestnut brown. Highly vesicular facies occur at the top and bottom of the flow, which can not have suffered much reduction of thickness by erosion.

The small body of basalt on the southeast slope of Blackcap Mountain is of the same kind as the rock which caps the mountain, but is too low down to be part of the same flow, in place. It is either intrusive in the andesite or - and this seems more probable-is a loose mass which has slid down to its present position in consequence of the disintegration and erosion of the underlying andesite.

Several hills about $1 \frac{1}{2}$ miles (2.5 kilometers) east of Black Butte and just outside of the eastern boundary of the area mapped (Pl. II) are capped with basalt, the cappings ranging from 100 to 200 feet (30 to 61 meters) in thickness and exhibiting considerable diversity in elevation and slope. The basalt is much like that on Blackcap Mountain, although much of it is less coarsely crystalline as seen under the microscope. Glass occurs only in some of the vesicular facies characteristic of the tops and bottoms of the floors. The olivine exhibits various stages of alteration to iddingsite or serpentine pseudomorphs. Two rather unusual varieties of the basalt call for brief description. 
One is a compact aphanitic rock, which caps a hill just outside of the extreme northeast corner of the district, as mapped in Plate II. Under the microscope this basalt shows a striking flow structure, the small crystals of plagioclase, olivine, and augite being nearly all arranged with their longest dimensions parallel.

The other, a somewhat porous, light-gray variety, is on the hilltop just east of the area of rhyolite mapped in the northeast corner of the district. The most noticeable feature of this rock, as seen in hand specimens, is a bright golden-brown mica. The small scales of this mica are particularly abundant in the irregular pores of the basalt, projecting from the walls of these little cavities and frequently partly embedded in calcite.

The microscope shows the rock to be a holocrystalline aggregate of calcic labradorite (near $A b_{1} A n_{2}$ ), augite, biotite, hornblende, magnetite, and apatite. (See Pl. VII, D.) Originally a little olivine was present, but this has been altered to a deep red-brown ferruginous serpentine or allied mineral. Calcite is fairly abundant, filling rough miarolitic or interstitial cavities. Although the calcite apparently began to crystallize in actual cavities in the rock, it has also directly attacked and replaced some of the contiguous labradorite. The line between calcite and labradorite is irregular but sharp, and the plagioclase crystals show no tendency to alter into calcite throughout their mass.

The brown mica is biaxial with small axial angle. The plane of the optic axes lies in the plane of crystal symmetry as in common biotite and phlogopite. The pleochroism is $\mathrm{X}$ light yellow, $\mathrm{Y}$ and $\mathrm{Z}$ bright-yellowish chestnut. The absorption scheme is $\mathrm{Y}=\mathrm{Z}>\mathrm{X}$. The optical character indicates that the mica is either biotite (meroxene) or phlogopite, the color suggesting the latter material. Inasmuch, however, as the rock as shown by the analysis under 2 on page 73 is by no means poor in iron, the mica is probably merely a biotite of rather unusual color.

The norm of this mica-bearing dolerite, calculated from analysis 2 on page 73 , is as follows:

Norm of mica dolerite.

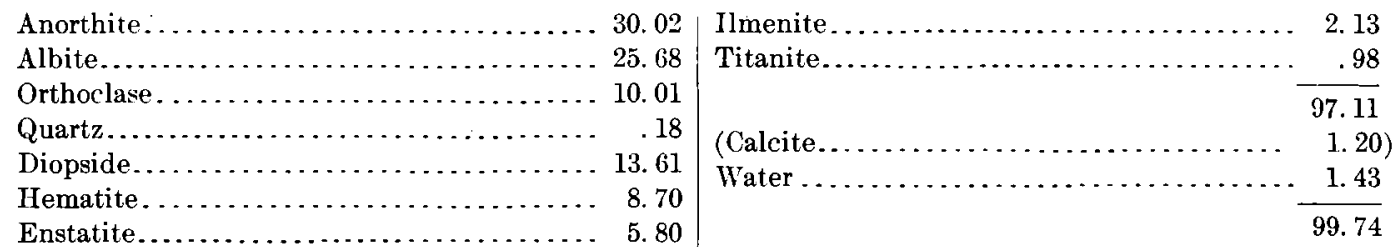

This rock also is a hessose in the quantitative classification.

On the east slope of Vindicator Mountain and near the eastern edge of the district, $1 \frac{1}{2}$ miles (2.5 kilometers) north of Blackcap Mountain, are small bodies of basalt that appear to be intrusive in the older rocks, and may fill conduits through which some of the extrusive basalt reached the surface.

The rock of the Vindicator Mountain areas is dark gray and compact, with small phenocrysts of plagioclase, augite, and hornblende. Microscopical examination leaves the character of the larger mass (Pl. II) somewhat in doubt, as the mineral supposed to have been olivine is entirely altered to calcite and serpentine and the groundmass is rather andesitic in texture. Some of the smaller masses shown, however, are clearly olivinitic basalt, with small phenocrysts of labradorite, augite, and olivine in a dense partly glassy groundmass.

The rock of the small areas north of Blackcap Mountain is compact and nearly aphanitic. It shows under the microscope abundant small phenocrysts of partly serpentinized olivine and of labradorite, in a groundmass of plagioclase, augite, magnetite, apatite, and a little glass. 


\section{CHAPTER VII.}

\section{QUATERNARY DEPOSITS.}

The post-Tertiary deposits of the Goldfield district comprise unconsolidated gravels belonging to two periods. The older gravels have been recognized chiefly to the south of Goldfield, along both sides of the automobile road to Bullfrog, being found in some places 500 feet (152 meters) above the bottoms of neighboring ravines. They are particularly abundant on the slopes of Mira Mountain. These gravels are apparently not well bedded, are very poorly exposed, and owing to their tendency to roll down the slopes and mingle with later detritus can not be accurately mapped. They are not shown on Plate II. The pebbles consist largely of rocks foreign to the district. Mr. W. H. Emmons estimated that about 40 per cent of them are of micaceous slate or phyllite, 20 per cent of dense dark-gray limestone, 15 per cent of hard quartzite and 25 per cent of andesitic and other dark volcanic rocks. Some of these rocks occur as bowlders a foot ( 0.3 meter) in diameter and nearly all are well rounded. The maximum thickness of these gravels is not known, although a shaft in one place shows them to be at least 50 feet ( 15 meters) thick.

It appears most probable that the material of these gravels was brought from the southwest by a stream which must at times have carried more water than is ever found in the present arroyos.

The later gravels and sands are those of the present stream courses, which, it should be understood, contain running water only at rare intervals and for brief periods. These gravels are of local derivation and in most places can not be definitely separated from the loose imperfectly washed detritus that covers so much of the district and is so serious an obstacle to the work of the prospector or geologist. On Plate II only the thicker and more extensive accumulations of alluvium are shown, for the reason that in this arid region the details of distribution of the superficial gravel and ubiquitous "wash" are of little importance compared with the structure and distribution of the underlying rocks. The areas of allurium shown, therefore, are merely those which are so thick or so extensive as to prevent the underlying rock structures from being satisfactorily deciphered.

No attempt has been made, so far as known, to work any of the gravels for gold, and it is doubtful whether they could be successfully exploited, even were abundant water available. For not only is the gold of the district very fine, but the concentration by running water has doubtless been far less perfect than in those regions where a comparatively stable system of perennial streams has steadily concentrated the gold into narrow and definite channels. In an arid region like that of Goldfield the channels are wide and ill defined and the process of erosion is too erratic and intermittent for effective concentration. Moreover, the total depth of erosion since the ores were deposited has been comparatively small, as will be shown later. 


\section{CHAPTER VIII.}

\section{GEOLOGIC STRUCTURE.}

The structure of the Goldfield district, as previously stated, is broadly simple. A Tertiary volcanic series resting upon the worn surface of much older rocks has been elevated into a dome of gentle curvature (see Pls. II and VIII), and this after some modification by faulting and igneous intrusion has been truncated by erosion so as to denude patches of the fundamental rocks in the central part of the uplift, leaving them surrounded by annuli of successively younger formations. This structure was afterwards covered, at least in part, by flows of lava which have in their turn been eroded from all but the outlying parts of the district.

Banner Mountain may be taken as the approximate center of the domically uplifted area. (See Pl. II.) The uplift, however, is not symmetrical, and Vindicator Mountain appears to correspond structurally to a local protuberance on the dome. It is quite possible that originally there was a depression here in the pre-Tertiary surface, since the oldest of the lavas, the Vindicator rhyolite, is found mainly on the flanks of this mountain. The symmetry of the dome is further modified, as will later be shown, by irregular intrusions of the dacite and by the Columbia Mountain fault. (See Pl. II.)

The scattered and relatively small areas of pre-Tertiary rocks now exposed throw little light on the structure of the old floor through which the lavas broke. The basal rock, in these exposures, is mainly alaskite, which has invaded and greatly disrupted a series of Cambrian sediments. It is probable that the alaskite or granite is the prevailing rock upon which the Tertiary rocks as a whole rest, but it is quite possible that included in this plutonic rock and forming parts of the floor may be masses of the Cambrian sedimentary terrane much larger than those visible on Columbia and Vindicator mountains.

It is doubtful whether, with the information now available, the configuration of the preTertiary floor can be ascertained with any accuracy. The contacts between alaskite and the volcanic rocks in the vicinity of Vindicator and Banner mountains show no sharp rugosities, but on the other hand they scarcely suggest that the alaskite was worn down to a smooth plain. That the old surface suffered considerable deformation in Tertiary time is evident from the relations shown on Columbia Mountain, where Tertiary rhyolite is intrusive into alaskite and Cambrian sediments. Doubtless equal or greater deformation has affected parts of the floor now buried, and the occurrence of such local disturbance complicates the problem of an ideal restoration of the surface as it was before the Tertiary volcanic eruptions began.

The fact that the pre-Tertiary rocks are exposed only in the central part of the eroded dome, or where, as on Columbia Mountain, faulting has modified the domical structure and brought the older rocks within the reach of erosion, indicates that the prevolcanic surface had low relief; otherwise knobs of alaskite or of Cambrian sediments would be found here and there projecting through the andesite. The pre-Tertiary floor was therefore in the main a rolling granitic surface diversified by rounded hills a few of which may have attained heights of 200 to 300 feet (61 to 91 meters) above the general level. None of the exposures in the district affords evidence of any considerable detrital accumulation on this old surface prior to the volcanic outbursts, although, as mentioned on page 37 , there is a little such material beneath the Vindicator rhyolite on Columbia Mountain, and the basal part of the rhyolite generally contains many inclusions of Cambrian shale.

Overlapping the pre-Tertiary core of Vindicator Mountain on its west and east sides are parts of the oldest lava in the district, the Vindicator rhyolite. This flow is at present not extensive, 


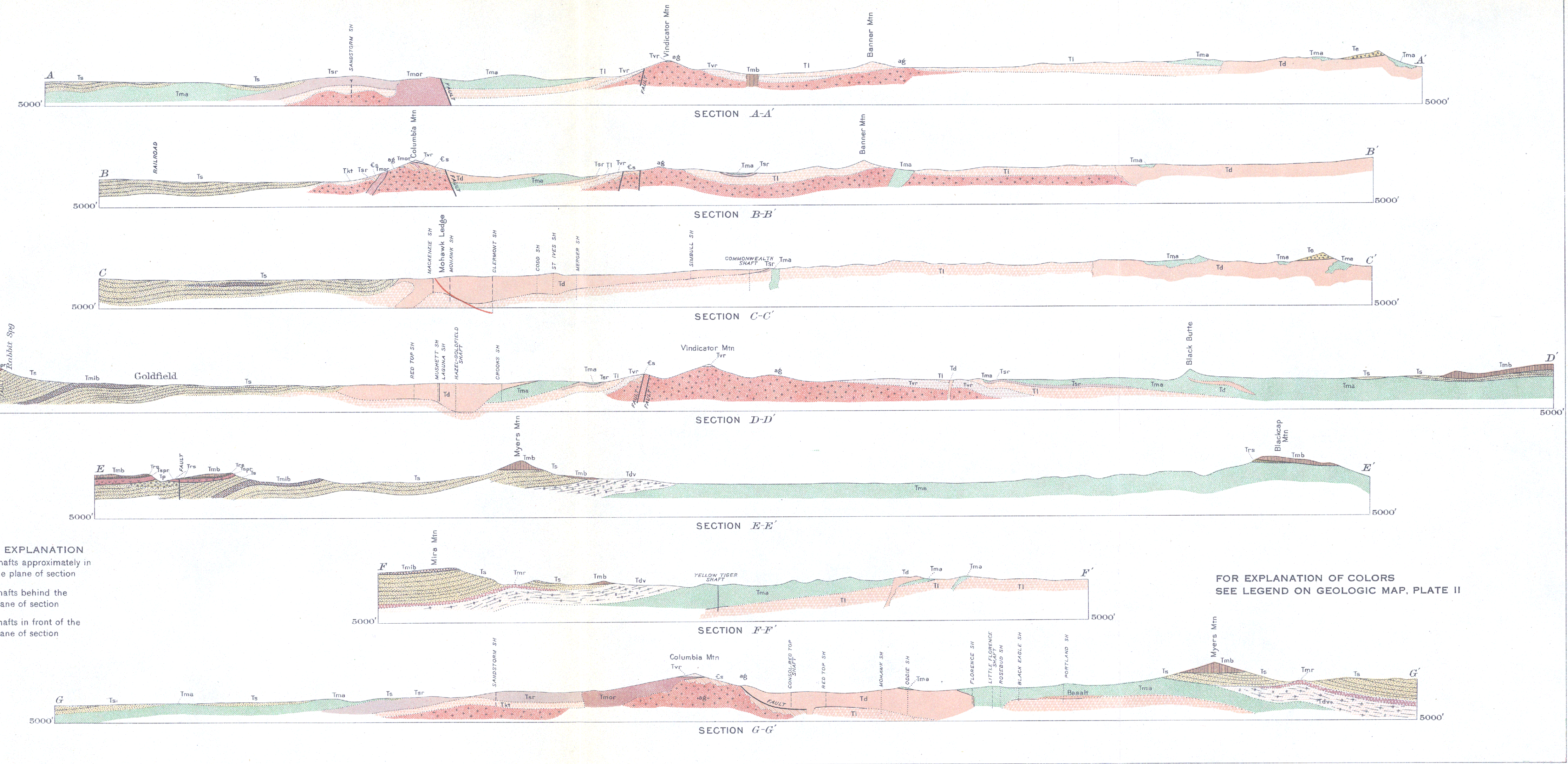

GEOLOGIC SECTIONS ACROSS THE GOLDFIELD DISTRICT, NEVADA

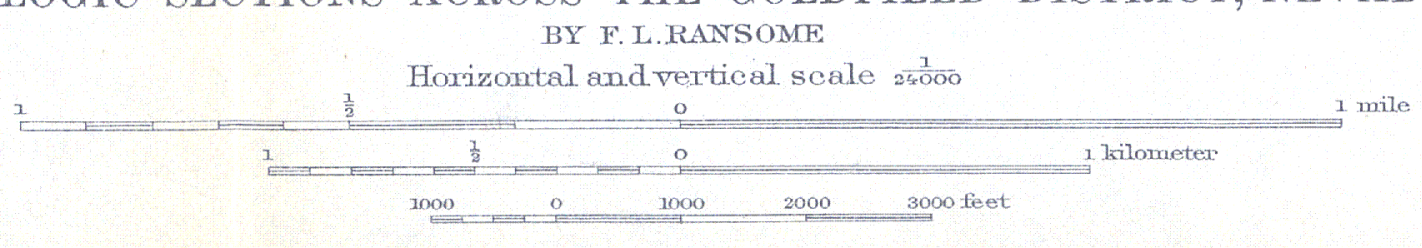



for it does not appear around other areas of alaskite exposed to view in the vicinity of Banner and Columbia mountains. Whether it is the product of a small local outburst which never extended far from the site of Vindicator Mountain, where it perhaps accumulated in a hollow, or whether there was considerable erosion between its eruption and the latite inundation is not known. The maximum thickness of the Vindicator rhyolite is estimated at about 200 feet (61 meters). The rhyolitic capping of Columbia Mountain is probably a remnant of the same flow.

The latite flow, which rests in part upon the Vindicator rhyolite but mainly upon the preTertiary floor, now forms the surface rock over a considerable area in the center of the dome. The average diameter of this area is about 2 miles (3.2 kilometers), but its outline, as may be seen from Plate II, is very irregular. This irregularity of outline, considered in connection with the definition of the bottom of the formation by the various areas of alaskite from which the latite has been stripped by erosion, and of the top by the residual patches of younger Sandstorm rhyolite which rest on the latite northeast of Banner Mountain, shows that the latite flow lies in a nearly horizontal position in the center of the dome, where it is not generally of great thickness. The estimated maximum is about 300 feet (91 meters).

Outside the main central area latite is exposed south of Columbia in consequence of the structural modifications of the dome brought about by the Columbia Mountain fault, as will be shown in subsequent pages.

Following the latite as one of the concentric structural elements of the dome is the Sandstorm rhyolite and associated Kendall tuff. As shown in Plate II, the rhyolite is exposed in a number of small irregular areas around the latite in the northwest half of the dome and occurs in small residual patches or outliers northeast of Banner Mountain. It is absent so far as known from the southeast half of the uplift. As in the case of the Vindicator rhyolite, it is not quite clear whether this absence is due chiefly to erosion or is a result of the original distribution of the flow. As will presently appear, however, there is reason to conclude that some erosion of the region took place after the eruption of the rhyolite and before the outbreak of andesitic lavas.

Reference to Plate II will show that on the south side of Vindicator Mountain one small residual mass of Sandstorm rhyolite is almost in contact with the alaskite. This indicates that the alaskite mass of the mountain was not entirely buried by the latite, but stood out in part as an island in the volcanic flood. Otherwise there should everywhere be a wide band of latite separating exposures of the younger rhyolite from those of alaskite.

It may appropriately be observed at this stage that in a volcanic sequence, such as is here dealt with, unconformities have not the same definiteness and significance as when they intervene between sedimentary rocks. In the latter case they usually record an elevation of the area of sedimentation, a change of sea bottom into land, erosion of this land, subsequent submergence, and renewed deposition of sediments on the eroded surface. In the Goldfield region there is no evidence of general submergence at any time during the prelacustrine epoch. The area as a whole was a land surface, and erosion was undoubtedly active during the entire period of volcanic accumulation. Each flow as it was poured out was at once attacked by air, rain, and streams. Such erosion was probably very uneven, and its results depended upon the character of the material erupted, the nature of the local topography, the length of time between eruptions, and probably other less obvious factors. In sedimentary rocks the existence of planes of stratification and the knowledge that originally these were nearly horizontal enables us to restore in imagination the surface initially exposed to erosion. No such restoration is possible in the case of the volcanic formations of Goldfiell. We may not assume that the flows spread evenly over the whole district, that they were of uniform thickness, or that the topography at the close of each eruption was even approximately a plain. It is as a rule impossible to say in how far the observable inequalities in the thickness and distribution of the various flows are due to original irregularity of deposit and how far to intervolcanic erosion.

The thickness of the Sandstorm rhyolite is variable. In the central part of the area it is probably not over 100 feet ( 30 meters) thick, but west of the Columbia Mountain fault, in the vicinity of the Sandstorm mine, the formation, which here is apparently made up of a 
series of thin glassy flows, becomes considerably thicker. The workings of the Sandstorm mine show that this rock extends to a depth of 200 feet (61 meters) and is underlain by another 200 feet of Kendall tuff. The increased thickness of the Sandstorm rhyolite in this part of the district and its irregular intrusion by the closely following Morena rhyolite suggests that both eruptions broke through the pre-Tertiary floor in this part of the district. Consequently the bottom of the Sandstorm rhyolite north of Columbia Mountain may be very irregular, and the extrusive rock may pass in depth into facies not distinguishable from the Morena intrusive type.

The Morena rhyolite, whose intrusion closely followed in time the extravasation of the Sandstorm rhyolite, does not appear in the domical structure as displayed east of the Columbia Mountain fault.

The main mass of Morena rhyolite that forms the northern spur of Columbia Mountain and the smaller bodies exposed in the vicinity of the Conqueror mine clearly cut irregularly through the Sandstorm rhyolite and through the pre-Tertiary rocks. These intrusive bodies have been subjected to the same stresses that have produced the general domical structure of the district, but they have introduced by their intrusion local disturbances whose effects mask the more general tectonic relations. The same statement, as will presently be seen, applies also in less degree to a younger intrusive rock, the dacite.

Although the contact between the two rocks is nowhere clearly exposed, there is little doubt that the Milltown andesite normally overlies both the Sandstorm and Morena rhyolites. This shows, not only that the intrusive rhyolite was erupted before the andesite flows swept over the region, but that sufficient erosion must have intervened to lay bare a rock, or a rock facies, that had solidified under some cover. Additional evidence of such postrhyolitic erosion is afforded by the many places where the Sandstorm rhyolite has been cut out and the andesite rests directly upon the latite, as near Diamondfield and along the entire southeast side of the dome. The thickness of material removed in the course of this erosion can not be accurately determined, but there are reasons for supposing that it was not great.

It has already been shown that prior to the outbreak of Tertiary volcanism the surface of the region was hummocky. The hills were neither high nor sharp, and the valleys were broad with gentle slopes. There was neither active erosion nor active deposition. After the latite flow had covered the region the surface was presumably more nearly a plain than before. There is no reason to conclude that the addition of this mantle of volcanic rock greatly accentuated erosive processes, and no evidence has been found indicative of any trenching of the volcanic terrane by streams.

Upon the latite, which probably underwent some local deformation at this time, was thrown out the Kendall tuff. This appears to have accumulated chiefly in basins or small valleys, and its deposition was immediately followed by the pouring out of the thin glassy flows of Sandstorm rhyolite, alternating in some places with small accumulations of tuff. The rhyolitic material probably accumulated to the greatest thickness near the vent or vents, which there is some reason to suppose lay north of the site of Columbia Mountain. Finally, the Morena rhyolite rose through fissures opened by earlier volcanic paroxysms and solidified as intrusive masses in the flows. There is nothing to indicate that the intrusive rock solidified under any other cover than the previously erupted Sandstorm rhyolite.

Subsequent preandesitic erosion appears to have done little more than level off and carry away such rhyolitic accumulations as rose above the general level of the region. Possibly there was some local subsidence north of Columbia Mountain, which accounts for so much of the rhyolite being left in that part of the district, while elsewhere it was reduced to a thin layer or entirely removed. There is nothing to show that the postrhyolitic erosion was able at any point to cut deeply below the latite terrane upon which the rhyolite was erupted. If the region between the beginning of the rhyolitic eruptions and the beginning of the andesitic period had been deeply buried it is improbable that erosion would have so nearly restored the general surface to its postlatite level and configuration. It seems reasonable to suppose, therefore, that the Morena rhyolite was intruded under a comparatively light load of extrusive (Sand- 
storm) rhyolite, and that a very moderate erosion sufficed to level off the region to the gently undulating surface which was to receive the andesitic flows and tuffs.

The distribution of the andesitic rocks has been described on pages 47 to 54 . If the intrusive dacite be for the present disregarded, the andesite forms a broad ring, the outer annulus of the successive eruptive formations exposed in the truncated dome. As shown in Plate II, this band is of very uneven breadth, its inner margin encroaching irregularly over the Sandstorm rhyolite and latite, and its outer border being determined by the still greater sinuosities of the edge of the overlapping Siebert formation. Its shape is modified also by the Columbia Mountain fault.

The Milltown andesite is the thickest of the eruptive formations entering into the structure of the dome. It is very difficult, however, to estimate this thickness, owing to the absence of any regular planes within the formation that might be confidently taken as corresponding to the general dip of the whole. The only shaft that has penetrated the andesite at a point where a direct section of the formation would throw light on its total thickness or general dip is the Yellow Tiger. The vertical section in this shaft gives 510 feet (155 meters) of andesite, which, as shown in Plate VIII, section F-F', may correspond to an actual thickness of about 600 feet (183 meters). The Milltown andesite is certainly not a single flow, but is probably built up of several overlapping lava sheets, with a minor proportion of tuff and perhaps some intrusive andesite. In the few localities where the composite character of the formation is shown the contacts between successive sheets are nearly horizontal. It is probable that the formation as a whole varies considerably in its dip at different places, but has in general a centrifugal inclination with reference to the domical structure of about $10^{\circ}$. The thickness is roughly estimated at from 600 to 800 feet ( 183 to 244 meters).

The next tectonic element to be considered after the andesite is the dacite. This rock, while involved in the architecture of the dome, is so irregular in its occurrence as to obscure rather than to accentuate the structure of which it is a part. The evidence of the intrusive relation of part of the dacite with reference to the andesite and older rocks is presented on page 58; it remains in this chapter to consider the form of the intrusive masses and their relation to the general structure.

The most important body of dacite from an economic point of view is that lying northeast of Goldfield and containing the principal mines of the district. Although the general form of the mass, particularly when considered with reference to the domical structure, leaves little room for doubt of its intrusive character, there are, unfortunately, no exposures in which the relation of this body to the andesite is clearly displayed at any one locality. In most places the contact can be determined with an accuracy commensurate with the scale of the map ( $\mathrm{Pl}$. II), but the actual plane of separation between the dacite and the rocks which it cuts is rarely visible or is obscured by alteration. The mass, as may be seen from the geologic map, practically cuts across the andesite annulus from east to west. It has the form of an irregular sheet.

The thickness of the dacite is least to the east, where the sheet thins to an edge, and is greatest along a trough-like depression which extends from the vicinity of the Hazel-Goldfield shaft toward Florence Hill. (See fig. 2.) This depression (see also Pl. II; Pl. VIII, sections $\mathrm{C}-\mathrm{C}^{\prime}$ and $\left.\mathrm{D}-\mathrm{D}^{\prime}\right)$ is in the general line of prolongation of the fault southward, due allowance being made for the dip of the latter. The depth of the bottom of the dacite along this line ranges from 685 feet (209 meters) at the Hazel-Goldfield mine, to 615 feet ( 187 meters) at the Clermont shaft. South of the Clermont shaft the dacite has probably not yet been penetrated in its thickest part. West of this line the bottom of the sheet in general rises at an average angle of about $30^{\circ}$, although as shown in section $\mathrm{C}-\mathrm{C}^{\prime}$, Plate VIII, a part of the mass appears to extend as a dike to an indeterminate depth. It is possible that future exploration may not only establish this abyssal continuation but may reveal other connections of the sheet with its deep-seated source.

Along its southern boundary the dacite sheet ends with a steep irregular intrusive contact against the Milltown andesite. There is nothing to show that it does not extend indefinitely downward along at least the western part of this contact. (See PI. VIII, section G-G' ${ }^{\prime}$.) 
That the under surface of the dacite is far from even is indicated by the data assembled in figure 2 and by the relation of the contact between this rock and the underlying formations south and southwest of Vindicator Mountain. The two deepest points yet found on the bottom of the dacite are, as already mentioned, at the Hazel-Goldfield shaft (685 feet or 209 meters) and at the Clermont shaft (615 feet or 187 meters). The Oddie shaft on the Combination Fraction claim has not penetrated through the dacite at 612 feet (187 meters), so that the thickest part of the sheet may be between this shaft and the Clermont. (See fig. 2.) Both east and west of this approximately north and south line, which may conveniently be referred to as the keel of the dacite mass, shafts pass out of the dacite at depths which, in a rough way,

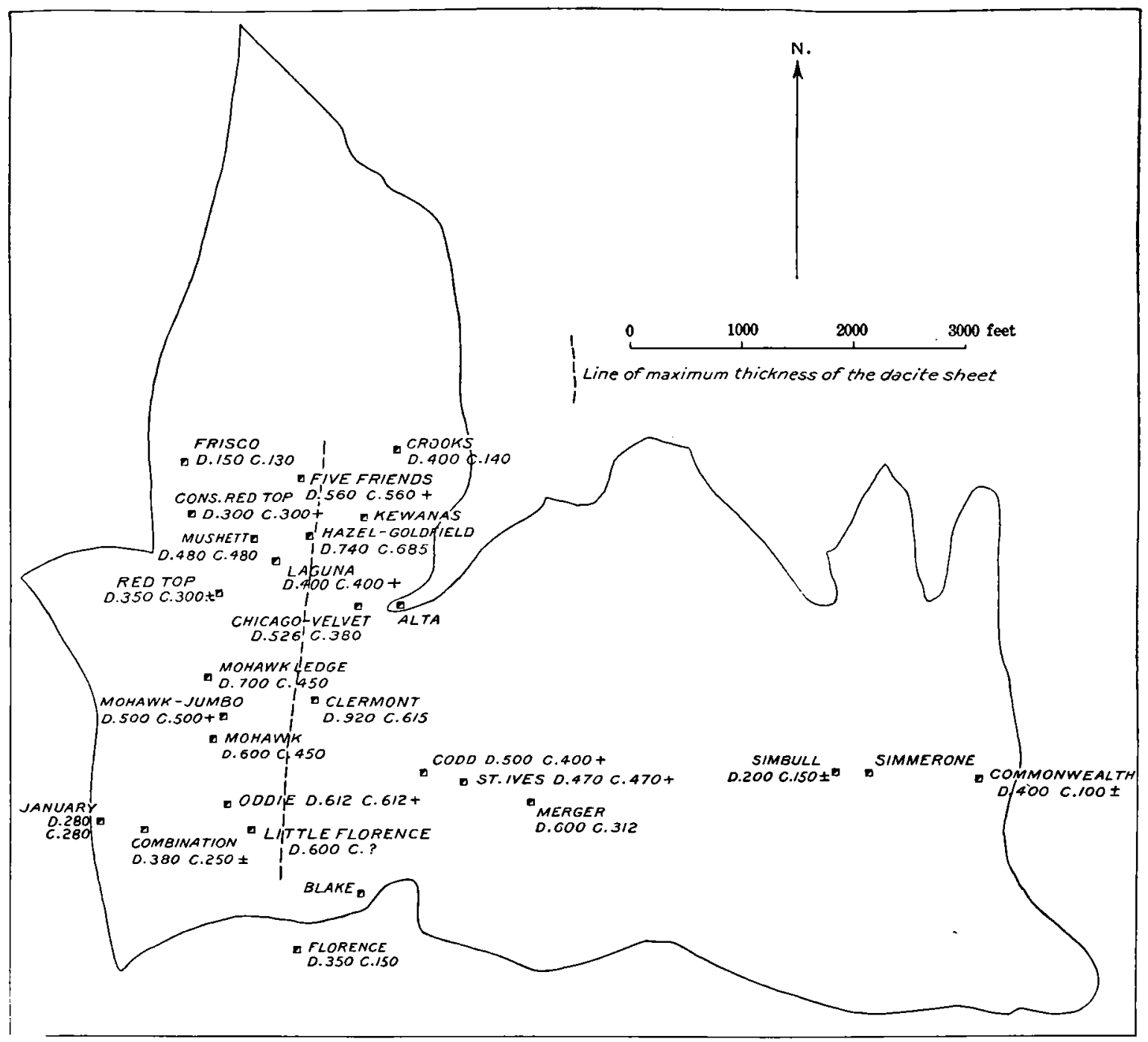

Figure 2.- Plan of the dacite mass near Goldfield, showing positions of shafts that penetrate it, their depths in feet (D), and the depths (C) at which they go into the underlying rocks.

vary inversely as the distance from the keel. There are, however, some notable irregularities, as is to be expected in an intrusive body. The Codd shaft on the St. Ives claim, for example, is in latite at 500 feet (152 meters) and is said to have gone through the dacite at about 400 feet (122 meters) or less. The St. Ives shaft, a short distance farther east and 470 feet (143 meters) deep, is still in dacite. A little farther east, the new Goldfield Merger shaft, according to a letter from Mr. H. P. Henderson, passes out of the dacite at 412 feet (125 meters). The collar of the St. Ives shaft, it is true, is about 15 feet (4.6 meters) higher than that of the Codd shaft and 25 feet (7.6 meters) higher than that of the Merger shaft. When these corrections 
are applied, however, the data furnished by the three shafts show that the bottom of the dacite does not rise regularly to the east.

Undoubtedly much remains to be learned regarding the configuration of the under surface of the dacite. This has been reached now in over a score of shafts, but these are not all so placed as to afford the most geological information. In most places the rocks at the contact are soft and the shafts closely lagged, so that for information concerning the change of formation the geologist must depend upon the memories and observations of those who performed the work of sinking; elsewhere the rocks are mineralized, as in parts of the Mohawk and Mushett mines, and their original character is thereby obscured. Some of the movements that have disturbed the rocks in this part of the district (in a manner and to an extent presently to be described) have affected the under contact of the dacite and probably in part caused the local softening which is its prevailing characteristic. The soft, gouge-like material ("mushy stuff") in the Goldfield Merger shaft is reported to be about 12 feet (3.6 meters) thick.

Without much question some of the irregularity in the lower surface of the dacite is due to a step-like structure produced by faulting. It is not possible at present to identify any of these faults at the surface or to trace them from point to point underground.

Fast of the Red Top mine a tongue-like area of Milltown andesite is shown on Plate II and figure 2 as extending into the dacite toward the Velvet mine. The relations of the rocks are here somewhat obscure. The andesite apparently underlies the dacite in part, but is here rather thin and is underlain by latite. Several shafts, including the Alta, 418 feet deep in 1908 , go through the andesite into latite, although the depth of the contact could not be ascertainerl. The Chicago shaft, just west of the Alta, is in dacite to a depth of 380 feet. The contact of the dacite with the Milltown andesite and the latite must at this place therefore be very steep. It is not exposed and it is not known whether it is an intrusive contact or a fault contact. Below 380 feet the Chicago shaft went through about 30 feet of soft andesite or andesitic tuff and then into latite, which was the rock in the sump (410 feet) in July, 1908.

As regards the original upper surface of the dacite sheet little information is available. The small area of Milltown andesite on the hill above the Mohawk mine is probably a remnant of the original cover of the laccolithic intrusion. This andesite is soft and decomposed, and since it was mapped in 1905 its surface has been largely covered up by dumps from the mines. It is evidently thin as it does not appear in the present underground workings.

Of the shapes of the other masses of dacite represented in Plate II little more is known than can be learned from a study of the mapped outlines, with reference to the topography. 'That they are for the most part very irregular in form is evident. Such irregularity, togetner with the distribution of the masses at variance with the rough concentric structure of the dome as a whole, is regarded as sufficient to establish the intrusive character of the dacite. Confirmatory evidence is supplied at a locality $1 \frac{1}{4}$ miles east of McLaughlin's well, practically on the line of section $\mathrm{C}-\mathrm{C}^{\prime}$, Plate VIII, where the dacite may be seen in close igneous contact with andesite, both rocks being comparatively fresh (see p. 58); and at various points along the southern contact, as shown on page 59 .

Although the dacite is for the most part unquestionably intrusive, there are some indications that the intrusion took place within a very moderate distance of the then existing surface. At the locality just mentioned the dacite not only shows glassy facies near the contact, but in some places exhibits flowage structure. Moreover, near Tognoni Springs the dacite, as previously shown, passes into a flow, showing that the lava in this part of the district actually broke through its thin cover and welled over the surface. Evidence of the same kind as that adduced in relation to the Morena rhyolite also supports the conclusion that the dacite intrusion was not deep-seated. The dacite is older than the Siebert formation, and so could not have served as cover. The only rocks in the district which can be supposed to have played this passive part are the andesite and older rocks cut by the dacite, and the dacite vitrophyre exposed in the southern part of the district. As stated on page 64, this dacite vitrophyre is supposed 
to have been erupted at nearly the same time as the dacite intrusion. It undoubtedly covered a considerable part of the district north of its present exposures, and may possibly have constituted a blanket of extrusive material under which the dacite solidified as superficial intrusions from the same magma reservoir that had supplied the vitrophyre.

The important dislocation which has been called the Columbia Mountain fault demands some consideration at this stage, particularly as regards its relation to the dacite intrusion. The fault, as shown in Plate II, has been traced from a point nearly east of Kendall Mountain to the eastern end of the town of Columbia, a distance of 2 miles. It dips to the east and has a normal throw, the Milltown andesite being relatively dropped against the older rhyolites and pre-Tertiary rocks of Columbia Mountain.

The structural effect of the fault is the uplift of the rocks west of it relatively to those east of it. As a consequence of the general erosion of the dome these locally uplifted older rocks, including the Cambrian sediments, alaskite, and rhyolites of Columbia Mountain, now appear at the surface, whereas in other parts of the district equally distant from the center of the dome they are buried under younger formations. The fault is very poorly exposed. It is followed by an inclined shaft at the Conqueror mine, where the dip is from $20^{\circ}$ to $25^{\circ}$. The shaly Sandstorm rhyolite which forms the foot wall is much disturbed and much of the

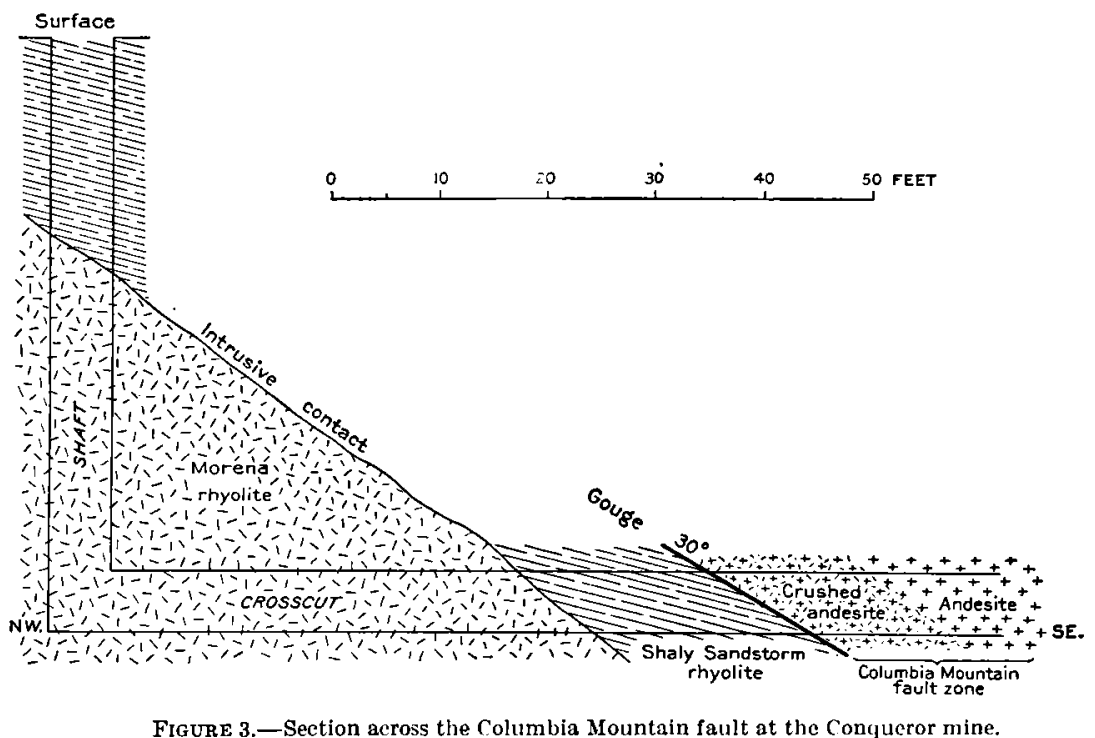
Conqueror workings. From this shaft southward there are no exposures of the fault plane until the southecstern slope of Columbia Mountain is reached. Here the Columbia Mountain No. 1 tunnel cuts through the fault plane, which separates crushed, fissured, and much-altered dacite from Cambrian sediments that are generally shattered and also show some fissuring approximately parallel with the main fault. The principal plane of dislocation appears to dip $45^{\circ} \mathrm{E}$. South of the tunnel and north of the water tank the outcrop of the fault passes through a saddle, and on the south slope of the mountain it coincides with a little ravine eroded in the soft, crushed material of the fault zone. A crosscut from the 200-foot level of the Booth shaft, just east of this ravine, is said to reach the fault, but this shaft was closed at the time of visit in 1908 .

The most southerly underground exposure of the fault is in the workings of the Consolidated Red Top Leasing Company. This shaft is about 250 feet east of the outcrop of the fault, which is rather indistinctly exposed in a railway cut. The bottom of the shaft, 300 feet deep, is in soft crushed dacite. A crosscut to the west, 30 feet in length, is in Cambrian shale at the face, and from this point a drift has been run south along the fault. This drift is all in soft, much-disturbed ground, shale and Kendall tuff being mingled in great confusion. The 
material is apparently all within the fault zone and it is doubtful whether the real foot wall has been reached. The position of the fault on this level taken in connection with the exposure in the railway cut gives a dip of $55^{\circ} \mathrm{E}$.

When the preliminary report on the district was prepared, the most reasonable explanation of the obscure structure south of Columbia appeared to be the postulation of a transverse northwest-southeast fault which was supposed to offset the main fault. The latter was thought to continue southward beyond this offset past the January mine and to constitute the boundary between dacite on the east and latite on the west. Thorough revision of the geologic mapping south of Columbia Mountain in 1908, aided by the numerous shafts sunk in this part of the district since 1905, many of which gave definite information where previously the kind of rock beneath the mantle of surficial material could only be guessed, showed that the original interpretation was erroneous. The hypothesis of a transverse fault had to be abandoned. Moreover, as shown on pages 58 to 59, the evidence bearing upon the relation of the dacite to the latite west of it, while not entirely conclusive, is more accordant with the supposition of an intrusive contact modified by many local fault slips than of juxtaposition effected primarily and chiefly by faulting.

The throw of the Columbia Mountain fault can not be accurately determined. It may amount to 400 to 500 feet (122 to 152 meters). (See Pl. VIII, section $A-\mathbf{A}^{\prime}$.)

It was supposed at one stage of the investigation that the Columbia Mountain fault was younger than the dacite, but the evidence now available points to a different conclusion. Reference to the geologic map (Plate II) shows the fault as ending about 600 feet (183 meters) northwest of the Red Top mine. At this place the dacite passes westward across the line of dislocation. South of the end of the fault the dacite is much fissured and the great ore bodies of the Red Top, Mohawk, Combination, Jumbo, and Florence mines occupy a zone of great disturbance which lies in the general path of the Columbia Mountain fault. Throughout this entire zone the dacite is traversed by an extraordinary number of fissures which carry soft gouge and which in the aggregate undoubtedly record much movement. So numerous are these slips, so varied in trend, and so frequently do individual fissures exhibit unexpected departures from a straight course that it is at present impossible to group them systematically or to identify any particular exposures as parts of a single dominant fault zone. The most that can be said is that the more important ones have a general north to north-northwest course. Can this fissuring record the whole of the movement represented by the Columbia Mountain fault? I believe not. It is too dispersed and irregular. There is at present no evidence that the dacite sheet as a whole has been displaced to anything like the extent it would have been had it been affected by the total movement represented by the Columbia Mountain fault. The hypotheses suggested as best accounting for the facts at present known are: (1) That the dacite was intruded after the main movement along the Columbia Mountain fault had taken place; (2) that the intruded magma to some extent followed the fault, possibly in some places coming up along it, and spread out where opportunity offered into sheetlike or laccolithic form; (3) that the Columbia Mountain fault continued, after the intrusion, to be a line of structural weakness and movement; and (4) that such renewed movements along the fault produced in the dacite, lying athwart the path of the dislocation, stresses which were relieved by complex fissuring of the brittle mass. Other stresses probably also contributed to this result, but it is believed that this revival of movement along the Columbia Mountain fault had a very important part in the fissuring and mineralization of the remarkable little area which has produced nearly all the gold thus far mined in the district.

As stated on page 39, the boundary between the Kendall tuff and the latite, just south of Columbia, is probably a fault. No geologic examination has been made of this contact, as it is not actually exposed at the surface, and the shafts in its vicinity had all been abandoned in 1908. This fault, like the Columbia Mountain fault, apparently ends at the dacite and is supposed to be older than that rock. South of it the Siebert formation laps over the prelacustrine rocks and little is known of their structure. Minor faults are certainly abundant in this part of the area and it is not improbable that future development, such as is planned by 
the White Rock Mining Company, may establish the existence of structurally important dislocations now concealed by the Siebert formation.

The faults in the vicinity of Vindicator Mountain are perhaps of the same age as the Columbia Mountain fault, but there is nothing to show that they may not be considerably older or younger. They are normal faults of moderate displacement and are not very well exposed. There are undoubtedly other faults in the district that have not been mapped. Those only are shown for which there is satisfactory evidence. There are many places where structural relations might be explained by hypothetical faults drawn where exposures are wanting or where the general disturbance and alteration admit the possibility of a fault while at the same time they prevent any definite proof or disproof of its presence.

Like the andesite, Sandstorm rhyolite, latite, and Vindicator rhyolite, the dacite vitrophyre is one of the annular elements of the domical structure, though apparently not a complete one. As exposed in the southern part of the district, it laps at a low angle over the andesite and is overlapped in turn by Meda rhyolite, andesite breccia, and Siebert formation. Its thickness is not accurately determinable, but is estimated at about 400 feet. If the dacite vitrophyre ever extended over the whole area now occupied by the Goldfield dome it has been eroded away from the northwestern half, where the Siebert formation rests directly upon Milltown andesite or older rocks.

The youngest rocks that participated in the domical uplift are the sediments of the Siebert formation and the volcanic flows intercalated with them, particularly the Mira basalt. The Siebert beds are prevailingly soft and are readily eroded, so that in most places they are covered by detritus which has been derived in large part from the underlying formation. Consequently the detailed structure of the beds is generally concealed or is very obscurely shown.

Along the northern border of the district the Siebert beds show little disturbance other than a gentle tilt away from the center of the dome. In some places, as north of McMahon Ridge, the erosion surface upon which the sediments accumulated appears to have been fairly even. In other places, as in the northeastern corner of the district, tuffaceous sands and beds of pumice seem to have accumulated in hollows amid hills. It is impossible, however, to distinguish with certainty between prelacustrine irregularities of surface and possible local deformation connected with postlacustrine basaltic outflows.

Along the western border of the district, north of Goldfield, the Siebert rocks are too poorly exposed to throw much light on their structure. That they were laid down upon an unevenly eroded surface is indicated by the character of the eastern boundary of the sediments as they lap up over the older volcanic rocks, and by the andesitic hill which rises through the lacustrine deposits near the Tonopah and Goldfield Railroad.

Southeast of Goldfield the Siebert beds are well exposed in the bluffs at the edge of the basaltic mesa, where the prevailing dip is about $18^{\circ} \mathrm{W}$. It is certain that in this part of the field the Siebert formation, as represented in sections D-D' and $\mathrm{E}^{\prime} \mathrm{E}^{\prime}$, Plate VIII, his been thrown into open folds. Existing exposures, however, are insuflicient to furnish the key to the details of this folding. If the former connection between the residual masses of Mira basalt south of Myers Mountain and the main part of the intercalated flow south of Goldfield were restored, the whole would form a buckled sheet nearly horizontal or with a low dip to the northwest along its northeastern margin, but with a dip of about $18^{\circ} \mathrm{W}$. where the Mira basalt passes under the mesa. (See Pl. VIII, section E-E'.)

On the east side of the Goldfield dome the annulus of Siebert beds is not complete. The andesite and dacite extend for 5 or 6 miles beyond the boundary of the area here described, and Ball's map (see Pl. IV) shows that the Siebert formation, if present, is covered by Quaternary deposits which overlap the Tertiary lavas.

With the post-Siebert deformation the Goldfield dome came into existence. Of the stresses which produced the structure practically nothing is known. Was the region gently arched by lateral centripetal pressure or was the ascensional force mainly a direct vertical upthrust? Were the rocks actually elevated or did the central part of the dome merely lay behind the rest of the region in a general subsidence? These are questions upon which some speculation 
is permissible provided the lack of real knowledge be not forgotten. We do know that throughout Tertiary time the entire region was the theater of volcanic activity and of crustal disturbances, the present results of which differ greatly in character in localities not necessarily far apart. The elaborate faulting described by Spurr at Tonopah, for example, has no counterpart in the structure at Goldfield, and this, in turn, has little in common with the faulting in the Bullfrog district. We may conclude with some reason that diastrophism or crustal movements and volcanism were genetically connected, and, with somewhat less confidence, that in general some subsidence followed the extensive transfer of lava from subcrustal regions to the earth's surface. As different lavas were erupted at different times in different parts of the region such subsidence, if it occurred, must have been intermittent and can scarcely be conceived of as proceeding at an equal rate over the entire tract affected by Tertiary volcanism. While one area was sinking an adjoining area might be quiescent or even rising; between the two would be developed stresses which might find relief in complex faulting. Thus the development of domical and other flexures and of local fields of faulting is in a general way susceptible of genetic correlation with volcanicity. The actual mechanism in each case, however, is entirely concealed.

After the Goldfield region had been domed, erosion appears to have reduced it to a surface of comparatively low relief. This was partly covered by the postlacustrine flows, of which those of olivine basalt are most important. Subsequent erosion, extending to the present, has cut through and carried away the greater part of these flows, leaving the remnants as tabular cappings to buttes and mesas in outlying parts of the district. These remnants, as may be seen from Plate II, occur at various elevations and have perhaps suffered some changes in altitude by crustal warping of the region. The observed differences in elevation of the bases of the various remnants of the basaltic flows, however. are not too great to be accounted for by the flowage of the lava over an originally uneven surface.

That some deformation has taken place subsequent to the basalt eruptions is shown by minor faulting southwest of Goldfield. The small hill at the mouth of Pozo Canyon is apparently part of a triangular fault block in which some of the rhyolite and basalt of the mesa have been dropped into the Siebert beds. Other minor faults are shown which slightly displace the rocks capping the mesa. (See Pl. II.)

These faults are comparable in age and character with the post-Siebert faults so abundant at Tonopah. Dislocations of this epoch, however, are of very slight structural importanco at Goldfield, although perhaps not entirely confined to the one locality scuthwest of town. Faults of similarly small throw occurring in the older volcanic formations in the central part of the dome might escape recognition. 


\section{CHAPTER IX.}

\section{GEOLOGIC HISTORY AND CORRELATION.}

\section{INTRODUCTION.}

Since the historical sequence has served in the preceding chapters as a framework for the orderly presentation of lithologic and structural description, the reader already has an insight into the geologic development of the Goldfield district. It is the purpose of the present chapter, however, to narrate the series of geologic events with greater clearness and with more regard to their broader relationships than was possible while the attention has been occupied with descriptive details - with the slow inductive steps that have led, as it were, to the crest of an eminence whence the whole region previously traversed may be comprehensively viewed. It is believed that this purpose will be served most directly by first summarizing the local geologic history with as little reference as possible to regional correlation. With the sequence of local events well in mind, the relations of the Goldfield rocks to those of the surrounding region may then be considered, and finally such conclusions will be drawn as are permissible regarding the Tertiary chronology and the succession of the lavas in this part of the Great Basin.

Such is the general plan of this chapter. The pre-Tertiary rocks, however, have so little prominence in the part of the geologic record with which this paper has chiefly to do, that it seems best to depart, with respect to them, from a rigidly systematic treatment and to combine some suggestions of correlation with the local narrative. This early clears the way for the concentration of an undivided attention upon the Tertiary.

\section{LOCAL GEOLOGIC HISTORY.}

BEFORE TERTIARY TIME,

The records of what took place prior to the opening of Tertiary time are fragmentary. During the early part of the Paleozoic, probably in the Cambrian, thin-bedded calcareous and quartzose sediments were laid down upon a surface of still older rocks. Of the pre-Cambrian surface no vestige is visible in the Goldfield district at the present time. Moreover, the reconnaissance of $\mathrm{S}$. $\mathrm{H}$. Ball ${ }^{a}$ over a region more than 8,500 square miles $(22,100$ square kilometers) in extent, lying mostly south and east of Goldfield, has revealed no rocks certainly older than the Cambrian. The nearest pre-Cambrian rocks shown by J. E. Spurr on his earlier reconnaissance $\operatorname{map}^{b}$ are at the south end of the Kingston Range, in California, 150 miles (241 kilometers) south-southeast from Goldfield and in the Kern Mountains and Snake Range, 200 miles (322 kilometers) to the northeast of the district. Ball ${ }^{c}$ notes that the Cambrian Prospect Mountain quartzite in the Specter Range, about 95 miles (153 kilometers) southeast of Goldfield, contains pebbles of sedimentary rock and of granite, thus giving a clue to the local character of the vanished pre-Cambrian terrane.

The masses of Cambrian rocks exposed in the Goldfield district on Columbia and Vindicator Mountains are mere fragments which probably belong in the upper division of the lower Cambrian as mapped by Ball-the Prospect Mountain limestone of Arnold Hague, ${ }^{d}$ renamed by

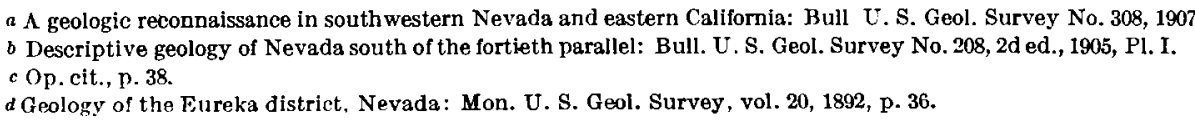


Walcott ${ }^{a}$ the Eldorado limestone. Rocks belonging to this division, according to Ball, ${ }^{b}$ are extensively exposed in hills to the north, west, and south of the Goldfield district and contain a lower shale member at least 1,000 feet (305 meters) thick, an overlying limestone several thousand feet thick, and probably a second shale member. The Goldfield masses are thought to represent remnants of the thick lower shaly member.

Although it is known that Ordovician, Silurian, and Carboniferous beds were deposited in southwestern Nevada, no representatives of these periods occur within the Goldfield district, nor, so far as known, within a radius of 40 to 50 miles (64 to 80 kilometers). The history of Paleozoic time subsequent to the Cambrian is locally blank. Presumably there was deposition, the products of which were afterwards swept away by erosion. The first authentic record following that of Cambrian deposition is supplied by the intrusion of the alaskite now exposed in the central part of the Goldfield dome. The geologic date of this intrusion, which greatly disrupted the Cambrian beds, is not certainly known, but; as shown on page 35, the work of King and later observers affords a strong suggestion that it took place at the close of the Jurassic or beginning of the Cretaceous, being thus generally contemporaneous with the main granitic intrusions of the Sierra Nevada.

As the alaskite has all the characteristics of a deep-seated or plutonic intrusive, it may be concluded that it solidified under a considerable thickness of other rocks. The undoubted deformation of the Cambrian rocks at the time of intrusion suggests that a mountain range may have come into existence in the Goldfield region at the opening of the Cretaceous.

Clarence King, ${ }^{c}$ thirty years ago, noted the absence of Cretaceous deposits from the section of the Great Basin lying between the Wasatch and Sierra Nevada ranges, and subsequent work has all tended to support the conclusion that throughout this long period that part at least of the Great Basin included within the boundaries of Nevada was a land mass undergoing erosion. ${ }^{d}$ The results of Spurr's and Ball's reconnaissances, as well as the local history recorded in the rocks at Goldfield, accord with this generalization. During the Cretaceous the region was greatly eroded. Whatever mountains may have existed on the site of Goldfield were destroyed, the once deeply buried alaskite was exposed over broad areas, and the country was characterized at the end of the period by a topography of low rounded hills, which swelled above rolling plains or merged into open, gently sloping valleys. There is no evidence of any extensive accumulation of soil or of any vigorous growth of vegetation upon this pre-Tertiary surface. So far as appears from the few exposures available, the slopes were of rock, here and there thinly veneered with stony detritus derived mainly from the metamorphosed Cambrian shales. The landscape at the close of the Cretaceous, could one have seen it, must have been expressive of long-continued crustal stability and of the waning power of denudation concomitant with the reduction of relief. It could have afforded little suggestion of the next scene in the geologic drama.

Although erosion reduced what is now the Goldfield district to comparatively low relief, Ball's work shows that no extensive peneplanation was effected over the surrounding region. His statement $e$ is:

A long period of erosion, extending at least to Eocene time, followed the post-Jurassic folding and consequent mountain building. This period was probably one of heavy rainfall and large rivers. No estimate can be formed of the amount of erosion, but it was sufficient to remove from the granite the covering beneath which it solidified. Notwithstanding the length of this erosion period, no peneplain was formed. From this it is inferred that the area was subjected to successive uplifts while being eroded. Where exposed beneath the oldest Tertiary formation, the Paleozoic rocks appear to have been eroded into mountain ranges, many of which have a north-south extension. Some of these mountains of Paleozoic rocks-for example, the Kawich Range-were fully as high and rugged as the present ranges.

a Walcott, C. D., Cambrian geology and paleontology. No. 5: Cambrian sections of the Cordilleran area. Smithsonian Miscell. Coll. No. 131?, Washington, 1908 , p. 184

b Op. cit., pp. 51-5?.

e U. S. Geol. Expl. 40th, vol. 1, Systematic geology, 1878, pp. 296-297.

d See also Chamberlin, T. C., and Salisbury, R. D., Geology, vol. 3, 1906 , figs. 379 and 388.

e Op. cit., p. 40. 
Farther north, in the Humboldt region, G. D. Louderback ${ }^{a}$ found that the post-Jurassic erosion resulted in a topography of very low relief, approaching a peneplain, and comparable, apparently, with that developed in the Goldfield district.

\section{TERTIARY PRELACUSTRINE EPOCH.}

At a time which can not be definitely fixed, but which may provisionally be identified with the Eocene, lavas broke through the eroded surface just described, and their appearance marked the beginning of a period of active volcanism, which continued through the Tertiary.

The first volcanic eruption in the Goldfield district is represented by the Vindicator rhyolite. This flow, as described on page 37, is exposed on the slopes of Vindicator Mountain and forms the summit of Columbia Mountain. Its original extent is unknown. It does not appear on the alaskite exposed near Banner Mountain, but its absence from that locality•may be due to erosion prior to the next volcanic outburst.

The Vindicator rhyolite was followed in the Goldfield district by one or more flows of latite, which probably covered the older rocks completely. The vents whence the latite issued are entirely unknown. The prevalent alteration of the rock interferes with a complete determination of its original character and renders comparison with rocks in neighboring districts uncertain.

There is, within the Goldfield district, no definite evidence of erosion of the latite prior to the succeeding eruptions. Ball, ${ }^{b}$ however, reports an erosion unconformity in the Kawich, Amargosa, and Cactus ranges, in the Bullfrog Hills, and in the Shoshone Mountains, ${ }^{c}$ between rocks supposed to be the equivalent of the latite and subsequent flows. In general accord with the views of Spurr, ${ }^{d}$ he regards this unconformity as marking the division between the Eocene and Miocene, thus placing the Sandstorm and Morena rhyolites and the Milltown andesite in the Miocene. The question whether they belong there will be considered later.

Following the latite, with perhaps an interval of erosion, came the eruption of the Kendall tuff and Sandstorm rhyolite. ${ }^{e}$ The tuff and the character of the rhyolite indicate the proximity of a local center of explosive eruptions which it is thought lay just north of the site of Columbia Mountain. Beneath the volcanic pile which probably rose in this part of the district were intruded the masses of Morena rhyolite and the solidification of these brought to a close the second epoch of rhyolitic eruptions. As described on page 78, erosion appears to have attacked with energy the volcanic accumulations and reduced them to such an extent that the intrusive Morena rhyolite was laid bare.

The Milltown andesite flows which, with some tuff and a local outpouring of basalt, record the next volcanic disturbance not only are one of the most important formations in the Goldfield district but, as Ball's map shows, are part of the largest area of such rocks in the entire region covered by his reconnaissance. Their distribution suggests that these lavas were erupted from vents within the tract now corresponding to the Goldfield Hills. The andesites of Goldfield constitute a volcanic complex in which biotitic hornblendic and pyroxenic andesites are inextricably involved, the connection in many places being apparently through an actual gradation of one variety into another.

After the cessation of the andesitic eruptions the series of lavas was faulted and was invaded by dacitic magma. It is probable that erosion had already begun to attack the andesites before the intrusion of the dacite, but of this there is no clear evidence, and the two periods of eruption were probably separated by an interval of time geologically brief. The reasons for supposing that the dacite was a comparatively superficial intrusion which passed into extrusive flows to the eastward have been given on page 81. It has also been suggested (p. 64), although not demonstrated, that the dacite vitrophyre also represents a part of the dacite magma which, perhaps a little later, broke through the thin cover of andesite and

\footnotetext{
a Basin range structure of the Humboldt region: Bull. Geol. Soc. America, vol. 15, 1904, pp. 307, 337.

b Op. cit., pp. 32-33.

c A small group of hills east of the Bullfrog district, in latitude $37^{\circ}$; not the Shoshone Range of the Fortieth Paraliel reports.

$d$ Succession and relation of lavas in the Great Basin region. Jour. Geology, vol. 8, 1900, p. (i37.

$e$ On Ball's reconnaissance map the areas of Sandstorm and Morena rhyolite north of Columbia are colored as 'middle Miocene rhyolite," which would make them later than the andesite and dacite of the Goldfield district. This is doubtless a mere oversight in the reproduction of the map.
} 
poured over the surface as lava flows. There were also minor contemporaneous eruptions of andesite, for flows of this rock (Chispa andesite) are associated with the flows of dacite vitrophyre in the southern part of the district.

Next came the eruption of the Meda rhyolite, followed probably by the intrusion of the andesitic dikes which cut the dacite vitrophyre in the southern part of the district and which are provisionally correlated with the eruption of the andesitic breccia exposed at the southern edge of the mapped area.

Whether there was any considerable erosion of the dacite and earlier volcanic rocks before the initiation of the lacustrine conditions next to be described is not clearly shown in the Goldfield district.

\section{LACUSTRINF: EPOCH.}

Up to the stage in the geologic history now reached there has been no indication that the Goldfield district was at any time during the Tertiary an area of sedimentation. Erosion was presumably more or less active, but its products were either carried to the sea, which is known to have extended in Eocene time into the Mohave Desert region, ${ }^{a}$ or were deposited in lakes outside of the Goldfield area.

After the dacitic eruptions, however, most of the area now known as the "Goldfield district" was submerged beneath the waters of a lake. This body of water was no local feature, but, as will later be shown, probably covered a large part of western Nevada and owed its existence to conditions that changed the aspect of a wide region. Since the lacustral sediments at Goldfield attain a thickness of probably 1,000 feet (305 meters), the lake was in all likelihood deep, although to some extent deposition and submergence may have gone on together. On the other hand, the character of the beds indicates that they were laid down at no great distance from land, and some of them may be regarded as shore deposits. The inference is that the submerged topography was of strong relief. The lake probably possessed a deeply indented shore line and was diversified by numerous rugged islands and peninsulas.

There can be little doubt that on some of the mountainous islands and about the shores of the lake volcanoes were in intermittent eruption. Clouds of siliceous volcanic dust must at times have swept over the ruffled surface of this inland sea, and pumice either fell into the water or was brought down by streams from the volcanic slopes to drift about, to gather in sheltered bays, and finally to subside in a water-logged condition to the bottom. Occasionally flows of lava appear to have entered the lake and spread over part of the sediments previously deposited on its bottom. These were chiefly thin sheets of rhyolite, but at one time there was an important flow of quartz-bearing basalt. Throughout this epoch erosion was attacking with energy the loose volcanic material supplied to the land by the eruptions and was cutting also into the older rocks. Great quantities of sedimentary material were thus carried into the lake to mingle with and alternate with the products of ash showers and the layers of diatom frustules, while coarse imperfectly rounded fragments were dropped near shore by torrents which rushed down the mountain sides.

The prevalence of diatomaceous deposits in the Siebert formation shows that the lake was fresh throughout most of its existence. The beds exposed in the district afford no suggestion of deposition under saline conditions.

Finally, through changes that were associated with, if not produced by, orographic movements, the lake was drained, its sediments were folded, perhaps faulted, and the Goldfield dome came into existence.

\section{POSTlaClstrine History.}

With the disappearance of the lake waters erosion began to attack the sediments, and soon stripped them away from part of the domical uplift, which, indeed, they may never have entirely covered. The final result of this period of denudation appears to have been the reduction of the region to a surface of low relief, with at least some local peneplanation, as is shown

a See Arnold, Ralph, and Strong, A. M., Somecrystalline rocks of the San Gabriel Mountains, California: Bull. Geol. Soc. America, vol. 16, 1905, p. 188, footnote. Apparently the first recognition of the Eocene age of these rocks was by W. P. Blake in the Pacific Railroad Reports, vol. 5, 1856 , map III. 
by the manner in which the horizontal lava flows of the mesa southwest of Goldfield lie upon the smoothly truncated edges of the old lake beds (Siebert formation). The accumulation of the fluviatile Pozo formation belongs to this period of erosion, which was followed by a renewal of volcanic activity, recorded by the two lava flows composing the Spearhead rhyolite.

Overlying the Spearhead rhyolite is the Rabbit Spring formation, consisting of rhyolitic sandstone and volcanic conglomerate, with a total thickness of about 15 feet (4.5 meters). This deposit may possibly have been laid down in a shallow transient lake, but the evidence for a return of lacustral conditions is far from conclusive. The deposit probably represents the action of shallow streams, which spread over the nearly horizontal surface of the lava flow. Whatever the origin of the Rabbit Spring formation, the time occupied in its deposition was brief, and the sedimentary material was soon covered by the Malpais basalt.

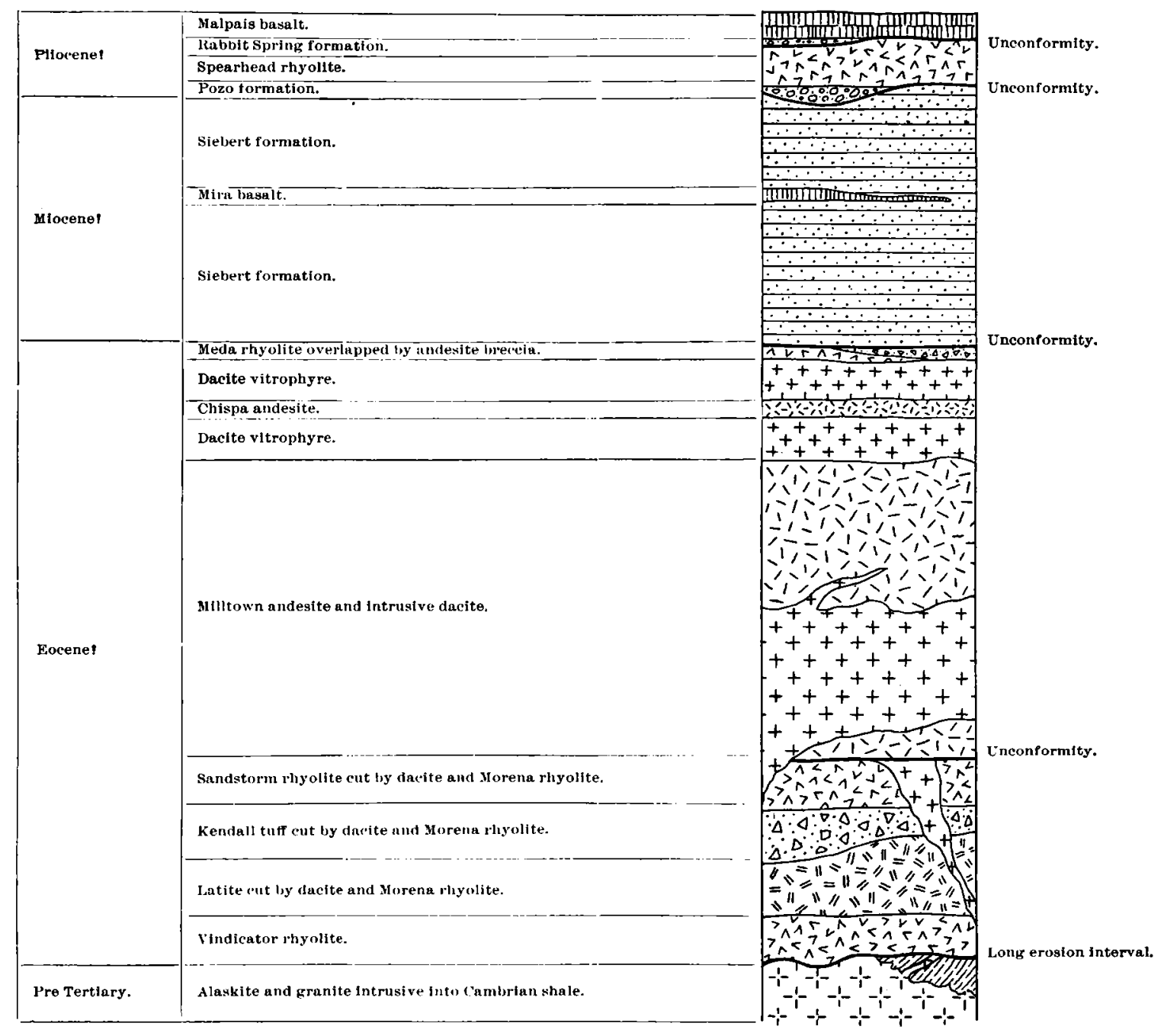

FIG URE 4.-Generalized columnar section of the rocks of the Goldfield district.

Since the basalt solidified the district has been subjected to some minor faulting and probably also to some unequal settling or warping of its surface. Erosion has cut through the basalt, dividing what was probably once a continuous sheet into the various remnants now capping mesas and flat-topped buttes, has excavated the broad valley in which the town of Goldfield lies, and has carved the hills into their present forms. As shown on page 75, there is some evidence in the shape of gravel deposits which indicates a stage in the erosion when the drainage was notably different from that now developed in the district. There is a possibility that this earlier drainage may have been associated with a brief lacustrine period, but the observable facts justify no more than this bare suggestion. 
The general sequence of events in the Goldfield district is summed up in the accompanying columnar section (fig. 4). For convenience in subsequent comparison and correlation, Ball's general columnar section of southwestern Nevada is reproduced as figure 5 .

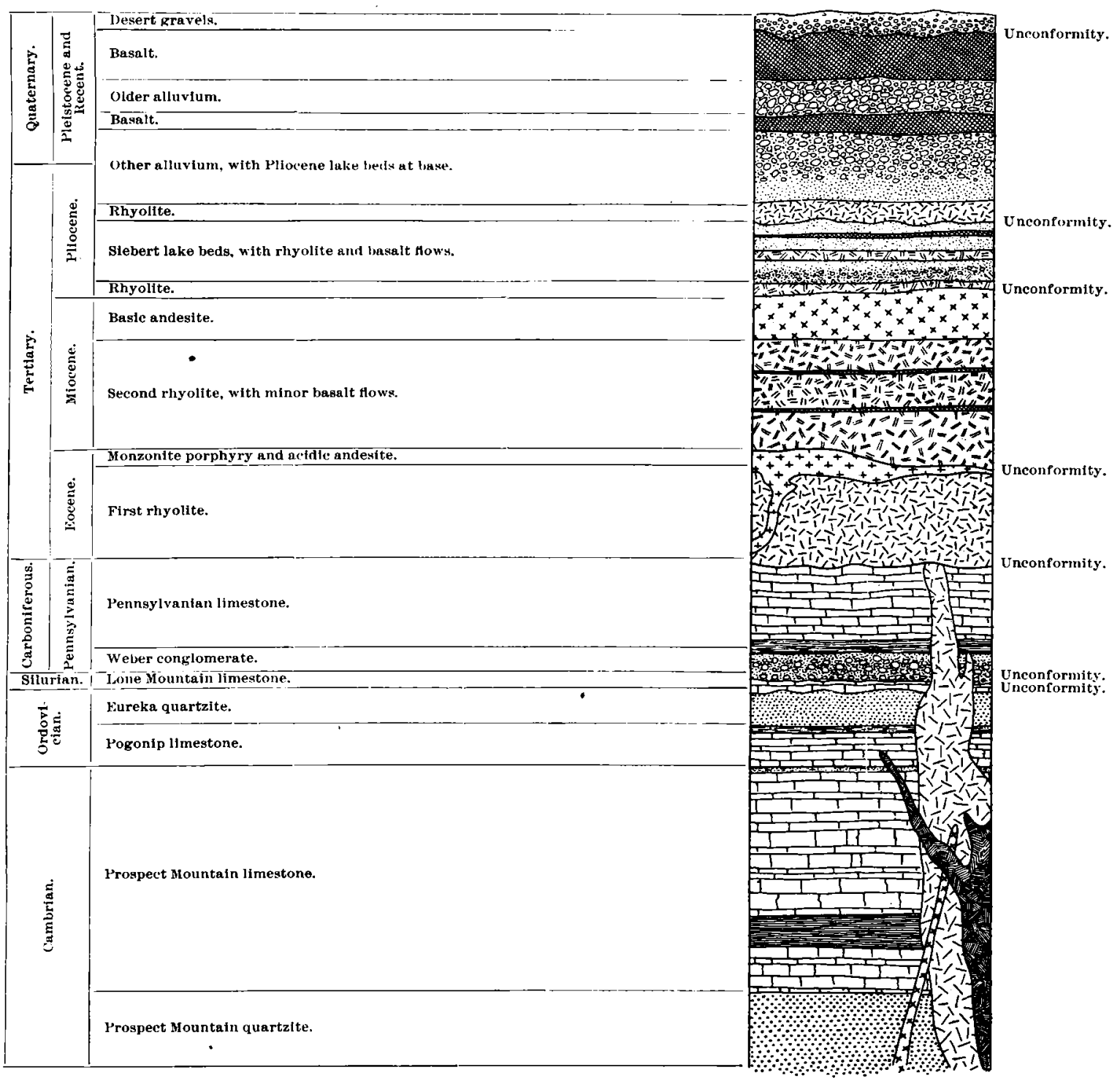

FTgure 5. -Columnar section of rocks of southwestern Nevada and eastern California. After S. H. Ball (Bull. U. S. Geol. Survey No. 308, 1907, p. 27) [The extension of the Pliocene down to include the Siebert lake beds is clearly an oversight. To be consistent with the table of Bulletin 308 (reproduced on page 93) and with the text of Ball's report, the base of the Pliocene should colncide with the unconformity at the top of the Siebert. The "Prospect Mountain" limestone is now known as the Eldorado limestone.-F. L. R.]

\section{CORRELATION OF THE GOLDFIELD TERTIARY ROCKS WITH THOSE OF THE SURROUNDING REGION.}

\section{INTRODUCTORY STATEMENT.}

Throughout that part of the Great Basin included in western Nevada marine fossils of later time than the Jurassic are unknown, and, as has previously been stated, the orogenic disturbances at the close of that period in all probability resulted in the final exclusion of the sea from the region. Thus definite paleontological correlation, such as is usually possible in the case of persistent and fossiliferous marine deposits, is not attainable. Recourse must be had to scanty fresh-water faunas or land floras as yet of more or less doubtful determinative value, preserved in lake sediments which, whatever may have been their original areal relations, are 
now scattered and isolated deposits. Under these circumstances the physical history of the region and the lithological character of the various eruptive rocks assume an importance not accorded them where more trustworthy means of correlation are available. That great physical events, such as the post-Jurassic deformation and erosion, have far-reaching effects and may legitimately be used as datum planes in correlation is of course true; but without any satisfactory paleontological evidence it is not always possible for the observer to be sure that any event which has left a locally conspicuous record is also the mark of a geologic revolution regional in its extent. In the case of correlation by lithology the possibility of error is much greater, since carefully studied districts in Nevada reveal not only the prevailing complexity of the volcanic sequences, lavas of similar character being in some localities several times recurrent, but also the very small areal extent of many of the eruptions.

In a comparison of the Tertiary portions of the various local geologic columns in southwestern Nevada two horizontal datum zones of wide regional extent are preeminently conspicuous. One is the unconformity between the Tertiary rocks and the rocks worn down by the post-Jurassic erosion interval. The other is the thick accumulation of lacustral sediments, known in different parts of the region as the Truckee group, ${ }^{a}$ the Esmeralda formation, ${ }^{b}$ Siebert tuff, ${ }^{c}$ and Siebert lake beds. ${ }^{d}$ The first datum is of so definite a character that it may be regarded chronologically as a horizontal plane. The second is less definite and, as will later appear, there is some question whether the base of these lacustrine sediments is not chronologically as well as physically a very irregular boundary, here sagging deep down into the earliest Tertiary and there rising into the latest part of that geologic period. However that may be, without further anticipation of later discussion, it is possible in the meantime to make use of the lacustrine epoch, corresponding more or less closely with King's Pahute Lake, as a datum plane in preliminary correlation on physical and lithologic grounds. To the details of such correlation we may now pass.

\section{PRELACUSTRINE ROCKS.}

The Vindicator rhyolite, the oldest of the volcanic rocks at Goldfield, is perhaps the equivalent of a rhyolite described by Ball ${ }^{e}$ as forming the main mass of the Stonewall Range, 18 miles southeast of Goldfield, and regarded by him as representing the earliest Eocene eruption. This relation, however, does not necessarily imply that the rhyolite of the two localities ever formed a single continuous flow. According to J. E. Spurr, ${ }^{f}$ rhyolite of corresponding age also occurs in the Silver Peak district, in the Panamint Range, in the Randsburg district, and near Daggett in the Mohave Desert.

The latite of Goldfield appears to correspond in age and geologic position to rocks embraced under "monzonite and biotite andesite" in the correlation table of Ball, $g$ here reproduced (p.96). This would make it equivalent in time of eruption and magmatic origin to the monzonite porphyry of the Kawich Range ${ }^{h}$ (50 miles (80 kilometers) east-southeast of Goldfield) and to the hornblende-biotite latite of the intervening Cactus Range. Ball's ${ }^{i}$ description of the latter rock indicates a very close resemblance to the latite of Goldfield, not only in original character but in mode of alteration.

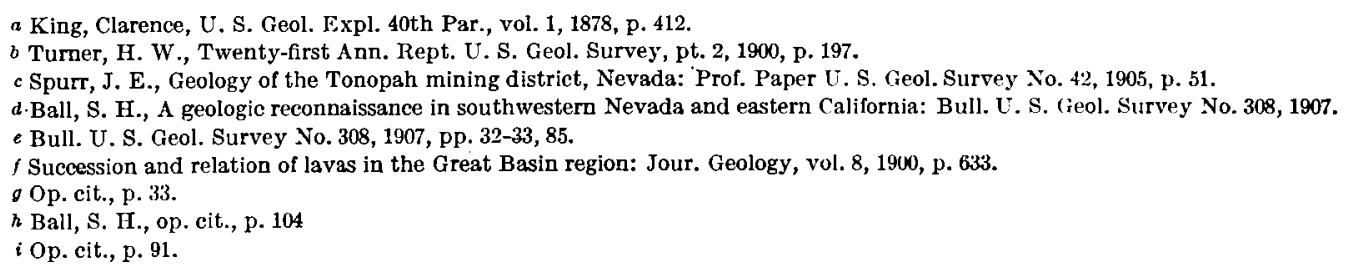


Correlations of Tertiary formations in rarious ranges of southwestern Nevada. ${ }^{a}$

[Symbol $\times$ shows presence of formation.]

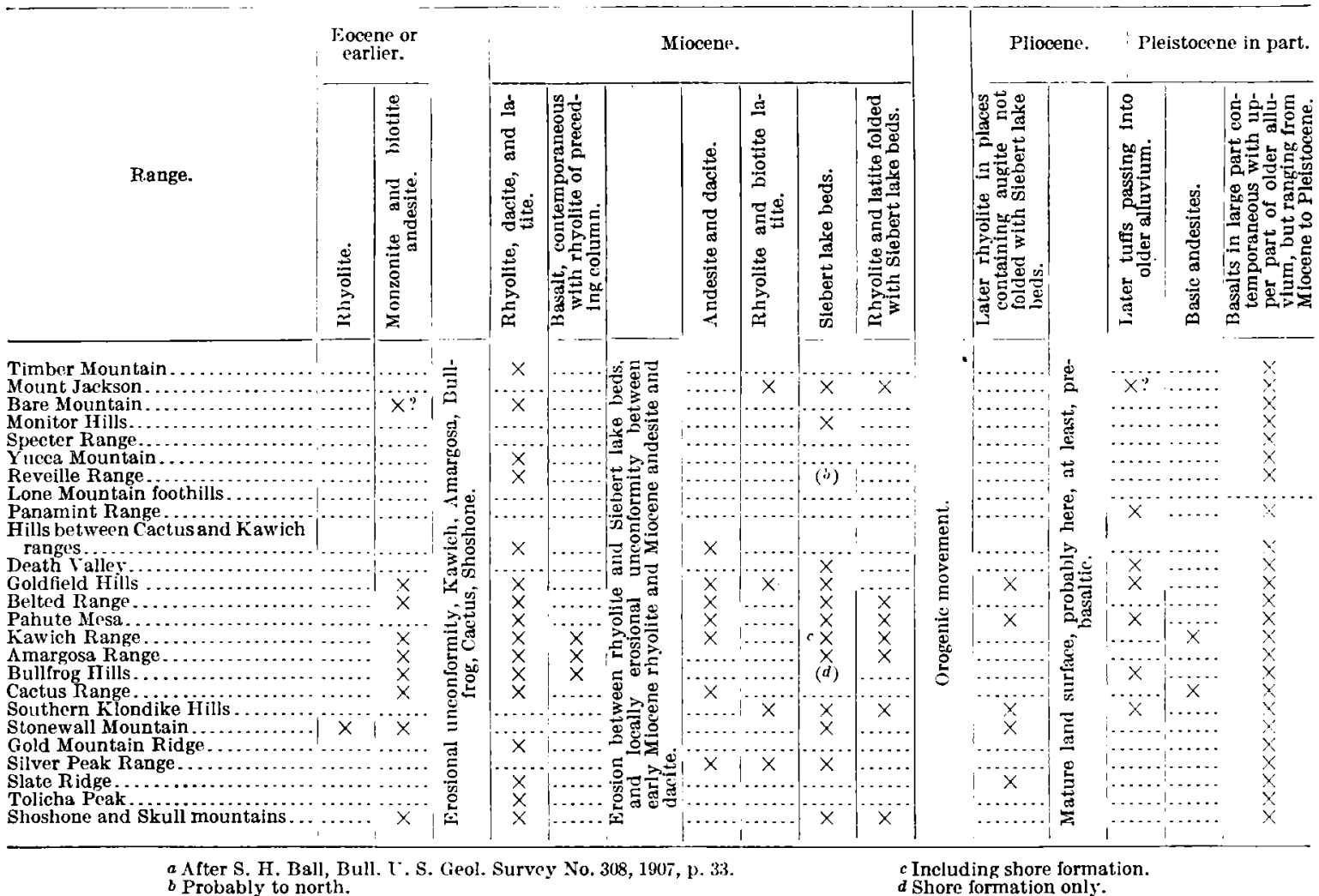

The next physical event recognized by Ball (see his table above) is an erosion interval marked by unconformity which he has observed in the Kawich, Cactus, and Amargosa ranges, in the Sboshone Mountains, and in the Bullfrog Hills. This unconformity, which he considers as corresponding with the end of the Eocene or the beginning of the Miocene, is not distinctly shown at Goldfield.

The Sandstorm and Morena rhyolites were apparently erupted contemporaneously with what Ball has called "early Miocene rhyolite," a formation which according to his reconnaissance map is of widespread importance in southwestern Nevada, making up the greater part of the Cactus, Kawich, Reveille, and Belted ranges and of the Bullfrog Hills. It is also the principal rock of Timber and Yucca mountains east of the Bullfrog district. The rhyolite of some of these areas, according to Ball, is associated with contemporaneous flows of dacite and latite, a relation not exhibited at Goldfield. As rhyolites were erupted at least half a dozen times during the Tertiary in this general region it is evident that correlation of these lavas from one range to another is, in our present stage of knowledge, tentative. The difficulty experienced in distinguishing by detailed work the 4 or 5 different rhyolites occurring in the Goldfield district shows that more than rapid reconnaissance will be necessary before it can be definitely asserted, for example, that the Sandstorm rhyolite is in part the equivalent of the much thicker series of rhyolites in the Bullfrog Hills.

The Milltown andesite of Goldfield is grouped by Ball with the dacite, and this group is correlated by him with rocks in the Belted, Kawich, Cactus, and Silver Peak ranges. The oldest Tertiary rocks described by J. E. Spurr ${ }^{a}$ in the Tonopah district, 30 miles (48 kilometers) north of Goldfield, are andesites which he designates "earlier" or "hornblende-biotite" andesite, and "later" or "biotite-augite" andesite. An interval of erosion is described between the two. These andesites may be of about the same age as the andesite at Goldfield, although 
the unconformity has not been recognized in the latter district and the rocks of the two areas are not petrographically identical.

In the Tonopah district also Spurr describes a series of dacites and rhyolites which correspond to a long period of eruptive activity and for the most part are older than, or are overlain by, the Siebert lake beds. He considers, however, that the dacitic eruptions and the lake beds belong to the same general period (Miocene), and shows that the lake beds after they had been folded, eroded, and covered by basalt were intruded by dacite. Thus there is a suggestion that the dacite of Tonopah may in part be equivalent to the dacite of Goldfield. Closer examination, however, renders this correlation questionable. In the first place there is no evidence at Goldfield that dacitic eruptions continued into the lacustrine epoch, although it can not be positively asserted that they did not do so. In the second place the dacites of the two districts are distinctly different rocks; that of Goldfield is a quartz-bearing andesite or true dacite, while those at Tonopah, as Spurr ${ }^{a}$ himself states, are not, strictly speaking, dacites at·all, but are siliceous quartz latites and rhyolites. This difference is brought out in the following table of chemical analyses:

Chemical analyses of Goldfield and Tonopah dacites.

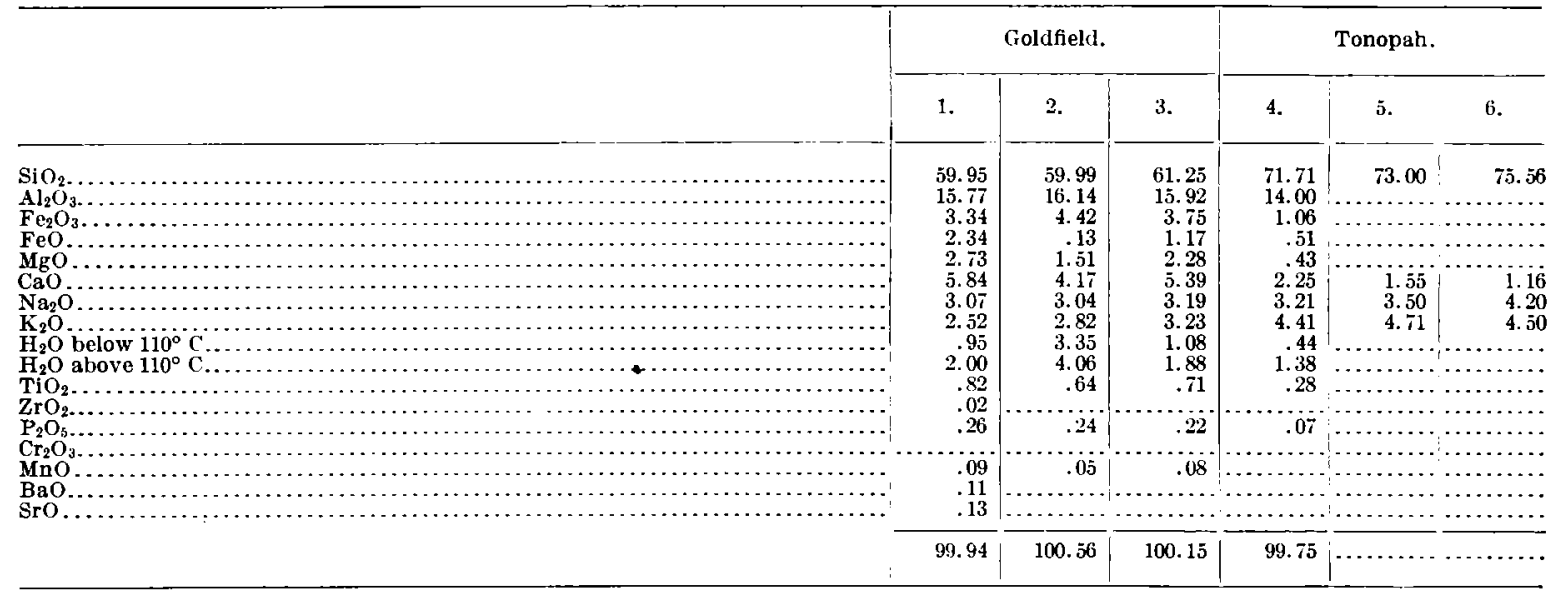

1. Dacite (G. 97), one-half mile (2.4 kilometers) northeast of Columbia Mountain, Goldfield district. George Steiger, analyst.

2. Dacite vitrophyre (G. 158), 1 mile (1.6 kilometers) south west of Blackcap Mountain, Goldfield district. George Steiger, analyst.

3. Dacite (G. 83), Diamond Peak, Goldfield district. George Steiger, analyst.

4. "Dacite," Brougher Mountain, Tonopah. George Steiger, analyst. (Spurr, op. cit., p. 57.)

5. "Dacite," Butler Mountain, Tonopah. E. T. Allen, analyst. (Spurr, op. cit., p. 57.)

6. "Dacite," Golden Mountain, Tonopah. F. T. Allen, analyst. (Spurr, op. cit., p. 58.)

Comparison of the three analyses of rocks from each district shows conclusively that the so-called dacites of Tonopah are quite distinct from the dacite of Goldfield. The Tonopah dacites, according to Spurr, ${ }^{b}$ all fall into the subrang toscanose of the quantitative system. H. S. Washington's ' tables include in this subrang 122 entries, of which 40 were originally described as granites, 31 as rhyolite, liparite, obsidian, etc., and 9 as quartz porphyry. Among the remaining 42 entries are trachyte, åkerite, quartz monzonite, toscanite, latite, etc., but only one dacite. The positions of the Goldfield dacite and dacite vitrophyre in the quantitative system have been given on pages 57 and 63 ,

It appears from the foregoing comparison that the dacite of Goldfield is not lithologically identical with the so-called dacites of Tonopah and that some of the latter are younger than the former. It is probable that some of the later of these Tonopah eruptions correspond in time with the thin rhyolitic flows known to be intercalated between the beds of the Siebert formation at Goldfield. On the other hand, some of the earlier "dacites" and rhyolites (i. e., Heller dacite, Fraction dacite breccia, and Tonopah rhyolite-dacite) at Tonopah, which Spurr ${ }^{d}$ shows

a Geology of the Tonopah mining district: Prof. Paper U. S. Geol. Survey No. 42, 1905, pp. 365, 9. b Op. cit., p. 60

$c$ Chemical analyses of igneous rocks: Prof. Paper L. S. Geol. Survey No. 14, 1903, pp. 159-173.

dOp. cit., p. 54 . 
to have been eroded before the deposition of the lake beds, although lithologically different, may be approximately equivalent in age to the dacite vitrophyre of Goldfield.

The merely tentative correlation thus far attempted in this chapter has had to do with volcanic rocks lying between the post-Jurassic erosion surface and the earliest Tertiary lacustral sediments. The extent to which these sediments, as now exposed in various areas, possess common lithologic, stratigraphic, and tectonic characteristics next demands attention, and the general discussion may be fitly introduced by a brief summary of the more important descriptive literature on the older Tertiary lake deposits of western Nevada.

\section{LACUSTRINE SEDIMENTS.}

King, ${ }^{a}$ who applied the name Pahute Lake to the great body of water which he supposed to have covered western Nevada in Miocene time, outlines the distribution of the lacustral sediments (Truckee group ${ }^{b}$ ) as follows:

The rocks of the group are limited on the east, within the boundaries of our exploration, by the one hundred and seventeenth meridian, and on the west by the abrupt wall of the Sierra Nevada. Northward they extend through Oregon and pass into Washington Territory, having their greatest development on Crooked River, the John Day, and the Malheur. South of our work they are well known in the valley of Walker River, but beyond that southward I am not aware of their having been observed.

King's description of a characteristic section of the Truckee group at a locality west of Carson sink, near the Southern Pacific Railroad, is as follows: ${ }^{c}$

The most important and characteristic development of this series within our limits is at the Kawsoh Mountains and along the southern extremity of Montezuma Range. The northern and eastern portion of the Kawsoh Mountains and the valley which lies north of them, separating their broken detached group of hills from the end of Montezuma Range, together offer a section of about 2,300 feet of Miocene beds, noting from the top as follows:

1. The upper 1,200 feet consist entirely of drab, mauve, gray, pale-buff, and white stratified trachytic tuff, intermixed with more or less detrital material. The beds are characterized by rapid changes of color and texture, are of very variable coarseness, and have a prevailing amount of glassy fragments, as if an enormous amount of the material were the glassy scoria and rapilli of violent and long-continued trachytic eruption. At intervals are beds of pure gray sand with a few seams of slightly marly clay. The microscope shows that this entire series is made up of angular and subangular fragments, many of them excessively small. There are some singular chalcedonic strata, 1 to 2 feet thick, of which the lower stratum plane is exceedingly rough, resting upon the trachytic tuff and including a great many minute fragments of the volcanic material, the upper surfaces being rudely botryoidal, the protuberances reaching the size of an egg. Toward the lower edge of this great series of trachytic tuffe, the upper limits of which are nowhere seen, the proportion of true detrital material-quartz and feldspar sand-becomes rapidly greater until the tuff is underlaid by-

2. Coarse, sandy grits, gray and yellow fragments, partially rounded, partially angular, with a Feet.

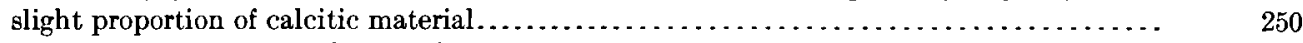

3. Saccharoidal limestone, rich in fresh-water mollusks . . . . . .

4. Marly grits, yellow and drab, rather coarse........................... 40

5. Fine-grained, friable, buff and gray sandstone, having a peculiarly sharp, gritty feel...... $\quad 70$

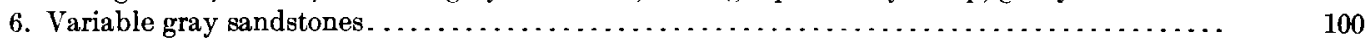

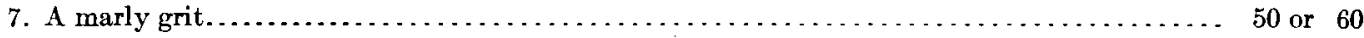

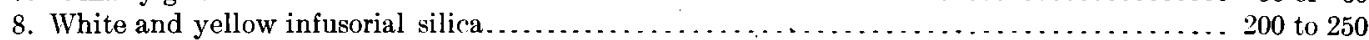

9. Palagonite tuff, base never seen, 250 feet being maximum exposure.

No lower members than the bed of palagonite tuff are observed in the Kawsoh Mountains, or in the southern end of the Montezuma; but in Warm Spring Valley, a small depression in the basaltic hills a few miles north of Hawkes's station, on Carson River, the palagonites, there remarkably well developed, are seen to be underlain by a light siliceous clayey bed made up of fine silt and comminuted infusoria. It is always far less pure than the white infusorial beds above the palagonites. Here, as everywhere, the series has an inclined position, dipping $15^{\circ}$ to $20^{\circ}$.

It is now well known that the rocks called trachyte in the Fortieth Parallel reports are mostly andesites, and consequently that the trachytic tuff referred to in the foregoing descriptions should be translated andesitic tuff. It may fairly be questioned, moreover, whether this

a Geol. Expl. 40th Par., vol. 1, 1878, p. 413.

$b$ The name "Truckee group" is not a very happy choice. Aithough the lake heds at Verdi, on Truckee River near the California line, are mapped as the Truckee group in the Fortieth Parallel Atlas, the typical and best exposures, according to King, are all to the east and south of the stream from which the formation presumably takes its name.

c Op. cit., pp. 415-416. Reference to Arnold Ilague's description of the Kawsoh Mountains (C. S. Geol. Expl. 40th I'ar., vol. 2, pp. 7(ij-7i') shows that King combined and generalized the actual sections there observed. 
change entirely expresses the facts and whether a reexamination of the section would not show a large proportion of rhyolitic material in the so-called trachytic tuff. To the northeast of the section just described, in the foothills of the West Humboldt Range, the sediments, according to King, ${ }^{a}$ are less characteristically volcanic and consist largely of coarse sands and gravels. Louderback ${ }^{b}$ describes these as consisting of "slightly consolidated granitic sands, diatomaceous earth, et cetera," dipping at about $35^{\circ}$ and overlain by basalt. King noted ${ }^{c}$ that the Truckee beds are everywhere upturned from $10^{\circ}$ to $25^{\circ}$ and, where associated with basalt, are cut through and overflowed by that rock.

The lake beds west of Reno and under the town of Verdi, mapped as Truckee Miocene in the Fortieth Parallel Atlas, are described by Arnold Hague as follows: ${ }^{d}$

That portion of the Truckee Valley lying directly west of the Virginia Range is a broad open basin covered by a thick deposit of Quaternary sands and gravels obscuring all the Tertiary strata below; these appear, however, farther up the valley, just above the town of Reno, and extend thence westward to the California boundary. These Tertiary beds line the valley on both sides of the river, and form a distinct deposit quite unlike those described from the lower Truckee Valley. They lie inclined at angles varying from $10^{\circ}$ to $15^{\circ}$, in general dipping to the southward away from Peavine Mountain, but considerably disturbed by local outbursts of volcanic rocks. Inasmuch as the beds are so highly inclined, and are older than many of the intrusive rocks of the region, they have been referred to the Miocene age, although they differ somewhat in lithological character from the Miocene strata of the Kawsoh Mountains and Montezuma Range, having much less volcanic material in their composition. They consist mainly of sandstones, with interstratified beds of friable sands, clays, and thin shales of prevailing light colors. So far as known, no animal remains have as yet been found in these beds, although stems, leaves, and partially carbonized vegetable matter are abundant in certain layers of shale. Perhaps the most characteristic feature of the basin, and one that suggests the Green River beds of the Elko region, is the presence of a number of seams of impure coal and carbonaceous shales. Outcrops of coal occur on both sides of the river north of the town of Verdi, dipping to the southward $10^{\circ}$. Another coal seam has been opened a long time on Dog (reek, a short distance north of Crystal Peak, but, so far as known, none of the deposits have as yet proved of any economical importance. No accurate measurements of the thickness of these Tertiary strata have been made, but there can not be less than 500 or 600 feet of conformable beds.

West of the locality just noted, in Truckee Valley, California, Iindgren ${ }^{e}$ has described Neocene lake beds consisting of yellowish sands and clays, the latter predominating, with brilliantly white beds, probably volcanic ash, containing diatoms. There are also several layers of coarse tuff and some seams of impure lignite. These beds, which show dips up to $10^{\circ}$, are capped in places with basalt, and are younger than the main andesitic eruptions of the Sierra Nevada. Lindgren suggests the equivalence of these deposits with those at Verdi.

D. T. Smith ${ }^{f}$ has briefly described a series of Tertiary sediments about 1,200 feet (366 meters) thick near Yerington in the valley of Walker River about 15 miles (24 kilometers) south of Wabuska, or 45 miles ( 72 kilometers) south of the Kawich Mountains, which apparently have considerable resemblance to the Truckee group and are inclined at angles up to $40^{\circ}$. These beds have yielded mammalian remains which W. J. Sinclair states are probably late Miocene or Pliocene and correspond to the faunas of the Mascall and Rattlesnake formations of Oregon.

In Gabbs .Valley, about 60 miles (96.5 kilometers) southwest of King's type locality for the Truckee group, Spurr has noted lacustrine beds, which he describes as follows: $g$

Near the center of the valley, just east of the low mountain spur which crosses it, and on the Reese River road, there are low ridges of gray, stratified marl containing leaf remains, alternating with gravels and more solid conglomerates. Some of the conglomerate contains comparatively abundant silicified wood. The conglomerate, when examined microscopically, proves to be volcanic. The pebbles are made up in part at least of spherulitic glass. Some pebbles contain phenocrysts of feldspar, of species indicating that the lava is andesitic, in a glassy matrix containing broken feldspar and biotite. Some of the shaly beds associated with the conglomerate are feldspathic tuff, made up of fine fibrous material, with larger broken fragments of feldspar and some shreds of biotite. These beds strike north and Bouth and dip about $8^{\circ} \mathrm{E}$.

a Op. cit., p. 414. See also IIague, Arnold, U. S. Geol Expl. 40th Par., vol. 2, 1877, p. 733

$b$ Basin Range structure of the II umboldt region. Bull. Geol. Soc. America, vol. 15, 1904, p. 301

c Op. cit., p. 413.

d U S. Geol. Expl. 40th Par., vol. 2, 1877, pp 849-850.

e Truckee folio (No. 39), Geol. Atlas U. S., U. S. Geol. Survey, 1897.

$f$ Geology of the upper region of the main Walker River, Nevada: Bull. Dept. Geology Univ. California, vol. 4, 1905, pp. $10,13$.

$g$ Descriptive geology of Nevada south of the 40th parallel: Bull. U. S. Geol. Survey No. 208, 2d ed., 1905 , p 107. 
Spurr correlates these sediments provisionally with King's Truckee group.

A few miles south of Gabbs Valley, in the Candelaria Mountains near Sodaville, Spurr ${ }^{a}$ notes-

a comparatively small area of brown, yellow, sometimes purplish, limy and sandy shales, argillaceous fine sandstones, and thin-bedded brown and yellow aphanitic limestones. This series strikes N. $65^{\circ} \mathrm{E}$. and dips $65^{\circ} \mathrm{NW}$. It is probably identical with the rocks of the Esmeralda formation a few miles to the south, in the southern end of the Monte Cristo Mountains.

The Esmeralda formation, described and nåmed by H. W. Turner, ${ }^{b}$ is well displayed in the Silver Peak district on the slopes of the Silver Peak and Montezuma ranges, about 15 miles (24 kilometers) west of Tonopah and Goldfield. According to Turner, "The beds are composed of sandstones, shales, and lacustral marls, with local developments of breccia and conglomerate on a large scale." He further describes the formation as containing intercalated volcanic flows and, near the base, some coal. The beds, according to this observer, have the enormous aggregate thickness of 14,800 feet (4,511 meters), are folded, and are capped unconformably by basalt. Turner suggests their correlation with the Truckee group of King.

Spurr refers to the Esmeralda formation as follows: ${ }^{d}$

These Tertiary deposits flank the edges of the mountains and underlie, in part at least, the Pleistocene veneer of the valleys. On account of folding and faulting since their deposition they arch upward along the sides of the mountains, although according to Mr. Turner they have not been found within 2,500 feet of the highest elevations. They consist of 'soft shales, sandstones, marls, tuffs, volcanic breccias, etc., with interbedded layers of andesitic and rhyolitic lava. The thickness of the whole accumulation is very likely several thousand feet. This mass has not yet been satisfactorily differentiated into separate members, but it undoubtedly contains materials deposited under widely varying conditions. Some of the beds are lake sediments; some appear to have been deposited in running water and were probably distributed by stream action. Others bear the marks of dry, subaerial origin. Also there is probably a great range in the period of deposition, as will be presently shown from a consideration of the fossil evidence. It is probable that practically the whole Tertiary, from the Eocene through the Pliocene, is represented. In short, it is probable that the beds are the record of the whole period of Tertiary sedimentation, beginning with the period when the Nevada land mass ceased to have free drainage to the ocean, at the close of the Cretaceous, through the whole of the climatically changing but in general arid Tertiary period, when the material eroded from the mountains was accumulated in the valleys, in lakes, or in subaerial sheets, down through the Pliocene. Both the early and more recent Pleistocene accumulations of the region are of very much the same nature as many of these Tertiary beds, and probably form a direct continuation of them; but in the Pleistocene material the proportion of lake beds does not appear to be nearly so large as in the Tertiary formations.

Eight miles (13 kilometers) north of Tonopah, near Ray, Spurr found "folded gravels, tuffs, lavas, and some white, thin limestones." He states that similar beds are found at several places between Ray and Sodaville and remarks that they are (were?-F. L. R.) probably continuous with a part of the Tertiary deposits of the Silver Peak and Monte Cristo mountains - that is, with the Esmeralda formation.

The same writer characterizes the Siebert tuff at Tonopah rather briefly as follows: ${ }^{c}$

The white stratified tuffs form a conspicuous feature of the geology near Tonopah. As a rule they are beautifully and uniformly bedded, and composed of well-assorted material. Where beds of conglomerate occur the pebbles are perfectly rounded. Since these sediments do not vary in character for thicknesses of several hundred feet, it is plain that they were laid down in a large body of standing water that lasted for a considerable length of time. That this body was a lake is indicated by numerous general considerations derived from the study of the geology of the surrounding region and by the presence of numerous fresh-water infusoria in some of the strata. In contrast to the general regular stratification, cross-bedded strata may occasionally be found, and at one place markings like those made by rills on a sandy shore were noted. These are probably shore and delta features.

The Siebert tuff is unconformably overlain by basalt on Siebert Mountgin, and both rocks are cut by a late intrusion of "dacite."

Descriptive geology of Nevada south of the 40th parallel: BulI. U. S. Geol. Survey No. 208, 2d ed., 1905, p. 114.

$b$ The Esmeralda formation, a fresh-water lake deposit: Twenty-first Annual Report U. S. Geol. Survey, pt 2, 1900, pp. 197-208; also Am. Geologist, vol. 25, 1900, p. 168.

c Op. cit., p. 198.

d Ore deposits of the Silver Peak quadrangle, Nevada: Prof. Paper U S. Geol. Survey No. 55, 1906, p. 19

$e$ Geology of the Tonopah mining district, Nevada: Prof. Paper U. S. Geol. Survey No. 42, 1905, p. 51.

79145-No. 66-09-7 
There can be no reasonable doubt that the Siebert tuff of Tonopah and the Siebert formation of Goldfield were once continuous deposits laid down in one lake. The two districts are less than 30 miles ( 48 kilometers) apart, the deposits are thick and lithologically similar, and the reconnaissance of $\mathrm{Ball}^{a}$ has shown that the formation is well represented in the Klondike Hills, about halfway between Goldfield and Tonopah. He found the Siebert beds making up a large part of Montezuma Peak, 7 miles ( 11 kilometers) west of Goldfield, where the faulted and folded lake beds attain an altitude of 8,426 feet (2,568 meters) on the summit of the peak. He also traced the formation westward to longitude $117^{\circ} 30^{\prime}$, where his area marches with the Silver Peak quadrangle, in which the Esmeralda formation was described in 1900 by Turner. Very curiously, Ball makes no reference to this formation, nor does he point out what would appear to be a conclusion from his own work, namely, that the Siebert Lake beds were laid down with at least a part of the Esmeralda formation in a common basin. ${ }^{b}$ Ball's description is as follows: ${ }^{c}$

Prior to the deposition of the Siebert Lake beds the Cambrian rocks had a rugged topography. These beds, 17 miles north of Lida, are coarsely conglomeratic, and inliers of limestone protrude through them, and outliers of lake beds occur on the Cambrian rocks. The lake beds cover a considerable area on the western border of the region under consideration, a somewhat smaller area near Montezuma Peak, and a small area 5 miles south of Alkali Spring. The northern boundary of the largest area is approximately correct as mapped. The southern boundary is less accurately drawn and some Tertiary igneous rocks may lie between the Cambrian rocks and the lake beds.

These beds, which are composed largely of rhyolitic material, consist of typically incoherent, unevenly granular, well-bedded sandstones. When unstained by iron, they are white in color, but brilliant reds and yellows are characteristic of many areas. Fine-grained beds alternate with conglomeratic layers containing pebbles of Cambrian rocks, quartz-monzonite porphyry, diorite porphyry, rhyolite, and igneous rocks of andesitic and basaltic affinities. The pebbles are well rounded or semiangular. Microscopic examination of several slides shows the presence of quartz and orthoclase crystals in a pyroclastic matrix.

Locally the Siebert Lake beds have been indurated by silicification along joints and in irregular bodies. Quartz, chalcedony, and opal fill cavities. The silicified portions weather into wall-like masses along joints and into grotesque topographic forms where silicification has been less regular.

Rhyolitic and dacitic flows are interbedded throughout the sediments, although they increase toward the bottom of the formation, and dacite appears to underlie it.

The lake beds at Montezuma Peak are about 1,100 feet thick. On the western border of the area mapped they are probably 200 or 300 feet thicker. The formation was for the most part deposited in an inland lake, although some portions were possibly laid down subaerially by explosive volcanic action.

Mr. R. H. Chapman found a piece of silicified wood at a point 4 miles west of Montezuma Peak. Mr. F. H. Knowlton, who kindly examined it, states that it is wood of a deciduous tree not older than the Tertiary. These sandstones are correlated with the Siebert Lake beds of Tonopah, described by Spurr.

South of the Goldfield district Ball's map shows areas of lake sediments which he correlates with the Siebert formation extending into Death Valley in latitude $36^{\circ} 30^{\prime}$. Ball refers to the lake beds on the west slope of the Funeral Mountains as follows: ${ }^{d}$

The rather large mass of later rhyolite and biotite latite to the southeast of Staininger's ranch has between its flows layers of white or light-colored incoherent tuffaceous sandstone, which readily breaks down into sand. The section at this point is as follows:

Section southeast of Staininger's ranch.

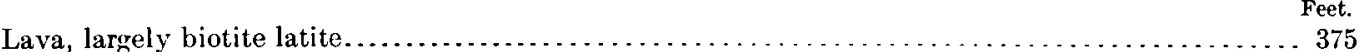

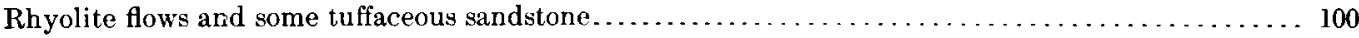

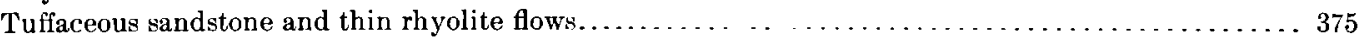

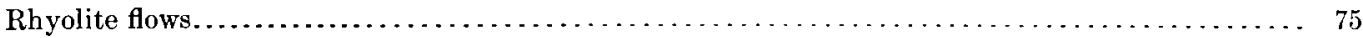

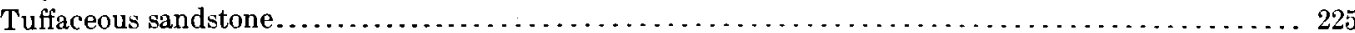

Between the lava and the sediments are minor erosional gaps, but these are probably current erosional unconformities, and the series is approximately all of one age. Bedding planes from 2 inches to 20 feet apart are well developed at some places.

a Geology of the Tonopah mining district, Nevada: Prof. Paper U. S. Geol. Survey, No. 42, 1905, p. 78, Pl. I,

$b$ A comparison of Ball's map (Bull. U. S. Geol. Survey No. 308, 1907, Pl. I) with the map of the adjoining region accompanying Spurr's report (Prof. Paper U. S. Geol. Survey No.55.1906, Pl. I), and purporting to be based on a manuscript map by H. W. Turner, shows that the area of Siebert Lake beds, which Ball maps for 6 miles along his western boundary, apparently changes abruptly to "Tertiary lavas" on Spurr's side of the line. This discrepancy, however it may in future be explained, is not likely to affect the general conclusion that the Siebert formation and at least a part of the Esmeralda formation were once areally continuous across the region now occupied by the Montezuma Range.-F. $L$. $R$.

$c$ Bull. U. S Geol Survey No. 308, pp. $5 \bar{i}-58$.

d Op. cit., pp. 165-166. 
Locally the tuffaceous sandstone lies unconformably upon folded Pogonip limestone. It is closely similar to that of the Mount Jackson hills and, like it, is overlain by siliceous lavas. This formation is, without much doubt, the Siebert Lake beds.

A number of small areas of conglomerate occur on the eastern slope of the Amargosa Range, east of boundary post No. 94, southeast of Daylight Spring, and north of Willow Spring. The rocks, varying from loosely to rather strongly consolidated material, consist of conglomerates and arkoses with a little shale. They range in color from green to red, yellow, or brown. Bedding planes, which are from 1 inch to 2 feet apart, are well developed. The pebbles in the conglomerate, which are very well rounded and many of them highly polished, reach a maximum diameter of 4 inches. They are derived principally from the Paleozoic rocks near by, with here and there a pebble of fine to medium grained granite, and in the area east of boundary post No. 94 some of earlier rhyolite. These rocks appear to be the shore deposits of a lake in which waves swept with considerable force. Material was transported from considerable distances, since granite does not now outcrop in the vicinity. Since the conglomerate contains pebbles of rhyolite and none of basalt, the deposits are younger than the rhyolite (early Miocene) and older than the basalt (Pliocene-Pleistocene), and in consequence of middle or late Tertiary age, presumably Miocene. They are approximately contemporaneous with the lake in which the Siebert Lake beds were deposited, and it is believed that they are shore deposits of that lake.

In that part of California lying east of the Sierra Nevada and north of the San Gabriel and San Bernardino ranges Tertiary lacustral deposits have been described by G. K. Gilbert, a H. W. Fairbanks, ${ }^{b}$ M. R. Campbell, ${ }^{c}$ and J. E. Spurr. ${ }^{d}$

Spurr, writing of the Death Valley region just south of the area examined by Ball, describes the early Tertiary lake sediments as follows: ${ }^{e}$

In the eastern part of the range, where the road crosses from the Amargosa Valley into Furnace Creek, there is found a great amount of conglomerate, forming high hills. These conglomerates are very coarse and contain rounded pebbles and bowlders of all sizes, made up of reddish and white quartzite and black and gray limestones bearing the badly preserved Paleozoic fossils above mentioned. The conglomerate is as hard and firm as the rocks from which it is derived. It is water laid and well stratified, and evidently a shore formation. The whole thickness exposed is estimated at 4,000 feet. It is sharply folded, together with the limestones from which it is derived, but it abuts abruptly against these limestones on the west.

Besides these rocks there occur, as parts of the same series, semiconsolidated gravels, with clays partially hardened to slaty shales, limy clays partially consolidated to argillaceous secondary limestones, and sands partially hardened to cherty and limy sandstones, all interbedded. All these, including the conglomerate and the limestone tufa, have a general light-yellow, often greenish, color, characteristic of the series.

This sedimentary series makes up the greater portion of the Funeral Range. Along Furnace Creek Valley and on both sides of it the mountains consist chiefly of yellow-green strata capped by basalt. The lava seems to occur interbedded with the sedimentaries, as well as overlying them. The series is here consolidated into a hard clay rock, with occasional thin sandstone, and the general yellow-green color is changed in places to reddish, yellowish, and pinkish. The rocks are often gypsiferous and contain abundant grass remains, which are, however, indeterminable. From the yellow-green Tertiary series in the hills just east of the mouth of Furnace Creek there has been taken much borax, which occurs as borate of lime in beds in the strata.

Near the summit of the pass, just east of Furnace Creek, there come in above the yellow-green Tertiary series softer, dark-brown, honeycombed conglomerates, recalling the similar rocks of Meadow Valley Canyon. Thin sheets of basalt are interbedded with the conglomerates, but the great sheets lie on top. Patches of this same upper conglomerate series were elsewhere observed, and at one place its contact with the underlying yellow-green series appeared slightly discordant. The conglomerate contains pebbles and bowlders which are chiefly of lava and must have been derived from the sheets of basalt which were periodically poured out during the deposition of the beds.

A rough estimate of the thickness of this whole series of slightly consolidated beds and volcanics puts it at not less than 4,000 feet, and the nature of the sediments shows that they must have been deposited in standing. water. The presence in some of the beds of gypsum, borax, and calcareous tufa shows that at some periods the waters in which the sediments were deposited were evaporated. They were, therefore, those of an inclosed lake, which was probably of great dimensions. It is likely that a large portion of the beds were deposited in fresh water at a period different from that in which the chemical precipitates were laid down.

Northward from Furnace Creek, at Silver Peak, are found beds of the Esmeralda formation, which are entirely similar in nearly every respect to those at Furnace Creek. Moreover, the fossils found in the Esmeralda beds indicate a nearly similar age to that indicated by fossils found in the Tertiary strata of the Mohave Desert, just west of Cajon Pass.

Spurr considers it probable that the beds at Furnace Creek represent nearly the whole of the Tertiary period. They are capped by basalt, which he considers may have been poured out in

a Rept. Geog. and Geol. Surveys W. 100th mer., vol. 3, 1875, pp. 142-143.

$b$ Geology of eastern California: Am. Geologist, vol. 17, 1896, pp. 67-69.

c Reconnaissance of the borax deposits of Death Valley and Mohave Desert: Bull. C. S. Geol. Survey No. 200, 1902

d Deseriptive geology of Nevada south of the fortieth parallel and adjacent portions of (alifornia: Bull. U. S. Geol, Survey No. $208,2 d$ ed., 1905.

e Op. cit., pp. 189-191. 
Quaternary time. In the same report are described similar lacustral deposits in the Panamint and other ranges of this region.

The general conclusions which may be drawn from the observations brought together in the foregoing pages are as follows:

There is in western Nevada, extending from the fortieth parallel down to about the thirtyfifth parallel, a chain of remnants of Tertiary lacustral deposits. These deposits are of great volume, estimates of total thickness in the various places where the beds are well represented ranging from a minimum of at least 600 feet (183 meters) at Tonopah ${ }^{a}$ to 14,800 feet $(4,511$ meters) at Silver Peak. ${ }^{b}$ The materials vary from place to place, but are preponderantly volcanic. They include true tuffs, largely rhyolitic, and detrital rocks of a wide range of coarseness derived from all the prelacustrine rocks and probably also from volcanic masses piled up and eroded during the lake period. Diatomaceous beds appear to be rather characteristic of the deposits north of the Death Valley region, while in and south of Death Valley descriptions indicate a greater abundance of clays with associated beds containing gypsum and borax. Lignitiferous beds, apparently in all cases in the basal part of the deposits, occur from Truckee River southward to the Mohave Desert. The beds are everywhere folded and faulted and in many places sheets of basalt have flowed over their eroded edges. It is clear that since the period of lacustrine deposition the region has undergone such deformation and erosion as to entirely remodel the topography; lake beds, for example, now forming the summit of Montezuma Peak, west of Goldfield.

Two opposed views have been held regarding these Tertiary lacustrine deposits. Clarence King ${ }^{c}$ regarded those with which he was familiar near the fortieth parallel as having been laid down in a single great Miocene lake which he called Pahute Lake, giving the name Truckee group, as we have seen, to the sediments. He believed that this lake stretched northward into the John Day basin in Oregon, and suggested that it extended also into the Mohave region of California. Most recent writers on the earlier Tertiary lacustrine deposits of western Nevada appear to have accepted King's conclusion that they were for the most part laid down in a single great lake. M. R. Campbell, however, writes as follows: ${ }^{d}$

From the observations noted above and from descriptions of other geologists, it is apparent that lake sediments occur throughout a wide extent of territory in the Great Basin region. Some writers have supposed that the various outcrops are parts of one extensive sheet of sediment which was deposited in a widespread but shallow lake, and consequently that they are all of the same age.

The data gathered during the present reconnaissance show that such is not the case. From the character and arrangement of the material composing these beds, it is apparent that most of the lakes occupied valleys, the bounding walls of which may be seen to-day with the coarse detrital material of the lake beds at their feet. As previously mentioned, the lakes undoubtedly existed at different geologic epochs, and from data now at hand it seems probable that lake-forming conditions existed practically throughout the Tertiary period (Eocene, Miocene, and Pliocene); but sedimentation was interrupted at intervals by violent crustal movements that tilted the earlier sediments and materially changed the topography of the country.

The truth of the matter is that it is impossible to demonstrate at the present time that a single lake covered the greater part of western Nevada in early or middle Tertiary time. Deformation and erosion have destroyed, beyond possibility of conclusive restoration, such continuity of sediments as may once have existed. Nevertheless the distribution, thickness, and character of the remnants are such as to lend strong support to the view that the greater number of them were deposited in one great water body corresponding to King's Pahute Lake. It is probable that there were other smaller lakes also, contemporaneous with Pahute Lake. Moreover, submergence and sedimentation may have been going on in certain greatly depressed parts of the lacustrine basin while erosion continued long in progress over other parts much later covered with water. Whether Pahute Lake extended, as King supposed, into Oregon is

a Spurr, J. E., Geology of the Tonopah mining district: Prof. Paper I:. S. Geol. Survey No. 42, 1905, p. 53.

$b$ Turner, H. W., The Esmeralda formation: Twenty-frst Ann. Rept. L. S. Geol. Survey, pt. 2, 1900, p. 202.

c U. S. Geol. Expl. 40th Par., vol. 1, 1878, pp. 413, 454

d Reconnaissance of the borax deposits of Death Valley and Mohavo Desert: Bull. U. S. Geol. Survey No. 200, 1902, pp. 21-22. 
yet unknown. Between the Goldfield-Silver Peak region and the Death Valley-Mohave Desert region there is a considerable gap in the chain of lacustral deposits. There is also a change in the character of the sediments, those of the southern region containing beds indicative of saline periods which apparently are not represented in the sediments of the northern region. This difference suggests that the older lacustrine deposits of Death Valley and the Mohave Desert were laid down in a body of water which, during part of its existence at least, was not connected with Pahute Lake.

Aside from the still doubtful extension of the Truckee beds northward into Oregon it is clear that Pahute Lake was a vast sheet of water, fully comparable in size with Lake Superior. King estimated the maximum thickness of the lacustrine deposits as at least 4,000 feet $(1,219$ meters), and it has been shown (p. 68) that the thickness of the beds in the Goldfield region is probably in the neighborhood of 1,000 feet (305 meters). Consequently, although deposition and submergence probably went on at the same time, there is reason to suppose that the lake was by no means generally shallow. On the other hand, the submerged topography was undoubtedly one of strong relief and the lake probably possessed a deeply indented shore line and was diversified by numerous islands.

\section{TERTIARY CHRONOLOGY OF THE WESTERN PART OF THE GREAT BASIN.}

As has previously been seen, the initial datum plane from which the beginning of Tertiary history must be reckoned is the interval of post-Jurassic deformation and erosion. The second and much less definite or satisfactory epoch is that of Pahute Lake. Knowledge of the age of the lacustral beds that in this report are provisionally correlated with the Truckee group would be a great step toward a clear understanding of Tertiary history in western Nevada.

Pahute Lake was supposed by King ${ }^{a}$ to have come into existence at the dawn of the Miocene. This conclusion was based mainly upon the supposed direct continuity of the Truckee group with the John Day formation in Oregon, ${ }^{t}$ the geologists of the Fortieth Parallel Survey realizing clearly that the scanty fresh-water fauna in the Truckee group in Nevada was not distinctive enough to determine whether the beds are Miocene or Pliocene. ${ }^{b}$ The Infusoria collected by Spurr ${ }^{c}$ from the Siebert beds at Tonopah are of no greater distinctive value, although he appears to have accepted without question the Miocene age of Pahute Lake. As no one has yet actually established the supposed connection of the Truckee group with the mammalbearing Miocene beds of the John Day basin, it must be admitted that the assignment of the Truckee group to the Miocene rests upon evidence that is far from satisfactory. Spurr ${ }^{d}$ and Balle accept the view of King, but G. D. Louderback ${ }^{f}$ is inclined to regard the group as Pliocene.

The opinion of the last-named author is perhaps based in part upon the work of Lindgren, ${ }^{g}$ who showed that lake beds in Truckee Valley, California, which he regards as probably equivalent to the lake beds at Verdi, Nev., are younger than the main andesitic eruptions of the Sierra Nevada, a conclusion which is suggestive of a late Tertiary age of at least some of the beds originally mapped with the Truckee group. In the lake deposits south of Wabuska, also, D. T. Smith, ${ }^{h}$ as before noted, found mammalian remains, from which W. J. Sinclair concludes that "the beds are probably late Miocene or Pliocene, corresponding to the Mascall and Rattlesnake formations of Oregon; but the material is not complete enough to determine these points with certainty."

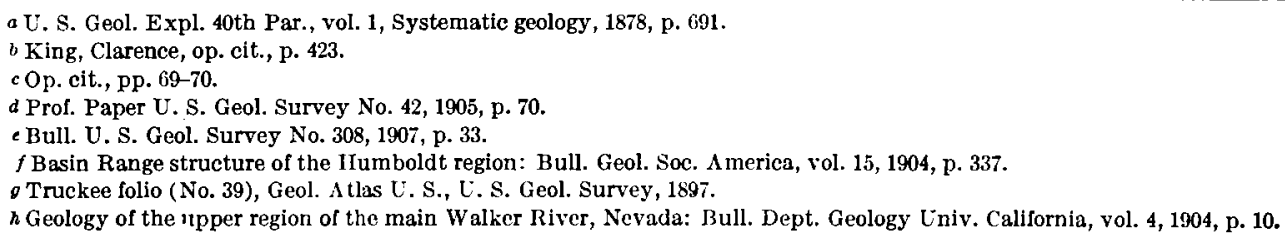


On the other hand, in the beds near Ray, Spurr ${ }^{a}$ found fresh-water shells concerning which W. H. Dall reported:

According to the literature the fresh-water beds from which these fossils came have been referred by Doctor White and Meek to the Wasatch, or Bear River Laramie, Eocene, which is believed to be nearly the equivalent of the lower Eocene or Chickasawan marine Eocene (Lignitic of old authors) of our southeastern coastal plain.

Dall lists only three forms and is not certain of the ilentity of these. Consequently the paleontological evidence can scarcely be regarded as establishing the Eocene age of the beds.

The Esmeralda formation has furnished molluscan, fish, and plant remains, ${ }^{b}$ but these do not fix the age of the beds, although Turner concludes that the formation as a whole is probably Miocene. Spurr ${ }^{c}$ believes that the Esmeralda formation was deposited under a wide range of varying conditions and probably represents the whole of the Tertiary.

In the El Paso Range, California, H. W. Fairbanks ${ }^{d}$ found fossil leaves which, according to F. H. Knowlton, are undoubtedly Tertiary and "seem to belong to the Eocene."

On the whole, therefore, paleontological data for the determination of the age of the Truckee group and its probably correlative deposits are both scanty and unsatisfactory. No evidence has yet come to light which discredits King's conclusion that extensive lacustrine deposition began with the Miocene. On the other hand, the basis for this conclusion must be admitted to be none of the surest, and the possibility that lacustrine conditions began in the Eocene can not be excluded. Paleontological evidence having been found inconclusive, the bearing of physical history upon the problem of the proper time subdivision of the Tertiary rocks may next be considered.

In discussing the correlation of the lavas in that part of the Great Basin adjacent to the fortieth parallel, King ${ }^{e}$ stated that the propylites are probably pre-Miocene and that the hornblende andesites are distinctly earlior than the Miocene strata (Truckee group), since these abut against eroded andesitic mountains. He concluded that the dacites also probably belong in Eocene time. On the other hand, the so-called trachytes were thought by him to belong in the Miocene, because the sediments of the supposedly Miocene Pahute Lake were thought to be largely composed of "trachytic" tuffs. For a similar reason some of the augite andesites were also placed in the Miocene. Afterward G. F. Becker ${ }^{f}$ showed that the propylite was merely an altered andesite. He also suggested ${ }^{g}$ that the trachytes of the Fortieth Parallel report would turn out to be mainly andesites, a result soon after fully established by Hague and Iddings. ${ }^{h}$ As Spurr ${ }^{i}$ has pointed out, the dacites of the earlier classification are in part rhyolites and in part latites. Moreover, it is clear from later work in the Great Basin that King's distinction between augite andesite and hornblende andesite is largely imaginary and certainly is not applicable as a criterion for determining the chronological succession of lavas over a wide region. Hague and Iddings ${ }^{j}$ showed that the so-called augite andesites of the Great Basin nearly all contain hypersthene, and the descriptions given in Chapter IV of this report serve to illustrate what close connection and gradations between biotitic, hornblendic, and pyroxenic andesites may obtain in a small area. Thus the broad generalization regarding the succession of volcanic rocks propounded by Von Richthofen and adopted with some modification by King has crumbled to pieces. The exceptions to so simple a sequence are too numerous to be ignored. The later attempt of Spurr ${ }^{k}$ to determine the general law of succession of the lavas of the Great Basin will be referred to in its proper place. The fact of present importance is

\footnotetext{
a Geology of the Tonopah mining district: Prof. Paper U. S. Geol. Survey No. 42, 1905, p. 66.

$b$ Turner, H. W., The Esmeralda formation: Twenty-Grst Ann. Rept. U. S. Geol. Survey, pt. 2, 1900, pp. 203-204. Knowlton, F. H., Fossil plants of the Esmeralda formation: Idem, pp. 209-220. Lucas, F. A., Description of a new species of fossil fish from the Esmeralda formation: Idem, pI). $223-224$.

c Ore deposits of the Silver Peak quadrangle, Nevada: Prof. Paper U. S. Geol. Survey No. 55, 1906, p. 18.

$d$ Geology of eastern California: Am. Geologist, vol. 17, 1896, p. 68.

e Op. cit., pp. 691-693.

$f$ Geology of the Comstock lode: Mon. U. S. Geol. Survey, vol. 3, 1882, pp. 81-90.

$\vartheta$ Op. cit., p. 374.

$h$ Volcanic rocks of the Great Basin: A m. Jour. Sci., 3d ser., vol. 27, 1884, p. 450

$i$ Geology of the Tonopah mining district: Prof. Paper U. S. Geol. Survey No. 42, 1905, p. 59.

j Loc. cit.

$k$ Succession and relation of lavas in the Great Basin region: Jour. Geology, vol. 8, 1900, pp. 621-646.
} 
that King recognized a considerable group of andesitic rocks as distinctly pre-Miocene-that is, as prelacustral - and another group of rock now known to be also andesitic, as belonging to the period of the Miocene Pahute Lake, because supposedly corresponding tuffs were deposited in that body of water. As has been shown, however, the Siebert formation at Tonopah and Goldfield is not essentially andesitic.

Apparently having uppermost in his mind the fact that the supposedly Miocene trachytes of King have turned out to be mainly andesites, Spurr ${ }^{a}$ makes the andesitic eruptions begin just before the opening of the Miocene. He designates the andesites at Tonopah as "earlier" or "hornblende-biotite" andesite and "later" or "biotite-augite" andesite and assigns both to the Miocene, although he describes an interval of denudation and an extensive series of "dacite-rhyolite" eruptions between the eruption of the later andesite and the formation of the Miocene lake in which the Siebert beds were deposited. In view of this interval, his statement ${ }^{b}$ that the eruption of the hornblende-biotite-pyroxene andesites was contemporaneous with the Miocene lakes is not clear. Spurr's general summary of the geologic history at Tonopah is as follows: ${ }^{c}$

The oldest of the Tertiary rocks within the area of the Tonopah map are probably early Miocene, and so far as known the volcanic manifestation began with an eruption of andesite. In this andesite were formed fracture zones, along which heated waters ascended and deposited the valuable veins of the region. Another extensive eruption of similar but slightly more basic andesite followed, and then there was probably a period of volcanic rest and of denudation. Eruption was resumed by the outbreak of volcanoes, which alternately ejected siliceous dacite and poured out volcanic mud and frequently pumiceous lava. Some of the material may have been accumulated in water; most of it was probably deposited upon the land. Later, more glassy dacite of a slightly different composition ascended from below in irregular channels and poured out on the surface as thin sheets, or exploded and formed tuffs. IIeated ascending waters followed the intrusive contacts of this lava and formed a group of quartz veins which contain gold and silver, but which are less important as regards strength and values than the veins formed after the eruption of the earlier andesite.

As these dacite-rhyolite eruptions quieted down a lake was formed in a basin, which may have been due to a depression of the crust consequent upon the previous copious eruptions. In this lake there accumulated quietly several hundred feet of sediments, with occasional light showers of ash from volcanoes, and, in the lower portions, some thin flows of dacite lava. Then the beds were lifted and became dry land. This uplift may have been due to the accumulation of additional volcanic material beneath this portion of the crust. Streams began to cut into the lake beds, the uplift was continued, and the whole district was tilted bodily to the west at an average angle of $20^{\circ}$. After this there were renewed outbursts, from probably new vents, which doubtless corresponded, in part at least, to the present mountains. On Brougher and Butler mountains explosive eruptions occurred, the material being dacitic, like that immediately preceding the lake deposits. Cones of ash, cinders, and bombs were built up, and there were occasional very thin and scanty glassy flows. On Siebert Mountain there was an explosive outburst of basaltic material, followed by a thin basalt flow. Subsequently columns of liquid lava welled up and stood in the vents of the volcanoes, but did not overflow. Some of these were composed of dacite, some of rhyolite. As these columns cooled, heated waters rose along their contacts and deposited chalcedony and other minerals, and mud dikes were injected into the soft intruded rocks. The explosive outbreaks and the intrusion of these large necks must have broken the rocks into blocks and displaced the blocks, for at this time many faults were formed.

On the cessation of this dacite-rhyolite period of volcanic activity there was a collapse or depression around the vents. This sinking took place largely along the fault planes, and was especially prominent around the volcanic necks, which, as they sagged, dragged down blocks of the intruded older rocks with them.

Since this time, which was probably somewhere in the Pliocene, erosion has been active, stripping away the débris covering from the dacite-rhyolite necks, and leaving them as hills, and in general removing the surface layers from the hills to the desert valleys.

In opposition to this view of the essential contemporaneity of the andesites and lake sediments stand not only King's recognition of andesites distinctly older than Pahute Lake, but Spurr's own work at 'Tonopah, in which he shows clearly that a notable interval of erosion separates the "later andesite" from the Siebert lacustrine epoch.

At Goldfield there is an extensive series of lavas, including the andesites, which are certainly older than the lake sediments. The reconnaissance of Ball also, as appears from the

a Succession and relation of lavas in the Great Basin region: Jour. Geology, vol. 8, 1900, p, 637; Geology of the Tonopah mining district: l'rof, Paper U. S. Geol. Survey No. 42, 1905, p. 69.

b Prof. Paper U. S. Geol. Survey No. 42, 1905, p. 69.

$\epsilon$ Geology of the Tonopah mining district: Prof. Paper U. S. Geol. Survey No. 42, 1905, pp. 67-68. 
table on page 93 and the columnar section on page 91 , shows that in the area studied by him that part of Tertiary time antecedent to lacustrine conditions was long enough for the eruption of many kinds of lava, including the andesites, and for the development of two erosion unconformities.

The situation may be summed up by saying that in the Goldfield region, and probably in other parts of southwestern Nevada, extensive eruptions of andesite took place after the extravasation of lavas which most workers in the region have tentatively assigned to the Eocene and before the formation of Pahute or Siebert Lake, which has been considered Miocene by King, Spurr, and Ball. Are these andesites to be placed in the Eocene or do they belong to the Miocene?

To this question, it must be admitted, no definite answer can yet be made. We know merely that a series of effusive and intrusive rocks intervenes between a pre-Tertiary terrane and a series of lake sediments and intercalated flows of questionable Miocene age. King ${ }^{a}$ regarded the beginning of the lake as coinciding with the dawn of Miocene time. The prelacustrine series is divided at certain horizons by unconformities and is unconformably overlain by the lake beds. No direct paleontologic evidence is available, and for the determination of the plane between the Eocene and Miocene, supposing Pahute Lake to have been Miocene, recourse must be had to local physical history. Spurr and Ball carry the Miocene back into the prelacustrine series, the latter making the division between the two periods coincide with an unconformity which, in the local sequence at Goldfield, comes between the latite and the Sandstorm rhyolite. My own preference is to regard the initiation of lacustrine conditions as the most significant physical revolution and, with King, to make that event mark provisionally the beginning of the Miocene, or, in any case, to regard it as one of the principal division planes in Tertiary chronology. I fully realize, however, that the physical event which appears most significant and epoch-making to one student may, in the opinion of another worker, take secondary rank. Moreover, new paleontologic evidence may at any time show that the beginning of the Miocene, and what appears to be the most important break in the continuity of physical history, are not necessarily coincident. Besides, although the andesites of Goldfield and Tonopah are distinctly older than the lake epoch, this proposition can not be asserted with equal confidence in regard to the dacite and dacite vitrophyre of Goldfield and the earlier of the so-called dacites of Tonopah. Still further, the beginning of the lacustrine conditions, as has been shown, may have been far from synchronous over the whole region.

So far as it goes, the evidence for an important prelacustrine epoch of volcanism and erosion supports the view that the lake sediments are at least not older than the Miocene. It may be considered very doubtful, however, whether it will ever be possible to correlate with precision the Tertiary events of the Great Basin with the well-recognized divisions of the marine deposits of the same period. Whether any close parallelism ever existed between the deposition of sediments known as Eocene, Miocene, and Pliocene along the Pacific margin and the complex manifestations of local voleanic activity, erosion, and lacustrine sedimentation that make up the history of the interior province is open to serious question.

The second great division of Tertiary time in western Nevada, provisionally called Miocene, came to an end with the disappearance of the lake and the folding of its sediments. Masked and confused as it is in some localities by later disturbances, this folding, accompanied by faulting, is recognizable as a generally synchronous revolutionary movement for the whole region and was possibly contemporaneous with the post-Miocene uplift of the Coast Ranges.

In the third division of the Tertiary, the provisional Pliocene of the Great Basin, King ${ }^{b}$ placed the sediments of his Shoshone Lake, calling them the Humboldt group. Russell ${ }^{c}$ afterward showed, however, that all the deposits described and mapped in the Fortieth Parallel reports as the Pliocene Humboldt group are really the deposits of Lake Lahontan and are 
Quaternary. Thus King's Pliocene Shoshone Lake, robbed of its sediments, has with progress of time become more nearly mythical than Spurr ${ }^{a}$ and Ball, ${ }^{b}$ to judge from their publications, appear to be aware. It is true that Spurr ${ }^{c}$ has noted deposits which are at altitudes above the highest known level of Lake Lahontan and which he believes were deposited in a Pliocene lake; but these observations alone appear scarcely sufficient to resuscitate King's conception of the vast Lake Shoshone. If Russell is right, Lake Shoshone was merely Lake Lahontan and was Quaternary.

At all events there are no deposits in the Goldfield district definitely referable to a great Pliocene lake. The Spearhead rhyolite, the Rabbit Spring formation, and the Malpais basalt are provisionally placed in the Pliocene because they are later than the folding and erosion of the supposed Miocene lake beds and have themselves suffered some deformation and much erosion. Finally, the gravels referred to on page 75 are supposed to correspond to the Quaternary epoch of expanded lakes represented by Lakes Lahontan and Bonneville. The shore features of this epoch are well displayed about Walker Lake, but it is not clear whether actual lacustrine conditions prevailed during the Pleistocene over the Goldfield region.

\section{THE ERUPTIVE SEQUENCE.}

For convenience of comparison the general succession of lavas in the Great Basin region according to Spurr ${ }^{d}$ is in figure 6 placed side by side with the observed succession in the Goldfield district. The order of age is from the bottom up.

The two columns in figure 6 show some general agreement in that the first rocks erupted were rhyolites and the last rhyolites and basalts. Moreover, between these earliest and latest products both columns show lavas of intermediate character. Spurr presents an elaborate twocycle scheme of regional differentiation into which it is possible to fit most of the locally observed sequences, under the supposition that each of these represents only a part of the record. If a basic rock appears in the wrong place in one line of descent from the parent andesitic magma it may be fitted into the other divergent line; thus if the local sequence be not too full it matters little, so far as conformity with the diagram is concerned, in what order the lavas were erupted. Even the rather full sequence at Goldfield can, by disregarding the quartz-bearing basalt and the basalt of the Portland mine, be shown to have a certain conformity to this scheme. Thus "1. Rhyolite" at Goldfield may be considered equivalent to "1. Biotite rhyolite and tordrillite;" "2. Latite" at Goldfield to "2. Latite(?)" in Spurr's scheme; "3. Rhyolite" and "4. Rhyolite" at Goldfield to "3. Biotite rhyolite;" "6. Andesite" at Goldfield to the andesitic part of Spurr's fourth group; the dacitic rocks at Goldfield to the biotite-hornblende dacite of Spurr's fourth group; and "12. Rhyolite" and "13. Olivine basalt" at Goldfield to the corresponding rocks in the fifth group of. Spurr's succession. Furthermore, the Goldfield column may be inverted or its members may be transposed in various ways and it will still fit into the same plan of recurrent general differentiation.

To some minds the conformity here shown may appeal as corroborative, but to others, impressed by the scanty representation of the numerous members of the ideal succession in any given locality, the capacity of the scheme for assimilating not only observed sequences, but imaginary ones, raises doubt whether it really represents natural processes. The basal assumption that every observed local sequence is a fragmentary expression of a regional two-cycle differentiation of a common magma having the composition of pyroxene-hornblende andesite is the uncertain foundation upon which the whole structure rests.

$a$ Origin and structure of the Basin Ranges: Bull. Geol. Soc. America, vol. 12, 1901, p. 246. See also, Louderback, G. D., Bull. Geol. Soc. America, vol. 15, 1904, p. 339, footnote.

$b$ Geologic reconnaissance in southwestern Nevada: Bull. U. S. Geol. Survey No. 308, 1907, p. 34

$c$ Geology of Nevada south of the 40th parallel: Bull. U. S. Geol. Survey No. 208, 2d ed., 1905, pp. 107, 117, 123-125

$d$ Succession and relation of lavas in the Great Basin region: Jour. Geology, vol. 8, 1900 p. 643. 
Study of the Goldfield district, moreover, does not indicate such parallelism between sequence and mineralogical composition as is presented by Spurr for the andesitic rocks, particularly in the fourth group of his synopsis.

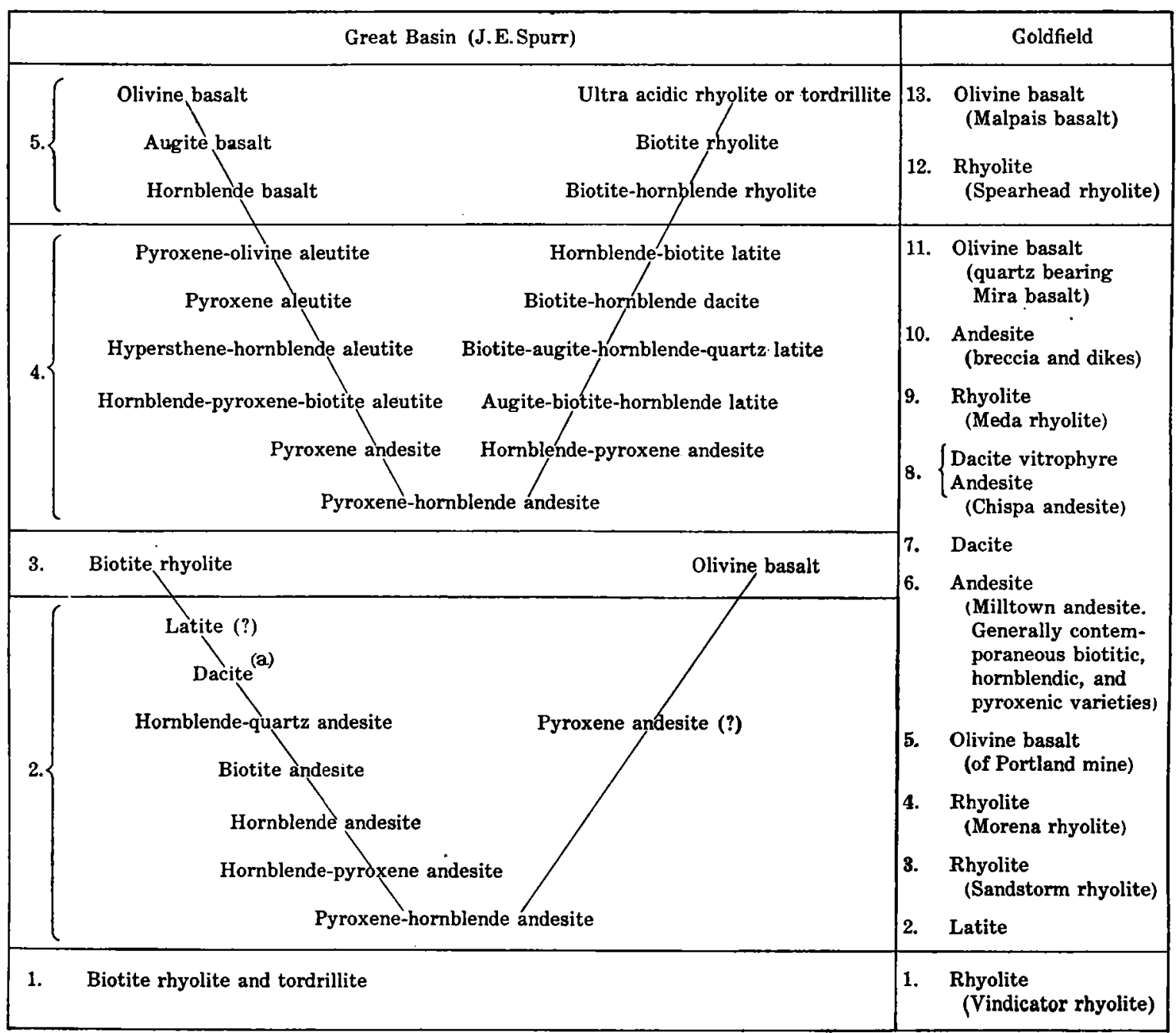

(a) Spurr's use of this name in the Tonopah report leaves the reader in some doubt as to what rock is here meant. F.L.R.

Figure 6.-Succession of lavas in the Great Basin and at Goldfield.

\section{TERTIARY CLIMATE.}

With the advance into the Tertiary the problem of climatic changes strongly challenges attention, not only on account of its obvious bearing on the discussion of erosion and lacustrine episodes, but also, as will later appear, in view of its being a possible factor in the process of ore deposition.

Clarence King states ${ }^{a}$ that-

the Eocene, as a whole, was remarkable over the Fortieth Parallel area for the intensity, rapidity, and grandeur of its processes of disintegration and removal. Like the deposits of the Alps and the enormous Eocene field of Asia, it stands out in the Tertiary as a great interval of degradation and sedimentation.

Presumably, therefore, the climate in the Great Basin region during Eocene time was comparatively humid. The coal and fossil leaves described by H. W. Fairbanks ${ }^{b}$ in the El Paso 
Range, California, and by H. W. Turner ${ }^{a}$ at the north end of the Silver Peak Range, point to the same conclusion, although the age of these coal-bearing beds is still not definitely known, and there is a possibility that they are Miocene.

Although Tertiary lacustrine conditions appear to have begun in a period sufficiently humid for the growth of coal-producing vegetation, there are clear indications in the beds of borax and salt in the southwestern part of the Great Basin that in that part of the region at least, periods of comparatively abundant water alternated with intervals of aridity. Thus throughout the Tertiary the climate of the Great Basin probably swung back and forth between moderate humidity and pronounced aridity. In this connection it is important to remember that under the physiographic conditions which appear to have characterized the Great Basin since the beginning of the Tertiary the existence of extensive lakes is consistent with only moderate humidity. A very slight persistent increase of precipitation at the present time, for example, would materially enlarge the existing lakes, whose levels are determined by a delicate, fluctuating balance between evaporation and rainfall. As Russell points out, the Quaternary climate in the Great Basin at the time of the greatest expansion of Lake Lahontan must still have been comparatively arid, since the lake never overflowed. The life history of the former lake shows "that its shores must have been at least as desolate and lifeless as the borders of the existing lakes of the same region." $b$

a The Esmeralda formation: Am. Geologist, vol. 25, 1900, p. 168.

$b$ Russell, I. C., Geological history of Lake Lahontan: Mon. U. S. Geol. Survey, vol. 11, 1885, p. 261. 


\section{CHAPTER X. \\ MINERALOGY OF THE DISTRICT. \\ INTRODUCTION.}

The accompanying table presents in alphabetical order the minerals recognized in the Goldfield district. Those of doubtful occurrence are printed in italics. Following the tabular statement are fuller notes on the more important minerals taken up in the same order as that followed in Dana's System of Mineralogy.

One mineral listed, namely, goldfieldite, is a new species; and it is possible that the minerals described as famatinite and bismite may also be species not hitherto recognized. Knowledge of these, however, is not as yet sufficient to justify the application to them of new names.

Minerals occurring in the Goldfield district.

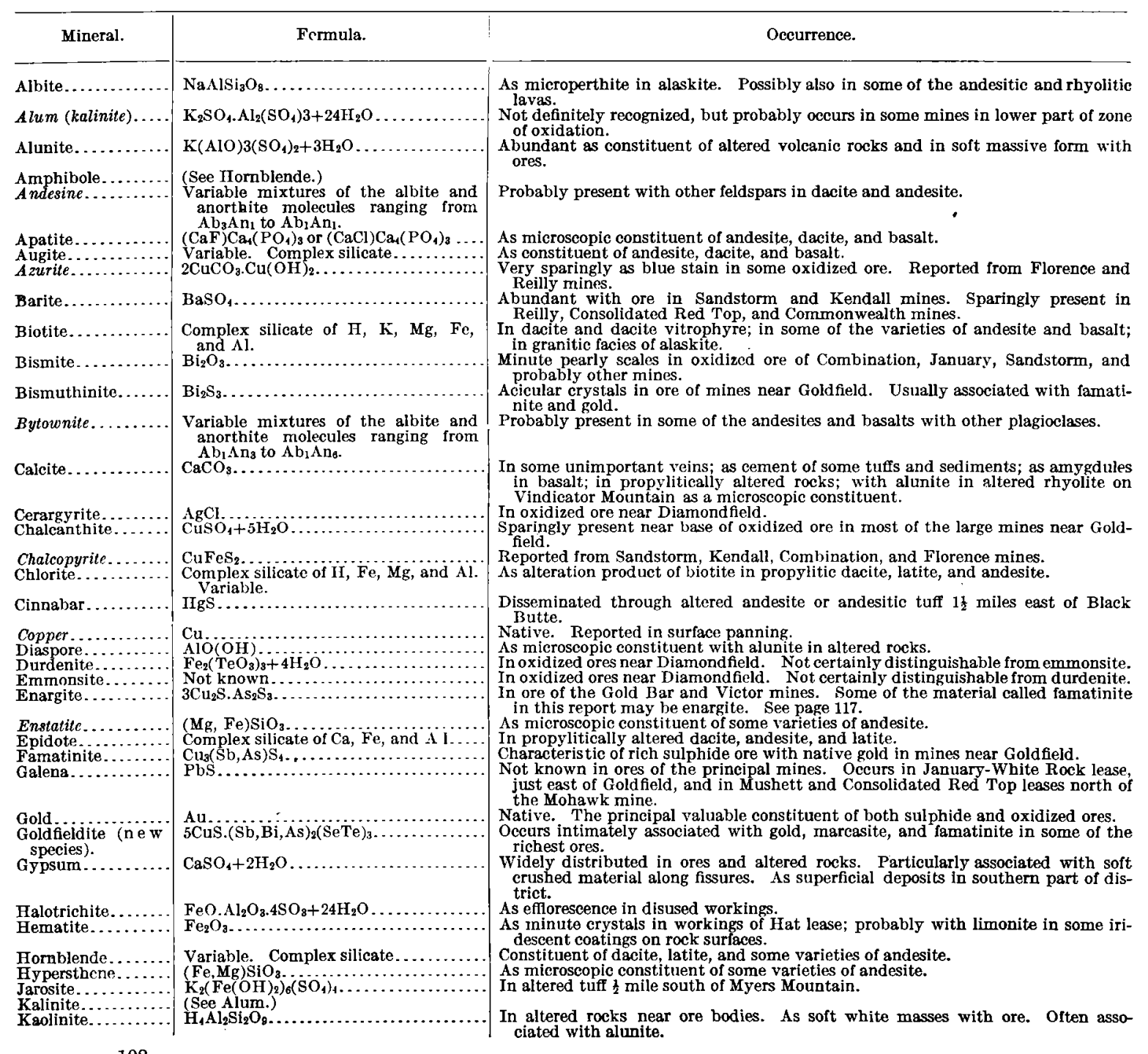


Minerals occurring in the Goldfield district-Continued.

\begin{tabular}{|c|c|c|}
\hline Mineral. & Formula. & Occurrence. \\
\hline Labradorite & $\begin{array}{l}\text { Variable mixtures of the albite and } \\
\text { anorthite molecules ranging from } \\
A b_{1} A n_{1} \text { to } A b_{1} A n_{3} \text {. }\end{array}$ & $\begin{array}{l}\text { The most common and abundant feldspar in the andesitic and dacitic rocks. Oc- } \\
\text { curs also in basalt. }\end{array}$ \\
\hline Limonite. & $\mathrm{H}_{6} \mathrm{Fe}_{4} \mathrm{O}_{9} \ldots \ldots \ldots \ldots \ldots \ldots \ldots \ldots \ldots \ldots \ldots \ldots$ & Abundant in earthy form in oxidized ores. As crusts on the croppings of some \\
\hline $\begin{array}{l}\text { Magnetite. . } \\
\text { Malachite.. }\end{array}$ & $\mathrm{Fe}_{3} \mathrm{O}_{4} \ldots \ldots$ & As microscopic constituent of the igneous rocks, especially basalt. \\
\hline Marcasite & $\mathrm{FeS}_{2} \ldots \ldots \ldots \ldots \ldots$ & $\begin{array}{l}\text { With pyrite, famatinite, goldfieldite, and bismuthinite in some rich sulphide ores. } \\
\text { In crushed rock and gouge along fissures. }\end{array}$ \\
\hline Massicot... - & $\mathrm{PbO}_{\mathrm{FeSO}} \mathrm{HH}_{2} \mathrm{O}$ & Yellow incrustations. Commonwealth ground, 2 miles east of Goldfield. \\
\hline Muscovit & $\mathrm{H}_{2} \mathrm{KAl}_{2} \mathrm{Si}_{3} \mathrm{O}_{12} \ldots \ldots$ & $\begin{array}{l}\text { In partly oxidzed ore of Combination mine. } \\
\text { As variety known as sericite. Sparingly present in altered rocks with alunite }\end{array}$ \\
\hline Oligoclase. & $\begin{array}{l}\text { Variable mixtures of the albite and } \\
\text { anorthite molecule ranging from } \\
\mathrm{Ab}_{6} \mathrm{An}_{1} \text { to } \mathrm{Ab} \mathrm{b}_{3} \mathrm{An} \mathrm{n}_{1} \text {. }\end{array}$ & As constituent of alaskite and of some of the rhyolitic rocks. \\
\hline Olivine.. & $(\mathrm{Mg}, \mathrm{Fe})_{2} \mathrm{SiO}_{4} \ldots \ldots \ldots \ldots \ldots \ldots \ldots$ & As constituent of basalt. \\
\hline Orthoclase & $\mathrm{KAlSi}_{3} \mathrm{O}_{8} \ldots$ & As constituent of alaskite and, as variety sanidine, of some of the rhyolites. \\
\hline $\begin{array}{l}\text { Petzite..... } \\
\text { Polybasite. }\end{array}$ & $\begin{array}{l}(\mathrm{Ag}, \mathrm{Au})_{2} \mathrm{Fe} \ldots \\
\mathrm{AggSbS}_{6} \ldots \ldots\end{array}$ & $\begin{array}{l}\text { Not identified, but may occur in ores near Diamondfield. } \\
\text { Possibly in ore from Florence mine. }\end{array}$ \\
\hline $\begin{array}{l}\text { Proustite } \\
\text { Pyrite. }\end{array}$ & $\mathrm{Ag}_{2} \mathrm{AsS}_{3} \ldots \ldots$ & Do. \\
\hline $\begin{array}{l}\text { Pyrite... } \\
\text { Pyroxene }\end{array}$ & (See Augite.) & Widely disseminated through altered rocks. Most abundant sulphide in ores. \\
\hline Quartz. . & $\mathrm{SiO}_{2} \ldots \ldots \ldots$ & $\begin{array}{l}\text { A constituent of alaskite, rhyolite, dacite, and of most of the sedimentary rocks. } \\
\text { In cryptocrystalline form is the principal constituent of the ledges. Occurs } \\
\text { sparingly in quartz-basalt. }\end{array}$ \\
\hline Rutile. & $\mathrm{TiO}_{2} \ldots$ & $\begin{array}{l}\text { As a microscopic constituent with alunite, diaspore, quartz, and pyrite in altered } \\
\text { dacite. }\end{array}$ \\
\hline Scapolite... & $\begin{array}{l}\text { Silicate of } \mathrm{Ca}, \mathrm{Na} \text {, and } \mathrm{Al} \text {. Composi- } \\
\text { tion variable. }\end{array}$ & Possibly as rare microscopic constituent in altered Sandstorm rhyolite. \\
\hline $\begin{array}{l}\text { Serpentine. } \\
\text { Sphalerite. }\end{array}$ & $\begin{array}{l}\mathrm{H}_{1} \mathrm{Mg}_{8} \mathrm{Si}_{2} \mathrm{O}_{8} \ldots \ldots \ldots \ldots \ldots \ldots \ldots \ldots \ldots \ldots \ldots \ldots \ldots \ldots \ldots \ldots \ldots \ldots \ldots \ldots \ldots \ldots \ldots \ldots \\
\mathrm{ZnS}\end{array}$ & $\begin{array}{l}\text { As alteration product of olivine in basalt. } \\
\text { Very sparingly in ores of the principal mines. Rather abundant in Mushett and }\end{array}$ \\
\hline Sulphur & S... & $\begin{array}{l}\text { neighboring leases. } \\
\text { In altered andesite or andesitic tuff, } 1 \text { mile east of Tognoni Springs. Reported }\end{array}$ \\
\hline Tellurides. & (See Goldfieldite and Petzite).. & Tellurides of gold occur in some rich ore, but have not been found in a form to \\
\hline Tellurite & $\mathrm{TeO}_{2} \ldots . .$. & Sparingly with a telluride of gold in the Goldfield-Belmont mine. \\
\hline Zircon. & $\mathrm{ZrSiO}_{4} \ldots$ & Occurs sparingly as an accessory constituent of some of the igneous rocks, espe- \\
\hline Zoisite. & $\mathrm{Ca}_{2}(\mathrm{AlOH}) \mathrm{Al}_{2}\left(\mathrm{SiO}_{4}\right)_{3}$. & $\begin{array}{l}\text { Not certainly identified, but may be present in some of the metamorphosed Cam } \\
\text { brian sediments. }\end{array}$ \\
\hline
\end{tabular}

NOTES ON THE MORE IMPORTANT MINERALS ASSOCIATED WITH THE ORE DEPOSITS.

SULPHUR.

Native sulphur occurs about 1 mile due east of Tognoni Springs as irregular interstitial bunches in a greatly shattered and much-bleached rock which appears to have been originally an andesite or andesite tuff-breccia. In places the sulphur serves as a matrix for the fragments of altered rock, which now consist almost wholly of cryptocrystalline quartz. Assiciated with the sulphur is some white pulverulent material which the microscope shows to consist of minute, rough, doubly terminated crystals of quartz. This crystalline powder is thus very similar to some in the Ione Star mine, described on page 244. The sulphur is massive and much of it occurs in lumps large enough to be easily sorted from the waste rock. Such prospecting as has been done, however, shows that the mineral is very unevenly distributed and the deposit is therefore of doubtful commercial importance. The sulphur was without much question deposited in connection with fumarolic activity or by hot sulphurous waters.

According to Mr. H. C. Morris, a little sulphur has been found in the croppings on the Blue Bull claim. Whether in this case also it records extinct solfataric action is not so clear.

Sulphur in considerable quantity occurs near Cuprite, 12 miles (19 kilometers) south of Goldfield. There are two main deposits. One, about $1 \frac{1}{2}$ miles (2.4 kilometers) northwest of the railway station, is on the summit of an oval hill composed of nearly horizontal beds of angular conglomerate probably belonging to the Siebert formation. These beds are in part silicified and contain abundant opal. Overlying these beds near the top of the hill is a nearly horizontal stratum of dazzling white ashy material, through which the sulphur is distributed in considerable masses. This bed is overlain by a layer of chalcedonic breccia, which was probably originally a layer of pumice. The rocks show evidence of strong solfataric action, which has bleached and silicified them, and has deposited the sulphur. The pulverulent material containing the sulphur 
was probably a rhyolitic glass or tuff now altered to pulverulent silica and alunite. The deposit is of oval plan and about 600 feet (183 meters) long, the thickness of the deposit being unknown. The sulphur apparently lies generally under the chalcedonic capping and would have to be mined by tunneling. A car or two of the material has been sorted and shipped from the various prospecting pits.

The second deposit is about half a mile northeast of Cuprite in solfatarically altered rhyolite pumice containing alunite. It is smaller than the one first described.

GOLD.

Over 95 per cent of the gold obtained in the district occurs in the free or native condition. Some tellurides are present, for tellurium was detected chemically by W. F. Hillebrand in 1905, ${ }^{a}$ and auriferous tellurides have been found in the Gold Coin and Goldfield-Belmont mines near Diamondfield. The presence of a ferric tellurite (emmonsite or durdenite) and the mineral tellurite in the Black Butte ores was noted in the preliminary report of $1907 .{ }^{b}$ Gold tellurides, however, have not been satisfactorily identified as visible constituents in the rich ores of the mines near Goldfield. A large part of the tellurium of these ores certainly belongs in the mineral goldfieldite, in which the gold is apparently embedded in the native state, not as a telluride of gold.

Although the particles of gold are uniformly very small they are usually visible on close inspection in all but the lower grades of ore. In the unoxidized ore the tiny specks of gold may be clustered so thickly in quartz as to give a yellow tint to the aggregate. Such ore is shown in Plates XXIII. XXV and XXVI. In more scattered and frequently in rather larger particles the gold may be embedded in famatinite or bismuthinite, or, as first shown by W. J. Sharwood, $c$ in a material supposed by him to be a mixture of tetrahedrite and a telluride, but which is probably the new mineral goldfieldite.

While there is evidently a very close association in this district between gold famatinite and bismuthinite, the precious metal appears to exist in these sulphur-bearing minerals as mechanical inclusions, and not as a chemically combined element. It is likely that a similar statement applies to the gold associated in much smaller proportion with pyrite in the lowergrade ores. In the pyrite, however, the gold is in a state of such minute division and is present in such small quantity that it has not been recognized under the microscope.

The gold thus far obtained from the mines has been, on the whole, unusually fine. An average of 34 assays of rich ore from the Mohawk mine, made for Mr. J. W. Finch, gave 330 ounces of gold, and 46.5 ounces of silver, to the ton. Probably not all of this silver was present in the native gold, since some of the other minerals in the ore may be argentiferous. The bullion from oxidized ores as deposited in the Carson City branch mint in 1904 was in some instances 0.9915 fine, worth $\$ 20.498$ an ounce. ${ }^{d}$

The most common gangue of the gold is cryptocrystalline quartz. In some varieties of ore the gold and quartz incrust fragments of altered dacite or andesite, as described on page 165 and are incrusted in turn by sulphides. Such is some of the rich ore of the Combination mine, shown in Plates XXIII, $A$, and XXVI. In other varieties the inner crust is composed of sulphides, and the gold is mainly in an outer envelope of gray flinty quartz, inclosing needles of bismuthinite (PI. XXIV, $A$ ). In some of the rich ore from the Engineers' lease a twofold deposit of gold was observed, a thin layer on the surface of a fragment of altered andesite, then a shell of quartz and bismuthinite, and then a broader crust of gold covered by a drusy film of the quartz. (See Pl. XXV, B.) In still other kinds of ore the gold, quartz, famatinite, bismuthinite, and pyrite are less regularly distributed. In the January mine, for example, some of the best unoxidized ore is a porous mass of gray flinty quartz, in places showing traces of former dacitic character, through which the gold and sulphides occur irregularly in specks and ill-

\footnotetext{
a Spurr, J. F., The ores of Goldfield, Nev.: Bull. U. S. Geol. Survey No. 260, 1905, p. 137.

b Bull. Li. S. Geol. Survey No. 303,1907, p. 36.

CMin. and Sci. Press, June 8, 1907, p. 731.

$d$ Rept. Director of the Mint on production of the precious metals in the United States during 1904, Washington, $1905, \mathrm{p} .142$.
} 
defined bunches. The gold is not evenly apportioned through the mass, but is concentrated in the immediate vicinity of the sulphides, although the minute particles of gold are themselves usually embedded in quartz. In order to test the apparent affinity of gold and sulphides, a lump of this ore was crushed and picked by hand into two parts, one containing most of the famatinite and the other most of the quartz. The sample having most famatinite afforded on assay 15.7 ounces of gold and 25 ounces of silver to the ton. The other portion gave 9.32 ounces of gold and 11.08 ounces of silver to the ton. It should be said that the poorer sample still contained much famatinite, bismuthinite, and pyrite, it being impossible to effect more than a very rough separation of the ore into quartzose and sulphide portions.

As seen by incident light with high microscopical power, the gold of the unoxidized ores appears as bright yellow hackly particles, with usually little more than a suggestion of crystalline aggregation. In a few instances particles suggestive of distorted or modified octahedrons have been observed strung together like beads into filiform aggregates, and rarely suggestions of octahedral planes and form can be detected in the smallest isolated specks embedded in quartz. The microscope shows that the gold and famatinite may be intimately intergrown, with no indication of one mineral being later than the other. A similar microscopic intergrowth of gold with a telluride was noted in ore from the Gold Coin claim, near Diamondfield.

In the oxidized ores the gold has the same general character as in the sulphide ores, being invariably in a state of fine division. One sometimes hears the gold referred to as "rusty," but this is usually a misnomer. The term appears to be often applied to gold in particles so small as not to be individually visible to the naked eye. Such particles when seen through a lens or microscope are clean and bright. The peculiar rusty-looking aggregates of gold, such as results from the oxidation of calaverite in the Cripple Creek district, have been observed in the Goldfield district only in some of the ore of Black Butte.

In the ores of the oxidized zone the gold is associated with limonite, quartz, kaolinite, alunite, barite, bismite, and in a few places with emmonsite or durdenite, tellurite, and hematite.

\section{COPPER.}

No native copper was observed in the mines, although its occurrence in minute quantities in the lower parts of oxidized ore bodies is not improbable. A few particles of copper are reported to have been found by panning near Diamondfield and on the Combination Fraction claim.

\section{BISMCTHINITE.}

The mineral bismuthinite is the trisulphide of bismuth $\left(\mathrm{Bi}_{2} \mathrm{~S}_{3}\right)$ and occurs in lead-gray acicular crystals belonging to the orthorhombic system.

Bismuthinite is present in much of the rich ore of the January, Combination, and Florence mines, and in the Mushett, Reilly, Engineers', Little Florence, and Rogers leases, as slender crystals embedded in cryptocrystalline quartz and associated with fumatinite and free gold. The crystals are frequently intergrown with both the gold and the famatinite. The appearance of the bismuthinite in specimens of rich ore is shown in Plates XXIII, $C$, and XXIV, $A$, and in thin section under the microscope in Plates XXVI, $A$, and XVII, $A$. The crystals are usually slender, ranging from delicate hair-like or capillary forms up to prisms a millimeter in breath. Crystals larger than are common occur in the Mushett and Little Florence leases. The prisms are often curved. In no case have terminal planes been observed, the ends of the crystals being irregularly pointed or frayed. The planes of the prism zone are also indistinct and apparently striated, much as in stibnite, which bismuthinite resembles in habit. They have one perfect cleavage, presumably that parallel to the brachypinacoid (010).

That the material of the crystals is sulphide of bismuth was proved by W. T. Schaller in the United States Geological Survey chemical laboratory.

In the Florence mine bismuthinite needles are abundant in nodular ore near the 300 -foot level. With their cryptocrystalline quartz matrix they form a shell around famatinite, which incrusts fragments of altered dacite, as described on pages 165 and 229 . In this place they 
are accompanied by abundant visible specks of native gold. In the rich ore of the Combination mine the shell of bismuthinite and quartz envelops a shell of quartz and free gold, as shown in Plates XXIII, $A$, and XXVI, $A$. In the January mine the bismuthinite is rather irregularly crystallized with quartz, famatinite, pyrite, and gold. Occasionally some regularity of arrangement is observable, however, as in the specimen of ore illustrated in Plate XXIII, $C$, where a banded structure is recognizable. In the Mushett lease the prisms of bismuthinite in some places form nearly solid crusts, which are usually associated with sphalerite.

While the needles of bismuthinite often run in all directions through the quartz and associated minerals, a radial or sheaf-like aggregation is rather characteristic, especially when the crystals are slender.

The mineral is so uniformly associated with gold in the Goldfield deposits as to afford by its presence one of the most reliable indications of rich ore.

In the process of oxidation the bismuthinite is changed to bismite.

Bismuthinite is not a very common mineral in deposits of the precious metals, and is not mentioned by Lindgren ${ }^{a}$ in his list of "minerals formed in ore deposits under varying conditions." It occurs with gold, chalcopyrite, and pyrite in the Gold Hill mine, Rowan County, N. C., ${ }^{b}$ and with specularite (crystalline hematite) in quartz at the Neigold mine near Silverton, Colo. $^{c}$ It is reported ${ }^{d}$ to occur also with almandine garnet and barite in the Granite mining district, Beaver County, Utah, and in Mono and Fresno counties, Cal. Its mineral associations in the Utah and California localities do not appear to have been fully described.

The mineral has been prepared artificially by Senarmont, ${ }^{e}$ who heated precipitated sulphide of bismuth with an alkali sulphide and water in a sealed glass tube; by Durocher, ${ }^{f}$ who conducted sulphydric acid and vapor of chloride of bismuth through a tube heated to redness; by Schneider, ${ }^{g}$ who fused together sulphur and bismuth in proper proportions; and by Carnot, ${ }^{h}$ who passed a current of hydrogen sulphide over a salt, oxide, or precipitated sulphide of bismuth at a dull red heat. It is of interest to note also that bismuthinite has been known to form in sedimentary beds from the distillates of burning coal seams. ${ }^{i}$

\section{GALENA.}

During the first few years of mining at Goldfield galena was unknown. It does not occur, so far as can be ascertained, in any of the large mines. It is found, however, in latite in the January-White Rock lease on the eastern edge of Goldfield, in the same rock in the MohawkRed Top lease just east of the Red Top mine, and according to recent reports is present in comparative abundance in parts of the Consolidated Red Top lease, one assay affording 12.5 per cent of lead. The ore of the Mushett lease also has a little galena associated with sphalerite, famatinite, bismuthinite, pyrite, gold, and goldfieldite. The mineral occurs also in the Five Friends lease.

SPHALERITE.

At the time of first visit, in 1905, the only occurrence of the sulphide of zinc known was a small speck which Mr. W. H. Blackburn had found in the Goldfield-Belmont mine near Diamondfield. Like galena, it is still a comparatively rare mineral in this district and has not been recognized in the ores from the large mines. It has proved latterly to be rather abundant, however, in the rich ore of the Mushett lease. Here it has generally been one of the later minerals to deposit and forms botryoidal crusts over the other sulphides. According to Mr. H. P. Henderson, some of this sphalerite afforded on assay 55.6 per cent of zinc with 1.8 ounce of gold and 7 ounces of silver per ton.

a The relation of ore deposition to physical conditions: Econ. Geology, vol. 2, 1907, p. 125.

b Genth, F. A., Rep. Geol. Survey North Carolina, vol. 1, 1875, appendix C, p. 58.

$c$ Ransome, F. L., Economic geology of the Silverton quadrangle, Colorado: Bull. U. S. Geol. Survey No. 182, 1901 (reprinted in 1903 ), p. 82.

d Dana, J. D. and E. S., System of mineralogy, 6th ed., New York, 1895, p. 38.

e Sur la formation des minéraux par voie humide dans les gi tes métallifères concrétionnés: Annales de chim. phys., vol. 32, 1851, p. 161.

$f$ Production artificielle, par voie sèche, des principaux minéraux contenus dans les gites métallirères: Compt. Rend., vol. 32, 1851, pp. 823-826.

$g$ Untersuchungen über das Wismuth: Pogg. Annalen, vol. 9, 1854, pp. 404-427.

Fouqué, F., and Michel Lévy, A., Synthèse des minéraux et des roches, Paris, 1882, p. 319.

$i$ Brauns, Chemische Mineralogie, Leipzig, 1896, p. 299. 
Sphalerite occurs also in the Mohawk-Red Top and Five Friends leases and probably in other lessee workings north of the Mohawk mine. It has also been noted in a small stringer in alaskite in the Lucky Boy prospect on Vindicator Mountain and in the ore of the Loftus and Davis lease on the Great Bend, northwest of Diamondfield.

CINNABAR.

The very characteristic sulphide of mercury (HgS), with its cochineal-red color and adamantine luster, occurs in the northeastern part of the district, but is not known in the gold deposits. The cinnabar rock outcrops on the Brooklyn claim, about $1 \frac{1}{2}$ miles east of Black Butte. The mineral forms irregular crystalline aggregates, up to an inch in diameter, rather abundantly disseminated through material which was probably once andesite or andesite tuff, but which has been intensely altered and is now a mass of cryptocrystalline secondary quartz, mottled with cinnabar and limonite. The deposit apparently is not of economic importance.

The occurrence of cinnabar in the Goldfield district, in view of the well-known association of this mineral with volcanic activity, is of interest in connection with the problem of the genesis of the gold ores, as will be more fully shown in another place (p. 174).

\section{CHALCOPYRITE.}

The tetragonal copper-iron sulphide $\left(\mathrm{CuFeS}_{2}\right)$, sometimes called "copper pyrite" or "yellow copper," is very rare in the Goldfield district. It has been reported in small quantity in the Sandstorm and Kendall mines, but was not seen in the course of the present investigation. E. A. Collins ${ }^{a}$ states that it has been found very sparingly in the Combination mine. A specimen of rich ore, said to be from the Florence mine, and in the possession of Mr. F. O. Altinger, of Goldfield, was examined by Mr. G. H. Garrey, who noted the occurrence of minute crystals of chalcopyrite lining small vugs and associated with bismuthinite, ruby silver (proustite?), and a mineral resembling polybasite in crystallization.

The rarity of chalcopyrite at Goldfield is remarkable, as most of the ores contain copper, and both sphalerite and galena, which often accompany this mineral in other districts, have been found in the leases north of the Mohawk mine.

PYRITE.

Common pyrite, the isometric disulphide of iron $\left(\mathrm{FeS}_{2}\right)$ is the most abundant and ubiquitous sulphide in the district. It is a constituent of practically all the rocks in the region except some of the later rhyolites, basalts, and lake sediments. It is disseminated through the propylitically altered andesite, dacite, and latite, where it has formed from the action of sulphide solutions upon biotite, hornblende, augite, and magnetite. As shown on page 179, it makes up a considerable percentage of the dacite that has undergone alunitic and kaolinitic alteration, particularly in the vicinity of the ledges. It is also finely disseminated through the altered rhyolites, although less abundant in these rocks than in those originally richer in iron-bearing silicates.

Within the ledges, pyrite occurs disseminated through the altered siliceous rock forming the gangue of the ore, in the form of small bunches and metasomatic veinlets, and as crusts with gold, goldfieldite, famatinite, bismuthinite, sphalerite, quartz, alunite, and kaolinite around fragments of altered rock.

In all of these occurrences the mineral usually forms aggregates. Individual crystals of free growth and large enough for the recognition of crystal habit are rare. Such faces as are visible indicate that the prevalent form is the pyritohedron, variously modified. When the crystals have been able to grow without mutual interference, as is the case in small vugs filled

a The Combination mine: Min. and Sci. Press, Sept. 28, 1907, p. 398.

$79145-$ No. $6(;-09-1$ 
with spongy friable quartz or in soft massive kaolinite or alunite, the usual form assumed is a sharp octahedron, in some cases modified by small cubic and dodecahedral faces. Such octahedral crystals were noted on the 250-foot level of the Florence mine. Small brilliant crystals embedded in alunite, from the 230-foot level of the Combination mine, show a dominant octahedron modified by small faces of the cube, dodecahedron and pyritohedron. Beautiful clusters of sharp, brilliant crystals from the Mushett lease show a similar combination, but with the pyritohedral faces dominant. The well-formed individual crystals are invariably small, most of them being less than a millimeter in diameter.

Pyrite with alunite, forming pseudomorphous aggregates after orthoclase, occurs in the Morena rhyolite at the Conqueror mine. Crystallized with gypsum it is found on the 150foot level of the Goldfield-Belmont mine.

While pyrite is widely distributed in the Goldfield district, few observers familiar with other mining regions can fail to note the absence from the known Goldfield deposits of any considerable masses of this mineral. It is everywhere present but nowhere aggregated into bunches or veins of any notable size or purity. This is undoubtedly due to the fact that the pyrite has formed mainly from the ferrous silicates and magnetite in the rocks and has undergone very little transportation or segregation. The fissuring, moreover, was not of a character to favor the accumulation of large solid masses of sulphides. The mineral is not all of one generation, as will be shown in the section on paragenesis on page 170 .

Whether the pyrite in the Goldfield deposits is auriferous is not easily determined. That it is not highly so is certain, since assays of the most pyritous ledge matter often show very little gold, and abundance of pyrite is generally a sign of poor, rather than rich ore. On the other hand, it is difficult to establish the absence of all gold from the pyrite, owing to the impossibility of obtaining this sulphide entirely free from other constituents of the ore in which the gold might be held. Undoubtedly pyrite might be obtained in the district which contains practically no gold; but the pyrite to which most interest attaches is that in, or close to, rich ore, and it is this selfsame pyrite which can not be separated with certainty from its associated minerals. Famatinite and bismuthinite, for example, which are known to contain particles of gold, may in turn be embedded in pyrite.

In order to obtain some light upon this problem, samples of pyritized dacite were collected from various mines and assayed. All the samples were taken within the general boundaries of the ore-bearing zones, the aim being to obtain material in which pyrite was the only sulphide and which at the same time lay as close as possible to ore. The pyrite in all of the specimens is disseminated in varying abundance through a gangue consisting chiefly of quartz and alunite. The assays were made by Ledoux \& Co., New York.

Assays of pyritized dacite.

[Ounces per ton.]

\begin{tabular}{|c|c|c|c|c|}
\hline Specimen. & Locality. & Gold. & Silver. & Remarks. \\
\hline G.624.. & Florence mine, 250-foot level, north end............. & 0.075 & 0.70 & Pyrite in minute erystals, abundantly dissemi- \\
\hline $\begin{array}{l}\text { G. } 819 \ldots \ldots \\
\mathrm{G} .818 \ldots \ldots \\
\mathrm{G} .714 \ldots \ldots \\
\mathrm{G} .713 \ldots \ldots\end{array}$ & 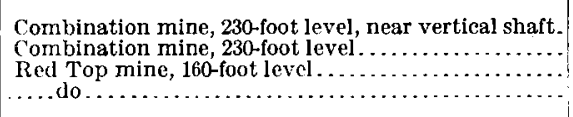 & $\begin{array}{l}.030 \\
.68 \\
.55 \\
.145\end{array}$ & $\begin{array}{r}.13 \\
2.60 \\
.05 \\
.20\end{array}$ & $\begin{array}{l}\text { nated. } \\
\text { Similar to above. } \\
\text { Pyrite very abundant. } \\
\text { So-called low-grade ore. } \\
\text { Do. }\end{array}$ \\
\hline
\end{tabular}

The results of these assays accord with the statement just made, that the pyrite is not rich in the precious metals. This is to be expected from the fact that most of the mineral was formed by the action of hydrogen sulphide on iron compounds already present in the rocks and not wholly from materials introduced by the ore-depositing agencies.

\section{MARCASITE.}

The orthorhombic disulphide of iron $\left(\mathrm{FeS}_{2}\right)$ is not always readily distinguishable from common pyrite, inasmuch as the latter mineral sometimes occurs in fibrous radial aggregates 
similar to those characteristic of marcasite. Specimens of marcasite usually decompose more readily than those of pyrite, but this test is not altogether reliable. In fact, as H. N. Stokes ${ }^{a}$ has shown, there is no simple test, in the absence of recognizable crystal form, that will invariably distinguish the two minerals. Stokes's own method, based on oxidation coefficients, is decisive, but requires special chemical apparatus and careful preparation of the sample to be tested. This method has not been applied to any of the material from Goldfield, and some doubt may therefore attach to the determination of individual specimens of iron sulphide as marcasite. On the other hand, there is evidence enough to establish the fact that a subordinate part of the iron sulphide associated with the ore bodies is of this species.

A specimen of rich ore from the Combination inclined shaft between the 180-foot and 230-foot levels shows native gold and quartz incrusted by pale yellow iron sulphide with a fibrous radial structure and mammillary surface. This is probably marcasite, although it shows no vitriolization after the lapse of a year since it was taken from the mine. Crystals with characteristic marcasite planes and twinning collected by $\mathrm{Mr}$. Lindgren from the Florence mine have proved equally stable. Many of these crystals, which incrust alunitized dacite, appear to be unmodified unit pyramids. Others are twinned, probably with a prism face (110) as twinning plane, although this is not clearly shown on the specimen. Crusts of marcasite and goldfieldite are closely associated in some of the richest ore in the Mohawk mine. This marcasite, which does not decompose as readily as some varieties, shows a generally prismatic habit, the sides of the closely crowded prisms being irregular and strongly striated. Terminal faces are rare and no measurable forms have been isolated.

Like gypsum, marcasite is rather characteristic of soft, crushed ore and of gouge, and appears in many places to be of later origin than most of the other sulphides. It occurs as concentric radially fibrous shells in soft, dark, and probably secondarily enriched ore streaks in the Combination, Reilly, and Florence ore bodies. As a rule these shells disintegrate on exposure to the air, with the formation of yellow films, apparently containing a little free sulphur, and of a brown fibrous efflorescence of iron sulphate. It is very abundant in soft gouge in some workings (Harrison shaft) opened by lessees just north of the Red Top mine and in leases on the February claim, south of the January mine.

On the 146-foot level of the Oddie lease workings in the Mohawk mine the ore body is traversed by a narrow regular fissure. The walls of this are covered by a botryoidal incrustation of iron sulphide which is supposed to be marcasite, although the crystal form is not very clearly shown.

\section{TELLURIDES OF GOLD.}

No tellurides of gold have been satisfactorily identified in the mines near Goldfield, although the presence of some tellurium in the ores has been shown by W. F. Hillebrand. ${ }^{b}$ In the preliminary report ${ }^{c}$ issued in 1907 , attention was called to the occurrence of emmonsite or durdenite and tellurite at Black Butte and to the conclusion that these ores prior to oxidation must have contained tellurides. It was also shown that a dark-gray mineral in irregular particles embedded in quartz and alunite forms part of the ore of the Gold Coin claim near Diamondfield. Tests by Mr. W. T. Schaller showed this mineral to contain much gold and tellurium, but no silver nor lead. It is thus probably a gold telluride, but the small size of the grains and the absence of crystal form rendered specific identification impracticable. A similar telluride occurs sparingly in the Goldfield-Belmont and probably also in other mines and prospects of this portion of the district.

With the opening of the Mohawk ore body in the Hayes-Monnette lease it was found that the gold of the rich ore is associated with notable quantities of tellurium. ${ }^{d}$

a On pyrite and marcasite: Bull. U. S. Geol. Survey No. 186, 1901.

o Spurr, J. E., The ores of Goldfield, Nevada: Bull. U. S. Geol. Survey No. 260, 1905, p. 137.

$c$ Ransome, F. L., Garrey, G. H., and Emmons, W. H., Preliminary account of Goldfield, Bullfrog, and other mining districts in southern Nevada: Bull. U. S. Geol. Survey No. 303, 1907, p. 36 .

d King, L. M., The sampling and assaying of a car of bonanza ore: Min, and Sci. Press, vol. 94, 1907, p. 241. In an editorial in the same number the statement is made that calaverite occurs in the Mohawk ore. The method of identification is not given and the statement is probably a conclusion from the ratio of gold and tellurium found in the ores, since no distinct crystals of this mineral have been found at Goldfield so far as can be learned. 
In June, 1907, W. J. Sharwood ${ }^{a}$ published a drawing of a thin section of Mohawk ore in which he shows particles of native gold embedded in a dark "sulpho-telluride," which he found-

gave strong reactions for sulphur, tellurium, copper, and iron, also for arsenic, antimony, gold, and silver (about 6 per cent and 1 per cent, respectively, of the two last) - a composition agreeing with the admixture of tetrahedrite and telluride suggested in the editorial referred to. To all outward appearance, however, the material seems to be uniform in character and gives no evidence of being such a mixture.

In a thin section of another specimen of Goldfield ore Sharwood detected particles resembling sylvanite associated with native gold. The dark-gray mineral supposed by Sharwood to be a mixture of tetrahedrite and calaverite is further described under "Goldfieldite." The particles thought to be sylvanite may have been marcasite, the resemblance of the marcasite of this ore to sylvanite in color, luster, and striations being deceptively close.

\section{PROUSTITE.}

Ruby silver $\left(\mathrm{Ag}_{2} \mathrm{AsS}_{3}\right)$ has been noted on only a single specimen, purporting to come from the Florence mine, and preserved in a private collection in Goldfield. The identification of the mineral was made by Mr. Garrey, who examined the specimen but was unable to obtain it for confirmatory tests. The occurrence of proustite in the district can not, therefore, be regarded as established.

\section{POLYBASITE.}

The mineral polybasite, essentially a sulphantimonite of silver $\left(\operatorname{Ag}_{9} \mathrm{SbS}\right)_{6}$, has not been identified with certainty in the Goldfield ores. Crystals of a form and color resembling polybasite were observed by Mr. Garrey, associated with a little ruby silver, in the specimen of ore referred to in the preceding paragraph. The ore was said to have come from the Florence mine.

\section{GOLDFIELDJTE.}

At the time of second visit to the district, in 1908, specimens were secured of the dark tellurium- and gold-bearing material from the Mohawk mine for the purpose of determining its mineralogical and chemical character. A piece of rich ore from the Mohawk-Combination lease (a consolidation of the Sheets-Ish and Kalfus leases) was broken up and the fragments of the dark telluric crust picked as free as possible from the gangue. These were crushed to pass through a 40-mesh screen and freed from fine dust. The grains were pickerl over several times under a lens and a separation effected into (1) yellow grains, (2) gray grains, and (3) mixed grains and gangue. The yellow grains proved to be marcasite.

The gray portion when examined under the microscope appeared homogeneous with the exception of a few minute specks of gold embedded in the gray mineral. The latter is dark lead gray with a high metallic luster. It is brittle, breaks with a conchoidal fracture, and has a hardness of 3 to 3.5 , although on account of the brittleness of the material it appears to be somewhat softer when crushed. No crystal faces have been detected. The small quantity of purified material, only 1.2 grams in all, was analyzed by Doctor Palmer with the following result:

Preliminary chemical analysis of goldfieldite.

\begin{tabular}{|c|c|c|c|}
\hline Copper.. & 33.49 & Gold........ & 0.51 \\
\hline Sulphur... & 21.54 & 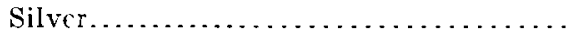 & .18 \\
\hline Tellurium. & 17.00 & 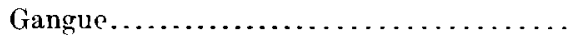 & 2.00 \\
\hline Antimony. & 19.26 & & \\
\hline Arsenic... & .68 & & 101.57 \\
\hline Bismuth.. & 6.91 & & \\
\hline
\end{tabular}

Of the gold about 0.40 per cent in terms of the whole analysis is combined, presumably with tellurium, and 0.11 per cent is native.

Doctor Palmer states that the mineral is essentially a cupric sulphantimonite in which part of the antimony is replaced by arsenic and bismuth and part of the sulphur by tellurium. He 
suggests that the analytical results approximate closely the formula $5 \mathrm{CuS}$. (Sb,Bi, $\mathrm{As})_{2}(\mathrm{~S}, \mathrm{Te})_{3}$. The minerals geocronite $\left(5 \mathrm{PbS} . \mathrm{Sb}_{2} \mathrm{~S}_{3}\right)$ and stephanite $\left(5 \mathrm{Ag}_{2} \mathrm{~S}_{2} . \mathrm{Sb}_{2} \mathrm{~S}_{3}\right)$ have analogous formulas whereas the known copper sulphantimonites and sulphantimonates are all cuprous salts.

As bismuthinite is a common mineral in these ores, the possibility that the material analyzed might be an intimate mixture of bismuthinite with some other mineral has been considered. If the analysis be calculated in molecular proportions, and the constituents of bismuthinite $\left(\mathrm{Bi}_{2} \mathrm{~S}_{3}\right)$ be subtracted, the following molecular quantities remain:

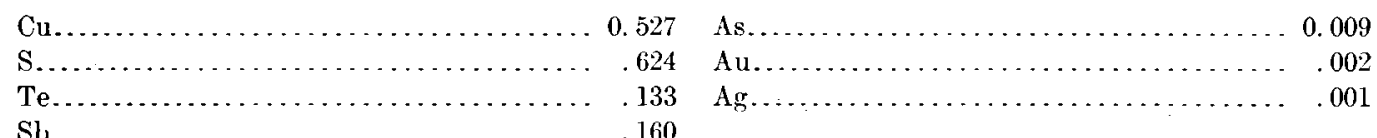

For famatinite the theoretical proportions are: $\mathrm{Cu}, 0.6 ; \mathrm{S}, 0.6 ; \mathrm{Sb}, 0.2$; so that the residue after subtraction of bismuthinite does not correspond very closely to famatinite, even if the tellurium be ignored. This constituent, it is to be observed, is far in excess of any quantity which could be accounted for as combined with the gold and silver, and a part of the gold is known to be free.

While determinative work on minerals such as the sulphantimonites, which rarely show crystal form and are often intergrown with other minerals, is as a rule more or less unsatisfactory, there seems to be no escape from the conclusion that the present mineral is a new species. It is provisionally so regarded and "goldfieldite" is suggested as an appropriate name. It is hoped that additional material can be secured for further analytical and microscopical investigation in the near future.

In some ore, especially that of the Mushett lease, the association of goldfieldite and famatinite is very close, and it is possible that such ore may contain intermediate species or varieties.

\section{ENARGITE.}

Crusts of a dark-gray brittle compound of copper, arsenic, antimony, and sulphur are characteristic of the ore of the Victor and Gold Bar mines. The substance is similar in habit and appearance to a mineral which is commonly associated with the rich ores near Goldfield and which, as will be shown, appears to correspond more nearly to famatinite than to any other known species. It presents some differences, however. It lacks for the most part the reddish tint of the famatinite, is rather more brittle, shows more tendency toward crystalline structure, and is not associated with rich ore. The crystal habit of the mineral is prismatic, the faces being longitudinally striated. It has at least one cleavage, although the crystals are too few and imperfect to permit determination of its crystallographic orientation. Mr. W. T. Schaller was able to isolate one crystal with rather uneven faces, which gave the following goniometric readings in the prism zone:

$$
\begin{aligned}
& 100 \wedge 110=41^{\circ} 30^{\prime} \\
& 100 \wedge 120=60^{\circ} 30^{\prime} \\
& 100 \wedge 1 \overline{1} 0=40^{\circ} 30^{\prime} \\
& 100 \wedge 100=179^{\circ} 30^{\prime}
\end{aligned}
$$

These agree fairly well with the calculated angles for enargite, which are-

$$
\begin{aligned}
& 100 \wedge 110=41^{\circ} 04^{\prime} \\
& 100 \wedge 120=60^{\circ} 09^{\prime} \\
& 100 \wedge 1 \overline{1} 0=41^{\circ} 04^{\prime} \\
& \overline{1} 00 \wedge 100=180^{\circ} 00^{\prime}
\end{aligned}
$$

As enargite and famatinite are isomorphous, however, the measurements serve only to rule out tetrahedrite, which contains the same constituents as famatinite or enargite, although in different proportions. It will presently be shown that the composition of the mineral called famatinite in this report is not normal, but indicates a variety between that mineral and its isomorph, enargite. It is likely that at Goldfield there are various representatives of the 
enargite-famatinite series separated by no sharp differences in composition. The mineral from the Gold Bar and Victor mines is probably nearer to the enargite end of the series than most of these varieties. Not all of the cupriferous material from the Gold Bar mine is of the same kind as that just described. Some of it is indistinguishable from the famatinite of the Florence and other mines nearer Goldfield.

\section{FAMATINITE.}

Forming part of the rich sulphide ore in most of the mines near Goldfield is a massive metallic mineral of dark-gray color, with a tinge of copper red. This has been commonly called "bornite." In the preliminary report on the district ${ }^{a}$ it was shown that the so-called "bornite" contained antimony, and accordingly it was there provisionally referred to as tetrahedrite, although attention was called to the possibility of its being famatinite.

In order to determine if possible the species of the mineral, a specimen of ore from the January mine was broken up, and material for chemical analysis was carefully picked out under a lens. The selected particles contained considerable quartz, a very little intergrown pyrite, and still less bismuthinite. The analysis is as follows:

Chemical analysis of mineral from January mine.

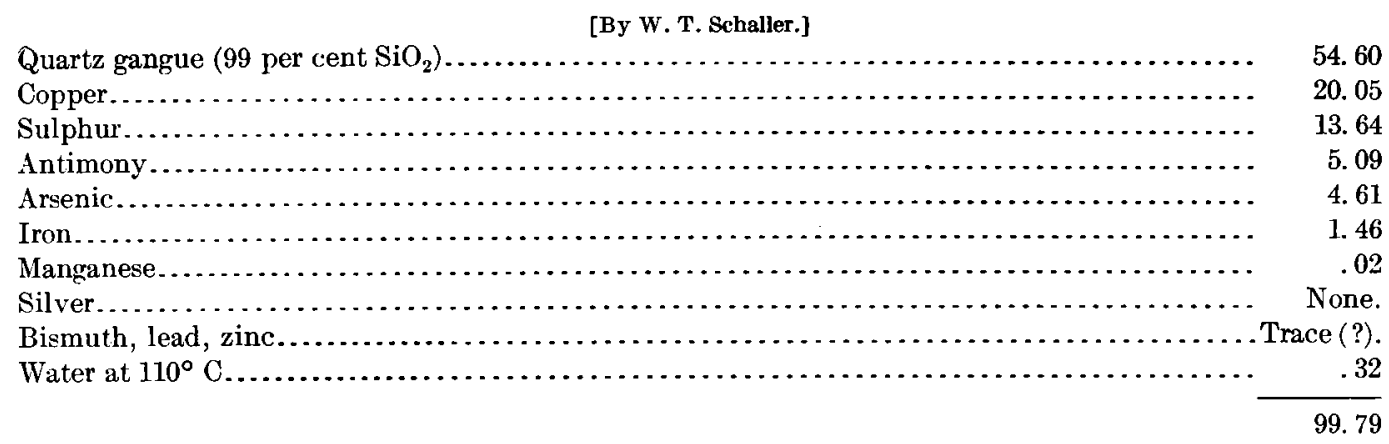

By elimination of the silica and obviously unessential or negligible constituents, and by recalculation to 100 , the analysis may be more simply stated as follows:

Composition of mineral from January mine.

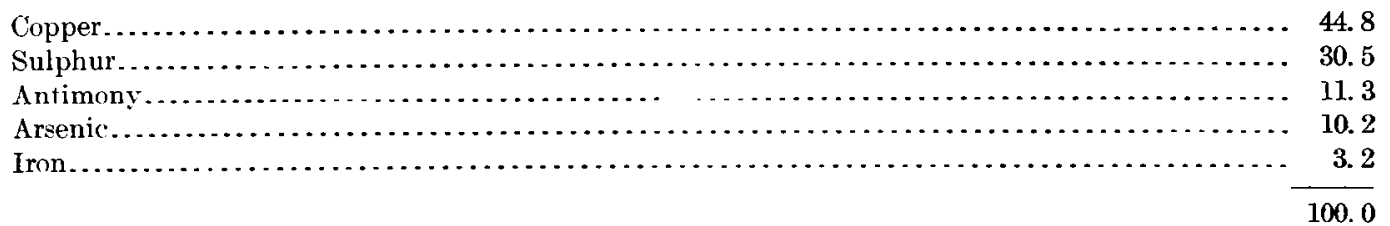

For comparison the theoretical compositions of tetrahedrite, tennantite, enargite, and famatinite are given below:

Theoretical compositions of tetrahedrite, tennantite, enargite, and famatinite.

\begin{tabular}{|c|c|c|c|c|}
\hline & $\begin{array}{l}\text { Tetrahe- } \\
\text { drite. }\end{array}$ & $\begin{array}{c}\text { Tennant- } \\
\text { ite. }\end{array}$ & Enargite. & $\begin{array}{l}\text { Famati- } \\
\text { nito. }\end{array}$ \\
\hline \multirow{3}{*}{ 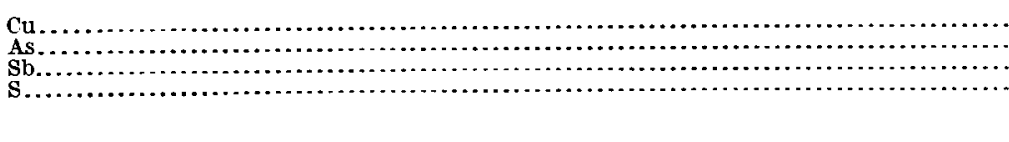 } & 52.1 & 57.5 & $\begin{array}{l}48.3 \\
14\end{array}$ & 43.3 \\
\hline & $\begin{array}{l}24.8 \\
23.1\end{array}$ & 25.5 & 326 & $\begin{array}{l}27.4 \\
29.8\end{array}$ \\
\hline & 100.0 & 100.0 & 100.0 & 100.0 \\
\hline
\end{tabular}

In nature, however, the antimony and arsenic mutually replace each other, giving rise to intermediate chemical compounds. Most analyses of enargite and famatinite show a little iron. 
While it is possible that in some varieties of these minerals the iron may be chemically combined, the Goldfield material is known to contain a little inseparable pyrite, and it is probable that all the iron found in analysis is present as pyrite. By eliminating the constituents of this pyrite and recalculating the analysis to 100 the following figures are obtained for the composition of the Goldfield mineral:

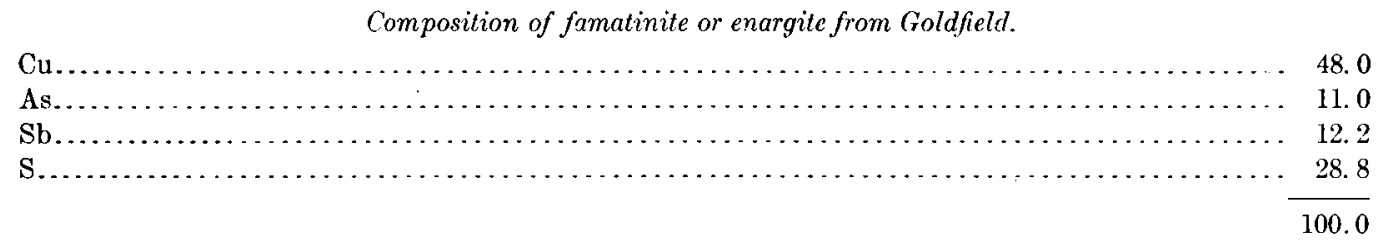

This composition is intermediate between theoretical enargite and theoretical famatinite. As both minerals are orthorhombio and isomorphous, the occurrence of an intermediate variety is not surprising. Attempts to calculate a simple formula corresponding to the foregoing percentage composition have not been successful, and it is not clear whether the copper is in the cupric or the cuprous condition. The atomic ratio of copper to sulphur in the Goldfield mineral is approximately as 7 to 8 . In a formula of the stephanite type it should be as 5 to 8 , in one of the famatinite type as 6 to 8 , and in one of the tetrahedrite type as 9 to 8 .

The Goldfield material can not be definitely assigned to either enargite or famatinite. Its massive habit, reddish-gray color, and slight preponderance of antimony over arsenic suggest, however, closer affinity with famatinite than with its corresponding arsenical isomorph, and as knowledge of the variety is insufficient to justify the application to it of a new name, it will be referred to as famatinite in this report.

The famatinite is comparatively abundant in the Florence, Jumbo, Combination, and January mines, where it is usually associated with rich ore and often contains visible particles of native gold.

Although gold does not appear to enter chemically into the constitution of the famatinite, the association of this mineral with the richest ore is often very marked. $A$ specimen of ore from a winze a few feet below the 250-foot level of the Florence mine was broken up and separated into two parts, one containing most of the pyrite (more abundant in this specimen than usual), the other most of the famatinite. The portion containing the most pyrite gave on assay 2.31 ounces of gold and 1.8 ounces of silver to the ton; the portion richer in famatinite gave 53.37 ounces of gold and 3.17 ounces of silver. This result is rather remarkable, as this particular ore shows no native gold under a hand lens. A similar separation was made of some ore from the January mine, although in this case the portion containing the less famatinite was mainly quartz, with probably no more pyrite than was present in the other portion. The portion with the most famatinite afforded on assay 15.70 ounces of gold and 25 ounces of silver to the ton; the quartzose residue gave 9.32 ounces of gold and 11.08 ounces of silver.

On the other hand, a sample from the 200-foot level of the Jumbo mine containing rather abundant famatinite was found on assay to contain only 0.26 ounce of gold and 0.25 ounce of silver to the ton. Thus famatinite and a high proportion of gold are not invariably associated.

\section{CERARG YRITE.}

Halogen compounds of silver appear to be very rare at Goldfield, owing doubtless to the fact that the proportion of silver in the ores is small. Nevertheless, it might have been expected, a priori, that in the oxidation of ores of such remarkable richness, in which the silver, though relatively unimportant, rises in some cases to over 60 ounces to the ton, noticeable quantities of cerargyrite would form.

The only mines in which any chloride of silver has been distinctly recognized are the workings of lessees on the Gold Coin claim of the Jumbo-Extension Company and the Toplitz lease on the Daisy No. 1 claim, both near Diamondfield. Cerargyrite occurs in the oxidized ore of 
the Gold Coin as minute, waxy, olive-green crystals implanted on limonite or rusty ledge matter. Owing to the high specific gravity of the mineral it can be separated with the free gold by panning. Associated with the gold, cerargyrite, and limonite are kaolinite and small quantities of an obscurely crystalline yellow mineral, which is a ferric tellurite, probably emmonsite or durdenite.

The ore from the Gold Coin claim is more argentiferous than most of the Goldfield ores, some assays showing nearly 2 ounces of silver to 1 of gold. This fact probably accounts for the presence of cerargyrite in the oxidized part of the deposit.

A few minute specks of light-green color noted in the ore of the Toplitz lease are probably embolite or bromyrite. The material was insufficient for chemical tests.

QUARTZ.

The quartz of the Goldfield district is a gray, aphanitic, flinty material bearing little resemblance to the white, coarsely crystalline variety characteristic of typical quartz veins the world over. The coarsely crystalline mineral, such as forms the gangue of the California gold veins, has filled open fissures, having been deposited from siliceous solutions. The greater part of the Goldfield quartz, on the other hand, occupies space once filled by shattered or fissured rock. To say that this rock has been silicified only partially expresses the facts. The quartz is in large part the silica of the original dacite, andesite, or rhyolite, as the case may be, left behind, as a more or less porous mass, in the removal of other constituents. In parts of this mass, where fissures are most abundant, additional silica has been metasomatically introduced. A further increment of silica has crystallized as quartz druses on the walls of cavities which are in part interstitial and in part the result of the removal of phenocrysts by solution. In such a mass of quartz the pyrite is probably in large part derived from ferrous silicates and magnetite in the original rock. It has, however, undergone some migration and segregation. The other sulphides and the gold have been for the most part metasomatically introduced, although to a minor extent they fill small cavities.

The steps in the conversion of rock into quartz are fully described in the chapter on metasomatic alteration, pages 176 to 186 .

In the Goldfield ores, quartz rarely occurs in crystals of such size as to be distinctly visible with the naked eye. They are mostly microscopic. Even in the druses of open cavities a lens is usually necessary to distinguish the individual faces of the crystals.

Under the microscope the flinty quartz appears as a finely crystalline mosaic of quartz grains. This may show no trace of the texture of the original rock, but quartz of the kind described is connected by insensible gradations with aggregates of quartz, alunite, kaolinite, and pyrite, in which the porphyritic structure of the dacite, andesite, or rhyolite is still recognizable. The microstructure of this cryptocrystalline quartz is illustrated in Plates XXVI and XXVII.

In the Goldfield-Belmont mine the altered andesite in places is traversed by dull-white stringers composed of a cryptocrystalline aggregate of quartz and kaolinite. Some of these veinlets grade into soft, nearly pure kaolinite. In the same mine is some white quartz, carrying a little pale-green sericite, which more closely resembles ordinary vein quartz than does most of the mineral in the district. Close inspection, however, shows that this material is a very finely crystalline granular aggregate. Some of it is porous with a structure suggesting incrustation of a prismatic mineral since entirely dissolved. This, however, is little more than a suggestion furnished by the resemblance of the material to quartz pseudomorphs after celestite at Cripple Creek. ${ }^{a}$ The quartz in the upper workings of this mine has in places been crushed to a loose sugary condition.

An unusual variety of quartz is found in the Gold Coin workings of the Jumbo-Extension Company, near Diamondfield. This is dark gray and cryptocrystalline. Its peculiar feature

a Lindgren, W., and Ransome, F. L., Geology and gold deposits of the Cripple Creek district, Colorado: Prof. Paper U. S. Geol. Survey No.54, 1906, p. 125. 
is a vesicular structure, the vesicles being smooth and spherical and ranging up to half an inch (12 millimeters) in diameter. Most of them are empty, but some are filled with alunite or kaolinite. The material is probably an altered, vesicular glassy volcanic rock. Whether it was originally a local vitreous facies of the andesite, which is the general country rock, or an included mass of rlyolite is not clear. The microscope shows a spotty quartz mosaic with faint suggestions of a former igneous texture.

As will be shown in the section on paragenesis, the quartz associated with the ores is not all of one generation.

In addition to its occurrence in the ledges, quartz is an original constituent of some of the igneous rocks of the district, particularly of the alaskite, rhyolites, and dacite. In the rhyolites and dacite it is present as rounded and embayed phenocrysts which, as they usually remain unchanged in the alteration connected with ore deposition and are readily distinguished from the fine-grained later quartz, serve as useful and reliable means of determining the original rock from which much of the ledge matter has been derived. On this account sections of some of the larger and more irregular quartz phenocrysts from altered dacite are shown in figure 7. Quartz also occurs as phenocrysts in the Mira basalt. (See p. 69.)

BISMITE.

The artificially prepared trioxide of bismuth $\left(\mathrm{Bi}_{2} \mathrm{O}_{3}\right)$ crystallizes in the orthorhombic system, although according to Dana ${ }^{a}$ the natural mineral is not crystallized, but is found in massive, disseminated, or earthy condition.

In the Goldfield district, bismite occurs in the January, Combination. Sandstorm, and probably also in other mines, as minute pearly scales with brilliant luster and of silvery whiteness. The luster of the scales is almost metallic and suggests at first glance delicate and untarnished crystals of native silver. The mineral is limited

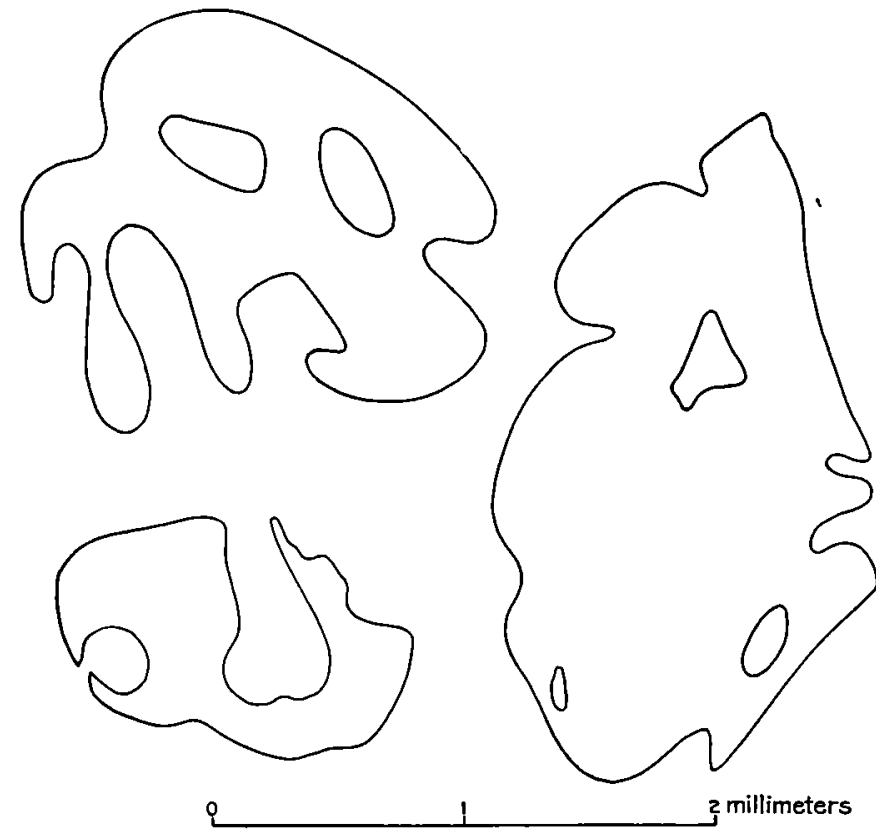

FIGUR 7.-Characteristic outlines of quartz phenocrysts in dacite. to the oxidized zone, is usually accompanied by limonite, and is frequently associated with rich ore. It occurs as single glittering scales or specks on the walls of cavities in spongy limonite or rusty ledge matter, as delicate frost-like films on the same materials, and as spongy aggregates with quartz. In the last-named form it is clearly pseudomorphous after bismuthinite, the material having consisted originally of a mass of bismuthinite prisms held together by a siliceous gangue. The prismatic structure of the bismuthinite is retained as hollow casts in the quartz, lined or partly filled with scales of bismite.

As natural crystals of bismite do not appear to have been found hitherto and as the mineral has been assigned to the orthorhombic system in Dana's and Hintze's mineralogies on the basis of Nordenskiöld's work on artificial crystals in 1860 and 1861, considerable interest attaches to the Goldfield occurrences on account of the crystallinity of the material.

When examined under the microscope in gently powdered material the crystals appear as thin colorless scales, with occasionally a suggestion of hexagonal outline. On account of their tenuity, it is rare that an edge view of a scale is obtainable. The larger flat-lying scales are dark in all positions between crossed nicols and give a negative uniaxial figure with convergent light. There are no colored rings and the double refraction is apparently not great. The 
refractive index, on the other hand, is rather high, being greater than that of anorthite. The mineral has a perfect basal cleavage, and the scales, viewed without the analyzing nicol, commonly show delicate interference colors due to the refraction and reflection at the surfaces of the exceedingly thin cleavage sheets.

Some of the best material obtainable was analyzed in the United States Geological Survey laboratory by W. T. Schaller, as follows:

\section{Chemical analysis of bismite.}

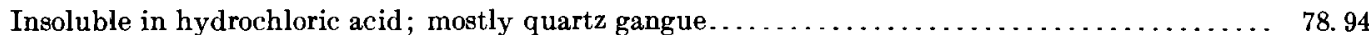

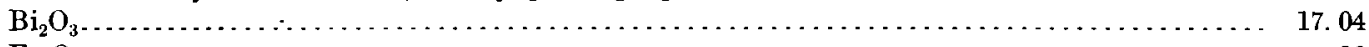

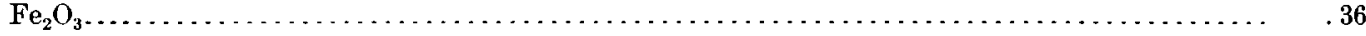

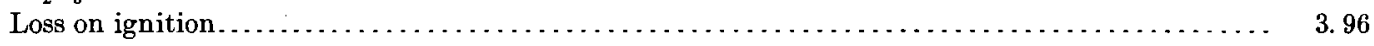

100. 30

The results show that the mineral is either bismite or else a hydrous oxide of bismuth. If the latter be the case the mineral is a new species. Attempts to isolate a sufficient quantity of the pearly scales from the gangue for separate analysis were not successful.

Mr. Schaller has kindly furnished the following crystallographic note:

The minute, tabular crystals are too incomplete to allow of a determination of their geometrical form by crystallographic measurements alone. From the uniaxiality of the crystals, their hexagonal outline, triangular markings on the base, and distribution of faces as far as seen, one seems justified in referring them to the rhombohedral division of the hexagonal system.

As given in detail further along, the $c$ axis is 0.5775 . Seven faces were determined as present; the base, five positive and one negative rhombohedra. Besides these, there were indications of two more positive rhombohedra. Below is given a brief description of these forms.

$c(0001)$. Always very large, even, and highly polished. Sometimes shows triangular markings or striæ, the faces parallel to these markings being taken as positive.

$o$ (10ī6). Occurs on two crystals, as broad faces giving, however, poor reflections. One face was considerably striated, giving two signals a degree apart.

$q(10 \overline{1} 5)$. Broad faces giving fairly good reflections.

$u(10 \overline{1} 4)$. Narrow faces, one striated with a fair reflection, and one as a line face giving a very poor reflection.

$k(10 \overline{13})$. Usually as a line face, striated and giving a very poor reflection.

$d ?(20 \overline{2} 5)$. A doubtful face, narrow, giving no distinct signal.

? (1012). Another doubtful face, broad, giving no distinct reflection.

$y(20 \overline{2} 1)$. Line faces, giving exceedingly faint reflections.

$z(01 \overline{1})$. The only negative rhombohedron observed. Very faint line faces, giving no reflection. Its negative position could be determined only on crystal No. 6 .

The measurements of the forms are shown below:

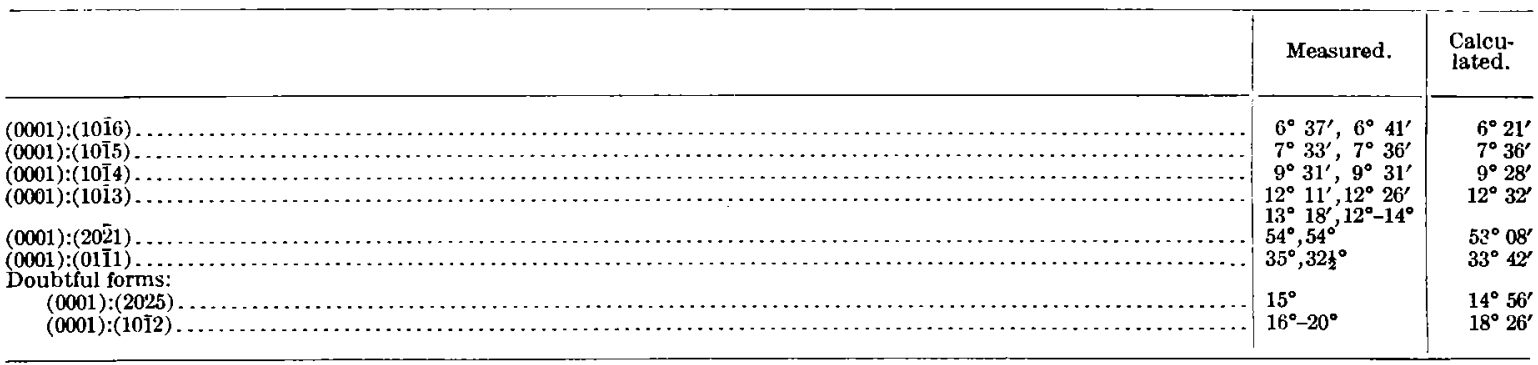

The value for the $c$ axis was obtained from three measurements that'were considered as the most accurate. The others gave values agreeing fairly well with the one adopted, as is shown below. The crystals were measured on the two-circle goniometer, and the $\rho$ angle for these forms is the angle between that form and the base.

The three best measurements are:

$$
\begin{array}{lrr}
\rho(10 \overline{1} 5)=7^{\circ} 33^{\prime} & \therefore p_{0}=0.6627 & \text { Crystal No. } 1 . \\
\rho(10 \overline{1} 5)=7^{\circ} 36^{\prime} & p_{0}=.6672 & \text { Crystal No. } 4 . \\
\rho(10 \overline{1} 4)=9^{\circ} 31^{\prime} & p_{0}=.6706 & \text { Crystal No. } 2 . \\
\multicolumn{4}{c}{\text { Average } p_{0}=.6668 ; c=0.5775 .}
\end{array}
$$


An average of the other measurements gave values closely agreeing. Thus:

$$
\begin{array}{lrl}
\rho(10 \overline{1} 6)=6^{\circ} 37^{\prime} & \therefore p_{0}=0.6960 & \text { Crystal No. } 3 . \\
\rho(10 \overline{1} 6)=6^{\circ} 41^{\prime} & p_{0}=.7031 & \text { Crystal No. } 6 . \\
\rho(10 \overline{1} 4)=9^{\circ} 31^{\prime} & p_{0}=.6706 & \text { Crystal No. } 6 . \\
\rho(10 \overline{1} 3)=12^{\circ} 11^{\prime} & p_{0}=.6477 & \text { Crystal No. } 6 . \\
\rho(10 \overline{1} 3)=12^{\circ} 26^{\prime} & p_{0}=.6614 & \text { Crystal No. 4. } \\
\rho(10 \overline{1} 3)=13^{\circ} 18^{\prime} & p_{0}=.7102 & \text { Crystal No. } 1 . \\
& \text { Average }=.6815 &
\end{array}
$$

The following measurements of faces giving no distinct reflections also showed close agreement.

$$
\begin{aligned}
& \rho(10 \overline{\mathrm{I}} 3)=12^{\circ}-14^{\circ}\left(\text { av. } 13^{\circ}\right) \quad p_{0}=0.69 \quad \text { Crystal No. } 1 . \\
& \rho(20 \overline{2} 5)=15^{\circ} \quad p_{0}=.67 \quad \text { Crystal No. } 2 \text {. } \\
& \rho(10 \overline{1} 2)=16^{\circ}-20^{\circ}\left(\text { av. } 18^{\circ}\right) \quad p_{0}=.65 \quad \text { Crystal No. } 1 \text {. } \\
& \rho(01 \overline{1} 1)=35^{\circ} . \quad p_{0}=.70 \quad \text { Crystal No. } 5 . \\
& \rho(01 \overline{1} 1)=32 \frac{1}{2}^{\circ} \quad p_{0}=.64 \quad \text { Crystal No. } 6 . \\
& \rho(20 \overline{2} 1)=54^{\circ} \quad p_{o}=.69 \quad \text { Crystal No. } 1 . \\
& \rho(20 \overline{2} 1)=54^{\circ} \quad p_{0}=.69 \quad \text { Crystal No. } 6 .
\end{aligned}
$$

The values for $p_{0}$ just given show that the interpretation of the forms is the correct one.

Of the six crystals (all incomplete) that were measured, only two are here figured. In figure $8 a$ is an orthographic projection of a crystal (No. 1), showing the trigonal distribution of the rhombohedra and the triangular marking on the base. $b$ shows a similar projection of crystal No. 6, with a negative rhombohedron.

An odd feature of these crystals is that the development of the faces is so uneven that no two faces of the same form are present on the upper half of a crystal, though this is in part due to the incompleteness of each crystal.

From the foregoing observations it appears that the natural bismite is not orthorhombic, but belongs to one of the uniaxial systems, probably the hexagonal. Its presence in oxidized ore appears to be uniformly indicative of bismuthinite in the original sulphide ore. Some migration, however, has taken place during oxidation, and the scales of bismite do not always occupy the exact positions of the parent needles of bismuthinite.

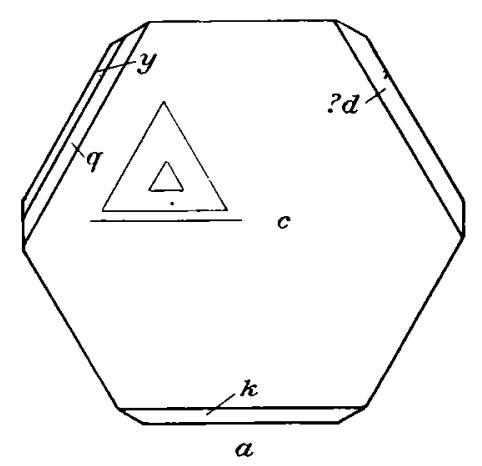

\section{TELLURITE.}

The oxide of tellurium $\left(\mathrm{TeO}_{2}\right)$ occurs sparingly with a telluride of gold in the Goldfield-Belmont mine, north of Diamondfield, as a crystalline honey-yellow mineral with subadamantine luster. Only one small speck of the mineral was obtained, which was determined chemically by Mr. W. T. Schaller.

\section{MASSICOT.}

A little lead, apparently in the form of the yellow oxide $(\mathrm{PbO})$, occurs in the workings of the No. 3 lease on the Commonwealth ground, a little more than 2 miles east of Goldfield. The supposed massicot, with probably various impurities, forms porous, sinter-like, yellow incrustations in the interstices of shattered and

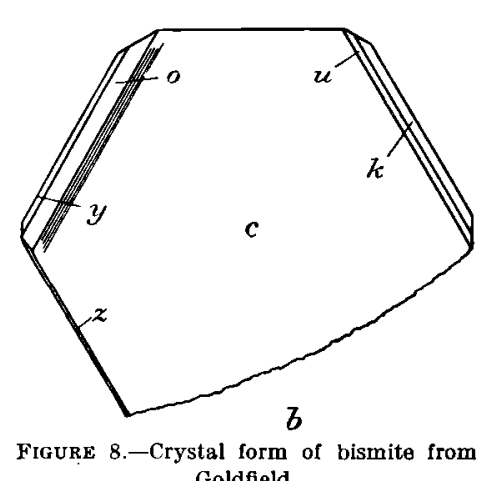
silicified latite, associated with kaolinite and alunite. Mr. W. T. Schaller found on chemical tests that the yellow material contains a little lead. The evidence that the metal in this earthy mixture is really in the form of massicot can not be regarded as conclusive.

\section{HEMATITE.}

The anhydrous oxide of iron $\left(\mathrm{Fe}_{2} \mathrm{O}_{3}\right)$ occurs in nature as the crystalline (rhombohedral) variety known as "specularite" and in various fibrous, botryoidal, massive, and earthy forms. The latter are generally distinguished from the hydrous oxide, limonite $\left(2 \mathrm{Fe}_{2} \mathrm{O}_{3} \cdot 3 \mathrm{H}_{2} \mathrm{O}\right)$, by a red 
instead of a brown or yellow streak or powder and of course by the absence of any notable quantity of combined water. Between limonite and hematite, however, are the intermediate species göthite $\left(\mathrm{FeO} \cdot \mathrm{H}_{2} \mathrm{O}\right)$ and turgite $\left(2 \mathrm{Fe}_{2} \mathrm{O}_{3} \cdot \mathrm{H}_{2} \mathrm{O}\right)$. As these various minerals frequently occur together, the determination of the mineral species represented in a massive aggregate of partially hydrated iron oxide is not always a simple matter. It is probable that some of the brilliant iridescent films described later under "Limonite" are in part hematite. Although apparently none of them is quite anhydrous, they for the most part give dark-red streaks.

In the croppings of what is known as the "Hat lease" on the Blue Bull ground, earthy red hematite associated with ocherous and botryoidal limonite is abundant as a cement of brecciated and silicified andesite. Close inspection of this material shows that some of the fragments are coated with thin glistening black films, which give a red streak like that of hematite. The microscope resolves this film into minute crystals of specularite, about 0.05 millimeter in diameter, implanted on a brown, finely botryoidal surface of a crust of limonite. These little crystals are not perfect. Some are mere rough black spherules with no distinct crystal planes. Others show one lustrous face, usually at the top of the spherule, while still others show combinations of several faces belonging apparently to flat rhombohedrons or to combinations of rhombohedrons with the basal pinacoid. Sketches of some of these faceted spherules are shown in figure 9. The crystal faces have the splendent luster of specularite.

In the workings of the same lease minute specks of iron oxide occur distributed through a massive fine-grained, sandstone-like aggregate of alunite. The specks give a red streak when the material is picked or struck, and may be hematite. Turgite $\left(2 \mathrm{Fe}_{2} \mathrm{O}_{3} \cdot \mathrm{H}_{2} \mathrm{O}\right)$ has a similar streak, however. A similar oxide occurs with jarosite or alunite on the south slope of Myers
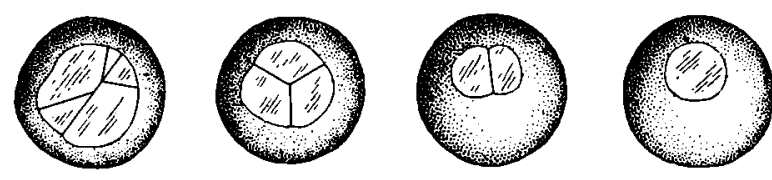

FIGURE 9.-Spherules of hematite with crystal facets; $\times 300$.

Mountain. The particles show no crystal form under the microscope and it is not possible to determine whether they are hematite or turgite, or, possibly, göthite. A similar mixture of red iron oxide with alunite and native gold forms part of the ore of the Simmerone mine. In the Lone Star mine, alunite, red oxide of iron, and quartz in small rough doubly terminated prisms form soft sandy aggregates.

RUTILE.

Rutile $\left(\mathrm{TiO}_{2}\right)$ forms microscopic crystals with alunite, quartz, and sulphides in some of the altered dacite of the Combination and Florence mines. It is probably distributed sparingly through much of the alunitized rocks of the district as an alteration of titanite or ilmenite by ore-depositing solutions.

\section{DIASPORE.}

The hydrous oxide or basic hydrate of aluminum, $\mathrm{AlO}(\mathrm{OH})$, crystallizing in the orthorhombic system as the mineral diaspore, has rarely been noted in connection with ore-bearing veins. It is a characteristic alteration product of corundum, and its best-known occurrences in this country are in the intensely metamorphosed rocks of Chester, Mass., Chester County, Pa., Macon County, N. C., and near Trumbull, Conn. According to Van Hise, ${ }^{a}$ biotite, gibbsite, haüynite, muscovite, nephelite, noselite, phlogopite, scapolite, and sodalite, as well as corundum, may all give rise to diaspore in the belt of weathering.

Diaspore was found by Cross ${ }^{b}$ associated with alunite, quartz, and kaolin in the altered rhyolite of the Rosita Hills, Colorado. It occurs also with quartz and kaolinite in altered latite in the Silverton district, Colorado. ${ }^{c}$

These occurrences in altered volcanic rocks in Colorado led to a search for diaspore in the alunitic and kaolinitic rocks of Goldfield. The mineral proved to be rather widely distributed as a microscopic constituent, although not present in great quantity at any one place.

a A treatise on metamorphism: Mon U. S. Geol. Survey, vol. 47, 1904, p. 232

$b$ Geology of Silver Cliff and the Rosita Hills, Colorado: Seventeenth Ann. Rept. U. S. Geol. Survey, pt. 2, 1896, pp. $316-317$.

c Ransome, F. L , Economic geology of the Silverton quadrangle, Colorado: Bull. U. S.Geol. Survey No. 182, 1901 (reprinted in 1903), pp.121-124. 
It has been found with alunite and kaolinite in Sandstorm rhyolite near the Sandstorm mine; in altered rhyolite from the west slope of Vindicator Mountain; with quartz, alunite, and a little rutile and sericite in altered dacite on the south slope of Preble Mountain; and with alunite, quartz, and pyrite in altered dacite from the Florence mine. In the last-named place, the pyrite, alunite, and diaspore are intimately crystallized together and are clearly of contemporaneous origin.

Diaspore occurs in the Goldfield rocks as rounded, colorless, anhedral grains which rarely exceed $0.5 \mathrm{~mm}$. in greatest diameter. These have one well-marked cleavage which is parallel to the plane of the optic axes. Sections transverse to the cleavage give a biaxial interference figure. The optical character of diaspore is positive, but owing to the large optic angle (over $84^{\circ}$ ) it is not always clear when dealing with small irregular grains whether the interference figure obtained corresponds to the acute or the obtuse bisectrix. Consequently attempts to determine the optical character from interference figures are likely to yield negative results on some grains and positive on others. ${ }^{a}$ The index of refraction of the Goldfield mineral is about 1.7 and the birefringence is such as to give green, yellow, and red of the second order in sections about 0.02 millimeter in thickness, thus corresponding closely to $\gamma-a=0.048$, the figure given for diaspore in Michel Lévy and Lacroix's table of birefringences. ${ }^{b}$

The optical properties leave little doubt of the identity of the mineral with diaspore. Additional assurance, however, is afforded by tests by Mr. Schaller in the United States Geological Survey chemical laboratory. He pulverized the rock from the Florence mine, and after removing the pyrite treated the powder with hydrofluoric acid. The undecomposable residue was microscopically examined and found to consist of particles of the mineral under investigation. These proved to have the chemical composition of diaspore.

\section{LIMONITE.}

The common brown or yellow hydrous oxide of iron $\left(2 \mathrm{Fe}_{2} \mathrm{O}_{3} \cdot 3 \mathrm{H}_{2} \mathrm{O}\right)$ is present in varying quantities in practically all of the oxidized ores of the Goldfield district and is the most characteristic product of the weathering or oxidation of pyrite. As pointed out on page 124, it is sometimes mixed with hematite and it is not always possible in any given ferruginous mixture to determine exactly what proportions of the various hydrated oxides are present.

Limonite as a rule is more abundant in ores having dacite or andesite for country rock than in those inclosed by rhyolite. This difference is partly accounted for by the fact that the oxidized dacitic and andesitic ores were originally more pyritic in consequence of the larger quantity of iron available in the femic minerals of these rocks than in the more siliceous rhyolites. As indicated on page 181, the pyrite of the Goldfield ores has not been introduced bodily as sulphide of iron by the ore-bearing solutions, but has to a great extent been generated by the attack of sulphurous waters upon iron silicates already present in the rocks.

The limonite of the Goldfield ores is generally earthy and mixed with kaolin, quartz, alunite, and other impurities. Often it is a mere rusty film on fragments of ledge matter. In a few places, as in some nearly horizontal seams on the 50-foot level of the Watson lease on the Florence claim, nearly pure limonite forms spongy masses suggestive of bog ore.

One of the most characteristic and conspicuous occurrences of limonite in the Goldfield district is that of thin coatings on the surfaces of some of the siliceous outcrops of the ledges. Such coatings are exceptionally well developed on the hilltops just east of the Blue Bull mine and on Banner Mountain, but may be observed at many other places.

The films are in some places dark steel gray with rounded, highly lustrous and finely botryoidal surfaces. In other places they exhibit gorgeous iridescence, the play of colors, due to the refraction of light by thin films, ranging from deep blue through purple, crimson, and orange to bright green. These films envelop loose fragments of the croppings or cover the surface of rock in place as brilliant expanses sometimes several square feet in unbroken extent.

a A supposed negative mineral resembling diaspore, referred to in an earlier paper (The association of alunite with gold in the Goldfield district, Nevada: Econ. Geology, vol. 2, p. 673), turns out to be diaspore in which the obtuse was mistaken for the acute bisectrix.

$b$ Les minéraux des roches, Paris, 1888. Reproduced also in Idding's Rock Minerals, New York and London, 1906. 
Such extensive coatings are often visible on the walls of joints which have gaped in consequence of the partial undermining of the siliceous croppings by the erosion of the softer country rock around and under them.

The iridescent limonite films are not confined to surface exposures, but occur in the oxidized ore of some of the mines, including the January and Combination. The Columbia Mountain No. 1 tunnel, on the east side of the mountain, extends for 300 feet through shattered Cambrian sediments in which the fragments are encrusted and cemented by iridescent botryoidal films of iron oxide.

The material of many of these films has a red streak and gives off less water in a closed tube than does ordinary limonite. It is probable that it consists in part of hematite, with perhaps some admixture of the hydrous oxides göthite, turgite, or limonite.

\section{CALCITE.}

The common rhombohedral carbonate of calcium $\left(\mathrm{CaCO}_{3}\right)$ is not an abundant mineral in the Goldfield district, and is absent, so far as is known, from the ore deposits.

Veins of yellowish, massive, and impure calcium carbonate, carrying a little oxide of manganese and small vugs and veinlets of clear crystalline calcite, traverse the beds of the Siebert formation on the west slope of Myers Mountain. They apparently contain neither sulphides nor gold and are probably later in age than the ore deposits. Similar veins occur in dacite, about a mile southeast of McLaughlin's well. Some of the material is porous and rusty, and the vein may prove to contain pyrite at greater depth.

Calcite serves as cement for some of the tuffs and conglomerates of the Siebert formation, and is a microscopic constituent of some of the propylitically altered andesite, latite, and dacite, as an alteration product of feldspar and augite. It occurs also as amygdules in some of the basalts and in interstices between the crystals in the same rocks. In the basalts the presence of calcite is not necessarily connected with noticeable decomposition of the primary minerals, and it is evident that in these rocks carbonate of calcium can be deposited in vesicles and miarolitic cavities within a comparatively short time after the solidification of the lava.

Calcite is also a microscopic constituent of alunitized rhyolite on the east slope of Vindicator Mountain. This is the only rock in which calcite and alunite have been found together in this district, and the association is probably not common. Its significance is discussed on page 194 .

FELDSPARS.

The pseudomonoclinic potassium feldspar orthoclase $\left(\mathrm{K} \Lambda \mathrm{Si}_{3} \mathrm{O}_{8}\right)$ is an important constituent mineral of the alaskite. In this rock it is usually microscopically intergrown with albite in the form of perthite.

As the clear variety known as sanidine it is abundant in the younger rhyolites. In the older rhyolites, such as those of Columbia and Vindicator mountains, it has been extensively altered to alunite. It does not always succumb to alteration in these rocks as readily as might be expected, however; a facies of the Morena rhyolite northwest of the Conqueror mine still contains much fresh sanidine, although the rock is full of secondary quartz and the original quartz phenocrysts show broad optically continuous accretions of the same mineral.

The most abundant calcium-sodium feldspars in the district are those ranging from andesine to anorthite. The anorthite occurs in the olivine basalt, and labradorite is the principal species in the dacite and andesite, and probably also in the latite, although the feldspar in the lastnamed rock is never fresh.

In the vicinity of the ore deposits the feldspars are invariably decomposed and have given rise to aggregates of alunite, kaolinite, quartz, pyrite, and diaspore. In the propylitically altered rocks they have usually been changed to calcite and quartz.

\section{EPIDOTE.}

Epidote, a somewhat complex basic orthosilicate of calcium, iron, and aluminum $\left(\mathrm{HCa}_{2}\right.$ $\left.(\mathrm{Al}, \mathrm{Fe})_{3} \mathrm{Si}_{3} \mathrm{O}_{13}\right)$ crystallizes in the monoclinic system and has a characteristic yellow-green color. 
It occurs at Goldfield with calcite, chlorite, and pyrite as a microscopic constituent of propylitically altered dacite, andesite, and latite, particularly as an alteration product of augite and biotite. It is not present as a rule in the immediate vicinity of ore, but is best developed in the greenish altered dacite northeast of MicLaughlin's well. In some of these rocks the aggregates of epidote pseudomorphous after the original femic minerals are visible with the naked eye. Where formed at the expense of biotite, the epidote usually occurs in lenticular lamellæ alternating with chlorite.

MUSCOVITE (INCLUDING SERICITE).

The white potassium mica $\left(\mathrm{H}_{2} \mathrm{KAl}_{3} \mathrm{Si}_{3} \mathrm{O}_{12}\right)$ occurs very sparingly in some of the alaskite, apparently as an alteration product of biotite and usually associated with epidote.

The fine scaly variety known as sericite, abundant in close association with some of the largest and most important classes of gold-quartz veins, is rare in the Goldfield district, and its occurrence is sporadic and exceptional rather than characteristic. It is found with quartz at the Goldfield-Belmont mine and imparts a pale-green tint to that mineral. As a subordinate microscopical constituent it is present with alunite in altered dacite from the south slope of Preble Mountain. It occurs also as an alteration product of feldspar in pyritized andesite near the Florence mine.

\section{KAOLINITE.}

The hydrous silicate of aluminum known as kaolin or kaolinite $\left(\mathrm{Al}_{2} \mathrm{O}_{3} \cdot 2 \mathrm{SiO}_{2} \cdot 2 \mathrm{H}_{2} \mathrm{O}\right)$ crystallizes in the monoclinic system, but commonly occurs in soft, white massive form, in which the individual crystals are too minute for the recognition of crystal form, even under the microscope.

Kaolinite is abundant in the Goldfield district, particularly in oxidized ores. It is not confined to the belt of weathering, however, but occurs also in the sulphide zone and as a constituent of unoxidized country rock in the vicinity of the ore bodies. The dacite from the 230-foot level of the Combination mine, of which an analysis is given on page 181, contains, for example, 24 per cent of kaolinite by weight. In such altered rocks the kaolinite forms very minutely crystalline aggregates of feeble birefringence as seen in thin section under the microscope. These aggregates have rather ill-defined boundaries and the kaolinite is intimately and contemporaneously crystallized with quartz, alunite, and pyrite. A very large part of the altered dacite in the vicinity of the ore bodies near Goldfield consists of these four minerals in varying proportions. A similar alteration has affected the latite penetrated by the workings west of the shaft on the bottom level (280-foot) of the January mine. Specimens from a zone of mineralization in this rock consist of quartz, kaolinite, and pyrite.

In the Goldfield-Belmont mine dull-white, fine-grained aggregates of quartz and kaolinite, associated with gypsum and pyrite, form veinlets in altered andesite below the level of oxidation. In parts of the ledges, in the sulphide zone, particularly in the Combination and Florence mine, kaolin and pyrite form irregular bunches, such material as a rule being of little or no value as ore. With alunite, quartz, and a little diaspore, kaolinite occurs in altered rhyolite in the vicinity of the Sandstone ledge, and with quartz, alunite, and a little calcite in rhyolite on slopes of Vindicator Mountain. The occurrence of kaolinite with alunite in the Commonwealth No. 3 lease has been described on page 130 .

Within the oxidized ores, kaolinite is sometimes very abundant. It occurs in soft pulverulent condition, mixed with alunite and slightly colored with yellow oxide of iron, in the Combination mine. Similar impure kaolinic material, of ten gold-bearing, is present in most of the oxidized ore bodies near Goldfield. In some places, as in the Red Top mine, pure, white, waxy kaolinite forms irregular veins and masses in limonitic, oxidized ledge matter. In the oxidized ores of the Sandstorm and Kendall mines there is much soft white kaolinite associated with barite and native gold.

BARITE.

The orthorhombic sulphate of barium $\left(\mathrm{BaSO}_{4}\right)$ is abundant in the ore of the Sandstorm and Kendall mines associated with kaolinite. The crystals, which are occasionally over an 
inch in length in the Kendall mine, are usually attached to silicified rhyolite, their free ends being embedded in the kaolinite. Some, however, are entirely surrounded by the latter mineral. The crystals are of simple tabular habit, being bounded by the unit prism (110) and the basal pinacoid (001). They are clear and colorless, with perfect cleavages parallel to the prism base. The association of the barite with kaolinite and oxidization in the Sandstorm and Kendall mines suggests that it may have been formed by the action of cold, percolating meteoric water.

In much smaller crystals, barite occurs with kaolinite in the Commonwealth No. 3 lease, 2 miles east of Goldfield, and with alunite and pyrite in the Reilly workings. The crystals in both these places are barely recognizable with the naked eye. Tubular crystals up to 2 millimeters in length embedded in soft alunite with pyrite or marcasite occur in the ore of the Consolidated Red Top lease.

As barite is known to form, independently of any thermal activity, in cavities in limestone and in boxes and pipes carrying certain mine waters, and as it is also deposited from the waters of both hot and cold springs, ${ }^{a}$ its mere occurrence throws little light upon the source of the solutions from which it was precipitated.

\section{GYPSUM.}

The monoclinic hydrous calcium sulphate $\left(\mathrm{CaSO}_{4}+2 \mathrm{H}_{2} \mathrm{O}\right)$ occurs in various forms in the Goldfield district.

About a mile southwest of Blackcap Mountain, near the Gold Crater road, are some superficial deposits mapped in Plate II. These are composed of very soft, porous, cream-colored material, somewhat resembling a light volcanic ash or some forms of impure diatomaceous earth. The deposits prove to be earthy gypsum and were probably formed by the evaporation of the waters of a spring now extinct or of some temporary pond in which was accumulated water rich in sulphate of calcium derived from the surrounding rocks.

A deposit of similar material lies about half a mile ( 0.8 kilometer) east of Blackcap Mountain. Here the gypsum has a very porous fibrous structure strongly suggestive of the fragile frost crystals which may be seen sprouting from moist ground in winter. This also is probably a local spring deposit.

In the form of clear crystals or broad plates of the variety known as selenite, gypsum is abundant at the surface along the outcrops of fissures, particularly along those accompanied by much crushed rock or gouge. Broad lustrous plates of the mineral may be obtained along the Columbia Mountain fault on the south slope of the mountain. Underground, gypsum is found in most of the mines, particularly in gouge seams and in soft crushed ground, sometimes accompanied by marcasite. Its occurrence underground is not limited to the oxidized zome. It is found in the Goldfield-Belmont mine, on the 150-foot level, or 50 feet (15 meters) below the natural water level, crystallized with quartz and pyrite, and may be noted in small nests in the soft pyritized andesite or dacite of many prospecting shafts. The mineral forms small veins in altered andesite about three-fourths mile (1.2 kilometers) northeast of Myers Mountain. It also occurs in seams in partially oxidized ore on the 50 -foot level of the Jumbo mine.

Gypsum is not a conspicuous or characteristic constituent of the Goldfield ores, but the mineral is widely distributed over the district and occurs near the surface in connection with all the Tertiary rocks with the possible exception of the rhyolites and the fresh olivine basalt.

\section{MELANTERITE.}

Natural ferrous sulphate $\left(\mathrm{FeSO}_{4}+7 \mathrm{H}_{2} \mathrm{O}\right)$ or iron vitriol forms in small quantities in the lower part of the zone of oxidation by the oxidation of pyrite and marcasite. It was noted as bluish-green veirlets on the 130 -foot level of the Combination mine and as a silky white efflor-

a Headden, W. P., The Doughty springs: Proc. Colorado Sci. Soc., vol. 8, 1905, pp. 1-30. 
escence in the unused workings of the Vernal mine, now part of the Goldfield-Belmont. The normal color of the salt is green, but it loses water on exposure and turns white. The material assumes its original color on moistening.

\section{CHALCANTHITE.}

Hydrous cupric sulphate $\left(\mathrm{CuSO}_{4}+5 \mathrm{H}_{2} \mathrm{O}\right)$ is sparingly present in some places near the base of the oxidized zone. It may readily be distinguished underground from melanterite by taking up a particle on a bright moistened knife blade. If any chalcanthite is present a film of copper will at once be deposited on the steel.

\section{HALOTRICHITE.}

White or slightly yellowish fibrous incrustations, having the astringent taste common to the alum group, occur in some of the mines near Goldfield, particularly in disused workings above the water level. Such efflorescent crusts were observed in abundance on the 190-foot (intermediate) level of the January mine in 1905. Samples of the mineral collected at that time were found by Mr. W. T. Schaller to contain sulphuric acid and rnuch ferrous iron, but no potassium, and to correspond in other respects to halotrichite $\left(\mathrm{FeO} . \mathrm{Al}_{2} \mathrm{O}_{3} \cdot 4 \mathrm{SO}_{3}+24 \mathrm{H}_{2} \mathrm{O}\right)$, a monoclinic or triclinic member of the alum group. The potassium alum, kalinite $\left(\mathrm{K}_{2} \mathrm{O}_{2} \mathrm{Al}_{2} \mathrm{O}_{3} .4\right.$ $\mathrm{SO}_{3}+24 \mathrm{H}_{2} \mathrm{O}$ ), is also a mineral likely to occur in deposits originally containing much alunite, but it has not been definitely recognized in the Goldfield district. Alunogen $\left(\mathrm{Al}_{2} \mathrm{O}_{3} \cdot \mathrm{SO}_{3}+18 \mathrm{H}_{2} \mathrm{O}\right)$ is another mineral of probable although not yet demonstrated occurrence in this locality.

\section{ALUNITE.}

The hexagonal (rhombohedral) hydrous sulphate of potassium $\left(\mathrm{K}_{2} \mathrm{O}_{3} \cdot 3 \mathrm{Al}_{2} \mathrm{O}_{3} \cdot 4 \mathrm{SO}_{3} \cdot 6 \mathrm{H}_{2} \mathrm{O}\right){ }^{a}$ known as alunite or, in massive form, as alumstone, is so abundant in the Goldfield district and so generally associated with the intense alteration of the rocks in the vicinity of the ore bodies that it must be regarded as one of the most characteristic minerals of the gold deposits. It is not limited, however, to the immediate vicinity of the ore deposits, but, as will be shown in the chapter on metasomatism, occurs in prcctically all of the Morena rhyolite, in the rhyolite about Vindicator Mountain, in the dacite and andesite of Preble Mountain, and elsewhere.

Alunite occurs at Goldfield chiefly in two forms: (1) as a soft, white or slightly pink material, closely resembling kaolinite, and like that mineral filling cavities in ledge matter or ore, and (2) as an integral constituent of altered rocks.

In the earthy, massive form, alunite is very abundant in the January and Combination mines, where it plays much the same part in the sulphide zone that kaolin does in the oxidized zone. It has been found in considerable quantity also in the Lone Star mine and in leases on the Commonwealth claims, about 2 miles east of Goldfield, and is probably not entirely absent from any of the ore bodies in dacite.

In the Combination mine much of the interstitial material between the nodules of rich native gold and sulphide ore near the 230 -foot level is alunite. As a rule, the pure massive alunite can be distinguished from the pure kaolinite by a faint pink tint. The crystallinity of alunite, too, is usually greater than that of kaolinite, and examination with a hand lens shows tiny crystal faces with pearly luster. The texture of kaolinite on the other hand is normally too fine to show crystal planes, even under the microscope, and with a hand lens it appears uniformly dull and earthy. Inasmuch as alunite is a sulphate, its distinction from kaolinite or sericite may readily be made by simple chemical tests.

While alunite is not entirely absent from the completely oxidized ores, most of the soft white material found filling crevices in the weathered zone has proved to be kaolinite. Kaolinite and limonite often occur together, but the association of alunite with an oxide of iron is

a Or, as written by IIillebrand and Penfield in Bull. U. S. Geol. Survey No. 262, 1915, p. 38, $\mathrm{K}_{2}\left[\mathrm{Al}(\mathrm{OH})_{2}\right]_{6}\left[\mathrm{SO}_{1}\right]_{\text {t. }}$

$79145-\mathrm{No} .6(6-0)-9$ 
comparatively rare. Kaolinite and alunite occur together, however, in some of the oxidized ore of the Combination mine. The material is pulverulent and slightly yellow, the color being perhaps due to the presence of some jarosite, a mineral isomorphous with alunite, but differing from the latter in containing iron instead of aluminum. ${ }^{a}$ The massive alunite in many places, particularly in the Combination mine, contains abundant small, embedded crystals of pyrite.

A somewhat unusual occurrence of massive alunite was observed in 1905 in a 95-foot shaft on the Commonwealth No. 3 lease, about 2 miles (3.2 kilometers) east of Goldfield. The country rock is silicified latite. This has been irregularly fissured and the fissures and irregular interstices are filled with faintly pink alunite, within which are embedded spherical nodules of snowy kaolinite ranging in size from that of a pea to that of a small marble.

In the Dixie mine, on the west slope of Preble Mountain, massive alunite, which in some places is very compact, with almost the texture and hardness of some varieties of opal, is abundant on the 110-foot level, filling fissures and irregular crevices in porous silicified dacite.

The most coarsely crystalline form of the mineral found is in an irregular veinlet, from a half to 3 inches (1.2 to 7.6 centimeters) in width, in altered dacite on the northeast slope of Preble Mountain. This material, as exposed at the surface, is a buff-colorer aggregate of platy, irregular crystals, and resembles some forms of coarse dolomite.

The greatest interest attaches to the alunite as a rock constituent. Attention was first directed to its occurrence in this form by the finding of small nests or crystalline aggregates, up to 5 millimeters in diameter, of a pale-pink mineral in a greatly altered nearly white rock exposed on the east shoulder of Vindicator Mountain, about 2 miles northeast of the town of Goldfield. The rock contains quartz phenocrysts and was probably originally a rhyolite. The microscope shows that the feldspar phenocrysts, as well as the groundmass, have been altered to an aggregate of quartz and alunite, the optical determination of the latter mineral being checked by chemical tests in the United States Geological Survey laboratory by Mr. George Steiger. With the alunite is associated a subordinate quantity of diaspore.

Microscopical study of the bleached altered rocks of the district soon showed that alunite is present in nearly all of them. The rhyolite forming the summit of Columbia Mountain, just north of the towns of Goldfield and Columbia, has been altered to a quartz-alunite rock, the alunite with some quartz forming pseudomorphs after the feldspar phenocrysts, which probably were originally orthoclase. Alunite is very abundant in the altered andesite and dacite of Preble Mountain and vicinity, and is present, down to the deepest workings, in practically all of the altered dacite which forms the country rock of the Mohawk Combination, Florence, January, Red Top, Jumbo, and other mines near Goldfield. Its characteristic appearance in thin sections is illustrated in Plates XXVIII, XXIX, and XXX. It is also abundant directly associated with the sulphide ores in these mines, and is in many cases intercrystallized with pyrite, as shown in Plate XXIX, $D$.

As a constituent of altered rocks in the Goldfield district, the alunite does not have complete crystal form. It is usually tabular in habit, the basal pinacoid being well developed and the rhombohedral faces being absent or indistinct. In thin sections (see plates above referred to) it shows distinct cleavage parallel to the basal pinacoid and parallel extinction with reference to the cleavage. The birefringence is apparently rather stronger than the difference $\gamma-a=0.018$ given in the table of Michel Lévy and Lacroix ${ }^{b}$ the interference colors in good thin sections being mostly yellow, but rising in places to red or blue of the first order. The mineral gives a positive uniaxial interference figure in sections showing no cleavage. The index of refraction is distinctly higher than the balsam of the slide (1.54), that given for the alunite of Tolfa being $\omega=1.572$ and $\varepsilon=1.592 .^{\circ}$

In some thin sections alunite might, on superficial examination, be mistaken for sericite. The latter mineral, however, has higher double refraction with the color mottling characteristic of the micas, has finer cleavage, and is optically negative. The difference in optical orien-

$a$ See Hillebrand, W. F., and Penfield, S. L., Some additions to the alunite-jarosite group of minerals: Bull. U. S. Geol. Survey No. 262 , 1905, pp. $32-41$.

$b$ Les minéraux des roches, Paris, 1888. Also Iddings, J. P., Rock minerals, New York and London, 1906.

c Iddings, J. P., op. cit., p. 476. 
tation is most quickly detected by the use of gypsum plate or quartz wedge. In alunite the higher colors appear when the basal cleavage is parallel to the direction of greatest elasticity in the plate or wedge. In sericite the higher colors occur in the transverse position.

The minerals most commonly associated with the alunite as constituents of the altered rocks are quartz and pyrite. Some of the andesite on the south slope of Preble Mountain has been altered to a nearly white, fine-granular aggregate consisting almost wholly of quartz and alunite. The altered dacite forming the country rock of the Goldfield group of mines consists of quartz, alunite, pyrite, and kaolinite in various proportions. In many varieties of the rock these minerals are accompanied by small quantities of diaspore.

The gold, famatinite, bismuthinite, and other constituents of the richest ore are generally inclosed in quartz, not alunite. The latter mineral, however, frequently occurs in the same microscopical section less than a millimeter distant from the metallic minerals. In ore from the Jumbo-Extension mine, near Diamondfield, alunite and a telluride of gold are crystallized together, as was found by the microscopical study of thin sections.

Calcite and alunite do not ordinarily occur together, but microcrystalline calcite, a little sericite, and probably some kaolinite have been found associated with much larger crystals of alunite in an altered rhyolite from the east slope of Vindicator Mountain. The molecular ratio of soda to potash in this alunite, as determined by Doctor Hillebrand, is as 40 to 45 . It is possible, however, that the result obtained for potash may be high in consequence of some decomposition of the sericite by the sulphuric acid used to dissolve the alunite.

The occurrence together of alunite and calcite, apparently developed simultaneously, shows that the alteration took place under conditions which did not permit the free escape of carbon dioxide. It is searcely conceivable, for example, that calcite could form in the presence of sulphuric acid percolating down from an overlying deposit of oxidizing pyrite.

As shown above, part of the alunite contains considerable sodium, and the calculations of the mineralogical compositions of some of the altered rocks from their chemical analyses, as will appear in the following chapter, indicate that most of the mineral occurring in the Goldfield district is not the pure potash salt, but is intermediate between alunite proper and natroalunite. ${ }^{a}$

Alunite differing in habit from most of the mineral thus far found near Goldfield occurs in the Hat lease on the Blue Bull Mining Company's ground, $1 \frac{1}{2}$ miles (1.4 kilometers) east of Goldfield. The country rock here is andesite. This has been locally brecciated and the fragments are silicified. Between the fragments, and cementing them together, is much bright red hematite, which in the croppings is partly changed to limonite. The workings when visited were only about 50 feet ( 15 meters) deep and the hematite extends at least to that depth.

Occurring as irregular bunches and streaks in this hematitic breccia is much soft, finegrained material of light-gray color with irregular reddish gray bands. In texture this material resembles a fine sandstone. It is firm, but can be crumbled between the fingers, and gives a reddish streak when struck with a pick.

Under the microscope the powdered material proves to be made up of small, sharply bounded, colorless crystals, the largest being less than 0.03 millimeter in diameter. The crystals are apparently octahedral, but in reality are probably combinations of a rhombohedron and basal pinacoid. They are doubly refracting and can not, therefore, belong to the isometric system.

Chemical tests by Mr. W. T. Schaller show the presence of alkalies and sulphuric acid, and the mineral is without much doubt alunite, natroalunite, or an intermediate variety of this isomorphous group. The crystals are associated with microscopic rosettes of hematite, the latter giving the red streak when the material is scratched. Such ore as had been sacked for shipment at the time of visit consisted mainly of this alunitic material.

The mineral is also abundant, with sulphur in altered rhyolitic pumice, near Cuprite, 12 miles south of Goldfield. 
As alunite is still a comparatively rare mineral, as it has not been recognized hitherto as an important mineral in ore deposits, and as its presence with the rich ores at Goldfield suggests problems of great interest connected with the genesis of epigenetic ores, some reference to other occurrences and to opinions held as to the origin of the mineral may not be amiss.

Alunite was first noted at Tolfa, near Rome, where it was used as early as the fifteenth century for the manufacture of potassium alum $\left(\mathrm{K}_{2} \mathrm{O} \cdot \mathrm{Al}_{2} \mathrm{O}_{3} \cdot 4 \mathrm{SO}_{3} \cdot 24 \mathrm{H}_{2} \mathrm{O}\right) .{ }^{a}$ This salt, containing 2 parts less of $\mathrm{Al}_{2} \mathrm{O}_{3}$ with 18 parts more of water, is obtained from the alunite by roasting and lixiviation. The mineral is found also on some of the islands of the Grecian Archipelago, near Muszay in Hungary, on Mount Dore in France, and in a few other localities in Europe, as well as with the opal of Queretaro, in Mexico. In the United States it has been described in the Rosita Hills, ${ }^{b}$ on Calico Peak, near Rico, ${ }^{c}$ in the National Belle mine near Silverton, ${ }^{d}$ and at Cripple Creek, ${ }^{e}$ all in Colorado. It occurs also at Tres Cerritos, Mariposa County, Cal. ${ }^{f}$ W. Lindgren ${ }^{g}$ found alunite in the Ryerson mine near Morenci, Ariz., associated with pyrite and kaolin. He regarded it as formed by the attack of descending sulphuric acid solutions upon sericite away from free oxygen. In Nevada alunite has been described by G. I. Adams ${ }^{h}$ as associated with sulphur and cinnabar at the Rabbit Hole mines, and by S. H. Ball as in a silicified rhyolite of the Cactus Range, east of Goldfield. ${ }^{i}$

Until recently, geologists and mineralogists have regarded alunite as formed exclusively by the attack of sulphurous fumarolic vapors upon feldspathic rocks. ${ }^{j}$ At Cripple Creek, however, the mineral was found only in the oxidized ore, and, like the kaolinite of that district, is probably secondary with reference to the original telluride ores. De Launay. ${ }^{k}$ moreover, has recently maintained with cogency that the alunite of Tolfa is probably not, as commonly supposed, a solfataric product, but is due to the action of percolating surface water, charged with sulphuric acid by the oxidation of pyrite, upon a particularly feldspathic facies of the trachyte. It is accordingly no longer justifiable to regard the occurrence of alunite as proof of former fumarolic activity. The mineral may form under very different sets of conditions, and it is necessary in seeking the explanation of any occurrence of it to keep alternative hypotheses in mind.

In all four of the Colorado localities the alunite occurs in regions which contain ore deposits. In the Rosita Hills and in the Rico and Silverton districts it is apparently not a product of superficial oxidation. No close kinship between this mineral and the ores, however, has been shown, although it was doubtless recognized by all the workers in those districts that there might be some genetic relation between the metallic sulphides and the volcanism of which the sporadic solfataric metamorphism of feldspathic rocks to quartz-alunite aggregates was one manifestation. It is worth noting in this connection that the indexes of two of the best and most recent works $l$ on ore deposits contain no reference to alunite, showing that the mineral has not been commonly recognized as one intimately associated with ores. Neither is it mentioned, so far as I am aware, in C. R. Van Hise's work on metamorphism. ${ }^{m} \quad J$. H. L. Vogt, ${ }^{n}$ however, in discussing metaso-

a For the latest account of this celebrated locality, with a bibliography, see De Launay, I.., I.a métallogénie de l'Italie. X. Geol. Cong., Mexico, 1906 , pp. 125-132.

$b$ Cross, Whitman, Geology of Silver Cliff and the Rosita Hills, Colorado: Seventeenth Ann. Rept. U. S. Geol. Survey, pt. 2, 1896, pp. 52-56; also Am. Jour. Sci., 3d ser., vol. 41, 1891, pp. 466-475.

c Cross, W., and Spencer, A. C., The geology of the Rico Mountains, Colorado: Twenty-first Ann. Rept. U. S. Geol. Survey, pt. 2, 1900, pp. 92-94.

d Hurlbut, F. B., On alunite from Red Mountain, Ouray County, Colorado: Am. Jour. Sci., 3d ser., vol. 48, 1894, pp. 130-131. Also Ransome, F. I., A report on the economic gcology of the Silverton quadrangle, Colorado: Bull. U. S. Geol. Survey No. $182,1901$.

e Lindgren, W., and Ransome, F. L., Geology and gold deposits of the Cripple Creek district, Colorado: Prof. Paper U. S. Geol. Survey No. 54, 1906 , p. 125.

f Turner, II. W., Rocks and minerals from California: Am. Jour. Sci., 4th ser., vol. 5, 1898, pp. 424-426.

The copper deposits of the Clifton-Morenei district, Arizona: Prol. Paper U. S. Geol. Survey No. 43, 1905, pp. 119-120, 169, 193-194.

h Adams, G. I., The Rabbit Hole sulphur mines near Humboldt House, Nev.: Bull. U. S. Geol. Survey No. 225, 1904 , p. 500.

$i$ Ball, S. H., A geologic reconnaissance in southwestern Nevada and eastern California: Bull. U. S. Geol. Survcy No. 308,1907, p. 48.

$j$ Cross, W., Geology of Silver Cliff and the Rosita Hills, Colorado: Seventeenth Ann. Rept. U. S. Geol. Survey, pt. 2, 1896, p.314. Cross, W., and Spencer, A. C., Geology of the Rico Mountains, Colorado: Twenty-first Ann. Rept. U. S. Geol. Survey, pt. 2, 1900, p. 33. Iddings, J. P., Rock minerals, New York, 1906, p. 476. Hillebrand, W. F., and Penfield, S. I., op. cit., p. 40.

$k$ Op. cit.

$l$ Beck, Richard, Lehre von den Erzlagerstätten, Berlin, 1901. Stelzner, A. W., and Bergeat, A., Dic Erzlagerstätten, Leipzig, $1904-1906$.

${ }_{n}$ A treatise on metamorphism: Mon. I'. S. Gcol. Survey, vol. 47, 1904.

$n$ Problems in the geology of ore deposits: Trans. A m. Inst. Min. Eng., vol. 31, 1902, p. 150. 
matic vein processes, has remarked: "I would mention also the formation of alum-stone, quartzalunite rocks, quartz-diaspore rocks, etc., and also the formation of bauxites, etc. But I do not know that these changes have been anywhere observed in genetic relation with ore veins."

\section{JAROSITE.}

The mineral jarosite is closely related, chemically and crystallographically, with alunite. The formula of jarosite proper is $\mathrm{K}_{2} \mathrm{O} .3 \mathrm{Fe}_{2} \mathrm{O}_{3} \cdot 4 \mathrm{SO}_{4} \cdot 6 \mathrm{H}_{2} \mathrm{O}$ or $\mathrm{K}_{2}\left[\mathrm{Fe}(\mathrm{OH})_{2}\right]_{6}\left[\mathrm{SO}_{4}\right]_{4}$ and the crystallization, like that of alunite, is rhombohedral. As Hillebrand and Penfield ${ }^{a}$ have shown, the potassium jarosite is merely one member of a series of which the other known members are natrojarosite, $\mathrm{Na}_{2}\left[\mathrm{Fe}(\mathrm{OH})_{2}\right]_{6}\left[\mathrm{SO}_{4}\right]_{4}$, and the remarkable plumbojarosite, $\mathrm{Pb}\left[\mathrm{Fe}(\mathrm{OH})_{2}\right]_{6}\left[\mathrm{SO}_{4}\right]_{4}$.

In view of the great abundance of alunite in the Goldfield district, it might be expected that some member of the related jarosite group would be not uncommon. Such expectation, however, has not been fulfilled. It is not even certain that the mineral presently to be described is really jarosite.

Half a mile south of Myers Mountain Mr. W. H. Emmons collected from the Siebert formation a specimen of tuff which proved to be of unusual character. It has the general appearance of a yellowish, sandy tuff which weathers red on exposed sufaces. Like the material from the Hat lease, it gives a hematite streak. A thin section shows the rock to be a tuff in which the larger fragments are irregular cuspate particles of clear volcanic glass. The bulk of the material, however, is a friable mass of microscopic yellowish crystals. The crystals are sharply bounded, and when seen in the pulverized material under the microscope resemble octahedrons. They are not isotropic in all sections, however, and are probably combinations of a basal pinacoid with a rhombohedron, giving a pseudo-octahedral form similar to that sometimes assumed by the mineral coquimbite. ${ }^{b}$ The crystals are minute, rarely exceeding 0.02 .5 millimeter in diameter. Their color is light yellow.

Chemical tests by Mr. W. T. Schaller in the United States Geological Survey laboratory showed the presence of alkalies and sulphuric acid, so that the mineral belongs without much question to the alunite-jarosite series. The yellow tint and the tendency of the rock to redden on weathering indicate that the crystals contain iron, and that therefore they are probably jarosite or some variety intermediate between jarosite and alunite. $A$ little scattered hematite occurs with the jarosite.

The tuff has evidently undergone alteration as a result of which the finer particles of volcanic glass have been changed to an aggregate of jarosite or some closely related mineral. The alteration has only slightly affected the larger glass sherds, which, as a rule, still retain their characteristic clastic outlines. Some of them, however, have been peripherally attacked, the glass being separated from the jarosite aggregate by finely jagged suturelike boundaries. Cracked or pumiceous fragments usually contain jarosite in the cracks or vesicles.

There is no evidence that the tuff ever contained any notable quantity of pyrite, and the sulphide solutions which effected the metamorphism must have had their source outside of the rock itself.

It is not improbable, as pointed out by W. F. Hillebrand, ${ }^{c}$ that a yellow coating on some oxidized ore collected in the district by Spurr is jarosite.

EMMONSITE AND DURDENITE.

Both emmonsite and durdenite are greenish-yellow or yellowish-green minerals of obscure crystallization and somewhat uncertain composition. ${ }^{d}$ They are essentially hydrous ferric tellurites, in which part of the tellurium may be replaced by selenium. The theoretical composition of durdenite is $\mathrm{Fe}_{2} \mathrm{O}_{3} \cdot 3 \mathrm{TeO}_{2} \cdot 4 \mathrm{H}_{2} \mathrm{O}$.

\footnotetext{
" Some additions to the alunite-jarosite group of minerals: Bull. U. S. Geol. Survey No. 262, 1905, pp. 32-41.

$\checkmark$ See Dana, J. D. and E. S., System of mineralogy, 6th ed., New York, 1895, p. 956, fig. 2.

c Bull. U. S. Gcol. Survey No. 260, 1905, p. 137.

$d$ See Ilillebrand, W. F., Two tellurium minerals from Colorado: Bull. U. S. Geol. Surviy No. 24i2, 1905, p. 56.
} 
At Black Butte a greenish-yellow mineral belonging to this group occurs in the oxidized parts of the ore bodies, particularly in connection with good ore. It forms tenuous crusts, often little more than a stain, along cracks in the ore, or is implanted on the walls and cavities as thin rosettes, resembling lichen growths and showing minute fibrous crystallization. It is associated with free gold, limonite alunite, and perhaps kaolinite. The mineral was determined by Dr. W. F. Hillebrand to be a seleniferous ferric tellurite.

A canary-yellow variety, also seleniferous, occurs in similar thin incrustations and specks with limonite, cerargyrite, and native gold in the oxidized ore of the Gold Coin claim near Diamondfield. Other occurrences will doubtless be noted with the increase in mining development near Diamondfield.

The mineral, as at Cripple Creek, results from the oxidation of ores containing tellurides. In the Gold Coin workings the original mineral is a telluride of gold of undetermined species. In Black Butte the parent mineral has not been recognized. 


\section{CHAPTER XI.}

\section{THE MINES: A GENERAL ACCOUNT OF THEIR DISTRIBUTION, DEVELOPMENT, AND OPERATION, INCLUDING ORE TREATMENT.}

\section{DISTRIBUTION AND UNDERGROUND DEVELOPMENT OF MINES.}

The important mines of the Goldfield district will be considered in two areal divisions, which may be conveniently designated the "Goldfield" and "Diamondfield" groups. Of these the first has supplied over 95 per cent of the output of the district and includes such well-known mines as the Mohawk, Combination, Florence, Jumbo, January, Red Top, and Sandstorm.

The belt of productive mines of the Goldfield group sweeps from Kendall Mountain on the north in a gentle curve, concave to the northeast, past Columbia Mountain and Milltown, to a point about half a mile southeast of the latter settlement. It may be subdivided into a cluster of mines on the north, including the Sandstorm, Kendall, and Conqueror, which are in rhyolite ; a very important aggregation northeast of Goldfield, which is mainly in dacite, and includes the Red Top, Mohawk, Combination, January, Jumbo, and part of the Florence mines; and, finally, some mines, principally lessee workings, east of Goldfield, in the Milltown andesite. The principal underground workings of the mines near Goldfield are shown in Plate IX, and the situation of most of the important leases may be seen from Plate X.

The mines of the Diamondfield group are aligned along McMahon Ridge north of the town, and stretch from Black Butte on the east for a distance of about a mile to the west. These are mainly in the Milltown andesite.

Although the positions of the mines are given on Plate I, some verbal and pictorial description will perhaps help the reader to visualize the conditions at Goldfield and to follow with greater interest a presentation of the ore occurrences which necessarily falls far short of reality.

On a quiet morning when the winds are not whirling clouds of desert dust through the town, one standing on Mira Mountain, about $1 \frac{1}{2}$ miles south of Goldfield, and looking nearly due north has before him the scene shown in Plate VI, $B$. The sharp peak conspicuous in the middle ground is Columbia Mountain. Southwest of it are the towns of Columbia and Goldfield, beyond which, to the north, shimmers the desolate valley followed by the railroad to Mina and Hazen. In the distant hills behind the mountain and a little to the left of its summit is Tonopah, 30 miles (48 kilometers) away. The buildings visible on the hill just west of Columbia Mountain are at the new 100-stamp mill of the Goldfield Consolidated Mines Company, of which only the foundations were completed when the view was taken. Just beyond them, but not in sight, are the Sandstorm and Kendall mines. A little east of south from the mountain and over the small basalt-capped hill in the foreground are the principal mines of Goldfield, the mill and head frame of the Florence mine being almost in line with the summit of the intervening hill. The large white dump at the right-hand side of the picture is that of the Little Florence on the south side of Florence Hill. If, before leaving Mira Mountain for a nearer view of the mines, the visitor turn to the west he may look over the basalt top of Malpais Mesa (PI. XI, $A$ ) to Montezuma Peak, about 8 miles (13 kilometers) away. On the slope under the basalt may be seen exposures of the Siebert formation and in the middle ground the road from Goldfield to Lida and Rhyolite.

Leaving Mira Mountain and walking north over the Siebert beds and Milltown andesite, which is covered in most places by soil and stony detritus, the visitor who approaches the Florence mine has the view shown in Plate XI, $B$. In the foreground is soil-covered Milltown andesite. The near dump to the left is that of the Black Eagle lessee shaft, 290 feet ( 88 meters) 
deep, the last rock on the dump being the latite which underlies the andesite. The shaft just behind this dump is the Rosebud, on the $\mathrm{O}$. K. lease, 500 feet (152 meters) deep. Beyond it is Florence Hill, crowned by the Little Florence shaft, 555 feet (169 meters) deep, with five short north-south levels and lateral crosscuts to shafts on each side of the hill. This is one of the famous Florence leases ${ }^{a}$ and produced about $\$ 1,500,000$ from ore in the Milltown andesite. Below the Little Florence dump, and in front of a dark ledge outcrop on Atlanta ground, is the 500-foot Rogers shaft on another rich lease block of the Florence-Goldfield Mining Companies' ground, and to the right of this are a number of shafts, most of them about 500 feet deep, which have been sunk in the hope of finding some continuation of the rich ore mined in the Little Florence and Rogers leases. Beyond and just to the left of the hill are the head frame and mill of the Florence mine.

The visitor may now go to the top of Florence Hill and look northwest at the view shown in Plate XII, $A$. Near at hand to the right is the Florence head frame. This shaft is 350 feet (107 meters) deep, with levels running generally northwest and southeast. Two levels, the 150-foot and the 250-foot, are connected with the Reilly lease shaft, which appears in the middle ground, just to the left of the center of the picture. This was a profitable lease in the northwest corner of the Florence claim and produced ore to the value of nearly half a million dollars in 1905. On the hill above and to the left of the Reilly are the Combination mine and mill. The Combination shaft, 380 feet (116 meters) deep, is connected by extensive levels with the Reilly shaft, with the January, of which the disused head frame ${ }^{b}$ appears just beyond the Combination buildings, and with the Mohawk workings, which ramify through the low hill to the right of the valley in the middle ground. The top of the head frame of the Mohawk shaft, 600 feet (183 meters) cleep, barely shows over the crest of this hill. The Mohawk has levels at 245, 350,450 , and 600 feet $(74,107,137$, and 183 meters). These connect with an irregular maze of lessees' workings, mostly above the 250-foot level, and extending over the greater part of the Mohawk No. 2 claim. In the valley to the right of the Reilly and in order from southeast to northwest are the Florence-Wheeler, the California-Florence, the Combination Fraction, and the Burns shafts. (See also Pl. IX.) Beyond them, near the high trestle which leads to the Mohawk ore bins, are the dumps of the Hayes-Monnette and other famous lease shafts on the Mohawk ground. These shafts have been dismantled, and their dumps are being culled over and shipped. The largest dump visible on the south side of the Mohawk hill is that of the Loftus-Davis lease shaft on the Combination Fraction claim, which connects through stopes with the Mohawk workings. Below it and to the left of the Florence head frame is the Oddie shaft, 612 feet (186 meters) deep, also on the Combination Fraction. Concealed by the Mohawk hill and between it and Columbia Mountain are many lessees' shafts on the Mohawk and Gold Wedge claims and the main shaft of the Red Top mine. The most important lease on the Gollfield Wedge claim is the Mohawk-Jumbo, with a shaft 500 feet (152 meters) deep, and extensive stopes on the deeper part of the Mohawk ledge. Just north of it is the Mohawk Ledge shaft, 700 feet deep. The Jumbo mine, 500 feet deep, is at the extreme right of the view, concealed by the Florence heal frame. The shaft is now dismantled, and the old workings will be undercut from the 600-foot Mohawk level and from the Goldfield Consolidated Mines Company's new Jumbo or Clermont shaft, 860 feet (262 meters) deep in January, 1909, which is about 1,000 feet (305 meters) north-northeast of the old Jumbo shaft. Beyond the Jumbo, to the north, are the Mushett (480 feet, or 146 meters, deep), Five Friends (560 feet, or 170 meters, deep), Hazel-Goldfield (740 feet, or 225 meters, deep), Mohawk-Red Top, and other leases on the ground of the Goldfield Consolidated Mines Company. The long dark building in the middle distance is the Goldfield $\mathrm{Cl}^{c}$ mill.

If the visitor, still standing on Florence Hill, will now turn to the east, he will see (Pl. XII, $B$ ) just below him to the left the Florence-Annex shaft, 500 feet (152 meters) deep, through

$a$ The word "lease" is so generally used in the district to designate not merely a contract but a mine worked by lessees that to avoid such use would savor of pedantry.

$b$ Since removed.

cThe company uses this, the chemical symbol of ehlorine, in its corporate name. 


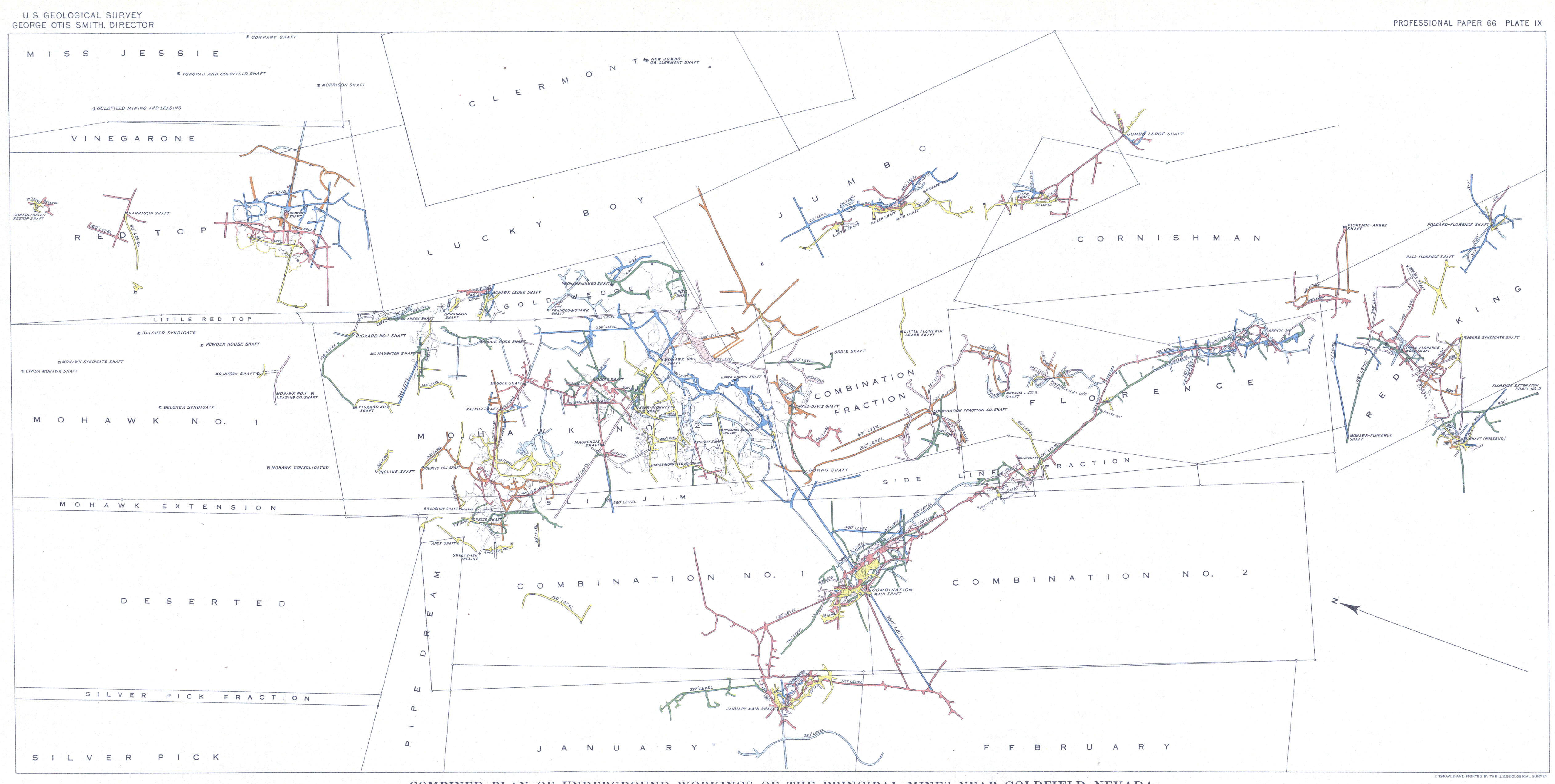

COMBINED PLAN OF UNDERGROUND WORKINGS OF THE PRINCIPAL MINES NEAR GOLDFIELD, NEVADA.

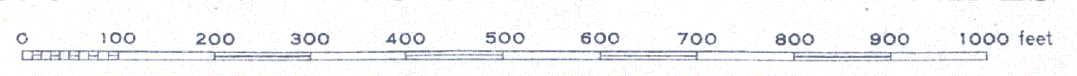





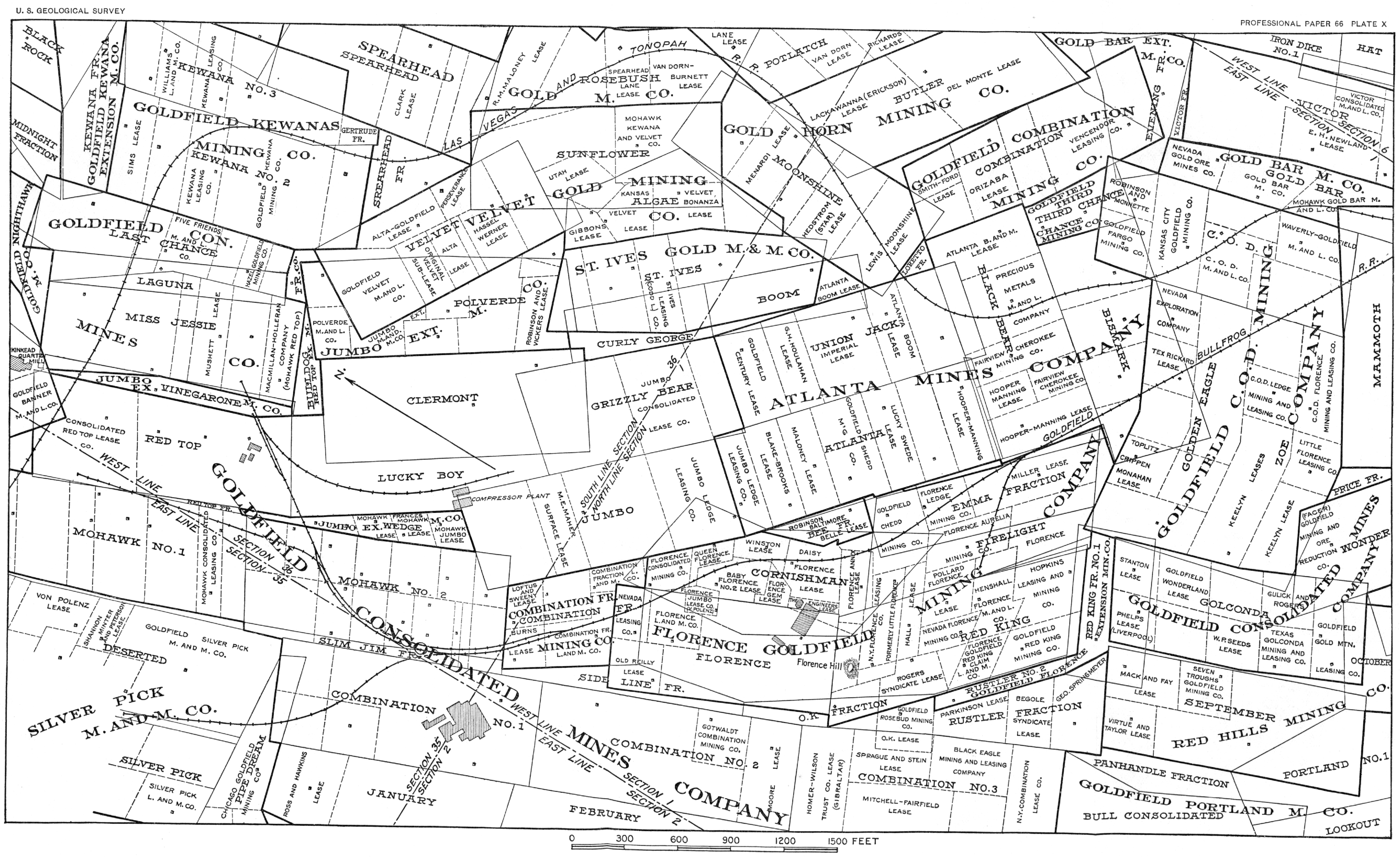

MAP SHOWING PRINCIPAL LEASE BLOCKS IN THE VICINITY OF GOLDFIELD.

Based on John Hagel's lease map for May, 1908 . 



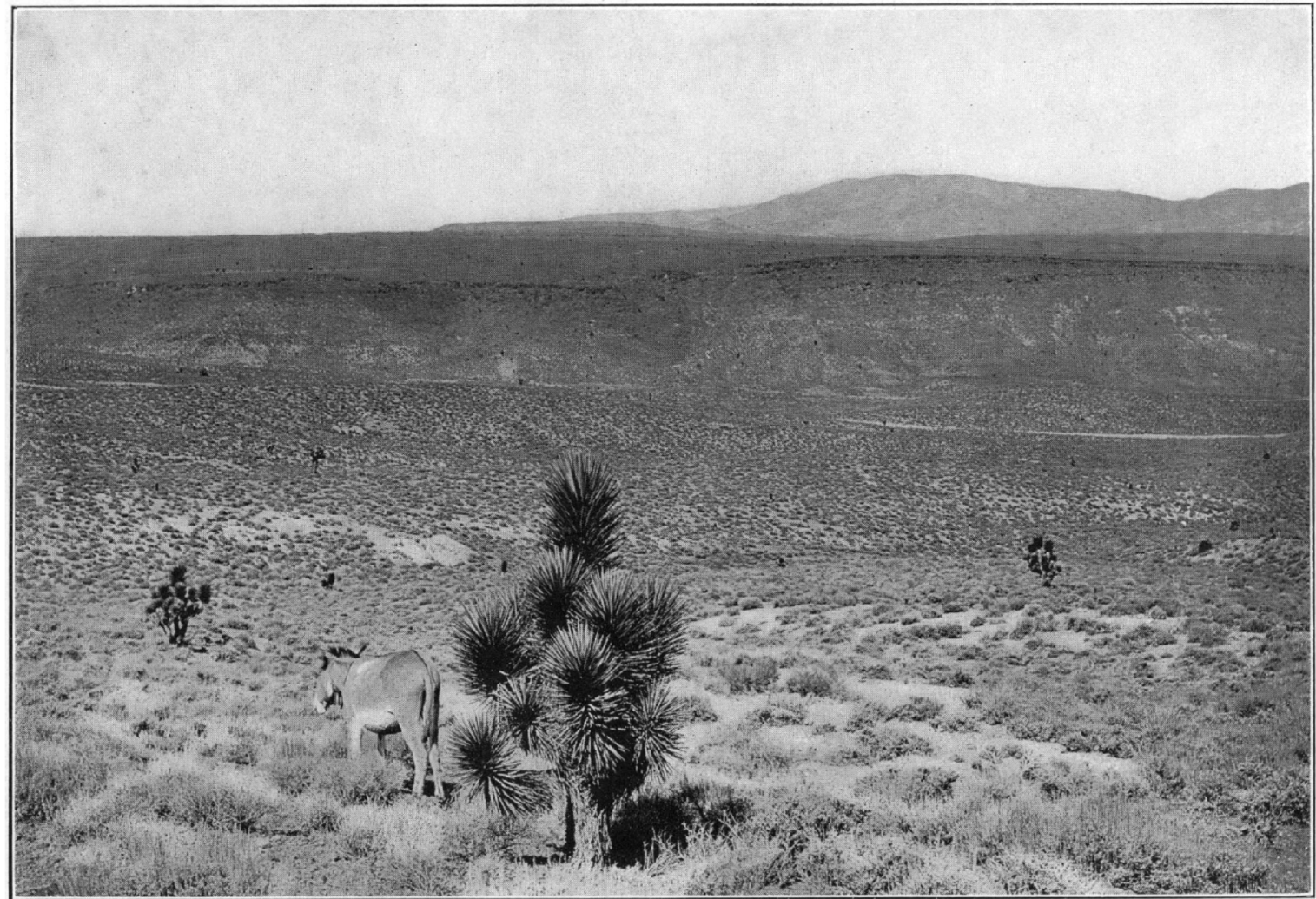

A. MALPAIS MESA; FROM MIRA MOUNTAIN.

Beyond the mesa is Montezuma Peak, composed largely of beds belonging to the Siebert formation. The same formation shows also in the steep slope below the basalt cap of the mesa.

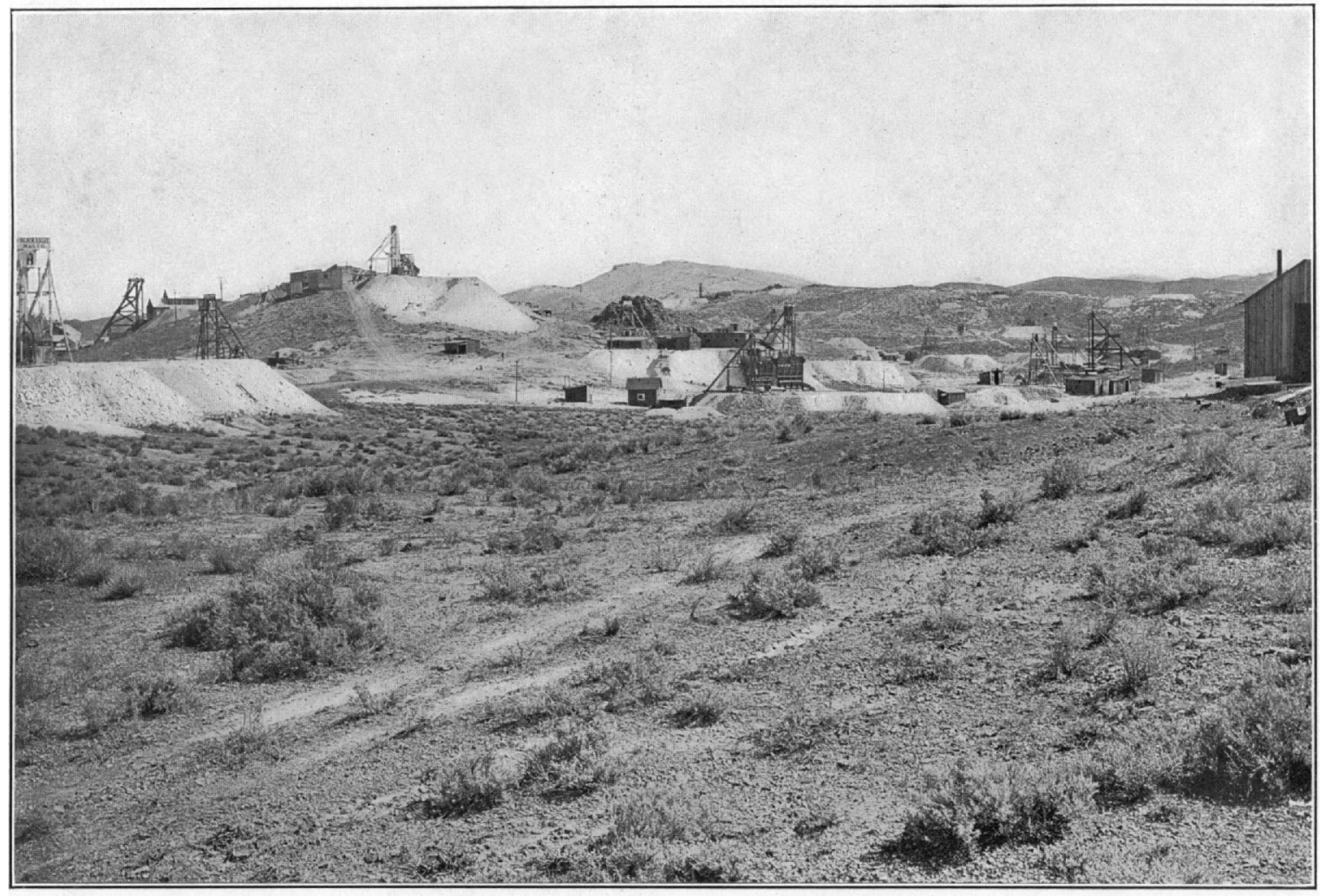

B. FLORENCE HILL; FROM THE SOUTH. 



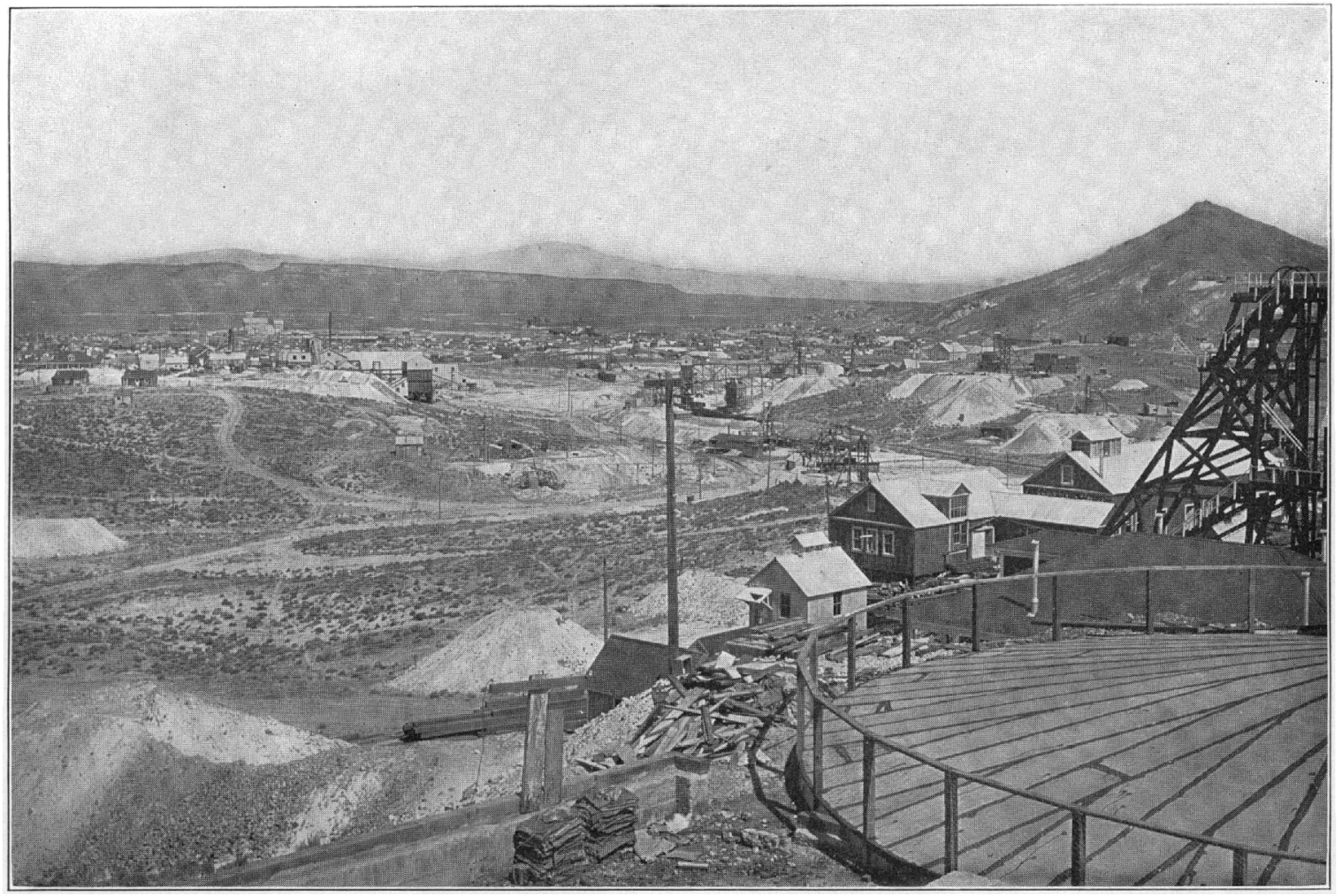

A.

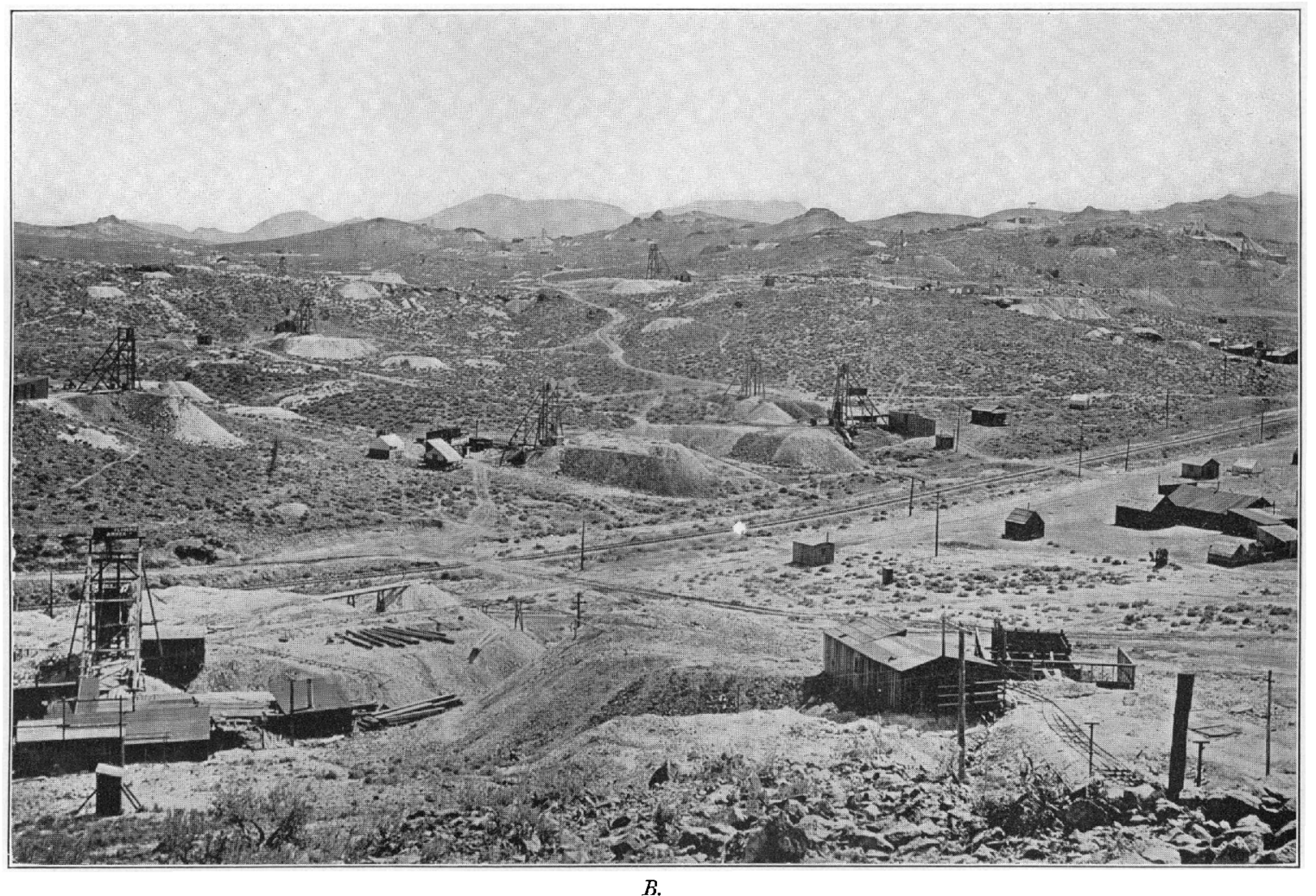

VIEWS FROM FLORENCE HILL.

$A$, Looking northwest; $B$, Looking east. 

which was hoisted rich ore from the Engineers' lease to a gross value of over $\$ 1,000,000$. To the right is the group of board buildings known as Milltown, and beyond the railroad is the ridge with typical ledge croppings which extends eastward beyond Preble Mountain. Nearly all the shafts visible on this ridge are prospects on the ground of the Atlanta Mining Company. Most of them are from 300 to 500 feet (91 to 152 meters) deep, with short exploratory levels. About a quarter of a mile ( 0.4 kilometer) beyond the shafts on the extreme right are the Gold Bar and Victor mines, about 300 feet (91 meters) deep, which thus far have been the most easterly productive mines of this belt. In the distance are the high dacitic hills, just outside of the mapped area and southeast of Tognoni Springs.

One who wishes further to overlook the district before examining the individual mines will do well to continue his walk northward and climb Columbia Mountain. Thence, looking southward, he may see Goldfield spread out, with the dark.edge of Malpais Mesa behind it,.and will see, a little east of the town, most of the mines visible from Florence Hill, with others which are concealed from that point by the hill southeast of the Mohawk mine. If the walk be extended northward along Morena Ridge, the Sandstorm and Kendall mines come into sight to the northwest (Pl. XIII, $A$ ), and to the east is an uninterrupted view (Pl. XIII, $B$ ) over lower country, underlain chiefly by Milltown andesite, to Black Butte and the town of Diamondfield. McMahon Ridge, seamed with trenches cut by prospectors, shows to the left of the town and butte.

The Sandstorm shaft is 400 feet (122 meters) deep, but all the ore from this and the Kendall mine, most of which has been shipped by lessees, has come from superficial workings. The deepest shaft in the Diamondfield group is the Daisy, 400 feet deep. The lateral work in this group is not extensive. In the mines near Goldfield, on the other hand, it was possible in 1908 to travel underground from the north corner of the Mohawk No. 2 claim by way of the Combination mine to the south end of the Florence claim, a distance of nearly 4,000 feet (1,219 meters), with the opportunity of making long detours in the mines passed through.

The following reference list, which is intended to summarize the principal shaft development in the district and to aid the reader as a key to Plate I and in looking up details regarding any particular shaft, aims to include, with a few exceptions, only those of 200 feet (61 meters) or more in depth. Even as regards these it is not complete, as there are many abandoned shafts in the district of which the depths, not ascertainable, may exceed 200 feet. There are also many prospect shafts of less than 200 feet in depth scattered over the district. Of these no account is taken. In general, the shafts listed are those whose positions are shown on Plate I. The depths and geologic information given were ascertained in July, 1908, although where later information has come to hand it has been used. The names listed are in most cases those by which the shafts are generally known rather than the official designations of the companies operating them. There is considerable confusion introduced into the naming of shafts through the practice by some lessee companies (for example, the Little Florence and Frances-Mohawk) of transferring their names from the original lease to other leases in different parts of the district. Some shafts also are known under more than one name, and changes in designation are not uncommon. The list illustrates well the remarkable energy that has been displayed in searching for the rich Goldfield ore bodies. These shafts alone, regardless of all drifting and crosscutting and of the numerous unlisted openings less than 200 feet (61 meters) deep, would, if put together, have a total length of over 80,000 feet (24.4 kilometers); they represent an expenditure of about $\$ 2,000,000$. 
Principal shafts in the Goldfield district. [A plus sign $(+)$ in the column of depths indinates that sinking was in progress when the figure was obtained or that there is reason to believe
that the shaft has since been deepened.]

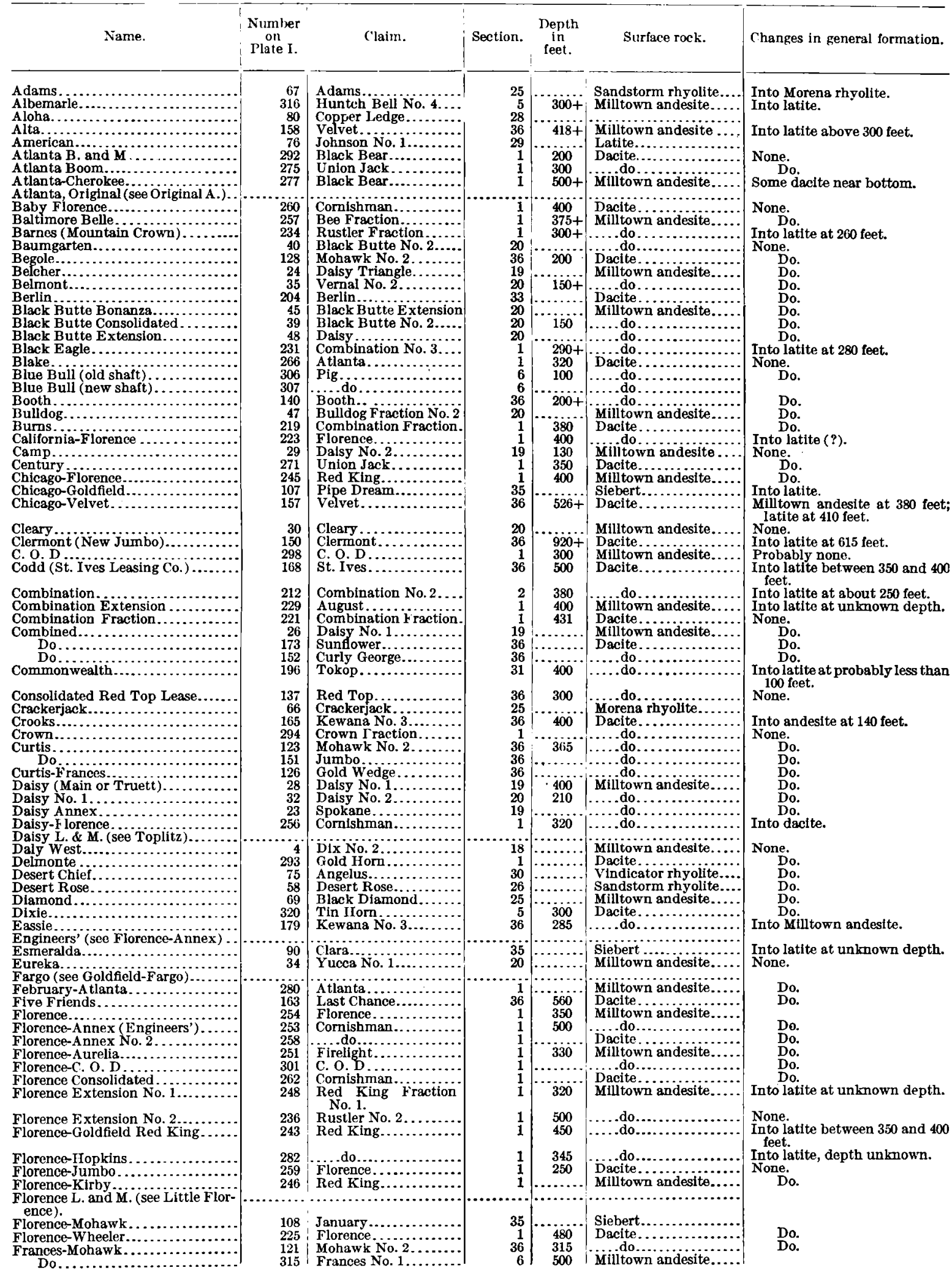




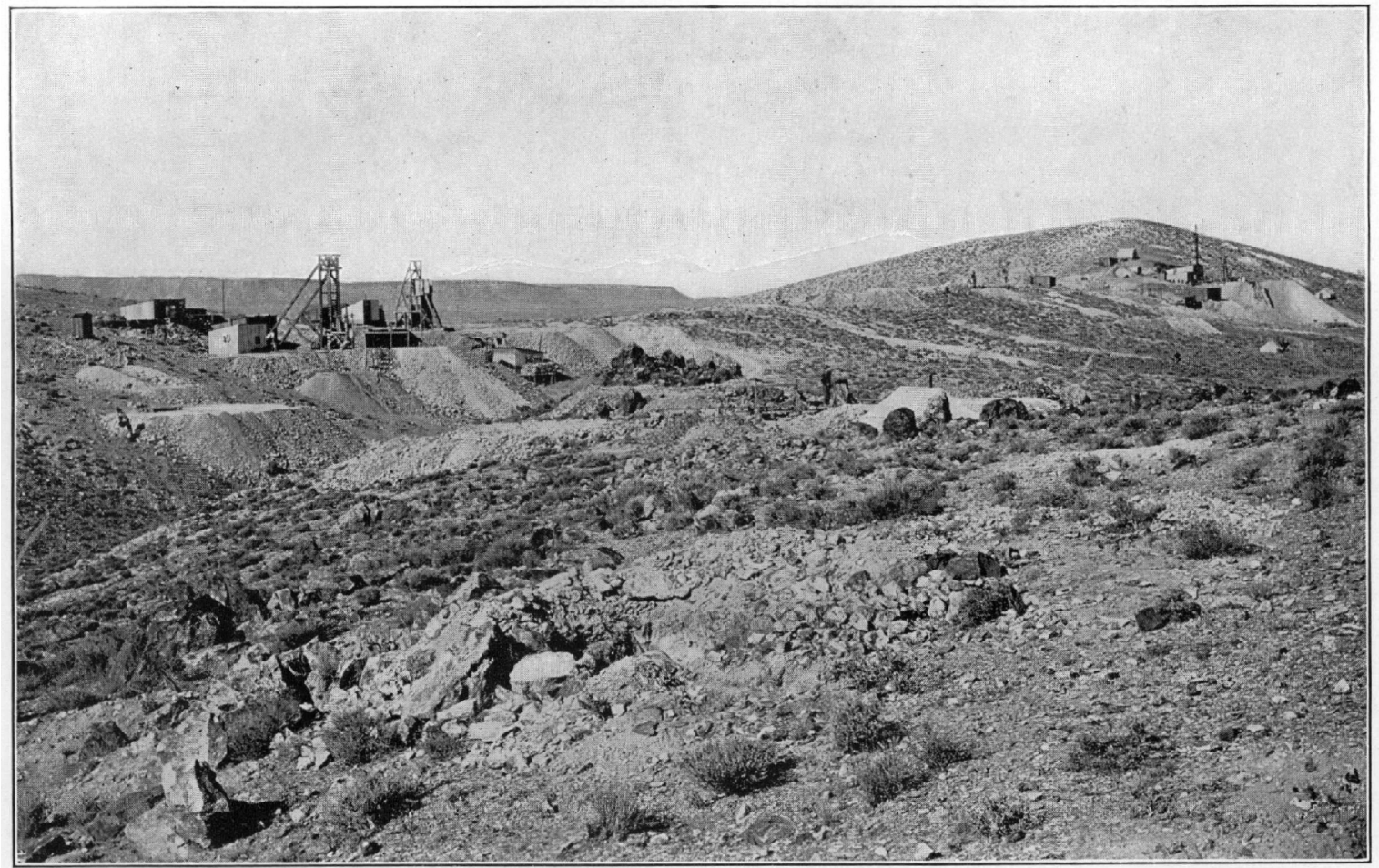

A. SANDSTORM AND KENDALL MINES.

From Morena Ridge, north of Columbia Mauntain.

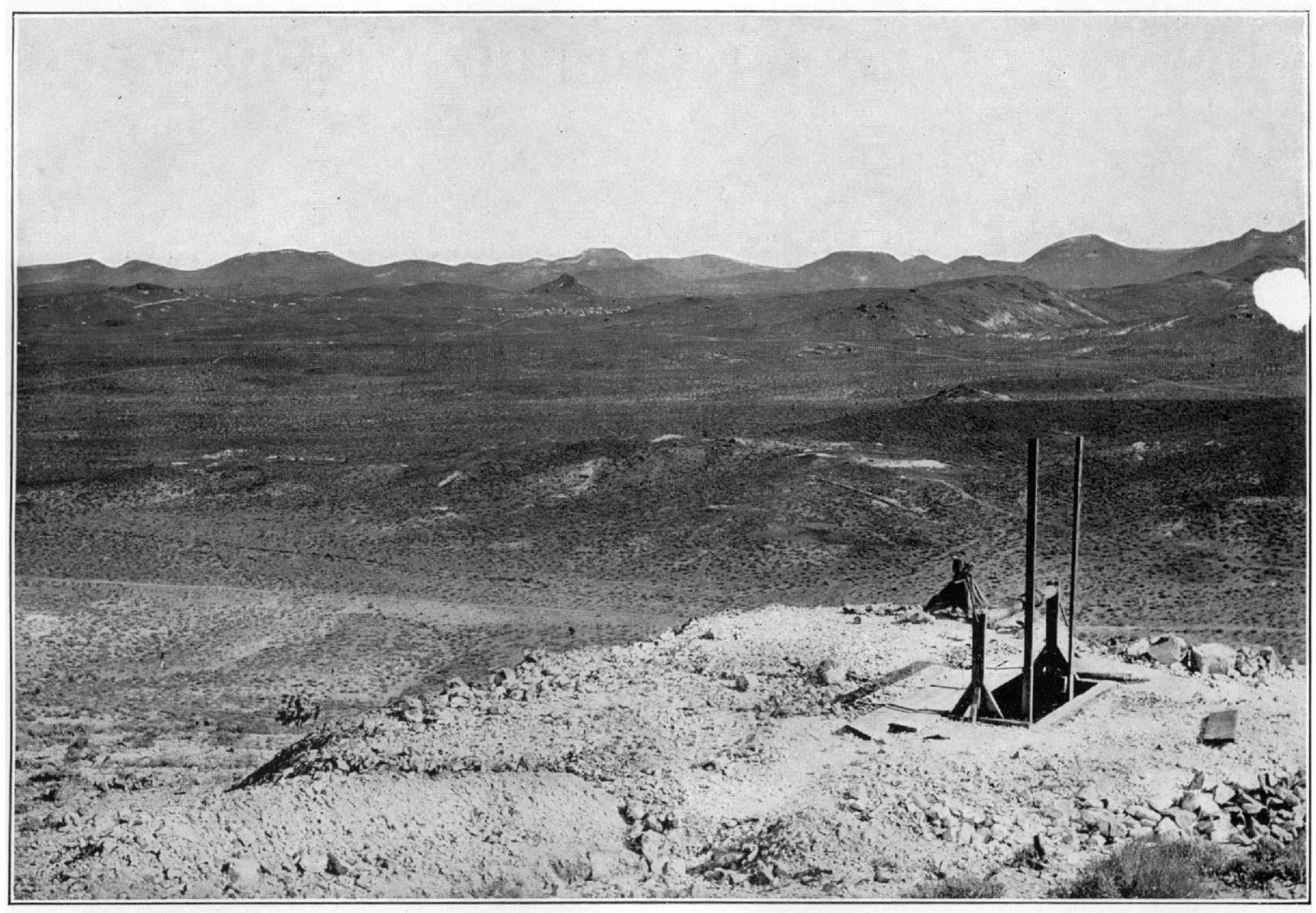

B. VIEW LOOKING EASTWARD FROM MORENA RIDGE TO DIAMONDFIELD AND BLACK BUTTE.

The principal mines near Diamondfield are on the ridge extending from Black Butte to the trenched summit of McMahon Ridge (on the Teft). 

DISTRIBUTION AND DEVELOPMENT OF MINES.

Principal shafts in the Goldfield district-Continued.

\begin{tabular}{|c|c|c|c|c|c|c|}
\hline Name. & $\begin{array}{c}\text { Number } \\
\text { on } \\
\text { Plate I. }\end{array}$ & Claim. & Section. & $\begin{array}{c}\text { Depth } \\
\text { in } \\
\text { feet. }\end{array}$ & Surface rock. & Changes in general formation. \\
\hline Frisco.. & 138 & Booth... & 36 & $150+$ & Dacite.. & $\begin{array}{l}\text { Into Kendall tuff or latite at } 130 \\
\text { feet. }\end{array}$ \\
\hline Fuller ..... & 268 & Jumbo..... . & 1 & 200 & .....do.......... & None. \\
\hline $\begin{array}{l}\text { Garrison } \\
\text { General Washingt }\end{array}$ & $\begin{array}{r}291 \\
68\end{array}$ & $\begin{array}{l}\text { Black Bear......... } \\
\text { Gen. Washington No.2 }\end{array}$ & $\begin{array}{r}1 \\
25\end{array}$ & $300+$ & 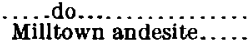 & $\begin{array}{l}\text { Into andesite below } 250 \text { feet. } \\
\text { None. }\end{array}$ \\
\hline Gibraltar......... & 228 & Combination No. $3 . .$. & 1 & $350+$ & .... do............... & Into latite at 340 feet. \\
\hline Gold Bar........ & $\begin{array}{l}300 \\
304\end{array}$ & Gold Bar......... & 1 & 300 & ..... do..... & Into latite, depth uncertain. \\
\hline Gold Bar M. and & $\begin{array}{l}304 \\
299\end{array}$ & $\begin{array}{l}\text { Morning Fr. } \\
\text { Gold Bar... }\end{array}$ & 1 & $475+$ & .....do... & $\begin{array}{l}\text { At dacte contact. } \\
\text { None. }\end{array}$ \\
\hline Goldbug........ & 2 & Goldbug... & 13 & & ...do. & Do. \\
\hline Gold Coin.. & 33 & Gold coin. & 20 & 150 & .....do.. & Do. \\
\hline $\begin{array}{l}\text { Do........ } \\
\text { Gold Crown. }\end{array}$ & $\begin{array}{r}218 \\
93\end{array}$ & (.....do...... & $\begin{array}{r}2 \\
35\end{array}$ & 420 & Z...do.............. & Do. \\
\hline Golden Daisy... & 22 & Daisy No. & 19 & & Mill town andesite. & $\begin{array}{l}\text { Do. } \\
\text { Do. }\end{array}$ \\
\hline $\begin{array}{l}\text { Goldfield-Bullion } \\
\text { Goldfield-Colum }\end{array}$ & 202 & Big byke. & 33 & 500 & Dacite ........... & Into latite at unknown depth. \\
\hline Goldfield-Colum & & & & & Latite............ & $\begin{array}{l}\text { Close to contact with Kendall } \\
\text { tuff. }\end{array}$ \\
\hline $\begin{array}{l}\text { Goldfield-Domini } \\
\text { Goldfield-F argo... }\end{array}$ & 296 & $\begin{array}{l}\text { Watson. } \\
\text { C. O.D. }\end{array}$ & $\begin{array}{r}23 \\
1\end{array}$ & 415 & Milltown andesite. & None. \\
\hline Goldfield-Federai & $\begin{array}{r}290 \\
79\end{array}$ & Mountain $\mathrm{F}$ & 28 & & ....do. do... & Do. \\
\hline Goldfield Merger & 305 & Moonshine. & 1 & 600 & Dacite... & Into latite at 312 feet. \\
\hline $\begin{array}{l}\text { Goldfield } \vec{M} \text {. O Ore } \\
\text { Goldfield-Red Hills }\end{array}$ & $\begin{array}{l}288 \\
249\end{array}$ & $\begin{array}{l}\text { Wonder.... } \\
\text { September. }\end{array}$ & $\begin{array}{l}1 \\
1\end{array}$ & $\begin{array}{l}350 \\
300\end{array}$ & $\begin{array}{l}\text { Milltown andesite...... } \\
\ldots \ldots \text { do................. }\end{array}$ & $\begin{array}{l}\text { None. } \\
\text { Latite at } 260 \text { feet. }\end{array}$ \\
\hline Goldfield-Red Ki & 232 & Combination & 1 & & 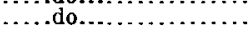 & Lalle al zou leet. \\
\hline Goldfield-Tomboy & 65 & Big Lize.... & 25 & & Sandstorm rhyolite. & None. \\
\hline Goldfields-Chedd & 252 & Emma Fraction & 1 & $\cdots \cdot \cdot$ & Milltown andesite.. & Do. \\
\hline $\begin{array}{l}\text { Gold Flat........ } \\
\text { Gold Horn (see I }\end{array}$ & 78 & Gold Flat....... & 29 & ...... & ....do.................. & \\
\hline Gold Mou & 287 & Golconda... & 1 & & Milltown andesite.. & None. \\
\hline Gold So & 198 & Johnson No. & 32 & 213 & Sandstorm rhyolit & Into Kendall tuff. \\
\hline Gold St & 289 & Gold Star Frac & 1 & & Milltown andesite.. & None. \\
\hline Goo & 193 & Silver Tip... & 31 & $\ldots . .$. & Dacite... & \\
\hline $\begin{array}{l}\text { Gordon a } \\
\text { Gotwald }\end{array}$ & 41 & Holiday Fracti & 20 & & Milltown andesite.. & Do. \\
\hline Gotwaldt. & 226 & Combination $\mathrm{N}$ & 1 & $300+$ & ....do............. & Into dacite at 80 feet. Into \\
\hline $\begin{array}{l}\text { Graham ........... } \\
\text { Grandma...... }\end{array}$ & $\begin{array}{r}31 \\
180\end{array}$ & $\begin{array}{l}\text { Daisy No. } 2 . \\
\text { Grandma... }\end{array}$ & $\begin{array}{l}20 \\
36\end{array}$ & 100 & Davite.. & $\begin{array}{l}\text { None. } \\
\text { Into Milltown andesite }\end{array}$ \\
\hline Great Bend (old & 16 & Great Bend No. 2. & 19 & 300 & Milltown andesite & $\begin{array}{l}\text { slight depth. } \\
\text { None }\end{array}$ \\
\hline Great & 15 & .....do............ & 19 & & .....do............... & None. \\
\hline Great Bend AI & 10 & Red Butte & 19 & & .....do... & Do. \\
\hline Great Bend Diad & 17 & Great Bend No. 1 & 19 & 400 & .....do.. & Do. \\
\hline Great Bend Extension. & 19 & Palace ......... & 19 & ……. & Ædo ............. & Do. \\
\hline $\begin{array}{l}\text { Greater Nevada. } \\
\text { Hall-Florence }\end{array}$ & $\begin{array}{r}72 \\
242\end{array}$ & Hesperian... . & $\begin{array}{r}30 \\
1\end{array}$ & 300 & Vindicator rhyolite. & Do. \\
\hline $\begin{array}{l}\text { Hall-Florence.... } \\
\text { Hat............. }\end{array}$ & $\begin{array}{l}242 \\
308\end{array}$ & $\begin{array}{l}\text { Red King... } \\
\text { Hat........ }\end{array}$ & $\begin{array}{l}1 \\
6\end{array}$ & $\begin{array}{l}300 \\
400\end{array}$ & Milltown andesite.. & Do. \\
\hline Hat............. & $\begin{array}{l}308 \\
116\end{array}$ & Mohawk No. 2 & 30 & $\begin{array}{l}400 \\
250\end{array}$ & Dacite $\ldots \ldots \ldots \ldots \ldots$ & \\
\hline Monnet & 119 & ...do........ & 30 & $\begin{array}{l}250 \\
270\end{array}$ & Dacite............. & Do. \\
\hline $\begin{array}{l}\text { Hayes-Monnet } \\
\text { Hazel-Goldfiel }\end{array}$ & 161 & Last Chance & & & ......do.......... & Do. \\
\hline $\begin{array}{l}\text { Hazel-Goldfie } \\
\text { Higginson.... }\end{array}$ & 131 & Gold Wed re & 30 & 740 & ..... .do. . & Into latite at 685 feet. \\
\hline $\begin{array}{l}\text { Higginson ..... } \\
\text { Do....... }\end{array}$ & $\begin{array}{r}131 \\
74\end{array}$ & Huby Silver. & $\begin{array}{l}36 \\
30\end{array}$ & & . do .............. & None. \\
\hline $\begin{array}{l}\text { Do......... } \\
\text { Highland..... }\end{array}$ & $\begin{array}{l}74 \\
49\end{array}$ & $\begin{array}{l}\text { Ruoy siver. } \\
\text { Dewdrop.... }\end{array}$ & $\begin{array}{l}30 \\
20\end{array}$ & $\cdots$ & Vindicator rhyolite. & Into alaskite at slight depth. \\
\hline Hooper-Manning. . . . . . . & 281 & Black Bear. & $\begin{array}{r}20 \\
1\end{array}$ & $\cdots \ldots$ & Dacite................ & - \\
\hline Imperial. $\ldots, \ldots, \ldots, \ldots, \ldots, \ldots$, & 273 & Union Jaek: & 1 & $\begin{array}{l}320+ \\
375\end{array}$ & & None. \\
\hline Do....... & 312 & Mary ...... & 6 & & 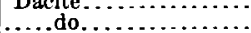 & Do. \\
\hline Iowa..... & 1 & & 15 & & Sicbert. & \\
\hline January ............. & 210 & January.. & 2 & 280 & Dacite..... & Into latite at 280 feet. \\
\hline $\begin{array}{l}\text { January-White Rock (see White } \\
\text { Rock No. 5). }\end{array}$ & & & & & & \\
\hline Jinks............. & 195 & Lone Star.. & 31 & & Dacite. & None. \\
\hline Anney & 269 & & 1 & 500 & .....do.. & Do. \\
\hline bo-Annex.......... & 133 & Wedge & 36 & & .....do.. & Do. \\
\hline Jumbo Extension L. \& & 149 & rde... & 36 & & .....do. & Do. \\
\hline Jumbo Ledge & 265 & Atl: & 1 & 350 & C......do. & Do. \\
\hline Jumbo Ledge Lease. . . & 270 & y Bear & 1 & 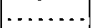 & …...do. & Do. \\
\hline Jumbo Wonder..... & 154 & Polverde... & 36 & & & Do. \\
\hline iter............ & & Red Light.... & 23 & & andesite. . & \\
\hline Kalfus......... & 127 & Mohawk No. 2 . & 36 & 270 & Dacite................ & Do. \\
\hline $\begin{array}{l}\text { Kansas City ....... } \\
\text { Keane.......... }\end{array}$ & $\begin{array}{r}297 \\
12\end{array}$ & $\begin{array}{l}\text { C. O. D.......... } \\
\text { Great Bend... }\end{array}$ & 19 & 300 & Milltown andesite... & Probably reaches latite. \\
\hline Keelyn $\mathrm{G} . \& \mathrm{G} . . .$. & 283 & Zoe......... & 1 & 300 & 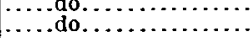 & $\begin{array}{l}\text { None. } \\
\text { Into latite between } 300 \text { and } 400\end{array}$ \\
\hline Keelyn No. 6. & $15 \overline{5}$ & Polverde. & 30 & & Dacite & None. \\
\hline Keelyn No. 22. & & & 1 & 408 & Milltown andesite. & Into latite between 300 and 400 \\
\hline Kendall... & 59 & Kendall.... & 26 & 368 & Sandstorm rhyolite.... & Into Morena rhyolite at about \\
\hline Kett ...... & 279 & Red King. & 1 & & Milltown andesite.. & $\begin{array}{l}150 \text { feet. } \\
\text { None. }\end{array}$ \\
\hline nas.......... & 162 & Kewana No. $2 .$. & 36 & 500 & Dacite..... & Into latite; depth uncertain. \\
\hline (old)... & 144 & Miss & 36 & & & None. \\
\hline (new)... & 146 & & 36 & 400 & .....do... & Do. \\
\hline nce....... & 272 & Atlanta. & 1 & & .....do... & Do. \\
\hline & 274 & Moc & 1 & & $\ldots$ do $\ldots \ldots \ldots$. & Do. \\
\hline Little Florence (Florenc & 241 & Red King. .............. & 1 & 500 & Milltown andesite. & Do. \\
\hline Little Florence (on Com & 222 & Combination Fraction & 1 & 600 & Dacite............. & None to 450 feet; record below \\
\hline Liverpool. & & Golconda. & 1 & $420+$ & Milltown andesite. & $\begin{array}{l}\text { Lnal anknown. } \\
\text { None. }\end{array}$ \\
\hline Loftu & 122 & nation Fraction & 30 & 531 & Dacite............ & Do. \\
\hline & 61 & Sands & 26 & 250 & Sandstorm rhyolite.. & \\
\hline Lone Star. ..... & 189 & Patrick.... & 31 & 100 & Dacite......... & Into latite near bottom. \\
\hline Boys.. & 182 & Lucky Boy. & 36 & 360 & Cambrian shale.. & Into alaskite. \\
\hline geles............ & 111 & Deserted..... & 35 & 300 & Dacite. . . . . . . . . . . & Into latite at unknown depth. \\
\hline $\begin{array}{l}\text { M. and H... } \\
\text { Mackenzie.. }\end{array}$ & $\begin{array}{r}92 \\
117\end{array}$ & $\begin{array}{l}\text { Silver Pick... } \\
\text { Mohawk No. }\end{array}$ & $\begin{array}{l}35 \\
36\end{array}$ & 300 & $\begin{array}{l}\text { Latite. } \\
\text { Dacite. }\end{array}$ & None. \\
\hline паскешіе.. & 111 & Mont & 30 & 300 & & \\
\hline
\end{tabular}


Principal shafts in the Goldfield district-('ontinued.

\begin{tabular}{|c|c|c|c|c|c|c|}
\hline Name. & $\begin{array}{c}\text { Number } \\
\text { on } \\
\text { Plate I. }\end{array}$ & Claim. & Section. & $\begin{array}{l}\text { Depth } \\
\text { in } \\
\text { feet. }\end{array}$ & Surface rock. & Changes in general formation. \\
\hline Madonna. & 319 & Bonanza. . & 5 & & Milltown andesite. & None. \\
\hline Magnet... & 200 & Gold King. & 32 & & Latite........... & \\
\hline Majestic........ & 203 & Ilobo............ & 33 & & Milltown a & \\
\hline Maloney......... & 164 & Kewana Fraction. & 36 & 195 & Dacite... & Do. \\
\hline Do............... & 267 & Atlanta.......... & 1 & 300 & Milltown and & \\
\hline $\begin{array}{l}\text { Mammoth......... } \\
\text { Mayne........ }\end{array}$ & 50 & $\begin{array}{l}\text { Amazon.......... } \\
\text { Gem }\end{array}$ & $\begin{array}{l}21 \\
26\end{array}$ & ...... & Alaskite. & Do. \\
\hline Do............. & 56 & Denver...... & 26 & & Sandstorm rhyolite.... & $\begin{array}{l}\text { Do. } \\
\text { Into alaskite at } 100 \text { feet. }\end{array}$ \\
\hline McNaughton..... & 132 & Mohawk No. 2. & 36 & 283 & Dacite................ & \\
\hline Midnight-Pawnee & 46 & Midnight Fractio & 20 & & ...do... & None. \\
\hline Milltown Fraction ... & 322 & Milltown Fraction. & 7 & & Milltown a & Do. \\
\hline Mitchell-Fairfield (Stoneham & 230 & Combination $\wedge \mathrm{o} .3$. & 1 & $220+$ & ....do... & Do. \\
\hline 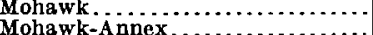 & $\begin{array}{r}124 \\
89\end{array}$ & $\begin{array}{l}\text { Mohawk No. } 2 . \\
\text { Dewdrop }\end{array}$ & $\begin{array}{l}36 \\
35\end{array}$ & 600 & Dacite. . & Into latite at 450 foet. \\
\hline Mohawk Consolidat & 109 & Mohawk No.1 & 35 & & Dacite. - & None. \\
\hline Mohawk Consolidat & 110 & $\ldots$ do......... & 35 & 200 & ....do... & Do. \\
\hline Mohawk-Florence. & 240 & Red King..... & 1 & 300 & Milltown andesite. & Do. \\
\hline $\begin{array}{l}\text { Mohawk-Jumbo ... } \\
\text { Mohawk Leasing C }\end{array}$ & $\begin{array}{l}125 \\
113\end{array}$ & Gold Wedge...... & 30 & 500 & Dacite.... & Do. \\
\hline Mohawk Leasing Co & $\begin{array}{l}113 \\
112\end{array}$ & $\begin{array}{l}\text { Monawk No. } 1 \ldots \\
\ldots \ldots \text { do. . . . . . . }\end{array}$ & $\begin{array}{l}35 \\
35\end{array}$ & & ....do. do. & Do. \\
\hline Mohawk Ledge... & 130 & Gold Wedge. & 36 & 700 & .do. & Into latite near 470 feet. \\
\hline [ohawk-Red Top & 147 & Miss Jessie... & 36 & 420 & ....do... & Into latite at $365 \pm$ feet. \\
\hline Mohawk Syndicate & 102 & Mohawk No. 1 & 35 & 300 & Kendall tuff.. & Into Cambrian shale at 280 feet. \\
\hline $\begin{array}{l}\text { Montezuma Lou Dil } \\
\text { Moore }\end{array}$ & 77 & Lou Dillon..... & 29 & & Milltown andesite..... & None. \\
\hline Moore . . . . . . . . . . & 227 & Combination No. $2 \ldots$ & 1 & & ... do $\ldots$. . . . & Into latite. \\
\hline Morrison ........ & 27 & Daisy No. 1.... & $1 \hat{9}$ & 370 & .....do... & None. \\
\hline Mushett.......... & 145 & Miss Jessie ..... & 36 & 480 & Dacite. . & Into latite near 480 feet. \\
\hline Nevada Amalgam & 101 & Mohawk No. 1 & 35 & & Kendail tu & Into alaskite. \\
\hline Nevada Exploratio & 290 & Golden Eagle. & 1 & 300 & Milltown and & None. \\
\hline Nevada King. ... & 201 & North Star.... & 32 & & Latite........ & \\
\hline Nighthawk... & 142 & East Side... & 36 & & Dacite.. & Do. \\
\hline Norcross... & 166 & Black Rock. & 36 & & .....do.. & \\
\hline Oakes. . & 8 & Oakes........... & 24 & & Milltown & Do. \\
\hline Oddie.......... & 220 & Combination $\mathrm{Fr}$ & 1 & 612 & Dacite... & Do. \\
\hline Do $\ldots . . .$. & 118 & Mohawk No. 2. & 36 & 300 & .....do... & Do. \\
\hline Oddie-Rose....... & 129 & Ko........... & 36 & 230 & .....do.... & Do. \\
\hline Old Kentuck.... & $\begin{array}{l}159 \\
190\end{array}$ & $\begin{array}{l}\text { Kewana No. } 2 . \\
\text { Economist.... }\end{array}$ & 31 & 300 & Milltown andesite. & Into Sandstorm rhyolite at 50 \\
\hline Original Atlanta. & 276 & Union Jack. & 1 & 275 & Dacite. & None. \\
\hline Eelvet.. & 156 & Velvet....... & 36 & $300 \pm$ & ...do.. & \\
\hline Oro.... & 143 & Midnight Fract & 36 & ....... & $\ldots$...do... & Do. \\
\hline Palace. & 11 & Rabbit's Foot.. & 19 & & Milltown andesite. & Do. \\
\hline & 309 & Neglected...... & 6 & & ....do... & Do. \\
\hline Parkinson........ & 235 & Rustler Fractio & 1 & & ....do. & \\
\hline Penn (Winston) & 264 & Cornishman.......... & 1 & 500 & Dacite... & Do. \\
\hline Peterson's Silver Pi & 104 & Deserted............. & 35 & & ......do... & Latite somewhere below 60 \\
\hline Pierre and Pugh.. & 21 & Thanksgiving Gift. & 19 & 100 & Mllltown andesite. & None. \\
\hline Pittsburg-Nevada. & 323 & Mayflower.... & 8 & 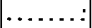 & ....do....... & Do. \\
\hline Pocahontas........ & 85 & Valley View. & 35 & $\cdots$ & Alluvium. . & Into Siebert. \\
\hline Pollard-Florence... & 247 & Red King...... & 1 & 500 & Milltown and & None. \\
\hline Portland ............... & 233 & Bull Con....... & 1 & 440 & Siebert...... & $\begin{array}{l}\text { Into Milltown andesite within } \\
\text { a few feet of surface. Into }\end{array}$ \\
\hline Portland-Florence & 277 & Emma Fraction & 1 & 250 & Milltown andesite. & None. \\
\hline Quartzite. & 43 & Quartzite No. 1 & 20 & 200 & .....do do.......... & Do. \\
\hline $\begin{array}{l}\text { Red Hill.. } \\
\text { Red King }\end{array}$ & 250 & September . . . & 1 & & .....do... & Par 20 \\
\hline Red Top........... & $\begin{array}{l}244 \\
135\end{array}$ & $\begin{array}{l}\text { Red King.... } \\
\text { Red Top..... }\end{array}$ & 30 & 350 & Dacite.. & Into latite between 2130 and 350 \\
\hline Red Top Fraction & 100 & Red Top Fracti & 3.5 & & Alaskite.... & $\begin{array}{l}\text { feet. } \\
\text { None. }\end{array}$ \\
\hline & 148 & & 30 & 360 & Dacite...... & \\
\hline Reilly........ & 224 & Florence......... & 1 & 210 & .....do... & Do. \\
\hline Rickard No. 1. & 134 & Mohawk No. 2 . & 36 & 200 & .....do... & Do. \\
\hline Rickard No. 2 . & 114 & ....do......... & 36 & 200 & ......do... & Do. \\
\hline Rochester..... & 205 & Lone Star... & 33 & & do $\ldots \ldots \ldots \ldots$ & Do. \\
\hline Rogers........ & 239 & Red King....... & 1 & 500 & Mill town andesite. & Do. \\
\hline Rosebud (O.K.). & 238 & Rustler Fraction & 1 & 500 & ....do............... & Do. \\
\hline Sandstorm (old) .......... & 62 & Sandstorm..... & $2 t$ & 400 & Sandstorm rhyolite.. & Into Kendall tuff at 200 feet. \\
\hline Sandstorm (new or Kruge & 63 & Kruger........ & 26 & 150 & ... do do.......... & Into Kendall tuff at bottom. \\
\hline Sheetz-Ish............ & 115 & Combination No & 35 & 150 & Dacite. - & None. \\
\hline Pick............ & $\begin{array}{r}106 \\
88\end{array}$ & Deserted......... & 35 & 175 & ....do... & Do. \\
\hline Silver Pick Extension. & $\begin{array}{r}88 \\
187\end{array}$ & White Streak... & 35 & $\cdots \cdots$ & Latite... & Do. \\
\hline Simbull........ & 187 & Kee................ & 31 & 200 & Dacite... & Into latite between 75 and 200 \\
\hline Sirnmerone... & 188 & Simmerone..... & 31 & 250 & ....do... & Into latite at unknown depth. \\
\hline Skylark ............ & 20 & Christmas No. 3. & 19 & & Latite... & None. \\
\hline $\begin{array}{l}\text { Smith (see Frisco) } \\
\text { Sovereign (see Gold }\end{array}$ & & & & & & \\
\hline Spokane. . . . . . . & 14 & Spokane No. 2 & 19 & & Milltown andesite. & Do. \\
\hline e-Stein.. & 237 & Combination & & & ... do ............. & Do. \\
\hline st. Ives........ & 169 & St. Ives............ & 36 & 470 & Dacite....... & Do. \\
\hline St. Ives Leasing (see Codd). & & & & & & \\
\hline Stoneham (see Mitchell-F.). & & & & & & \\
\hline Sunnyside................ & 314 & Mollie No. 1.. & 6 & & Milltown andesite..... & Do. \\
\hline Tacoma...... & 3 & Tacoma........ & 13 & & .....do... & Do. \\
\hline Texas-Golconda. . & 286 & Golconda....... & 1 & 300 & .....do... & Into latite at 290 feet. \\
\hline Third Chance............... & 295 & Third Chance... & 1 & & .....do... & Dump shows dacite. \\
\hline Toplitz (Daisy L. \& M.).... & 18 & Daisy No. $1 \ldots$. & 19 & 250 & ... do... & None. \\
\hline Truett............... & 120 & Mohawk No. $2 \ldots$.... & 36 & 275 & Dacite....... & Do. \\
\hline United Mines................ & 192 & II ansbros. No. $2 . . . .$. . & 31 & & Latite........ & \\
\hline Velvet (Kansas City lease)... & 172 & Sunflower......... & 36 & & Dacite............ & \\
\hline Vencendor............. & 303 & Combination........... & 1 & 415 & Mill town andesite..... & Close to dacite contact. \\
\hline & 302 & Yictor................. & 1 & 300 & .... do. . & \\
\hline 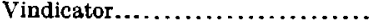 & 70 & Vindicator............. & 25 & & Sandstorm rhyolite... & \\
\hline
\end{tabular}


OPERATION OF MINES.

Principal shafts in the Goldfield district-Continued.

\begin{tabular}{|c|c|c|c|c|c|c|}
\hline Name. & $\begin{array}{l}\text { Number } \\
\text { on } \\
\text { Plate I. }\end{array}$ & Claim. & Section. & $\begin{array}{l}\text { Depth } \\
\text { in } \\
\text { feet. }\end{array}$ & Surface rock. & Changes in general formation. \\
\hline $\begin{array}{l}\text { White Rock No. } 2, \ldots \ldots \ldots \ldots \ldots \\
\text { White Rock No. } 3 \ldots \ldots \ldots \ldots \ldots\end{array}$ & $\begin{array}{l}209 \\
213\end{array}$ & $\begin{array}{l}\text { White Rock.... } \\
\text { White Horse... }\end{array}$ & $\begin{array}{l}\mathbf{2} \\
2\end{array}$ & 300 & $\begin{array}{l}\text { Siebert...... } \\
\ldots . . \text { do..... }\end{array}$ & $\begin{array}{l}\text { Into latite at } 100 \text { feet. } \\
\text { Into latite; depth not ascer- }\end{array}$ \\
\hline $\begin{array}{l}\text { White Rock No. } 4 \\
\text { White Rock No. } 5 \text { (January-W. } \\
\text { White Rock No. } 6 \text {. } \ldots \ldots \ldots \ldots \ldots \ldots \\
\text { White Rock No. } 7 \text {. } \\
\text { Wilbur }\end{array}$ & $\begin{array}{l}214 \\
215 \\
216 \\
207\end{array}$ & 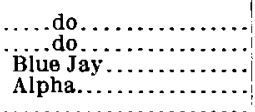 & $\begin{array}{l}2 \\
2 \\
2 \\
2\end{array}$ & $\begin{array}{c}400 \\
520+\end{array}$ & 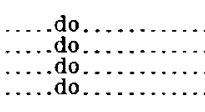 & $\begin{array}{l}\text { talned. } \\
\text { Do. } \\
\text { Do. } \\
\text { Do. } \\
\text { Into latite at } 280 \text { feet. }\end{array}$ \\
\hline 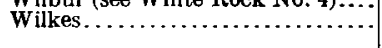 & 60 & Sandstorm.................. & 26 & & Mill town andesite & $\begin{array}{l}\text { Close to contact with Sand. } \\
\text { storm rhyolite. }\end{array}$ \\
\hline $\begin{array}{l}\text { Yellow Tiger } \ldots \ldots \ldots \ldots \ldots \ldots \ldots \ldots \\
\text { Zinn-Florence. } \ldots \ldots \ldots \ldots \ldots \ldots \ldots\end{array}$ & $\begin{array}{l}310 \\
263\end{array}$ & $\begin{array}{l}\text { Lindsay............... } \\
\text { Cornishman......... }\end{array}$ & $\begin{array}{l}6 \\
1\end{array}$ & $\begin{array}{r}600+ \\
\cdots \cdots\end{array}$ & $\begin{array}{l}\text { Milltown andesite } \\
\text { Dacite............ }\end{array}$ & $\begin{array}{l}\text { Into latite at } 510 \text { feet. } \\
\text { None. }\end{array}$ \\
\hline
\end{tabular}

The names of the following shafts were not ascertained:

\begin{tabular}{|c|c|c|c|c|c|}
\hline $\begin{array}{l}\text { No. on } \\
\text { Plate I. }\end{array}$ & Claim. & Section. & $\begin{array}{l}\text { No. on } \\
\text { Plate I. }\end{array}$ & Claim. & Section. \\
\hline 191 & Alhambra...... & 31 & 5 & Lucky Strike No. $3 . .$. & 16 \\
\hline 73 & Atlanta.............. & 30 & 321 & Nevada Eagle........ & 4 \\
\hline 36 & Black Butte Extension. & 20 & 9.5 & Piedmont Fraction. & 35 \\
\hline 38 & Black Butte No. $1 . . .$. & 20 & 98 & Plaza Fraction..... & 35 \\
\hline 217 & Butte. & 2 & 167 & Polverde........... & 36 \\
\hline 25 & Daisy Triangle? & 19 & $1 \overline{0} 3$ & .... do do.......... & 36 \\
\hline 324 & Davoren Boy...... & 8 & 9 & Red Butte No. 1... & 19 \\
\hline 105 & Deserted........ & 35 & 51 & Red Rock.......... & 21 \\
\hline 103 & $\ldots$. do.... & 35 & 57 & $\operatorname{Rex} \ldots \ldots \ldots \ldots$ & 26 \\
\hline 184 & Frisco & 36 & 185 & Rosebush.. & 36 \\
\hline 99 & Gold Banner. & 35 & 194 & Silver Tip........ & 31 \\
\hline 285 & Golconda........ & 1 & 44 & South Quartzite... & 20 \\
\hline 13 & Great Bend No. $2 \ldots$ & 19 & 170 & 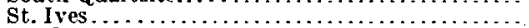 & 36 \\
\hline 311 & Hidden Treasure.............. & 6 & 171 & Sunflower.,., & 36 \\
\hline 199 & Johnson No. $2 \ldots .$. & 32 & 176 & & 36 \\
\hline 55 & Joshua.......... & 26 & 208 & Triangle.... & 2 \\
\hline 181 & Kewans No. 3 . & 36 & 175 & Velvet........... & 36 \\
\hline 183 & Lazy George....... & 36 & 97 & 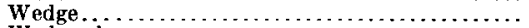 & 35 \\
\hline 197 & Little Brownle.... & 32 & & 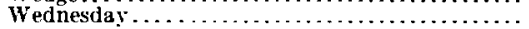 & 2 \\
\hline 91 & Lou Dillon............ & 35 & 174 & 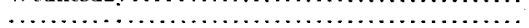 & 36 \\
\hline
\end{tabular}

\section{MINING COSTS.}

The only mine that has recently afforded full and significant data on mining costs is the Combination. According to the report of the Goldfield Consolidated Mines Company for the year ending October 31, 1907, the normal average costs from June to October of that year, a not very favorable period, were as follows:

Costs per ton at Combination mine.

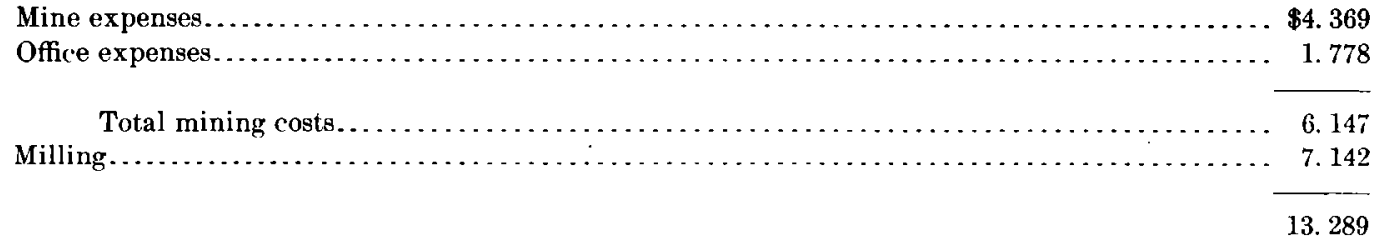

For September, 1908, the mining costs were brought down to $\$ 3.15$ and the milling costs to $\$ 6.13$, a total of $\$ 9.28$.

The company expects in the near future, when the new mill is in operation, to reduce the total mining and milling cost to about $\$ 5$ a ton and to be able to handle $\$ 8$ ore at a profit. This is probably a somewhat optimistic estimatc, although in July, 1908, ore was being broken in some of the Combination stopes at a cost of only 33 cents a ton.

In the year ending November 1, 1907, the average cost of all development in the Red Top mine was $\$ 9.02$, and in the Mohawk mine $\$ 11.42$, a linear foot.

Shaft sinking as a rule is rapid at Goldfield and costs from $\$ 20$ to $\$ 30$ a foot. At the end of 1905 the deepest shaft in the district was the old Jumbo, 450 feet deep, and the deepest 
level then being worked was the 280 -foot level of the January mine. In July, 1908, there were at least 4 shafts 600 feet or more in depth, 18 shafts from 500 to 600 feet in depth, 22 shafts from 400 to 500 feet in depth, 39 shafts from 300 to 400 feet in depth, and probably at least 50 shafts from 200 to 300 feet in depth. As shown by the preceding table, much work has been done since that time. The Little Florence shaft, containing two hoisting compartments, with separate manway and fully timbered, was completed in thirty-nine and one-half days. In this case it was possible to work both by sinking and raising. The main Combination shaft, 380 feet deep, is said to have cost $\$ 22$ a foot for the original two compartments. (The shaft has since been enlarged.) Recently the Gold Bar Fraction Mining Company contracted for 250 feet of shaft sinking at $\$ 26.50$ per foot, the contractor to furnish all materials, tools, and labor. Tunneling or crosscutting usually costs from $\$ 4$ to $\$ 5$ a linear foot.

\section{POWER.}

Horse whims were used on some of the early leases in Goldfield, but were soon supplanted by the more economical and much more efficient gasoline hoists. In 1905 these hoists, ranging from 12 to 30 horsepower, were in almost universal use. The Combination and January mines at this time were hoisting with steam, the former using wood at $\$ 11$ a cord for fuel, and a few mines had begun to use electric power generated at Bishop, Cal. At present this is the most generally used power in the district, and will run the new mill of the Goldfield Consolidated Jines Company. Hoisting at the main Mohawk shaft is at present done by air compressed by electric power. The air on its way to the hoist passes through the boilers, which are partly filled with water warmed by a low fire. It is the intention, however, when active work is resumed and more air is needed underground, to hoist with steam, using oil as fuel.

Electricity is supplied to the Goldfield district by the Nevada-California Power Company, which has displayed much enterprise in utilizing the water power at Bishop, Inyo County, Cal., and in carrying transmission lines across wide stretches of desert. At Bishop Creek, 98 miles (158 kilometers) from Goldfield and 104 miles (167 kilometers) from Tonopah, the company has built large reservoirs and has installed dynamos capable of generating 16,000 horsepower. There are two separate transmission lines to Goldfield and Tonopah, each capable of carrying the full load, and thus providing against any long interruption of the current. The electricity is sent over these lines at 50,000 volts, is distributed to the mines at 6,600 volts, and is used for motor driving at the standard voltage of 440. In July, 1908, the power consumption in the Goldfield district was 3,500 horsepower. The power company estimated that 2,500 additional horsepower would be utilized at the beginning of 1909 , when presumably the Goldfield Consolidated mines and mill, the Florence mine and mill, and the Goldfield $\mathrm{Cl}$ mill will all be in operation. The rates for continuous service, based on peak loads measured on the motor side of transformers, are as follows:

Vet rates for electric power per horsepouer per month.

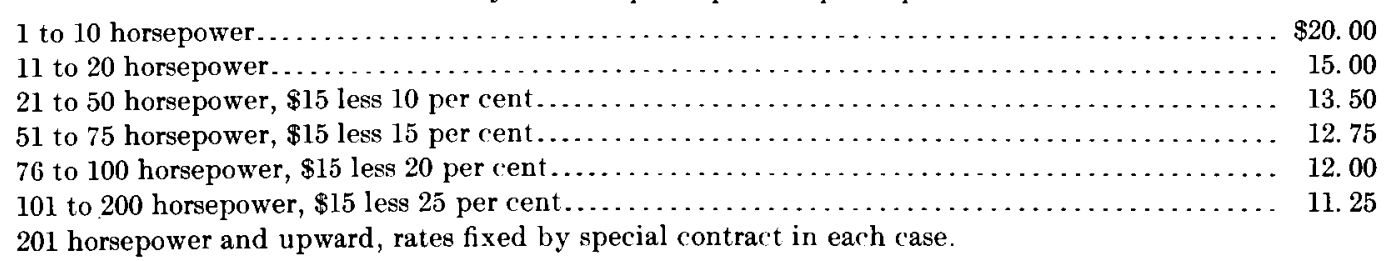

Users of the power are required to furnish transformers and other connecting apparatus.

\section{WATER SUPPLY.}

The water supply of Goldfield was originally obtained from a well 90 feet (27 meters) deep, with lateral drifts, situated near the mouth of Pozo Canyon. This was yielding about 15,000 gallons (56,250 liters) a day in 1905 , but experience with shallower wells in this vicinity had shown that the available water at any given depth was exhaustible. The present supply, furnished by the Goldfield Consolidated Water Company, comes from springs near Lida, which the company estimates can be made to yield from 500,000 to $1,000,000$ gallons $(1,875,000$ to 
$3,750,000$ liters) in twenty-four hours. The 7 -inch riveted steel pipe line is about 30 miles (48 kilometers) in length and has a capacity of 450,000 gallons (1,687,500 liters) in twentyfour hours. This line was completed in October, 1907, and is at present (November, 1908) delivering 250,000 gallons $(937,500$ liters $)$ per diem. The water flows to a point about 3 miles (5 kilometers) from Goldfield and is thence pumped over Malpais Mesa.

The water supply of Columbia, which is of good quality, comes from Rabbit Spring and from a well 180 feet (55 meters) deep, just south of the old Goldfield Reduction Company's (Gardiner) mill. This well was yielding about 10,000 gallons (37,500 liters) per diem in 1908 . The greater part of the water comes in from the sides above 100 feet (30 meters) in depth and at the time of visit stood within 2 feet ( 0.6 meter) of the surface.

Since 1905 the Combination mine has had an independent water supply derived from Alkali Springs, situated 10 or 11 miles (16 to 18 kilometers) northwest. The springs are warm (about $60^{\circ} \mathrm{C}$.) and the water collected by tunnels is discharged into a concrete tank of 200,000 gallons (750,000 liters) capacity, whence it is pumped to the mine. The flow from the springs is 67,500 gallons $(253,125$ liters) in twenty-four hours. A partial analysis of this water by A. A. Hanks shows the following constituents:

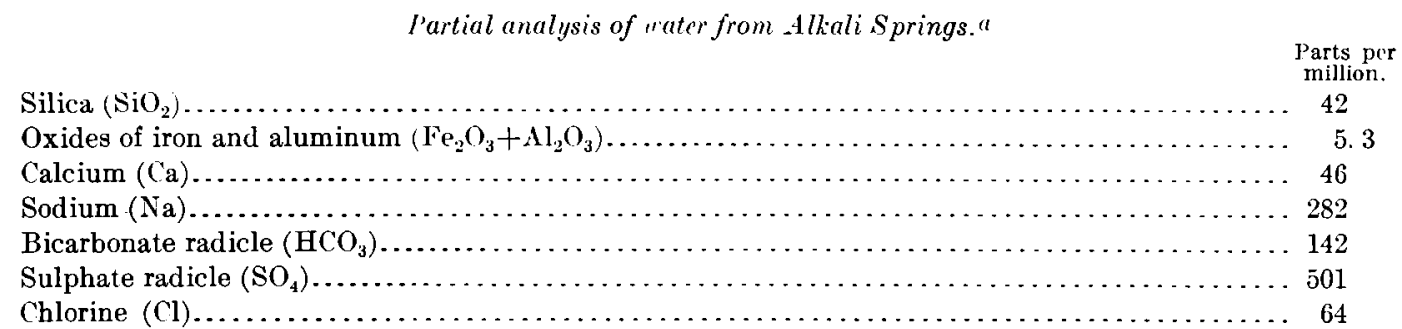

The Florence-Goldfield Mining Company has recently constructed a pipe line from Indian Springs, about $5 \frac{1}{2}$ miles (9 kilometers) west of Goldfield. This line, which is partly of wood and partly of steel, is expected to supply about 100,000 gallons (375,000 liters) per twentyfour hours. No pumping is necessary.

\section{TREATMENT OF THE ORES.}

The first important production from the district came from the Combination mine, and from December, 1903, to May, 1905, the ore was shipped to the smelters, being hauled by wagons first to Candelaria, 65 miles (104 kilometers) away, and later to Tonopah, 30 miles (48 kilometers) distant. The total shipping and treatment charges on Combination ore in 1904 averaged $\$ 57.24$ a ton on ore of an average value of $\$ 419.24$ a ton. During this year careful tests were made by F. L. Bosqui, ${ }^{b}$ following which in 10 -stamp mill was built. This was designed originally for oxidized ore only, and was built in two symmetrical parts, the intention being to use one-half for custom work. The scheme of treatment is shown in figure 10, compiled from Bosqui's paper. Afterwards, when sulphide ores were found, 10 more stamps and the equipment shown on the right-hand side of the diagram were added. Wet crushing, amalgamation, concentration, and cyanidation of the tailings is the general process employed, full details of which may be found in the paper above referred to and in a recent article by T. A. Rickard. ${ }^{c}$ The concentrates are shipped to the smelters.

The Combination mill, although not without some recognized defects in plan, has proved very successful when the character of the ore and the conditions under which milling is carried on at Goldfield are considered. According to Bosqui the total cost of milling and cyaniding in January, 1906 , was $\$ 10.268$ per ton, and in May of the same year $\$ 5.828$. It was expected that the cost would be still further lowered, but from June to October, 1907, it averaged $\$ 7.142$ per ton, and in September, 1908 , was $\$ 6.13$ per ton. The average recovery is 90 per cent and the daily capacity about 70 tons.

a Ball, S. H., op. cit., p. 19: The analysis has been recalculated to the standard form now employed by the Survey. $b$ Ore treatment at the Combination mine: Min. and Sci. Press, vol. 93, 1906, pp. 413-415, 451-454.

$c$ Goldfield, Nev., V: Min. and Sei. Press, June 20, 1908, p. 840. 


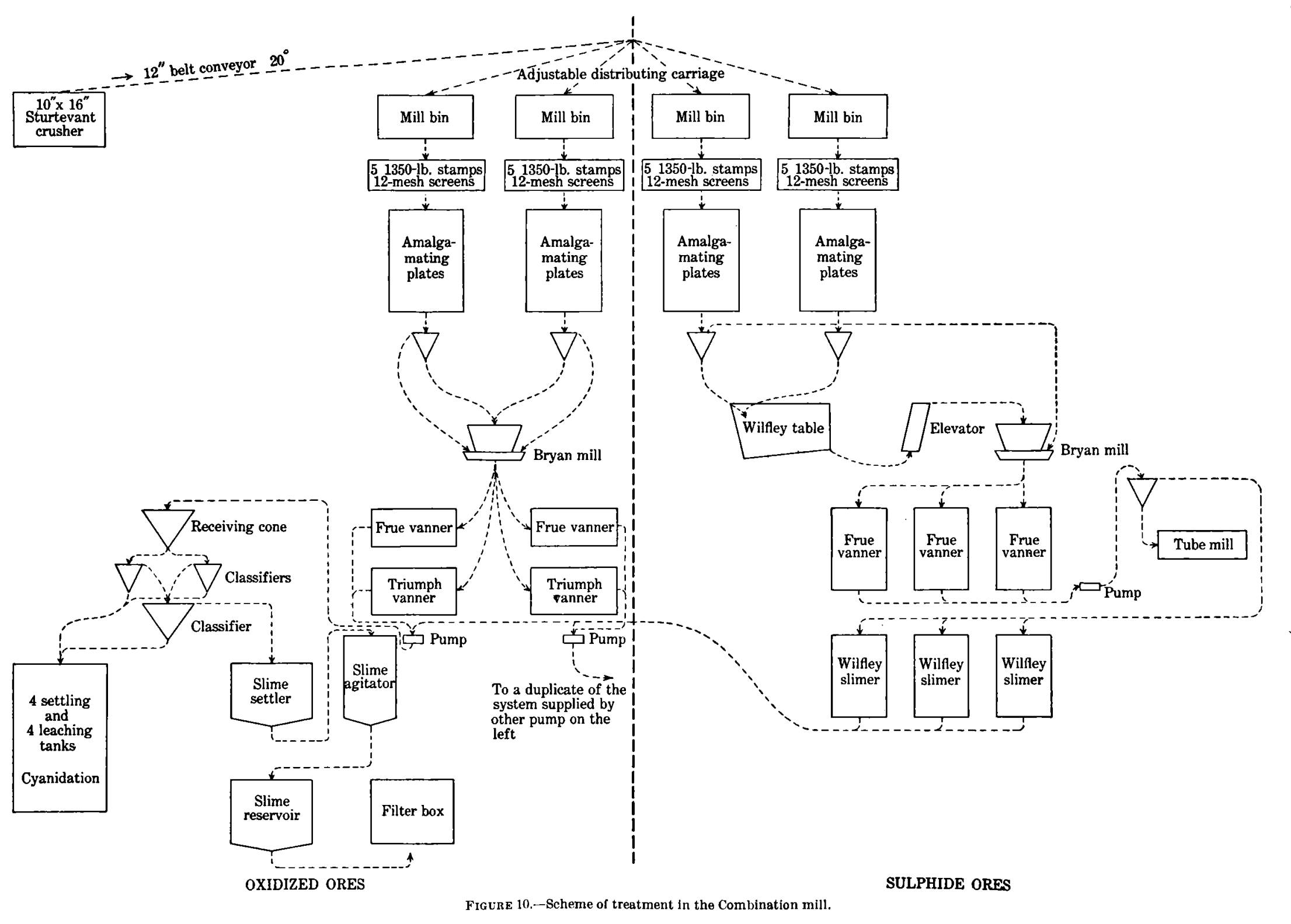


Up to the latter part of 1908 the Combination mine was the only property equipped with its own mill in actual operation. The new 20-stamp mill at the Florence mine was then practically complete, but wis not running.

At the time of first visit, in 1905, there were four custom mills and one sampler in the district. The pioneer mill was that of the Goldfield Reduction Company (Gardiner mill), situated about 1,000 feet (305 meters) northeast of Rabbit Spring. The New Western Reduction Company paid 85 per cent of the assay value for ore, subtracting a charge of $\$ 12$ a ton for milling. The Nevada Goldfield Reduction Company, popularly referred to as Frank's mill, bought ore outright and milled it, or, in the case of ore from the January mine, paid 95 per cent of the assay less $\$ 12$ a ton for treatment. The American Milling and Water Company bought ore or milled it at an average charge of $\$ 12$ a ton. The Columbia Sampling and Ore Company acted as sampler or purchaser only, shipping the ore out of the district for treatment. The total maximum capacity of the three custom mills running in 1905 was about 70 tons a day. The processes employed in these mills were similar to that used in the Combination mill, but the American Milling and Water Company's plant was the only one equipped for cyanidation.

According to an estimate made by Francis A. Thomson, superintendent of the New Western Reduction Company, and published in the Goldfield Sun of September 14, 1905, the average daily production of the Goldfield mines at that time was 70 tons of shipping ore, of an average value of $\$ 200$ a ton, and 100 tons of milling ore, at an average value of $\$ 40$ a ton. In general, ore of lower grade than $\$ 100$ a ton was milled in the district. The Combination Mines Company milled all of its ore except that exceeding $\$ 600$ a ton in value, which was shipped.

The freight rates on ore to San Francisco, Salt Lake City, or Denver in 1905 ranged from $\$ 8$ a ton for ore under $\$ 25$ in value to $\$ 22$ for $\$ 300$ ore. For richer ores, from 3 to 5 per cent of the value per ton in excess of $\$ 300$ was added to the $\$ 22$ rate. For example, on $\$ 2,000$ ore the freight would be $\$ 22$ plus 5 per cent of $\$ 1,700$, or $\$ 107$ a ton. Smelting charges were $\$ 10$ a ton on all siliceous ores, with an additional charge of $\$ 1$ a ton if the silica were unusually high.

With the exception of the Combination, the mines either shipped their ore directly or disposed of it to one of the four reduction or sampling companies in the district.

At the time of second visit, in 1908, the Combination mill was running practically as in 1906, the Florence Company had completed a 20 -stamp mill, and the construction of a 100 -stamp mill for the Goldfield Consolidated Mines Company, to cost $\$ 750,000$, was well advanced. Some changes had taken place in the custom plants. The works of the Columbia Sampling and Ore Company, northwest of Columbia, had been remodeled by the Western Ore Purchasing Company, which samples and buys ore, selling it to the smelters. No schedule of rates was obtained from this company, but their charges on 5-ounce ore from one lease in July, 1908, are known to have been $\$ 25$ a ton for freight and treatment, the gold being paid for at 95 per cent of the total value figured at $\$ 20$ per ounce. The Nevada Goldfield Reduction Company, although changed in personnel, was still in operation, but the other mills had closed. The following description of the Nevada Goldfield Reduction Company's plant is taken from Rickard's article (p. 841):

This plant includes a sampler with a capacity of 450 tons per diem and a cyanide mill treating 100 tons per diem. The surplus ore is sold to the smelting companies. The equipment of the mill includes 20 stamps, of 1,250 pounds each, by which the ore is crushed to 12 mesh in a 0.50 to 1.25 pound $\mathrm{KCy}$ solution. The pulp on issuing from the mortar goes over amalgamating plates and then to eight Wilfley concentrators, classifying into three products, namely, concentrate, sand, and slime. The concentrate assays from $\$ 200$ to $\$ 1,000$ per ton, and is shipped to the smelters; the sand goes first to an Allis-Chalmers tube mill, 5 to 22 feet, reducing it to a screen size of less than 100 apertures per linear inch; from the tube the reground product passes over supplementary amalgamating plates and then to classifiers, the oversize from which is reground after going over a Wilfley. The leaching plant, which receives the pulp after the free gold and rich sulphides have been partly extracted by concentrators, includes eight vats of 22 by 5 feet and three agitator vats of 24 by 16 feet. Three vacuum filters of the Butters type strain the gold-bearing solution, which is further clarified by passage through a 5-ton American filter press, remodeled by E. S. Leaver, the superintendent of the mill.

$79145-N_{0} .60-09-10$ 
A new plant, designed by John E. Greenawalt, had been built by the Goldfield Cl Mill Company northwest of Columbia, but was not yet open to custom. In Mr. Greenawalt's absence from Goldfield I was unable to examine these works. Mr. Rickard's visit was more fortunately timed, and his account ${ }^{a}$ is here quoted:

The roasting furnace is a rabble roaster of the muffle type; it has a porous hearth and is heated with producer gas manufactured from coal (coming from Helper, in Utah) enriched with crude oil (from Bakersfield, Cal.). From this furnace the roasted ore goes to a cooling cylinder, at the end of which it is moistened before delivery into a bin. From the bin it is transferred to large vats by means of a grab bucket of 60 cubic feet (nearly 3 tons) capacity, operated by a traveling electric crane. The chlorination vats are of wood, sealed by a wooden cover, dipping into a launder filled with water. When silver ore is being treated 2 per cent salt is added before crushing, so as to get a good mixture. The leaching in the vats is done by a strong solution of chlorine in water- 7 to 8 pounds free chlorine per ton of solution. Leaching requires three to four days. The seven vats are each 22 feet diameter and 8 feet deep. The gold solution is withdrawn by gravity and pumped into a storage vat, and thence drawn to the precipitating boxes, resembling the zinc box of a cyanide plant. The precipitation of the gold is effected electrolytically, the anode being graphitized carbon and the cathode lead shaving containing 1 per cent zinc, the presence of the zinc hastening the corrosive action. The slime of lead, gold, and silver while still moist is mixed with flux and briquetted. The briquets are melted in a reverberatory furnace and then refined in a cupel.

The chlorine is generated electrolytically. At first salt was obtained from Hazen, in Nevada, but it was found to contain over 5 per cent silica, from sand blown across the dry lake; the salt now used comes from Salt Lake and costs $\$ 16.25$ delivered. The solution of chlorine water is made in an absorbing tower; this consists of two sheet-iron stacks lined with glazed sewer pipe, with cement between the pipe and the outer iron. Inside is placed a filling of hollow clay balls, each of them having eight perforations. The chlorine gas is introduced at the bottom of the stacks and water is made to trickle down from the top, the large surface thus offered facilitating absorption.

The mill has a nominal capacity of 100 tons per diem. The ore is crushed to 14 mesh and the roaster is 100 feet long.

In the summer of 1908 the Goldfield Consolidated Mines Company were conducting experiments in the small Kinkead mill on Columbia Mountain for the purpose of devising a mode of treatment for the concentrates which would make the company independent of the smelters. The experiments were successful and the company is building a special plant on the lines suggested by them. According to a statement courteously furnished by Mr. J. H. Mackenzie, the general manager, the process depends on fine grinding and cyanidation. Its only peculiarity is a preliminary treatment of the concentrates to prevent the destruction of the cyanide solution by the sulphides.

The new mill of this company, situated on the west slope of the ridge south of the Sandstorm mine, will probably be in operation by the end of 1908 and should greatly increase the output from the Consolidated group of mines. The flow sheet of this mill is shown as figure 11.

The rich ore shipped by lessees is usually hand sorted at the surface, although in some cases, as at the Engineer's lease, the ore is so free from waste that it is shipped just as it comes from the stopes. Sorting as practiced by lessees is generally a rough and wasteful process. The coarse pieces after passing over grizzleys are picked over and cobbed without any preliminary washing, so that many rich lumps go on the dump. The waste piles of the successful leases are consequently valuable and are nearly always reworked, being, as a rule, picked over again by hand. The Little Florence dump, for example, was sold for $\$ 10,000$, and the purchaser realized \$16,152.83 from the ore culled from it between June 1 and November 30, 1908. In this case water was available and hose was used advantageously to clean the lumps before sorting.

Most of the crude ore and concentrates shipped from Goldfield has gone to the smelters on San Francisco Bay and in the Salt Lake Valley, Utah. The freight rates to these points are the same, and where ore is diverted to other smelters the difference in freight, if any, goes to the account of the smelter receiving the shipment. Prior to September, 1907, the freight schedule was as follows:

a Goldfield, Nev., V: Min. and Sci. Press, June 20, 1908, pp. 841-842. 
Freight rates from Goldfield to San Francisco and Salt Lake Valley prior to September, 1907.

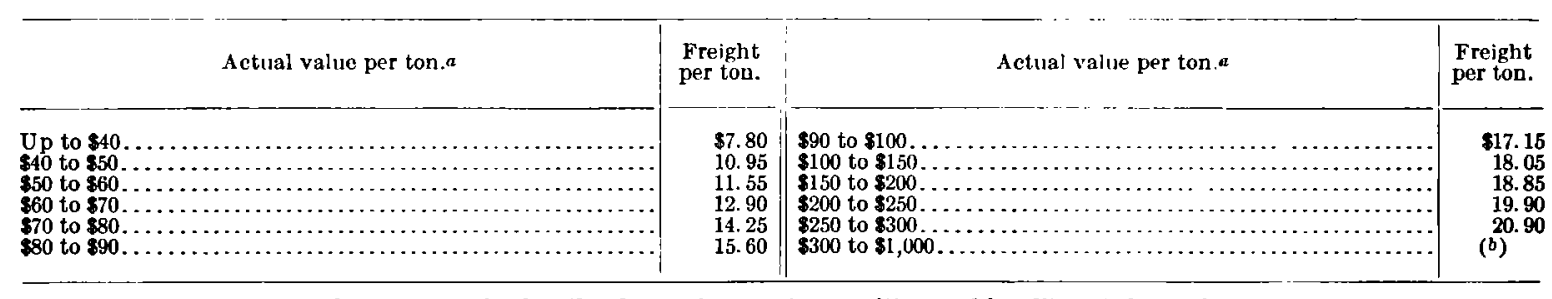

a Gross assay value less the charges for assaying, smelting, and handling at the smelter.

$b$ Add to rate for $\$ 300$ ore 2 per cent of the value above $\$ 300$ per ton.

CONCENTRATION SCHEME OF THE GOLDFIELD CONSOLIDATED MILL

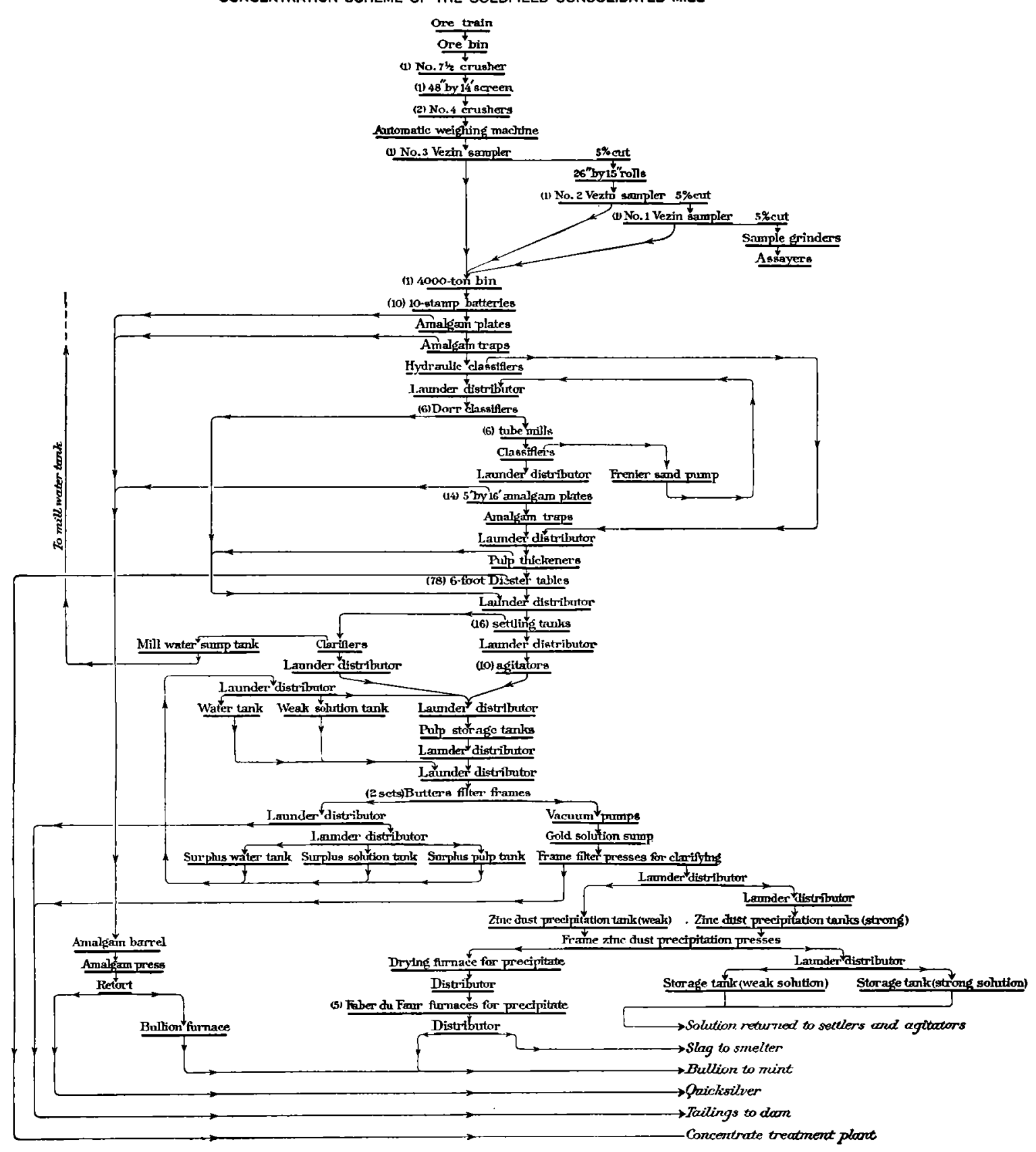

Figure 11.-Scheme of treatment in the new Goldfeld Consolidated mill. 
The smelter charges at this time were as follows;

Smeller schedule prior to September, 1907.

\begin{tabular}{|c|c|c|c|}
\hline & Assay value of gold and silver per ton. & $\begin{array}{c}\text { Charge per } \\
\text { ton for } \\
\text { treatment. }\end{array}$ & $\begin{array}{l}\text { Price paid } \\
\text { for gold } \\
\text { per ounce. }\end{array}$ \\
\hline $\begin{array}{l}\text { jp to } \$ 70 \ldots \\
\$ 70 \text { to } \$ 100 \ldots \\
\$ 100 \text { to } \$ 300 \\
\text { Over } \$ 300 \ldots\end{array}$ & ……, & $\begin{array}{r}86 \\
7 \\
8 \\
9\end{array}$ & $\begin{array}{r}\$ 19.00 \\
15.00 \\
19.50 \\
19.75\end{array}$ \\
\hline
\end{tabular}

In October, 1907, owing to the general financial situation, the rates were raised until the total freight and treatment charges on $\$ 100$ ore amounted to $\$ 45.35$.

On December 13, 1907, the following freight schedule went into effect and was still in force in June, 1908:

Freight rates from Goldfield to San Francisco and Salt Lake Valley December 13, 1907.

\begin{tabular}{|c|c|c|c|}
\hline Actual value per ton. & $\begin{array}{l}\text { Freight } \\
\text { per ton. }\end{array}$ & Actual value per ton. & $\begin{array}{l}\text { Freight } \\
\text { per ton. }\end{array}$ \\
\hline 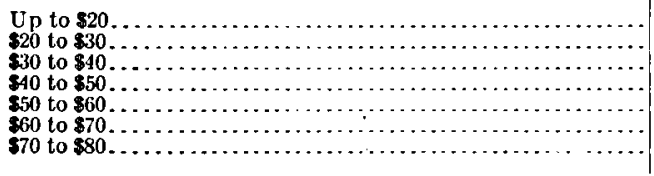 & $\begin{array}{r}\$ 6.00 \\
7.10 \\
7.80 \\
10.00 \\
11.00 \\
12.00 \\
13.00\end{array}$ & 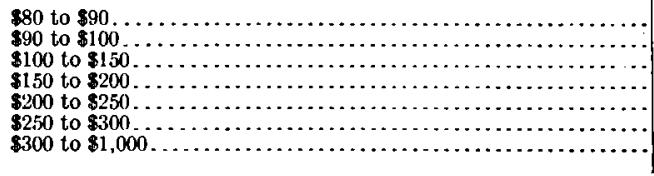 & $\begin{array}{r}\$ 14.00 \\
15.00 \\
16.50 \\
18.00 \\
19.50 \\
20.90 \\
(a)\end{array}$ \\
\hline
\end{tabular}

a Add to rate for $\$ 300$ ore 2 per cent of the value above $\$ 300$ per ton.

In this schedule freight agents are instructed to refer shippers offering ore of greater value than $\$ 1,000$ per ton to the express companies. If accepted as freight, the following additional charges are levied:

Freight on exceptionally rich ore.

\begin{tabular}{|c|c|}
\hline Actual value per ton. & Freight per ton. \\
\hline $\begin{array}{l}\$ 1,000 \text { to } \$ 1,500 \ldots \ldots \ldots \ldots \ldots \ldots \ldots \\
\$ 1,500 \text { to } \$ 2,000 \ldots \ldots \ldots \ldots \ldots \ldots \ldots \ldots\end{array}$ & $\begin{array}{l}\$ 20.90 \text { plus } 3 \text { per cent of excess value over } \$ 300 \text {. } \\
\$ 20.90 \text { plus } 4 \text { per cent of excess value over } \$ 300 \text {. } \\
\$ 20.90 \text { plus } 5 \text { per cent of excess value over } \$ 300\end{array}$ \\
\hline
\end{tabular}

It is evident from a casual inspection of these rates that they are based, not on the cost and responsibility of the service performed, but on the expectation of what the shipper may be made to pay. The railroads, unless forced to by legal proceedings, assume no greater responsibility on ore above $\$ 100$ per ton in value and exact the additional rates for rich ore, even when expressly released from special liability. ${ }^{a}$

a $\mathrm{As}$ this report goes to press announcement is made of a new freight schedule promulgated by the Tonopah and Tidewater Railroad. As given in the Mining and Scientific Press for December 20,1908 , the new rates are as follows:

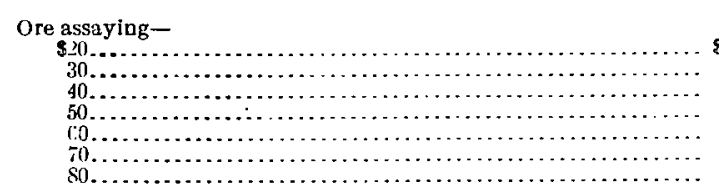

\begin{tabular}{r|rr} 
& & 50 \\
3.90 & \\
4.40 & \\
4.80 & \\
5.25 & \\
6.75 & \\
7.50 & &
\end{tabular}

$$
100 .
$$

re assaying -

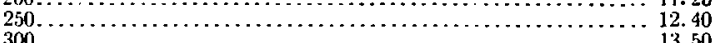


TREATMENT OF THE ORES.

On February 6, 1908, the following smelter schedule became effective

Smeller schedule of February 6, 1908 . GOLDFIELD ORES.

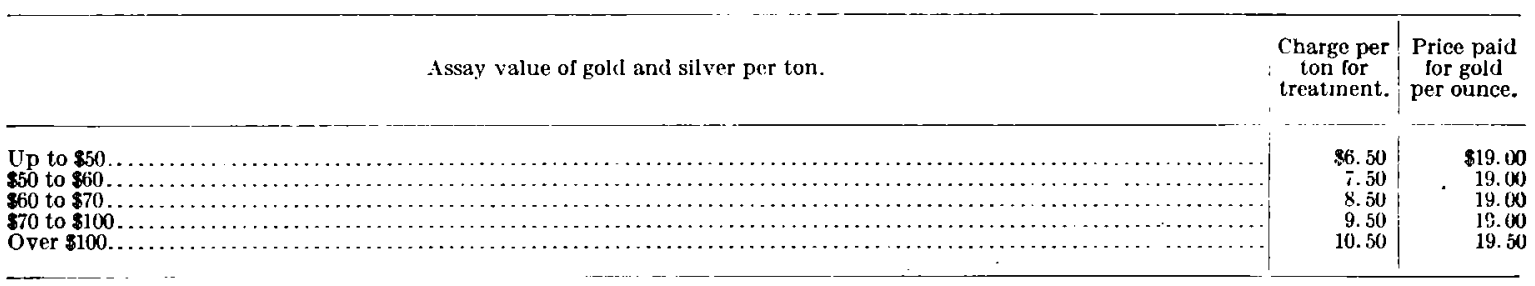

In addition to above treatment charges, where gold contents exceed 5 ounces per ton, add $\$ 0.50$ for each ounce or fraction thereof in excess of 5 ounces.

Silver to be paid for, if 1 ounce or over, at 95 per cent of New York quotation.

On ores under $\$ 60$ gross value a charge of $\$ 0.25$ will be made for each per cent of sulphur in excess of 3 per cent.

GOLDFIELD CONCENTRATES.

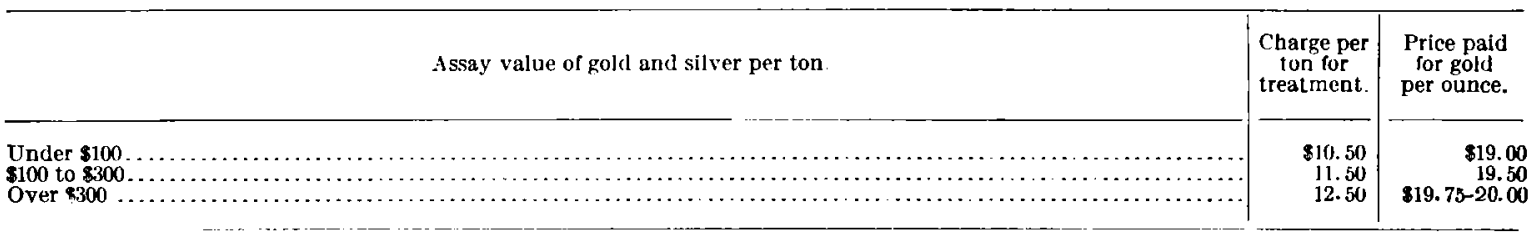

In addition to above treatment charges, where gold contents exceed 5 ounces per ton, add $\$ 0.50$ per ton for each ounce or fraction thereof in excess of 5 ounces, and where gold is under 5 ounces per ton add $\$ 1.50$ for each ounce or fraction thereof under 5 ounces.

The treatment charges in the foregoing table are those upon which the American Smelting and Refining Company bases its contracts. The actual charges for treatment are 50 cents less in each case-viz, $\$ 6$ instead of $\$ 6.50$, etc. - the not altogether luminous explanation being current that the sampling works, which act as brokers or buyers for the smelters, charge the lower rate and the smelter company "protects" them. Attention may be called also to the modifying addenda which follow the tabular parts of the schedule, particularly that under concentrates. Here the rate for $\$ 100$, or 5 -ounce, concentrates is $\$ 10.50$. For concentrates containing a fraction of an ounce less than 5 ounces of gold per ton the charge becomes $\$ 10.50$ plus $\$ 1.50$, or $\$ 12$. For concentrates containing a fraction of an ounce over 5 ounces of gold per ton the charge becomes $\$ 11$.

In addition to the freight and smelting charges the shippers have to pay from $\$ 1.50$ to $\$ 2$ a ton for the sampling. 


\section{CHAPTER XII.}

\section{THE LEDGES.}

\section{DEFINITION.}

The Goldfield deposits, in all that pertains to the genesis of the ore, are most closely allied to metasomatic fissure veins. Yet they can scarcely be included within that class. They are intimately related to fissuring, but only a small part of the ore has actually filled fractures (spaces of discission). These fractures, moreover, rarely show that regularity in form and that persistency in strike and depth which are connoted with the term "vein" or "vein fissure." Structurally the deposits are irregular masses of altered and mineralized rock traversed by multitudes of small, irregularly intersecting fractures, such fracturing passing in many places into thorough brecciation. There are exceptions to this character. Certain deposits exhibit in part more regularity of form and there is reason to suppose that at depths greater than those now reached such approaches to lode-like form may become more numerous. But within the mass of rock extending from the surface to a depth of 600 feet (183 meters), a mass which includes all the ore bodies thus far exploited, the deposits can not be called lodes or veins without giving to these words unusual meanings or without tacitly ascribing to the mineralized bodies a tabular form that they rarely possess.

In view of these considerations, the word "ledge,"a already in use by miners in a less definite sense than "vein," will be employed in this report to designate the masses of silicified or otherwise altered rock in which the ore bodies are found. This word, although suggested by the outcrops of such material, will be applied at all depths where any distinction is possible between an alteration intimately associated with the ores and a more extensive alteration of country rock. It will be applied, moreover, to rock which has undergone alteration of the kind charteristic of the immediate vicinity of ore bodies, whether or not ore is known to be present.

The actual ore bodies or pay shoots occur within, but are seldom coextensive with the ledges or ledge matter.

The proposed usage of ledge is not intended to restrict the word to a special technical meaning but rather to avoid the use of vein and lode, which, while broadly used by miners, are employed with some definiteness in scientific writing.

\section{DISTRIBUTION.}

The ledges, considered as topographic features and independently of ore bodies, are extraordinarily abundant in the Goldfield district. To them the topography owes most of its minor roughness; many small knobs are crowned with iron-stained masses of ledge matter and the slopes of the larger hills are ridged and studded with the same material. As stated on page 16, these rough outcrops are in most, if not all, cases purely residual, and stand out, like pebbles in a clay bank, because the softer rock has been eroded from around them. Many of them in fact rest like giant pebbles on the tops of knobs and have no downward continuation into the soft rock beneath them. Some of these loose superficial masses of ledge matter east of Goldfield are shown in Plate XIV, $A$. Prospecting tunnels have been driven directly under some of them.

a "In mining, ledge is a common name in the Cordilleran region for the lode, or for any outcrop supposed to be that of a mineral deposit or vein. It is frequently used, as reef is in Australia, to designate a quartz vein." - Century Dictionary.

"A rocky outcrop or reef. * * * Mining. A metal-bearing rock stratum; a quartz vein."—Standard Dictionary. 


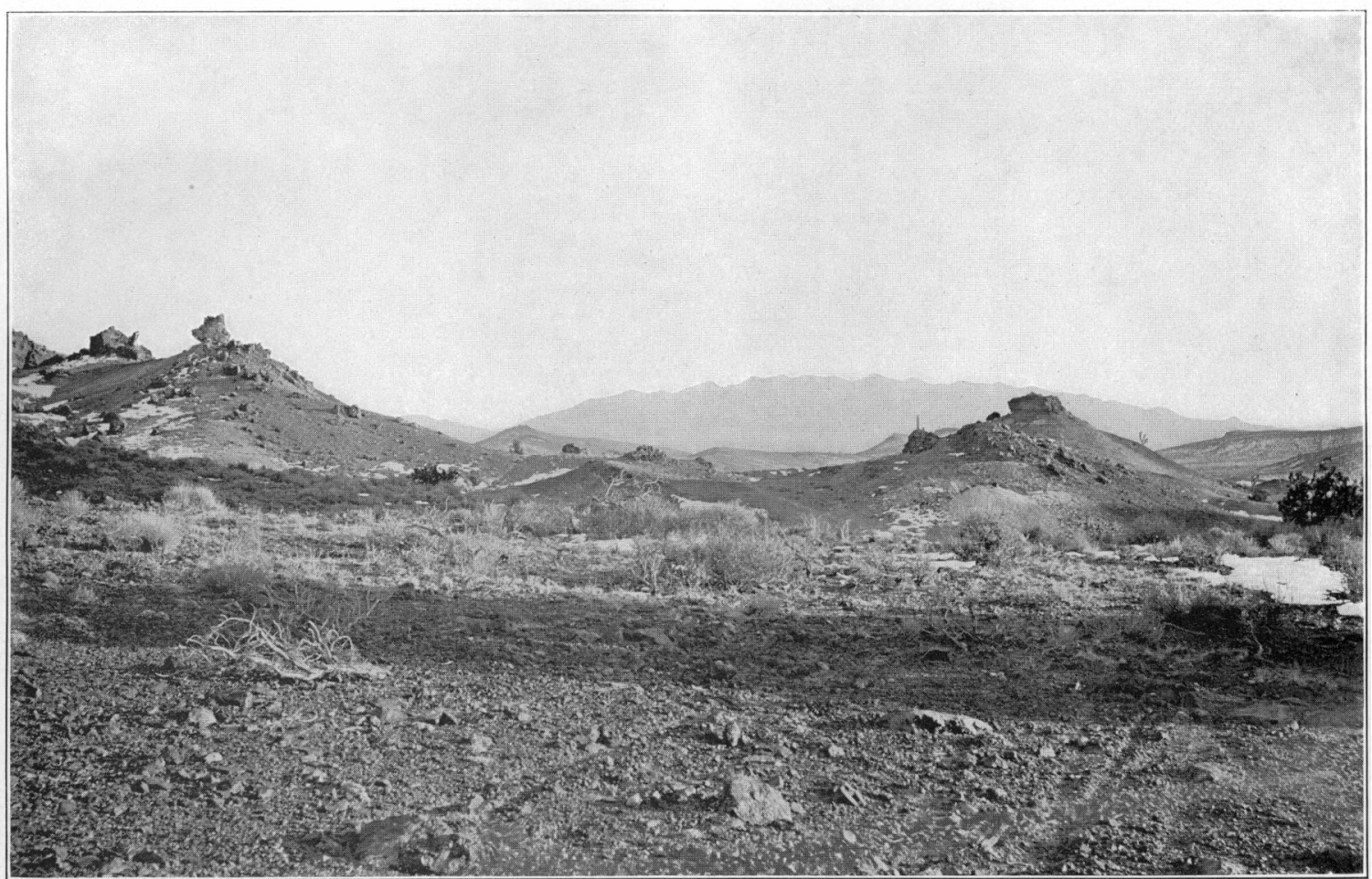

A. LEDGE OUTCROPS IN MILLTOWN ANDESITE ABOUT 2 MILES EAST OF GOLDFIELD.

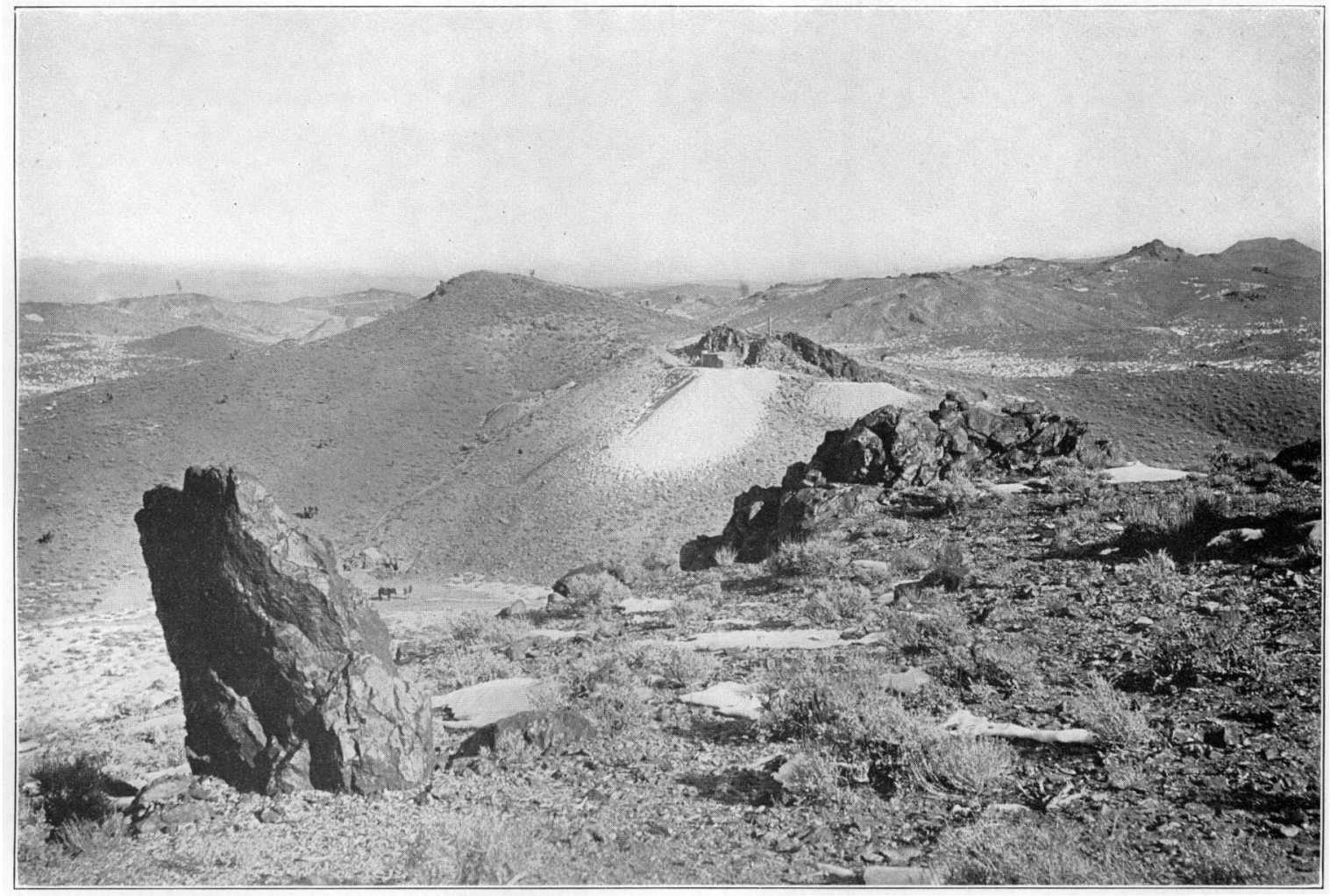

B. LEDGE OUTCROP IN DACITE BETWEEN THE BLUE BULL AND COMMONWEALTH MINES.

The conspicuous white dump is alunitic material from a lease on the Lone Star ground. The rough knob on the sky line near the right side of the view is Banner Mountain. 

On the geologic map, Plate II, an attempt has been made to show the general distribution of the ledges by plotting the principal outcrops in the field with a plane table. The result at best is only an approximation to the truth, as the boundaries between ledge matter and soft altered country rock are often indefinite and are seldom clearly exposed at the surface. For this reason, and to avoid obscuring the other geologic features of the map, the generally linear outcrops are indicated by lines and round or irregular bosses by dots. Noattempt has been made to indicate the relative size of outcrops. Moreover, many small outcrops are omitted, while in some places, as on the east side of Vindicator Mountain, the alteration to ledge matter has affected areas so broad that they could only be properly indicated by washes of color or by some device of shading. But while rigid accuracy in the cartographic representation of them is thus unattainable, the map serves to bring out the general distribution and some of the peculiar features of the ledges. The ledge outcrops east of Goldfield are shown on a smaller scale in figure 12 .

Plate II shows that a conspicuous belt of ledges, about a mile wide, stretches from the vicinity of Columbia and Goldfield in a gentle curve, at first nearly southeast but gradually sweeping to the east, past Preble and Blackcap mountains and beyond the eastern boundary of the area subjected to detailed study. As shown in Plate XV, $A$, which is a view eastward from Blackcap Mountain, the characteristic ledge topography continues for a mile or two beyond that summit, and merges finally into the desert plain that separates the Goldfield Hills from the Stonewall and Cactus ranges. Nowhere in the belt are the ledges more numerous or conspicuous than between Milltown and Blackcap Mountain, yet along this stretch no mines of the first rank have been developed. On the other hand, from the comparatively few ledges between Milltown and Columbia has come over 95 per cent of the gold sent out from the district. As regards geologic distribution, it is to be observed that most of the productive ledges are in the area of dacite northeast of Goldfield; a very large number, of which only a few near Milltown have proved productive, are in andesite; others, of which a few have been found to contain

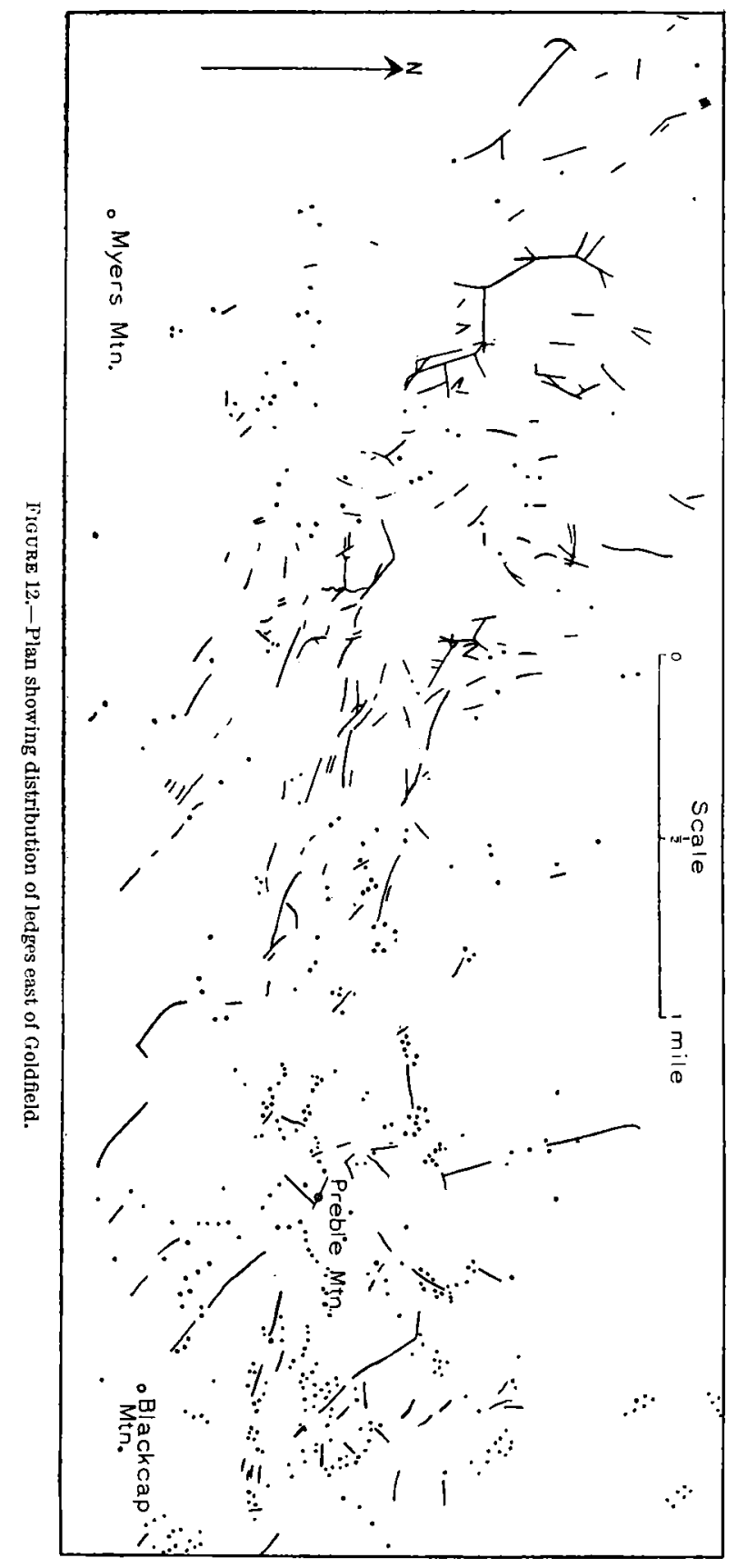
a little ore, are in the dacite mass of Preble Mountain; and a few of no known economic importance are in the area of Espina breccia, northeast of Preble Mountain. Isolated ledges in andesite occur south of the main belt, up to the northern edge of the dacite vitrophyre, and there are a few not very prominent ones in the latter rock.

A second belt of ledges is recognizable extending in a general easterly direction from the vicinity of Kendall Mountain through McMahon Ridge and Black Butte to the eastern border 
of the district. This belt is much less prominent than the southern or Preble Mountain belt. At its eastern extremity it spreads and becomes indefinite. It is connected rather loosely with the southern belt by scattered ledges in the neighborhood of Tognoni Springs and in the dacite east of McLaughlin's well.

The northern belt of ledges is mainly in the Milltown andesite, although it crosses a mass of dacite near Black Butte. It contains some productive ore bodies in McMahon Ridge and Black Butte but no mines of the first rank.

In addition to these principal belts ledges are distributed, without any particular alignment or regular grouping, over the central part of the district between the two principal belts, Banner
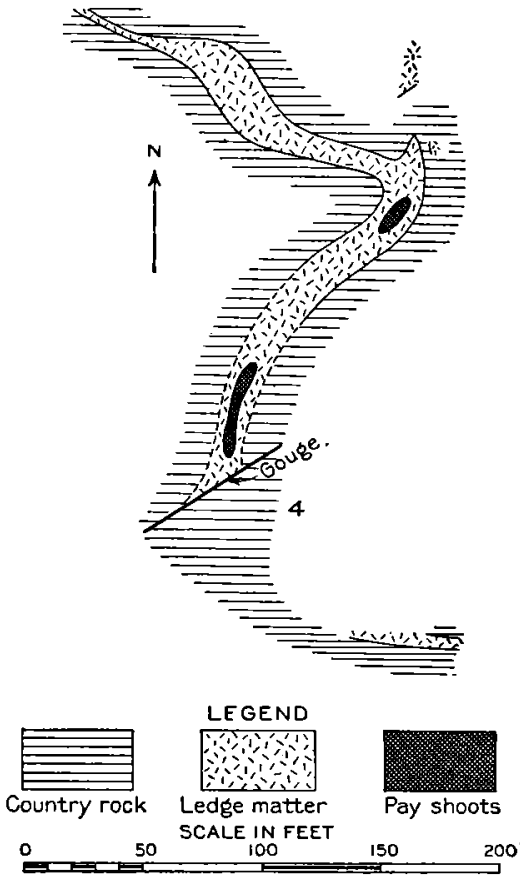

FIGURE 13.-Plan of ledge matter and pay shoots on the 100-foot level of the Florence mine.
Mountain being traversed by many of more than usual conspicuousness and regularity $(\mathrm{Pl}$. X $V, B)$. Others outcrop between Banner Mountain and Diamondfield. Vindicator Mountain exhibits much metamorphism of the ledge-forming type and many isolated outcrops of ledge matter; but distinct linear ledges are not so well developed here as on Banner Mountain. Most of the scattered ledges and groups of ledges in the central part of the district are in latite and none of them has yet proved productive.

The Sandstorm, Kendall, Adams, and Conqueror ledges in rhyolite, north of Columbia Mountain, are perhaps best regarded as a group by themselves. As regards position, however, they are not sharply marked off from the northern or Black Butte belt.

\section{TREND OR STRIKE.}

The greater number of the ledges are irregular masses of no definite trend. Others, of which the proportion appears magnified by the method of representation adopted in Plate II and figure 12, have linear outcrops and are evidently related to fissures or fissure zones of some persistency, attaining in extreme cases a length of a quarter of a mile (0.4 kilometer). These, as a glance at Plate II will show, exhibit great diversity of direction and in some parts of the field, particularly near Milltown, ledges of various trends are linked together in complex chains. Most of the productive ledges near Goldfield have a north to northwest strike.

Although diversity of strike is one of the most conspicuous features of the ledges as a whole, there is some approach to uniformity in the tendency of the longer ledgres to conform in direction to the general trend of the belt in which they lie.

The linear ledges are in most cases straight or but slightly curved. Others, such as the January and Florence ledges, are sharply bent. (See Pl. XVI and fig. 13.)

\section{DIP.}

Accurate data on the dip of a ledge are obtainable only where mining has been carried to some depth. A large number, probably most of the ledges, have nearly vertical dips. Others,

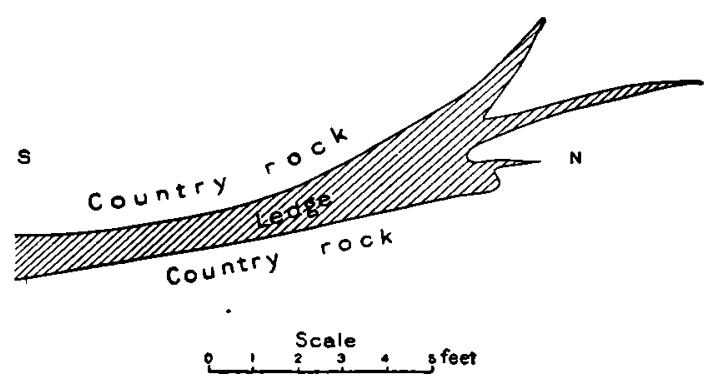

FIGURE 14.- Vertical section through an irregular flat ledge, as seen in the west wall of the Black Butte tunnel. such as the mass of ledge matter capping Black Butte, and the so-called Flat vein in the same hill, are nearly horizontal. (See also fig. 14.) The Mohawk ledge as a whole (see fig. 15) has 


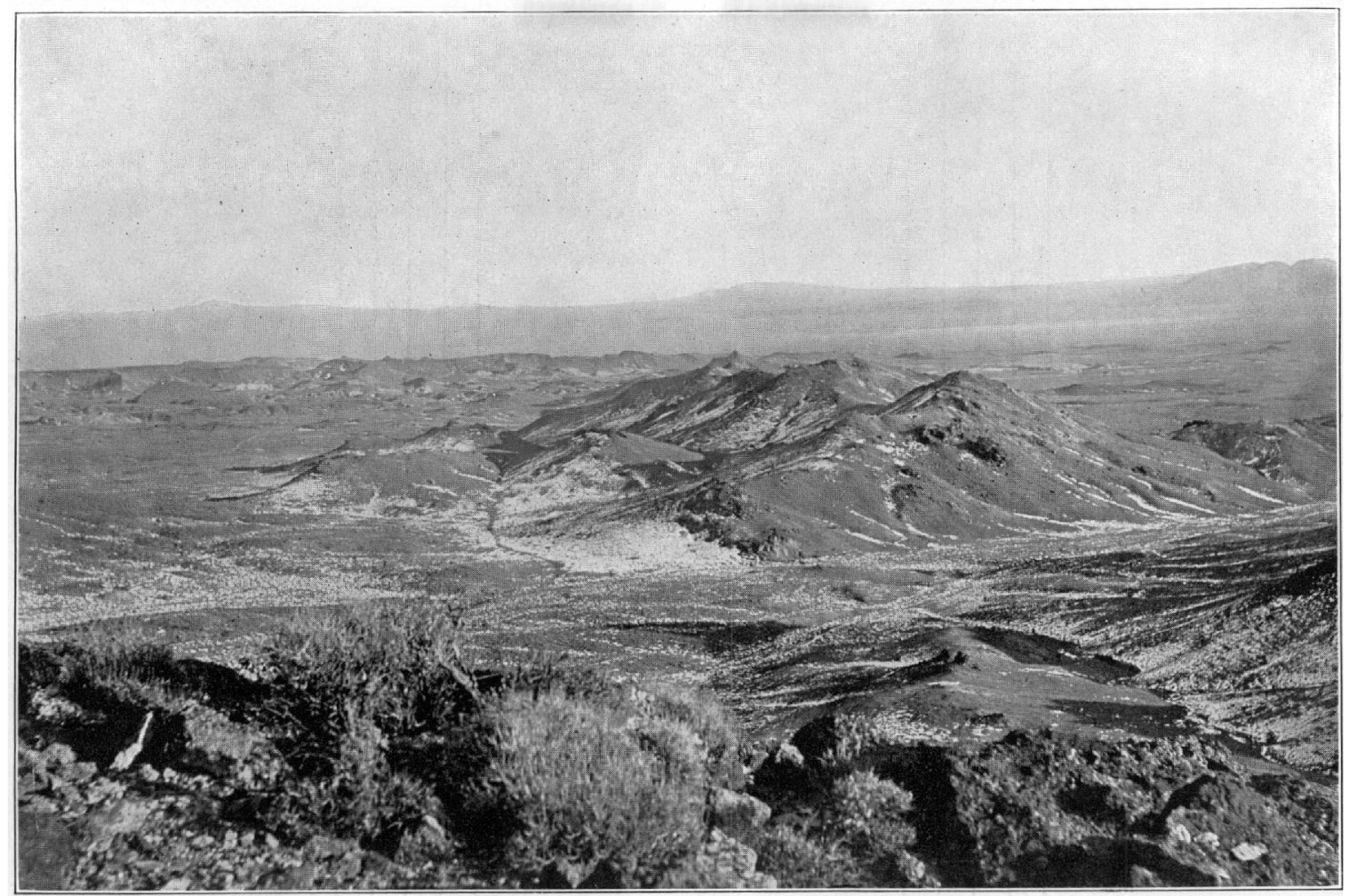

A. LEDGE OUTCROPS EAST OF BLACK CAP MOUNTAIN.

In the distance is Stonewall Flat with its white central playa; beyond is the Cactus Range.

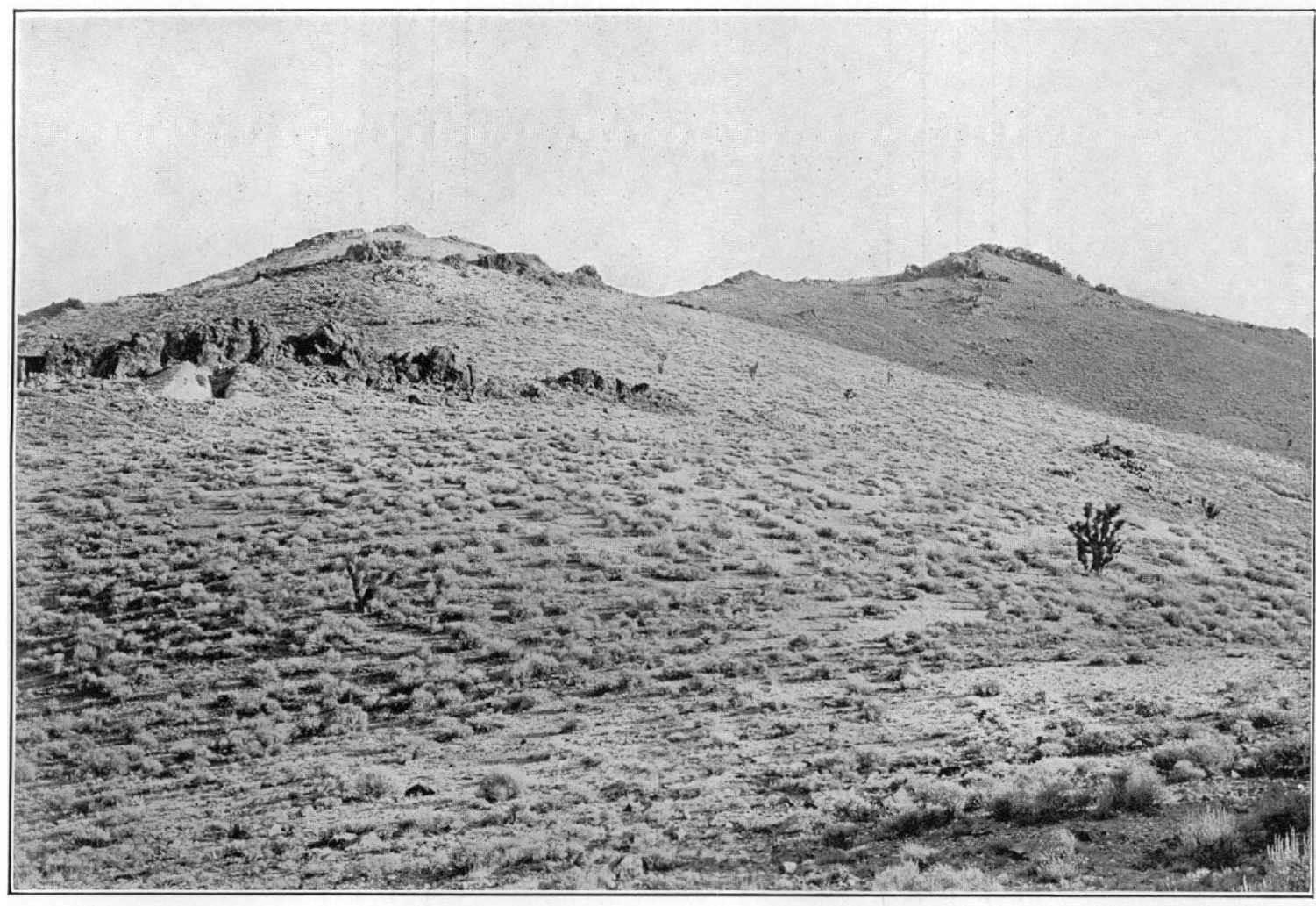

B. LEDGE OUTCROPS IN LATITE ON BANNER MOUNTAIN. 



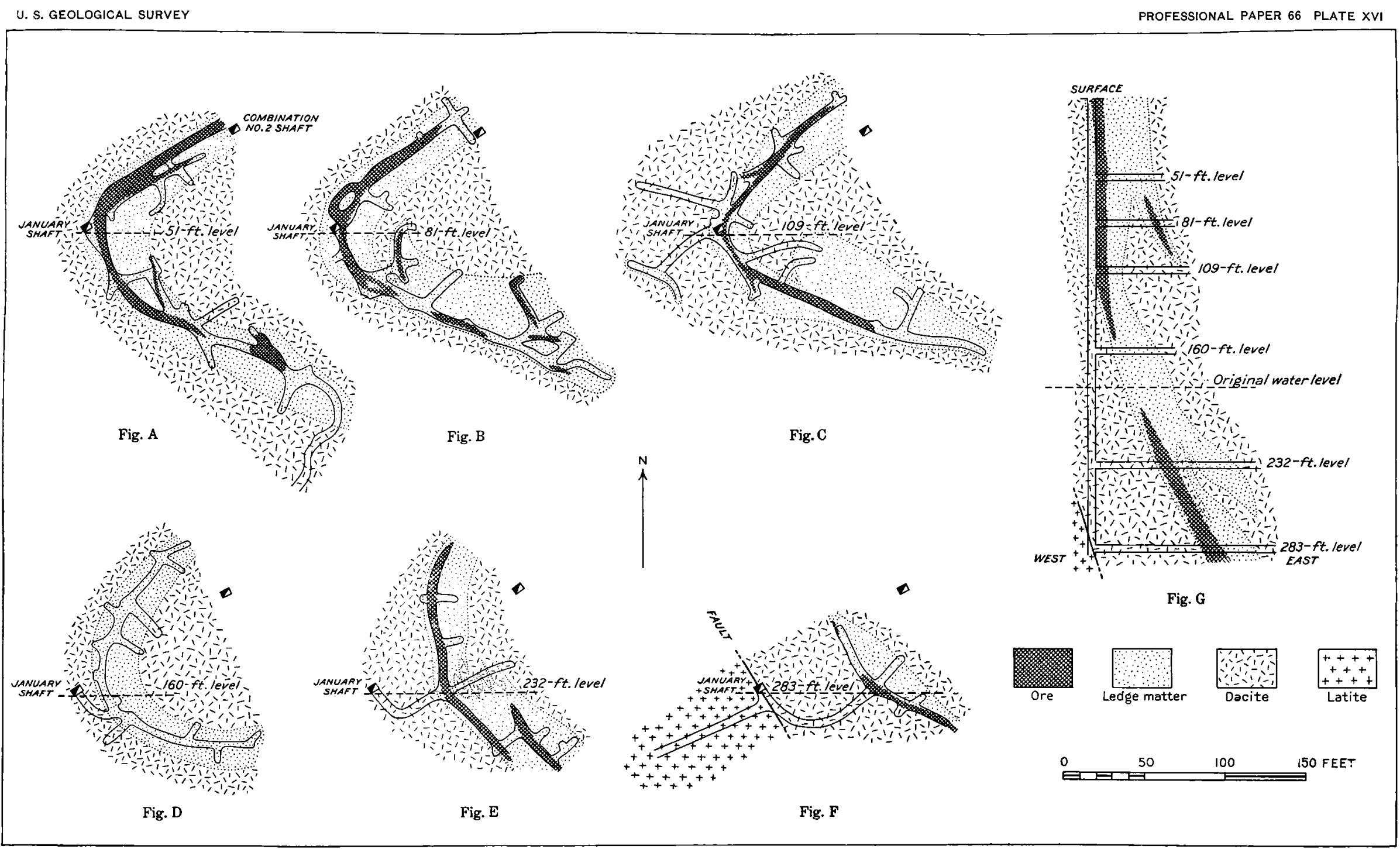
PLANS OF THE PRINCIPAL LEVELS OF THE JANUARY MINE, WITH A DIAGRAMMATIC SECTION, SHOWING RELATIONS OF ORE, LEDGE MATTER,
AND COUNTRY ROCK. 

a dip of $35^{\circ}$ to $45^{\circ}$ to the east. The Combination ledge, while very irregular, also dips to the east, the angle of dip becoming very low on the deeper levels. (See Pl. XVII.) Most of the ledges that have been followed down for a few hundred feet show changes in dip such as are rarely found in typical veins or lodes. These changes are well illustrated in the January, Combination, Reilly, and Florence workings. (See Pls. XVI and XVII and figs. 16 and 17.)

\section{SHAPE.}

The shape of the ledges has been partly indicated in the preceding description. It has been shown that they range from roughly equidimensional, irregular masses to nearly vertical or inclined, undulating, lodelike plates or sheets. Vertical pipes, of generally circular or elliptical section, such as the Anna Lee chimney of the Portland mine, ${ }^{a}$ may occur in the Goldfield district, but mining operations have not yet revealed any good example of this form of deposit.

As examples of fairly regular, lodelike ledges may be cited parts of the main ledge of the Combination mine (described on $p$. 211), the Jumbo ledge (p.221), and the Little Florence ledge (p. 223). The Mohawk ledge as a whole is generally lodelike, but is a very broad ill-defined mass, whose boundaries are as yet imperfectly known. Regularity observable on a given level is no guaranty of vertical regularity or persistence, as is shown by the sections of the Combination mine (see p. 212 and Pl. XVII) and by the changes in dip of the Combination and Reilly ledges.

$a$ Lindgren, W., and Ransome, F. L., Geology and gold deposits of the Cripple Creek district, Colorado: Prof. Paper U. S. Geol. Survey No. 54, 1906, p. 447 .
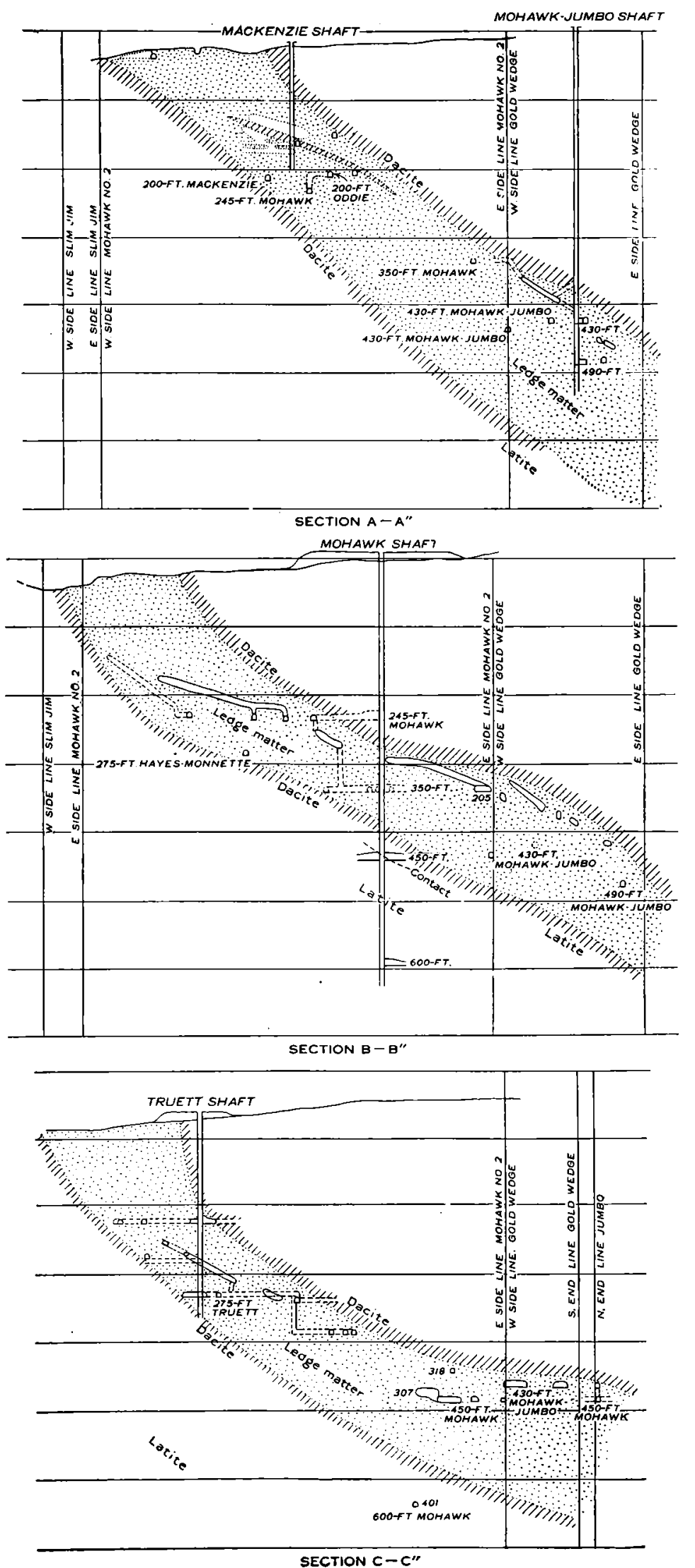

Figure 15,-Sections across the Mohawk ledge on lines shown on Plate XXXIII. 
Some ledges, like that of the Florence, while showing a fairly rectilinear outcrop, prove on exploitation to be exceedingly irregular in plan and to change in direction from level to level, as illustrated by the map of the Florence workings (Pl. XXXV) and by figures 13 and 17. The

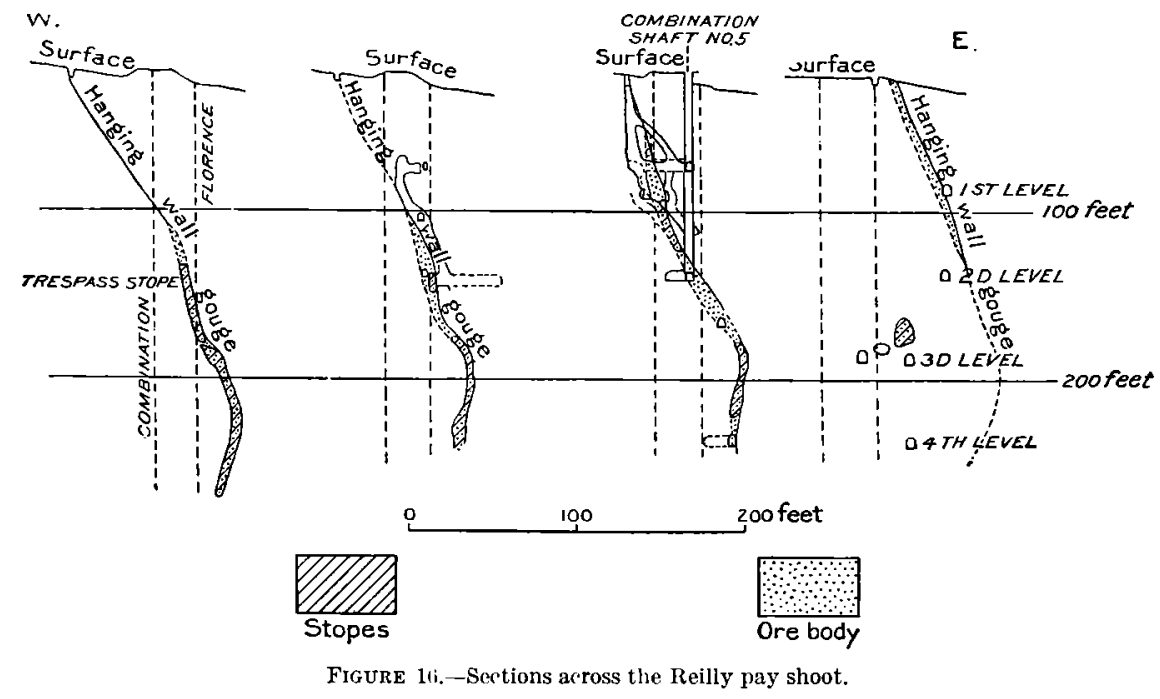

January ledge, described in detail on page 217 , best exemplifies a curved ledge and illustrates well the manifold irregularities of form characteristics of the Goldfield deposits. (See Pl. XVI.)

The modifications in form manifested by the ledges with increase in depth are not only of
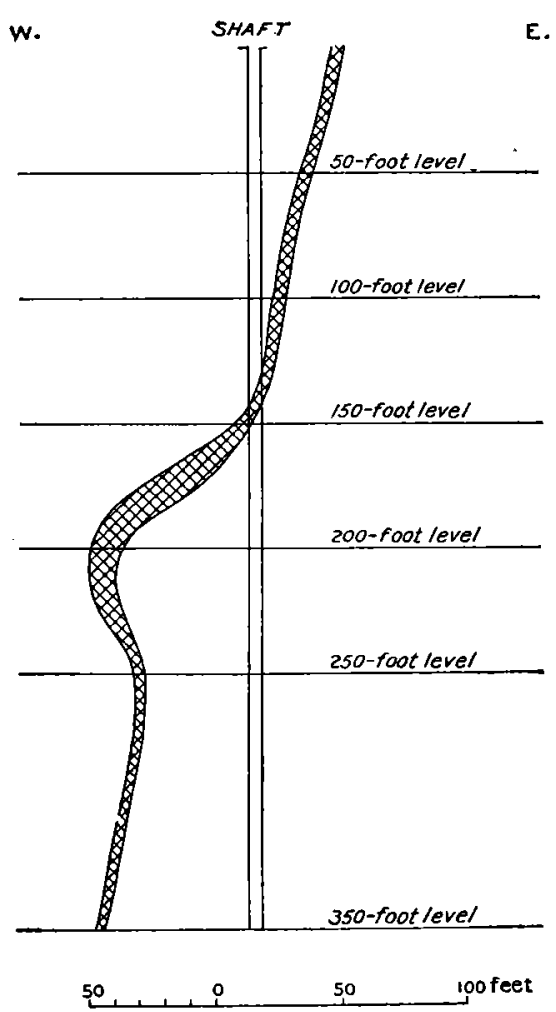

Figure 17.-Section across the Florence pay shoot near the main shaft, showingr changes in dip. much scientific interest but are of great practical signifi-

E. cance. The study of this feature of the deposits is hampered by the fact that below the zone of oxidation the distinction between ledge matter and the general country rock of the mines is less well marked than on those levels where original differences in composition and structure have been accentuated by the selective action of weathering. Moreover, the number of mines that have attained sufficient depth and horizontal extent to throw much light on this question is still small.

The available data favor the view that silicification, which is the principal chemical distinction of the ledge matter as a whole, becomes less as the depth increases. Accompanying this change is a tendency of the ledges to become narrower and more lodelike. The change is not entirely regular and does not take place everywhere at the same depth.

In the January mine the ledge on the 283-foot level still shows some silicification, but is much narrower than above and is straighter and more lodelike, as shown by Plate XVI. A similar simplification of form with narrowing and a notable decrease in silicification appears in the Florence ledge below the 250-foot level. (Seep. 227.) In the St. Ives mine the levels above the 150 -foot show broad irregular masses of silicified ledge matter, while the 250 -foot level is in soft fissured pyritized dacite showing only partial silicification along the fissures. In the Mohawk mine the ledge on the 600-foot level, so far as could be determined from the limited exposures of it in 1908, is narrow and more lodelike than on the upper levels.

Quite independently of ore and value, then, the ledges, as structures differentiated from the country rock by silicification, tend to become narrower, simpler, and more rectilinear in plan with 
U. S. GEOLOGICAL SURVEY

PRofessional PAPER 66 PLATE XVII

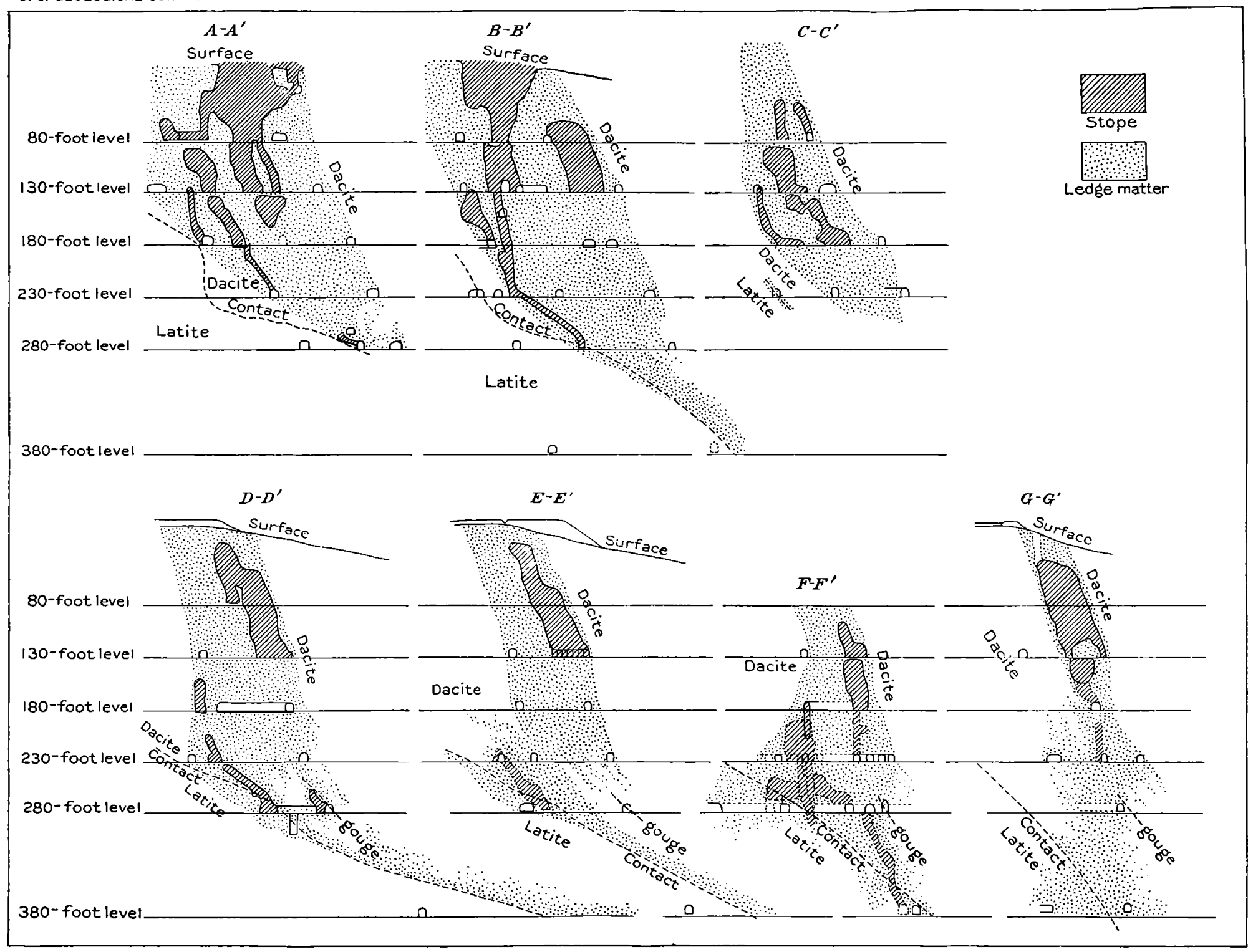

SECTIONS ACROSS THE COMBINATION LEDGE ON LINES SHOWN ON PLATE XXXIV. 



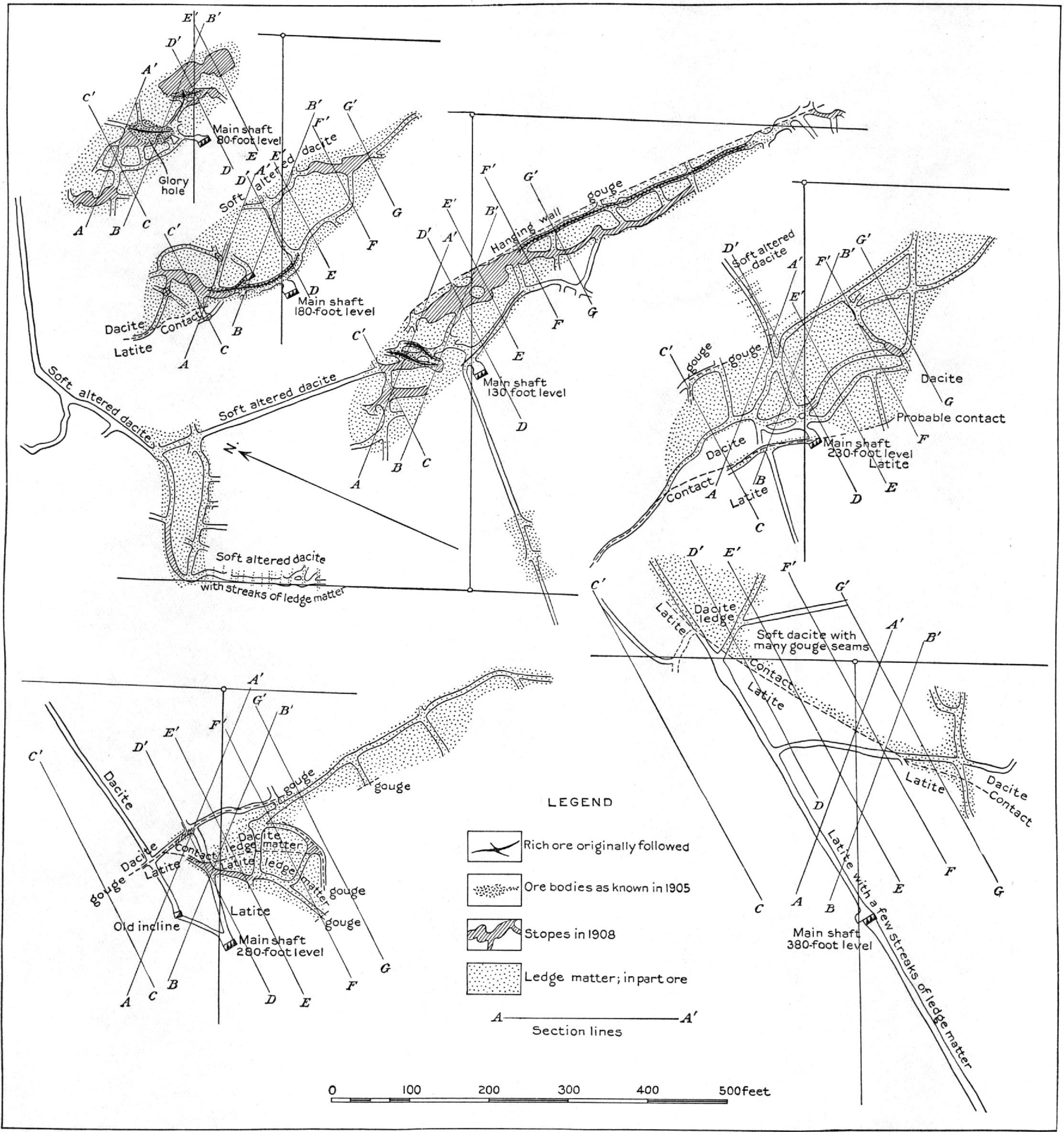

PLANS OF LEVELS OF THE COMBINATION MINE, SHOWING APPROXIMATE HORIZONTAL DISTRIBUTION OF LEDGE MATTER AND ORE. 

increase of depth. This suggests that below a depth of about 500 feet (152 meters) most of the ledges will show a gradual change to sulphide impregnations, or metasomatic veins, along zones of fissuring.

Ledges having the form of nearly horizontal sheets occur in the district, but have not proved of much economic importance. Figure 13, page 155, illustrates a small ledge of this type in Black Butte. Another, from which ore has been stoped, is the Flat vein on the south side of the same butte, described on page 247.

In this connection attention may be directed to the tendency of the Mohawk and Combination ledges to flatten out to the east as they reach the bottom of the dacite (see fig. 15 and Pl. XVII). This behavior is extremely interesting; and the bottom level of the Mohawk, as shown on page 206, just fails to answer the important questions suggested by this relation of the ledges to the dacitelatite contact. It is known that a short distance east of the Mohawk workings the bottom of the dacite in general rises toward the east. The 600-foot level of the Mohawk apparently cuts the ledge very near what may be called the keel of the dacite mass. To the west of the ledge on this level the bottom surface of the dacite dips to the east. A short distance to the east of the ledge on the 600-foot level the bottom surface of the dacite dips to the west. What becomes of the ledge below this level? Will it steepen and go down through the latite with probably some change in mineralogical character? Is there in the latite a dike of dacite which the ledge will accompany downward? Or will the ledge be no longer traceable for any considerable distance below the main dacite sheet? The importance of these questions is obvious, but unfortunately they can not be definitely answered until more underground work is done. The probability is that the ledge will continue down into the latite as a low-grade metasomatic fissure vein with pyrite as its principal metallic constituent. ${ }^{a}$

\section{MATERIAL AND MINOR STRUCTURES.}

As the most important ledges are in dacite, the material of those in this rock appropriately receives first attention.

Within the zone of oxidation, the ledge matter is usually a rusty, shattered, or brecciated mass that commonly contains, here and there, bunches and streaks of kaolinite, which may be mixed with limonite or alunite, or both. The fragments of the breccia may be loose, with considerable interstitial limonitic or kaolinitic material, or may be cemented by quartz, limonite, or hematite. Excellent examples of such hard cemented breccias may be studied on the ridge east of the Blue Bull mine, and views of them are given in Plate XIX. The fragments of the breccias vary much in size, and it is impossible to draw any definite line between brecciation and close irregular fissuring. In many places the rock appears to have been shattered without any noticeable displacement, rounding, or trituration of the fragments.

The ledge matter as a whole is porous and permits the downward percolation of atmospheric water, while the soft pyritized dacite on both sides is relatively impervious. Hence, oxidation extends much deeper in the ledges than in the adjoining country rock and gives rise to a sharp color-distinction between rusty ledge matter and gray pyritized dacite.

The fragments in the oxidized ledge matter, which were originally dacite, are usually stained with iron oxide and now consist of gray, flinty, aphanitic quartz with a porous texture. Close inspection of this material shows occasional phenocrysts of quartz which have persisted practically unchanged while other minerals have altered to secondary aggregates around them. The pores are spaces once filled by feldspar and by femic (ferromagnesian) minerals in the original dacite. These minerals were first changed, during ore deposition, into aggregates consisting chiefly of alunite and pyrite, respectively. Later, during the progress of oxidation, the pyrite and alunite were removed and the spaces they once occupied were lined with drusy films of quartz. The removal, however, is complete only near the surface. In much of the

$a$ Since this was written the mining periodicals report (January, 1909) that the Clermont shaft has cut the Mohawk ledge at a depth of 856 feet (261 meters), or 241 feet ( 73 meters) below the bottom of the dacite. The ore found here is said to assay $\$ 22$ per ton. The character of the ledge matter is not stated. 
rusty ledge matter the fragments, when freshly broken, show pyrite and alunite. Not all of the pyrite and alunite are distinctly pseudomorphous, but these minerals are in part disseminated in minute crystals through what was once the groundmass of the dacite.

Below the limit of oxidation the ledge matter is usually less siliceous, less porous, and of course is not discolored by oxides of iron. The many small fissures and interstices in the mass are commonly filled with a soft white substance which is usually alunite or a mixture of alunite and kaolinite. The material of the fragments, or between the fissures, shows more clearly than in the oxidized zone that it is altered dacite, the feldspar phenocrysts being represented by aggregates of alunite instead of by quartz-lined cavities. These changes will be more fully treated in the chapter on metasomatism (p. 176).

Sheeted structure, suggestive of that in the Cripple Creek district, ${ }^{a}$ characterizes some parts of the Red Top, Mohawk, January, and Jumbo ledges, but is not common in the district. A small section of the Jumbo ledge in which this structure is well developed is shown on Plate $\mathrm{XX}, B$. The nearly parallel fissures are for the most part mere cracks rendered more prominent by silicification of their walls. Some are perceptibly open, their walls being lined with drusy films of quartz. The plates of dacite between the fissures are partially silicified and contain pyrite and alunite. Well-marked sheeting is displayed also in the Lone Star ledge.

In some ledges and parts of ledges there is no evidence of more than one period of fissuring and mineralization; others have had a more complex history and contain fragments which show signs of an earlier fissuring and silicification. In the latter case, the ore is associated with the younger disturbance. Some ledges, also, have undergone some fissuring after the primary ore deposition, as will be shown in subsequent pages.

Fissures filled with gouge which may contain gypsum, pyrite, and marcasite occur in some ledges, often as local division planes between ledge matter and country rock. The age of such fissures is not always determinable. A gouge seam may be formed very early in the history of a deposit and is likely to remain as a permanent feature, owing to the fact that gouge is relatively impervious to solutions and often retains its soft plastic character, while fissured rock alongside of it is profoundly altered. Such gouge-filled fissures remain planes of relatively easy movement and the material within them may be slowly squeezed and kneaded throughout the entire period of ore deposition. They may even continue to register such adjustments and displacements as take place in the ledges up to the present time As pointed out in another place $^{b}$ the soft condition of gouge is no proof of recent origin. In many cases it appears to be the record of continued movement which was initiated before ore deposition and continued after it had ceased. Still other fissures are plainly later than the first ore deposition and appear in the ore bodies as streaks of soft dark material, often carrying more gold than the adjacent ore.

Ledges in andesite have not been so fully explored as those in dacite, but they exhibit similar structural features. They are exemplified by the ledges worked in the Engineers', Little Florence, and Rogers leases in Florence Hill. The discovery of these ore bodies trom 1906 to 1908 shows that andesitic ledges may contain ore fully as rich as those in dacite. The ledges near Diamondfield are mostly in the Milltown andesite. Their character below the zone of oxidation appears to be different from that of the ledges near Goldfield. They are less siliceous, being as a rule soft, crushed masses, with none of the structures so characteristic of the pay shoots of the Goldfield group of mines, presently to be described. In their oxidized portions, however, these andesitic ledges are as hard and siliceous as any in the district.

The only rhyolitic ledge in which extensive work has been done is that of the Sandstorm and Kendall mines. Within the oxidized zone, the fissured rhyolite is thoroughly silicified and the walls of fissures and the surfaces of fragments are often encrusted with barite. The interstices are filled with kaolinite, usually more or less rusty and containing in many places

a See Lindgren, W., and Ransome, F. L., Geology and gold deposits of the Cripple Creek district: Prof. Paper U. S. Geol. Survey No. 54. 1906, p. 160.

$b$ Ransome, F. L., and Calkins, F. C., The geology and ore deposits of the Coeur d'Alene district, Idaho: Prof. Paper U. S. Geol. Survey No. 62 1908 , p. 120. 


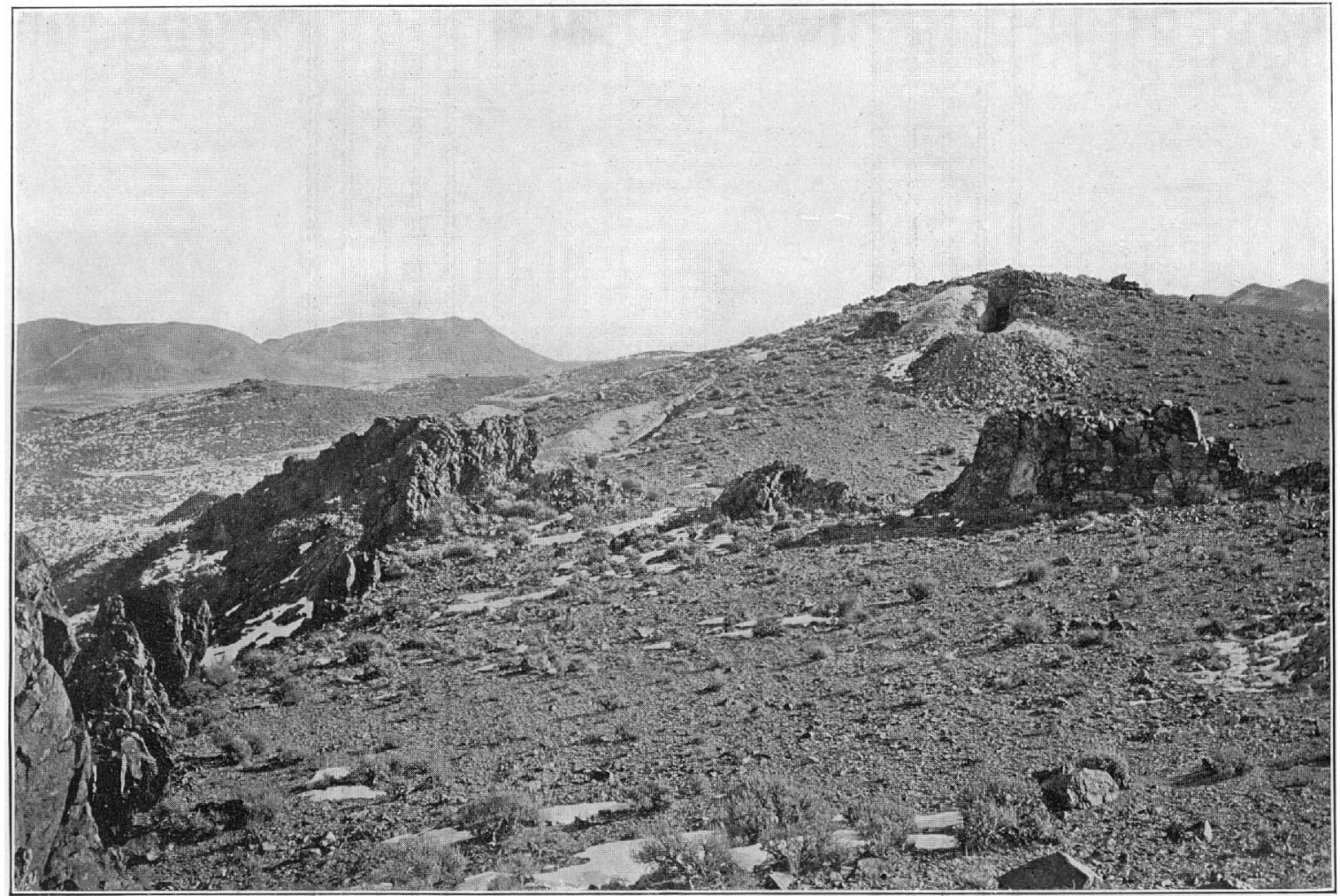

A. DACITIC LEDGes MEeting ON RIDGe NEAR the COMMONWEALTH MINE.

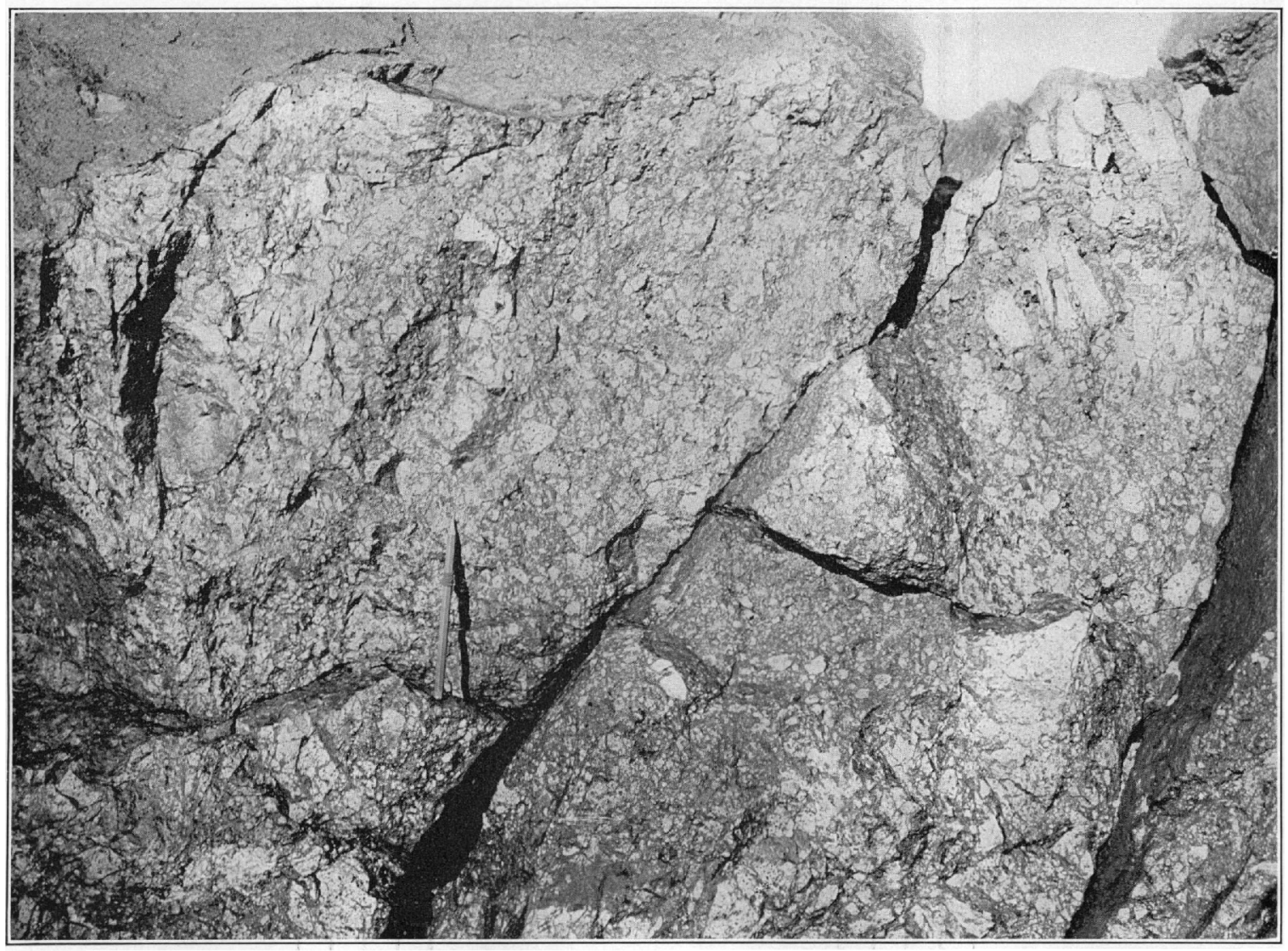

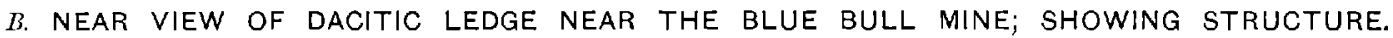




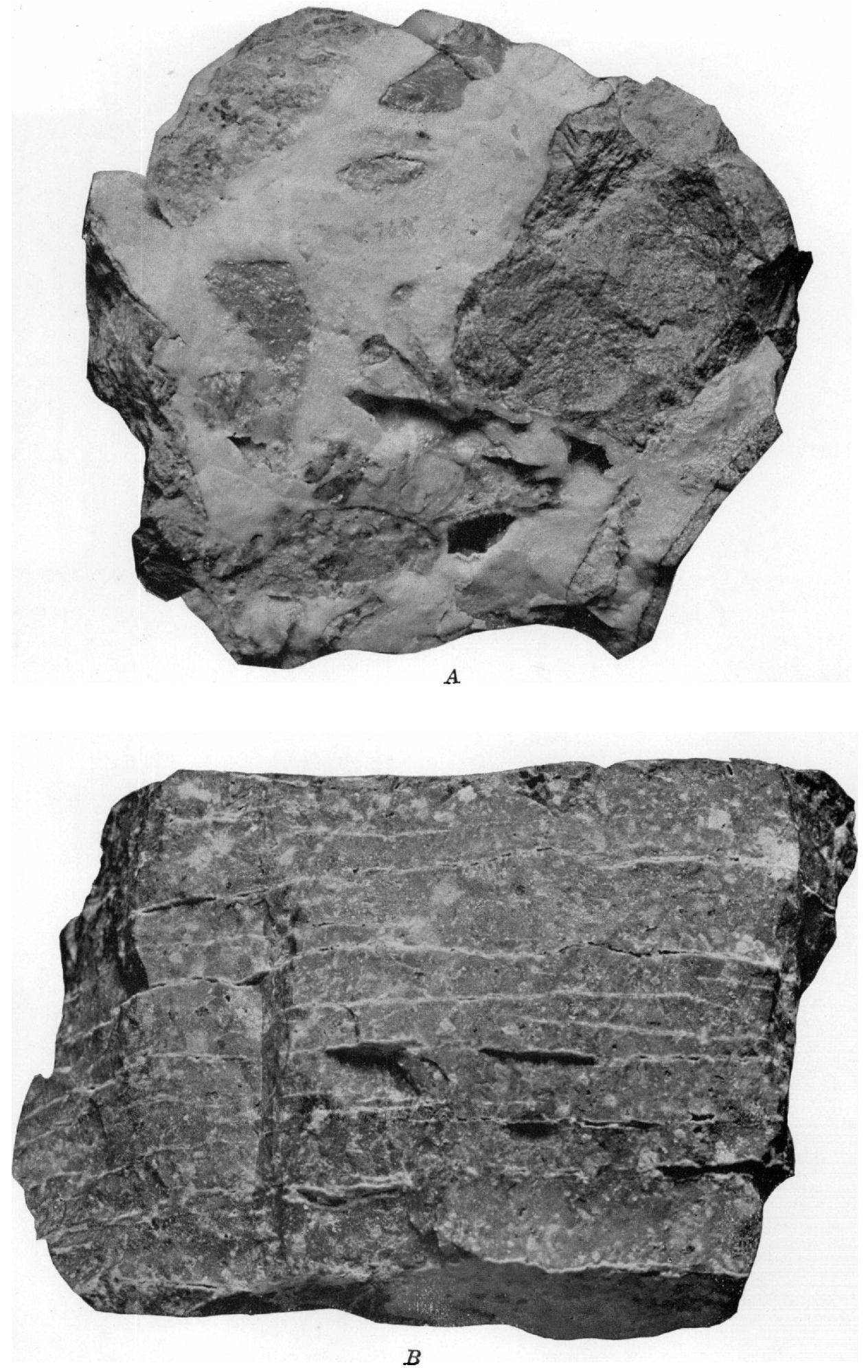

LEDGE STRUCTURES (NATURAL SIZE).

1. Veinlets of compact quartz and kaolinite in altered andesite (G. $76_{5}$ ); Goldfield. Belmont mine. B. Sheeted dacite and low.grade ore (G. 732); Jumbo mine. Dacite is alunitized. Fissures lined with quartz. 

crystals of barite. Below the zone of oxidation there is little to distinguish ledge material from the altered rhyolite in the vicinity of these mines.

The origin of the fissuring constitutes a problem that will be attacked in a later chapter. It may be pointed out at this place, however, that fissuring of the kind described has all the characteristics of fracturing that has taken place close to the surface or under very slight load. The multitude of small fractures, becoming noticeably less abundant and individually more regular within a depth of a few hundred feet, is clearly the comparatively superficial expression of more deep-seated and regular dislocation. Such complex fractures, as T. C. Chamberlin ${ }^{a}$ has well emphasized, are secondary phenomena related to more profound and more simple movements, and from the point of view of dynamics they are accessory, not essential. A similar, although less pronounced, change in the fissuring of the rocks at Cripple Creek at various depths has been pointed out and has received like explanation. ${ }^{b}$ At Goldfield the rocks when ruptured appear to have been under less load than at Cripple Creek.

The evidence furnished by the fissuring is thus in full accord with that derived from the geologic history of the Goldfield region as presented on page 86.

$a$ The fault problem: Econ. Geology, vol. 2,1907 , p. 590 .

$b$ Lindgren, W., and Ransome, F. L., Geology and gold deposits of the Cripple Creek district, colorado: Prof. Paper U. S. Geol. Survey No. 54, 1906. p. 167. 


\section{CHAPTER XIII.}

\section{THE PAY SHOOTS AND ORES.}

\section{DISTRIBUTION.}

In a broad way the general distribution of the ores with reference to the various rock formations has been indicated in the preceding chapter. It is safe to say that over 80 per cent of the gold obtained in the district has come from the intrusive body of dacite that lies just northeast of Goldfield. In this rock chiefly are the Red Top, Laguna, Mohawk, Combination, January, and Florence ore bodies. Next in importance are the ore bodies in andesite, a class of more recent development, which includes the pay shoots of the Little Florence, Rogers, and Engineers' leases, and the deposits near Diamondfield with the exception of the Flat vein on the south side of Black Butte, which is in dacite. The only ore bodies of proved importance in the rhyolite are those of the Sandstorm and Kendall mines, and these are superficial.

\section{RELATION TO LEDGES.}

In some deposits ore and ledge matter are practically coextensive; but usually, and particularly in the larger deposits, the ore constitutes a small part of the entire ledge. This is particularly true in the oxidized zone, where the ledges are wide and irregular and where more or less secondary concentration of the gold has taken place. In such ledges the ore may occur within the mass as irregular pods or bunches, or it may lie on one side of a body of ledge matter, with the country rock forming practically one wall. (See Pis. XVI and XVIII.)

\section{SHAPE.}

Description of the shape of the Goldfield ore bodies is difficult because the ore bodies themselves are inherently vague. The pay shoots as a rule have nothing to distinguish them structurally from barren ledge matter. They have no boundaries other than the invisible limits beyond which the assayer's returns show stoping to be unprofitable. The change from very rich ore to practically barren ledge matter may take place within a short distance, but it is nearly always a gradation, not a definite boundary. The size of pay shoots, and to some extent their shape also, depend, therefore, upon conditions which determine the grade of ore that can be profitably treated at any given time. If the economic boundary between ore and waste be placed at $\$ 25$ a ton, a given ore body will have a definite shape and size. If the limiting value be reduced to $\$ 20$ a ton, the same ore body will be larger. We may assume that its shape will be somewhat similar to that defined by the higher value, but beyond this we can not go without such detailed and systematic exploration of pay shoots as is hardly ever practicable in this district. In reading the following statements as to the form and dimensions of pay shoots these conditions should be kept in mind.

In general, the pay shoots are fully as irregular as the ledges with which they are associated. Some of them are roughly equidimensional masses, others are lenticular, some are approximately spindle shaped, with the large axis nearly vertical, and still others are tabular or platelike, although such sheets of ore are often curiously twisted or warped. The striking feature of the ore bodies as a whole is the absence of, rather than the approximation to, any regularity of form. While many of the pay shoots conform to the trend of the inclosing ledge, others do not.

Some idea of the shapes of pay shoots as determined by stoping may be had from Plate XVI, which shows plans of the ore bodies on successive levels of the January mine, with a 
generalized section through the workings. The change in form in passing from one level to another is very striking, although the levels are only 50 feet ( 15 meters) apart. Similar changes are shown in the Combination mine, as illustrated in Plate XVIII. In both these mines the tendency of the pay shoots to become narrower and more regular with increase of depth, corresponding to the tendency already noted in connection with the ledges, is well marked. The richest ore on the upper levels of the Combination mine occurred in chimney-like shoots of short stope length. These either pinched out at slight depth (see p. 213) or merged below with shoots of different form. When the mine was revisited in 1908 it was found that the outlines of the original rich shoots had been in most places obliterated by the enlargement of the stopes in consequence of the lower grade of ore that it is now possible to mill at a profit. Details of the pay shoots of the January and Combination mines will be found on pages 211 to 219 .

Beyond the fact that their longer dimensions usually lie nearly in the general plane of the ledge the Mohawk pay shoots have little regularity of form, particularly on the upper levels. This may well be seen in the Hayes-Monnette stope (Pl. XXI, $B$ ), easily reached from the 245-foot level of the main shaft. This is a great chamber, or rather a series of chambers, one opening unexpectedly into another, and without special illumination the visitor finds it difficult to realize its shape or size. It is over 100 feet (30 meters) in height and of very irregular plan, the total stope length being about 75 feet (23 meters). Below the 245 -foot level the HayesMonnette shoot merges with other pay shoots stoped from the Truett and Frances-Mohawk lease shafts (see PI. XXXIII) and with an irregular chain of ore bodies extending down to the bottom of the main Mohawk workings. Only by long familiarity with the mine or by the aid of a carefully constructed model is it possible to gain any satisfactory conception of the shapes of these pay shoots as indicated by existing stopes. That they are on the whole of flat form and lie generally with the ledge and not across it is shown by figure 15 and Plate XXXIII.

Among the pay shoots which approach tabular form may be mentioned the southern part of the main shoot of the Combination mine above the 130 -foot level. As worked on this level in 1905 , the pay shoot, then known as the No. 2 shoot, was near the hanging wall of the ledge and had a maximum width of about 6 feet ( 1.8 meters) and a length of 300 feet (91 meters) or more. In 1908, however, the whole ledge had been stoped to a width of 40 feet (12 meters). In spite of the regularity of the ore on this part of the 130-foot level the pay shoot, as shown by Plates XVII and XVIII, does not extend directly down to the lower levels.

The Reilly pay shoot is also of tabular or flat lenticular form, but shows striking changes in dip and strike, as illustrated in figure 16 and Plate XXXV. In the Florence mine the principal pay shoots are roughly lenticular masses of which the stope length rarely exceeds 100 feet (30 meters). The maximum stoping width of the large Sweeney shoot was about 18 feet (5.5 meters). These masses occur in a very irregular ledge (see pp. 227 to 229) and are not of great persistency in the line of pitch. Even the relatively large Sweeney shoot has a vertical range of little more than 100 feet (30 meters). (See fig. 17.) The pay shoot of the Jumbo mine appears to have more regularity than is usual in this district, but not much is yet known as to its behavior below the 250-foot level. Near the surface the ore body has a practically continuous stope length of over 500 feet (152 meters), and in one or two places is as much as 20 feet ( 6 meters) in width.

Flattened shoots lying in the plane of the ledge, but with stope lengths so short as to suggest the pipelike or chimney-like form, occur in the Mushett and Engineers' leases. In the latter mine the pay shoot apparently does not extend below the 300 -foot level. The pay shoots of the original Little Florence lease also are roughly lenticular with short stope lengths, and, so far as known, do not extend below a depth of 500 feet (152 meters).

In addition to the larger pay shoots, small, irregular, isolated bunches of ore, often of high grade, are rather characteristic of the district. Such were the bodies mined during the early days of Goldfield in the Velvet, St. Ives, Commonwealth, Lone Star, and Simmerone mines and in some of the mines in and near Black Butte. The sudden springing into notice of some hitherto obscure mine in consequence of the discovery of a rich bunch of ore; glowing descriptions of high-grade shipments in the local newspapers; and, in a few weeks or months, 
the cessation of shipments and an unheralded return to prospecting and development-these are the familiar stages of an oft-repeated story in the Goldfield district.

The oxidized ore bodies hitherto worked in the Sandstorm and Kendall mines differ from most of the pay shoots of the other mines in that they do not pass downward directly into sulphide ores. As a rule, the ore bunches, which are very irregular, rest upon an uneven although generally nearly horizontal floor of hard, silicified rhyolite, which shows little sulphide mineralization. Some of these shoots extend from this floor to the surface as nearly vertical pipes. Others are flat-lying masses in which the horizontal dimensions exceed the vertical. Up to the end of 1908 no ore had been found in these mines below a depth of 80 feet (24 meters).

As compared with ore bodies of other gold districts, such as Cripple Creek, those of Goldfield are small, although the disparity in size would undoubtedly be less if the definitions of ore and waste were the same in the two districts. One of the largest stopes in the Goldfield district at the end of 1905 was the curved opening on the northern part of the January ledge, which extends from the surface nearly to the 160 -foot level. The maximum stope length of this body was about 200 feet (61 meters) and the greatest width of ore about 25 feet (7.6 meters). Another large opening is the Sweeney stope in the Florence mine (PI. XXI, $A$ ). From this a lenticular body of ore about 100 feet (30 meters) in diameter and up to 18 feet (5.5 meters) in width was extracted.

Of late years some large stopes have been opened in the Combination mine. The so-called "glory hole," of which a view is shown in Plate XXII, $A$, is an irregular opening probably over 100 feet ( 30 meters) long, up to 75 feet ( 23 meters) wide and 80 feet (24 meters) deep, while below it, as shown in Plate XVII, are continuous although narrowing stopes down to the 280-foot level. Another large stope is that east of the main shaft, which on the 130 -foot level is nearly 500 feet ( 152 meters) long and up to 40 feet (12 meters) wide, its height being trom 100 to 150 feet (30 to 46 meters). The Hayes-Monnette stope in the Mohawk, as already described, is also a large one, and when the new mill of the Goldfield Consolidated Mines Company is in operation some very large openings will undoubtedly be made in the Mohawk ledge, which as yet has supplied only high-grade ore.

In comparison with such bodies of ore as were taken from stopes in granite in the Portland, Stratton's Independence, and Ajax mines at Cripple Creek, the largest known pay shoots at Goldfield are small. The tenor of the ore mined, however, is much higher than in the Colorado district.

\section{RELATION TO FISSURING.}

Although, as will be fully explained in a later chapter, metasomatic replacement has played no small part in the formation of the ore deposits as a whole, that process and the ores themselves are very closely controlled by fissuring. Such complete replacement of rock by masses of sulphides as takes place in some limestones, a replacement which in that rock may extend for considerable distances from the fissures supplying the active solutions, is not found at Goldfield. There fissuring, not relative solubility or chemical instability of the country rock, has determined the shape of the deposits. The irregularity of the ore bodies, like that of the ledges, is consequent upon the unusual complexity of the fissuring. In any ore-bearing ledge the ore is found where the fissuring has been most intense and where originally there were abundant openings to admit the depositing solutions. The favorable conditions are clearly rather loose, open fissuring or shattering, not followed by any such extensive movement as would squeeze the shattered material together and clog the interstices between the fragments with impervious gouge. In many places there appears to be a close connection between ore deposition and the intersections or junctions of divergent zones of fissuring. Good examples of this feature are found on the 80-foot and 130-foot levels of the Combination mine (see Pl. XVIII), and in the Rogers, Sandstorm, and Kendall mines. As stated on page 156, some ore bodies show recurrent fissuring; where ore is traversed by later fissures, these and the material adjacent to them are usually richer than the rest of the ore. Such later fissuring may thus modify the original shape of an ore body. 


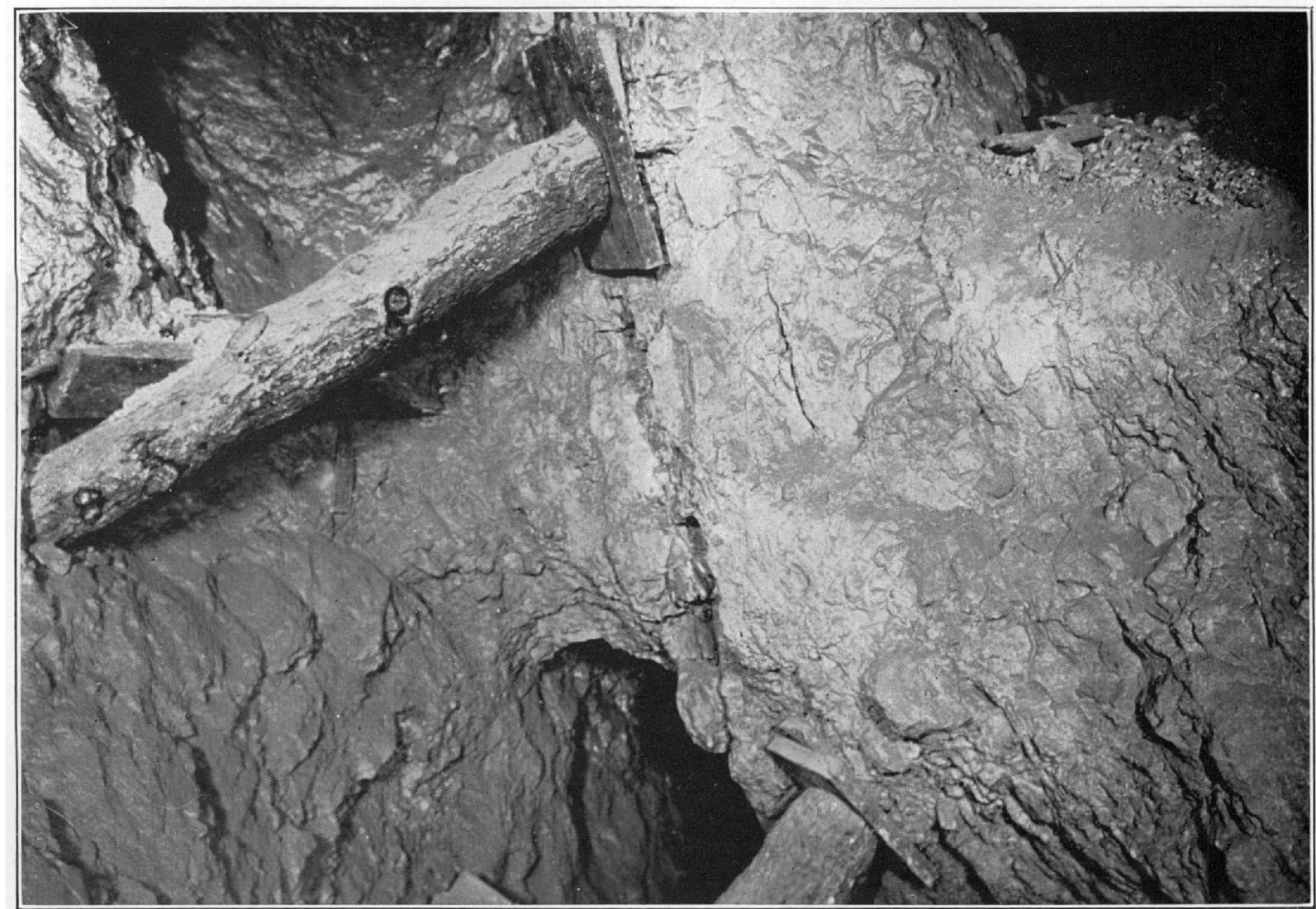

1. PART OF THE SWEENEY STOPE IN THE FLORENCE MINE.

Note shattered ledge matter and absence of any regular boundary between ore and waste.

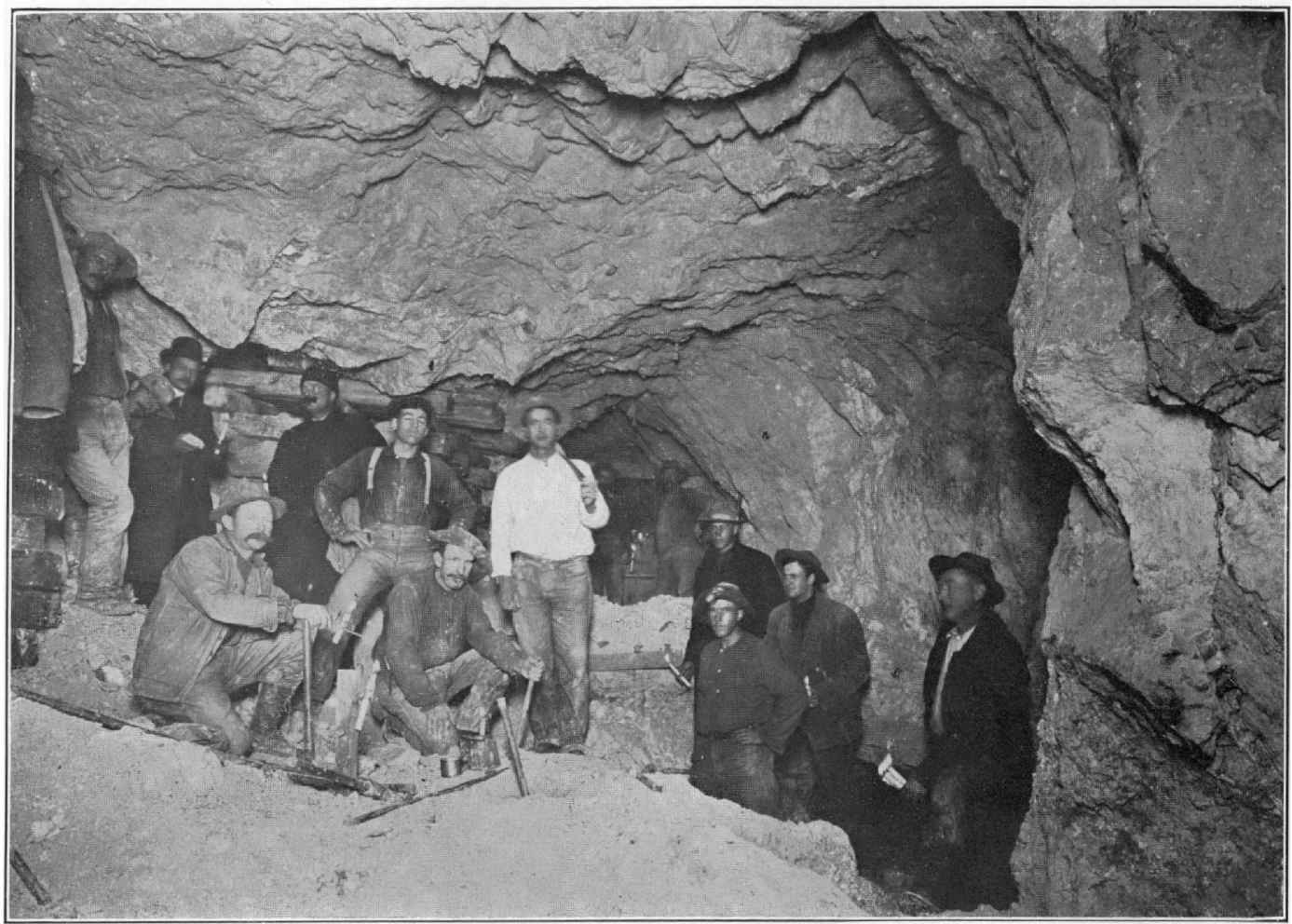

R. THE HAYES-MONNETTE STOPE IN 1906.

Afterward much enlarged. Photograph by P. E. Larson. 



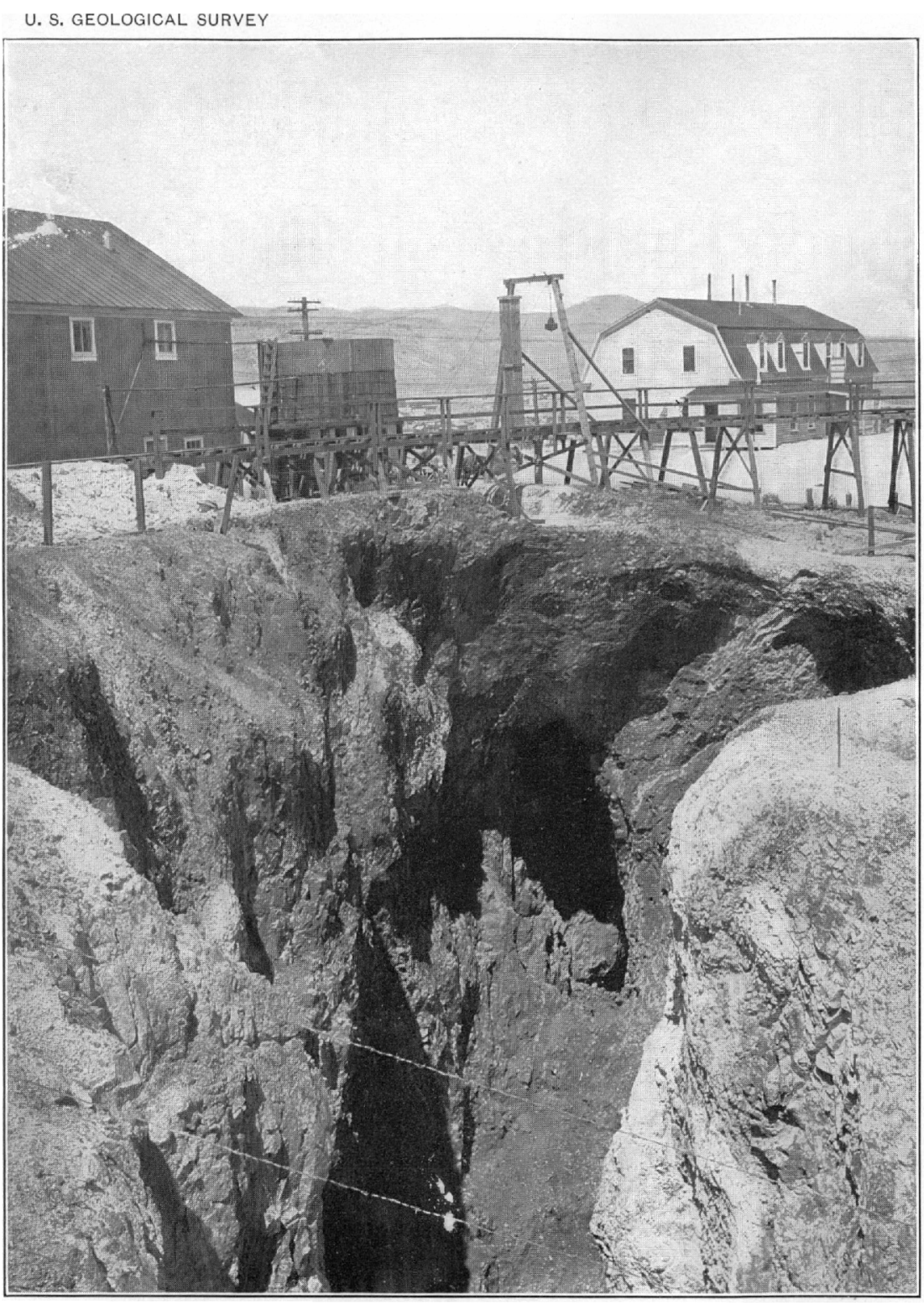

1. the "glory hole" of the combination mine.

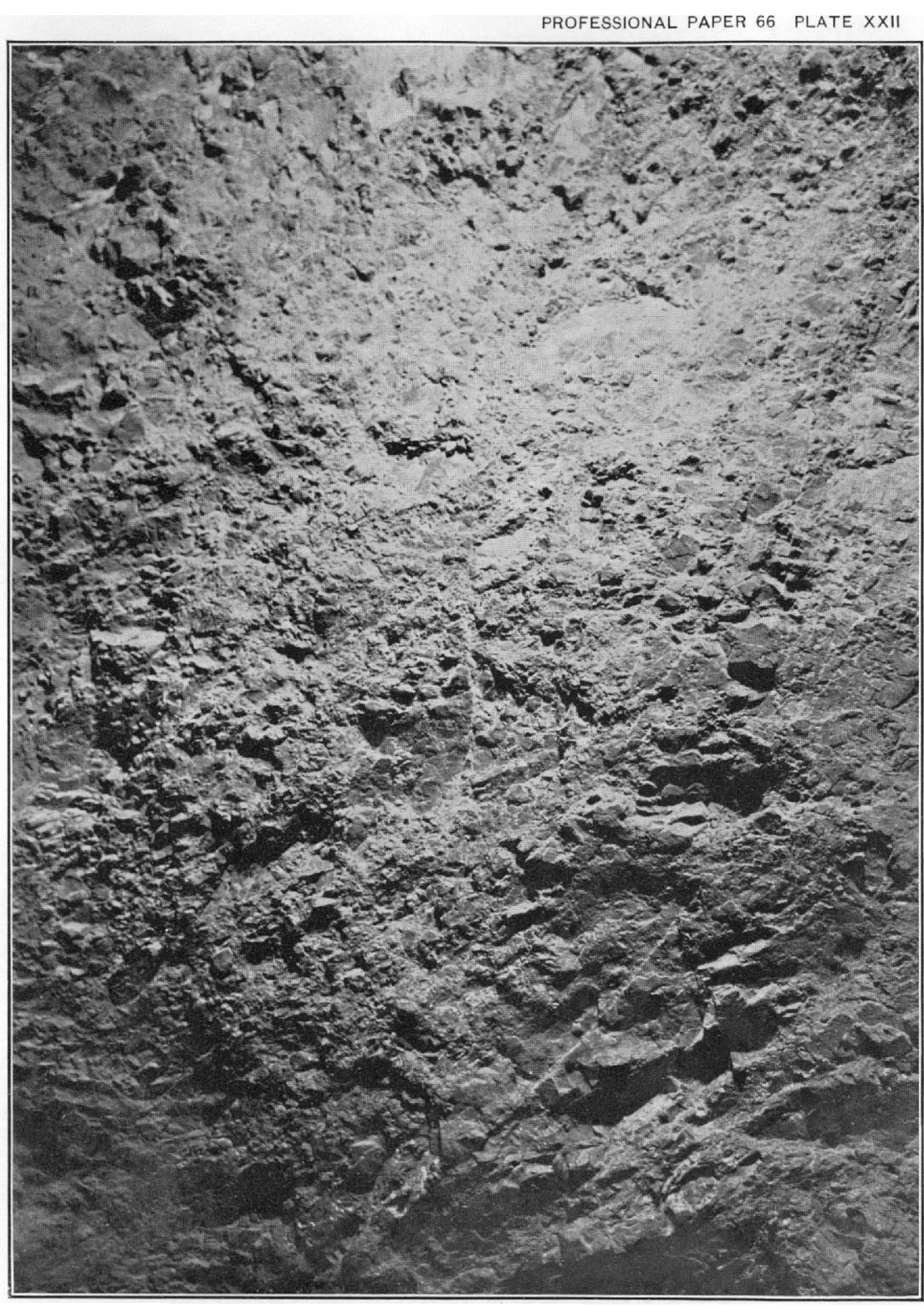

B. Ledge matter on the 150-Foot LeVel of the florence mine. 

Mere character of fissuring, however, as visible within a few hundred feet of the surface, is only one of several factors determining ore deposition. The district abounds in illustrations of the fact that fissuring, apparently of the most favorable kind, is not necessarily followed by the accumulation of an ore body. The fissure complex must evidently be connected with still deeper channels in such a way as to give access to ore-bearing solutions, and probably also with lateral and superficial channels through which other solutions could pass to mingle with the waters of deep origin and precipitate their valuable constituents. Thus locality and the features of a former topography were probably both of great importance in determining whether a given mass of shattered rock should become an ore body.

That some further modifications of the original shapes of pay shoots take place in the course of oxidation is highly probable, although the steps of such change can not usually be traced. Oxidation implies changes in volume of the constituents of the mass with more or less gravitative readjustment or settling, minor fissuring, and some migration of material by resolution and redeposition.

\section{EFFECTS OF FAULTING.}

So far as known the ore bodies have not as a rule been greatly modified by faulting subsequent to ore deposition. In this respect they differ in striking fashion from the veins of Tonopah. It must be pointed out, however, that the difficulties in the way of the recognition of notable faulting at Goldfield are very great. The ability to recognize important dislocations depends very largely upon the degree to which the faulted structures were initially regular and persistent. When, for example, a well-defined regular vein which has been followed for some hundreds of feet ends abruptly at a fissure filled with attrition products, faulting is at once suggested and in many cases is easily demonstrated. At Goldfield, however, the initial regularity is lacking. It is known that ore bodies in this district show unexpected and erratic changes in direction and may terminate abruptly without faulting. There is in many cases no a priori ground for supposing that beyond the apparent end of an ore shoot is another body, once continuous with it, but now displaced. The evidence of movement both in and around the Goldfield ore bodies is abundant, but the interpretation of this movement - the discrimination between slips of structural importance and those whose total displacement is measurable in inches rather than feet-is as a rule impossible or inconclusive. If a pay shoot ends at a seam of gouge, and if a few hundred feet away another pay shoot is found on the other side of a similar gouge-filled fissure, there is as a rule no means of identifying the two bodies as originally part of the same mass, nor can it be assumed in this district, where gouge seams are known to bend through angles of $90^{\circ}$ or more, that the gouge in contact with the two masses of ore occupies one continuous fissure.

The difficulty in the way of identifying gouge-filled fissures from point to point by means of a few isolated exposures is well illustrated by the plan (fig. 18) of the 350-foot level of the Mohawk mine, a level on which the so-called hanging wall of the ledge is visible at more places than elsewhere in the mine. Near the upper Curtis shaft this wall, which is defined by a gouge seam dividing ore or ledge matter from soft, altered dacite, has a curved but generally northerly course. Near the Mohawk shaft the hanging wall swings to the east and a similar seam of gouge traverses the ledge matter, passing through the shaft. The two fissures must join or intersect about 100 feet south of the main shaft. Near the Mohawk-Jumbo stope the hanging wall turns northwest. As a whole it is a very sinuous curve. The hanging wall is probably not a single fissure, but a series of fissures, each one of which serves as hanging wall for a short distance and then passes either into ledge or country rock. The significance of this is that the hanging wall is probably as erratic in section as it is in plan. Neither in plan nor section can its true course be drawn from a few isolated exposures.

The conditions as regards faulting may perhaps be best understood by keeping in mind the facts that the ledges as a whole are hard, brittle masses of irregular contour, and that the altered country rock in which they lie is as a rule soft and plastic. The result of any competent compressive stresses applied to the whole system would be to cause more or less slow 
flowage of the soft country rock around the masses of ledge matter, and in some degree to deform the latter by fracturing or, if the system were much strained, by faulting. On a small scale the process is illustrated by the conditions in some serpentine masses, such as those in the Coast Ranges of California, where the pressure due to the increase of volume consequent upon serpentinization of the original peridotite has caused the softer portions of the mass to flow around the harder slickensided nodules. Such a conception, it is believed, best explains the prevalent fractured condition of the ledge matter and its frequent separation from the neighboring soft country rock by curved seams of gouge. That the entire mass of country rock (dacite, latite, and andesite) near Goldfield, with its included ledges, has been subjected to stresses capable of effecting such a result will be evident to anyone who examines the exploratory workings of the Kewanas, Combination, Fraction, or Portland shafts, or who studies the longer crosscuts into country rock in the principal productive mines. It is the general squeezing which such rock has undergone and the abundance of gouge-filled fissures that constitute one of the chief difficulties in tracing any structurally important fissures through it.

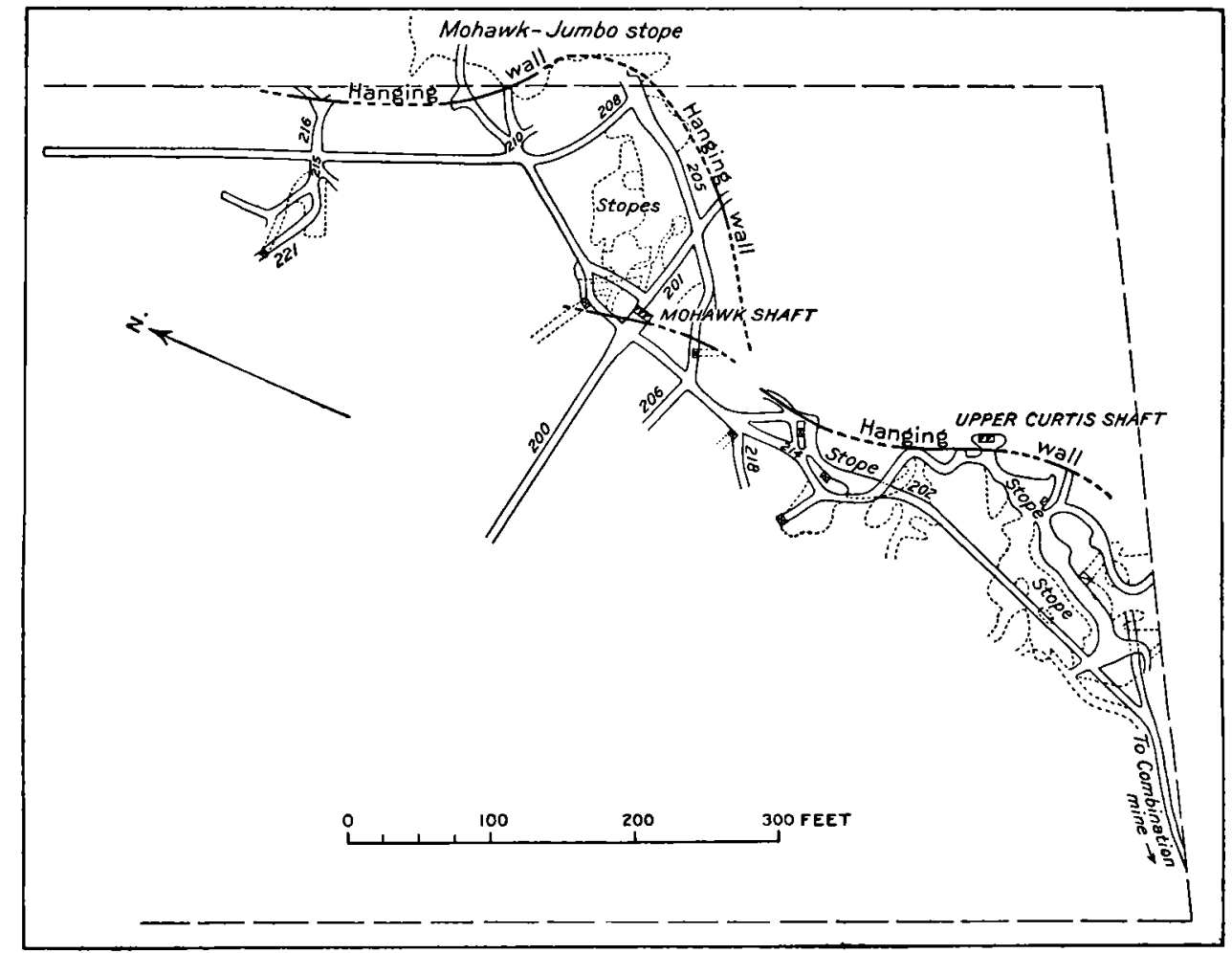

Figure 18.-Plan of the 350-foot level of the Mohawk mine, showing irregularity of the so-called hanging wall.

A few faults of small throw have been recognized in the Mohawk and Combination mines, but these do not materially aflect the shapes of the ledges and pay shoots. There is a possibility, as pointed out on page 212, that the irregularity of the Combination ledge below the 180-foot level, shown in Plate XVII, may be in part due to faulting generally parallel to the eastwarddipping dacite-latite contact, but this is a mere suggestion. Probably the strongest indication of important faulting of ore bodies comes from the relation of the Florence ledge to that of the Engineers' lease, which is described on page 232 and illustrated in Plate XXXV. In this case it is reasonable to suppose that the Engineers' ore body is displaced about 50 feet (15 meters) to the northeast from the Florence ledge by a curved fault, which dips to the southeast. (See fig. 28, p. 226.) Whether there is a corresponding displacement in the opposite direction between the Engineers' ledge and that of the Little Florence lease is not clear.

In conclusion, the possibility that some of the other ore bodies have been extensively displaced by important faults is not denied. It does not appear, however, that there is any evidence now available which adequately supports such a supposition. 
PAY SHOOTS AND ORES.

\section{INFLUENCE OF COUNTRY ROCK.}

The fact that so many of the larger and better ore bodies are in dacite has naturally made that rock a great favorite with prospectors, and in many cases anxiety to prove its presence has led to the erroneous identification of andesite or latite as dacite. The presumption in favor of dacite as an ore carrier was, however, far greater in 1905 than now, since the Little Florence, Rogers, and Engineers' leases have proved that just as good ore may be found in the Milltown andesite as in the dacite. It has always been difficult to see in what inherent properties the dacite had any advantage over the Milltown andesite. The chemical difference between the two rocks, as has been shown on pages 50,52 , and 56 , is very slight, and the only constant mineralogical difference is the presence of scattered phenocrysts of quartz in the dacite. That the Milltown andesite can be silicified and form ledges to as great an extent as the dacite is shown by the hundreds of outcrops east of Milltown, and by the strong flinty ledges of Kendall Mountain, McMahon Ridge, and Black Butte. It is true that the fresh dacite is a slightly more brittle rock than the average Milltown andesite, and perhaps on this account afforded better channels for the ore-depositing solutions in the early stages of mineralization. Its generally larger porphyritic crystals of feldspar may also be somewhat in its favor as regards ore deposition. The phenocrysts of quartz may have served as nuclei or centers of precipitation of silica from the ore-bearing solutions. While these slight differences may make the dacite a slightly better depository for ore than the Milltown andesite they do not seem sufficient to account for the overwhelming preponderance of the ore bodies in this rock, particularly as some ore equally good occurs in andesite. As regards areal distribution this preponderance is probably a matter of locality rather than petrography. In other words, the large ore bodies of the Mohawk and Combination mines occur where they do, not because the country rock is dacite instead of andesite, but because some conditions outside of the visible dacite mass determined the influx of highly auriferous solutions to those particular places.

As regards the latite also, recent developments in the larger mines and in the Hazel-Goldfield lease have tended to remove some of the prejudice against this rock based upon the fact that no ore bodies of any consequence have yet been found wholly within it. That ledges of the ordinary Goldfield type may occur in the latite is well shown on. Banner Mountain and elsewhere, but, perhaps owing mainly to its texture, the rock appears rather less susceptible of silicification than the dacite and andesite. The ordinary change observable near Goldfield is to a soft alunitic mass carrying abundant disseminated pyrite. Nevertheless, as described on pages 206 and 214, some excellent ore has been found in the latite near the dacite contact in the Mohawk and Combination mines. According to Mr. H. P. Henderson, ${ }^{a}$ the Hazel-Goldfield lease, also, has opened some ore in latite at the 718 -foot level. ${ }^{b}$ This, while encouraging as regards the future of the mines below the dacite, still does not offset the fact that the latite near the surface and away from the dacite has thus far proved barren. The evidence from experience suggests that the latite is a less favorable rock for ore deposition than either the dacite or the andesite.

The only ore of consequence found in rhyolite is that of the Sandstorm, Kendall, and Conqueror mines. This is oxidized ore, and all efforts to trace it down to workable bodies of sulphide ore have been futile. The probability that large or persistent bodies of ore will be found in any of the rhyolites appears to be small. The ore-bearing capacity of the pre-Tertiary rocks is problematic. As exposed at the surface they contain nothing of value so far as known. It is likely that the larger mines near Goldfield will have to sink to a depth of 1,000 feet (305 meters) or more before reaching the Cambrian shale or the alaskite. The probabilities at that depth are discussed on page 200. 


\section{PLATE XXIII.}

\section{Ore Structures (natural size).}

A. Very rich ore (G. 604). Combination mine. Polished face of altered dacite (d). Part of a fragment coated with gold and sulphides. The inner dark band to the right is gold in quartz. The outer dark band, separated from the gold by a narrow indistinct film of quartz, is famatinite. The external coating is chiefly alunite and pyrite. The photomicrograph of Plate XXVI, $A$, is from the same specimen.

$B$. Marcasite (G. 643). Florence mine. Incrusts a fragment of altered dacite. The white material partly covering the botryoidal marcasite is alunite.

C. Rich ore (G. 809). January mine. Polished face. The gray matrix is quartz. The irregular dark inclusions in the right-hand third of the specimen are famatinite; those in the left-hand third are bismuthinite; those in the middle zone are mostly bismuthinite, but some are famatinite.

D. Rich ore (G. 641). Florence mine. Polished face. Shows fragments of altered dacite coated with gold and sulphides. Interstices are filled with spongy quartz. Order of deposition from within out is gold, pyrite, famatinite, quartz. Gold is not visible in all of the fragments and in none of them forms a complete envelope. The specimen illustrates modification of shape of original dacite fragments by alteration and solution. Most of them have, inside of the sulphide shells, a shadowy envelope of cryptocrystalline quartz. This grades irregularly toward the centerinto alunitized dacite, which still retains traces of its original texture. The gold particles are for the most part clustered in this siliceous envelope.

E. Ore (G. 628). Florence mine. Polished face. Shows part of a fragment of altered dacite with shell of sulphides and quartz on left-hand side. The dacite fragment records at least two periods of fissuring and quartz deposition prior to the deposition of the sulphide shell.

F. Ore (G. 88). January mine. Polished face. Shows a fragment of altered dacite with outline modified by solution, incrusted with quartz, famatinite, bismuthinite, and pyrite. Gold is probably present, but is not visible. The dacite kernel contains alunite pseudomorphs after feldspar and, like the specimen illustrated by figure $\mathbf{E}$, was fissured and at least partly altered prior to the envelopment of the fragment by sulphides. The peripheral shella, from within out, are (1) a thin film of quartz, (2) a thin film of pyrite, and (3) an aggregate of quartz, bismuthinite, and famatinite much like that in figure $\mathrm{C}$.

\section{PLATE XXIV.}

\section{Ore Structures (Natural size).}

A. Rich nodular ore (G. 642). Florence mine. Fracture surface. A kernel of altered dacite is enveloped (1) by a not wholly continuous film of pyrite, (2) by a shell of famatinite, and (3) by a thick crust of dark cryptocrystalline quartz carrying famatinite, bismuthinite, and native gold.

$B$. Oxidized ore (G. 718). Red Top mine. Shows cavernous texture of cryptocrystalline quartz. 
U. S. GEOLOGICAL SURVEY
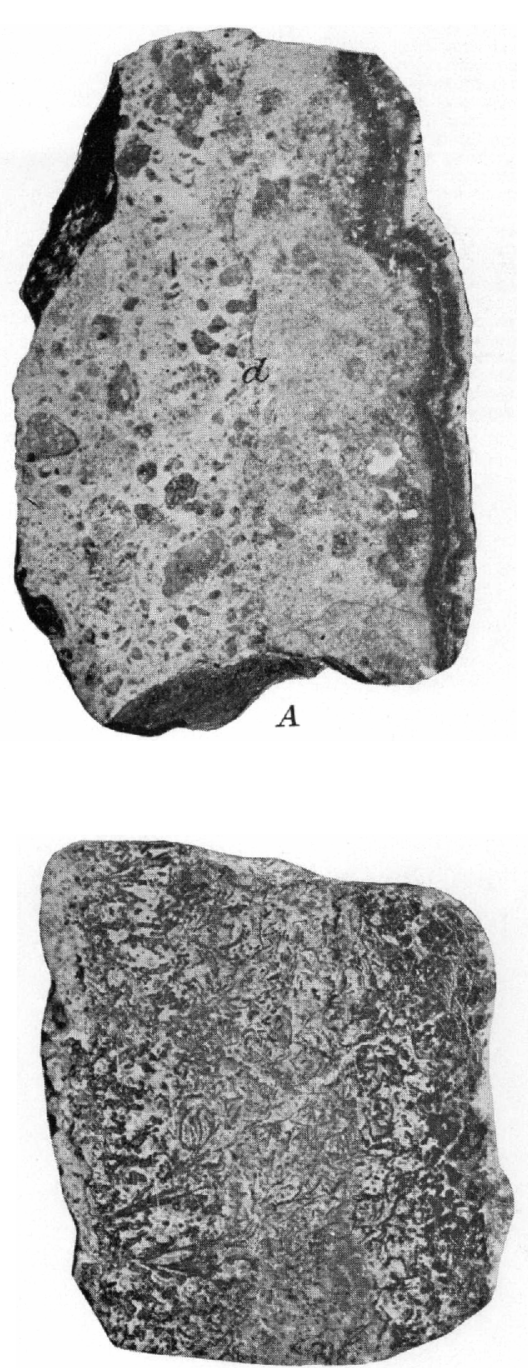

C

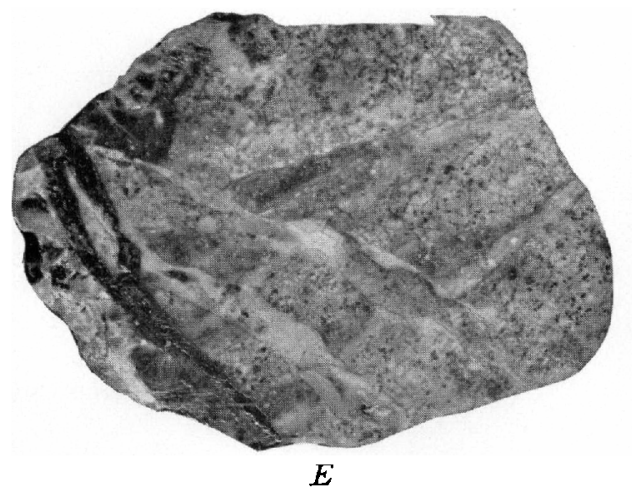

ORE STRUCTURES.
PROFESSIONAL PAPER 66 FLATE $X X 111$
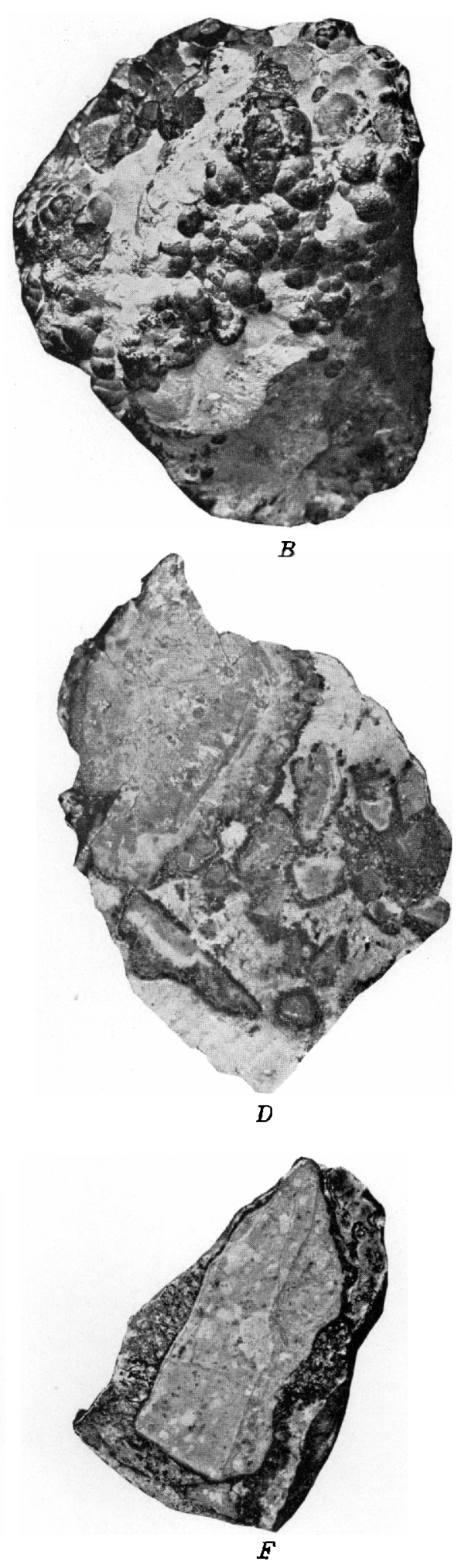


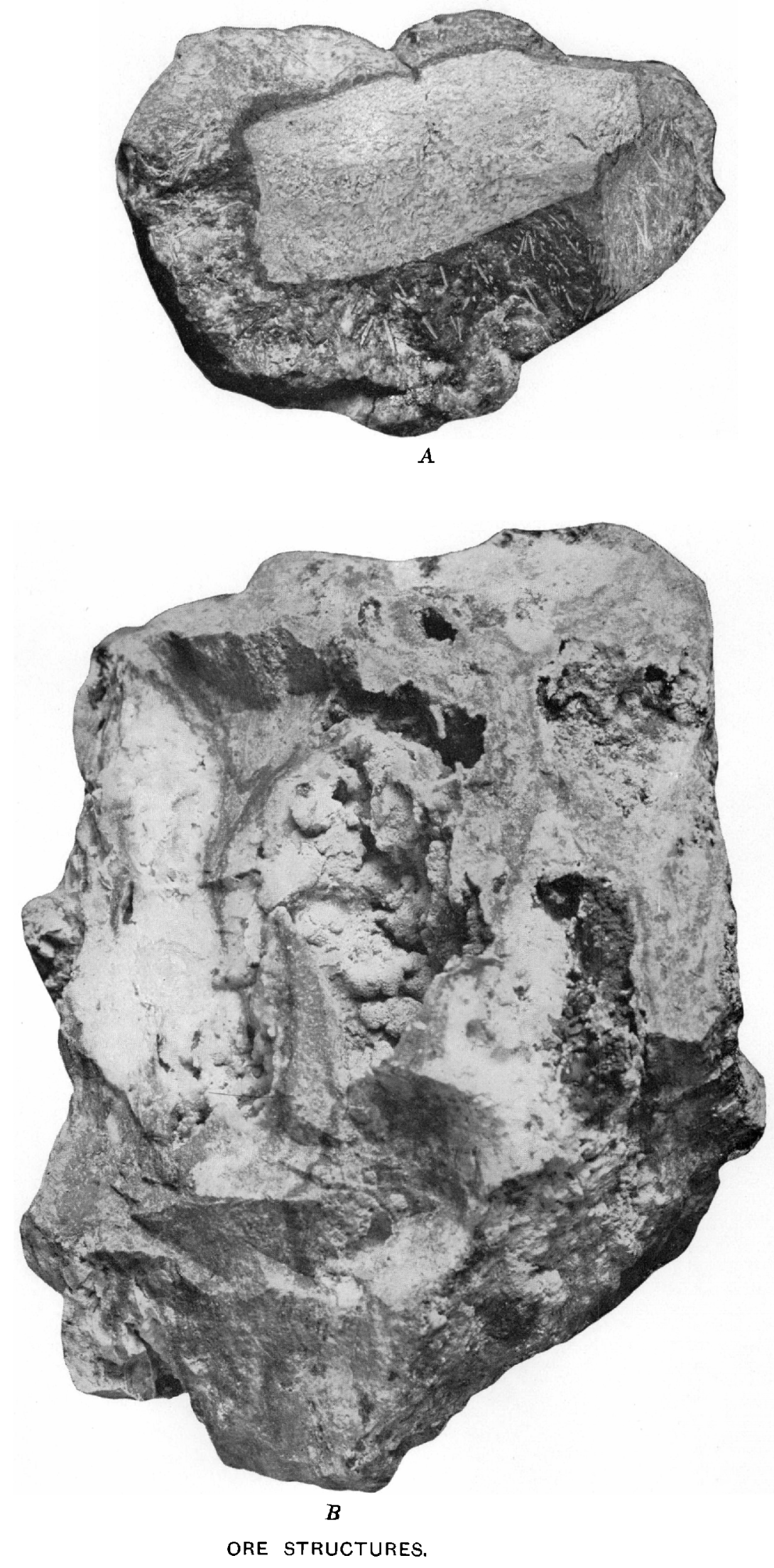



\section{MINERALOGICAL AND CHEMICAL CHARACTER OF THE SULPHIDE ORES.}

The typical unoxidized ore as it occurs in the dacite or andesite near Goldfield, particularly in the mines south of the Mohawk, consists of pyrite, bismuthinite, and a reddish-gray cupriferous mineral having the general composition of an arsenical famatinite (see p. 118), in a rather dark gray, flinty, quartz gangue. Native gold is usually associated with these minerals, particularly with the bismuthinite and famatinite, and in the rich ore may be easily visible. In ore of the Mohawk type, however, the gold is as a rule less conspicuous. The native gold is in many ores embedded chiefly in the quartz, but it may occur also in minute particles in bismuthinite, goldfieldite, or famatinite.

Concentric shells of ore minerals about greatly altered rock fragments are rather characteristic of the best ore. (See Pls. XXIII, XXIV, and XXV.) Specimens from the Combination mine (PI. XXIII, A) show an inner zone of free gold and quartz up to an eighth of an inch in thickness. This is covered by a shell of famatinite and this by an outer crust of pyrite. In the Florence mine similar fragments (PI. XXIV, $\boldsymbol{A}$ ) show, first, a shell of pyrite, then one of famatinite, and, finally, a thick crust of quartz speckled with native gold, famatinite, and pyrite, and transfixed by needles of bismuthinite. Some of the particles of gold are embedded in the compact quartz, others are inclosed in the bismuthinite. The different crusts are not in every case sharply defined nor are they necessarily continuous.

In the ore of the Engineers' lease two distinct crusts of gold have been observed. Thus in the specimen illustrated in Plate XXV, $B$, there is, next to the fragment of altered andesite, a thin discontinuous film of famatinite covered in places by a similar film of gold. Outside of this is a relatively thick layer of quartz and bismuthinite needles. Incrusting this is a second shell of gold particles in quartz about one-sixteenth of an inch in thickness. This in turn is covered by a skin of drusy quartz or is succeeded by a mass of cemented fragments of flinty quartz containing gold, famatinite, bismuthinite, and pyrite irregularly distributed through it. Another specimen from the same lease is shown in Plate XXV, A. Here the andesite fragments, which are silicified and full of fine pyrite, are coated first with pyrite, then with famatinite, and then with bismuthinite, all in very thin shells. Outside of these is an envelope of gold and outside of this envelope a thick shell of dark-gray dense quartz carrying gold and needles of bismuthinite. Both specimens are shown in natural size.

The native gold of these ores is often in particles so fine and so closely crowded in the gangue that the precious metal resembles a streak of yellow ocher, and it is only under a lens that the luster of the particles appears truly metallic.

Opportunities for examining the richest Mohawk ore in place were not patticularly good at the time of the visit in 1908. Specimens which were seen, however, show the same habit of crustification around fragments of rock as has been described. In the Mohawk ore, however, the most valuable crust is not a yellow aggregate of quartz and gold, but a dark-gray mixture of goldfieldite, and native gold, closely associated with marcasite, as described on page 116 .

The ore of the Mushett lease on the Miss Jessie claim northeast of the Red Top mine is structurally and mineralogically one of the most interesting in the district. The proportion of sulphides to gangue is greater than in most of the mines. The metallic minerals noted are pyrite, famatinite, bismuthinite, sphalerite, and a dark-gray mineral identical in appearance with that analyzed and described on page 116 , and probably like it the new species goldfieldite. This material is rich in gold, specimens which to the naked eye show not a particle of the native metal yielding over $\$ 8,000$ a ton on assay. The crustification in the Mushett ore is not very regular, but the minerals have formed in the following general succession: (1) Pyrite; (2) famatinite, bismuthinite, goldfieldite; (3) sphalerite; and (4) pyrite. The sphalerite in some places forms botryoidal crusts over the prisms of bismuthinite, which attain a larger size in this ore body than in other known occurrences in the district.

The material forming the extreme outer crust of the nodular ores of Goldfield or filling interstices between the altered and incrusted rock fragments is in most places a soft mixture of alunite and pyrite. 
The appearance of some of the typical rich ores in thin section under the microscope is illustrated in Plates XXVI and XXVII, which are accompanied by full descriptive notes. The very fine grain of the flinty quartz gangue is shown in these photomicrographs.

The proportion of silver in the Goldfield ores is usually rather small, the average of 34 assays of rich ore from the Mohawk mine, made for Mr. J. W. Finch, at one tıme general manager, giving 330 fine ounces of gold and 46.5 ounces of silver to the ton. In the Florence mine the ore of the deeper levels contains more copper and silver than that near the surface. A shipment from the 250-foot level in 1905 contained 100.8 ounces of gold and 3.5 ounces of silver per ton, and 3.5 per cent of copper. The highest silver assays from the upper levels, according to Mr. Frank Oliver, formerly superintendent of the mine, was less than 2 ounces per ton. There are some indications of a similar change in the Combination mine as regards the relation of silver and gold. A specimen of heavily pyritized dacite collected in 1905 from the 230-foot level was sent to E. E. Burlingame \& Co., Denver, for assay. This material, apparently consisting entirely of pyrite, quartz, and a little alunite, afforded 0.68 ounce of gold and 2.72 ounces of silver per ton. The sample was chosen in an attempt to find material representative of a type of ore likely to prevail at greater depths than 500 feet (152 meters). The ores near Diamondfield generally contain a larger proportion of silver than those near Goldfield.

Tests and chemical analyses of the ores made for scientific and technical purposes have from the first nearly all shown a little tellurium, although no tellurium mineral was recognized in the mines close to Goldfield until the discovery of the Mohawk ore bodies. Tellurides of gold, not sufficiently well crystallized for a determination of their species, occur in the Jumbo Extension and Goldfield-Belmont mines, near Diamondfield, and both tellurite and emmonsite (or durdenite) were found in 1905 in the oxidized ore of neighboring properties. ${ }^{a}$ W. F. Hillebrand has detected some selenium with the tellurium of these minerals. The tellurides are in some cases intergrown with native gold.

Most of the analyses of Mohawk ores made in connection with the prosecution of ore thieves show about 2 per cent of tellurium, which. as explained on page 116, is probably due mainly to the presence of goldfieldite.

The first sphalerite found in the ores of the district appears to have been a small speck noted in the Goldfield-Belmont mine by Mr. W. H. Blackburn in 1905. The mineral has since been found to be abundant in the Mushett and neighboring leases near Goldfield, where it formed subsequently to the rich ore.

Galena was unknown in the Goldfield district in 1905. It has latterly been observed in several leases, as noted on page 112 .

Chalcopyrite, a common mineral in most mining districts, was not found at Goldfield in the course of the present investigation, but it is said to occur sparingly in the Sandstorm and Florence mines. E. A. Collins ${ }^{b}$ notes very small quantities of chalcopyrite and zinc blende in the Combination ore.

The common gangue of the unoxidized ore is quartz. This is usually compact, almost flinty, in texture, although porous in mass, and in most cases bears unmistakable evidence of having resulted from the silicification of dacite, andesite, or latite. Large vugs and conspicuously crystalline quartz, such as are found in typical veins the world over, are practically absent from the Goldfield district, where the free development of quartz crystals in open spaces is represètited only by drusy films, lining pores left by the solution of phenocrysts, or incrusting small interstitial cavities in brecciated material. The appearance of typical quartz gangue as seen in thin section under the microscope is shown in Plates XXVI and XXVII. Even where the quartz, as in Plate XXIII, C', does not appear to have directly replaced a mass of rock, it is always cryptocrystalline and is usually full of little vugs. In such cases it appears to have filled spaces an inch or two across by the slow concretion of thin films on projecting crystals of bismuthinite and by the final coalescence of these films, leaving only a few small vugs. In other

\footnotetext{
a Ransome, F. L., Preliminary account of Goldfield, Bullfrog, and other mining districts in southern Nevada: Bull. U. S. Geol. Survey No. 303,1907 , p. 36 .

$b$ The Combination mine: Min. and Sci. Press, September 28, 1907, p. 398.
} 
PLATE XXV. 


\section{PLATE XXV.}

\section{Ore Strdctures (Natural size).}

A. Rich nodular ore (G. 995). Engineers' lease. Polished surface. Fragments of altered andesite, silicified and pyritized, with an envelope of at least six layers. Next to the andesite is a thin irregular shell of pyrite. Outside of this is a shell of famatinite. Outside of the famatinite is a nonmetallic film, probably alunite and quartz, which shows as a white line in the illustration. Outside of this is a thin layer of quartz containing particles of famatinite. Enveloping this is another shell of quartz containing minute gray needles which are probably bismuthinite. Covering this is a yellow envelope of quartz and gold. Last is a thick outer shell of quartz, bismuthinite, and gold.

B. Rich ore (G. 994). Engineers' lease. Polished surface. At top is a fragment of altered andesite. Under this is a thin film of famatinite, gold, and quartz. "This is succeeded by a broad dark band, which is an aggregate of quartz and bismuthinite. Below this is a second band of gold and quartz. The lower part of the specimen is a mass of cemented flinty quartz fragments carrying famatinite, bismuthinite, pyrite, and gold. The white areas are alunite. 


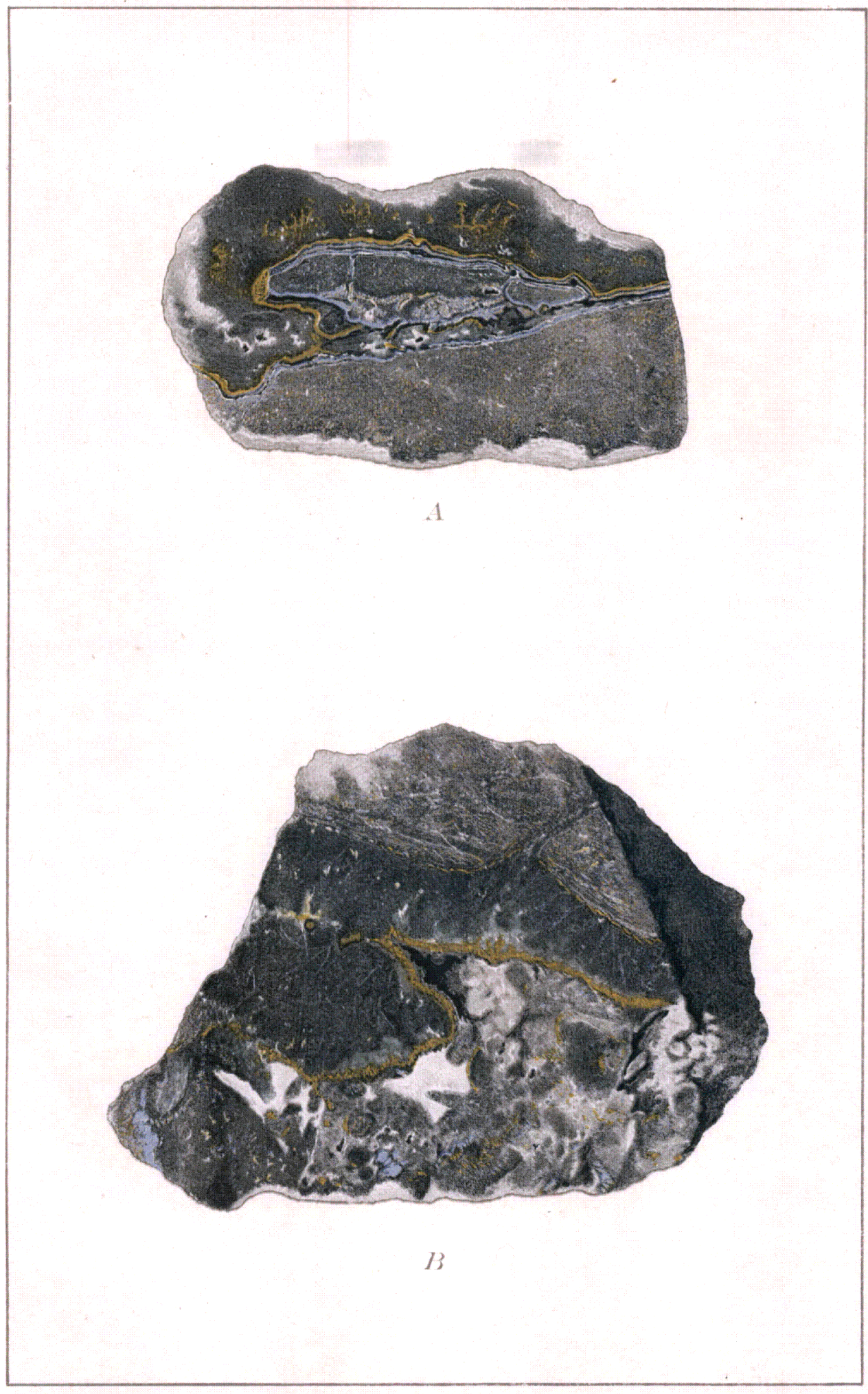

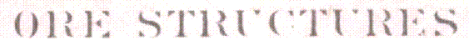



cases the films have started from fragments of rock lying in the cavity or fissure and have gradually thickened until the space became filled.

Associated with the quartz in much of the ore are soft white substances, such as the miners commonly call "talc." Chemical and microscopical tests of the white material show that in most cases it is either alunite or kaolinite or a mixture of the two. ${ }^{a}$ Sericite, supposed when the preliminary report ${ }^{b}$ on the district was written to be also abundant, proves on further study to be very rare and is certainly nowhere an abundant or characteristic mineral in the ore deposits. Gypsum, while not known with actual sulphide ore, is very abundant in the altered rocks within a hundred feet or so from the surface, and does occur crystallized with quartz and pyrite in the Goldfield-Belmont mine, below the belt of oxidation.

As a rule, the gold and auriferous sulphides are embedded in quartz. Alunite, however, is often so close to the gold as to appear in the same microscopic field, and the telluride of gold in the Jumbo Extension mine is partly embedded in alunite.

Some idea of the chemical composition of typical rich dacite ore may be had from the following analyses of unoxidized ore from the Mohawk mine kindly furnished by Mr. J. W. Finch, consulting geologist for the Goldfield Consolidated Mines Company, and by Mr. Charles $\mathrm{S}$. Thomas, jr. These analyses are given in the form reported by the analysts to the company, since in most cases they contain ambiguities, like "iron oxide," not safely translatable into more scientific expressions.

Analysis of composite sample of nine lots of Mohawk ore shipped early in 1907.

[Lochiel M. King, analyst. Reported February 13, 1907.]

\begin{tabular}{|c|c|c|}
\hline Water (combine & 7.00 & Zinc $(Z n) \ldots \ldots \ldots \ldots \ldots \ldots$ Very slight \\
\hline Silica $\left(\mathrm{SiO}_{2}\right) \ldots$ & 66.30 & Lime $(\mathrm{CaO}), \ldots \ldots \ldots \ldots \ldots \ldots$ \\
\hline Copper $(\mathrm{Cu}) . .$. & 2.08 & Magnesia $(\mathrm{MgO}) \ldots \ldots \ldots \ldots \ldots \ldots \ldots \ldots$ \\
\hline Bismuth (Bi)... & .35 & Sulphur $(\mathbf{S}) \ldots \ldots \ldots \ldots \ldots \ldots$ \\
\hline Tellurium ( $\mathrm{Te}$ ). & 2. 42 & Gold (Au) \\
\hline Antimony ( $\mathrm{Sb}$ ) & Traces. & Silver $(\mathrm{Ag})$. \\
\hline $\operatorname{Iron}(\mathrm{Fe}) \ldots .$. & - $\quad 3.83$ & Unaccounted for..... \\
\hline Alumina $\left(\mathrm{Al}_{2} \mathrm{O}_{3}\right.$ & 9.09 & \\
\hline
\end{tabular}

It may be noted in connection with the foregoing analysis that 2 per cent of gold is equivalent to 40 pounds avoirdupois, or 541.4 fine ounces per ton.

Analyses of Mohawk ore.

[W. D. Arnett \& Co., analysts. Reported December 17, 1906.]

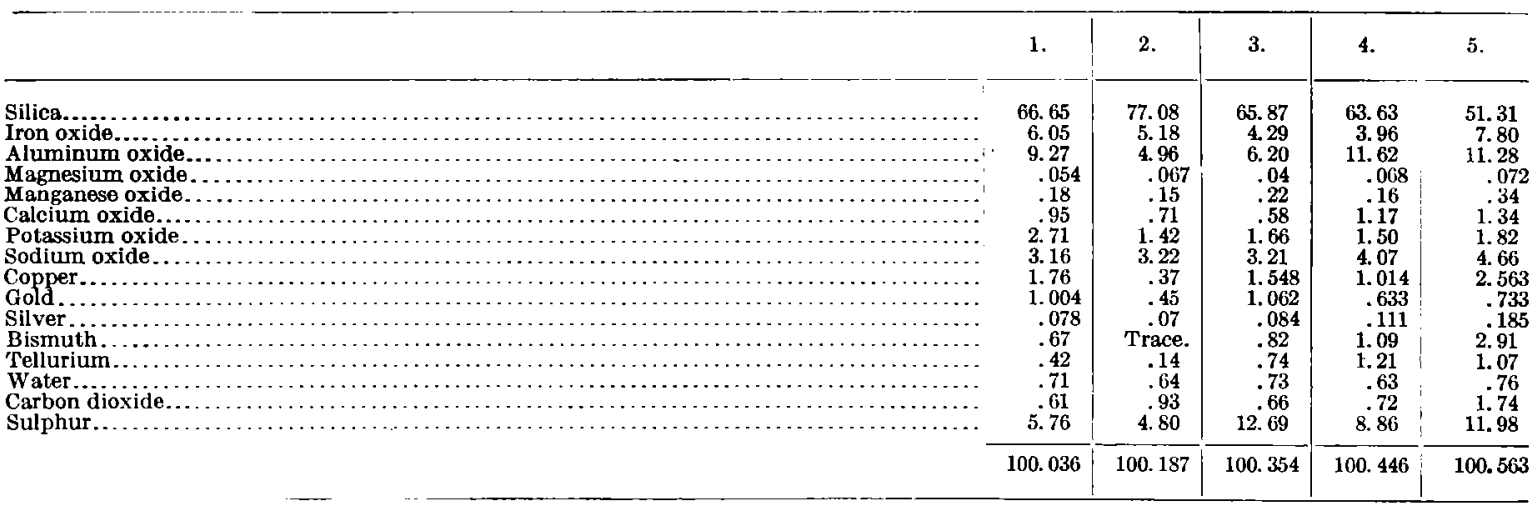

a E. A. Collins, in his recent good description of the Combination mine (Min. and Sci. Press, vol. 95, 1907, p. 398), refers to the ore as "a mixture of soft kaolinized material and hard dacite." The "kaolinized material" is chiefly alunite.

b Bull. U. S. Geol arvey No. 303, 1907, p. 35. 


\section{PLATE XXVI.}

\section{Photomicrographs of ores.}

$A$. Very rich ore (G. 604). Combination mine.

Right-hand side of section shows altered dacite, consisting of quartz, kaolinite (k), alunite, and finely disseminated pyrite. To the left of this is a band (about 3 inches wide in the illustration), consisting of finely divided native gold, famatinite, and bismuthinite in a gangue of minutely granular quartz. The gold, famatinite, and bismuthinite all appear black in the microphotograph, but over 75 per cent of these black areas represent gold. To the left of this band the quartz is a little more coarsely crystalline and contains bismuthinite and famatinite, with subordinate native gold. The specimen from which this section was made is shown in Plate XXIII, $A$. Nicols crossed. Magnified 40 diameters.

$B$. Rich ore (G. 389). Combination mine, 180-foot level.

The large black area, a little to the right of the center of the photomicrograph, is chiefly pyrite (p). The smaller black areas above it, however, are famatinite $(\mathrm{t})$, inclosing particles of native gold. Some of the smaller black specks are gold alone. The matrix or gangue is dacite, altered to an aggregate of quartz, alunite, and probably some kaolinite. A few of the original quartz phenocrysts $(q)$ appear in the illustration, while larger and more characteristic ones occur in parts of the thin section not included in the photograph. Nicols crossed. Magnified 40 diameters.

\section{PLATE XXVII.}

\section{Photomicrographs of Ores.}

A. Rich ore (G. 627). Intermediate or 300-foot level of Florence mine. The order of deposition is from the lower left-hand corner of the photomicrograph to the upper right-hand corner. The large black areas in the lower left-hand corner are pyrite $(p)$ and famatinite ( $t$ ), forming a crust on silicified dacite (dq). The famatinite generally envelops the pyrite. Deposited upon these is a crust of fine granular quartz $(q)$ and irregular prismatic crystals of bismuthinite (b). Holes in section (h). No gold is visible in this particular section. Nicols crossed. Magnified 40 diameters.

$B$. Ore (G. 87). January mine. Illustrates structure resulting from silicification of much brecciated dacite. The black areas are famatinite $(t)$ and pyrite $(p)$, in many places intergrown. These are surrounded by a very finegrained aggregate of quartz. The more coarsely crystalline quartz $(q)$ contains a few vugs (h). Nicols crossed. Magnified 40 diameters. 

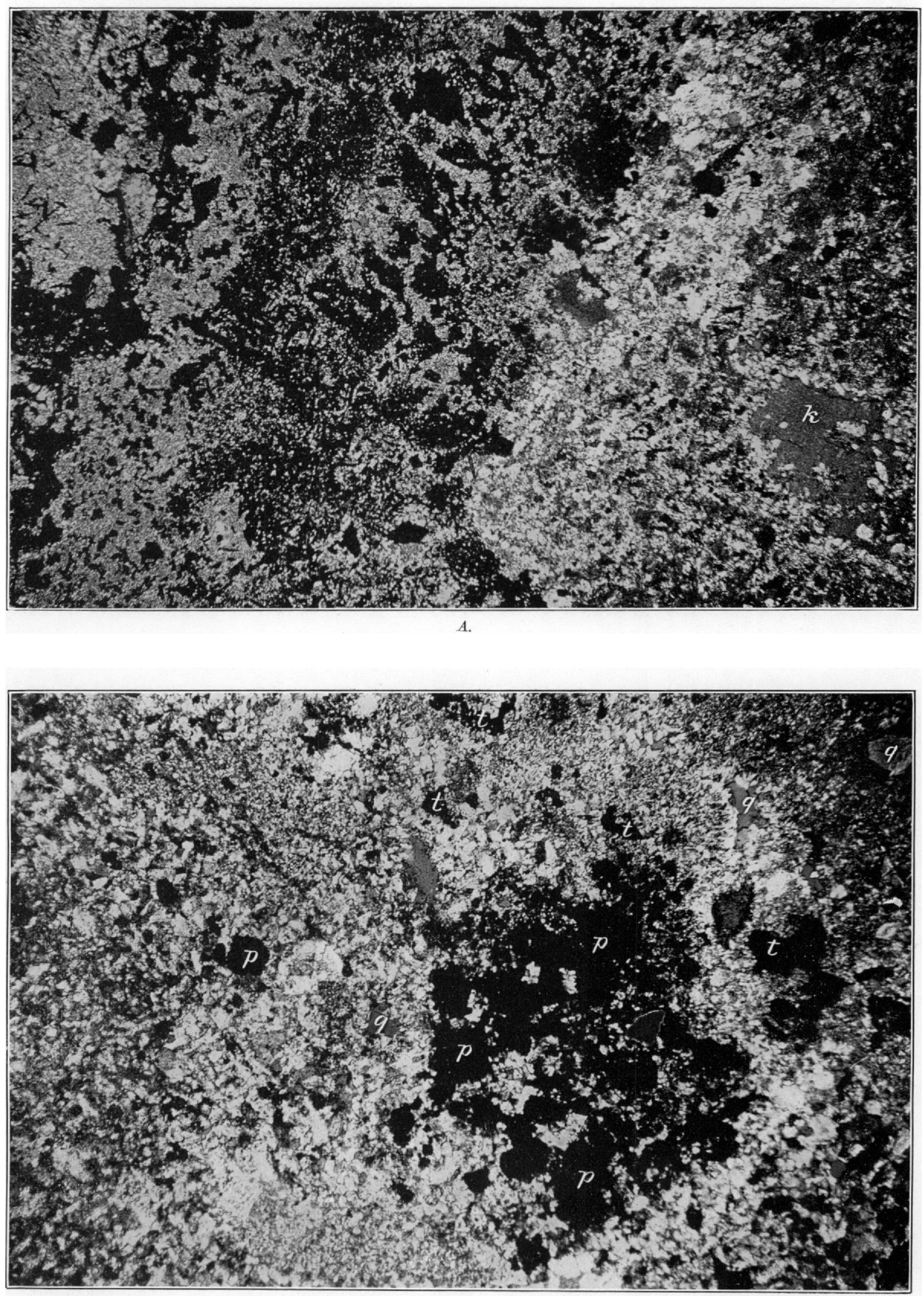

$B$.

PHOTOMICROGRAPHS OF ORES. 


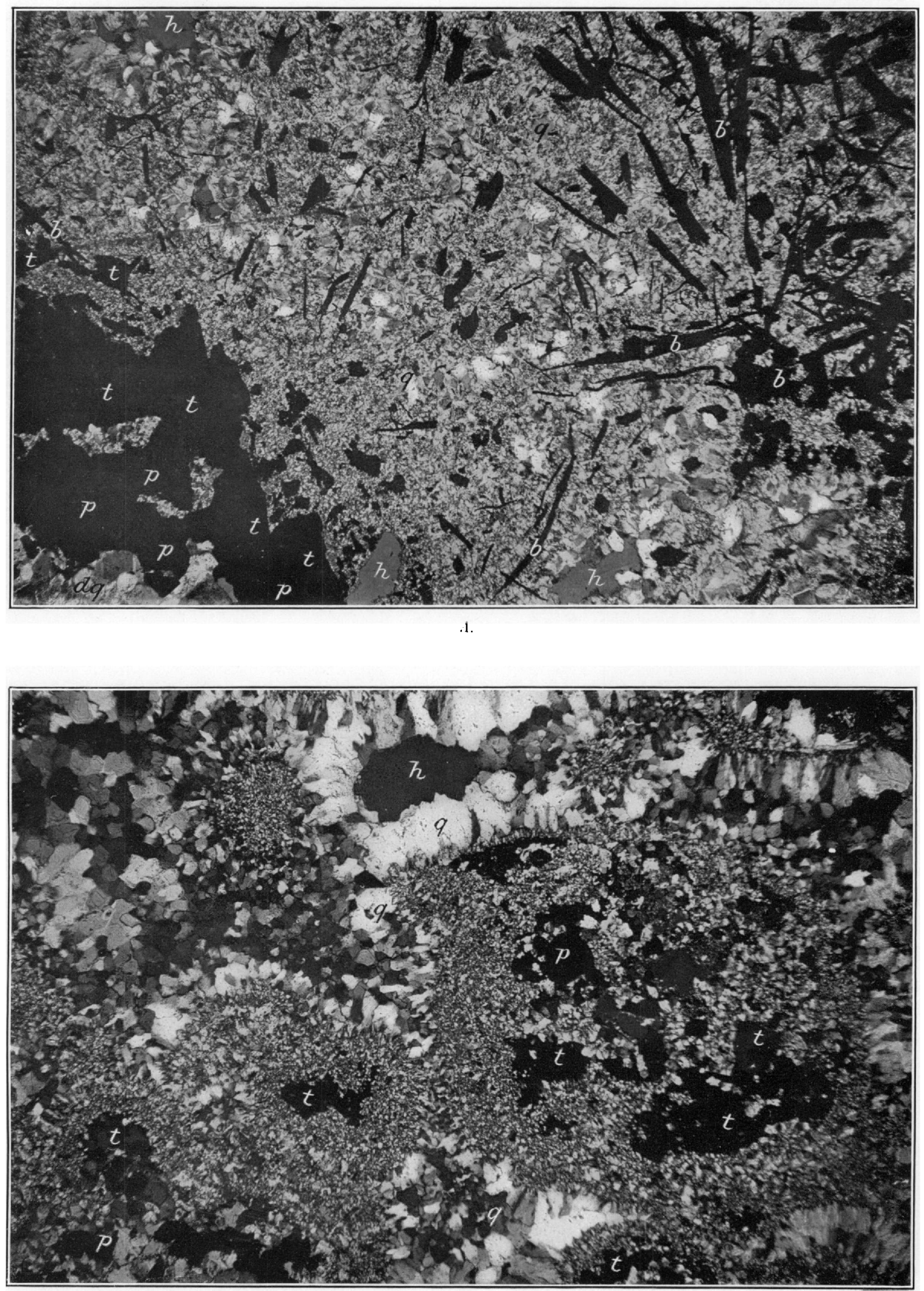

$B$.

PHOTOMICROGRAPHS OF ORES. 

Analyses of Mohawk ore-Continued.

[Vou Schulz \& Low, analysts. Reported February 27, 190i.]

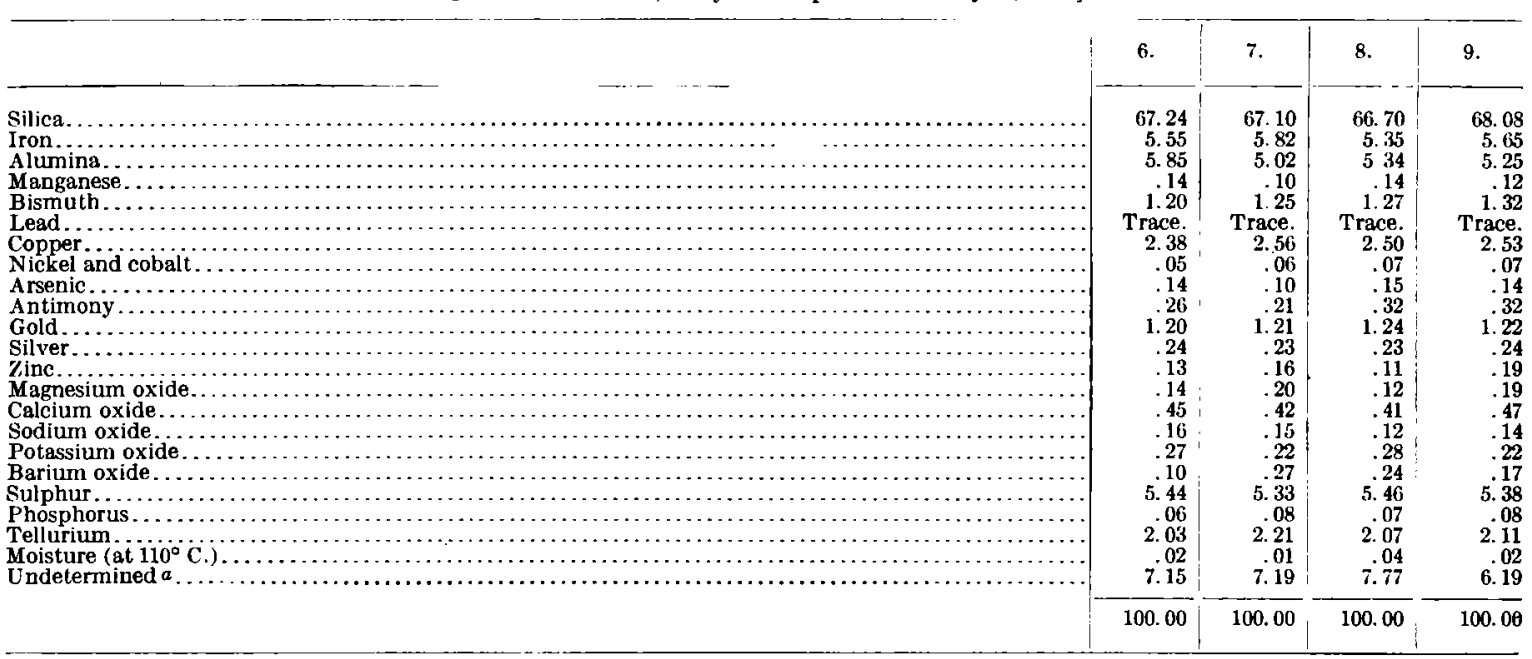

a This is probably in part combined water and in part oxygen combined with various bases. -V. S. \& L.

All of the foregoing analyses were made on material recovered from thieves or "highgraders." Those which follow were made on ore taken by Mr. Thomas from the 220-foot level of the Hayes-Monnette workings.

Analyses of Mohawk ore.

[Von Schulz \& Low, analysts. Reported April 22, 1907.]

\begin{tabular}{|c|c|c|c|c|c|c|}
\hline , & 10. & 11. & 12. & 13. & 14. & 15. \\
\hline 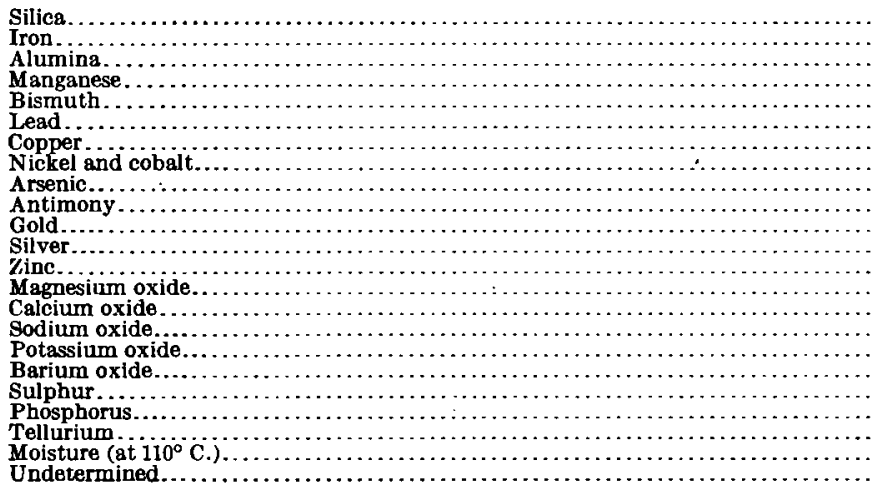 & $\begin{array}{r}64.28 \\
6.92 \\
6.18 \\
.12 \\
1.22 \\
\text { Trace. } \\
2.35 \\
.06 \\
.11 \\
.30 \\
1.22 \\
.28 \\
.14 \\
.19 \\
.49 \\
.12 \\
.27 \\
.19 \\
5.39 \\
.07 \\
2.11 \\
.03 \\
8.16\end{array}$ & $\begin{array}{r}68.46 \\
5.21 \\
5.04 \\
.12 \\
1.25 \\
\text { Trace. } \\
2.42 \\
.05 \\
.10 \\
.25 \\
1.30 \\
.25 \\
.11 \\
.17 \\
.45 \\
.12 \\
.26 \\
.21 \\
5.24 \\
.08 \\
2.10 \\
.02 \\
5.79\end{array}$ & $\begin{array}{r}67.27 \\
5.82 \\
5.65 \\
.18 \\
1.36 \\
\text { Trace. } \\
2.29 \\
.08 \\
.15 \\
.36 \\
1.49 \\
.29 \\
.16 \\
.20 \\
.45 \\
.15 \\
.26 \\
.14 \\
5.26 \\
.05 \\
2.27 \\
.02 \\
6.10\end{array}$ & $\begin{array}{r}68.40 \\
5.61 \\
5.44 \\
.15 \\
1.21 \\
\text { Trace. } \\
2.49 \\
.07 \\
.12 \\
.28 \\
1.33 \\
.25 \\
.19 \\
.19 \\
.42 \\
.14 \\
.25 \\
.21 \\
5.48 \\
.06 \\
\mathbf{2 . 0 6} \\
.04 \\
5.61\end{array}$ & $\begin{array}{r}67.20 \\
5.47 \\
5.82 \\
.10 \\
1.18 \\
\text { Trace. } \\
2.36 \\
.07 \\
.15 \\
.26 \\
1.37 \\
.25 \\
.17 \\
.10 \\
.46 \\
.11 \\
.24 \\
.24 \\
5.44 \\
.06 \\
2.14 \\
.03 \\
6.69\end{array}$ & $\begin{array}{r}67.98 \\
5.28 \\
5.86 \\
.11 \\
1.20 \\
\text { Trace. } \\
2.39 \\
.06 \\
.15 \\
.35 \\
1.34 \\
.26 \\
.14 \\
.18 \\
.46 \\
.14 \\
.27 \\
.20 \\
5.45 \\
.08 \\
\mathbf{2 . 1 2} \\
.03 \\
5.98\end{array}$ \\
\hline & 100.00 & 100.00 & 100.00 & 100.00 & 100.00 & 100.00 \\
\hline
\end{tabular}

PARA GENESIS.

The paragenesis or order of formation of the minerals in the unoxidized ores is, as in most ore bodies, complex. In general the deposition of pyrite, quartz, and alunite appears to have gone on throughout the entire period of ledge formation. On the other hand, there is abundant evidence to show that much of the gold, tellurides, bismuthinite, goldfieldite, marcasite, and famatinite were introduced after considerable progress had been made in the special kind of rock alteration which produced the ledges. It appears that some at least of these siliceous masses were fractured and that the richest ores were deposited in the shattered portions. 
The following sequences have been observed in the rich crustified ore:

Combination mine: (1) Altered latite; (2) marcasite and goldfieldite; (3) gold and quartz; (4) famatinite and bismuthinite.

(1) Altered dacite; (2) pyrite; (3) quartz; (4) pyrite; (5) alunite.

(1) Altered dacite; (2) gold and quartz; (3) famatinite; (4) bismuthinite and quartz.

(1) Altered dacite; (2) gold and quartz; (3) famatinite, bismuthinite, famatinite, and gold in quartz; (4) pyrite and alunite.

Florence mine: (1) Altered andesite or dacite; (2) pyrite; (3) famatinite and gold; (4) bismuthinite, gold, and quartz with some pyrite and famatinite.

(1) Altered dacite; (2) pyrite; (3) famatinite and quartz.

(1) Altered dacite or andesite; (2) pyrite; (3) famatinite; (4) bismuthinite and quartz; (5) pyrite, quartz, and alunite.

Mushett lease: (1) Altered dacite; (2) goldfieldite; (3) famatinite, bismuthinite, and quartz; (4) pyrite, sphalerite, and alunite.

(1) Altered dacite; (2) pyrite; (3) sphalerite; (4) alunite.

(1) Bismuthinite; (2) pyrite, sphalerite, and alunite; (3) sphalerite; (4) alunite.

(1) Bismuthinite, telluride (?), and famatinite; (2) sphalerite; (3) pyrite and alunite.

Engineers' lease: (1) Altered andesite; (2) famatinite; (3) pyrite and famatinite in massive aggregate.

(1) Altered andesite; (2) famatinite; (3) bismuthinite, quartz, and a little gold; (4) gold and quartz; (5) gold, bismuthinite, and quartz.

(1) Altered andesite; (2) famatinite; (3) gold and quartz; (4) bismuthinite and quartz; (5) gold and quartz; (6) quartz; (7) alunite.

Rogers lease: (1) Altered andesite; (2) gold and quartz; (3) bismuthinite, famatinite, gold, and quartz.

(1) Altered andesite; (2) gold and dark quartz; (3) white quartz.

Little Florence lease: (1) famatinite; (2) bismuthinite and quartz; (3) gold and quartz; (4) pyrite and alunite. (1) pyrite, quartz, and alunite; (2) famatinite; (3) bismuthinite and quartz.

Consolidated Red Top lease: (1) pyrite and quartz; (2) famatinite; (3) pyrite or marcasite, alunite, and barite.

Attempts to fit the foregoing observations into a single definite general sequence have not been successful. In some specimens there are repetitions not found in others. In some specimens certain of the minerals have formed in definite succession while in others these same constituents have crystallized together in a single crust. The altered rock on which the first crust is deposited generally contains abundant alunite and disseminated pyrite. In some varieties of ore the boundary between this nucleus and the first crust is definite (see Pl. XXIII); in others there is more or less gradation, the disseminated pyrite in some cases becoming more abundant near the surface of the rock fragment and merging with the first pyritic crust. As a rule famatinite has formed before the bismuthinite, although both minerals are indiscriminately distributed through some crusts. When marcasite is present as a constituent of rich ore it is closely associated with famatinite or goldfieldite. The free gold and bismuthinite are generally in close association, although in some specimens the greater part of the gold is of earlier generation than the bismuthinite and in others is later. Sphalerite, galena, and marcasite, where present with rich ore, belong to a period of deposition later than that of the gold or gold-bearing constituents.

\section{MINERALOGICAL CHARACTER OF THE OXIDIZED ORES.}

Oxidized ores have supplied a large part of the gold produced, and in some mines, particularly the Sandstorm and Kendall, no sulphide ores are as yet known. As a rule the oxidized ore is a soft, shattered, more or less earthy material usually stained brown by oxide of iron. Fragments of rusty porous quartz are mingled with kaolin, alunite, gypsum, alum (halotrichite), oxide of iron, and various earthy mixtures of no definite mineral composition. Some of the rich ore, as in the Sandstorm mine, is a nearly white, impure kaolin, gritty from the presence of minute crystals or grains of quartz, and containing all through it abundant specks of free gold. Barite, in crystals up to an inch in length, is abundant in this ore, but may be an original constituent. In the Red Top mine some of the richest ore being taken out in 1905 was a firm gritty ocher, of bright yellow color, containing abundant very fine particles of gold. This yellow 
material is perhaps in part jarosite. ${ }^{a}$ In the January and Combination mines some of the most characteristic rich ore consists of porous rusty quartz (silicified dacite), in which the pores and crevices are partly filled with yellow, earthy limonite and tiny pearly scales of bismite, the oxide of bismuth. In some specimens these scales form pseudomorphs after bismuthinite. They are usually a sign of rich ore, but are occasionally found in low-grade or barren material. Halotrichite, a member of the alum group, and alunite are rather abundant in the oxidized ore of the January mine. In the mines at Black Butte the richest oxidized ore usually shows little greenish-yellow specks of a ferric tellurite, which Dr. W. F. Hillebrand has determined to be either emmonsite or durdenite. The presence of this mineral shows that the original sulphide ore contained one or more tellurides. Tellurite, a honey-yellow crystalline mineral, which is the oxide of tellurium and should not be confused with the salts of tellurous acid known to chemists as tellurites, was noted in a partly oxidized telluride ore from the Goldfield-Belmont mine near Black Butte. Melanterite (hydrous ferrous sulphate), in some cases mixed with a very little chalcanthite (hydrous copper sulphate), occurs in the partly oxidized ore of the Combination and Florence mines.

The valuable constituent of the oxidized ores is native gold. Native silver and halogen compounds of silver have not, so far as known, been noted in the mines of the Goldfield group, but cerargyrite and probably a little embolite occur in some of the Diamondfield ores. The gold, which has undoubtedly undergone some concentration in the process of oxidation, is in most of the ores finely divided, and even in the richest ores might easily be overlooked by one not accustomed to its appearance. Some of the Sandstorm ore on close examination resembles a fine, somewhat rusty sandstone having gold as the cementing material.

\section{VALUE OF THE ORES.}

As a whole the ores thus far mined at Goldfield are unusually rich. Prior to January 1, 1905 , the Combination mine shipped a total of 1,166 tons of ore, having an average assay value of $\$ 419$ per ton. This ore averaged 20.22 ounces of gold and 2.68 ounces of silver per ton. The best ore from the mine was taken from the small No. 3 shaft, which afforded about 309 tons, valued at $\$ 159,000$, or $\$ 514$ per ton. Approximately 59 tons of this averaged, according to Mr. Edgar A. Collins, 54.8 ounces of gold per ton, which is equivalent to a value of nearly $\$ 1,100$. This ore, which was oxidized, contained only 1 ounce of silver to each 20 ounces of gold.

J. E. Spurr ${ }^{b}$ estimated in 1904 that the average value of the ores mined in the Goldfield district was from $\$ 200$ to $\$ 300$ per ton or more. In 1905 the average value of shipping ore was about $\$ 200$ per ton and of milling ore from $\$ 40$ to $\$ 50$ per ton.

Shipments averaging over $\$ 1,000$ per ton are by no means uncommon. One of $14 \frac{1}{2}$ tons from the Kendall mine is said by Spurr ${ }^{c}$ to have yielded $\$ 45,783$ net in the preliminary milling, while the tailings still contained about $\$ 1,000$ a ton. A shipment of sulphide ore from the Florence mine, made in 1905, just before the date of visit, averaged 100.8 ounces of gold, 3.5 ounces of silver, and 3.5 per cent of copper, giving a gross value of over $\$ 2,000$ per ton. The silver in this shipment was unusually high for an ore from this part of the district.

Some extremely rich ore was obtained from the Reilly lease, occasional specimens several inches in diameter being nearly one-half gold. Several shipments from this lease are said to have assayed $\$ 20,000$ a ton, and, according to Mr. Frank Oliver, one lot of over 4 tons was worth $\$ 6,000$ to $\$ 7,000$ a ton.

Some of the ore from the vicinity of Diamondfield carries a greater proportion of silver than that from the mines near Goldfield. A specimen containing famatinite, taken from the Quartzite mine of Black Butte, yielded on assay 11.06 ounces of gold and 115.70 ounces of silver per ton. Samples of mineralogically similar ore from the Goldfield-Belmont mine assay,

a Spurr, J. E., Ores of Goldfield, Nev.: Bull. U. S. Geol. Survey No. 260, 1905, p. 137.

$b$ Bull. U. S. Geol. Survey No. 260, 1905, p. 136.

c Op. cit., p. 136. 
according to Mr. W. H. Blackburn, yielded 1 to 2 ounces of gold and from 30 to 60 ounces of silver per ton. A similar high proportion of silver is found in the ore of the Jumbo Extension mine. Some bunches of ore in the Blue Bull mine also show a very high proportion of silver, one assay giving 382 times as much silver as gold. ${ }^{a}$ Some ore from the Hat lease on the Blue Bull ground assayed 174 ounces of silver and 4 ounces of gold to the ton. Such ratios, however, are very uncommon.

Although, as is to be expected in a new district, much of the very rich ore has been oxidized, yet some of the sulphides in the mines near Goldfield have exceeded in value anything found in the oxidized zone above them. Such was the case in part of the Combination mine, and in the Reilly workings. A still more striking example of the wonderful richness of some of the sulphide ores is furnished by the Hayes-Monnette Mohawk lease. From the ore body discovered by these lessees there was shipped in January, 1907, to the Selby Smelting and Lead Company, the richest carload of ore ever sent out of the district. The net weight of this ore was $95,537 \frac{1}{4}$ pounds. It assayed (dry) 609.61 ounces of gold and 75.38 ounces of silver per ton. The gold was paid for at $\$ 20$ an ounce on the assay return; the silver at $68 \frac{3}{8}$ cents an ounce, after deduction of 5 per cent for loss in smelting. Cost of treatment was $\$ 10.50$ per ton, sampling and assaying $\$ 150$, refining $\$ 327.22$, and expressage $\$ 8,810.50$. The net proceeds received by the shippers from the smelter were $\$ 574,958.39$ for the single car of ore. Even richer ore (620 ounces of gold to the ton) was being sacked under the old Reilly workings, on the 280-foot level of the Combination mine, in 1908.

One of the richest carloads of unsorted ore shipped from the district was from the lease of the Florence Annex Company on the Cornishman and Firelight claims in the latter part of 1907. This lot weighed 40 tons and assayed $\$ 948$ per ton, corresponding to a total gross value of $\$ 37,920$.

\section{AREAL VARIATIONS IN THE ORES.}

Although all of the Goldfield ores have certain mineralogical and chemical features in common, there are some well-marked differences in the ores from different parts of the district. Some of the most interesting and important changes are those which may be observed in passing from the Rogers lease at the south end of the Goldfield bonanza belt to the Mushett lease at the north end, a distance of a little less than a mile. By this it is not meant that no rich ore occurs north or south of these leases, but merely that these mark the limits of the most productive area as at present known. From the Rogers lease to the Combination mine the ore of the rich pay shoots is all much alike, although as a rule the product of each mine has slight individual peculiarities whereby one thoroughly familiar with the different workings can identify it. The essential characteristics of this ore are the presence of visible native gold, so distributed through the flinty quartz as to form the dull yellow crusts already described, the presence of abundant bismuthinite and famatinite, and the absence of recognizable tellurides, sphalerite, or galena. The quartz varies in color from nearly white, as in some of the Rogers ore, to a dark gray, as in some of the Engineers' ore. The famatinite or bismuthinite are not equally prominent in all of the ore, nor is the relation of the gold to these minerals exactly the same in each pay shoot. The gold in some stopes may occur in the hardest and most flinty parts of the quartz; in others, as in the Reilly stope on the 280-foot level of the Combination mine, part of the free gold may be in a mixture of alunite and pyrite which can be crumbled in the fingers. Notwithstanding these differences the rich ore of the Combination, Reilly, Florence, Engineers', Little Florence, and Rogers mines is as a whole very similar.

With the opening of the Mohawk mine ore of a different type was found. In the typical rich Mohawk ore native gold, bismuthinite, and famatinite are less conspicuous than in the mines to the south. So far as I am aware this mine has never produced specimens showing such broad bands of finely divided yellow gold as have come from the other mines mentioned and as are figured in Plates XXIII and XXV. Instead, the best ore has the dark telluric crusts described on page 116, which are mixtures of goldfieldite and marcasite. Free gold may or may not be visible. 
The change between the typical Combination ore and the typical Mohawk ore is not entirely abrupt, for ore of the Mohawk character has been found in what is known as the 316 stope on the 280-foot level of the Combination mine. From the same stope, also, has come ore intermediate between the two types.

North of the Mohawk mine there is a change to ore of the Mushett type, in which goldfieldite is associated with sphalerite and a little galena.

From the Mushett lease to the mines near Diamondfield there is an interval of about 3 miles, in which no rich sulphide ores of any consequence have been found. Mineralogically the Diamondfield ores resemble those of the Mushett and neighboring leases rather than those of the mines south of the Mohawk. Most of them, however, are soft crushed masses with little of the interesting crustification which is so marked a feature near Goldfield. The proportion of sulphides to gangue is less at Diamondfield than in the Mushett lease.

East of the Rogers lease is another gap of three-quarters of a mile to the Gold Bar and Victor mines, which have still another variety of ore. The best of this is of relatively low grade. The cupriferous constituent, which is abundant, is apparently nearer to enargite than to famatinite. No tellurides have been recognized, and neither visible native gold nor bismuthinite is common.

\section{OBSERVED CHANGES IN DEPTH.}

Observations to determine what changes, if any, take place in the unoxidized ores with increase of depth are limited to a vertical range of about 450 feet (137 meters), which is the distance from the base of the oxidized zone to the bottom of the Mohawk mine. Within this rather short range the mineralogical changes are not very marked. The minerals associated with the very rich ore at depths of 200 or 300 feet (61 or 91 meters) have been found also at lower levels. Alunite, as a constituent of the altered rocks, is as abundant in the deepest parts of the ledges yet reached as it is nearer the surface, and it appears from this that there was no essential change in the general chemical character of the ore-bearing solutions. As a soft interstitial filling, however, the mineral is slightly less abundant on the 600 -foot level of the Mohawk than it is at higher levels in this and other mines. The explanation of this is thought to be physical rather than chemical. It is to be expected that spaces formed by fracturing in the deeper parts of a ledge would be smaller and less numerous than where the strained material is under a lighter load.

Some pay shoots have shown a decided diminution in value before reaching a depth of 500 feet (152 meters), but the changes in both horizontal and upward directions from the kernel of a bonanza may be fully as notable, and where deposits have shown themselves to be so irregular as those of Goldfield caution is prescribed in deducing a general law from a few examples. To assume, because one pay shoot ends at a depth of 200 feet (61 meters), that no more ore will be found below it would, in this district, be much like relinquishing as useless all prospecting beyond the horizontal limits of the same body. From the condition of the mines in the latter part of 1905 an observer would have had some ground for supposing that little if any ore of 5-ounce or better grade would be found below a depth of 300 feet (91 meters). Subsequent events have shown that such a sweeping conclusion would have been erroneous. A tendency, however, toward a decrease of tenor below a depth of about 300 feet was noted in the preliminary report on the district, ${ }^{a}$ where it was also stated that "there is considerable evidence in favor of the conclusion that ores of the grade now required for shipment are not likely to extend to as great a depth as 1,000 feet." These figures obviously were not intended to represent actual depths below the collars of individual shafts, but are round figures referable to a mean or generalized surface. Later observations are in full accord with this earlier statement, which is far from an assertion that no rich ore occurs at a greater depth than 300 feet (91 meters). In the Mushett lease very rich ore is known to extend to a depth of 429 feet (131 meters) and in the Rogers lease to 550 feet ( 168 meters). These deposits, however, are thus far rather exceptional. There is good ore on the 600 -foot level of the Mohawk, but it is 
of much lower grade than that shipped from the Hayes-Monnette stope above the 250-foot level. Ore has recently been found also at 718 feet (219 meters) in the Hazel-Goldfield lease, but its character and quantity are as yet undetermined.

On the whole, observation indicates a general although not uniform decrease in the tenor of the ores in the deeper workings. The gold, goldfieldite, bismuthinite, and, to a less extent, famatinite become less conspicuous, while pyrite is relatively more abundant. The bearing of this change and its interpretation as regards the future development of the mines will be considered in a subsequent chapter.

\section{ORIGINAL DEPTH OF THE ORES NOW VISIBLE.}

It is important, before taking up the problem of genesis, to obtain if possible some idea of the relation of the present surface to that which existed when the ores were precipitated. How many vertical feet of rock, in other words, have been removed since ore deposition began? As a rule the investigator of a mining district is fortunate if he can form an estimate of such erosion that he is reasonably sure comes within a few thousand feet of the truth. At Goldfield the data permit a probable approximation within a few hundred feet.

The dacite near Goldfield rests partly on the Milltown andesite, but mostly on latite. Immediately after its intrusion, therefore, the dacite may have been covered by the greater part, possibly 700 or 800 feet (213 or 244 meters), of the Milltown andesite. This cover was doubtless much broken by the force of the intrusion, and in consequence was easily eroded. The presence of abundant dacitic fragments in the basal part of the Siebert formation between Goldfield and Columbia indicates that before the lacustral epoch closed the dacite had been laid bare and was being actively eroded. The presence of this coarse littoral material suggests further that the site of the future mines was not one of the deepest parts of the lake, but for a time at least was unsubmerged land. At the close of the lake epoch, therefore, the present productive area of dacite must have been buried under considerably less than the 1,000 feet (305 meters) of sediments estimated on page 68 as the maximum local thickness of the formation. With the disappearance of the lake, erosion began, and this may have further thinned the overlying sediments before ore deposition ceased. At the most, however, this erosion did not reduce the surface below the general level of the peneplain at the base of the Spearhead rhyolite (see Pl. VIII, sections D-D' and E-E'), since the completion of the peneplain, as shown by the alunitized fragments in the Pozo formation already referred to, must have been subsequent to ore deposition. A rough restoration of this plain over the site of the present mines would carry it about 300 feet (91 meters) above the existing surface of the dacite, indicating at least that amount of erosion since the ores were deposited.

On the whole, therefore, and without referrence to any regional changes of level, it appears that the surface of that part of the district containing the principal ore bodies was not more than 1,000 feet (305 meters) higher than at present, and the difference may have been some hundreds of feet less. The general geologic relations of the deposits, therefore, indicate comparatively superficial origin.

The structure and the mineralogical character of the deposits point to the same conclusion. The intricacy, irregularity, and lack of persistency of the fissuring are indicative of rupture under small load. The change in tenor of the ores at moderate depths is suggestive of deposition controlled in part by proximity to the surface. The presence of cinnabar and native sulphur not, it is true, in the ore deposits themselves, but in the same province or region, is, as De Launay ${ }^{a}$ has shown in his study of the Italian metallogenetic provinces, and Villarello ${ }^{b}$ for the metalliferous regions of Mexico, in harmony with the view that the ore deposits were formed in a comparatively superficial zone. The presence of abundant antimony, bismuth, and tellurium, and the extraordinary richness of the Goldfield ores have similar significance. Like the deposits at Cripple Creek, those of Goldfield exhibit a mineralogical character that

a La métallogénie de l' Italie: Cong. géol. intern., Mexico, 19k6, Compt. Rend., vol. 1, 1907, p. 561.

$b$ Sur le remplissage de quelques gisements métallifères: Cong. géol. intern., Mexico, 1906, Compt. Rend., vol. 1, 1907, p. 548. 
is suggestive of origin through processes connected with volcanism and active at moderate or slight depth. The original surface at Cripple Creek was probably from 2,000 to 5,000 feet (610 to 1,524 meters) above the present one. The erosion at Goldfield has certainly been much less.

\section{AGE OF THE DEPOSITS.}

The gold deposits are obviously younger than the dacite. As the postdacitic rocks have been eroded from the productive part of the district the relation of the ores to them is not directly shown.

On the north slope of Mira Mountain, and at a few other places along the southern border of the district, the beds of the Siebert formation show some alunitic alteration similar to that characteristic of the Goldfield ledges. A few miles west of Goldfield, between Mesa and Montezuma Peak, the Siebert beds are sufficiently mineralized to have induced considerable prospecting at the Red Peak, Houlihan, and Sassy Sal mines. Some of the beds contain disseminated pyrite, and one layer, apparently once pumiceous, has been changed to a mass of opal and chalcedony. The alteration appears to have been effected by thermal or solfataric action. Whether alunite also occurs at this locality is not known, although the appearance of some of the altered rocks suggests its presence. Near Cuprite, about 12 miles south of Goldfield, both alunite and sulphur occur in association with opalized material similar to that just described and supposed also to belong to the Siebert formation. The deposition of the sulphur and the associated alteration are believed to be indicative of solfataric action.

It thus appears that considerable mineralization occurred after the deposition of the Siebert formation, and although, so far as is known, no valuable deposits of gold are contained in these beds there is a suggestion of similarity between the mineralizing processes which have affected that formation and those recorded in the Goldfield ledges.

No fragments of alunitized rock or of ore have been found in material known to belong to the Siebert formation. This purely negative evidence is, of course, not of much value, but it is mentioned in order that observers in future may be on the watch for such an occurrence. A fragment of dacite with alunitized feldspars, or, better still, a bit of the characteristic Goldfield ore found in any shaft known to be in unaltered Siebert beds, would show that the ore deposits were formed before these deposits were laid down. Such evidence as is available, while very unsatisfactory, favors the view that the ore deposits are younger than the lacustral sediments.

On the other hand, the Pozo formation is certainly younger than the ore bodies, for as exposed near Meda Pass the partly consolidated gravels of this deposit contain abundant fragments of alunitized dacite. The Spearhead rhyolite and the Malpais basalt are thus younger than the ores.

How merely tentative is the application of the Tertiary chronologic scale to the Goldfield deposits has already been pointed out. In terms of this provisional usage the age of the ores is late Miocene or early Pliocene. 


\section{CHAPTER XIV. METASOMATIC PROCESSES. ${ }^{a}$ \\ TYPES OF ALTERATION.}

Three types or stages of alteration are recognizable. Where the chemical activity has been most intense the rocks have been changed to porous, fine-grained aggregates consisting essentially of quartz. This is the material of which are composed the hundreds of craggy points and ledges that are characteristic of the topography of the district. Although most of these ledges, so far as known, contain no ore bodies, yet until recently no ore has been found that was not in or alongside such quartz rock. Some of the discoveries made in 1906, however, show that very rich bodies of ore may occur at places where there is no siliceous outcrop.

The second type of alteration is one in which the rock is changed to a comparatively soft, light-colored mass of quartz, kaolinite, alunite, and pyrite. At any given locality the boundary between the rocks representing the two kinds of alteration may be fairly sharp; but the proportions of quartz, kaolinite, and alunite vary widely, and consequently, over the field at large, gradations in composition and hardness may be found between these two typical metamorphic products. Both types are usually associated with the ores and are most conspicuously displayed over a belt of country stretching east from Goldfield past Preble Mountain. This mountain, in fact, is composed chiefly of andesite and dacite that have undergone alteration of the kinds described.

The third type of alteration has effected less conspicuous results than the other two, and its products are not closely associated with the ores. It consists in the development of calcite, quartz, chlorite, epidote, and pyrite at the expense of the original minerals and groundmass, and is thus propylitic in character. Rocks which have undergone this form of alteration, chiefly andesite, latite, and dacite, still retain something of their original color and texture, the principal external sign of change being a greenish tint instead of the usual dark gray of the fresh rock, and a lack of luster in the phenocrysts.

The propylitic type is rather sharply marked off from the alunitic type by the presence of calcite and by the usual absence of alunite, these minerals having been observed together only at one place, on the east slope of Vindicator Mountain, where very minutely crystalline calcite, sericite, and probably some kaolinite have been found associated with much larger crystals of alunite in altered rhyolite. The occurrence together of alunite and calcite, apparently developed simultaneously, shows that the alteration took place under conditions which did not permit the free escape of carbon dioxide. It is scarcely conceivable, for example, that calcite could form in the presence of sulphuric acid percolating down from an overlying deposit of oxidizing pyrite.

The alteration of the alunitic type is not confined to the vicinity of known ore bodies, but is prevalent over wide areas not recognized as ore bearing. The general relation of ore bodies to alunitization is shown in figure 19 , in which the area affected by alunitic alteration is indicated with as much accuracy as is possible where there is no real boundary to be shown.

\section{COMPARISON OF FRESH AND ALTERED DACITE.}

Inasmuch as the largest and richest ore bodies are in the dacite and as the rock is uniform in character, it was chosen for a close study of the alteration effected by the ore-depositing agencies. Such comparison is especially favored by the fact that the most intense alteration

a The greater part of this chapter was published as a paper entitled "The association of alunite with gold in the Goldfield district, Nevada" (Econ. Geology, vol. 2, 1907, pp. 667-692). 
is often local, and consequently it is possible to obtain specimens of fresh and altered rock within moderate distances of each other. The two specimens of dacite analyzed and compared were taken about 11 miles (2 kilometers) apart.

The fresh dacite has been fully described on pages $55-88$.

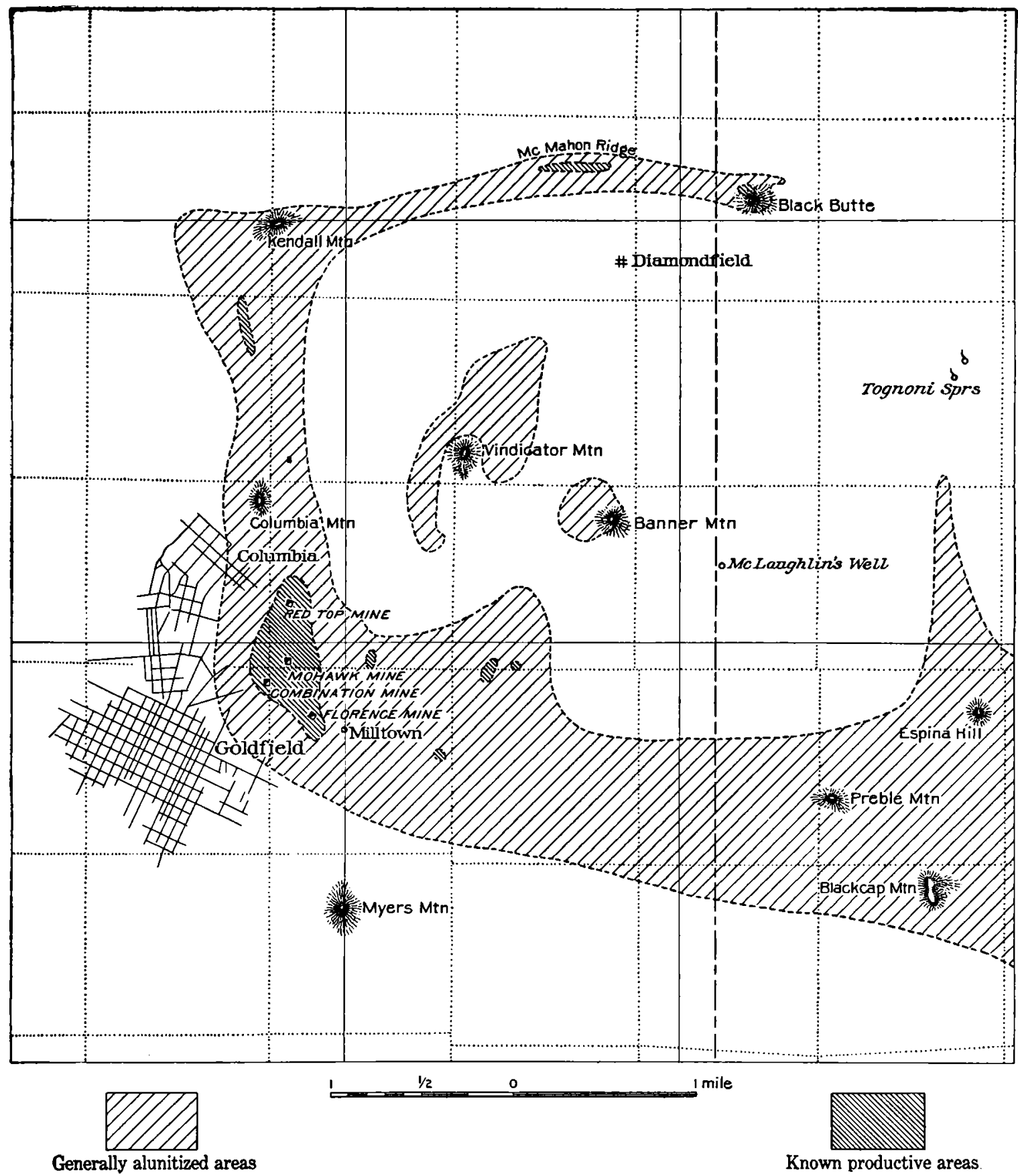

FIGURE 19.-Diagram showing the portions of the Goldfield district in which the rocks have undergone extensive alunitic alteration.

The altered dacite, of which a chemical analysis by Mr. George Steiger is given under 2 (p. 181) was taken from the 230 -foot level of the Combination mine, in a place to which oxidation had not extended. The original water level in this mine appears to have been at about 130 feet from the surface, near which depth the oxidized ore gives place to sulphides. The rock analyzed is the typical wall rock of this and adjacent mines.

79145 -No. $66-09-12$ 


\section{PLATE XXVIII.}

\section{Photomicrographs of Alunitized Rocks.}

A. Vindicator rhyolite (G. 26). Summit of Columbia Mountain. Shows alteration of feldspar phenocrysts, probably chiefly orthoclase, to aggregates of alunite (a). The originally glassy groundmass (g) is now a fine-grained aggregate of quartz, kaolinite, and alunite. The black areas in the photomicrograph are an opaque white substance resembling leucoxene, an alteration product of ilmenite. There are two small phenocrysts of quartz (q). Holes in the section are indicated by $H$. Ordinary light. Magnified 40 diameters.

$B$. Same as $A$. Nicols crossed, bringing out more clearly the aggregation of the secondary minerals.

C. Dacite (G. 398). Combination mine, 230-foot level. Typical country rock showing large alunite pseudomorph after labradorite. With the alunite (a) is an isotropic material, probably opal (o). The black areas are mainly pyrite, in part disseminated through the groundmass and in part aggregated into pseudomorphs after biotite and other ferromagnesian constituents. The groundmass $(\mathrm{g})$ is a fine-grained aggregate of quartz, alunite, and pyrite. Holes in section (h). Ordinary light. Magnified 40 diameters.

$D$. Same as $C$. Nicols crossed.

\section{PLATE XXIX.}

\section{Photomicrographs showing Alteration of Dacite.}

A. Fresh dacite (G.97). Half a mile northeast of Columbia Mountain. See chemical analysis on page 56. Contains phenocrysts of labradorite (1), biotite (b), augite (not shown), and abundant smaller crystals of hornblende (hb) in a hyalopilitic groundmass. Hole in section (h). The rounded and embayed quartz phenocrysts are not abundant. None appears in the part of the section photographed. The labradorite phenocryst at the bottom of the figure exhibits a characteristic border of glass inclusions. Ordinary light. Magnified 40 diameters.

$B$. Altered dacite or ledge matter (G. 712). Red Top mine, 160-foot level. The original structure of the dacite is still recognizable, but the rock is now an aggregate of quartz and pyrite. The feldspars, or their pseudomorphs, have been carried away in solution, leaving cavities (h). The black areas and specks are pyrite, in part aggregated as pseudomorphs after biotite and hornblende. The original quartz phenocrysts $(q)$ are alone unchanged. The former hyalopilitic groundmass has become a fine granular aggregate of quartz, sprinkled with pyrite. Nicols crossed. Magnified 40 diameters.

C. Altered dacite country rock (G. 393). Combination mine, 230-foot level. See chemical analysis on page 181 . Rock is entirely recrystallized, with the exception of the quartz phenocrysts (not shown) to an aggregate of quartz, alunite (a), kaolinite, and pyrite. The rock, when examined with low power, still shows traces of its original structure. Original ferromagnesian constituents are represented by patches of pyrite and feldspars by areas of alunite. Such an aggregate of alunite appears at the bottom of the figure. Nicols crossed. Magnified 40 diameters.

D. Altered dacite (G. 634). Florence mine, 200-foot level. Large areas of the section, seen under low power, show vestiges of original structure. The part of the section figured illustrates chiefly the development of alunite throughout the groundmass and the crystallization of this mineral with pyrite (black). The rock consists essentially of alunite, quartz, and pyrite. Ordinary light. Magnified 40 diameters.

\section{PLATE XXX.}

\section{Photomicrographs illustrating Alteration of Rocks.}

A. Dacite country rock (G. 653). Florence mine, 350-foot level. The phenocrysts of labradorite have been altered to aggregates of alunite (a) and a veinlet of alunite extends diagonally across the section. The black spots are almost all pyrite. The groundmass ( $\mathrm{g}$ ) is an aggregate of quartz, alunite, kaolinite, and pyrite. Ordinary light. Magnified 40 diameters.

B. Ledge matter (G. 397). Combination mine, 230-foot level. Low-grade ore. Illustrates extreme alteration of shattered or crushed dacite. Original structure obliterated. The black areas are pyrite in a gangue of microcrystalline quartz. Nicols crossed. Magnified 40 diameters.

C. Altered andesite (G. 766). Goldfield-Belmont mine. Original structure of andesite has been obliterated. Rock is now an aggregate of quartz $(q)$, kaolinite $(k)$, and pyrite. It was shattered prior to alteration and is traversed by white veinlets (not shown) of crystalline quartz and kaolinite. Nicols crossed. Magnified 40 diameters. 
U. S. GEOLOGICAL SURVEY

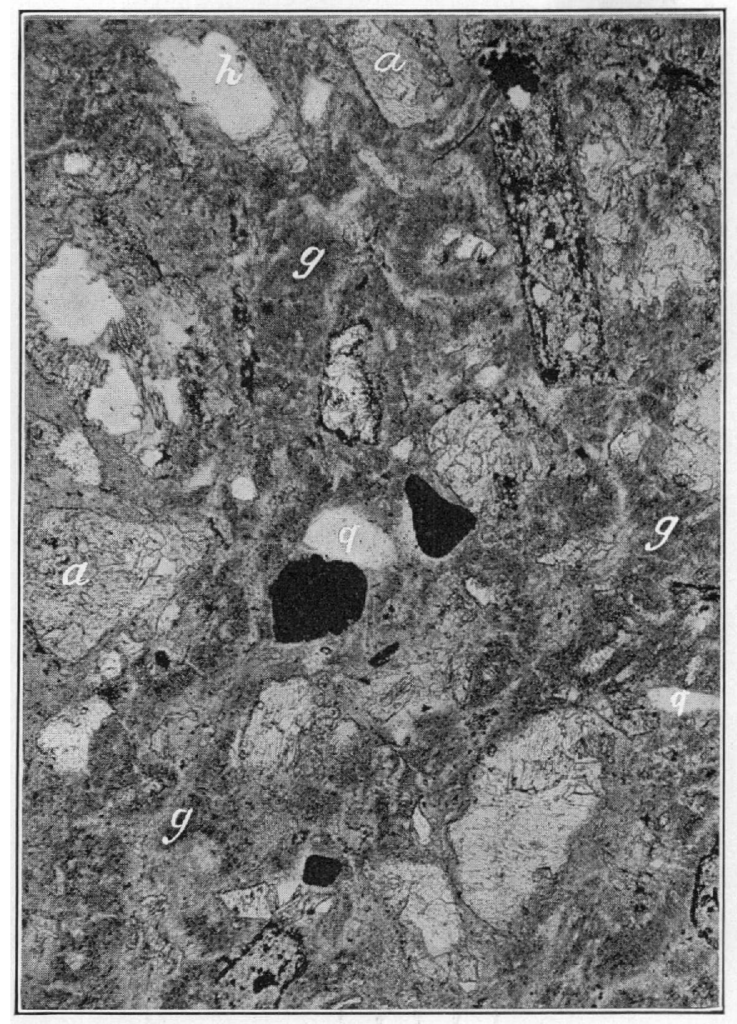

A.

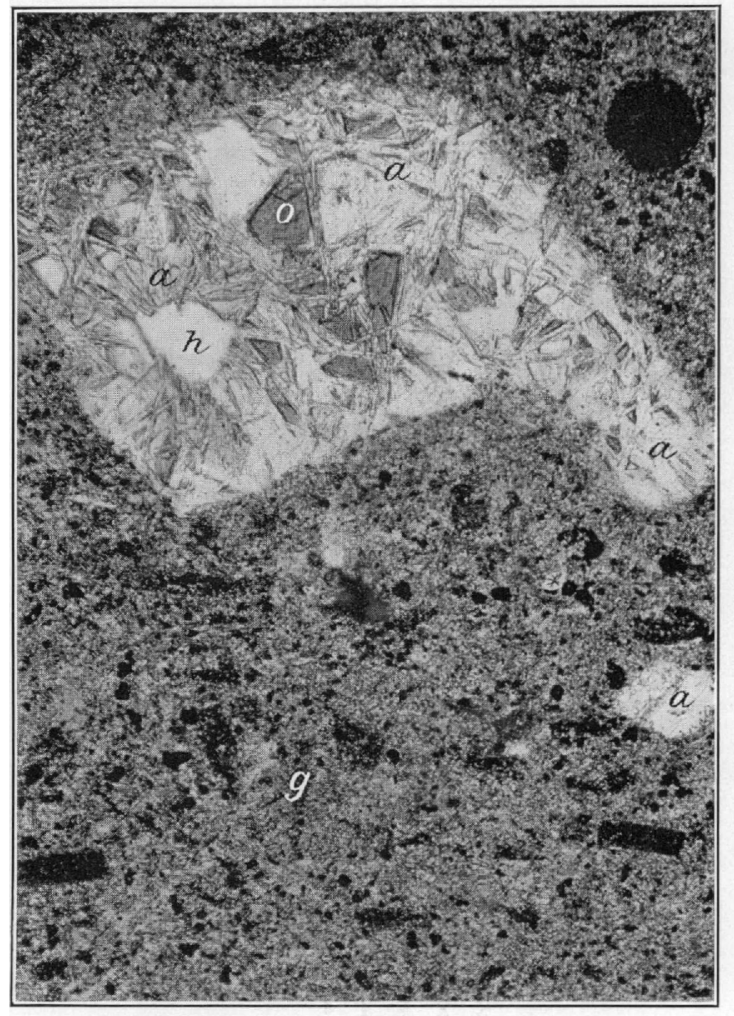

C.
PROFESSIONAL PAPER 66 PLATE XXVII

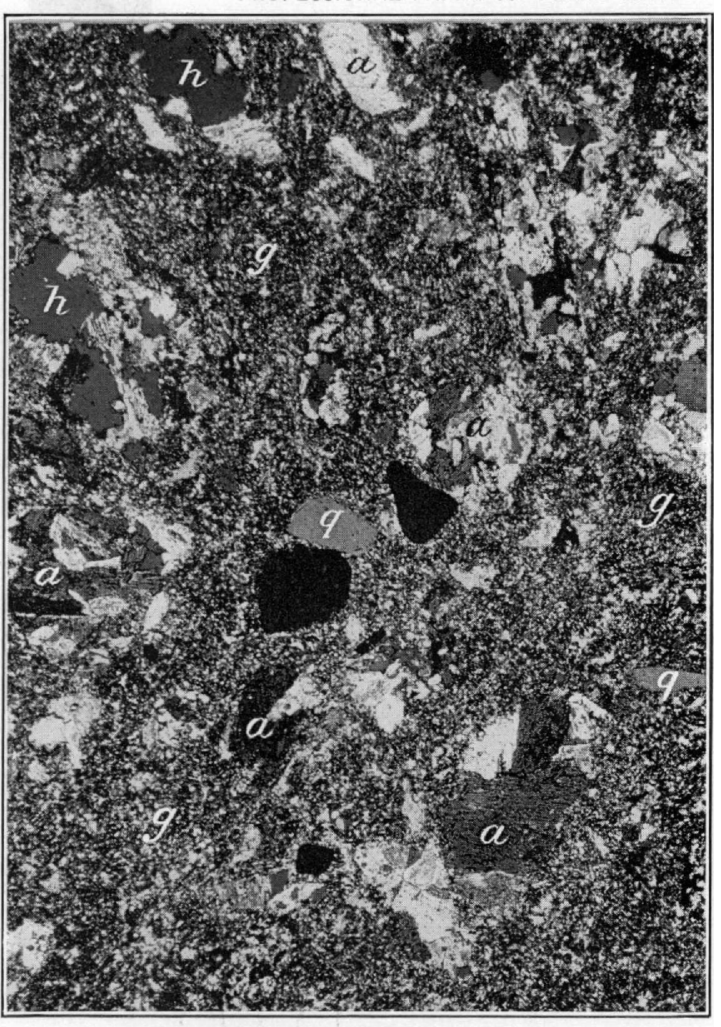

$B$.

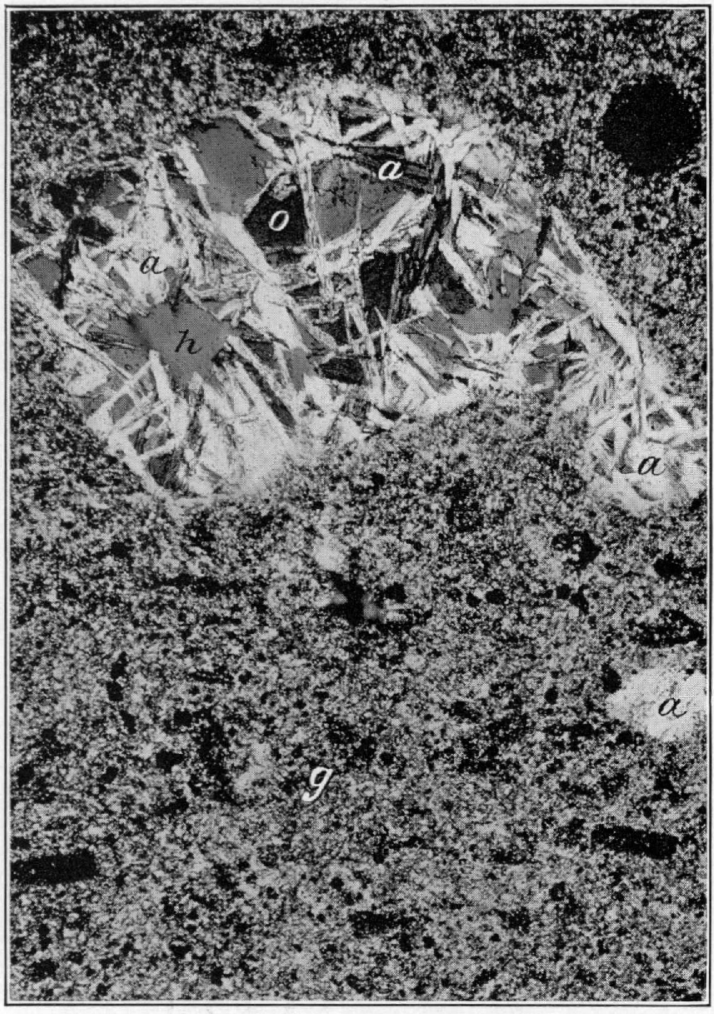

D.

PHOTOMICROGRAPHS OF ALUNITIZED ROCKS. 

U. S. GEOLOGICAL SURVEY

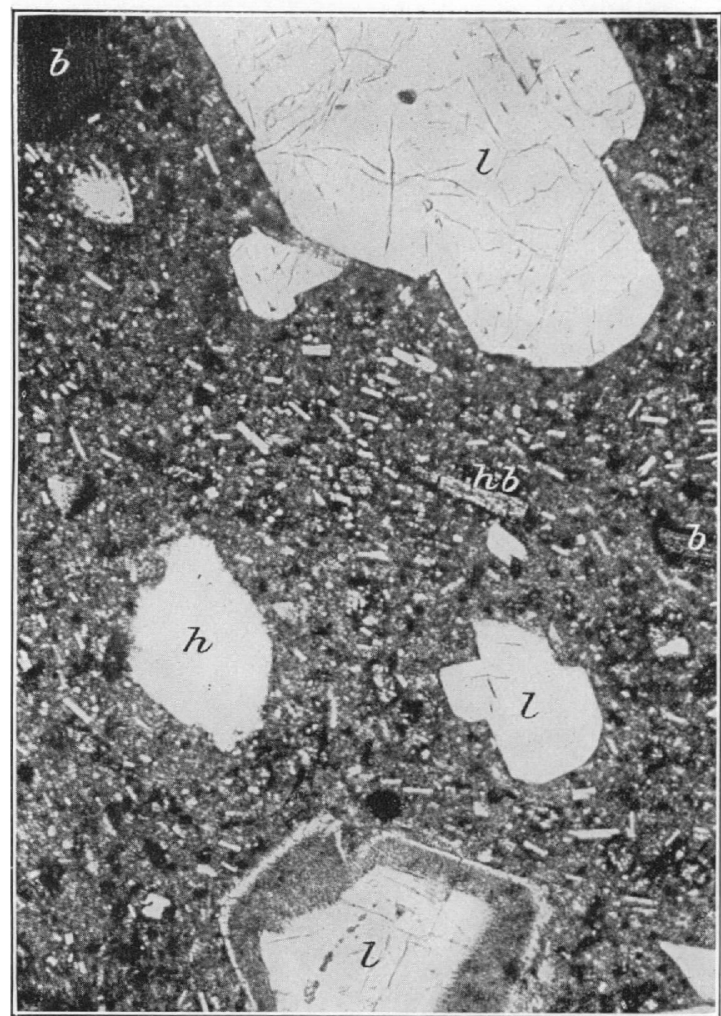

$A$.

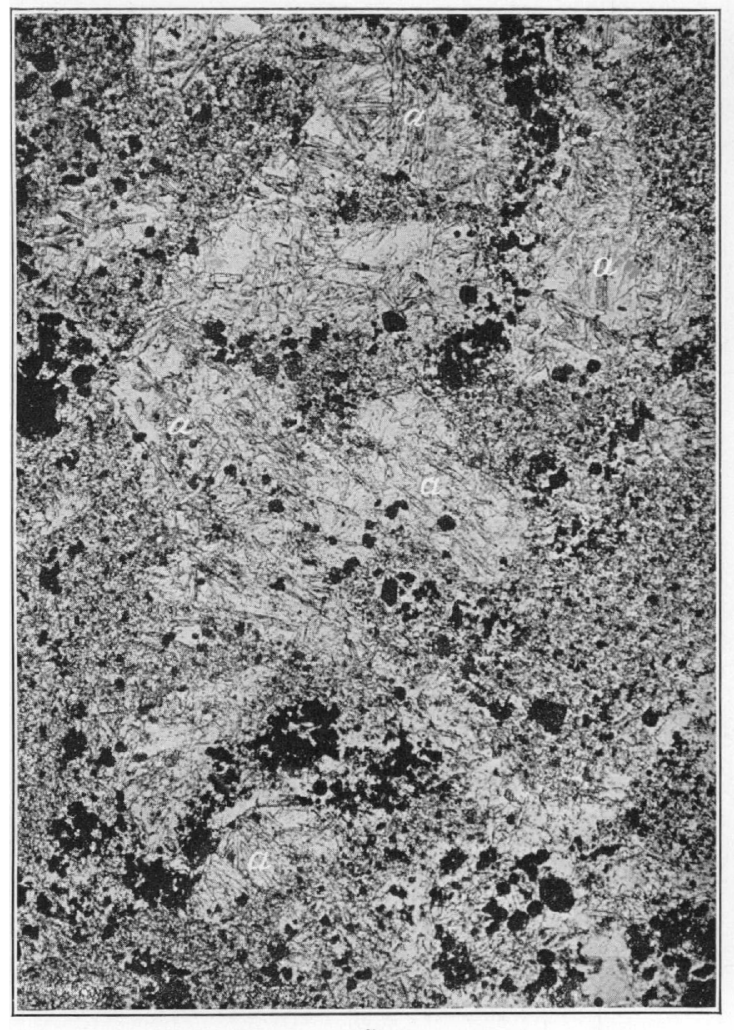

PROFESSIONAL PAPER 66 PLATE $X X I X$

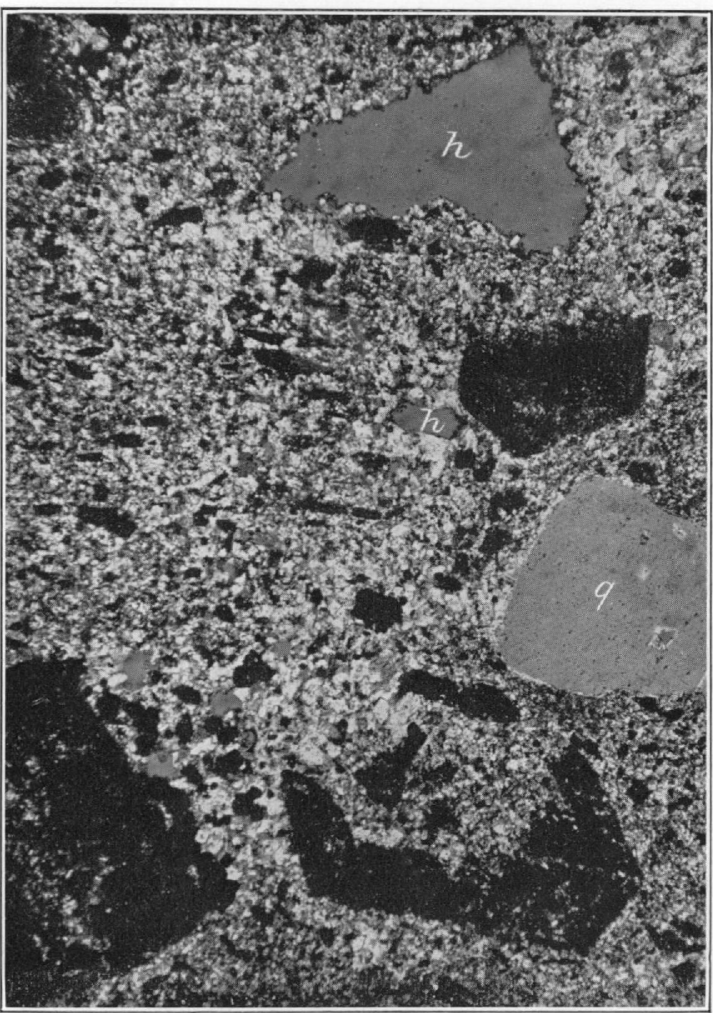

$B$.

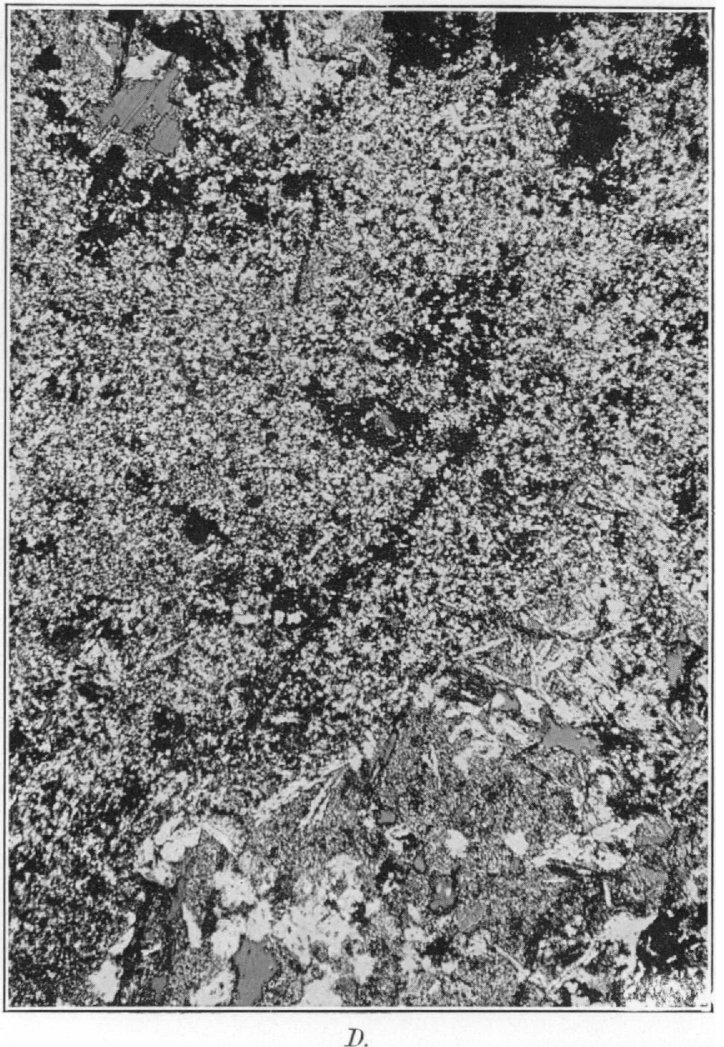

PHOTOMICROGRAPHS SHOWING ALTERATION OF DACITE. 



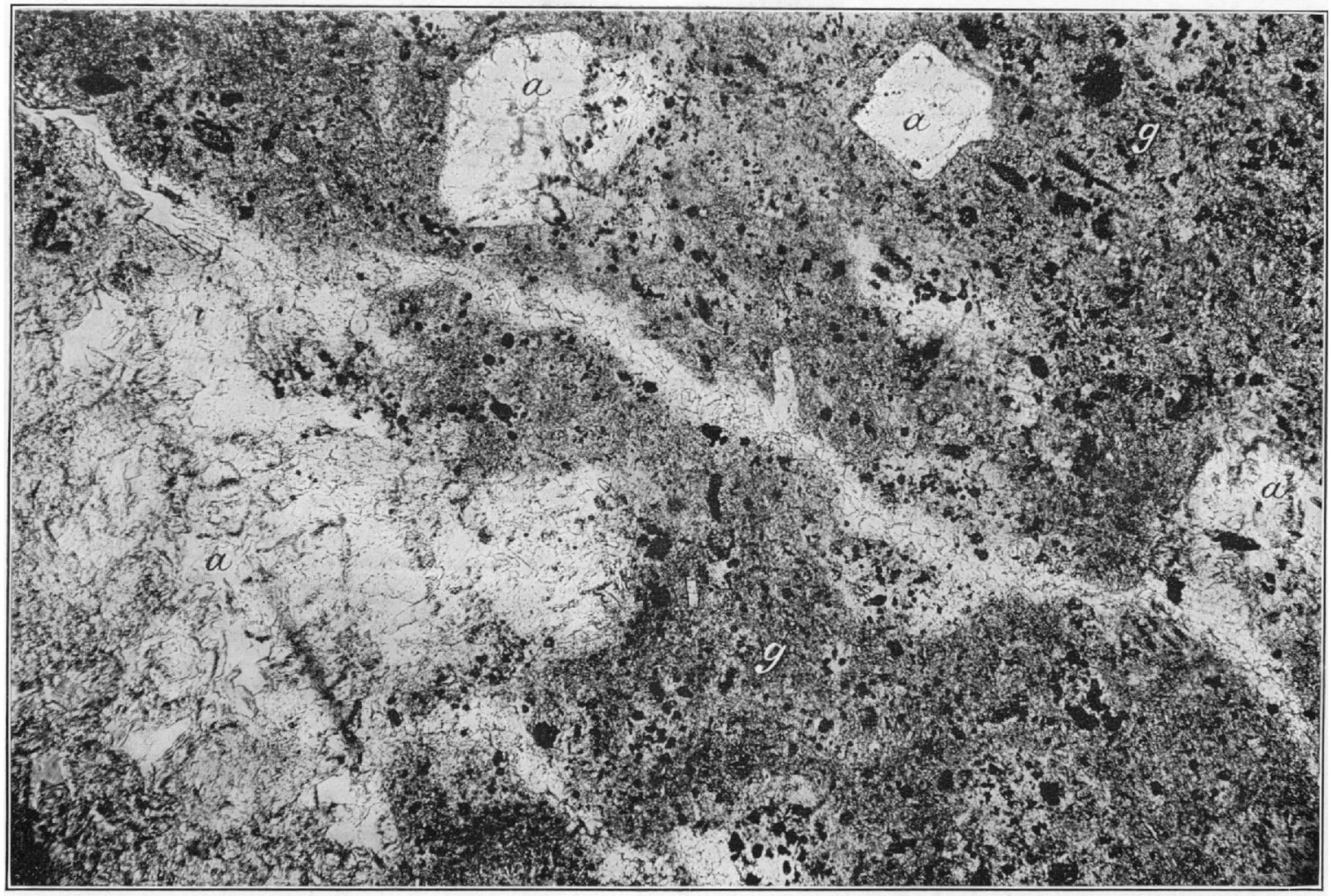

A.
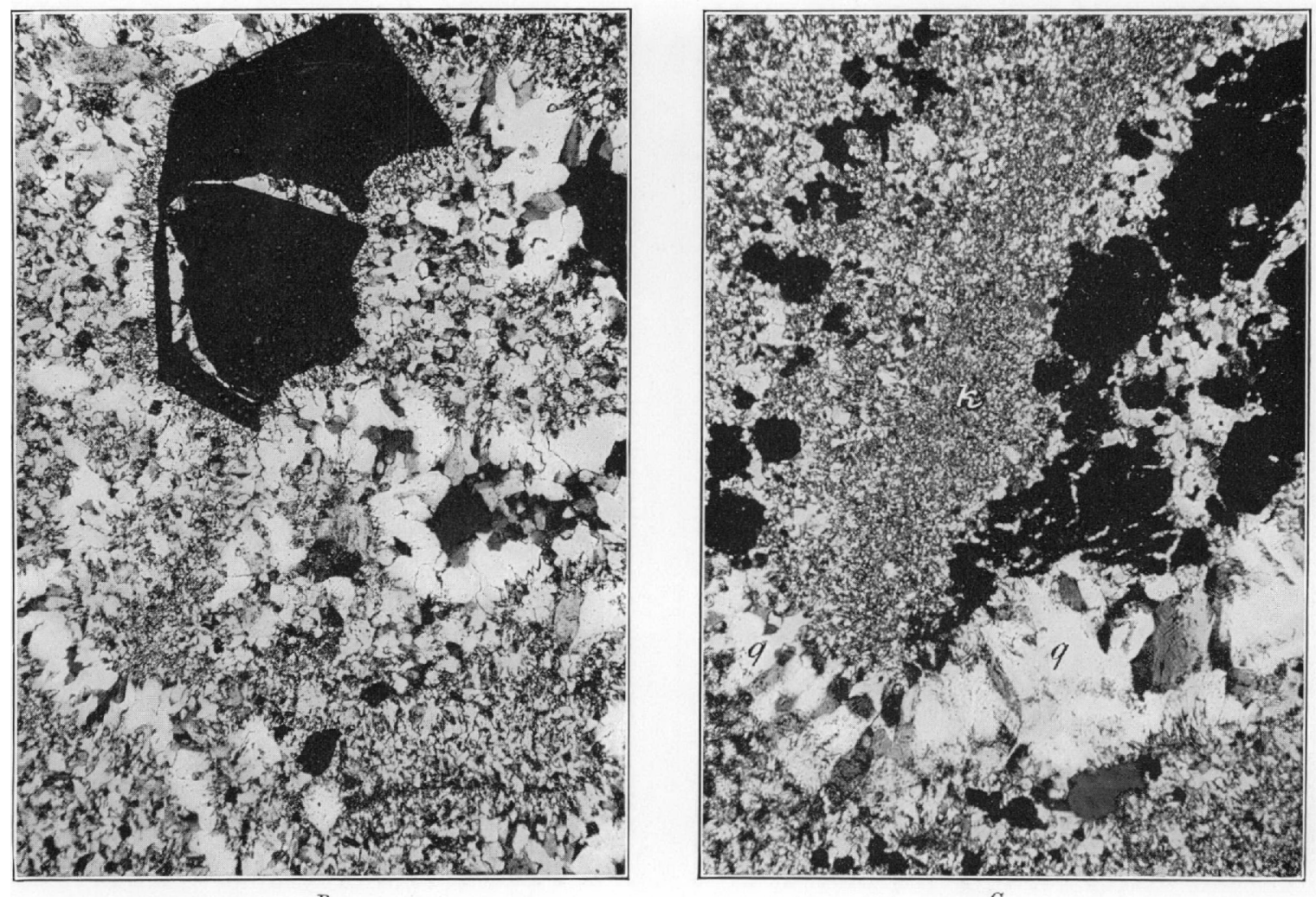

PHOTOMICROGRAPHS ILLUSTRATING ALTERATION OF ROCKS. 

The altered rock is light gray, flecked with numerous dull white spots which represent the original feldspar phenocrysts. The few quartz phenocrysts are unchanged, but the ferromagnesian, or, more briefly, femic, minerals have wholly disappeared. Pyrite, in small, disseminated crystals, is abundant.

Under the microscope, it is seen that the only original constituents are the quartz phenocrysts, even these showing some development of pyrite along irregular microscopic cracks, and an occasional small crystal of zircon. The feldspars are changed to aggregates of minutely crystalline kaolinite and tabular crystals of alunite, some of the latter being arranged in sheaflike bunches (see Pl. XXVIII). The alunite has the form characteristic of it in this district, sections cut at large angles with the basal pinacoid having the shape of narrow laths with irregular ends. The length of these lath-shaped sections rarely exceeds half a millimeter. The alunite, when cursorily examined under a low-power lens, may easily be mistaken for sericite (muscovite), although of course this error is quickly dispelled on closer study, sericite being optically negative and alunite positive. The interference colors, moreover, although bright, particularly in the larger crystals, are of a lower order than those of sericite. Quartz also accompanies the alunite and kaolinite in some of the pseudomorphs after labradorite. Diaspore, while not present in the rock analyzed, occurs in the alunitized dacite of the Florence mine and elsewhere. (See p. 125.)

The former femic constituents can be recognized from the fact that they contain little or no kaolinite, the quartz and alunite being here associated with abundant pyrite. In some cases the pseudomorphous aggregate still preserves a suggestion of the former cleavage of the biotite or of the outlines of hornblende.

The groundmass is changed to a fine-grained aggregate of kaolinite, quartz, alunite, and pyrite. The last-named mineral occurs also in irregular microscopic veinlets.

As the rock is wholly crystalline and is made up of minerals of approximately constant composition, it is possible to calculate with some precision the actual mineralogical constitution from the chemical analysis. This, in percentages of mass, is as follows:

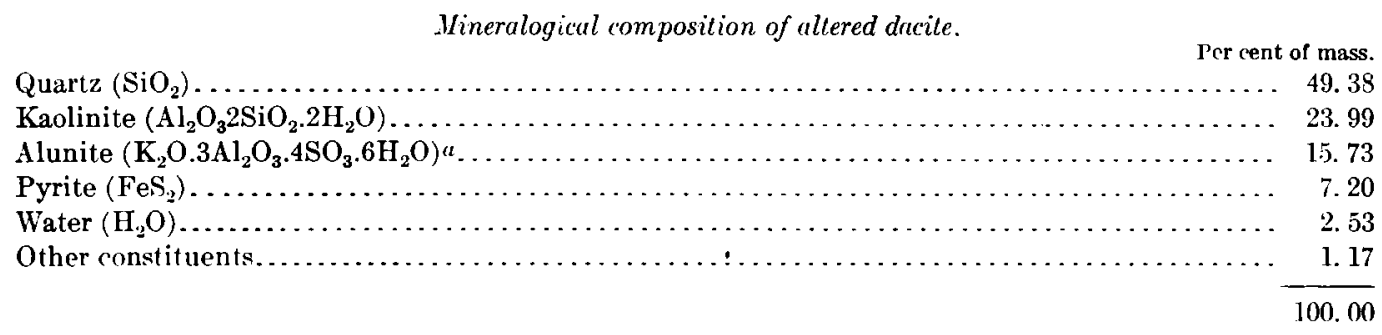

The various stages and variations in the alteration of the dacite, as seen in thin section under the microscope, are illustrated in Plates XXVIII to XXX, which are accompanied by full descriptive notes.

Compared as they stand, the two analyses show close agreement in silica, alumina, titanic oxide, and phosphorous pentoxide. When all the iron in both analyses is calculated as ferrous oxide, that of the altered rock shows a loss of only 0.7 per cent, so that in this respect also the two analyses are very close together. On the other hand, the analysis of the altered rock shows a loss of practically all the lime and magnesia, most of the soda, and one-half of the potash. It has gained a large quantity of combined water, nearly 6 per cent of sulphuric anhydride, and nearly 4 per cent of sulphur.

Such a direct comparison of analyses, however, while indicating in this case the general character of the change that has taken place in the dacite, is really a comparison of equal masses of the two rocks, or, more strictly speaking, of the two powders as prepared and weighed

$a$ The molecular proportions of potash and soda as calculated from analysis 2 , page 181, are respectively 11 and 14 . All of the potash and 8 of the soda molecules are needed to satisfy the 75 molecules of $\mathrm{SO}_{8}$. Consequently the Goldfield alunite is a soda-bearing variety. In an altered rhyolite from the east slope of Vindicator Mountain, the molecular ratio of soda to potash in the alunite, as determined by Doctor Hillebrand, is as 40 to 45 This rock, however, contains a little sericite, and it is possible that the result obtained for potash may be high in consequence of some decomposition. of the sericite by the sulphuric acid used to dissolve the alunite. 
for analysis, and as Lindgren ${ }^{a}$ pointed out some years ago, would accurately portray the character of the alteration only under two conditions, namely: (1) That the specific gravity or density of the rock is unchanged by the metamorphism; and (2) that the alteration has not produced any change of volume in the rock mass as a whole, such a change, for example, as takes place when peridotite alters to serpentine. It is essential in an investigation of this kind to determine what materials have been added to or subtracted from a unit volume (or unit mass) of fresh rock in order to produce a given alteration product.

The changes undergone by a given volume of rock can be determined most simply if the alteration is unaccompanied by swelling or contraction of the whole rock mass. The altered dacite shows no indication of increase of bulk. The field evidence of such swelling would comprise irregular fracturing and squeezing of the rock, the presence of curved slickensided surfaces, and pressure effects in the microscopical texture of the altered dacite. Contraction would probably be more difficult to detect. Any notable degree of shrinkage, however, would be likely to record itself by the development of many irregular open cracks or by some modification of the original texture of the rock, such as the distortion of phenocrysts. Evidence of either kind being absent, it may be concluded with some confidence that whatever volumetric change has taken place is to be sought in a comparison of the porosity of the two rocks and not in change of total bulk.

The porosity of the fresh dacite is exceedingly slight and is not apparent under the microscope. An accurate specific gravity determination of the rock powder used for analysis, made by Mr. George Steiger, gave the figures $2.654 .^{b}$ He also determined the specific gravity of the whole hand specimen as 2.63 , the difference between the two results being an approximate measure of the porosity. The specific gravity of the altered dacite, which is noticeably porous, as calculated from the mineralogical composition on page 179, assigning to the 1.17 per cent not accounted for the average specific gravity of the other constituents, is 2.769. ${ }^{c}$ Determinations by Mr. Steiger gave 2.766 for the powdered rock and 2.49 for the hand specimen. These figures indicate that the substance of the altered rock has gained 4.2 per cent in weight and that, notwithstanding this gain, a given volume of rock, under the supposition of constant volume, has suffered a net loss of 5.3 per cent in weight consequent upon an increase of porosity.

Since the volume of a given mass of rock, in cubic centimeters, is, for all practical purposes, equal to its weight in grams divided by its specific gravity, the percentage of pore space in the fresh dacite is obtained from the equation

$$
\frac{287.4}{2.63}-\frac{287.4}{2.654}=\frac{287.4}{2.63} x
$$

where 287.4 is the weight of a specimen of dacite in air, 2.63 the specific gravity of the rock mass, 2.654 the specific gravity of the poreless mineral constituents, and $x$ the proportion of pore space, which in this case is equal to 0.9 per cent. In the altered rock, the proportion of pore space is 9.9 per cent, showing an increase in porosity of 9 per cent of the initial volume.

The chemical changes undergone by the dacite are shown in the accompanying table. Columns $1 \mathrm{~b}$ and $2 \mathrm{~b}$ are not essential as regards the process illustrated, although they represent a step in the reasoning. They are of value also as showing that specific gravity determinations of rock powders, while useful in calculations of the mineral compositions of rocks, are of minor importance in a comparison of this kind, in which it is necessary to know the specific gravity of the mass as a whole, including its pores. Incidentally, it may be remarked that when the specific gravity of a rock is given in connection with its chemical analysis, the method by which the density was determined should be indicated.

\footnotetext{
a Metasomatic processes in fissure veins: Trans. Am. Inst. Afin. Eng., vol. 30, 1901, pp. 591-595.

$\checkmark$ The specific gravities of the powders were determined by placing weighed quantities in water in a tared picnometer and boiling them at low temperatnre under reduced pressure. They were then kept for some hours in a thermostat and quickly weighed at $25^{\circ} \mathrm{C}$. The specific gravities of the rock masses were obtained by weighing them in air and quickly in water. The figure 2.49, obtained for the altered dacite, is probably slightly too high in consequence of some absorption by pores open to the surface.

$c$ The figures used for the specific gravities of the minerals were: Quartz 2.66, kaolinite 2.61, alunite 2.(10, and pyrite 5 .
} 
In columns $1 \mathrm{c}$ and $2 \mathrm{c}$ are given the number of grams of each constituent in 100 cubic centimeters of each rock, the figures being obtained by multiplying the percentage figures in columns $1 \mathrm{a}$ and $2 \mathrm{a}$ by the respective specific gravities of the fresh and altered dacite. The gains and losses of each constituent are given in grams in column 3 , and in percentages of total initial mass in column 4 . The gains and losses as given in this column are also shown graphically in figure $20{ }^{a}$ The last column, 5 , gives the percentage of loss of each constituent and perhaps most clearly displays the nature of the change.

It appears that the rock has lost a little of its silica, more of its alumina, nearly all of its magnesia and lime, threefourths of its soda, and two-thirds of its potash. On the other hand, the water has greatly increased, a large amount of sulphuric anhydride has been added and the iron has been converted to pyrite. The iron oxides in column 1c correspond to 11.08 grams of metallic iron, while the pyrite in column 2c corresponds to 8.4 grams of iron and 9.6 grams of sulphur.

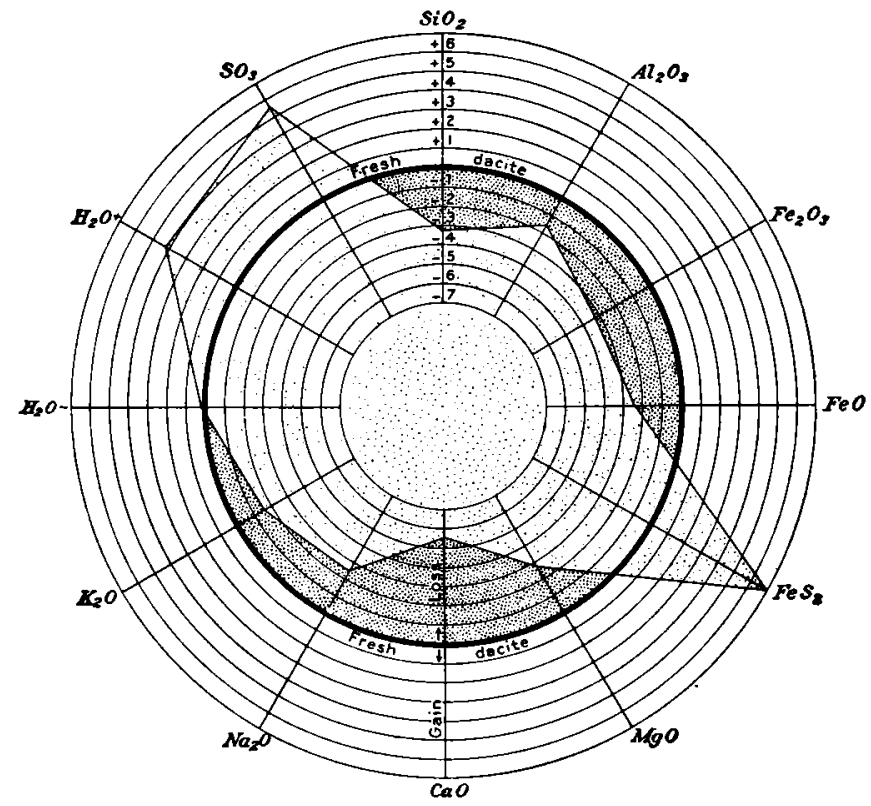

Figure 20.-Diagram illustrating gains and losses of each chemical constituent in terms of percentage of mass of original fresh dacite. Radial distance between successive circles corresponds to 1 per cent. Gains are outside, and losses inside, of the heavy circle representing fresh dacite. A reas have nosignificance. The quantity of iron originally in the dacite therefore not only was sufficient to form all the pyrite in the altered rock but has suffered a loss of over 27 per cent.

Chemical alteration of dacite.

\begin{tabular}{|c|c|c|c|c|c|c|c|c|c|c|c|c|}
\hline & 1. & 2. & 1a. & $2 a$. & lb. & $2 \mathrm{~b}$. & $1 c$. & $2 c$. & 3. & 4. & 5. & \\
\hline \multirow[t]{2}{*}{ 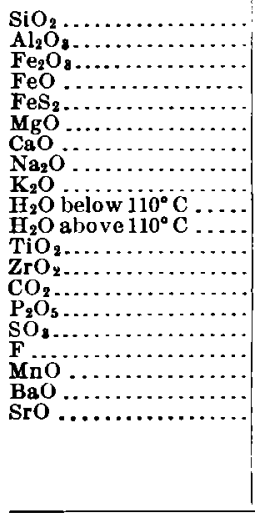 } & $\begin{array}{r}59.95 \\
15.77 \\
3.34 \\
2.34 \\
\text { None. } \\
2.73 \\
5.84 \\
3.07 \\
2.52 \\
.95 \\
2.00 \\
.82 \\
.02 \\
\text { None. } \\
.26 \\
\text { None. } \\
\text { None. } \\
.09 \\
.11 \\
.13\end{array}$ & $\begin{array}{r}60.53 \\
15.32 \\
.20 \\
7.14 \\
.20 \\
.06 \\
.41 \\
.84 \\
1.06 \\
1.33 \\
6.60 \\
.80 \\
.01 \\
\text { None. } \\
.27 \\
5.97 \\
\text { Trace. } \\
\text { Trace. } \\
\text { Not looked } \\
\text { for. }\end{array}$ & $\begin{array}{r}60.86 \\
16.01 \\
3.39 \\
2.37 \\
\text { None. } \\
2.77 \\
5.92 \\
3.12 \\
2.56 \\
.97 \\
2.03\end{array}$ & $\begin{array}{r}60.75 \\
15.37 \\
.20 \\
.14 \\
7.23 \\
.06 \\
.41 \\
.84 \\
1.06 \\
1.33 \\
6.62\end{array}$ & $\begin{array}{r}161.52 \\
42.49 \\
9.00 \\
6.29 \\
\text { None. } \\
7.35 \\
15.71 \\
8.28 \\
6.79 \\
2.58 \\
5.39\end{array}$ & $\begin{array}{r}168.04 \\
42.52 \\
.55 \\
.39 \\
20.00 \\
.16 \\
1.14 \\
2.32 \\
2.93 \\
3.67 \\
18.31\end{array}$ & $\begin{array}{r}160.07 \\
42.11 \\
8.91 \\
6.23 \\
\text { None. } \\
7.28 \\
15.57 \\
8.21 \\
6.73 \\
2.55 \\
5.34 \\
\end{array}$ & $\begin{array}{r}151.27 \\
38.27 \\
.50 \\
.35 \\
18.00 \\
.15 \\
1.02 \\
2.09 \\
2.64 \\
3.31 \\
16.49\end{array}$ & \begin{tabular}{|r}
-8.80 \\
$-\quad 3.84$ \\
-8.41 \\
$\quad 5.88$ \\
+18.00 \\
-7.13 \\
-14.55 \\
$-\quad 6.12$ \\
$-\quad 4.09$ \\
$+\quad .76$ \\
+11.15 \\
$-\ldots \ldots$
\end{tabular} & $\begin{array}{l}-3.35 \\
-1.46 \\
-3.20 \\
-2.23 \\
+6.84 \\
-2.71 \\
-5.53 \\
-2.33 \\
-1.55 \\
+.29 \\
+4.24 \\
\ldots \ldots \ldots\end{array}$ & \begin{tabular}{r}
$-\quad 5.50$ \\
$-\quad 9.12$ \\
-94.39 \\
-94.38 \\
\hdashline$\quad 97.94$ \\
-93.45 \\
-74.72 \\
-60.77 \\
$+\quad 29.80$ \\
+206.87 \\
\end{tabular} & \multirow[t]{2}{*}{ 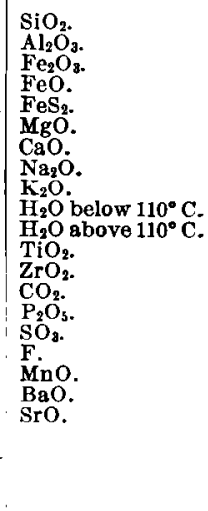 } \\
\hline & 99.94 & 100.80 & 100.00 & 100.00 & 265.40 & 276.60 & 263.00 & 249.00 & -14.00 & -5.32 & & \\
\hline
\end{tabular}

1. Chemical analysis of fresh dacite. George Steiger, analyst. Specific gravity of powder analyzed 2.654. Specific gravity of rock mass 2.63. 2. Chemical analysis of altered dacite. George Steiger, analyst. Specific gravity of powder analyzed 2.766. Specific gravity of rock mass 2.49. 1a. Analysis 1, recalculated to summation of 100 , with minor constituents omitted.

2a. Analysis 2, recalculated to summation of 100 , with minor constituents omitted.

1b. Constituents, in grams, in 100 cubic centimeters of fresh dacite free from pores. Specific gravity 2.654.

2b. Constituents, in grams, in 100 cubic centimeters of altered dacite free from pores. Specific gravity 2.766.

1c. Constituents, in grams, in 100 cubic centimeters of fresh dacite with 0.9 per cent pore spase Specific gravity 2.63 .

2c. Constituents, in grams, in 100 cubic centimeters of altered dacite with 9.9 per cent pore space. Specific gravity 2.49.

3. Gains and losses in grams of each constituent in the alteration of 100 cubic centimeters of dacite to the same volume of altered product.

4. Gains and losses of each constituent in percentage of mass of the original 100 cubic centimeters of fresh dacite.

5. Gains and losses of each constituent in percentage of its own original mass in 100 cubic centimeters of fresh dacite.

a This simple mode of presentation was adopted before the appearance of Leith and Harder's elegant diagrams in Bull. U. S. Geol. Survey No. 338. It is retained in the belief that a diagram which is intended to give quantitative expression to all details of a process is likely to be more intricate than illustrative. 
Comparisons of fresh and altered rocks are sometimes made by assuming the constancy of one constituent and recalculating the analysis of the altered rock accordingly. Such a method in the present case would give erroneous results.

The metamorphic agent was evidently a strongly acid solution carrying sulphydric and sulphuric acids, and possibly sulphurous acid. Whether the sulphuric acid which was doubtless the direct agent in the formation of the alunite was present in the original solution from the first, or whether it was derived from the hydrogen sulphide, by oxidation at some stage in the movement of the solution toward its point of attack upon the rocks now visible, is a question which will be discussed in Chapter XVI. The absence of sulphates from contact ore deposits indicates, however, that oxygenated sulphur compounds are not given off directly from solidifying magmas. The solution was capable of decomposing the silicates in the rocks, carrying part of their constituents away, reacting with the iron of the magnetite and silicates to form pyrite, with the potassium and aluminum to form alunite and with the aluminum to form kaolinite. The large percentage of loss in calcium, potassium, and sodium shows that the active solution was far below its saturation point for these elements, and was therefore, within the range of depth investigated, entirely different in character from the alkaline solutions which deposited the large class of sericitic and calcitic gold-quartz veins exemplified by those of California.

Not all of the dacite is altered to exactly the same product as that just described. Some varieties contain diaspore as a microscopic constituent. Others, which may be classed as ledge matter or ore rather than country rock, contain more quartz and pyrite. On the south slope of Preble Mountain, near the summit, the dacite in some places has been altered to a white fine-granular rock, not unlike quartzite or marble in general appearance. This is a nearly pure aggregate of quartz and alunite, with very little pyrite. The original texture of the rock, except for the presence of an occasional phenocryst of quartz, is entirely obliterated.

\section{CHANGES IN OTHER ROCKS.}

The metasomatic changes effected by the ore-depositing solutions in the latite, andesite, and rhyolite of the district have not been studied in the same detail as that in dacite. Even were conditions for close comparison of fresh and altered rock as favorable as in the case of dacite, such study would not be likely to throw any new light on the general nature of the process. The andesite differs but slightly from the dacite in chemical and mineralogical composition and alters to products not always distinguishable from those derived from the dacite. A similar statement applies to the latite, alunitized modifications of which may be studied on the lower levels of the deeper mines, in various shafts northeast of Goldfield, and in the quarry on the south edge of Columbia, where the original rock has been changed to a soft, white, porous mass which is chiefly alunite.

The altered forms of rhyolite differ from those of other rocks mainly in the presence of less pyrite, owing to the fact that the rhyolite originally contained little iron in the form of oxides and silicates. Alunite is very abundant in the altered rhyolite, and, as shown in Plate XXXI, forms comparatively coarsely crystalline aggregates pseudomorphous after orthoclase. Such aggregates may be well seen in the rhyolite capping Columbia Mountain, near the Conqueror mine, and on Vindicator Mountain. 
A chemical analysis of altered rhyolite from the eastern shoulder of Vindicator Mountain, one-fourth mile ( 0.4 kilometer) from the summit, is given below:

Chemical analysis of altered rhyolite.

[George Steiger, analyst.]

\begin{tabular}{|c|c|c|c|}
\hline $\mathrm{SiO}_{2} \ldots \ldots \ldots \ldots$ & 75.78 & $\mathrm{ZrO}_{2} \ldots \ldots \ldots \ldots$ & 0.02 \\
\hline$\cdots \ldots \ldots \ldots \ldots \ldots \ldots \ldots$ & 10.65 & $\mathrm{CO}_{2} \ldots$ & .76 \\
\hline $\mathrm{Fe}_{2} \mathrm{O}_{3} \ldots \ldots \ldots \ldots \ldots \ldots \ldots$ & .68 & 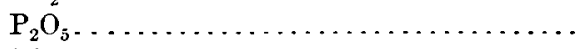 & \\
\hline FeO $\ldots \ldots \ldots \ldots \ldots \ldots \ldots \ldots$ & .16 & 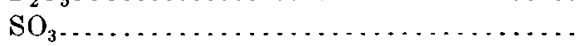 & 4.73 \\
\hline 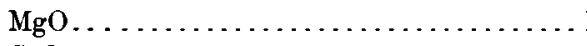 & None. & & None. \\
\hline $\mathrm{CaO} \ldots . .$. & 1.67 & $\mathrm{MnO}$. & Non \\
\hline$\ldots \ldots \ldots \ldots \ldots \ldots$ & .22 & $\mathrm{BaO}$. & \\
\hline 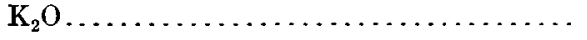 & .96 & $\mathrm{SrO}$. & Non \\
\hline $\mathrm{H}_{2} \mathrm{O}$ below $110^{\circ}\left({ }^{\prime} \ldots \ldots \ldots \ldots \ldots \ldots\right.$ & 1. 16 & & \\
\hline $\mathrm{H}_{2} \mathrm{O}$ above $110^{\circ} \mathrm{C} \ldots \ldots \ldots \ldots \ldots \ldots \ldots \ldots$ & 3.54 & & \\
\hline $\mathrm{TiO}_{2}, \ldots \ldots \ldots \ldots \ldots \ldots \ldots \ldots \ldots$ & .12 & & \\
\hline
\end{tabular}

The rock analyzed (G. 333) is nearly white and shows small spots of light-pink alunite. Under the microscope, in ordinary light, it shows embayed quartz phenocrysts and the outlines of feldspars, in a groundmass which still retains much of the fluidal structure of a glassy rhyolite. Between crossed nicols, however, the whole rock, with the exception of the quartz phenocrysts, is seen to have undergone recrystallization. In the new aggregate, alunite forms the largest crystals. These have grown partly in the groundmass, partly in the original feldspar phenocrysts. Many of the latter, however, are altered to extremely fine-grained aggregates, in which it is difficult to identify the constituent minerals. Most of the calcite shown by chemical tests and analysis to be present in the rock appears to be in these fine aggregates, as the mineral is very inconspicuous in the thin sections. Some of these aggregates certainly contain sericite and kaolinite. Relatively large plates of alunite inclosed in these fine-grained pseudomorphic aggregates are common. The groundmass is mainly a very fine-grained mixture of quartz, kaolinite, calcite, sericite, and a little iron oxide, probably from pyrite. The secondary minerals, except the iron oxide, so far as microscopic examination shows, were all formed contemporaneously.

The calculation of the mineralogical composition of this altered rock from its chemical analysis, in terms of microscopically recognized minerals, is not entirely satisfactory. The carbon dioxide of the analysis is too low to combine with all the lime as calcite, while the alkalis do not quite suffice to satisfy the sulphuric anhydride for alunite, and no potassium is left for the sericite known to be present. Consequently, all of the alumina, after that necessary for alunite is taken out, must be calculated as kaolinite, whereas some of it should undoubtedly be combined in the sericite molecule. These conditions, since the chemical analysis may be regarded as trustworthy, suggest the presence of gypsum $\left(\mathrm{CaSO}_{4}+2 \mathrm{H}_{2} \mathrm{O}\right)$, which, if it occurs in the fine aggregates with kaolinite, can not be satisfactorily identified by microscopical methods. By calculating all of the carbon dioxide as calcite, the balance of the lime as gypsum, the balance of the sulphuric anhydride as alunite, the balance of the potash as sericite, and the residual constituents as quartz, iron oxides, and water, the following is obtained as the approximate mineralogical constitution of the altered rhyolite:

Mineralogical composition of altered rhyolite.

Per cent of mass.

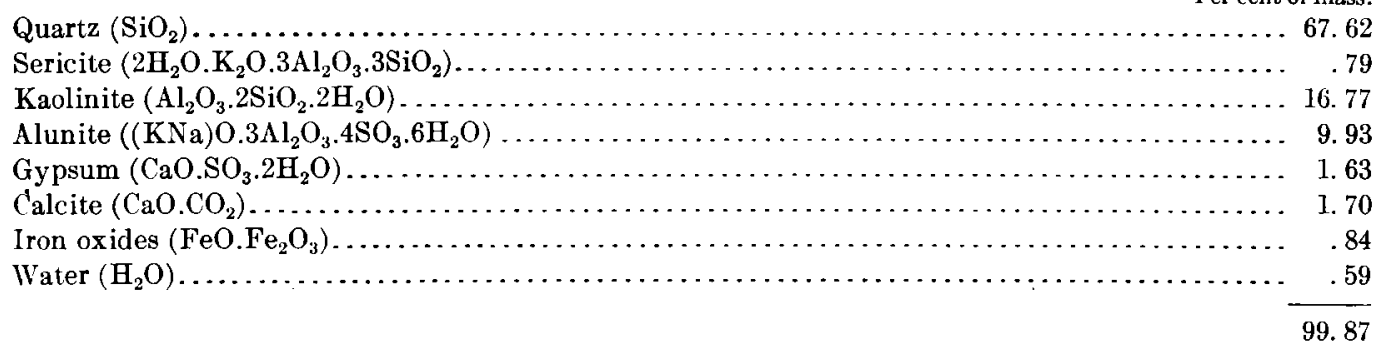




\section{PLATE XXXI.}

\section{Photomicrograph of Alunitized Rhyolite.}

A. Vindicator rhyolite (G. 326). West slope of Vindicator Mountain. Shows alunite (a) pseudomorphs after orthoclase. Quartz phenocrysts $(q)$ are unaltered. Black areas are opaque, white, earthy pseudomorphs after biotite. The groundmass $(\mathrm{g})$, which retains its original flow structure, has been altered from a glass to an aggregate of quartz, kaolinite, and alunite. The rock contains a little diaspore, not shown in this section. Ordinary light. Magnified 40 diameters.

$B$. Same as $A$. Nicols crossed, showing aggregation of alunite and devitrification of the groundmass. 


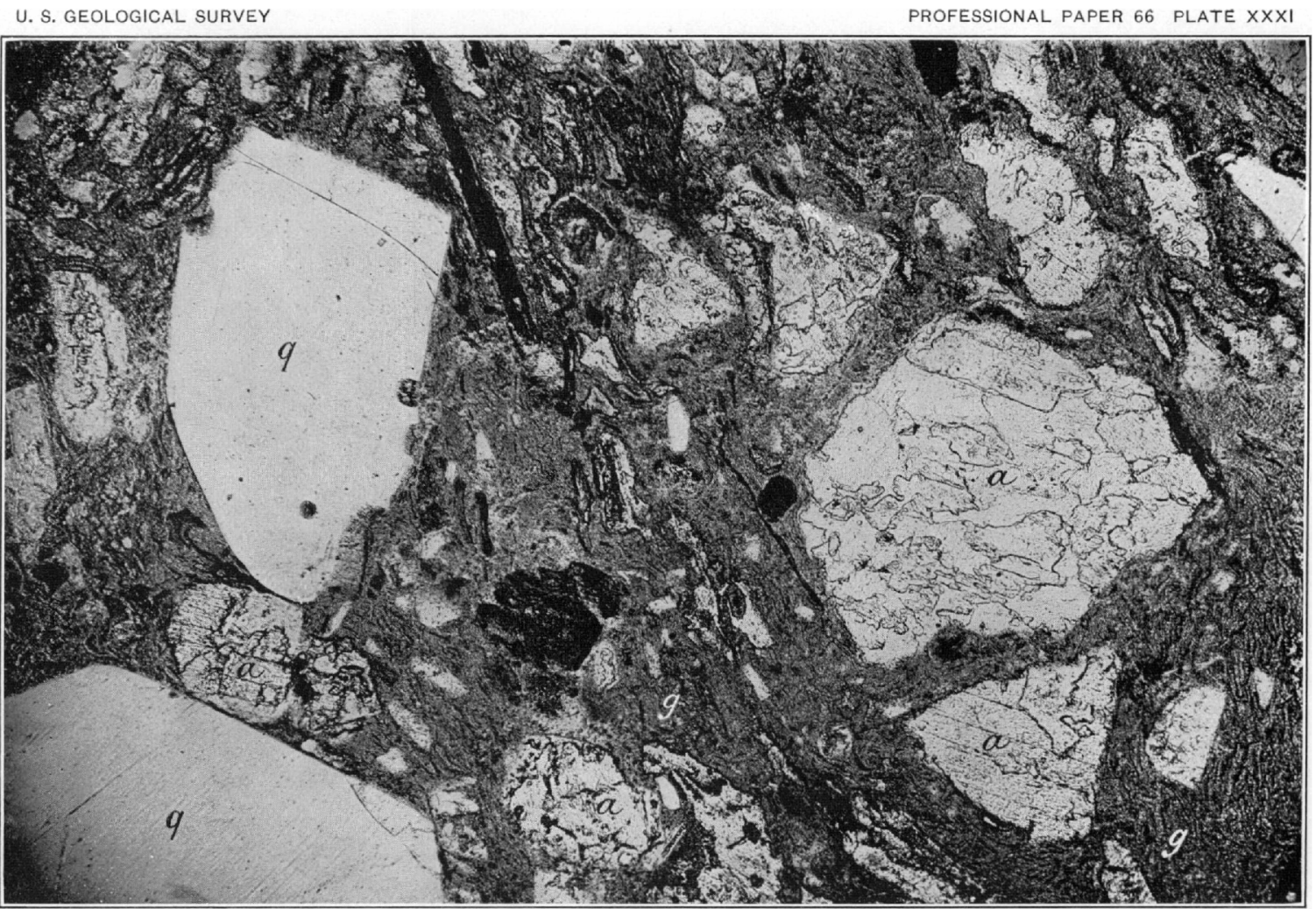

i.

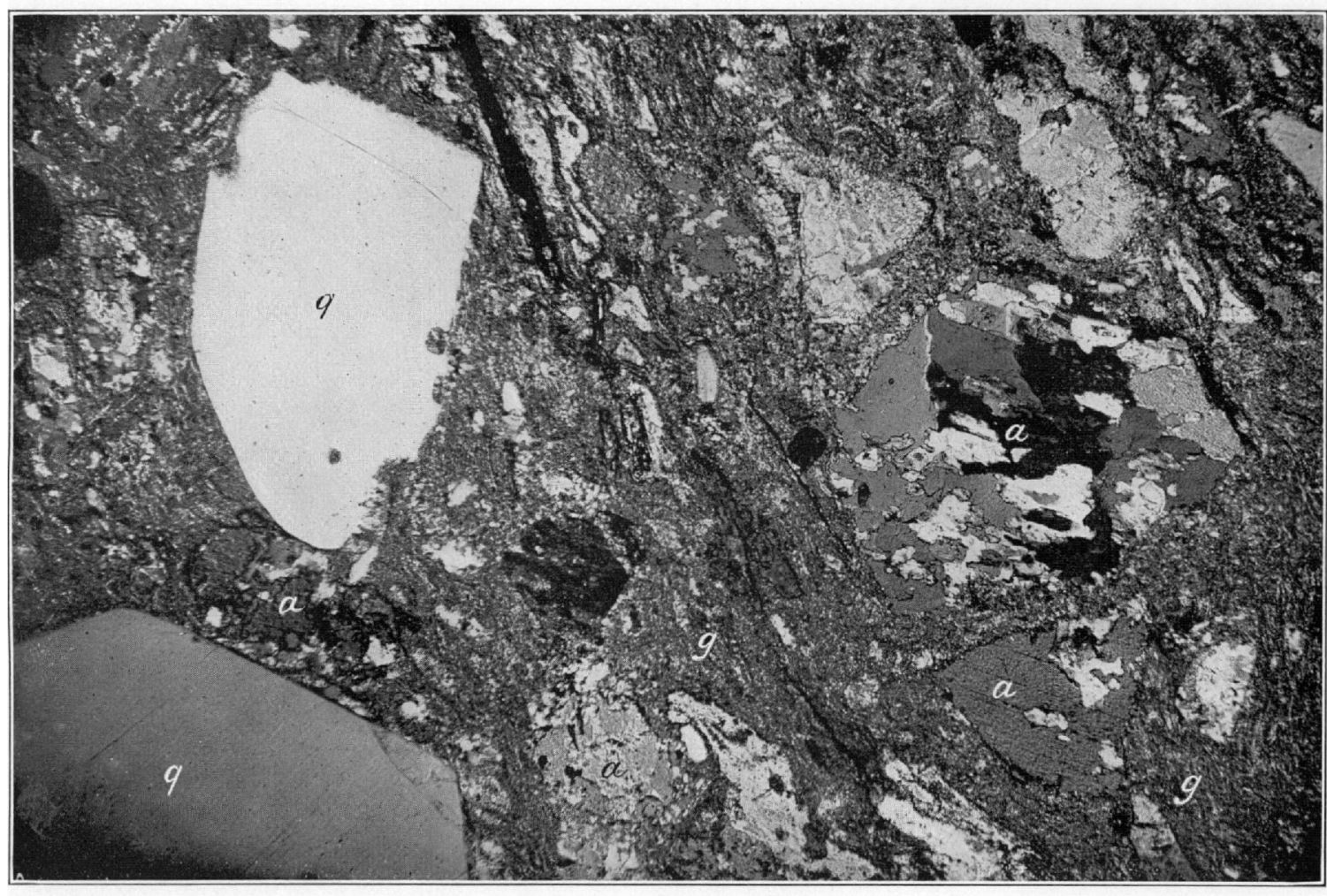

$B$.

PHOTOMICROGRAPHS OF ALUNITIZED RHYOLITE. 

This result is not entirely convincing, as the quantity of sericite obtained by calculation appears to be a little less than is actually present in the rock, and the occurrence of gypsum is not established beyond question.

In the presence together of calcite, alunite, and sericite, this rock is exceptional. Other specimens from the same locality show much quartz, alunite, and kaolinite, with some diaspore, but no calcite or sericite.

The rhyolite, as might be expected from its originally siliceous character, tends to become completely silicified in the vicinity of fissures, as is exemplified in the neighborhood of the Sandstorm mine.

\section{THE ORE-DEPOSITING SOLUTIONS.}

The mineralogical character of the Goldfield ores and the alteration of the wall rock show that the solutions or vapors which deposited them carried gold, copper, bismuth, antimony, a little arsenic and tellurium, hydrogen sulphide, and probably sulphurous and sulphuric acids. The solvent action of the solutions upon quartz was comparatively slight, as shown by the fact that the original phenocrysts of the dacite still retain their characteristic embayed outlines when the rest of the rock is altered to quartz, alunite, and kaolinite. The quartz set free by the decomposition of the silicates has for the most part recrystallized as fine-grained aggregates. A small proportion, as we have seen, has been carried away in solution, perhaps in part to be recrystallized in small neighboring fissures, and in part permeating the surrounding less-altered rocks. Large masses of coarsely crystalline vein quartz are absent from this district, and it seems necessary to conclude not only that the ore-bearing solutions were poor in silica but that, in spite of their energetic attack upon the rocks, they were not good solvents for quartz. The apparently intense silicification of the country rock in proximity to fissures appears at first glance to point to a different conclusion. The conversion of a rock containing 60 per cent of silica to a fine-grained pyritic quartz aggregate does not, however, necessarily imply the direct addition of 40 per cent of silica. The result may be attained by the removal of most of the bases, the conversion of the iron to pyrite, and the development of a porous texture such as is favorable for ore deposition and is characteristic of the Goldfield ledges. Moreover, it is probable that some of the silica shown to have been abstracted from the altered dacite may have been concentrated in the immediate vicinity of the fissures. Certainly, whatever silica was originally in the solutions did not travel far from the fissures through which they rose.

Whether the solutions were notably ferruginous is doubtful. As compared with other districts, the pyrite at Goldfield is not abundant, and all of that in the country rock can, as has been shown, be accounted for without any addition of iron. There has, in fact, been an abstraction of iron which may have been sufficient to form the pyrite in the actual ore, upon the supposition that the dissolved iron, like the silica, migrated toward the fissures.

In general the heavy metals brought in by the solutions remained within or very close to the multitude of small, irregular fissures that afforded opportunity for the depositional process. The sulphur acids, on the other hand, penetrated the wall rock for considerable distances.

It is very probable that the ore-bearing solutions contained carbon dioxide, although the ores and the rock adjacent to them are free from carbonates. Field evidence in this district, as well as in the Coeur d'Alene district ${ }^{a}$ in Idaho, indicates that this constituent, when of volcanic origin, becomes active in the formation of carbonates only at comparatively low temperature, and that it tends to penetrate to greater distances from the source of supply than some of the other constituents. The third, or propylitic type of alteration described on page 176, is thought to be largely due to the extensive permeation of the rocks by solutions containing carbon dioxide. It thus constitutes an outer aureole to the more intense metasomatism associated directly with the ores.

$a$ Ransome, F. L., and Calkins, F. C., The geology and ore deposits of the Coeur d'Alene district, Idaho: Prof. Paper U. S. Geol. Survey No. 62, 1908. 
It may be recalled, in this connection, that Sainte-Claire Deville and Ieblanc, ${ }^{a}$ in their studies of Italian volcanic gases, found that sulphurous and carbonic acids never occurred together, although the association of sulphydric and carbonic acids was frequent. They concluded that, as a rule, the emanation of carbon dioxide marks a later and cooler stage of solfataric activity. The transition from one type to the other, however, can hardly be abrupt.

Just what became of the lime and magnesia removed from the altered dacite has not been determined. A part, at least, of the calcium was probably taken into solution as hydrous sulphate and deposited in fissures as gypsum, this mineral being known to occur in the district in places where its formation can scarcely have resulted from the action of surface waters. Still another part and some of the magnesium may have been carried as carbonates into the rocks affected by metamorphism of the third or propylitic type and there deposited metasomatically as calcite or dolomite. It has not yet been ascertained, however, whether there has actually been any addition of calcium or magnesium to these carbonatized rocks.

a Mémoire sur la composition chimique des gaz rejetés par les évents volcaniques de l'Italie méridionale: Annales chim. phys., vol. 52, 1858, p. 45. 


\section{CHAPTER XV.}

\section{UNDERGROUND WATER AND DEPTH OF OXIDATION.}

When mining began, the average level of underground water in the district was from 100 to 150 feet (30 to 46 meters) below the general surface. The Combination mine first had water at 130 feet ( 40 meters), the January at 180 feet ( 55 meters), the Red Top at 140 feet ( 43 meters), the Silver Pick shaft, near Columbia, at 100 feet (30 meters), and various shafts near Diamondfield at about the same depth. As is usually the case, water was found at less depth in low ground than on high, the Dixie shaft on Preble Mountain being dry at 300 feet (91 meters), as is also the Lucky Boys shaft, 360 feet (110 meters) deep, on Vindicator Mountain, while some wells near town have furnished water at 40 or 50 feet (12 to 15 meters). At Rabbit and Tognoni springs, and at a spring near the mouth of Pozo Canyon, water comes to the surface. All these are ordinary hillside springs, the water seeping from the higher ground in their vicinity.

In none of the mines has the flow of water been so large that it could not be easily kept down by bailing or with ordinary pumps. When the Combination was the deepest mine, the quantity of water hoisted to keep the 280 -foot level free was probably not over 3,000 gallons $(11,250$ liters) in twenty-four hours. The White Rock prospecting shaft in the northern part of the town of Goldfield is one of the wettest in the district. It was 520 feet (158 meters) deep in July, 1908, and goes through 280 feet (85 meters) of Siebert beds and overlying wash into latite. It thus drains a thick mass of porous sediments and at times it has been necessary to hoist 30,000 gallons $(112,500$ liters) in twenty-four hours to keep down the water.

Most of the wells in the district are in the Siebert beds or in the intercalated flow of Mira basalt. The latter is the principal water-bearing horizon for domestic wells of moderate depth (50 to 70 feet, or 15 to 21 meters) in the southern part of town. In 1906 the Goldfield brewery derived its water supply entirely from a 50-foot (15-meter) well in the basalt. The supply from wells in the Siebert beds is uncertain and is not always proportional to depth. In the latter part of 1905 the Goldfield Reduction Company was getting about 4,500 gallons ( 16,875 liters) in twenty-four hours from a 200-foot (61-meter) well and the New Western Reduction Company 2,000 gallons $(7,500$ liters) or less from a 250 -foot (76-meter) well. The well at the ice works, 100 feet (30 meters) deep, yielded 4,000 gallons (15,000 liters) per diem in June, 1905, but only 2,000 gallons in the following October. A well sunk in 1908, just south of the Gardiner mill, is 180 feet ( 55 meters) deep, and is said to yield about 10,000 gallons $(37,500$ liters) in twentyfour hours, most of which comes in at points less than 100 feet (30 meters) deep. This well is rather remarkable in that the water rises to within a few feet of the surface, showing that it is under some artesian head. It undoubtedly taps the same flow that gives rise to Rabbit Spring.

The town water supply came originally from wells in Pozo Canyon. The first well yielded about 8,000 gallons (30,000 liters) per diem in August, 1904, at a depth of 25 feet (7.6 meters). This soon diminished, and in November the well was deepened 10 feet (3 meters) and horizontal drifts were run from the bottom. The supply then rose to 15,000 gallons $(56,250$ liters $)$, but fell off again when a new well was sunk lower down the canyon. This second well at first gave 20,000 gallons (75,000 liters) per diem, but in September, 1905, was furnishing only 15,000 gallons, the well being 90 feet ( 27 meters) deep, with drifts. Both wells are in the Siebert beds.

The Pocahontas well, at the roundhouse of the Las Vegas and Tonopah Railroad, is 840 feet (256 meters) deep. Its yield is about 24,400 gallons $(91,500$ liters) in 24 lours. Water was first found at 94 feet ( 28 meters), but the flow was small and no increase was noted until a depth of 450 feet (137 meters) was reached. 
The ground water of the district without question represents merely the storage of that small part of the scanty local precipitation which is not evaporated before it can sink into the ground. Extensive pumping soon lowers the water in any one place and the subsequent influx is small. There is a permanent seepage from Malpais Mesa, as shown by springs and by some of the wells, but the quantity of water thus supplied to the sediment-filled basin under Goldfield probably does not average more than 20,000 gallons $(75,000$ liters) per diem and may be considerably less. The general level of the ground water is being steadily lowered by mining operations, and there is no suggestion whatever of any influx of thermal or abyssal waters at the present time.

The character of the underground water varies. That from the wells and springs is fairly good as desert waters go and is not so strongly charged with salts as to give it perceptible taste. The water from many prospect shafts also is potable. But in mines where bodies of ore are in course of oxidation the water, as shown by the analysis of that from the January mine on page 220 , is heavily charged with sulphates and probably in many places with free sulphuric acid. The quantity of sulphides in the Goldfield deposits is not great, and in more humid regions their oxidation probably would not give rise to such concentrated solutions. At Goldfield, however, the ground water has little natural circulation, receives only slight accessions of fresh water, and has a correspondingly slow underground run-off.

In general, the bottom of the oxidized ore corresponds closely to the original ground-water level. In comparison with most deposits in arid regions, therefore, the vertical range of oxidation is short, being only about 150 feet (46 meters). The change from oxidized to sulphide ore is as a rule sharp, and there is no evidence of any large fluctuation in the ground-water level. The character of the oxidized ore has been described on page 170. The question whether oxidation has been accompanied by notable enrichment of the sulphides below is so closely connected with the whole problem of ore genesis that its consideration belongs rather to the next chapter. 


\section{CHAPTER XVI.}

\section{GENESIS OF THE DEPOSITS.}

\section{STATEMENT OF THE PROBLEM.}

Since the preceding chapters contain an ample presentation of the problem now awaiting solution, only a brief recapitulation is needed of some of the most significant facts with which an adequate explanation of ore genesis must harmonize.

Beyond all question the intimate association of unusually rich gold ores with the mineral alunite is the most remarkable feature of the deposits and is the one that promises to shed most light on their origin. Alunite is not a common mineral, and although it was recognized in small quantity in the oxidized zone at Cripple Creek it is at Goldfield alone, so far as is at present known, that it is found with sulphides and tellurides as a characteristic mineral of unoxidized gold ores. The presence of this mineral and the kind of alteration undergone by the rocks containing it prove, as shown in Chapter XIV, that the ores were deposited from solutions containing sulphuric acid. Whether this acidity was an original property of the gold-bearing solutions or whether the solutions, primarily of different character, became acidic at the place of precipitation, or during their journey thither, are questions presently to be considered.

Other chemical and mineralogical features of the ores to be kept in mind are the occurrence of telluride and selenide of gold, sulphide of bismuth, and compounds of copper, sulphur, antimony, and arsenic (enargite, famatinite, and goldfieldite) of which the mineral species is not in every case determinable, the cryptocrystalline character of the quartz, and the extraordinary concentration of the gold. Due consideration must be given also to the volcanic history of the region, the recent age of the deposits, the slight depth at which they were formed, and, as a corollary of these facts, the brief time and the short vertical distance available for any secondary concentration that may be postulated in connection with erosion.

Attention will first be directed to the question of the source of the sulphuric acid, since if it can be satisfactorily answered the other phases of the main problem should crystallize clearly about this nucleus.

\section{THE DIRECT VOLCANIC HYPOTHESIS.}

That some fumaroles emit sulphur dioxide has long been known. As early as 1858 SainteClaire Deville and Leblanc ${ }^{a}$ found it in gases from Vesuvius and other Mediterranean volcanoes. From one fumarole in the crater of Vesuvius they collected a gas which proved to contain hydrochloric acid and sulphur dioxide in the ratio of 86.2 parts of the former to 13.8 parts of the latter, together with water vapor and the constituents of ordinary air. They concluded from their investigations that carbon dioxide and sulphur dioxide never came simultaneously from the same fumarole. This, however, does not accord with the results of some other workers, as is shown by the following table prepared by F. C. Lincoln, ${ }^{b}$ which is of theoretic interest, from the fact that calcite and alunite occur together at one place in the Goldfield district. (See p. 183.)

\footnotetext{
a Mémoire sur la composition chimique des gaz rejetés par les évents volcaniques de l'Italie méridionale: Annales chim. phys., $3 d$ ser., vol. 52, p. 45,1858 .

b Econ. Geology, vol. 2, 1907, p. 802 .
} 
Fumarole gases containing both $\mathrm{CO}_{2}$ and $\mathrm{SO}_{2}$.

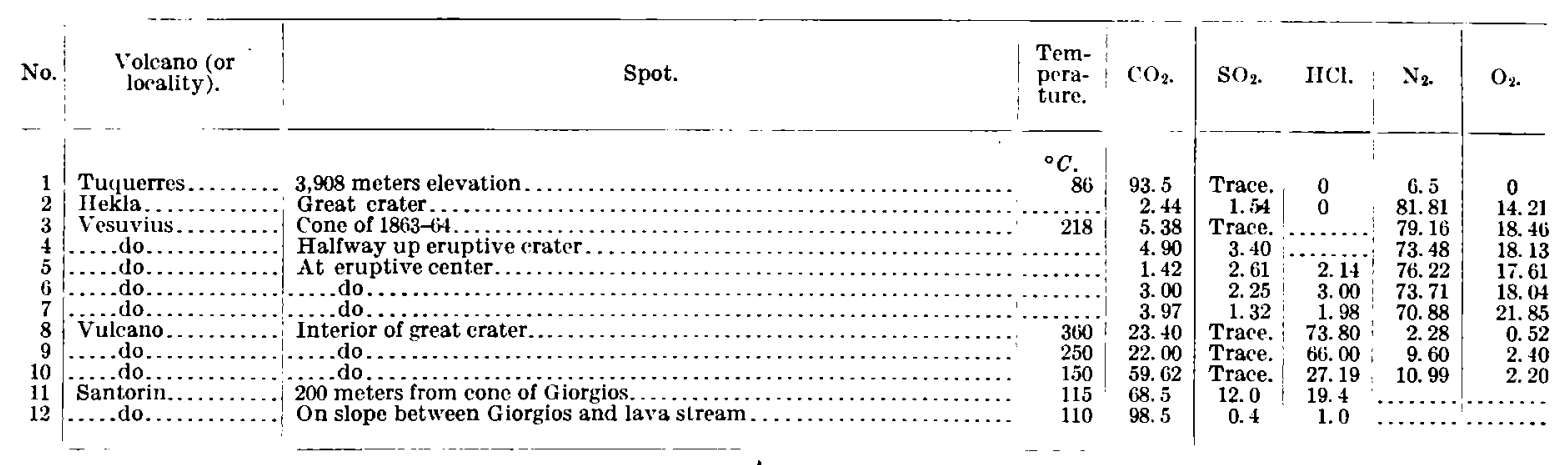

A uthorities: (1) Boussingault, J. B., Annales chim. phys., 2d ser., vol. 52, 1833, p. 21. (2) Bunsen, R. W., Annales chim. phys., 3d ser., vol. 38, 1853, p. 259. (3) Franco, Compt. Rend., vol. 66, 1868, p. 159. (4) Franco, Compt. Rend., vol. 66, 1868, p. 1352. (5-7) Franco, Annales chim. phys., 4th ser., vol. 30, 1873, pp. 98-99. (8-10) Fouqué, F., Compt. Rend., vol. 61, 1865, p. 565. (11-12) Gorceix, H., Compt. Rend., vol. 75, 1872, p. 270.

Van Hise ${ }^{a}$ states that in the gases emitted from fumaroles and solfataras sulphur dioxide is probably next in abundance to steam. This, however, does not appear to accord with the testimony of published analyses of volcanic gases. F. C. Lincoln, ${ }^{b}$ on the basis of 50 selected analyses, concludes that, after steam and nitrogen (the latter being difficult to rank owing to the possibility of admixture of air), carbon dioxide is the most important gas, followed by hydrogen sulphide and sulphur dioxide.

Sulphuric acid or sulphuric anhydride is apparently still less common in volcanic emanations than sulphur dioxide. Geikie " states that "occasionally, also, the production of sulphuric acid is observed at active vents," which probably means merely that the acid is formed superficially by oxidation of sulphur dioxide. In the interesting crater lakes of Taal volcano described by R. F. Bacon ${ }^{d}$ free sulphuric acid is present in large quantities. It is apparently formed, however, by the oxidation of fumarolic sulphur dioxide which bubbles up through the boiling water.

On the whole, it appears to be very doubtful whether sulphuric acid or sulphuric anhydride is actually emitted from the deeper part of any volcanic vent. There is a strong suggestion, moreover, that the sulphur dioxide which streams from some fumaroles is not all of deep-seated origin, but may in part be due to an admixture of air with the true telluric gases, particularly with hydrogen sulphide. Here we are confronted, however, with the difficulty of distinguishing sharply between primary and secondary volcanic products. At what depth, for example, must water or oxygen be introduced in order to be classed as a primary volcanic product? By magmatic water do we mean only such as has been locked in the earth's interior since the planet took its present form, or may we mean also water that the magmas have subsequently absorbed in some such manner as that advocated by S. Arrhenius? e May not the water emitted from volcanoes be both magmatic and meteoric as these terms are used by most writers? This is still a vexed question, although the available evidence favors the view that meteoric water does not reach the sources of magmas. $f$ Granted that the water of volcanic eruptions, however introduced or formed, comes mainly from the molten magma, there is no a priori difficulty in postulating the emission of oxygen compounds of sulphur, since Fouqué $\theta$ has shown that in some cases the constituent gases of water are dissociated and the liberated oxygen might under some circumstances unite with sulphur. As a matter of fact, however, the oxides of sulphur are not nearly so common or abundant, and when they do occur are not so clearly of deep derivation, as is hydrogen sulphide.

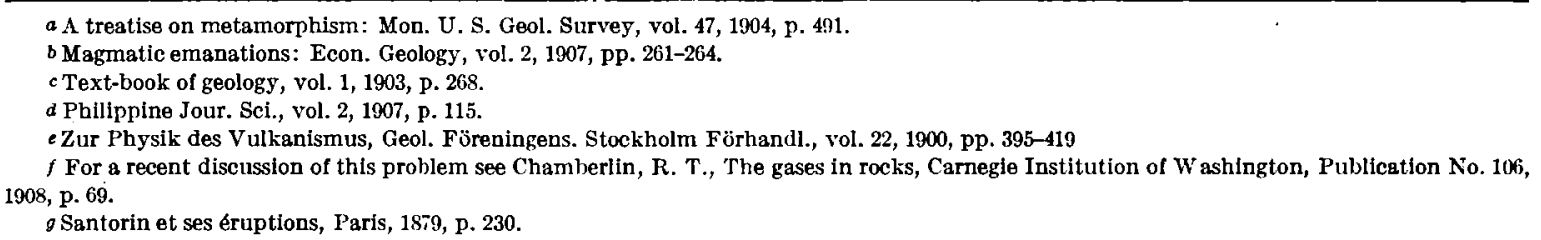


There is evidence also of the deep-seated formation of sulphuric acid in the presence of sulphates, such as barite and celestite, ${ }^{a}$ as primary minerals in some veins. Recently, too, Lindgren ${ }^{b}$ has called attention to the occurrence of anhydrite as a primary mineral with tourmaline and chalcopyrite at the Cactus mine in the Frisco district, Utah. The presence of the minerals haüynite $\left[\left(\mathrm{Na}_{2} \mathrm{Ca}\right)_{2}\left(\mathrm{NaSO}_{4} \mathrm{Al}\right) \mathrm{Al}_{2}\left(\mathrm{SiO}_{4}\right)_{3}\right]$ and noselite $\left[\left(\mathrm{Na}_{4}\left(\mathrm{NaSO}_{4} \mathrm{Al}\right) \mathrm{Al}_{2}\left(\mathrm{SiO}_{4}\right)_{3}\right]\right.$ in phonolitic rocks proves that under some circumstances sulphur trioxide may be present in molten magmas, and consequently may exist in magmatic solutions. There are, however, no phonolitic rocks known at Goldfield.

While these occurrences are to be regarded as favoring the view that sulphuric acid can form at volcanic centers, their testimony, as regards importance in ore deposition, is opposed by the absence of sulphates from contact metamorphic deposits and of sulphuric acid from most hot springs. Springs carrying sulphuric acid are, it is true, not unknown. The water of a hot acid spring at the so-called geysers of Sonoma County, Cal., according to an analysis by Thomas Price, contains 145 grains of free sulphuric acid per gallon. ${ }^{c}$ Other springs at the same locality contain smaller quantities of the same acid. All these waters, however, are saturated with hydrogen sulphide, and it is possible that the sulphuric acid may have been formed by the oxidation of the sulphydric acid within the zone penetrated by surface waters. Hot sulphuric acid springs occur also in the Coso Range, Inyo County, Cal., accompanied by deposits of sulphur containing hydrogen sulphide. ${ }^{d}$ Similar acid springs carrying hydrogen sulphide issue from sulphur deposits near Maverick Springs, El Paso County, Tex. The water from one of these, according to E. M. Skeats, ${ }^{e}$ contains 136 parts per 100,000 or 79.08 grains per gallon of free sulphuric acid. W. T. Lee has described a similar occurrence at Sulphurdale, Utah. ${ }^{f}$ Analyses of 11 other springs' waters containing less sulphuric acid than those above mentioned are given by F. W. Clarke. $g$

The chemical activity of free sulphuric acid in spring water would of course lead to the rapid formation of sulphates during the upward course of the water and to consequent neutralization of the free acid. But there is a limit to such rapid neutralization and in persistent and copious springs it might be expected that some free acid would in most cases be brought to the surface were it commonly generated below. Furthermore, if sulphuric acid were formed in any considerable quantity at great depth during volcanic activity we should expect to find alunite a more common constituent of rocks which have been uncovered by erosion than experience indicates. Moreover, it is questionable whether waters rich in sulphuric acid would be efficient carriers of gold, sulphides, and tellurides. It is probable that they would precipitate these constituents from the alkali sulphide solutions, of which the solvent efficiency has been repeatedly shown by experiment ${ }^{h}$ and by geologic evidence.

In view of these considerations, and of others presently to be brought forward, the hypothesis, suggested with some favor in a preliminary paper, ${ }^{i}$ that the ore-depositing solutions may have come from below already charged with sulphuric acid, has been abandoned.

\section{HYPOTHESIS OF DERIVATION OF THE SULPHURIC ACID FROM THE OXIDA-} TION OF PYRITE.

The hypothesis that the alunitization of the rocks at Goldfield was effected by cold sulphate solutions percolating generally downward from masses of oxidizing sulphides, principally pyrite, has some facts in its favor. The small quantity of impure alunite found at Cripple

a Lindgren, W., and Ransome, F. L., Geology and gold deposits of the Cripple Creek district, Colorado: Prof. l'aper V. S. Geol. Survey No. 54, 1906 , pp. $220-221$.

$s$ Oral communication before the Geological Society of Washington. Abstract in Science, n. s., vol. 28, 1908, p. 933.

c Anderson, Winslow, Mineral springs of California, San Francisco, 1892, p. 150

¿ Anderson, Winslow, op. cit., p. 254.

e Bull. Univ. Texas Min. Survey No. 2, 1902, p. 34

$f$ Water resources of Beaver Valley, U tah: Water-Supply Paper U. S. Geol. Survey No. 217, 1908, pp. 19-20.

$g$ Data of geochemistry: Bull. U. S. Geol. Survey No. 330, 1908, pp. 155-157.

$h$ As regards tellurides see Lindgren, W., and Ransome, F. L., Geology and ore deposits of the Cripple Creek district, Colorado: Prof. Paper U. S. Geol. Survey No. 54, 1906, pp. 223-224.

$i$ The association of alunite with gold in the Goldfeld district, Nevada: Econ. Geology, vol. 2, 1907, p. 688. 
Creek was undoubtedly formed in this manner, and observations indicate that a part of the alunite at Goldfield, namely, some of the soft varieties which fill interstices in the partly oxidized ore, may have been, if not originated, at least dissolved and redeposited during oxidation. According to De Launay ${ }^{a}$ the alunite at the classic locality of Tolfa is the product of such solutions acting upon a particularly feldspathic trachyte. The formation of alunite by cold percolating solutions probably requires these to be more strongly acid than is necessary for the production of kaolinite.

The intimate association of the alunite with kaolinite at Goldfield has a bearing on the problem. The origin of this mineral has been the subject of much recent discussion, ${ }^{b}$ the general trend of which is to emphasize the connection between kaolinization and weathering. Lindgren ${ }^{c}$ has recently intimated that although he himself formerly referred to the mineral as characteristic of certain classes of veins, kaolinite should not be considered as a gangue mineral of any class of ore deposits except those formed under the influence of oxidation. In a subsequent paragraph he somewhat modified this statement by the expression of belief that "kaolin is rarely formed by alkaline hot water at any considerable depth below the surface." The preponderant weight of careful observations made during the last few years is unquestionably on the side of the thesis thus moderately stated; and the occurrence of kaolinite at Goldfield, where the intimate association of the mineral with the alunite, gold, sulphides, tellurides, and sulphantimonites, as determined by microscopical work, shows that all were formed at the same time and by one general process, is an additional point against what has been called the direct volcanic hypothesis.

Much kaolin originally described by various authors as formed by the solutions which first brought up the ores associated with it has later been proved to have resulted from oxidizing processes, it being one of the most characteristic products of the action of percolating, weakly acid solutions upon aluminous rocks. The kaolin at Cripple Creek is a good example. Much so-called primary or pneumatolytic kaolin, moreover, has been shown to be sericite, and some is perhaps alunite.

On the other hand, these facts seem scarcely to warrant the total elimination of kaolinite from the list of gangue minerals found in ore deposits, the connection of which with oxidation is at least not obvious, and which are certainly not affected by ordinary weathering. The mineral occurs as an original constituent of some of the ores of the San Juan Mountains, Colorado, ${ }^{d}$ and W. H. Weed ${ }^{e}$ has described it as a product of the metasomatic action of the waters of Boulder Hot Springs, Montana, upon granite. Kaolinization has also been noted by Béla von Inkey $f$ in the dacitic country rock of the Nagyang veins, the material being afterwards investigated by F. Kollbeck, ${ }^{g}$ whose analysis indicates a mixture of kaolinite and sericite.

The principal objections to the view that the alunitization at Goldfield is connected with the oxidation of older pyritic ores are based largely on what appears to be the quantitative insufficiency of the proposed explanation. No such available primary masses of sulphides are known, and study in the district has failed to bring to light any bodies of sulphides that are distinctly older than the ores and that are not accompanied by alunite. There is no evidence yet found which indicates the superposition of a distinctly younger phase of deposition characterized by the formation of alunite upon an older phase not associated with that mineral. The mines at Goldfield are still comparatively shallow, but they have penetrated about 500 feet below the bottom of the weathered ores, and if the alunitization were the result of ordinary weathering it is likely that secondary products would somewhere have been found distinctly imposed upon earlier nonalunitic material. It is probable that at a depth greater than that

a La métallogénie de l'Italie: Cong. géol. intern., Mexico, 1906, vol. 1, 1907, p. 681.

$b$ See especially Zeitschr. prakt. Geologie, 1907 and 1908.

c The relation of ore deposition to physical conditions: Econ. Geology, vol. 2, 1907, p. 120.

$d$ Ransome, F. L., Economic geology of the Silverton quadrangle, Colorado: Bull. U. S. Geol. Survey No. 182, 1901, p. 73.

e Mineral vein formation at Boulder IIot Springs, Montana: Twenty-first Ann. Rept. U. S. Geol. Survey, pt. 2, 1900, p. 253.

$f$ Nagyág und seine Erzlagerstiitten, Budapest, 1885, p. 143.

$g$ Untersuchungen über die Zersetzung des Quarztrachyts neben Goldersgängen von Nagyág: Oesterr. Zeitschr. f. Berg- und Huttenwesen, vol. 36,1888 , pp. 25-27. 
now attained alunite will become less abundant, but the change will, it is believed, be gradual, and there is nothing to indicate that it will exhibit such a definite relation to the general ground-water level as might fairly be expected under the hypothesis now underconsideration.

The alunitization of the rocks, as shown on page 176 and by figure 18 , is very extensive and is by no means confined to the immediate vicinity of known ore bodies. Except in the zone of superficial oxidation the alunite is crystallized with pyrite and consequently has not formed under conditions involving the destruction of this sulphide in the zone now accessible. To account for the alunitization by the oxidation of pyrite would require the assumption that the material stripped from the district by erosion was much more heavily pyritized than the rocks at present visible. The thickness of this vanished overburden, as has been shown, can scarcely have exceeded 1,000 feet (305 meters) and probably was very much less. Moreover, the period available for alunitization was geologically very brief, since the process had already taken place when the Pozo formation was laid down. We are thus confronted by the contrast of a process remarkable for the extent and intensity of its action with conditions which, if not markedly unfavorable, were at least not such as would be expected to produce the observed effects under the present hypothesis. The remarkable concentration of the gold and associated minerals in these deposits appears to be out of all proportion to any leaching action possible within the time and distance available. This discrepancy will, it is believed, become more marked when the character and genesis of the metallic minerals of the ores are considered, as they will be in connection with the next hypothesis.

\section{HYPOTHESIS OF SIMULTANEOUS SOLFATARISM AND OXIDATION.}

The third hypothesis to be tested postulates that the ore constituents were brought up in hot solutions charged with hydrogen sulphide, a little carbon dioxide, and probably also with some alkali sulphides; that the hydrogen sulphide was oxidized at and near the surface to sulphuric acid, which percolated down through the warm rocks to mingle with the uprising currents carrying sulphydric acid; and that the precipitation of the richest ores took place in the zone where the two kinds of solutions mingled and as a consequence of such mingling. As Van Hise ${ }^{a}$ has pointed out, the chemical reactions of weathering and of solfataric action are not so different as might be supposed, and this process differs from that of the second hypothesis chiefly in greater intensity of action and in the smaller demands that it makes on time and erosion. The hypothesis differs from the first one considered mainly in that the sulphuric acid acted as the precipitant rather than as the carrier of the ore constituents which came up in sulphide solutions. This latter view has the initial advantage of being in much better accord with all that has been learned of the chemistry of natural sulphide deposition than is the first supposition. Any explanation of the origin of the Goldfield deposits which calls for natural solvents radically different from those which carried the carefully studied ores of Tonopah, the Comstock, Grass Valley, Cripple Creek, and many other districts in this country and abroad is burdened at the outset with presumptive improbability.

In accordance with the third hypothesis the hot ascending waters carried abundant hydrogen sulphide, as shown by the extensive change to pyrite of the iron originally present in the dacite and other rocks as a constituent of magnetite and silicates. This change was not confined to the rocks now alunitized, but extended outward to what has been called the propylitic aureole of alteration. The experiments of Becker ${ }^{b}$ and Doelter, ${ }^{c}$ supported by studies of metasomatically altered wall rock in various districts, suggest that the sulphur of the original solutions was in part combined with or accompanied by sodium and potassium. The changes in the dacite investigated in Chapter XIV, notwithstanding the development of the potassium- and sodiumbearing mineral alunite, do not show any addition of alkalies to the original rock, but such negative evidence does not prove that no alkali sulphides were present in the primary solutions.

a A treatise on metamorphism: Mon. U. S. Geol. Survey, vol. 47, 1904, p. 494.

$b$ Geology of the quicksilver deposits of the Pacific slope: Mon. U. S. Geol. Survey, vol. 13, 1888, chap. 15.

c Einige Versuche uber die Löslichkeit der Mineralien: Tschermak's Min. n. petr. Mitth., vol. 11, 1859, p 319.

$79145-\mathrm{N}(1.66-09-13$ 
They may have been largely oxidized to sulphates and carried away to accumulate in the playa deposits of the region, just as is happening at the present day at Alkali Spring. (See p. 143.) If so, it is to be expected that at greater depth than is now reached at Goldfield the feldspars of the rocks are extensively sericitized with some addition of alkalies. That the ore-bearing solutions contained carbon dioxide is indicated by the alteration of calcium-bearing silicates to calcite in the propylitic zone. It is not to be supposed that calcite would form abundantly in rocks soaked with sulphuric acid. It does occur, however, with alunite in rhyolite on the east slope of Vindicator Mountain, and this association of minerals is probably the result of local conditions which retained under pressure and fixed in combination the carbon dioxide that otherwise would have escaped in the presence of the acid solutions necessary for the production of alunite. Such local conditions of pressure are more readily conceivable in connection with hot uprising waters than under the circumstances of ordinary weathering.

In addition to sulphydric and carbonic acids the solutions carried the following, either as compounds or in ionized condition: Gold, silver, copper, zinc, lead, bismuth, antimony, arsenic, tellurium, and selenium. They probably contained also some iron and silica, although the study of rock alteration recorded in Chapter XIV shows subtraction, not addition, of these constituents to the wall rock. On the other hand, the actual ledge matter contains more silica and pyrite than was in the original rock. How much of this excess was contributed by the uprising solutions directly and how much was merely concentrated from the surrounding country rock is not determinable. There was probably some direct addition, however, from deep-seated sources in the immediate vicinity of the fissures.

It has been shown that the fissuring of the district was very complex and irregular, affording innumerable devious channels for the passage of solutions. Thus the hot solutions presumably reached the surface at many places, and this distribution of the outflow must have been far more favorable to oxidation of the hydrogen sulphide to sulphuric acid and to the subsequent activity of the latter than if the uprising waters had flowed from a single vent. There is reason to believe (see p. 107) that the climate at the time the ores were deposited was comparatively arid. It is likely, therefore, that the mineral-bearing solutions, upon reaching the surface, were not only oxidized but were concentrated by evaporation as they flowed over the surface or percolated down through the rocks. The sulphuric waters as they penetrated downward must have exerted a strong leaching action on the superficial rocks similar to that observable at Sulphur Bank, Cal., at the present day, where basalt has been altered to spongy masses of snowy silica by the removal of its basic constituents. At moderate depth the acidic descending solutions met uprising solutions charged with hydrogen sulphide and ore constituents, and mingled with them in a zone characterized by the presence of sulphydric, sulphurous, and sulphuric acids and by the simultaneous development of alunite and sulphides. The vertical range of this zone must have been considerable--probably 1,000 feet (305 meters) or more. The mixing of the solutions may have been effected partly by differences in density between the hot ascending currents charged with gases and the cooler descending waters, partly by convection, partly by diffusion, and perhaps partly by osmotic action. The sulphuric acid solutions would in general have greater power of penetrating the substance of the country rock than would the silica and the in part colloidal bases of the uprising solutions. ${ }^{a}$ It is to be remembered also that the rocks at the time of ore deposition were as a whole hard and brittle, had been recently fractured, and were much more generally permeable than at present, when much of the country rock, softened by alteration, is incompetent to maintain open fissures. Evidently, with the process once initiated, the waters reaching the surface would no longer represent the original ore-bearing solutions, but would be mixtures of these with sulphate waters and would contain various constituents abstracted from the rocks during alunitization, as shown in Chapter XIV.

At no time in their history were the depositing solutions, if we may judge from their work, strong solvents for silica, and the quantity of this constituent transported by them was small.

a See Sullivan, E.C., Experiments on the separation of the constituents of a solution by filtration through a mineral filter: Econ. Geology, vol. 3, 1908, pp. 750-756. 
The ledges, it is true, are siliceous, but most of the quartz was derived from the rock now altered to ledge matter and from the alunitized rock in the vicinity. Some silica doubtless came up with the solutions, but had these been very siliceous it is to be expected that they would have filled all interstices with solid crystalline vein quartz of the usual kind. On the contrary, the quartz at Goldfield is flinty or cryptocrystalline, and occurs either as a metasomatic mineral replacing the country rock or as porous vuggy fillings formed by the accumulation of successive thin crusts, the process having rarely gone far enough to produce a solid mass of quartz. In this respect the deposits at Goldfield resemble those of Cripple Creek. It is possible that the crystallinity of vein quartz does not depend wholly or chiefly on the supply of silica available but is largely a function of pressure and temperature. At one end of the series may be the coarsely crystalline quartz of the pegmatite dikes or veins; at the other end the cryptocrystalline quartz of deposits formed close to the surface. If so, the character of the quartz at Goldfield is to be added to the other evidence in favor of superficial origin of the deposits.

It is believed that the process outlined as the third hypothesis best explains the abundant formation of alunite, with subordinate diaspore, and the intimate association of these minerals with the sulphide ores and especially with the pyrite in the altered rock which surrounds the ores. This explanation of the genesis of the alunite is in accord with the experiments of SainteClaire Deville, ${ }^{a}$ who produced the mineral artificially by subjecting, for several months, fragments of volcanic rock, suspended in water, to a stream of hydrogen sulphide mixed with air. By providing an efficient precipitant (sulphuric acid) supplied continuously to a definite zone traversed by the uprising metalliferous solutions, the hypothesis appears to account well for the remarkable concentration of the gold and associated constituents in this zone. As already mentioned, it is difficult to harmonize the extent and intensity of the alunitization with the hypothesis of oxidation of lean deposits during erosion. It is still more difficult to explain by such secondary enrichment the unusual concentration of the gold with so much tellurium and bismuth as are present in the Goldfield ores.

Many of the important minerals of epigenetic deposits, as is well shown in the useful tables compiled by W. Lindgren ${ }^{b}$ and W. H. Emmons ${ }^{c}$ can be formed under different conditions and by solutions of diverse origin. The individual minerals that can be accepted with confidence as characteristic of a single bathymetric zone and of a single mode of genesis are certainly very few. Taken altogether, the minerals of the Goldfield ores suggest deposition at moderate or slight depth. They are not, however, as a group characteristic of what is ordinarily understood as secondary enrichment. The tellurides particularly, in view of the recent investigation at Cripple Creek, ${ }^{d}$ are more indicative of deposition from uprising hot solutions than of enrichment by cold descending waters.

\section{STAGES OF DEPOSITION.}

It has been shown in the descriptive portions of this report that some of the richest ore is of later deposition than some of the siliceous ledge matter. The relation of this fact to the various hypotheses suggested may appropriately be considered at this place. As regards the sulphide ores at least three depositional stages have been recognized. These are (1) deposition of pyrite with famatinite, and probably also with some bismuthinite, gold, quartz, and alunite along zones of fissuring, associated with alunitization and pyritization of the neighboring country rock; (2) deposition of rich nodular ores in zones of shattering in the previously formed ledge matter; (3) deposition of narrow streaks of soft, dark, amorphous ore, often very rich in gold, along fissures in the main ore bodies. These stages are not everywhere recognizable. Moreover, it is doubtful whether they tell the whole story. It is highly probable that fracturing followed by renewed deposition has been repeated many times in the course of the formation of the most

a De l'altération, par voie naturelle et artificielle, des roches silicatées, au moyen de l'acide sulfhydrique et de la vapeur d'eau: Compt. Rend. vol. 35,1852 , pp. $261-264$.

$b$ The relations of ore deposition to physical conditions: Econ. Geology, vol. 2, 1907, p. 125.

c A genetic classification of minerals: Econ. Geology, vol. 3, 1908, pp. 618-622.

d Lindgren, W., and Ransome, F. L., Geology and gold deposits of the Cripple Creek district, Colorado: Prof. Paper U. S. Geol. Survey No. 54, 1906, p. 204, and Chapter XI. 
important masses of ore, introducing a complexity which makes the record undecipherable. To determine whether a given mass of rich ore, with its characteristic concentric crustification, represents one or more periods of mineralization is by no means always easy. The mere fact that the gold, tellurides, and sulphides form shells around masses of dacite or andesite which have been changed to aggregates of quartz, alunite, and pyrite is not proof that the kernels had been altered before the crusts enveloped them. Many of the fragments, in fact, show by their rounded contours and by slight textural and chemical differences in radial directions that the solutions which deposited the ores acted also upon the kernel which they were incrusting. (See Pls. XXIII to XXV). On the other hand, specimens such as those figured in Plate XXIII, $E$, prove that crusts of gold and sulphides may be deposited around fragments of rock that have been at least twice fissured and twice subjected to the action of solutions that deposited quartz, alunite, and pyrite. In other ore bodies there is no clear evidence of more than one period of mineralization.

The third stage of deposition referred to, that which produced narrow seams of soft, dark, rich ore in some of the ore bodies, is not quantitatively of great importance. These seams may be very rich, but they are generally less than an inch ( 25 millimeters) in width and are filled with a mixture of attrition material and sooty sulphide mixtures of no definite mineralogical character. They are probably due to recent enrichment by the chemical action of the present ground water. This, as has been shown on page 220, is in some places strongly acidic and is probably capable of dissolving and redepositing alunite and some of the sulphides.

\section{SUMMARY OF GENESIS.}

In accordance with the hypothesis of simultaneous solfatarism and oxidation it is believed that after the intruded dacite had solidified, but possibly beiore it had entirely cooled, the district and part of the surrounding region was subjected to stresses of unknown origin. These found relief in a very complicated system of fissures, which were unaccompanied by any considerable displacement of the rocks. Hot waters carrying abundant hydrogen sulphide with some carbon dioxide and the various metallic constituents of the ores rose in these fissures. The dissolved hydrogen sulphide was oxidized in part to sulphuric acid in the upper parts of the fissure zones and at the surface. The resulting acidic solutions percolated down through the shattered rocks, changing their feldspars to alunite, mingling with the uprising sulphide solutions, and precipitating the greater part of their metallic load as ore. The original solutions apparently were not everywhere equally rich in gold, since in many parts of the district ledges were formed which have not proved to be of any value. The most highly mineralized waters rose along a north-south belt about three-quarters of a mile in length and along the line of the Columbia Mountain fault, near Goldfield. Just what significance should be attached to this coincidence of fault and mineralization is not clear. As suggested on page 83 , the fissuring along this belt may have been occasioned by a renewal of movement along the predacitic fault line. The presence of the fault fissure may also have favored deep connection with the ore sources. These suggestions, however, are not susceptible of proof and would have more weight did not some good ore occur in other parts of the district.

It is believed that during this first stage of deposition most of the ledges were formed, much of the country rock was softened and alunitized, other parts farther from the fissures were propylitically altered, and some masses of good ore were deposited.

The ledges at this time were presumably harder than the altered rocks which inclosed them, and it would seem at first thought that any subsequent fissuring would avoid the siliceous masses and pass through the softer material. To some extent it probably did so, the stresses finding relief in gouge-filled, curved, and irregular slips through the country rock. Movements in the soft country rock, however, which is more or less plastic near the ledges, could not fail to exert on these rigid brittle masses stresses which would deform them, like the quartz pebbles in some squeezed and schistose conglomerates, by many small fractures rather than by a few simple fissures. The fractured ledge masses would be.pervious to solutions, while the surround- 
ing squeezed country rock would be relatively impervious. Some ledges after fracturing were perhaps cut off from communication with the rising mineralizing solutions and are to-day comparatively barren. Others to which these waters had access, particularly those in which considerable sulphide deposition had previously taken place, were enriched by the revival of the circulation of hot ascending sulphide solutions and cooler descending sulphate solutions mingling in the manner already described. The conditions during this second stage of mineralization would probably be more favorable for the concentration and deposition of very rich ore than during the first stage. The shattered ledges may be likened to great sponges in the pores of which were provided ideal conditions for chemical reactions and precipitation, the sulphides already formed probably aiding directly in withdrawing gold and fresh sulphides from solution. ${ }^{a}$ It is not necessary to suppose that all the ledges were subjected simultaneously to this second fissuring or that all were affected by the same number of recurrent depositions. The richest ore bodies probably occur in those ledges which were most often fractured and which at the same time retained most continuously an open connection with the deep source of the hot sulphide waters. Movements in the ledges have continued up to very recent times and may be still in progress. They are no longer followed, however, by any manifestation of thermal action, although they have afforded opportunity for some minor enrichment by waters which have passed downward through the belt of weathering.

Objection may be made to the foregoing hypothesis on the ground that, although the sulphur and cinnabar deposits of Sulphur Bank, California, exhibit a mode of deposition similar to that suggested for the Goldfield ores, no other important gold deposits are known to have formed in this manner. It may be said, in reply, that no gold deposits comparable with those of Goldfield are known, and it is no valid ground for surprise that their unique character leads to an explanation different from that applicable to gold veins such as those of the Mother Lode belt in California. If the explanation here given is correct it follows that the conditions for the formation and preservation from erosion of deposits of the Goldfield type must be rare. Climate alone may exert a controlling influence. If the original sulphide solutions rose in a region of abundant rainfall, deep soil, and luxuriant vegetation, oxidation of the hydrogen sulphide to sulphuric acid would take place less rapidly, and most of the acidic solution, instead of sinking deep into the ground, might flow off in streams. Such part as did seep down and survive the reducing action of organic compounds would mingle with a ground water diluted by copious rains and too rapidly renewed by run-off and additions to be of great chemical activity.

In a region of rapid erosion the entire zone of alunitization might be removed in a geologically short time and deposits of no unusual character be left.

\section{ULTIMATE SOURCE OF THE ORE-BEARING SOLUTIONS.}

What was the ultimate source of the solutions that brought up the ores? Consideration of this question takes us into a region where facts and hypotheses, inference, and speculation are distinguishable with great difficulty, and where, in consequence, dogmatism finds congenial soil. A genetic connection with volcanicity is strongly suggested by the geologic history of the region and is well-nigh proved by the chemical character of the solutions and by the presumably high temperature at which they issued. This connection is indicated also by some points of similarity, particularly the presence of tellurides, between the Goldfield ores and those of Cripple Creek, for which deposition from hot magmatic solutions appears more nearly demonstrable than for any district yet studied in equal detail. The thesis that the hot uprising solutions at Goldfield emanated directly and solely from some crystallizing magma is, however, still far from proof.

The possible share, in much ore deposition, of water that at some time in its history was precipitated from the atmosphere is not to be lightly dismissed. The argument, frequently advanced, that the dryness of most very deep mines precludes the primary concentration of ores by meteoric water is not of great cogency. Its validity depends on the assumption that 
the present conditions of permeability in the rocks are the same as when the ores were deposited. This obviously is not true. If it were, deposition by water from any source would have been impossible. The fracturing which permits the ascent of hot solutions also in most cases favors the descent of surface water. According to Arrhenius ${ }^{a}$ there is no reason why this descending water should not penetrate to, and in the gaseous state be absorbed by, molten magmas. Evidence has already been presented which shows that during the deposition of the ores the rocks at Goldfield were more permeable to descending water than at present, or alunitization would probably never have extended so far and so deep. It is supposed that this downwardmoving water was for the most part water that had first risen to the surface, but who can say how much rain water mingled with this and how deep the resulting mixture actually penetrated?

The work of Gautier, ${ }^{b}$ also, shows how volcanic action, by heating masses of solid rock and generating therefrom large quantities of water and of the same gases as are emitted from fumaroles, may play a part in ore deposition which is not dependent on the original water content of the intruding magma.

Although not inclined to deny the very important part played by volcanism in ore deposition, and while convinced that volcanic emanations have been largely responsible for the formation of the Goldfield ore bodies, I believe that we are not in a position to insist on the all-sufficiency of hypogene waters (that is, juvenile or original magmatic waters) to account for the deposition of most epigenetic deposits. The cooperation of water from different sources is not a negligible possibility and in the complex conditions and delicate adjustments incident to such cooperation is perhaps a suggestion of the reason why ore deposits are exceptional rather than invariable accompaniments of igneous intrusion. The mineralizing capacity of cold artesian solutions is ordinarily slight. Most masses of intrusive rock, on the other hand, are not associated with productive mineral deposits. It is possible, however, that conditions most favorable for ore deposition may result when magmatic and meteoric water, and perhaps water of other kinds than is usually implied by these terms, contribute to the final result

\section{PRESENT ABSENCE OF VOLCANIC ACTIVITY.}

So far as can be determined from existing mine workings volcanic activity, notwithstanding its geologic recency, has completely died out at Goldfield. The mines receive no hot or warm water and no gases such as at Cripple Creek mark the final stage of expiring volcanism. This is rather remarkable, since many of the springs in this part of Nevada are thermal, and Spurr ${ }^{c}$ found that at Tonopah the temperature increases downward at more than the normal rate. The highest rock temperature recorded by him was $78^{\circ} \mathrm{F}$. $\left(25.6^{\circ} \mathrm{C}\right.$.) at a depth of 766 feet (233 meters) in the Ohio Tonopah shaft. Recently, however, water at a temperature of $86^{\circ} \mathrm{F}$. $\left(30^{\circ} \mathrm{C}\right.$.) has been encountered at a depth of 1,250 feet ( 381 meters) in the Mizpah shaft. ${ }^{d}$ Although no appreciably warm water occurs at Goldfield it is possible that refined temperature observations in the deeper shafts lately available might show a trace of the former heat in a temperature gradient somewhat higher than the normal for nonvolcanic regions. It is to be remembered that the waters of the Comstock lode had a temperature of only $70^{\circ} \mathrm{F}$. at the 600 -foot level. ${ }^{e}$

It does not appear possible to connect the volcanic contribution to the Goldfield deposits with a magma corresponding definitely to any of the eruptive rocks in the Tertiary sequence. The supposition that the principal metallic constituents (with the exception of the iron) and some at least of the water in which these were carried issued from a body of dacitic magma is an attractive one, but has little real evidence in its favor. It may be remarked in this connection that a chemical analysis of the glassy, extrusive dacite vitrophyre shows 3.35 per cent of water

a Zur Physik des Vulkanismus: Geol. Föreningens Stockholm Förhandl., vol. 22, 1900, pp. 395-119.

$b$ La genèse des eau $x$ thermales, etc.: Annales des mines, 6th ser., vol. 9, 1906, pp. 316 370. Translated in Fi.on. (irology, vol. 1, 1906 , p. 688.

$c$ Geology of the Tonopah mining district: Prof. Paper U. S. Geol. Survey No. 42, 1905, p. 263.

$d$ Letter from Mr. W. H. Blackburn, superintendent of the Tonopah Mining Company.

e Becker, G. F., Geology of the Comstock lode: Mon. U. S. Geol. Survey, vol. 3, 1882, p. 252. 
driven off below $110^{\circ} \mathrm{C}$. and 4.06 per cent lost above that temperature, a total of 7.41 per cent. The intrusive dacite, on the other hand, contains 2.95 per cent of water, 2 per cent being driven off above $110^{\circ} \mathrm{C}$. It is not quite certain that these two rocks had the same magmatic origin, but if so the dacitic magma originally contained a large quantity of water, much of which was expelled during the solidification of the more crystalline facies, as shown by the difference of over 4 per cent between the water of the two analyses. If the ore solutions came from this magma they presumably rose from portions solidifying at such depth as would develop a still higher degree of crystallinity than in the visible dacite and lead to a further expulsion of water and mineralizing constituents. It is quite possible, however, that the ores emanated from a magma differing in composition from any one of the eruptive rocks in the district.

\section{GOLDFIELD TYPE OF DEPOSIT.}

The recognition of alunite as a characteristic constituent of the Goldfield ores and the demonstration of its genetic relation to them establishes a new type-that of alunitic and kaolinitic gold-quartz veins - in the classification of epigenetic deposits based upon the kind of metasomatism effected in the wall rock by the ore-depositing solutions. While the Goldfield deposits are probably too irregular in form to come under the usual definition of vein, yet in all that relates to genesis of the ores there is no essential difference between them and what is usually termed a metasomatic fissure vein.

According to Robert $T$. Hill, ${ }^{a}$ mineralization very similar to that at Goldfield has affected the rocks in the mining district of Alunite, ${ }^{b} 22$ miles (35 kilometers) southeast of Las Vegas, Nev. Prospecting is in progress but no ore bodies of importance have yet been found.

This chapter may fittingly be closed by recalling to mind how complex is the problem of genesis of most deposits of the precious metals and how uncertain in character are the data available for its solution. These are fragmentary and only in small part consist of definite facts with known quantitative values. A careful sifting of more or less doubtful evidence is all that is possible and the result is usually a matter of judgment rather than of mathematical proof. As regards Goldfield the evidence has been presented without conscious bias and the conclusions are submitted to the reader with full realization that no one of the three hypotheses suggested is certainly impossible. Were the question referred to a geological court its decision might not be unanimous.

a Camp Alunite, a new Nevada gold district: Eng. and Min. Jour., vol. 86, 1908, pp. 1203-1206.

b A new na:ne for a district prospected years ago and formerly known as Railroad Pass. 


\section{CHAPTER XVII.}

\section{PRACTICAL CONCLUSIONS.}

If the genesis of the Goldfield deposits has been correctly inferred it follows that the deposition of rich ore is connected with alunitization. It follows, further, that at some depth not yet determined the alunitic phase of alteration is replaced by metasomatism of a different kind, probably sericitic, accompanied by ores of lower grade. To a depth of 600 feet (183 meters) there is little if any decrease in the abundance of alunite, but there are indications of generally lessening tenor of the ores. There may be individual exceptions to this last statement, but few thoroughly familiar with the underground workings in the district and capable of impartial judgment are likely to question its essential truth.

Even if the rocks below the depth of 600 or 700 feet (183 or 213 meters) were the same as those above, it is believed that considerable changes in the character of the deposits might be looked for in the next 300 or 400 feet (91 or 122 meters) of vertical development. The rocks, however, are not the same, and this fact renders prediction very uncertain. The latite, which generally underlies the dacite and Milltown andesite, may prove nearly as good an ore bearer as the latter two rocks. This, however, is a little doubtful. Most of the shafts in the principal mineral belt may at any depth below 1,000 feet (305 meters) enter rhyolite, Cambrian shale, or alaskite, and although no one can with certainty assert the barrenness of these formations their present record in this district is not encouraging.

The tendency of the main ledges near Goldfield to flatten out to the east on the lower levels is also rather disconcerting, although the significance of this feature can not be fully understood until the deep levels are further developed. This behavior does not prove that the ledges may not somewhere regain a steeper dip and continue down through the predacitic rocks, but it defers the confirmation of that hopeful supposition, increases the difficulty of exploitation, and introduces greater possibilities of losing pay shoots by faulting. ${ }^{a}$

Above the 500-foot (152-meter) plane the productive possibilities of the district are still great. In the principal mines there are large reserves of ore which can be milled at a profit, although most of the richest portions have been mined by lessees. In the announcement of the Goldfield Consolidated Mines Company at the end of 1906 the ore reserves of the Mohawk, Jumbo, Red Top, and Laguna mines were estimated at $\$ 7,750,000$. This was said to be "exclusive of low-grade ore," and did not include the Combination and January mines, later acquired. In the same announcement it is estimated that at least $\$ 30,000,000$ gross may be produced from known ore shoots in the Mohawk mine alone. The quantity of ore available is undeniably large, but in no district are the difficulties in the way of estimation greater, owing to the irregular shape, erratic distribution, and wide range in tenor of the pay shoots.

Many new ore bodies are likely to be found in the rich belt near Goldfield, although so thoroughly has this part of the district been explored that it is not probable that any deposit of the importance of the Mohawk ledge has escaped detection. On the other hand, the productive areas are steadily being enlarged by the discovery of new ore bodies, and in spite of much fruitless prospecting over the district at large the possibility of success in some hitherto unproductive localities is still open.

There is, and probably always will be, a large element of chance in the discovery and mining of deposits of the precious metals, and it is vain to expect that geologic study, no

a According to the Engineering and Mining Journal of January 2, 1909, the Clermont shaft has cut the Mohawk pay shoot at 856 feet (261 meters), or 241 feet ( 73 metcrs) below the bottom of the dacite. The ore is said to assay $\$ 22$ a ton. This is encouraging as regards the possibilities in the latite. 
matter how conscientiously and ably pursued, can eliminate all of the risks of the search. The obscure conditions that determine the movements of underground solutions and influence the precipitation of their contents can rarely be discovered from the relations of the rocks at the surface. Geology can seldom do more than suggest intelligent trial; and he who undertakes extensive prospecting without a realization of the ratio of success to failure and without being prepared to shoulder the latter, is playing desperately against chance. On the other hand, it must be admitted that were prospecting in general conducted with the same caution and with the same careful scrutiny of probabilities as obtains in ordinary business many deposits which have yielded fortunes to their discoverers would never have been found. There are few gold districts that are not indebted to some man's blind good fortune. This has been well illustrated at Goldfield, and the brief but eventful history of the district teaches that surprises may be in store for one who presumes to say with assurance what ground is ore bearing and what ground is not.

Local experience has shown a close connection between rich ore and alunitization. This association is of value as indicating the better chances of a prospect in alunitic material than of one outside of it. On the other hand, the presence of alunite is no proof of the presence of gold, even in this district, as many have learned to their cost, and the hasty generalization that alunitized rocks, wherever found, must be gold-bearing rocks is wholly unwarranted. The occurrence of this mineral means simply that rocks containing some potassic and aluminous silicate have been acted upon by sulphuric acid. A second deduction is that these rocks must have contained pyrite or else have been subjected to solfataric action. In either case mineralizing processes have been active and gold or other metals may have been concentrated. The reasonable conclusion is merely that the locality is worthy of some prospecting.

Local experience at Goldfield has shown also that the rich ores are more or less intimately associated with the craggy siliceous outcrops characteristic of the district. This does not mean that all such are auriferous, nor does it mean that no bodies of ore occur under topographic depressions floored with soft rock. It is evident that the dip of a ledge or pay shoot must carry it in places under rock which is soft at the surface. Experience does suggest, however, that exploration near ledge outcrops is more likely to yield results than shafts sunk at a distance on low ground or in areas covered deeply by lacustrine or alluvial deposits, unless such shafts are put down to cut a known ledge on the dip.

With reference to the areal distribution of the deposits, no part of the district appears likely to surpass in richness the small elongated area containing the Red Top, Mohawk, Combination, Jumbo, and Florence mines. The geologic conditions which have determined the remarkable preeminence of this limited area are not certainly known, although, as suggested on page 83 , the relation of the Columbia Mountain fault to the dacite may partly account for the exceptional concentration of gold. As regards general geologic features the belt of conspicuous outcrops stretching from the vicinity of Milltown past Preble Mountain appears promising. It has been very persistently prospected, however, with but indifferent or negative results. 


\section{CHAPTER XVIII.}

\section{DETAILED DESCRIPTION OF THE MINES OF THE GOLDFIELD CONSOLIDATED MINES COMPANY.}

\section{INTRODUCTION.}

The mines to be described in this chapter, in general order from north to south, are the Red Top, Mohawk, Jumbo, Combination, and January. The history of the consolidation of this group has been given in Chapter I, and the relative positions of the mines are described on page 136 and shown in Plate IX. The close connection or proximity of the various underground workings, not only of those belonging to this group, but of the workings of other companies and of lessees, although it increases the difficulties of systematic treatment, has a compensating advantage in that it saves some repetition of descriptive details. Certain features well displayed in one mine will be fully described, while the same characteristics occurring less conspicuously in another member of the group will merely be briefly noted. The space devoted to the description of each mine depends less upon the size or productivity of the property than upon the information its workings supply relative to the geologic occurrence and genesis of the Goldfield ores.

\section{RED TOP MINE.}

IIISTORY.

The Red Top mine, although older than the Mohawk, was late in development in comparison with the January, Combination, and Jumbo mines. In April, 1904, some ore was found by lessees, but this apparently was not of great extent, for the mine attracted little further attention until February, 1905, when the main ore shoot was opened by the Red Top Mining Company. By November in the same year the mine had produced ore to the value of $\$ 60,000$, and in December it became one of the principal mines in the district. Its total gross production up to the consolidation in November, 1906, was $\$ 308,515.60$. Under its present ownership the mine produced ore of the gross value of $\$ 201,025.51$ from December 1,1906 , to October 31 , 1907. At the time of last visit, in July, 1908, no work was in progress in this property, although mining will undoubtedly be resumed when the company's new mill is in operation.

\section{UNDERGROUND WORKINGS.}

At the time of first visit, late in 1905, the Red Top shaft was 180 feet deep, with levels at 100 and 165 feet. These two levels, which were short, ran generally north-northwest and southsoutheast. There had been no stoping at the time the mine was studied, all the ore having been taken from drifts and from a raise above the 100-foot level. At the time of second visit the workings had been developed as shown in Plate XXXII. Unfortunately, the levels above the 165-foot level were not accessible at that time, and some of the long crosscuts to the west on the lower levels, which probably pass from dacite into latite, had caved. The ground in the vicinity of this contact is in most places very soft, constant attention being required to keep it from falling.

Extensive stopes have been opened in the oxidized ore between the 165-foot level and the surface, but practically no attempt has been made as yet to handle the sulphide ores below that level. 


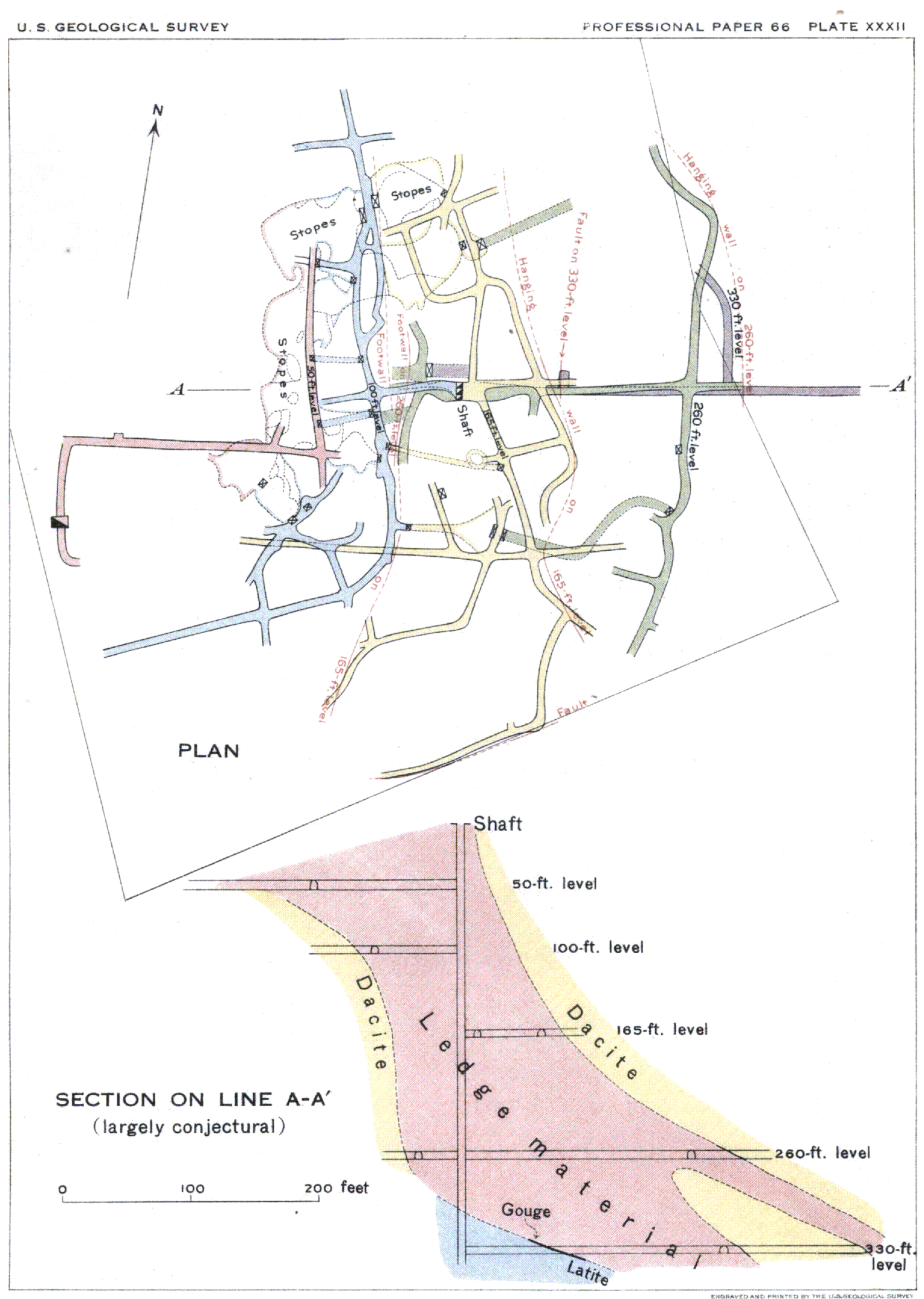

PLAN AND SECTION OF RED TOP MINE 

GEOLOGIC RELATIONS.

The Red Top workings are principally in clacite and dacitic ledge material. The shaft, however, goes into latite between the 260-foot and 330-foot levels, as shown in Plate XXXII. The exact place of the contact in the shaft could not be determined. On the 330-foot level the contact lies 80 feet east of the shaft, and is, locally at least, a fault, accompanied by a seam of tough black gouge about 2 feet in width. It dips east at a low angle. The latite under the gouge is much crushed and is traversed by many smaller seams of gouge. The dacite in the hanging wall of the fissure is alunitized and silicified. This fault lies in the general course of the Columbia Mountain fault and probably represents some of the later movement along that fissure.

THE I.EDGE.

The Red Top ledge as exposed at the surface is unusually wide. It apparently consists of several closely spaced zones of mineralization which trend in a north-northwest direction and altogether attain a width of about 150 feet. The outcrop, however, is short, probably not over 200 feet in length, and the superficial aspect of the ledge is that of a great bunch of rusty silicified dacite. The actual form of the ledge is very unsatisfactorily shown by the underground workings. On the 165-foot level the ledge matter varies in width from 100 to 200 feet, and on the 260-foot level is still wider. As a rule, crosscuts show it to be separated from the soft country rock by seams of gouge which in general dip to the east. It is by no means certain, however, that the hanging wall as drawn in Plate XXXII corresponds to a single continuous fissure, and it is still less likely that the fissure which locally forms the hanging or foot wall at any given place on a level is the same as the fissure forming the corresponding wall on the level below. The foot wall particularly appears to be much steeper between the 100-foot and 260-foot levels than the dips of the observed individual fissures would indicate. In a few places ledge matter grades into country rock without any indication of movement between the two.

Points of access to the bounding surfaces of the ledge are at present far too few for the construction of a reliable cross section. The section shown in Plate XXXII is to be taken, not as a representation of fact, but as a provisional essay at interpretation. Future work will modify it, but for the present it has its use as a graphic summary of what is known and as an attempt to visualize a conception of what may be.

On the south the Red Top ledge appears to be separated from the ledges of the Mohawk No. 2 and Wedge claims (see Pl. IX) by soft altered dacite, and it is the presence of this soft ground that has enabled erosion to cut the little depression through which the road runs just south of the mine buildings. This ground has not been much explored. It is evidently considerably fissured, and the 165-foot level, as shown in Plate XXXII, when pushed southward encountered and followed for some distance a fissure striking about $\mathrm{N} .60^{\circ} \mathrm{E}$., and dipping $35^{\circ} \mathrm{S}$. It was through this gap in the continuity of the ledge matter that the hypothetical cross fault referred to in the preliminary report was supposed to pass. It is no longer necessary to assume such a fault, but future underground work may establish a relation between an apparent slight offsetting of the Red Top ledge, with reference to the trend of the Mohawk ledge system (see PI. IX), and a possible zone of displacement running near and approximately parallel to the south end line of the Red Top claim. This is merely a suggestion, as there is no definite evidence as yet that any important faulting has taken place along this line.

On the north the Red Top ledge also appears to end rather abruptly. Development from the Harrison shaft (PI. IX), now abandoned, showed great disturbance of the dacite, but no ledge matter nor ore. On the other hand, the Consolidated Red Top shaft a little farther north and on the same line was in ledge and ore in 1908. It is probable that the ending of the Red Top ledge to the north is due primarily to the original irregular character of the mineralization, and not to any important cross faulting. 
The general material of the ledge is similar to that of other ledges in dacite. Kaolin is abundant in the oxidized part, forming irregular seams and bunches in the shattered, altered, rusty dacite. Where pure and waxy the kaolin is rarely gold bearing. Certain gritty varieties, however, in which the kaolinite is mixed with minute quartz grains or crystals and more or less stained with limonite, are highly auriferous. Partial oxidation of the ledge matter extends down to the 165 -foot level. The unoxidized material differs in no essential respect from the ledge matter of other mines in dacite. It contains abundant pyrite and alunite. Much of the dacite in the ledge, particularly on the 330-foot level, is divided into thin plates by closely spaced sheeting, the narrow fissures being filled with alunite and quartz.

THE PAY SHOOTS.

Not enough work had been done at the date of first visit to determine the shape and distribution of the pay shoots. They appeared to be irregular and to occur mainly near the hanging wall of the ledge. All the ore taken out in 1905 was oxidized. The only sulphide seen on the 165-foot level was pyrite, and none of the unoxidized ore then visible appeared to be of shipping grade. Two specimens taken as representative of this pyritic material yielded on assay less than $\$ 3$ per ton. Some of the oxidized ore, on the contrary, was rich, one assay obtained in 1905 giving about $\$ 12,500$ to the ton. The best of the oxidized ore was a soft, yellow ocherous mixture of kaolinite, quartz, limonite, and native gold. Some of the oxidized ore was very carious, consisting of masses of silicified dacite in which cavities, probably at one time partly filled with sulphides, had been etched out by solutions. (See Pl. XXIV, B.) These cavities were lined with drusy quartz and partly filled with kaolinite, with possibly some alunite.

The sulphide ore exposed in the lower levels of the Red Top in 1908 appeared to be of relatively low grade as a whole, showing little free gold, famatinite, or bismuthinite, such as characterize the rich ores in the Combination and Florence mines. No tellurium mineral has been recognized as yet in this mine. Some very good sulphide ore, said to assay from $\$ 100$ to $\$ 200$ a ton, has been opened on the 165-foot level south. This shows specks of famatinite and crystals of pyrite in a quartz alunite gangue. A body of $\$ 75$ ore also is known on the 260 -foot level, west of the shaft.

The ore body, as is usual in the Goldfield mines, is of irregular shape. Its total length is about 300 feet. There was no opportunity to study the pay shoots in 1908 , and it is doubtful whether enough work has been done to determine the shape and extent of the sulphide ore bodies.

\section{MOHAWK MINE.}

\section{INTRODUCTION}

The history of the Mohawk mine is an essential part of that of the district and has already been related on pages 18-20. The total gross production of the mine up to the end of 1907 amounts to approximately $\$ 10,000,000$. The following table, compiled from the prospectus and first annual report of the Goldfield Consolidated Mines Company, while not complete and possibly containing a slight overlap or duplication of the production from leased ground in November, 1906, is of some interest as showing the important part played by lessees.

Some features of the production of the Mohawk mine.

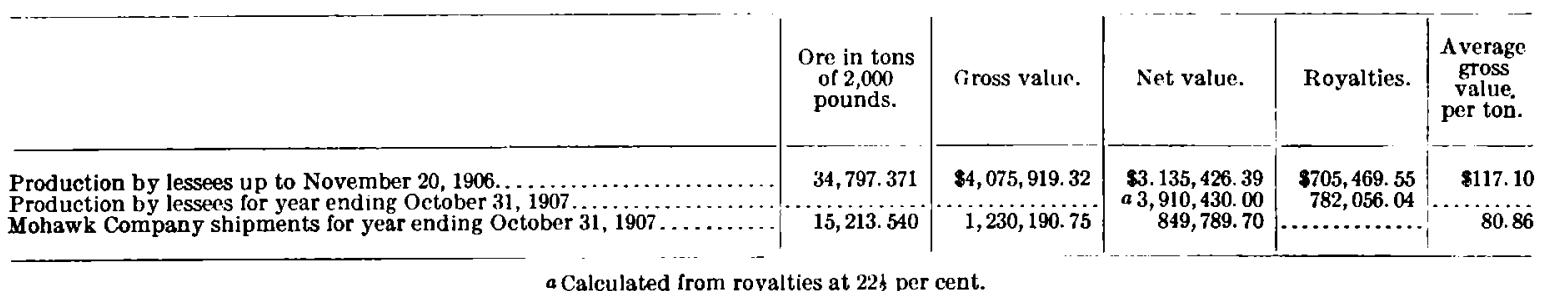


The royalties for the second period in the foregoing table were distributed as follows:

Royalties, Goldfield Mohawk Mining Company, year ending October 31, $190 \%$.

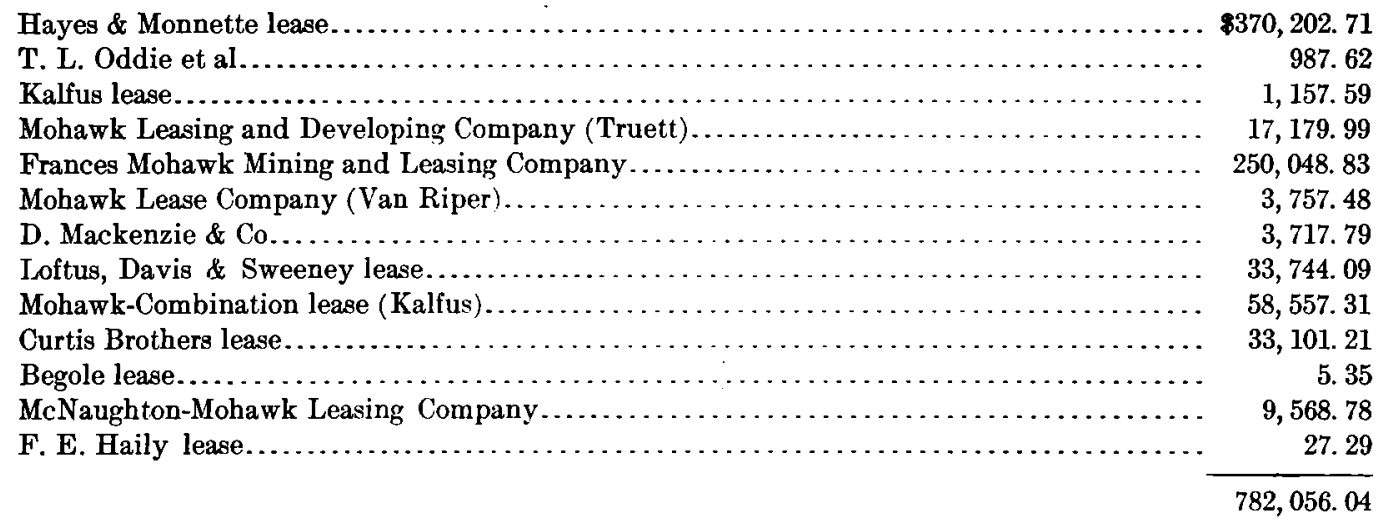

During the single month of October, 1906, the Hayes-Monnette lease produced $\$ 1,300,000$. The richest shipment weighed 47.7 tons and contained 609.6 ounces of gold and 75.4 ounces of silver per ton, the gross value of the shipment being approximately $\$ 584,800$.

\section{UNDERGROUND WORKINGS.}

In 1905 there were two shafts on the Mohawk No. 2 claim, the Hayes-Monnette No. 1 and the Kalfus shafts. Neither was in ore, and neither so far as could then be seen, was any more promising than dozens of other prospects in the district. The highest assays that had been obtained from these workings did not exceed \$4, although the Kalfus shaft was then 200 feet deep and had considerable exploratory work on three levels.

After the discovery of rich ore in April, 1906, lessees began a very active exploration of the whole claim through more than 15 shafts. Before the leases expired, the Goldfield Consolidated Mines Company sank what is now the main Mohawk shaft. The plan of the present workings is shown in Plate XXXIII. The Mohawk shaft is 600 feet deep, with levels of $246,350,450$, and 600 feet below the collar. These main levels, which lie mainly in the southeast part of the claim, connect at various places with the intricate maze of lessees' workings, which are mostly above the 246 -foot level. It is possible to go by rather devious routes through these workings from the north end to the south end of the claim. Connections exist also with the lessee workings on the Gold Wedge fractional claim and with the levels of the Combination Fraction mine. The 350-foot Mohawk level connects with the 380-foot level of the Combination mine, through which it is possible to pass into the January mine and through the Reilly workings into the Florence mine. With the exception of the Sheets-Ish incline (see PI. XXXIII), and some ground adjacent to it, the lessee workings were for the most part accessible in 1908:

The general trend of the Mohawk ledge zone is very nearly north and south and the general dip is at angles ranging from $30^{\circ}$ to $45^{\circ} \mathrm{E}$. Thus successively deeper levels are farther and farther east, and some of the deepest stoping in the district has been done in the MohawkJumbo lessee workings on the Gold Wedge claim. There are practically continuous stopes down the general dip of the ledge from within 100 feet of the surface at the Hayes-Monnette No. 1 shaft to the 600-foot level of the Mohawk.

About 900 feet northeast of the southeast corner of the Mohawk No. 2 claim is the new Jumbo shaft on the Clermont claim. 'This is expected to cut the Mohawk ledge at a depth of 800 feet. It is at present 612 feet deep, and the company is driving to connect this shaft with the 600-foot level of the Mohawk. ${ }^{a}$ 


\section{GEOLOGIC RELATIONS.}

The principal country rock of the Mohawk mine is dacite. The main shaft, however, goes into latite at the 450-foot level and the crosscut from the bottom of the shaft to the ledge on the 600-foot level is almost wholly in this rock. The contact between the dacite and latite is exposed in very few places and these throw little real light on its character. The relations visible on the 600-foot level at the time of visit are illustrated in figure 21 . About 30 feet south of the station the crosscut goes through a strong seam of gouge and beyond this the latite is soft and is traversed by many gouge-filled fissures. Some dacite appears in the east side of the crosscut, but on account of the soft, disturbed character of the rocks its relation to the latite is

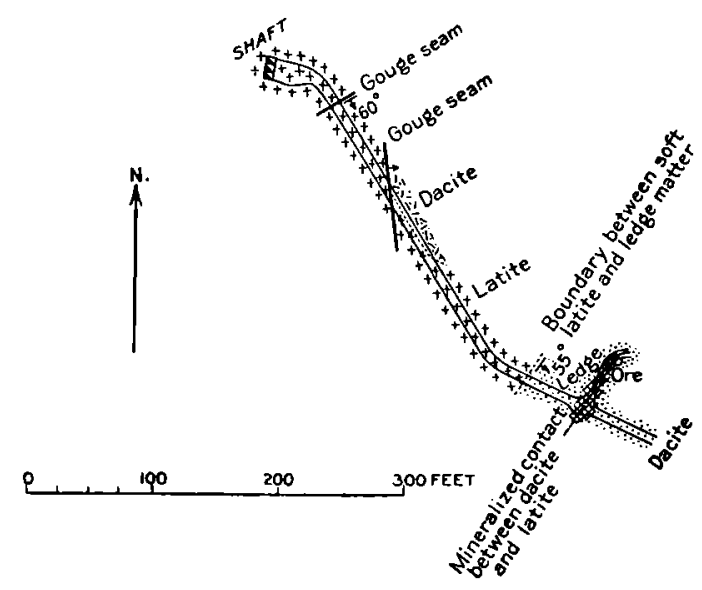

FigURE 21.-Geologic plan of the 600-foot level of the Mohawk mine. far from clear. It is perhaps in part faulted against the latter rock, but at one place the contact appears to be of the irregular kind characteristic of intrusion. The boundary between the soft, altered latite and the siliceous variety constituting ledge matter is sharp, but is not accompanied by gouge and does not appear to be a fault plane. The actual contact between the latite and dacite is within the ledge matter, both rocks being locally changed to ore. This mineralization has obscured the original character of the contact, but.the latite at the point where the drift leaves the crosscut clearly dips under the dacite at an angle of approximately $15^{\circ}$. The observed relations are sketched in figure 22 , and are interpreted as indicating a probable igneous contact between the dacite and the older latite. It is believed that this point in the Mohawk mine is very near the bottom of the thickest part of the dacite sheet, and that further developments to the east will probably show the dacite-latite contact dipping generally to the west. From the structural point of view the work on the 600 -foot level at the time of visit was entering into a very interesting and critical stage.

On the 450-foot level the dacite-latite contact is exposed at the main shaft. At this place there is no mineralization and the two rocks appear to have been brought together by faulting, as they are separated by a seam of gouge which dips to the east. The distance in a straight line between this exposure, which is partly concealed by the shaft timbering, and the one on the 600 -foot level is about 380 feet. Does the contact extend approximately as a plane between these two points? Is it rolling? Is it broken and stepped by faults? The present workings furnish no definite answers to these questions and the distance is obviously too great, considered in connection with known irregularity in the contact elsewhere, to be bridged by assumptions. The contact is probably not regular, but the extent to which it departs from a plane and the manner of this departure, whether by faulting or by intrusion, can not be determined.

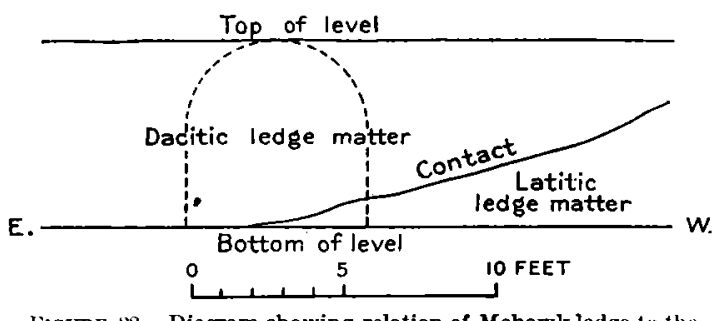

FIGURE 22.-Diagram showing relation of Mohawk ledge to the dacite-latite contact on the $600-$ foot level.

The contact was seen at one other place on the 450-foot level. This is in the crosscut west from the Mohawk shaft under and past the Mackenzie shaft. (See Pl. XXXIII.) Most of the crosscut is in the usual soft pyritized latite, but about 25 feet west of the Mackenzie shaft dacite appears. Both rocks at the contact are soft and altered, and it is impossible to determine whether the contact is due to intrusion or faulting. The dacite west of the contact is comparatively fresh and unmineralized and extends beyond the face of the crosscut. It is supposed to be a large dike cutting up through the latite and connecting with the dacite sheet above as shown in Plate VIII, section C-C'. This conclusion, however, is by no means certain. 


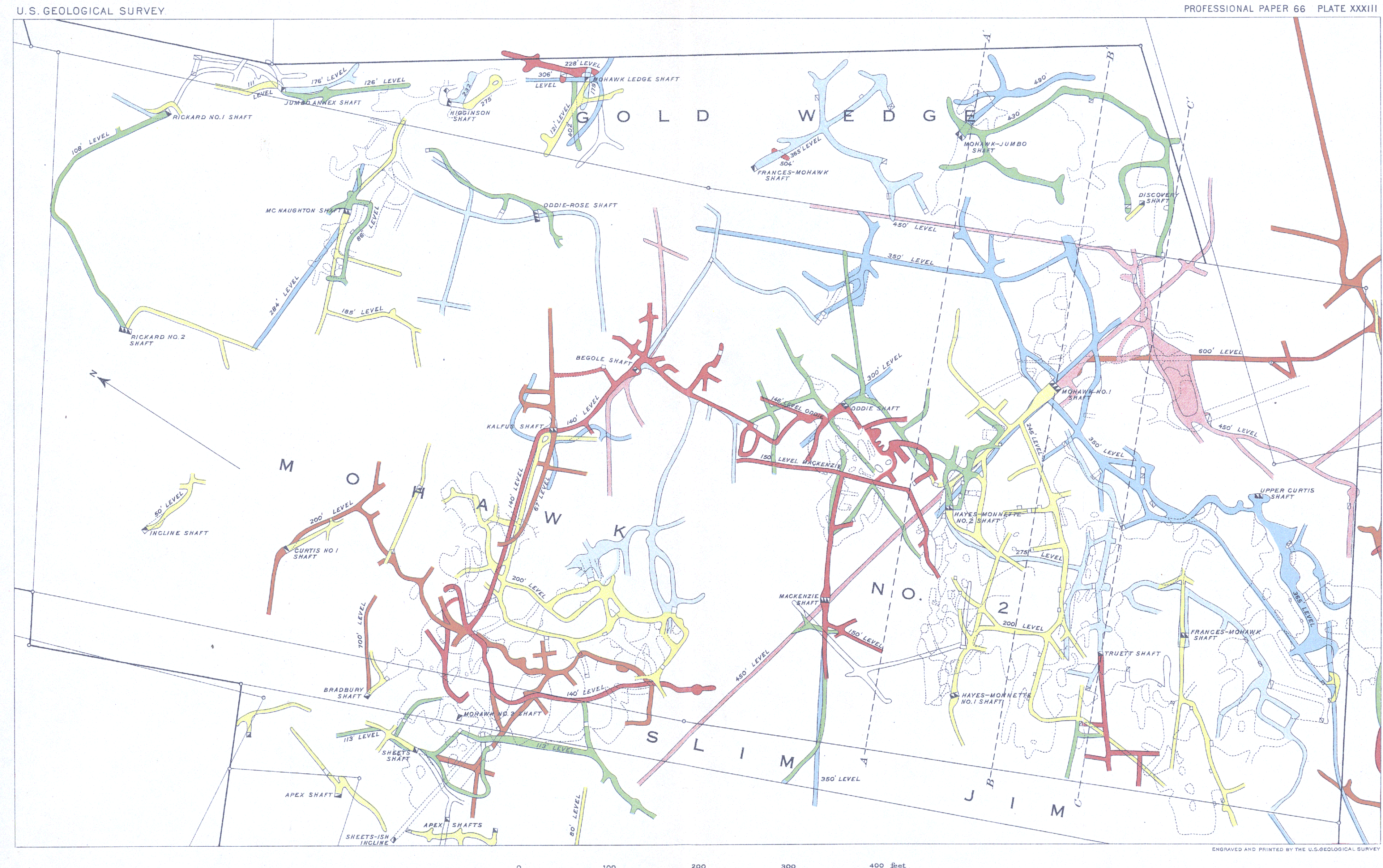

PLAN OF THE MOHAWK MINE, SHOWING ALSO THE WORKINGS OF LESSEES ON THE GOLD WEDGE CLAIM 

On none of the levels above the 450 -foot does latite appear, so far as known. The scantiness of the data which the Mohawk mine furnishes on this interesting geologic feature is apparent.

In an intermediate inclined drift above the 215 stope on the 350 -foot level (see fig. 18, p. 162) a mass of soft pyritized latite was noted which appeared to be a block included in the dacite.

FORM AND DISTRIBLTION OF TIIE LEDGES.

The ore-bearing ground of the Mohawk is sometimes referred to as if it were a single welldefined lode or ledge with definite walls. The propriety of such usage is questionable, although it is difficult in practice to avoid it altogether. The productive zone as a whole trends about N. $5^{\circ}$ E., and extends from the south corner of the Mohawk No. 2 claim to the vicinity of the McNaughton shaft near the north corner, a distance of about 1,200 feet. The general dip of the whole is at an average between $30^{\circ}$ and $45^{\circ} \mathrm{E}$. The ore nowhere reaches the surface, although it approached within about 50 feet of it in the Sheets-Ish incline. (See Pl. XXXIII.) Consequently the surface affords practically no indication of the width or outline of the ore-bearing zone. The cross sections shown in figure 15 indicate a probable width of outcrop of about 200 feet, but this is largely conjectural.

These sections show.the outline of the ore-bearing ground only in the most general fashion, it being evident from the few workings cut by each section that the available data are far from sufficient to establish the form of so irregular a mass. Moreover, the material represented as ledge matter in the illustration includes much soft dacite which has the usual character of the country rock, and the material represented as country rock includes some bunches of ledge matter. Furthermore, the real outlines of the ledge matter are undoubtedly not the smooth curves shown in the illustration, but are broken and stepped by many minor faults.

The difficulty of interpolating with assurance between known points underground is illustrated by figure 18, which is a plan of the 350-foot level. The so-called hanging wall is probably visible in more places on this level than on any other. Near the upper Curtis shaft this wall, which is a gouge seam dividing ore or ledge matter from soft, altered dacite, has a curved but generally northerly course. Near the Mohawk shaft the hanging wall swings to the east and a similar seam of gouge traverses the ledge matter, passing through the shaft. The two fissures must join or intersect about 100 feet south of the main shaft. Near the Mohawk-Jumbo stope the hanging wall turns northwest. As a whole it is a very sinuous curve. The hanging wall is probably not a single fissure but a series of fissures, each one of which serves as hanging wall for a short distance and then passes either into ledge or country rock. The significance of this is that the hanging wall is probably as erratic in section as it is in plan. Neither in plan nor section can its true course be drawn from a few isolated exposures.

Inspection of the general mine map ( $\mathrm{Pl}$. IX) shows that the Mohawk stopes all end on the south along a nearly east and west line passing about 100 feet north of the Burns shaft on the Combination Fraction claim. This line corresponds in part with the valley followed by the railroad between the Combination and Mohawk mines. The rock under this valley, as shown by workings from the Burns shaft and by the connecting drifts between the Mohawk and Combination mines, is generally soft and is much disturbed. It contains, however, more or less ledge matter which forms a link between the Mohawk ledge and the Combination ledge, as will be shown in the description of the latter mine.

On the north the Mohawk ledge becomes ill-defined in the vicinity of the Rickard No. 1 shaft and shows much disturbance. Whether there is any direct connection between the Mohawk and Red Top ledges is not known. Moreover, where more or less ledge material occurs very erratically distributed through the dacite, as it does in the strongly mineralized area containing these mines, it is often most difficult to decide what does and what does not constitute a connection between one ledge and another.

The ledge worked from the Sheets-Ish incline (see Pl. XXXIII) has, so far as known, no direct connection with the ledge exploited in the main Mohawk mine. It has the same strike and a similar dip to the east. From the plan of the workings the Sheets-Ish ore bodies appear 
to be in the foot wall of the Hayes-Monnette shoot. A section across this shoot, however, shows that it has an average dip to the east of about $30^{\circ}$, and that if it continued to the surface at this angle it would outcrop from 100 to 200 feet east of the line of strike of the Sheets-Ish shoot. Both, therefore, are probably in the same zone of mineralization, although so far as present workings show they are separated by soft barren dacite. The Sheets-Ish ore is presumably near the foot wall of the zone, while the Hayes-Monnette shoot is in general nearer the hanging wall.

Just north of the Kalfus shaft is the theoretical apex of a ledge which has a nearly east and west course near the surface and dips to the south. The strike of this ledge on successively lower levels becomes more nearly north, and the ledge finally appears to merge with the northsouth Mohawk ledge. It is a striking example of the irregular spurs or offshoots which are characteristic of the Goldfield ledges and which render it impossible to ascertain the shape and extent of one of them until it has been very thoroughly explored.

The material of the Mohawk ledges is chiefly dacite which has undergone the kind of alteration described on pages 176 to 186 . There are all gradations between dacite which is soft with alunite as the principal secondary mineral, and the flinty quartzose varieties which as a rule constitute the ore. Irregular fracturing or shattering is a less characteristic feature than in the Combination mine and much of the rock on the Hayes-Monnette stopes is closely sheeted. Similar sheeting was noted also in the new drifts on the 600-foot level. Alunite is abundant throughout the ore-bearing ground, both as a megascopic and microscopic constituent of the altered dacite and as the filling of the innumerable small fissures.

Although in many places there is a fairly abrupt change from the generally siliceous material recognized as ledge matter to the generally soft alunitized dacite recognized as country rock, there are many parts of the mine where the change is gradual and where it is impossible to make any sharp distinction between the two. Moreover, the masses regarded as ledge matter nearly everywhere contain ill-defined masses of dacite of the same character as the country rock.

Most of the Mohawk workings are below the zone of oxidation, which in general does not extend much more than 100 feet in depth.

When the Mohawk mine was examined, practically no stoping was in progress and conditions were not the most favorable for a study of the ledge material. Moreover, such study had previously been made in the Combination and other mines, and in the account of these the reader will find additional details which it is unnecessary to repeat in the description of the Mohawk.

FORM AND DISTRIBUTION OF THE PAY SHOOTS.

The pay shoots of the Mohawk mine, as shown by the stopes in the plan (Pl. XXXIII) and sections (fig. 15), are irregular bodies of ore distributed through the ledge matter into which they grade. Up to the present time there has been little attempt at working low-grade ore, and the stopes as a rule represent the rich kernels of bodies which will undoubtedly be more extensively worked in the future, and of which the size and shape is as yet very imperfectly known. The great stope between the two Hayes-Monnette shafts, which produced in round figures $\$ 5,000,000$ from ore averaging $\$ 400$ a ton, extends from near the 245 -foot level to the bottom of the oxidized ground, a vertical distance of nearly 150 feet. This rich shoot, as shown in Plate XXXIII, did not extend straight down the dip of the ledge but pitched to the north. Its stope length was about 75 feet. It was exceedingly irregular in form, however, and its dimensions and plan varied greatly at different levels. The stope as seen in 1908 was a succession of great chambers, suggestive rather of the surprises and ramifications of a natural cavern than of an artificial excavation. The view of the stope shown in Plate XXI, $B$, was taken at an early stage in its development and illustrates very imperfectly the size and shape which it afterwards attained.

As shown by Plate XXXIII, other rich irregular shoots of ore were worked from the Truett, Frances-Mohawk, Upper Curtis, and Loftus and Davis shafts, each shaft, in the order named, 
cutting the ore at greater depth. These ore bodies form practically one continuous shoot which connects directly with that worked in the Hayes-Monnette lease and has been explored down to the 600-foot level of the Mohawk. South of the main shaft, on the 350-foot level, there is a chain of stopes on this ore shoot for a distance of about 350 feet. On the 450-foot level ore in the same general shoot has been stoped to a width of 20 feet and for a length of over 100 feet. The ore from this stope was sorted to a shipping grade of $\$ 100$ a ton, the second-class material being piled in the stope. A winze, shown in Plate XXXIII, hat been sunk on this ore for a distance of 170 feet at the time of visit and showed an average value of about $\$ 55$ a ton.

Too little work had been done on the 600-foot level in 1908 to determine the size of the shoot at that depth. Where opened, however, the ore body showed a width of 33 feet of $\$ 50$ to $\$ 60$ ore with considerable lower-grade material on each side. Much of the ore now separating these irregular stopes will undoubtedly be mined in the future and the general continuity of the whole shoot thus becomes more apparent. Probably also enlargement of the stope will connect this shoot with the one that was stoped from the 350-foot level east of the main shaft and that has been profitably mined through the Mohawk-Jumbo lease shaft on the Gold Wedge claim. Above the 350-foot level this stope is in places fully 50 feet wide. The usual width (perpendicular to the walls, which dip at about $35^{\circ} \mathrm{E}$.) is from 6 to 10 feet.

As shown in Plate XXXIII, an extensive body of ore was worked by lessees through the Sheets-Ish and Kalfus shafts. This ore came nearly to the surface, and was worked to a vertical depth of about 240 feet. The maximum stope length is about 250 feet. Good ore is known below the lessees stopes, but the relation of this ore shoot to the shoots opened in the main Mohawk workings remains to be discovered.

In some parts of the mine the ore ends abruptly against fissures carrying gouge. These appear to be minor faults, and probably in most cases correspond pretty closely to what was originally the boundary of the ore. No persistent faults of large throw have been recognized nor does it appear that any large body of ore has been seriously displaced by faulting.

The Mohawk has produced very little oxidized ore, and the sulphide ore differs in character from that known in the district prior to the discovery of the Hayes-Monnette ore body. Much of the ore from this lease, even when of high grade, consisted of sheeted alunitized dacite, which to the eye showed little evidence of its value. Some of the richest material, however, contained fragments of dacite encrusted with marcasite and a dark-gray homogeneous mineral. These shells, which are up to a quarter of an inch in thickness, contain tellurium and gold, and the dark mineral has commonly been referred to as a telluride. It is chiefly goldfieldite, with some included gold, as is shown on page 116 . Visible native gold, bismuthinite, and famatinite have not been found as abundantly in the Mohawk ore as in that of the mines farther south.

\section{COMBINATION MINE.}

HISTORY ANI) PRODUCTION.

Many of the following facts with reference to the eurly history of the mine are taken from an article by Edgar A. Collins, ${ }^{a}$ formerly superintendent of the property.

The Combination ledge, which outcrops about two-thirds of a mile northeast of the center of Goldfield, was located on May 24, 1903, by A. D. Myers and R. ('. Hart, the latter soon selling out to T. D. Murphy. In October of the same year four full claims (Combination Nos. 1, 2, and 3 , and Hazel Queen) and three fractional claims on or near the original ledge, with six additional claims (Golconda, Wonder, Mammoth, Goldstone, Red Boy, and Victor) lying a short distance southeast of the main group, comprising in all about 175 acres, were bonded for Boston and Chicago capitalists who organized the Combination Mines Company. The capital stock issued amounted to $\$ 320,000$ out of a total capitalization of $\$ 400,000$. The bond was for $\$ 75,000$, $\$ 5,000$ being paid in cash, the balance distributed over a period of twelve months. The lessees

a The Combination mine: Min. and Sci. Press, vol. 95, 1907, p. 39\%.

79145-No. $67(;-09-14$ 
had the privilege of working the property, paying a royalty of 25 per cent of the net value of the ore, with the understanding that such royalty was to apply on the purchase price. These terms show how little suspected at that time was the remarkable richness of the Goldfield bonanzas.

The workings when the company took the property consisted of a shallow open cut and a tunnel some 50 feet in length, which crosscut the ledge about 30 feet below its croppings. This exposed about 30 feet of ore, of which 10 feet averaged $\$ 150$ to the ton and the remainder $\$ 20$ to the ton. There were also some shallow pits which showed ore ranging up to $\$ 10$ a ton in value.

Shipments began in November, 1903 , the first car averaging $\$ 160$ per ton-the lowest in grade that was ever sent out, according to Mr. Collins. The average gross value of the ore shipped up to May, 1905 , when milling began, was $\$ 404$ per ton. The ore was at first hauled by wagons to Candelaria, 65 miles away, at a cost of $\$ 12.50$ per ton. With extension of the railroad to Tonopah in 1904 the wagon haul was shortened to 30 miles. Owing to the excessive freight charges, however, on ore assaying over $\$ 300$ per ton, the richest ore was sacked and stored, pending the completion of a mill.

In May, 1905, the company had completed a 10-stamp mill and had installed a pumping plant and pipe line capable of supplying 75,000 gallons per twenty-four hours. The source is Alkali Spring, 10 miles to the northwest.

Upon the completion of the mill some of the rich ore, carrying 48 to 55 ounces of gold to the ton, was milled, about 62 per cent of the gold amalgamated, and the tailings sacked and shipped to the smelter. This process was regarded as safer and more economical than shipping the original ore under the sliding scale of freight charges then in force.

By October, 1904, the mine had much more than paid for itself, and the first dividend, $\$ 40,000$, was declared. By the end of the year, according to the first annual report of the company, 1,166 tons of ore had been shipped, with an average value of $\$ 419$ per ton, or a total gross value of $\$ 489,209$. The cost of shipment and treatment averaged $\$ 57$ per ton, leaving the net value of the ore $\$ 362$ per ton. The average contents of this ore were 20.22 ounces of gold and 2.68 ounces of silver per ton. By the end of 1905 the mine had produced ore to the gross value of $\$ 1,250,000$, and had paid about half a million in dividends.

In 1905 the mill was enlarged to 20 stamps and electric power substituted for steam. Tube mills were also added early in the following year.

By the end of 1904 the Combination mine was about 300 feet deep, with 5 levels. The water was subsequently allowed to rise above the bottom level and attention was confined to the development and extraction of rich ore bodies nearer the surface.

In the latter part of 1906 the Combination mine was consolidated with the Red Top, Jumbo, Mohawk, January, and other mines in the Goldfield Consolidated Mines Company.

\section{NDERGROUND WORKINGS.}

The Combination mine is worked through a vertical shaft with 6 main levels at depths of $80,130,180,230,280$, and 380 feet. The assembled levels are shown in plan in Plate XXXIV, and their vertical distribution is illustrated in Plate XVII. The 130 -foot level is the most extensive, connecting on the northwest with the workings of the January mine and on the southeast with those of the Reilly shaft in the No. 1 lease block of the Florence ground. Up to the end of 1905 the Combination was operated through a crooked inclined shaft which followed the ledge down to the 230 -foot level, all hoisting being done with a bucket. A vertical shaft, with a counterbalanced cage operated by electric power, was completed in the early part of 1906 and has since been enlarged to 2 hoisting compartments.

The small rectangular areas shown in Plate XXXIV, at the northwest corner of the Florence claim, call for a word of explanation. In 1906 a legal contest was imminent between the Combination and Florence companies over the question of the ownership of certain ore stoped by the Reilly lessees. The clispute was finally compromised by the Florence transferring to the Combination a small block of unstoped ground from the Florence claim while the Combination Mines Company deeded to the Florence-Goldfield Mining Company the block from which most of the ore in dispute had been taken. These blocks are bounded by vertical planes. 


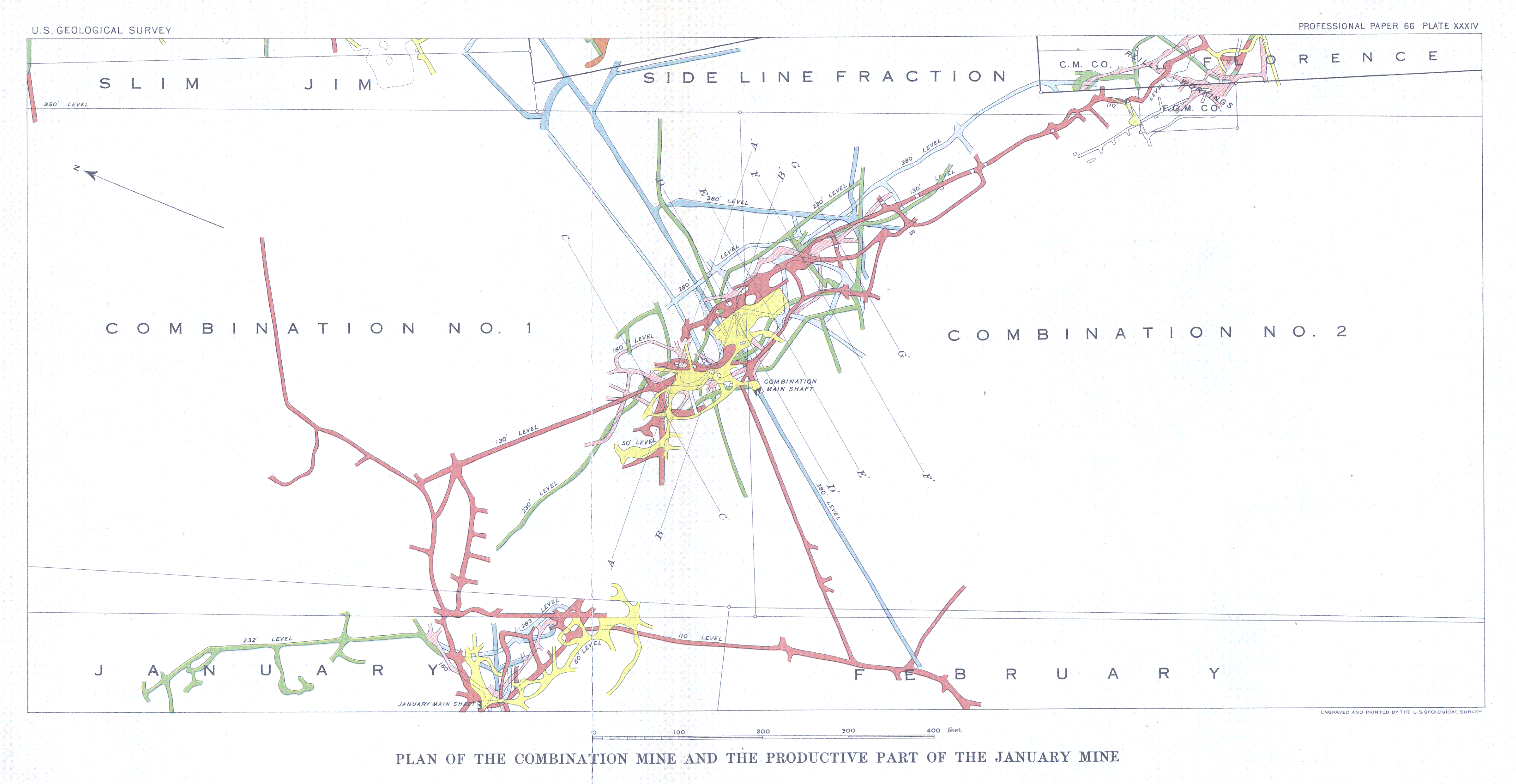



GEOLOGIC RELATIONS.

The general geology of the mine is simple. The 80 -foot and 130 -foot levels are entirely in dacite. In the early days of mining the ledge matter produced by the alteration of this rock was often called rhyolite. Latite appears first on the 180-foot level (see Pl. XVIII), and as the contact dips to the east more and more of this rock is exposed on successively lower levels. The details of this contact are not well known. The dip varies from place to place. On the line of section $\mathrm{D}-\mathrm{D}^{\prime}$ (Pl. XVII) the average dip is probably not over $30^{\circ}$ and on the 380 -foot level is not over $15^{\circ}$. Farther southeast the dip increases, as shown in the sections of Plate XVII, which, it should be borne in mind, are not at right angles to the general strike of the contact. Where the rocks at the contact are soft some slipping has as a rule taken place. Where, however, an ore body lies at the contact the latter is close and irregular. Although its original character is largely obliterated by the mineralization the contact at such places (for example, stope No. 316 on the 280-foot level) suggests igneous intrusion.

Some faulting has probably taken place since the ore bodies were formed, but, as in the Mohawk, seams of soft gouge occur at so many places that it is impossible, without undertaking special development work for the purpose, to trace any given seam through from level to level. No evidence is yet available that indicates any extensive displacement of the ore bodies.

\section{FORM AND DISTRIBUTION OF THE LEDGES.}

The Combination claims were located on one of the rusty siliceous ledges common in the district, the actual pay shoots or ore bodies, as subsequently found, constituting portions only of the ledge matter. In the following pages the ledges will first be described and then attention will be directed to their inclosed or associated pay shoots.

As exposed at the surface the main ledge appears to have a simple linear character and to trencl N. $50^{\circ} \mathrm{W}$. It can be traced for a distance of about 1,000 feet, the Combination shaft being nearly in the middle of the line of outcrop. To the northwest the ledge has not been followed beyond its junction with the curved January ledge. To the southeast it becomes indistinct near the Reilly shaft, although the ledge appears to lie in the same zone of fissuring that is conspicuous in the Florence mine, southeast of the Reilly shaft.

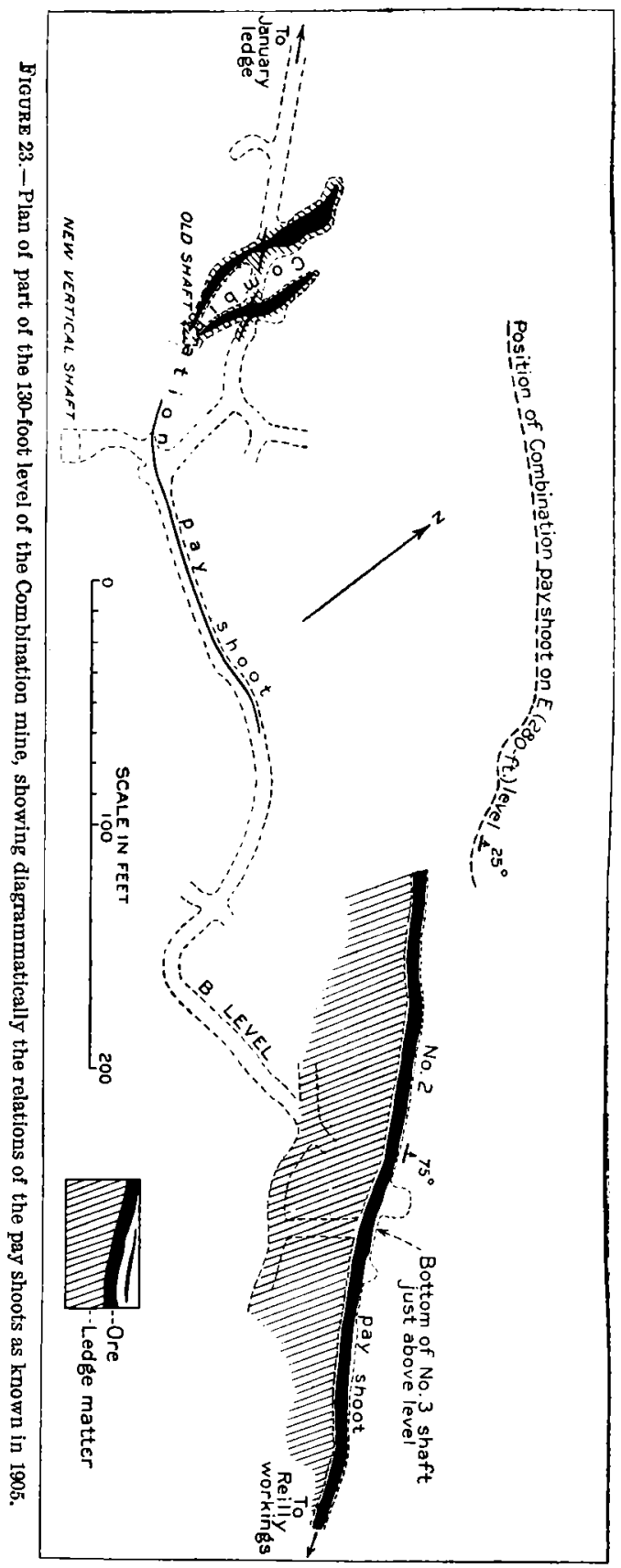

The underground workings of the Combination mine show two ledges, between which no direct connection has yet been established. These are best displayed in the plan of the 130foot level. (See Pl. XVIII.) On this level the main ledge has been developed from a point about 150 feet northwest of the shaft southeastward into the Reilly workings. When the mine was first studied in 1905 this main ledge was not known to be continuous underground, the 
conditions then obtaining being illustrated in figure 23, taken from the preliminary report. Since that time large stopes have been opened in the ground between what were then known as the Combination shoot and the No. 2 shoot (see fig. 23) and the continuity of the main ledge established, as shown in Plate XVIII.

The northwest part of the 130-foot level goes through about 200 feet of generally soft altered dacite into the January ledge, which has not yet proved very productive within the Combination mine. This ledge, as is shown on page 127 and in Plate XXXIV, curves in the January claim so that the southeast end of the January workings is in line with the main Combination ledge as developed on the 130-foot level. The intervening ground has not been explored, and it is possible that the Combination and January ledges may yet be found united. If so, the ledge as a whole on the 130-foot level has the remarkable plan shown in figure 24 . Below the 130-foot level the Combination workings do not reach the January ledge, nor do they* as yet satisfactorily reveal the outlines of the Combination ledge. So far as possible these outlines are approximately shown in Plate XVIII.

The Combination ledge as a whole dips to the east, but as may be seen from the sections of Plate XVII the mass is exceedingly irregular. The general dip to a depth of about 250 feet

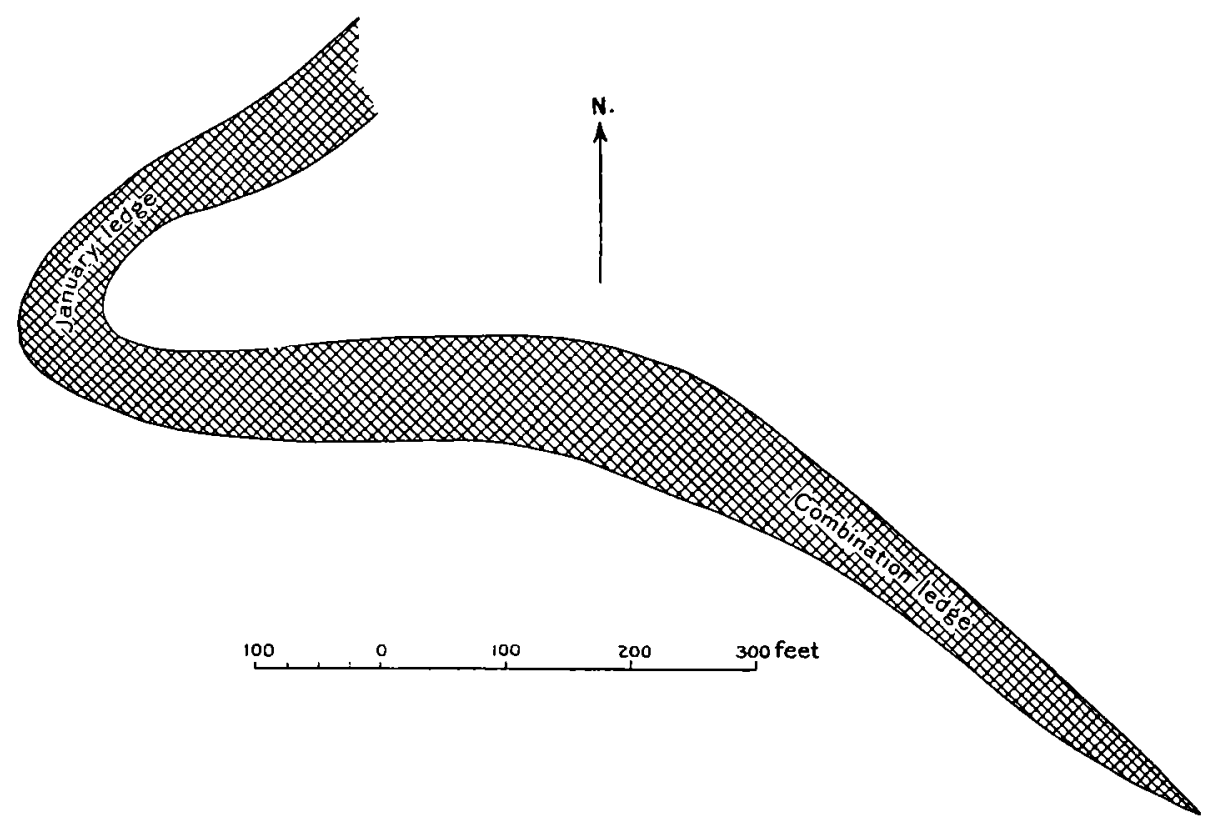

FIGUR F 24.-Diagram showing possible plan of the combined January and combination ledges.

is from $60^{\circ}$ to $70^{\circ}$. Below this, near the contact of the dacite with the latite, the dip decreases and the ledge shows a tendency to flatten toward the east. Very little is known of the hangingwall side of the ledge matter on the lower levels.

The boundary between ledge matter and dacite or latite is in some places a gouge seam or fault. The hanging wall of the ledge on the 130-foot level is in general well defined by a seam of tough leathery gouge up to an inch in thickness. This seam is particularly distinct in the vicinity of the Reilly workings. In some places it contains well-formed crystals of gypsum which must have crowded aside the tenacious clay to make room for themselves. In many parts of the lower workings there is a gradual change from ledge matter to country rock. An attempt has been made to indicate such a transition in the sections of Plate XVII. As in the Mohawk mine, the shape of the ledge has probably been somewhat modified by faulting, but the data for discriminating such modification from the great initial irregularity of the mass are not available. There is a suggestion that some of the irregularity of the ledge between the 180-foot and 280-foot levels (see Pl. XVII, sections E-E', F-F', and G-G') may be due to faulting nearly parallel with the contact. 
MATERIAI, OF THE I.EDGES.

The typical ledge matter of the upper levels is a loose porous mass of rusty angular fragments of altered dacite. There are all gradations, from material which is merely traversed in all directions by cracks to loose rubble-like masses with many open interstices between the fragments. The interstices are often partly filled and the fragments coated with yellow or brown ocher, sometimes associated with much kaolinite. The fragments themselves, when broken, prove to be hard masses of gray porous quartz of generally flinty texture, but showing, in spite of intense alteration, the original quartz phenocrysts of the dacite. The pores are in part irregular in shape, but in part they represent spaces left by the removal of the feldspars and of pyrite. They are usually lined with small quartz crystals, and when the rock is broken open are found to contain water, even in dry parts of the mine. The pyrite in these fragments is seldom completely oxidized, small disseminated crystals being abundant in the denser portions of the flinty quartz. Small pearly scales of bismite are associated with the ocherous limonite in some parts of the ledges, particularly in the January ledge and in the southeastern part of the Combination ledge. While often associated with rich ore the bismite also occurs in ledge matter of no value.

Below the zone of oxidation in the Combination the marked distinction between ledge matter and the alunitized and pyritized dacite vanishes. The contrast in color between the rusty ledge matter and the unoxidized country rock in the upper levels of course disappears in the sulphide zone, but more is involved than mere loss of color distinction. In the lower levels the sulphides are associated with much alunite, and the ore and ledge matter is in many places apparently less siliceous and softer than in the oxidized zone. Whether, however, there is really less silica in a cubic meter of this softer unoxidized material than in the harder but much more porous ledge matter of the upper levels is a nice question and one not to be answered offhand. In other words, it is doubtful whether or not the unoxidized ledge matter which grades insensibly into the country rock in the deeper levels could be converted by the mere removal of some constituents into a mass as hard and siliceous as the ledge matter of the oxidized zone.

The pyritized dacite, even when close to rich ore, carries very little gold, assays of such material seldom giving over 40 to 50 cents to the ton. The disseminated pyrite is clearly very slightly auriferous.

\section{FORM AND DISTRIBUTION OF THE PAY SHOOTS.}

The pay shoots in the Combination mine are such portions of the ledges as contain enough gold and silver to be classed as ore. As a rule, it requires a trained eye to distinguish ore from barren ledge matter, and some ore is recognizable as such only by panning or assaying. There is no real boundary as a rule between ore and mere ledge matter.

Under these circumstances it is a difficult matter to describe the form of the ore bodies, inasmuch as this varies from time to time. Originally only the rich streaks of ore were stoped, but afterwards, as improved milling facilities rendered possible the treatment of lower grade material, these stopes were greatly enlarged. Descriptions of ore shoots based upon the stoping down prior to 1906 are not applicable to present conditions. Detailed descriptions of form suggested by existing stopes would likewise be of little value a few years hence.

In Plate XVIII, showing the plans of the levels, an attempt has been made to illustrate some of the changes made in the apparent shapes and sizes of the pay shoots in the course of development. The illustration shows the streaks of rich shipping ore known in 1905, the approximate outlines of the stopes at the end of that year, and the present stopes. From this plate and the sections of Plate XVII, the reader may gain a better idea of the irregular shapes and distribution of the ore bodies than can be given by words. He should bear in mind the gradation of ore into ledge matter and the probability that in a few years many stopes now separate will coalesce.

The original Combination pay shoot came to the surface near the old inclined shaft and according to Mr. Collins had a stope length of 120 feet and a width of from 30 to 50 feet. This 
has been mostly stoped, leaving an open pit or "glory hole" (Pl. XXII, $A$ ), which is being steadily enlarged. Probably a large part of the ledge matter exposed on the present 80-foot level will finally go through the mill.

On the 130-foot level the best ore near the shaft in 1905 occurred on short, nearly northsouth fissure zones which cross the general trend of the ledge. The very richest portions, although irregular, showed a tendency to form vertical pipes or "chimneys."

- The first pay shoot discovered in the southeast part of the mine in what was known in 1905 as the No. 2 ledge (see fig. 23), was found in the No. 3 shaft, which goes down in the footwall side of the ledge. This little shoot was elliptical in plan and was practically confined to the shaft. It pinched at 30 feet in depth. The ore was not particularly rich at the surface, but at a depth of 15 feet ore was found which in places carried 150 ounces of gold to the ton. In all, this small shoot of oxidized ore produced about $\$ 65,000$.

When the ore gave out in this shaft, a crosscut was run to the hanging wall of the No. 2 ledge, and this opened up the main No. 2 pay shoot. This, as worked on the 130-foot level in 1905 , was a fairly regular streak of oxidized ore lying within the ledge matter, but close to its hanging wall, which dips at angles ranging from $60^{\circ}$ to $75^{\circ} \mathrm{NE}$. The ore had a maximum width of about 6 feet, but it passed with no plane of separation into ledge matter, and the width of ore stoped was determined solely by the conditions of economic mining at that time. This pay shoot had been stoped at the time of first visit to a length of about 300 feet. It is not actually continuous with the Reilly shoot, but the two are connected by a distinct zone of fissuring. Since 1905, as shown in Plates XVII and XVIII, stopes have been opened along the foot-wall side of the ledge in this part of the mine and have in places been carried across the full width of the ledge. They have also been carried northwest until they are almost continuous with the stopes north of the shaft, on what was formerly supposed to be a distinct pay shoot. (See fig. 23.)

Comparison of Plates XVII and XVIII brings out some interesting features regarding the behavior of the pay shoots with increase in depth. It appears that the ore bodies are fully as erratic in a vertical direction as they are in horizontal directions. The large ore body, for example, on the 130-foot level, cut by sections $\mathrm{B}-\mathrm{B}^{\prime}, \mathrm{D}-\mathrm{D}^{\prime}$, and $\mathrm{E}-\mathrm{E}^{\prime}$, does not extend in full strength to the 180-foot level, and on the 230-foot level is unknown. While good ore has been stoped from the 280 -foot level, the value of the ledge below this, where it flattens with the dacite-latite contact, has not yet been determined. Although some good ore in latite has been opened on the 380-foot level east of the shaft, the extent of the body had not been ascertained at the time of visit in 1908.

CHARACTER OF ORE.

The ore of the Combination mine includes oxidized and unoxidized varieties. The typical rich sulphide ore is a rather loose mass in which the fragments consist of altered dacite and are surrounded by thin shells of gold and sulphides. These fragments vary greatly in size and shape. Most of them, however, are probably less than 6 inches in diameter. Many are much smaller, and having been rounded by chemical action give the ore a decided nodular appearance.

The dacite of these fragments, some of which show signs of an earlier period of brecciation and cementation, exhibits various stages of alteration. Some of it is changed to a dense flinty quartz with irregular drusy pores. Other fragments, and these are apparently the more numerous, contain much alunite with the quartz, the alunite appearing partly as soft white pseudomorphs after feldspars. Minute crystals of pyrite are nearly everywhere abundantly disseminated through this altered dacite, but they certainly do not carry more than a very small part of the gold in the ore.

The outer, highly mineralized crust of these fragments varies from a few millimeters to a centimeter in thickness. The metallic minerals are not everywhere arranged in precisely the same sequence nor developed in the same relative abundance. In what may be regarded as typical rich ore, however, the inner layer of the auriferous envelope is a somewhat indefinite dull 
yellow band which close examination shows to consist of fine particles of gold embedded in quartz. In the richest specimens this band may be as much as 5 millimeters in width. A section of these bands as seen under the microscope is shown in Plate XXVI, $A$.

As seen in hand specimens of ore, there is no definite boundary between the auriferous band and the kernel of altered dacite. It appears, in fact, as if the gold had penetrated the substance of the rock and crystallized metasomatically at the expense of some of the rock constituents. The microscope shows, however, that there is a distinct surface of demarcation between the golden envelope and the dacitic kernel. The kernel contains disseminated pyrite, while the auriferous band is usually free from this mineral, the irregular hackly particles of gold being intimately associated with famatinite and bismuthinite. The microscope shows also that the gold and associated metallic minerals are embedded in an exceedingly fine-grained aggregate of quartz with a little kaolinite, the aggregate being noticeably finer grained than that resulting from the alteration of the dacite in the kernel. It is also free from quartz phenocrysts, as far as seen. The minute quartz granules of this aggregate exhibit shadowy, wavy extinction, suggestive of an extremely fine fibrous or chalcedonic structure. The contact between this auriferous envelope and the material of the kernel, which is still recognizable as altered dacite, while definite, is ragged in detail and is not such as would result from the mere accretion of material upon a smoothly rounded surface. Nevertheless, the form of the fragments shows that some preliminary rounding did take place, this being effected by attrition probably aided by solution. Subsequently the auriferous envelope was deposited, neither by direct accretion nor by partial penetration and metasomatism, but by a narrowly confined process which appears to have involved complete recrystallization of a thin peripheral part of each fragment with the introduction of much gold and probably the removal of some constituents originally present. The extreme fineness of grain of the quartz which constitutes the immediate matrix of the gold indicates that the auriferous solution was a poor solvent for silica. Whether the alteration of the dacite kernel, with the development within it of alunite, took place while the fragments were receiving their initial rounding, or while the gold was being deposited, is in most cases an indeterminate question. As will presently appear, this alteration may have been taking place during both periods and may have continued to a later stage of ore deposition.

Outside of the envelope of native gold there is, on most fragments, a layer of famatinite. This varies much in thickness, and where it is not present its place is taken by pyrite or marcasite. The latter two minerals are not always readily distinguishable, as pyrite frequently occurs in radial crusts such as are characteristic of marcasite. Where the crystal form is not sufficiently well developed to serve as a means of distinction, the tendency of marcasite to disintegrate after specimens have been kept for a few months may be utilized. Such specimens show an efflorescence of sulphur, and the sulphuric acid formed attacks the paper label or tray upon which the material may be resting. The iron sulphides in some cases coat the famatinite directly; in others they rest upon an intervening crust of drusy quartz.

In Plate XXIII, $A$, is illustrated some very rich ore from the 230 -foot level. In this the band of gold is from 2 to 4 millimeters in diameter. The fragment which it incrusts is clearly itself a breccia and must have been cemented into a firm rock again prior to the deposition of the gold. The microscope shows this older breccia to be now an aggregate of fine crystalline quartz, with pyrite and kaolinite. Alunite does not happen to be present in any considerable quantity in this specimen.

The interstices between the larger fragments such as have been described are usually filled with smaller, less distinct fragments, similarly incrusted, with bunches of famatinite and with much alunite. Some kaolinite may be mixed with the alunite, and both minerals generally contain embedded crystals of pyrite. Such pyrite crystals often exhibit the common pyritohedral habit, but in many specimens they are all octahedral. Films of drusy quartz are not uncommon in the ore, but nowhere in the mine were any quartz crystals seen of sufficient size to permit recognition of their crystal planes without a lens. Solid masses of vein quartz are entirely absent. 
Ore of the kind described has in some places been subjected to later crushing and brecciation. Such material often shows dark, soft streaks of obscure sulphides, and some of it is rich in gold.

By way of summary, it may be said that the unoxidized ore of the Combination mine shows at least three stages of chemical and physical activity. These are as follows: (1) Brecciation of the dacite and cementation by fine crystalline quartz apparently formed by recrystallization of the silica in the rock. How much of the pyritization and alunitization of the rock belongs to this period is difficult to say. (2) Rebrecciation, rounding of fragments by attrition and solution, and deposition of gold, famatinite, and bismuthinite, associated with pyrite, marcasite, alunite, kaolinite, quartz, a little telluride of gold, and some silver. (3) Later crushing along fissure zones and some secondary concentration of the gold, probably by descending waters. There is no evidence that the first stage contributed any valuable constituent to the deposit. The gold, silver, bismuth, copper, tellurium, etc., appear to have been introduced in the second stage of the process.

With the exception of the small shoot of oxidized ore found in the No. 3 shaft, the richest ore in the mine has been the first hundred feet of the unoxidized ore in the original No. 1 shoot, near the main shaft.

While it was known in 1905 that the unoxidized ore of the Combination contains some tellurium, no mineral recognizable as a telluride had been detected. Since then rich telluride ore, closely resembling that of the Mohawk mine, has been found in stope No. 316, above the 280-foot level, about 150 feet east of the shaft. 'This ore occurs partly in latite.

The oxidized ore, as already mentioned, is not readily distinguished from ordinary oxidized ledge matter. The gold is visible at some places, but at more it is masked by yellow ocherous limonite from the decomposition of pyrite or marcasite. Kaolinite is rather abundant in the oxidized ore, while alunite is rare. The hydrous copper carbonates are rarely seen in the thoroughly oxidized ore, although they occur in small quantities in the zone of partial oxidation. Alum, gypsum, and melanterite (ferrous sulphate), the latter sometimes mixed with a little chalcanthite, occur usually in seams or as efflorescent coatings in or just below the oxidized zone.

The chunge from oxidized to sulphide ore in the Combination mine takes place at a depth of about 140 feet.

\section{UNDERGROIND WATER.}

Water was reached in the Combination mine at approximately the 130-foot level. In 1905 from 1,500 to 2,000 gallons were hoisted daily to keep the water below the 230-foot level, and when the 280-foot level was open the quantity raised was greater. In 1908 the mine was making practically no water, being drained by deeper adjacent workings.

\section{JANUARY MINE.}

HISTORY.

Prior to its absorption by the Goldfield Consolidated Mines Company, the January mine was owned by the Goldfield Mining Company, their holdings comprising, in addition to the January and February claims just west of the Combination ground, 5 claims in other parts of the district. At the beginning of the year 1904, a lease on the January claim was granted for one year to L. L. Patrick and others, who within a month began to make shipments. The lease is reported to have proluced 1,000 tons of high-grade ore, yielding $\$ 199,489$ and $\$ 286,000$ wcrth of ore, runging from $\$ 30$ to $\$ 100$ per ton. In January, 1905, the company began to operate the property themselves, with notable success. In 1906 the mine was merged with the Mohawk, Combination, Jumbo, and Red Top. The present owners were not operating the January in 1908 and had abandoned the old shaft. Future work will be from the Combination shaft. 
UNDERGROUND WORKINGS.

The January mine was worked through a vertical shaft about 300 feet deep, connecting with six rather irregularly spaced levels, as shown in Plate XVI. The general plan of these levels is crescentic, with the concave side to the east. The workings are remarkably compact and all the ore thus far mined lies within the space between the outer curve of the crescent and the chord formed by the east side line of the January claim. Some of the ore bodies, however, undoubtedly extend eastward into the Combination claims. Since the mine was studied the 110-foot, 232-foot and 283-foot levels have been extended as shown in Plate XXXIV, but these later workings could not be seen in 1908. The following description relates to the mine as it was when in active operation at the end of 1905 :

\section{GEOLOGIC RELATIONS.}

The main workings of the January mine are in the same dacite that forms the country rock of the Combination mine. At the 283-foot level, however, the shaft cuts a fissure filled with soft crushed rock. Owing to the softness of the ground shaft and drift had to be closely lagged, and the fissure was not well exposed at the time of visit. It apparently dips steeply northeast and separates dacite on that side from latite on the southwest. Both rocks, particularly the dacite, show great disturbance in the vicinity of the fissure and are thoroughly altered, containing abundant alunite and disseminated pyrite.

FORM OF THE LEDGE.

The January ledge is one of the most remarkable that have been exploited in the district. Its peculiar form can best be understood by reference to Plate XVI. In the first three levels the ledge curves from a course of about N. $70^{\circ} \mathrm{W}$. to one bearing N. $55^{\circ} \mathrm{E}$. It thus turns through an angle of about $125^{\circ}$, the shaft being situated at the elbow.

So decided a change in strike suggests that the ledge may be due to the intersection of two distinct zones of fissuring. This, however, is not the case. The outer curve of the ledge is smooth and regular and the distinction between ledge and country rock, particularly on the upper levels, is sharp. That the country rock which bounds the ledge on the northwest, west, and southwest should be entirely free from fissuring is of course not to be expected. Such fractures as occur, however, are small and have rather the character of irregular jointing than of fissure zones which could be taken as the straight continuation of either limb of the crescentic ledge through and beyond the bend at the shaft. In fact the minor fissuring observable in the dacite at the shaft appears in most instances to be tangent to the bold sweep of the ledge, and the smooth outline of the curve as visible in the empty stopes of this part of the mine affords no suggestion of any break in the dacite wall such as would be expected were the turn in the ledge the result of the intersection of two rectilinear fissure zones.

As the general map of the workings shows, the part of the ledge northeast of the shaft dips to the northwest, the angle of dip becoming lower as the ledge is followed northeast. The ledge south of the shaft, on the other hand, dips to the northeast. In other words, each successively lower level shows a slight rotation, in a direction contrary to the hands of a watch, 'about the shaft as a vertical axis. Moreover, below the 109 -foot level the whole ledge pitches to the east, as shown by the increasing length of the crosscuts from the shaft in Plate XVI. On the 232-foot and 283-foot levels the ledge is apparently becoming more nearly rectilinear in strike. It thus appears that the January ledge, even when stripped of minor complexities of form, is by no means simple in shape.

The minor complexities referred to arise from the variations in width of the ledge and the irregular projections of ledge matter into the country rock on its concave side. These latter are so abundant and so irregular that any section such as that shown in Plate XVI is necessarily diagrammatic, the mine levels, close as they are, being too far apart to reveal every detail of structure. 
In general, the distinction between siliceous ledge matter and the soft alunitized and pyritized country rock is fairly sharp in the January mine. In the oxidized zone, especially, the contact is almost a geometric surface. There is very little evidence of movement, however, between ledge matter and country rock, and there is seldom any gouge to mark the plane of division.

Small streaks or lenses of ledge matter, apparently not connected with the main ledge, have been found in crosscuts west of the shaft. That on the 283-foot level is a lodelike mass in latite.

MATERIAL OF THE LEDGE.

The material of the oxidized portion of the ledge is of the same general character as that described in the Combination mine. Below the oxidized zone the ledge matter is perhaps a little more readily distinguished from the ordinary country rock than in the Combination mine, the ledge being, as a rule, harder and apparently more siliceous than the country rock. Mineralogically, however, there is little difference between the two forms of altered dacite. Both are chiefly quartz and alunite with more or less pyrite. The ledge usually shows more fissuring and brecciation and contains small quartz-lined fissures or cavities. In some places on the bottom level (283-foot) of the January the ledge is a sheeted zone, showing tiny vuggy veinlets of quartz between slabs of dacite in which the feldspars are altered to faint-pink aggregates of alunite. The pyrite in such ledge matter may be no more abundant than in the softer country rock through which it is universally disseminated. Much of the alteration to ledge matter, on the lower levels, has been clearly facilitated by close sheeting of the rock, the fissures being usually less than an eighth of an inch in width. They can in places be seen crossing alunite pseudomorphs after feldspar without perceptibly faulting them. In other places the dacite has been shattered to fragments. The feldspars in these fragments have been changed to alunite and the latter mineral is in places very abundant as an interstitial filling between the fragments. In addition to their internal alteration the fragments in some places show peripheral layers or crusts of quartz, alunite, and sulphides. These are not all mere incrustations. Some fragments have been rounded, apparently by chemical action, and have a whitish outer layer which the microscope shows to be a very fine-grained aggregate of quartz and alunite. This differs from the quartz-alunite aggregate of the central part of the fragment in being of finer and more even grain and in retaining no trace of the dacitic texture. It is apparently a secondary crystallization of the already altered rock, in the course of which even the quartz phenocrysts are attacked and merged into the fine resulting aggregate. Other fragments, of more or less rounded outline, are encrusted by a thin dark layer of pyrite (with perhaps other sulphides). This is coated with a crust of drusy quartz and this in turn covered by and the whole nodule embedded in soft pulverulent alunite, which in places carries crystals of pyrite. Such material resembles some of the rich ore in the Combination mine, but where studied in the north drift of the 230-foot level of the January mine the material is of little value. As in the Combination mine, there is a noteworthy absence of any quartz crystals large enough to allow the recognition of distinct crystal planes with the naked eye. Whatever processes may have been at work in the formation of the ledge matter, their capacity for dissolving silica and transporting it to places where crystals of some size might develop was exceedingly slight.

\section{FORM AND DISTRIBUTION OF THE ORE BODIES.}

Probably a better idea can be obtained of the distribution and form of the January pay shoots from Plate XVI than from any verbal description. They differ from the rest of the ledge matter in no essential respect save that of richness, and as a rule are without definite boundaries. On the first three levels there is a fairly regular curved pay shoot which conforms to the general curvature of the convex side of the ledge. Except for the curved strike this pay shoot has a lodelike form, and in the part of the mine northeast of the shaft has been stoped to a maximum width of about 15 feet. Just above the 160 -foot level this pay shoot dies out. 
There is a similar shoot of sulphide ore, however, on the 232-foot and 283-foot levels, but it has not yet been opened to as great a length as in the oxidized zone.

In addition to these pay shoots which follow the outer curve of the ledge, there are a number of smaller, irregular shoots distributed with little uniformity through the inner or concave part of the ledge. These are irregular bunches of ore which trend in various directions and rarely extend continuously from one level to another.

It is noteworthy that the poorest level in the mine, the 160 -foot, is the one nearest the original water level. No ore bodies are known on this level.

CHARACTER OF THE ORE.

The oxidized ore is of the same general type as that described in the Combination mine. The oxide of bismuth, bismite, is rather abundant in the oxidized zone of the January, and usually accompanies ore of high grade. It is present, however, on the barren 160 -foot level. The bismite occurs in some places as minute pearly scales in loose limonitic material, but in some varieties of the ore is clearly pseudomorphous after the needles of bismuthinite, from which it has been derived by oxidation.

The typical sulphide ore consists of highly siliceous altered dacite containing specks and irregular bunches of reddish-gray famatinite, accompanied by pyrite and needles of bismuthinite, the latter being usually inclosed in the famatinite.

In varieties of the ore pyrite is abundant. In others it is decidedly subordinate to the famatinite and bismuthinite. All three sulphides are so closely intergrown as a rule that it is almost impossible to effect a mechanical separation of them.

In some places the sulphides and minutely crystalline quartz form small veinlets, a section of one of these being figured in Plate XXIII, $C$. Such material seems to have resulted from the alteration and mineralization of crushed dacite rather than from the filling of an open crevice. The entire process of ore deposition illustrates very feeble capacity for the filling of open spaces, the ore containing many small cavities which have never been filled with either quartz or sulphides.

The altered dacite of the gangue shows original residual phenocrysts of quartz. The feldspars are partly dissolved or obliterated, partly altered to pinkish-white aggregates of alunite. The material is porous, being full of small irregular vugs lined with quartz druses and in some instances filled with alunite. These pores usually contain water when the rock is freshly broken.

Such ore evidently represents the alteration and mineralization of a shattered portion of the dacite. It is in some places traversed by seams of secondary crushing, which carry streaks of soft dark sulphides of obscure and probably mixed character. Such seams are generally the best part of the ore, and indicate some enrichment subsequent to the deposition of the bulk of the ore.

In another form of ore the dacite has been sheeted prior to mineralization, instead of being brecciated. Such ore as a rule contains less sulphides than the other kind and is probably never of so high a grade. The famatinite and bismuthinite particularly occur chiefly where the dacite has been thoroughly shattered, and experience has shown that the gold is associated with these two sulphides.

The richest ore in the mine has been found in the oxidized zone. The original water level in the January was at a depth of 160 feet. This may have been lowered somewhat by previous work in the Combination mine. But even if some allowance be made for such artificial depression, the fact remains that the poorest level in the mine is that nearest the old water surface. The best sulphide ore on the 283 -foot level at the end of 1905 had a gross value of about $\$ 150$ a ton, and the highest assays were obtained from soft dark streaks traversing the mass of the ore. 


\section{UNDERGROUND) WATER.}

At the end of 1905 a small pump sufficed to keep the 283-foot level free from water. The only water actually observed flowing into the mine was a small stream at the north face of this level.

A sample of mine water was analyzed in December, 1905, in the Dearborn laboratories, Chicago, by Edgar \& Carr, chemists, for the purpose of testing its suitability for use in the steam boilers. The analysis is as follows:

\begin{tabular}{|c|c|}
\hline & Grains per gallon. \\
\hline Silica.. & $\ldots \ldots 2.990$ \\
\hline Sulphates of iron and aluminum (principally iron).... & 80.200 \\
\hline 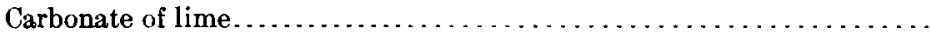 & None \\
\hline Sulphate of lime..................... & 58.455 \\
\hline Carbonate of magnesia................ & None \\
\hline Sulphate of magnesia............. & 22.971 \\
\hline Sodium and potassium sulphates................ & 72. 194 \\
\hline Sodium and potassium chlorides.... & 11. 880 \\
\hline Loss, etc..................... & 1.145 \\
\hline Total soluble solids.. & 249.835 \\
\hline Suspended matter......... & 41.580 \\
\hline 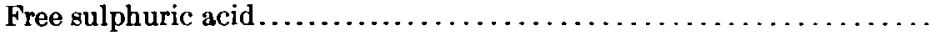 & Trace \\
\hline Total soluble incrusting solids...... & $\ldots 141.645$ \\
\hline Total soluble nonincrusting solids. $\ldots \ldots \ldots \ldots \ldots \ldots \ldots \ldots \ldots \ldots \ldots \ldots$ & $\ldots 108.190$ \\
\hline 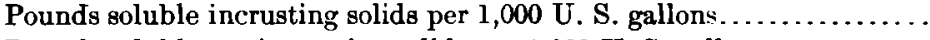 & $\ldots .20 .23$ \\
\hline Pounds soluble nonincrusting solids per 1,000 U. S. gallons. . . . . . . . . & $\ldots .15 .45$ \\
\hline
\end{tabular}

The analysts remark that the water-

contains a little less than 250 grains of solid matter in solution and a little over $41 \frac{1}{2}$ grains in suspension, per United States wine gallon of 231 cubic inches. It also contains a trace of sulphuric acid. Undoubtedly this water in its original condition carried a considerable quantity of free sulphuric acid, but due to the fact that sample was shipped in a can, it has been materially neutralized by the iron of the can itself, producing sulphate of iron, which accounts for the large amount of same above given. $a$

The analysis is accordingly very inaccurate and is of value only as affording some indication of the general character of the water. The sample analyzed was probably taken from the pump discharge and represents a mixture of the normal ground water of the district with solutions which have trickled down through the oxidizing ore. Much of the percolating water on the lower levels contains aluminous salts, as shown by its taste and by the deposition of halotrichite in efflorescent form on the walls of drifts.

\section{JUMBO MINE.}

HISTORY.

The Jumbo mine lies just north of the Florence, the main Jumbo shaft being half a mile north of the Florence shaft and the same distance east of the Combination shaft. The holdings of the Jumbo Mining Company in 1905 comprised the Jumbo, Lucky Boy, Grizzly Bear, and Clermont claims, all forming a compact group. Practically all the development is on the Jumbo claim, which was located by C. D. Taylor on May 19, 1903. In the following October the property was bonded for $\$ 100,000$, but crosscuts at a depth of 50 feet having failed to open up ore the bond was relinquished. In March, 1904, the Jumbo Mining Company was organized, and during the following spring leases were let to six or more different sets of lessees. Most of the lease blocks extended for 100 feet along the lode, although the northernmost, or RidgeCurtis lease, was 300 feet in length. The lessees soon found ore and the ledge became an object of great activity, each block having its own shaft. The daily output from all leases in August, 
1904, was estimated at $\$ 10,000$ a day. ${ }^{a}$ The total gross production from these leases to their expiration early in 1905 was approximately $\$ 1,100,000$. The most productive single lease was the Bowes-Kernick, near the middle of the claim, which expired October 31, 1904, after a net production of $\$ 258,000$. The royalty paid by the lessees to the company was 20 per cent of the gross output.

Throughout the greater part of 1905 the Jumbo mine was involved in litigation and no ore was mined. In 1906 it was included in the consolidation with the Combination, January, Red Top, Mohawk, and other mines and is now the property of the Goldfield Consolidated Mines Company. Nothing has been done in the old workings since the consolidation and the shaft has been allowed partly to fill with water. It is the intention of the company to reach the ore body from the Mohawk and new Jumbo (Clermont) shafts.

\section{UNDERGROUND WORKINGS.}

As each lease block was worked through an independent shaft and as the levels were not run at uniform intervals and do not all connect with those of adjoining blocks, the underground workings of the Jumbo mine are in a rather chaotic condition. The section of ledge worked by the lessees is about 600 feet in length and their operations extended to a maximum depth of 250 feet. The deepest level in 1905 was the 250 -foot level on the Bowes-Kernick lease, near the middle of the productive ledge. This connects with a vertical shaft sunk in the country rock just west of the ledge. After the expiration of the leases the company made this the main shaft, and by the end of 1905 had sunk it to a depth of 450 feet. The ledge, however, had not then been crosscut below the 250 -foot level. A general plan of the principal levels is shown in Plate IX.

THE LEDGE.

The Jumbo ledge, which so far as developed is entirely in dacite, outcrops prominently for a distance of about 700 feet. Its general course is about $N .16^{\circ} \mathrm{W}$. Underground development shows it to be nearly vertical on the upper levels, although the east side is commonly called the hanging wall, and the 300-foot level, not accessible at the times of visit, indicates an eastward deflection of the ledge at that depth. The deposit is more regular and lodelike in form than most of those in the district, much of it being a distinct zone of parallel sheeting in the dacite, resembling some of the typical lode structure of Cripple Creek. The belt of regular sheeting is in most places from 4 to 6 feet wide, but the alteration and mineralization, as shown by stopes, may attain a width of fully 20 feet. Brecciation of the rock, so characteristic a feature of the Combination, January, and Florence ledges, is notably absent from the Jumbo. The sheeting, as at Cripple Creek, has been effected with very little slipping of one sheet of rock past another, and no gouge seams were noted in the workings accessible in 1905. The ledge has no true walls, the sheeted structure and the more intense alteration of the dacite which accompanies it grading into the usual softer country rock, which contains much alunite and disseminated pyrite.

Within the ground opened by lessees the sheeting is more regular toward the north, the structure being excellently shown at the north face of the 200-foot level of the Fuller-Macdonald lease $(\mathrm{Pl} . \mathrm{XX}, B)$. In the Vermilyea and Zinn leases, to the south of the Bowes-Kernick lease, the lode divides into at least two branches, the sheeting is less regular, and at the south end of the Zinn workings the ledge becomes rather indistinct.

In general, the distinction between ledge matter and country rock is less easily made in this mine than in most of those described, owing to the gradual passage of one into the other.

THE PAY SHOOTS.

Near the surface the Jumbo ledge proved almost continuously productive for a distance of 500 to 600 feet along the strike. The stopes ranged from 2 or 3 up to 20 feet in width. Too 
little systematic work has yet been done to determine the limits of the pay shoot below the zone of oxidation, which extends to a depth of about 200 feet. A little stoping on sulphide ore has been done near the 250-foot level, but the ore apparently is not there of high grade. At the south end of the ledge the two main branches into which the ledge divides both carry ore. At the north end of the productive zone, in the Ridge-Curtis lease, about $\$ 200,000$ worth of ore was stoped between the surface and the 50-foot level. Below that level no ore was found, although prospecting was carried to a depth of 200 feet.

In the Bowes-Kernick lease, on the other hand, the stopes on the 150-foot level were carried the full length of the block, 100 feet. Below this they shorten and come to a point on the 250-foot level.

\section{CHARACTER OF ORE.}

The oxidation in the upper levels has followed the fissures of the sheeted zone. These, which are rarely more than a small fraction of an inch in width, are filled with rusty material consisting of limonite, kaolinite, gypsum, and probably some alunite. Oxidation has also extended from the fissures for varying distances into the intervening slabs or sheets of dacite, converting the disseminated pyrite into limonite. No gold was seen in the stopes at the time of visit, but it is said to have occurred mainly in the rusty seams of the sheeter zone.

Below the zone of oxidation the fissures are lined with films of quartz, the middle part being empty or filled with alunite. Pyrite is apparently not abundant except as finely disseminated crystals in the dacite. On the 200-foot level some of the seams.carry famatinite. This, however, did not appear to be associated with much gold, an assay of a sample from the south face affording only 0.26 ounce of gold and 0.25 ounce of silver to the ton.

The rock between the fissures is dacite which has been changed to an aggregate of quartz, alunite, and pyrite, the alunite chiefly pseudomorphous after feldspar. The original quartz phenocrysts of the dacite are the only constitutents not affected by this kind of alteration. This ledge rock differs from the general country rock in containing more quartz and consequently in being of superior harlness.

Much of the ore shipped by lessees was of very high grade. One lot of 14 tons from the Bowes-Kernick lease netted $\$ 36,000$, or $\$ 2,571$ a ton. The smelter settlement on 14 sacks of ore shipped in November, 1904, from the Richard lease, which was immediately south of the BowesKernick lease, was at the rate of $\$ 4,960$ a ton.

As shown on Plate IX, considerable exploration has been carried on by lessees on the 350foot level of the Jumbo Ledge or Becker shaft, in an attempt to find a continuation of the rich ore formerly worked through the Zinn shaft. In 1908 this level was mostly in soft disturbed dacite, containing some large irregular masses of ledge material but no visible ore.

\section{MINES AND PROSPECTS OPERATED BY LESSEES.}

\section{INTRODUCTION.}

The principal mines operating in 1908 under leases from the Goldfield Consolidated Mines Company were the Five Friends and Hazel-Goldfield on the Laguna and Last Chance claims, the Mushett and Mohawk-Red Top on the Miss Jessie claim. and the Consolidated Red Top on the Red Top claim. All these are situated north of the Mohawk workings, as may be seen from Plate X. Southeast of the Combination mine shafts were being sunk by many groups of lessees. None of these shafts was in ore in 1908, and with the exception of the Rosebud none was connected with any extensive lateral development. Among them may be mentioned the Gotwaldt, Moore, Gibraltar, Stein, Mitchell-Fairfield, Rosebud, Black Eagle, Liverpool, Texas-Golconda, and Facer shafts. The positions of these leases are shown in Plate X. The Mushett and Consolidated Red Top leases were shipping ore in 1908.

\section{FIVE FRIENDS LEASE.}

The shaft of the Five Friends lease was 350 feet deep at the time of visit, but, as reported by Mr. H. P. Henderson, it had been deepened to 560 feet at the beginning of December, 1908 . A plan of the levels is shown in ingure 25. The country rock of the lease is dacite of the usual 
character. No ore has yet been found, although the north-south drifts on the 275 -foot level follow a narrow seam which dips $30^{\circ}$ to $40^{\circ} \mathrm{E}$. and carries a little crumbling sphalerite and galena.

\section{MUSHETT I.EASE.}

At the time of visiting the Mushett lease the principal level connected with the bottom of the 430-foot shaft. A plan of the workings is shown in figure 26. The 429-foot level at

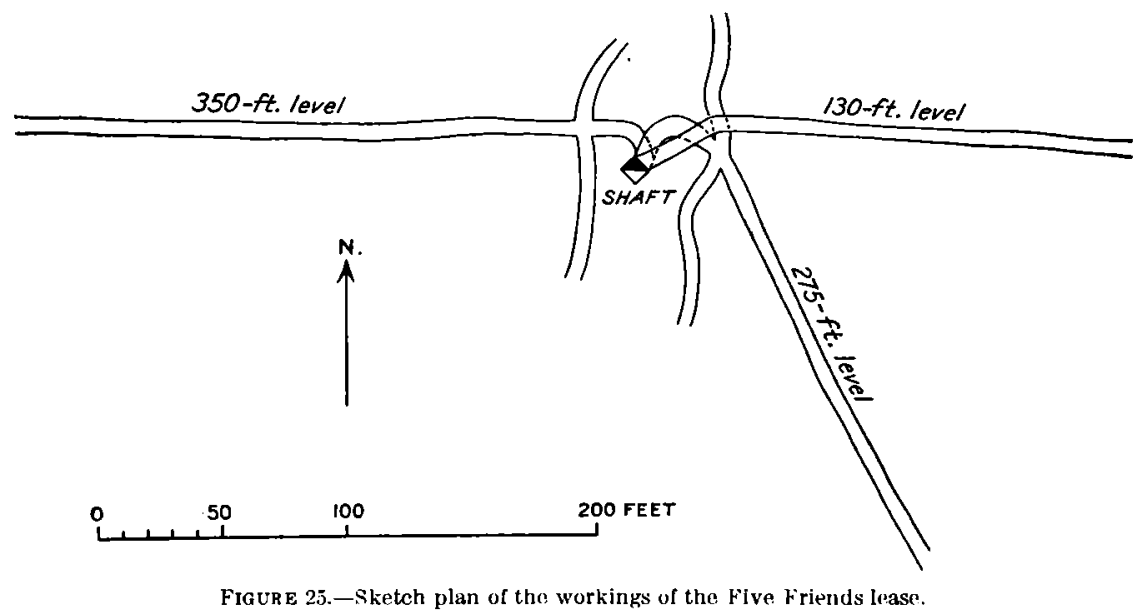

the time of visit was wholly in dacite, which, near the ore body, shows the usual alunitic alteration. The main drift runs nearly north and south and follows a mineralized streak in the dacite, which at one place widens to a pipelike ore body. The narrower part of the mineralized streak is chiefly remarkable as carrying rather abundant sphalerite, a mineral which has hitherto been remarkably rare at Goldfield. A sample of this sphalerite assayed for the Goldfield Consolidated Mines Company gave 1.8 ounces of gold and 7 ounces of silver per ton, with 55.6 per cent of zinc.

The ore body, as shown in figure 26 , dips from $25^{\circ}$ to $35^{\circ} \mathrm{E}$., and pitches north. Its stope length varies from 12 to 20 feet and the width from a few inches to 7 feet. The ore is of high grade, some assays showing a tenor of $\$ 8,000$ a ton. Mineralogically the ore is unique in this district. It contains abundant sphalerite, pyrite, bismuthinite in crystals unusually large for this district, famatinite, and some telluride rich in gold. Alunite is abundant, both as a constituent of the altered dacite, as the filling of small fissures, and as a soft interstitial material in the ore. Further particulars of the Mushett ore are given on pages 165 and 170 , and in the chapter on mineralogy under the various minerals mentioned above.

Since the date of visit (July, 1908) the contact between the dacite and latite has been cut on the 429 -foot level at a point about 160 feet west of the shaft. Both rocks are said to be altered to

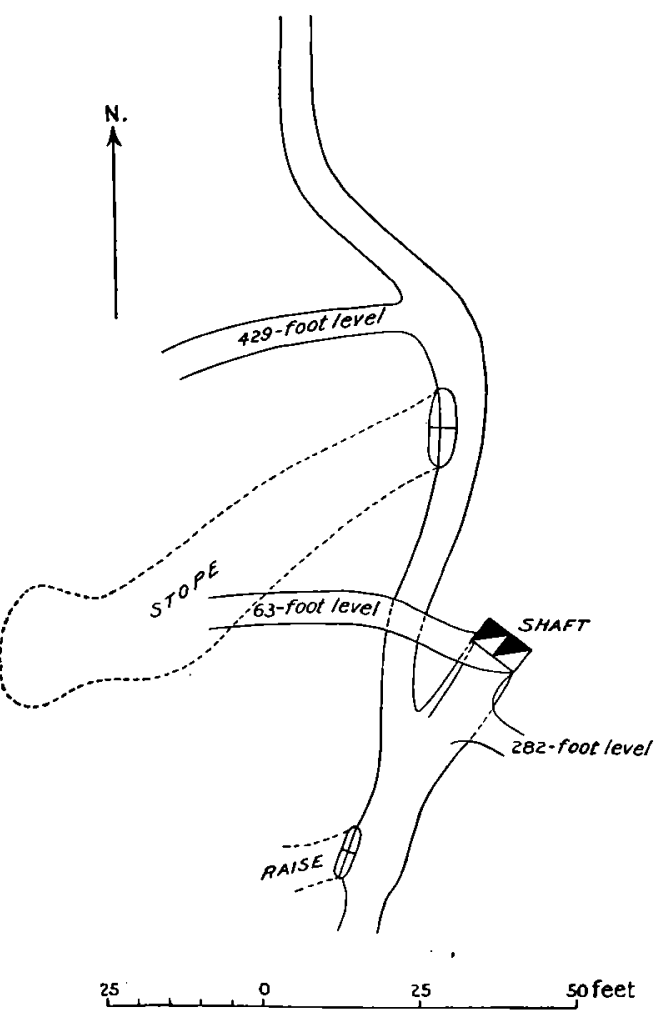

Figure 2ti. - Plan of the workings of the Mushett lease. ledge matter near the contact. On the new 480-foot level the contact, according to a letter from Mr. H. P. Henderson, appears to be about 50 feet east of the shaft, and is in ledge 
matter. These observations indicate a dip of about $15^{\circ} \mathrm{E}$., and are of interest as showing the tendency of the ledge to flatten out and follow this contact for a way instead of continuing straight down into the latite.

MOHAWK-REL, TOP IEASE.

The Mohawk-Red Top workings at the time of visit consisted of one level at the bottom of the 420-foot shaft. This level, shown in figure 27, is in latite, and the shaft is said to have passed out of dacite at a depth of about 365 feet. The latite shows considerable mineralization, being partly silicified and containing pyrite and alunite. It is traversed by many approximately parallel fissures which strike generally north and dip at angles of $40^{\circ}$ to $50^{\circ} \mathrm{E}$. One such fissure followed in the eastward (Irift contains a little crumbling sphalerite and galena, which, although in a different rock, resembles the material in the Five Friends lease.

(ONSOLIDATED REI TOP IEASE.

The Consolidated Red Top shaft is 300 feet deep, with levels at 200, 225, and 150 feet bolow the surface. There are also some short, abandoned upper levels driven by earlier lessees.

The shaft is in dacite, which, near the bottom, is much crushed, having in part the consistency of gouge. This condition is due to movement along the Columbia Mountain fault,

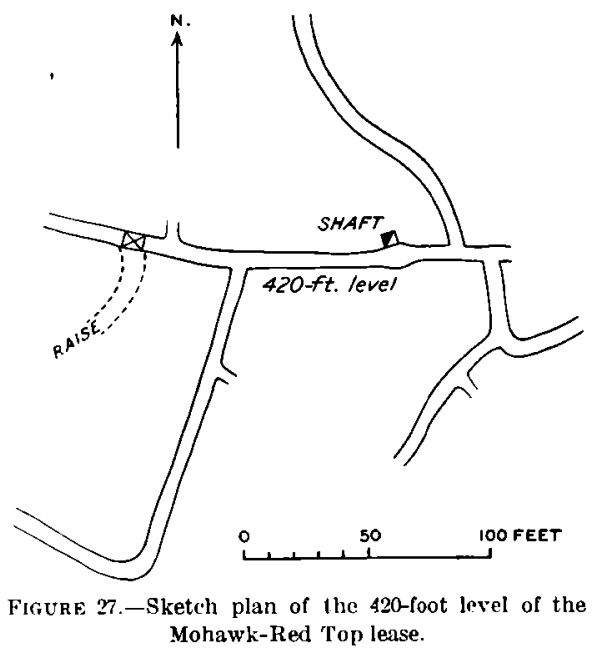
for the Cambrian shale appears on the 300-foot level just west of the shaft. The shale itself is greatly disturbed, and the level, which extends westward for about 30 feet, probably does not reach the foot wall of the fault zone. $A$ drift has been run south along the fault and shows black shale and Kendall tuff, both much crushed and disturbed. No ore has been found on this level.

On the 150 -foot level a strong ledge is exposed. This strikes N. $20^{\circ} \mathrm{W}$. and dips $40^{\circ}$ to $50^{\circ} \mathrm{E}$. It consists of the usual altered dacite, which, near the indefinite hanging wall, has a sheeted structure, while near the foot wall this grades into a brecciated rubble-like mass. The whole ledge on this level is about 80 feet wide, but like all similar deposits in Goldfield is irregular. Some traces of ore having been found on this level, the lessees started a new level at 225 feet, and in July, 1908, found a body of good ore about 100 feet east of the shaft. This ore, like that of the Mushett, contains much sphalerite, which forms friable crusts around fragments of silicified and alunitized dacite. Associated with the sphalerite are free gold, pyrite, famatinite, galena, and probably some tellurium compounds. Some of this ore assayed in the latter part of 1908 gave 42.1 ounces of gold and 34.5 ounces of silver per ton, with 5 per cent of copper and 12.5 per cent of lead. This, it will be seen, is a remarkable ore for this district.

HA7EL-GOLDFIELD LEASE.

The IIazel-Goldfield lease on the Last Chance claim was not in ore at the time of visit, the shaft being then 415 feet deep. According to Mr. Henderson, the shaft was 740 feet deep on December 6,1908 , and passed into latite at 685 feet. He reports that the contact where cut in the shaft dips about $60^{\circ} \mathrm{NW}$. This, as he remarks in his letter, is probably local and may be a minor fault plane. A new level at 713 feet is entirely in latite, much of which is ledge matter. Some good assays (from $\$ 200$ to $\$ 300$ ) have been obtained on this level, and at last report the lessees were shipping some ore.

OTHER LEASES.

The other leases on the Goldfield Consolidated Mines Company's ground call for no special description. Those which afford information on the geologic structure of the district are referred to in the appropriate places in Chapter VIII. 


\section{CHAPTER XIX.}

\section{DETAILED DES(RIPTION OF THE MINES OF THE FLORENCE-GOLDFIELI) MINING COMPANY.}

\section{INTRODUCTION.}

The principal mine of the Florence-Goldfield Mining Company is the Florence, situated just east of Goldfield on the north side of Florence Hill. The company owns the Florence, Red King, Cornishman, Firelight, and Emma claims, forming a compact group, as is shown in Plate XXXV. This ground as a whole has been very productive and is remarkable for the number of highly successful leases which have been taken upon various parts of it. The most notable of these were the Sweeney (in the Florence mine proper), Reilly, Little Florence, Florence Annex, Rogers, and Engineers' leases. (See Pl. XXXV.) The approximate gross production of these leases is as follows:

Gross production of Florence leases.

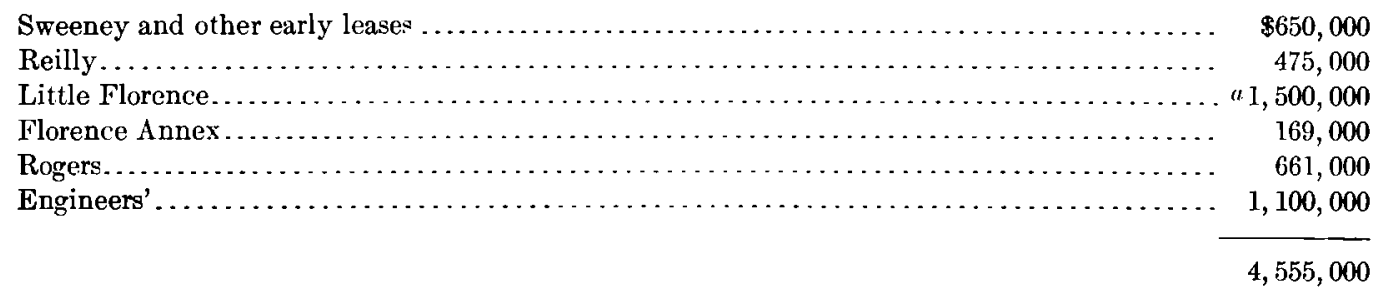

For over a year practically no underground work has been done in the Florence mine. The company has been building a mill, laying a pipe line, and improving its surface equipment. In the meantime lessees have been taking out rich ore up to within 300 feet of the main shaft.

\section{FLORENCE MINE.}

HISTORY.

The Florence claim was located on May 19, 1903, by Charles D. Taylor, but shortly afterward passed into the control of T. G. Lockhart and A. D. Parker. As was the case with all of the important mines except the Combination, the first ore bodies were found and exploited by lessees. The most successful of these early leases was that granted to Sweeney, Nixon, Wingfield, and Hennessy, usually known as the "Sweeney lease." These lessees found little to encourage them and after exploring the ledge at a depth of 50 feet they relinquished the work to Durgan, Elkins, and others, but retained a half interest in the lease. Shortly afterward the 100-foot level opened up the south pay shoot and penetrated the top of what subsequently proved to be one of the largest single ore bodies yet worked in the district. Shipments began in the summer of 1904, and according to Mr. Frank Oliver, superintendent of the Florence mine, the total production from leases prior to January 15, 1905, when the company began to operate the mine, was $\$ 650,000$. Some of the ore mined by the lessees was very rich, although far surpassed by later shipments from the Mohawk mine. One lot of 75,678 pounds, treated by the Western Ore Purchasing Company in August, 1904, had a value of $\$ 40,170.80$, corresponding to about 53 ounces of gold per ton. Another lot of 1,855 pounds was valued at $\$ 7,350.45$, equivalent to 396 ounces per ton.

$a$ This is merely a rough and conservative estimate from the known net production, which was $\$ 1,285,000$. $79145-$ No. $66-09-15$ 
The Florence-Goldfield Mining Company was capitalized at $\$ 1,250,000$, and the total gross output of the mine up to the end of 1905 amounted to about $\$ 1,500,000$.

\section{UNDERGROUND WORKINGS.}

At the end of 1905 the Florence mine was developed to a depth of 350 feet. It was worked through a vertical shaft with levels at $50,100,150,200,250$, and 350 feet, and an intermediate level at 300 feet below the collar of the shaft. These levels have a general trend of about $\mathrm{N}$. $15^{\circ} \mathrm{W}$., but they are most of them exceedingly tortuous, as may be seen from Plate XXXV. They somewhat resemble the workings of the January mine in showing a sharp elbow-like curve on the upper levels, which becomes less pronounced with increasing depth.

At the time of second visit, in 1908, the mine was idle. The 150-foot and 250-foot levels had been driven out to the Reilly shaft, but otherwise the workings were practically the same as in 1905 .

\section{GEOLOGIC RELATIONS.}

The chief feature of geologic interest in the Florence mine is the contact between the dacite and the Milltown andesite. Most of the Florence workings are in dacite. On the other

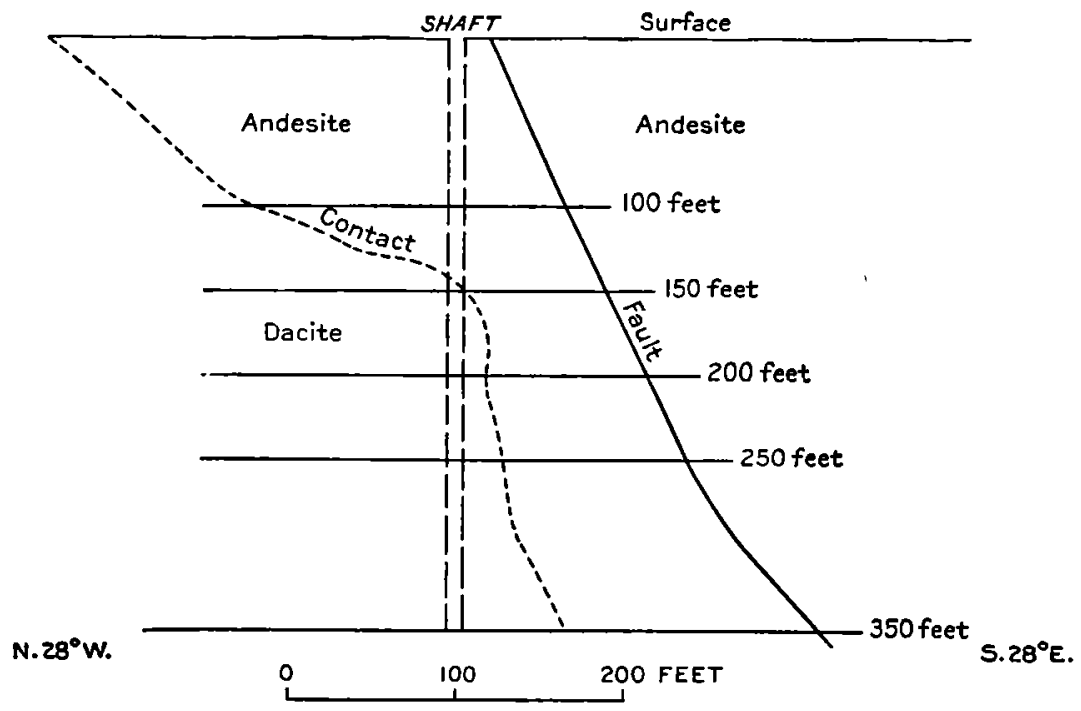

Figure 28.-Diagrammatic section through the Florence mine showing the cross fault and the daciteandesite contact. Plane of section passes 20 feet south west of shaft. hand the Engineers', Little Florence, Rogers, and Rosebud workings are in andesite. At the surface the rather obscure contact appears to be about 250 feet north of the Florence shaft. The 50-foot level (a short one not shown in $\mathrm{PI}$. XXXV) is probably entirely in Milltown andesite, although the alteration of the rock leaves its original character uncertain. At the 100-foot level the shaft is still in andesite. The dacite in the Florence mine, especially near the contact with the andesite, is usually finer

grained and less porphyritic than elsewhere, quartz phenocrysts are less abundant and conspicuous, and the two rocks in their altered condition may be exceedingly difficult to distinguish. For some distance north of the shaft on this level the character of the country rock is in doubt. Dacite certainly occurs on this level at a point 180 feet in a straight line northwest of the shaft. The rock south of this is believed to be mainly andesite, although it may contain some intruded tongues of dacite. On the 150-foot level the contact is just south of the shaft. It could not actually be recognized, but the shaft itself is certainly in dacite, and undoubted andesite occurs in the drift leading south from the station. On the 200-foot level the contact is obscured by mineralization, but appears to be less than 20 feet south of the shaft. On the 250-foot level the workings south of the shaft had caved in 1908, but observations made in 1905 showed that the south drift passes from dacite across an obscure contact into rock which is certainly andesite. The 350-foot level examined in 1905 is probably nearly all in dacite, although some andesite may appear at the extreme south end. This part of the workings could not be seen in 1908. The facts available from the Florence mine indicate that the dacite ends against the andesite with an igneous contact, and that this contact, below the 150-foot level, as illustrated in Plate VIII, section G-G', and in figure 28, has a steep dip to the south. 


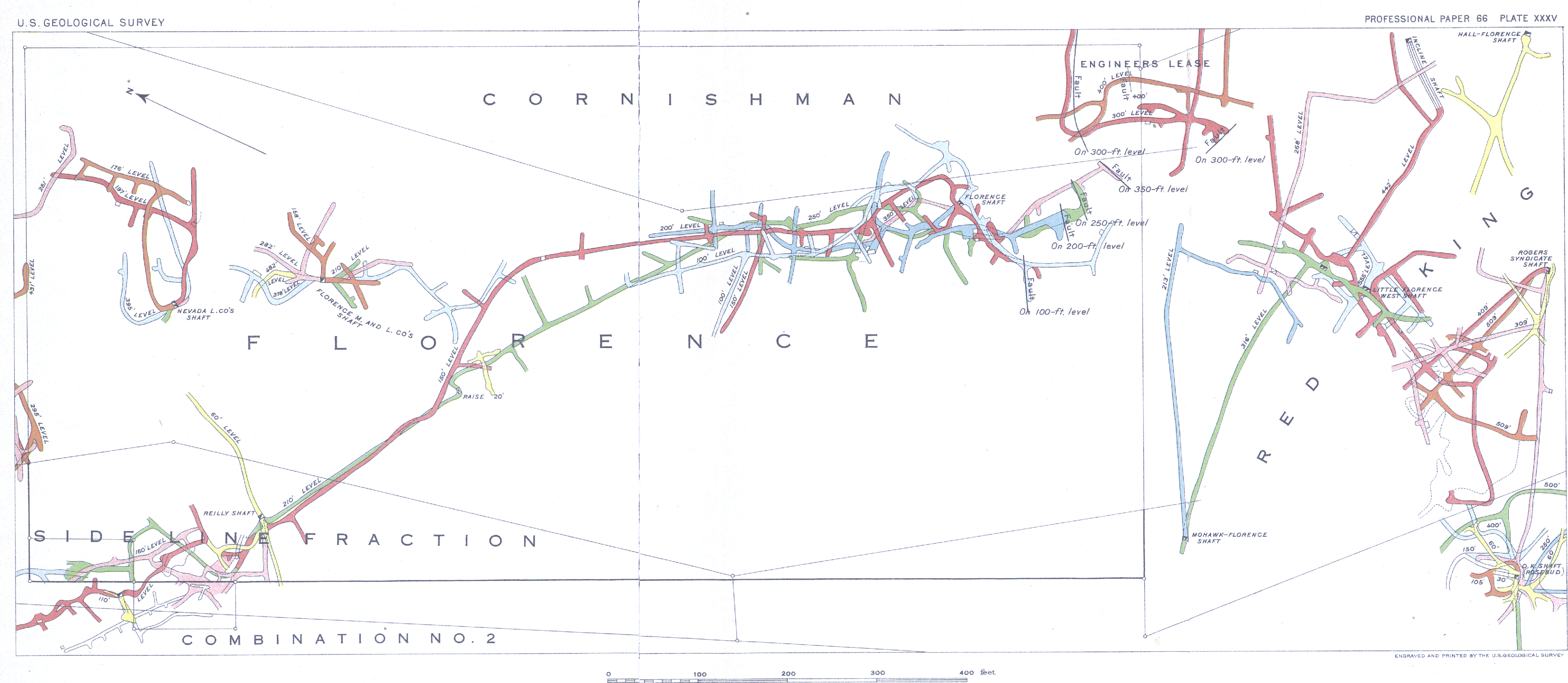

PLAN OF FLORENCE MINE, SHOWING ALSO SOME OF THE ADJACENT WORKINGS OF LESSEE COMPANIES 
About 100 feet south of the shaft the 100-foot level passes through a seam of gouge which strikes $\mathrm{N} .55^{\circ} \mathrm{E}$. and dips southeast. This seam limits the main mass of ledge matter on this level, as shown in figure 13, and apparently fills a fault fissure. Similar seams are found at the southern ends of the 200-foot, 250-foot, and 350-foot levels, as illustrated in Plate XXXV. The strike and djp as observed at these various exposures vary, but when plotted in section, as in figure 28, the points of observation determine a line of slight curvature. This, without much doubt, corresponds to a single fault which in general cuts off the Florence ledge on the south. As may be seen from Plate XXXV the change in strike is progressive from level to level. The observed dips at the various levels agree also with the dips indicated by the curve plotted in figure 28. The fault is in the andesite, and lies as shown in figure 28, southeast of the irregular dacite-andesite contact.

As exposed at the south end of the 350-foot level the fault plane has a dip of $40^{\circ}$ at the southwest end of the exposure, but gets steeper toward the northeast. The fissure carries a few inches of soft gouge and is accompanied by considerable disturbance of the adjacent andesite, which in the hanging wall is soft and pyritized, with some narrowly spaced sheeting near the fissure. There is pyrite in these fractures, showing that some mineralization has taken place since the faulting.

The direction and amount of displacement along this fault are not determinable from the Florence workings. About 140 feet north of the main fault, on the 350-foot level, an approximately parallel fissure has offset the part of the ledge south of it about 6 feet to the east. This suggests that the effect of the larger fault has been to throw the ledge south of it to the east also. Some additional light on this question is furnished by the workings of the Engineers' lease, which will be described later.

\section{FORM OF THE FLORENCE LEDGE.}

At the surface the Florence ledge appears as a line of rusty siliceous outcrops, which extend from the vicinity of the shaft north-northwest toward the Reilly and Combination mines. The ledge, however, does not actually join that of the Reilly, but ends, superficially at least, just north of the line of contact of dacite with andesite. (See Pl. II.) From this ledge some outcropping spurs run off to the east, one of them being indicated on Plate II.

The general shape of the Florence ledge, as explored underground, is probably more irregular than that of the January mine, and its boundaries are not so well determined by existing workings. On the 50-foot level (PI. XXXV) the curved northeast-southwest drift is in oxidized ledge matter of unknown width, and apparently follows the line of greatest shattering in the country rock. The crosscut northwest of the shaft is in soft altered andesite containing much kaolinite and probably alunite. The whole level shows much fracturing and disturbance of the rock, and all the material is oxidized. On the 100-foot level the ledge assumes more definite form. It is generally oxidized, while the less pervious pyritized and alunitized country rock shows practically no limonite. Ledge matter and country rock thus contrast sharply in color. The plan of the ledge matter on this level, so far as it can be determined from existing workings, is shown in figure 12 . The contact between ledge matter and country rock is almost everywhere sharp. In a few places there is a seam of gouge between the two kinds of material, but as rule there is no dividing fissure or gouge recognizable. On the south the ledge is cut off by a fault, as already described. On the 150-foot level the ledge is narrower and less definitely bourided, there being insufficient oxidation at this depth to accentuate the difference between the two kinds of material. The general dip of the ledge down to this level is to the west, at an angle of about $75^{\circ}$.

Near the 150-foot level the dip flattens, and between the 150-foot and 200-foot levels expands to a maximum width of about 18 feet in the part of the mine adjacent to the shaft. (See fig. 17, p. 154.) Here was the large body stoped under the Sweeney lease. This wide part of the ledge continues down to the 200 -foot level with a dip of $35^{\circ}$ to $40^{\circ}$. It then steepens, narrows, and as shown in figure 17, dips east down to the 250 -foot level. Near this level it 
again turns and dips west at a high angle. In other parts of the mine the changes in dip from level to level are less well known. The plan of the workings, Plate XXXV, indicates that they are as great as those shown in figure 17, but vary in direction on any given level in different parts of the mine. In the southern part of the workings the general dip is northeast.

The long drifts to the Reilly shaft on the 150-foot and 250-foot levels are largely in ledge matter, but this is irregular and is not continuous along the drifts, which here and there cut through masses of soft altered dacite. The irregular distribution of the ledge matter is in part original, but is in part due to minor faulting.

THE PAY SHOOTS.

The first pay shoot of any importance in the Florence mine barely reaches the 50-foot level, near the end of the south drift, the ledge from this level to the surface being practically barren. This ore body was found to increase in size downward and on the 100-foot level has been stoped for a length of about 40 feet and to a width of 3 feet. This was all oxidized ore. Another pay shoot appears on this level just east of the shaft and is apparently the top of the large body stoped below the 150-foot level. On the latter level the ore shoot south of the shaft has apparently pinched out. Just north of the shaft, however, the 150-foot level enters a pay shoot which, prior to the Mohawk discoveries, was of unusual dimensions for this district. The stope length of this shoot on this level is about 50 feet. The ore pinches above the level and apparently has not been followed through to the small stope on the level above. Below the 150-foot level, however, the ore body flattens in dip and has been stoped to a maximum width of 18 to 20 feet. The width, however, varies greatly and the ore has no walls. (See Pl. XXI, A.) In parts of this body the rich ore is divided into two layers by a thin sheet or horse of low-grade ore. Near the 200-foot level the ore body steepens with the ledge and becomes nearly vertical. The stope length on this level is 75 or 80 feet and the greatest width about 12 feet. The ore varies much in width, however, and extends irregularly and without definite boundaries into the shattered and altered dacite. This pay shoot appears to end just above the 250 -foot level.

At the time of visit, in 1905, neither of the principal ore bodies known in the upper workings appeared to reach the 250-foot level. At the south end of the level, however, a stope about 90 feet in length had been opened on ore up to 7 feet in width. This width probably corresponds only to the ore of shipping grade, much low-grade or milling ore being left in the walls of the stope. This pay shoot evidently does not extend up to the 200-foot level and is probably not directly connected with the ore body stoped south of the shaft, above and for a short distance below the 100-foot level. A winze has been sunk on it and some stoping done from the 300-foot or intermediate level. High-grade $(\$ 500-\$ 600)$ sulphide ore has been taken out from this stope to a width of 6 feet. The deposit here is lodelike, although without definite walls. It dips to the northeast at about $80^{\circ}$. Below the intermediate level the ore decreases in value and it is questionable whether it continues to carry ore of shipping grade down to the 350-foot level. No stoping had been done from this level at the time of visit. The most mineralized part of the ledge showed a sheeted structure, the slabs of pyritized, alunitized, and silicified dacite being separated by very narrow veinlets of quartz.

The pay shoot just described lies south of the Sweeney ore shoot, of which no direct downward continuation has yet been found on the 250 -foot level. It is in line with the Sweeney shoot, however, and it is possible that the ore of the two shoots may prove to be connected. If so, the combined pay shoot pitches very strongly to the southeast between the 200-foot and 250 -foot levels.

In the development of the workings to the north, some ore was found late in 1905, at the end of the 250-foot level. This ore, while in the general Florence ledge zone, is not directly connected, so far as known, with the ore shoots just described and is probably a separate shoot. Its limits have not yet been determined.

In the Florence, as in the other mines described, it is clear that the ore is not coextensive with the ledge, nor does it accompany the ledge to the same extent or with the same regularity 
and persistence as do the pay shoots of typical veins their fissures. It forms irregular rich bunches or bonanzas of comparatively short stope length and of no great individual persistency in depth. There were indications in 1905 that in the bottom of the mine the ledge was taking on the character of a metasomatic fissure vein with greater regularity of mineralization, but with a notable decrease in the value of the ore.

The study of the Florence pay shoots in 1905 was unsatisfactory on account of the absence of accurate stope maps and even of good plans of the levels. In 1908 better maps were available, but the condition of the mine was not then favorable to examination.

\section{CHARACTER OF TIE ORE.}

The oxidized ore of the Florence mine was never very abundant, and was practically confined to the south ore shoot, which was stoped between the 50-foot and 100-foot levels. Very little of this ore was visible in 1905 . It appears not to have been essentially lifferent from the oxidized ore of the Combination and January mines.

The ore of the large stope worked between the 150-foot and 200-foot levels under the Sweeney lease was mainly sulphide material. The low-grade portions of this body, which alone were available for examination in 1905 , consist of rock which was probably originally dacite, although it is altered so thoroughly that there is no certain means of distinguishing it from andesite. The material is now a fine-grained aggregate of quartz and alunite, with much disseminated pyrite in small crystals. It is minutely fissured, many of the fissures being approximately parallel and giving the deposit a sheeted structure parallel to the greater dimensions of the ore body. There are no definite walls, the ore grading without any break into the country rock. The smaller fissures are filled chiefly with cryptocrystalline quartz, the little veinlets being rarely more than an eighth of an inch in width. Larger fissures and irregular interstices where the fracturing is less regular are lined with drusy quartz and filled with alunite. Pyrite, besides being disseminated through the rock, occurs also in the fissures, where it often forms films which lie next to the walls and are covered by quartz. It also occurs embedded in the quartz and alunite. Minute white crystals, probably barite, are also present in the soft alunite, which in some places is probably mixed with kaolinite. No free gold was seen in this material, although it was presumably visible in some of the rich ore taken from this stope and may have been associated with famatinite. The dependence of mineralization upon fissuring is well illustrated in the low-grade ore left in the stope, pyrite being most abundant in and near the fissures.

The ore stoped between the 250-foot and 300-foot levels is nodular, somewhat resembling some of the rich ore in the Combination mine. Fragments of altered dacite, whose contours have clearly been modified to some extent by the chemical action of the depositing solutions, have been incrusted with sulphides. The inner crust is generally pyrite and is usually less than 0.1 inch in thickness. Outside of this is a crust of famatinite up to a quarter of an inch in thickness. This in turn is enveloped in a layer of cryptocrystalline quartz transfixed by needles of bismuthinite and containing also a little pyrite and famatinite. The outer surface of this siliceous envelope is rough or botryoidal with small quartz crystals and is coated with alunite. Small octahedral crystals of pyrite occur in this drusy crust and in the alunite. The latter mineral, perhaps in some places mixed with kaolinite, fills the interstices between the nodules. It also occurs in the kernels of the nodules as an alteration product of the original feldspars of the dacite. The appearance of a typical rich nodule is shown in Plate XXIV, $A$. In the richest specimens much free gold is visible. It occurs chiefly in the quartz and bismuthinite zone, embedded in both these minerals. The succession of minerals, it will be observed, thus differs from that in the rich nodular ore of the Combination mine, in which the gold is deposited mainly in the siliceous crust next to the dacite kernel.

Not all of the ore in this pay shoot shows the nodular character in equal degree. In places where the dacite has been much shattered prior to mineralization and where consequently the solutions have acted upon finely broken material, the pyrite, famatinite, bismuthinite, quartz, 
and gold have crystallized into more irregular aggregates. The nodular structure appears to have been best developed where the fragments acted upon were of moderate size and where the interstices between them were not packed with comminuted material.

The nodular structure is not confined to rich ore. Fragments of dacite coated with pyrite that is in turn covered by quartz druses, with a little famatinite, occur on the 250 -foot level where the ledge is of low grade. No bismuthinite, however, was noted in this material.

A notable increase in copper has been noted on the 250-foot and 300-foot levels in the Florence mine as compared with the upper levels. The proportion of silver, also, is said to increase with the copper. A shipment of ore from the 250-foot level made late in 1905 carried 100.8 ounces of gold and 3.5 ounces of silver to the ton, with 3.5 per cent of copper. This is the most silver per ton yet found in the ore, according to Mr. Oliver, formerly superintendent, the usual quantity of silver in ores from the higher levels being from 1 to 1.5 ounces per ton. Even 3.5 ounces of silver to 100.8 ounces of gold, however, must be regarded as a very small proportion. It is only about one-fifth of the proportion of silver to gold in the rich ore shipped from the Hayes-Monnette lease on the Mohawk mine, for example.

None of the ore on the 350-foot level of the Florence mine at the end of 1905 was of shipping grade. The highest assays afforded about $\$ 60$ a ton, the greater number giving only $\$ 25$ to $\$ 30$. Pyrite was the only sulphide seen on this level at the time of visit.

\section{UNDERGROUND WATER.}

Comparatively little water enters the Florence mine, the lowest level in 1908 being kept free by hoisting from 30 to 40 buckets of water each day.

\section{MINES OPERATED BY LESSEES.}

REILLY LEASE.

The Reilly mine, or "lease," as it more often called, is at the northwest corner of the Florence claim, in what is known as lease block No. 1 of the Florence ground. The workings adjoin those of the Combination and are on the same general ledge. The lessees' stopes were carried into the ground then owned by the Combination Mines Company, and a dispute arose, which was settled by a compromise, as described on page 210. The Reilly mine has not been operated for over two years. The Goldfield Consolidated Mines Company, however, has carried its 280 -foot level under the bottom of the old stopes and was taking out some very rich ore in the summer of 1908.

The first lease on block No. 1 was taken by F. G. Lockhart, one of the owners of the Florence claim, and George McClelland. They found no ore and relinquished the lease. Later a second group of lessees met with little better success. They opened a small shoot of ore on the 60-foot level, but missed the main ore body. In April, 1905, B. J. Reilly secured a six months' lease of the ground. On June 21 he found some ore, but it was not until August that the extent and richness of the bonanza was realized. Messrs. McKane and Campbell were taken into partnership about this time, and their united energies were bent to the task of extracting as much ore as possible before the expiration of the lease on October 19, 1905. The royalties paid by these lessees to the Florence-Goldfield Mining Company correspond to a gross production of $\$ 475,000$. The estimate that an additional $\$ 60,000$ worth of rich ore was stolen is probably a conservative one.

When visited in 1905, just after the expiration of the lease, the Reilly workings (Pl. XXXV) comprised a crooked shaft 210 feet deep with four levels, the important drifts being all north of the shaft. On the 60-foot level crosscuts were run northeast and southwest, but revealed nothing of value. A drift to the northwest follows what appears to be the northeast wall of the Combination ledge. It opened a small body of ore, which apparently was not connected with the main shoot afterwards found. The 110-foot level passed under this small ore body and was then turned to the north until it cut a fissure containing a tough, leathery clay gouge containing 
crystals of gypsum. This fissure, followed to the northwest, led into the main ore shoot, which was stoped for about 60 feet on this level and for about 30 feet above it.

The 160-foot level was first run as a crosscut to the southwest. It was then turned northwest and at a point about 100 feet a little north of west from the shaft came into an irregular body of ore. A crosscut of 50 feet to the north finally reached the main ore shoot. (See Pl. XXXY.)

The 210-foot level pursues a still more devious course. After first running west, it turns into a north crosscut of 90 feet in length. It then follows a gouge-filled fissure for 35 feet to the northwest and then crosscuts back southwest to the main ore body.

The Reilly workings are entirely in dacite and present no geologic features of special interest. The dacite is for the most part soft, with much disseminated pyrite and abundant alunite. It is traversed by numerous fissures, of which the more persistent have a general northwestsoutheast course. Some of these fissures carry clay gouge, some are associated with irregular segregations of pyrite. Most of them appear to have no close association with ore bodies.

The ledge matter in the Reilly workings is irregularly distributed through the soft altered dacite and is not nearly so well defined a belt as is the ledge on the southeast part of the 130foot level of the Combination mine. Crosscuts driven across the general line of the ledge in various places have shown only gouge-filled fissures in soft alunitized dacite, with here and there streaks and bunches of harder material such as might be termed ledge matter. The body of ore found on the 60-foot level and the one found nearest the shaft on the 160-foot level are associated with masses of ledge material which apparently are mere irregular bunches in the soft dacite. The ore of the main pay shoot is in most places inclosed in disturbed alunitized dacite with the usual disseminated pyrite. Distinct and persistent zones of characteristic ledge matter, such as the one which accompanies the pay shoot on the 130-foot level in the Combination mine, are absent in the Reilly workings.

The main Reilly pay shoot, as shown in Plate XXXV and figure 16, is a curiously warped or twisted sheet of ore, which does not reach the surface and varies much in stope length on different levels. Above the 160-foot level the general dip is northeast, while below that level, at least to the 210-foot level, the dip is reversed and the ore is inclined toward the southwest. As a rule the ore has no definite walls and the maximum width of the stopes in 1905 was about 15 feet. Undoubtedly, under the exigencies of the lease much low-grade ore was left standing. On the northeast side of the ore there is a rolling gouge-filled fissure which on the upper levels appears to serve here and there as a hanging wall. In many places, however, the ore apparently does not extend to this gouge. The smaller ore body shown near the third level is apparently an isolated mass inclosed in soft alunitized dacite.

Both oxidized and sulphide ore are found in the Reilly mine, but the conditions for observing either in place were not favorable at the time of first visit. Practically all of the rich ore in sight had been extracted, and development for the opening of new bodies had not begun. Rich sulphide ore was known to exist in a winze below the 210 -foot level, but this was filled with water. Some of the sulphide ore from this winze carried over 300 ounces of gold to the ton. In June, 1908, the Goldfield Consolidated Mines Company were stoping under the bottom of this winze on the 280-foot Combination level. This ore lies close to the hanging-wall gouge, which here dips to the west and is thus locally the foot wall. The rich ore streak as then exposed came into the drift obliquely from the southwest and wedged out against the gouge. It is a narrow shattered zone in siliceous ledge matter with much interstitial alunite and pyrite, the best ore as a whole being soft and friable. It contains abundant native gold, some of the ore carrying up to 620 ounces to the ton.

Much of the rich ore shipped by the lessees was nodular in character, concentrically coated fragments of altered dacite being embedded in so-called "talc," which was probably chiefly alunite. Other specimens show pyrite, famatinite, bismuthinite, and free gold in a porous cryptocrystalline quartz gangue. Such ore appears to have resulted from the alteration of finely crushed dacite. Some of the richest of such masses consist of little else than gold and white quartz, the gold being so abundant and in such fine particles as to give a general 
yellow tint to the quartz. One unfamiliar with Goldfield ores might readily mistake this golden pigment for a superficial ferruginous stain. In some specimens small crystals of barite are embedded in alunite, which encrusts fragments of altered dacite. Other varieties of the ore show a firm interstitial filling or cement of fine-grained porous quartz with pyrite, famatinite, bismuthinite, and gold. The fine-grained texture and minutely vuggy character of this filling indicates that it has not filled entirely open spaces but has replaced finely comminuted dacite. . Marcasite, as well as pyrite, occurs in some parts of the ore body. It is of later origin than at least a part of the pyrite.

The ore of the body stoped west of the shaft on the 160-foot level consists of shattered dacite, the interstices between the fragments being partly filled with alunite. The fragments themselves are hard, dense aggregates of quartz, alunite, and pyrite, the original plagioclase phenocrysts being now pseudomorphs of alunite, and the original femic minerals being now chiefly pyrite and quartz. The quartz phenocrysts alone remain unchanged. The surfaces of these fragments are incrusted and partly penetrated by a thin envelope of dark sulphides. A lens shows these to consist of the usual association of pyrite, famatinite, bismuthinite, and free gold.

The oxidized ore seen in the Reilly workings presents no characteristics calling for special description. The lower limit of oxidation is irregular, mixed oxide and sulphide ore occurring on the 160-foot level.

\section{ENGINEERS' LEASE.}

The Engineers' lease block, as shown in Plates IX and X, lies in the southeast corner of the Florence claim. The first work in this vicinity was done by the Florence-Annex leasing company, who sank a shaft on the Cornishman claim, crosscut west on the 300-foot level, and stoped ore to the value of about $\$ 169,000$ from the northeast corner of the Red Kins claim. One shipment of 40 tons of this ore in November, 1907, averaged $\$ 948$ a ton. The shaft is 500 feet deep and considerable work has been done on the 400-foot and 500-foot levels. The only ore bodies so far discovered, however, are above the 300-foot level. The Florence-Annex lease expired on February 12, 1908, and early in the following May H. P. Taylor and L. Price began work on the Engineers' lease through the Florence-Annex shaft. On June 15 they broke into a body of ore on the 300-foot level, a short distance north of that stoped by the former lessees. At the time of visit at the beginning of July, 1908, the lease had already produced about $\$ 60,000$, and at its expiration on November 8, 1908, it had paid over half a million dollars in dividends and was credited with a total gross production of $\$ 1,100,000$.

The country rock of the mines is andesite. This is cut by two fault fissures which limit the ore-bearing ground to the north and south. (See Pl. IX.) The northern fault dips south at about $55^{\circ}$ and is supposed by Messrs. Taylor and Price to be the same fissure that cuts off the Florence ledge, as described on page 227. This is probably true, although, as shown on Plate IX, there is a considerable difference in strike, probably about $40^{\circ}$, between the fault in the Florence mine and the fissure in the Engineers' lease. Such curvature, however, is by no means unusual in the fissures of the Goldfield district. The 300-foot level, after passing north through the fault gouge, turns east and continues to the end in a soft mass of crushed andesite, which is probably within the fault zone. The fault which cut off the ore at the south end of the 300 -foot level has been recognized only at this one place, and its trend is not known. It apparently runs in a nearly east and west direction and has a dip to the south.

The Engineers' pay shoot lies just south of the northern fault, although the ore did not extend quite to the fissure. Its stope length was about 50 feet, the average width was about 2 feet, and the height of the stope at the time of visit was 110 feet. The strike of the ore body was about $\mathrm{N} .30^{\circ} \mathrm{W}$. The dip was $80^{\circ} \mathrm{NE}$. It was thus a nearly vertical pipelike mass, of small elliptical cross section, and was one of the richest bodies of its size yet mined in the district.

In the drift on the 300-foot level the only suggestion of ore was a mere seam of kaolinite or alunite. A raise was put up on this and soon reached the pay shoot, which continued to improve in value upward. At the time of visit the ore being taken from the top of the stope averaged about $\$ 2,000$ a ton. 
The best ore was much shattered and somewhat slickensided material in which many of the fragments were concentrically coated with gold, bismuthinite, famatinite, and pyrite. The stope showed very clearly that the rich ore had been deposited after the andesite had already undergone silicification. Specimens of this ore are illustrated in Plate XXV and described on page 165. It is very similar to some of the rich ore of the Florence and Reilly workings.

LITTLE FLORENCE LEASE.

The Little Florence lease lies immediately south of the Engineers' lease and the main Florence workings, the relative positions of the three mines being shown in Plate IX. The main shaft of the lessees was sunk only a few feet south of the summit of Florence Hill. Work was begun early in 1907, and at the expiration of the lease on April 26, 1908, the total gross production amounted to at least $\$ 1,500,000$.

The main shaft is 555 feet deep, with levels at $213,268,316,442$, and 555 feet below the collar. The 268-foot and the 442-foot levels, as shown in Plate IX, connect with an inclined shaft on the east slope of the hill and the 213-foot and 316-foot levels with the Mohawk-Florence shaft on the west slope. These latter shafts were the original workings, and it was while making a connection between them for air that the rich ore was discovered. Subsequently the main shaft was completed by simultaneously sinking and raising. At the time of visit in 1908 no work was in progress and only a brief examination could be made.

The country rock of the Little Florence is andesite throughout. The ore body, while far from regular, is more veinlike in form than most of those exploited in the district. The ore was found at a depth of about 250 feet and the pay shoot did not extend quite to the 213foot level. It was about 5 feet wide where first cut and averaged about $\$ 400$ a ton. The pay shoot strikes north and south and was stoped in this lease for a length of about 200 feet. On the south it continues into the Rogers lease. On the north too little work has been done to determine what becomes of the ore in that direction. Until the ground between the Little Florence workings and those of the Engineers' lease and Florence mine is thoroughly explored it will be impossible to determine how far irregularity of deposition and how far subsequent faulting are responsible for the lack of continuity between the ore bodies of these three mines. The Iittle Florence ore body between the 213-foot and 268-foot levels is short and narrow, dipping to the east at $75^{\circ}$. Below the 268-foot level it becomes longer and divides into two rich streaks separated by a horse of siliceous ledge matter about 15 feet wide. The east shoot is the better on the 316-foot level. On an intermediate level 40 feet below the 442 -foot level the two streaks of ore come together and form the widest mass of ore in the mine. On the 555-foot level there is abundant ledge matter, but this is bunchy and of low grade. Gouge seams are numerous and in places the ledge matter is cut off by faults.

The rich ore stoped from this lease appears to have been similar to that of the Engineers' and Florence mines. The only place where any of the better grade of ore was visible in 1908 was at the north end of the 316-foot level. This shows the nodular character so common in the rich ore of the Goldfield mines, and contains native gold, bismuthinite, famatinite, pyrite, quartz, and alunite. Some of the bismuthinite from the Little Florence is as coarsely crystalline as that in the Mushett lease.

\section{ROGERS SYNDICATE LEASE.}

The Rogers lease adjoins the Little Florence to the south (Pl. IX) and is on the same ledge. Ore was found in October, 1907, on the 409-foot level, and the lease expired on July 11,1908 , after a gross production of about $\$ 660,000$ from 7,000 tons of ore. The average value per ton was about $\$ 95$, although some was very much richer.

The workings consist of a shaft about 520 feet deep, with levels at $165,309,409$, and 509 feet, and a sublevel at 559 feet. (See Pl. IX.) The principal stoping was done from the 409-foot and 509-foot levels and from the sublevel.

The general country rock of the Rogers lease is the Milltown andesite, which, where not transformed into ledge matter, is as a rule soft and much altered. The shaft is in this material 
and the principal levels crosscut through it for about 150 feet west-northwest to reach the ledge. This, which is a continuation of the Little Florence ledge, is exceedingly irregular and practically comes to an end in the Rogers lease. In some places it grades into soft andesite, but in others there is a definite seam of gouge between ledge and country rock. These seams vary greatly in dip and strike and are apparently local slips between hard and soft material, not persistent faults traceable from level to level.

What may be called the Little Florence pay shoot, although it is not absolutely continuous, but rather a zone of rich bunches of ore, extends into the Rogers lease for about 75 feet, and has been stoped in places above the 409-foot and 309-foot levels. These bunches of shipping ore are small and occur where the ledge matter is cut by intersecting fissures which are clearly later than the primary silicification. The shoot as a whole is nearly vertical, and with its containing ledge matter ends irregularly near an east-west vertical plane passing through the shaft.

The second and more productive pay shoot is not so obviously a continuation of that known in the Little Florence. It was first cut about 275 feet west of the shaft on the 409 -foot level and near the Red King side line. The ore body, as shown by the stope in Plate IX, went very little above the level, but grew longer downward and on the 509-foot level had a stope length of 90 feet. It extends for at least 50 feet below the 509-foot level, but how much farther is not known. The grade is not as good on the sublevel as above. The width of the ore is not uniform, ranging from a few inches up to 4 or 5 feet. The general dip is between $45^{\circ}$ and $50^{\circ} \mathrm{E}$. Thus although on the 409-foot level this pay shoot appears to be separated from the Little Florence shoot, they must, if both persist, come together below the 509-foot level. There is probably at least some ledge matter joining the two.

The same zone of ledge matter that contains the main Rogers pay shoot continues into the $\mathrm{O}$. K. or Rosebud lease, where it has been explored northeast of the shaft. It appears as the blunt irregular end of a wide zone of sheeted, silicified, and afterwards brecciated andesite in much-disturbed soft rock, originally of the same kind. The best assays of this ledge matter, although the rich ore of the Rogers lease came almost to the dividing line between the two leases, do not give over $\$ 20$ per ton.

OTHER LEASES.

There are many other leases on the Florence in the vicinity of the Rogers and Engineers' leases, some of which, as the Pollard-Florence, have deep shafts and considerable lateral work, but no ore. Such geologic information as these workings afford has been referred to in the appropriate places. Description of each prospect in detail is unnecessary. North of the Florence shaft, also, there are a number of leases on the Cornishman claim, of which the workings are not shown in Plate IX. Most of these are on nearly vertical zones of sheeting and silicification in the dacite, with trends a few degrees west of north. Such for example is the Baby Florence, which has produced some ore from rich bunches in a ledge of this character. Considerable work has been done in this mine to a depth of 400 feet, but the ore thus far found is all above the 150-foot level. These ledges appear to occupy not very persistent zones of minor fissuring in the hanging wall of the main Florence ledge. 


\section{CHAPTER XX.}

\section{DETAILED DESCRIPTIONS OF THE LESSER MINES AND PROSPECTS OF THE GOLDFIELD GROUP.}

\section{SANDSTORM MINE.}

The Sandstorm claim, situated about 2 miles north of Goldfield, was staked on December 2, 1902, by Messrs. Stimler and Marsh, and according to popular tradition was the first mining location in the district. But although claims were probably first laid off in this vicinity there is some doubt whether the distinction of primacy belongs strictly to the Sandstorm. Other claims in the group owned by the Sandstorm Mining Company are the Kruger, Magnolia, and Stimler fraction. Efforts to find ore were at first unsuccessful, and it was not until December, 1904, that J. R. Davis, J. P. Loftus, and A. H. Mayne, lessees, found rich ore and began shipping. Some of the best ore from these leases (No. 5 and No. 6 blocks) has carried as much as $\$ 4,600$ per ton. The royalty paid was 30 per cent of the net value of the ore extracted. In 1905 the Sandstorm Mining Company began working No. 6 block. The total production from the Sandstorm mine to the end of that year has been locally estimated at about $\$ 250,000$. Very little work was in progress in 1908, and the following account is based mainly on what could be seen at the end of 1905 .

As is usual in mines worked in small blocks by lessees, the underground workings of the Sandstorm do not accord with any general plan of development. On No. 5 block, which was being worked by Messrs. Loftus, Davis, and Mayne in 1905, there is a shaft 130 feet deep, sunk on the dip of the ledge, which is $68^{\circ} \mathrm{E}$. No stoping had been done below the 50 -foot level in 1905. At 138 feet a crosscut has been driven through the ledge into the hanging-wall country. This shaft was being sunk to a depth of 250 feet in compliance with the terms of the lease. On the No. 6 block, which lies just south of No. 5, is a vertical shaft which was about 125 feet deep at the end of 1905. All stoping in this block at the time of first visit had been above the 50-foot level. A station had just been cut, however, for an 80-foot level, in which some rich ore was exposed. Above the 50-foot level short drifts and stopes have been run at various grades and levels wherever the ore led. In 1908 the main shaft was about 400 feet deep. Extensive exploration, however, on the 200-foot and 400-foot levels has revealed no ore, and these are for the present abandoned.

The upper Sandstorm workings are all in the Sandstorm rhyolite, and this was the only rock visible at the time of first visit. The main shaft, however, is said to go through this at a depth of about 200 feet into Kendall tuff, and a crosscut from this shaft southeast reaches alaskite.

The Sandstorm-Kendall ledge, shown in Plate XIII, $A$, outcrops boldly as a zone of strongly silicified rhyolite, 40 to 50 feet wide. The outcrop is of lodelike character and can be followed without difficulty for at least a quarter of a mile. Its strike is about N. $8^{\circ} \mathrm{W}$. Where crosscut on the 138-foot level in the Sandstorm mine its width is from 35 to 40 feet, but the workings are not yet extensive enough to afford much information concerning the size and shape of the ledge underground.

The material of the ledge differs from that of the dacitic ledges in containing comparatively little iron oxide; it is not conspicuously rusty. This difference is evidently due to the fact that the rhyolite before its conversion into ledge matter contained few ferromagnesian minerals, and 
consequently there was little iron in the rock to be converted into pyrite, such as by subsequent oxidation gives the rusty character of the ledges in dacite and andesite. In the typical Sandstorm ledge matter the rhyolite has been converted into dense cryptocrystalline quartz. This is full of small irregular cavities lined with crusts of tiny quartz crystals. Much of the material, in fact, has a decidedly spongy texture. Within this hard silicified rhyolite are irregular masses of softer kaolinitic and limonitic material, and it is in such softer portions of the ledge that the ore occurs.

Alunite is not so abundant in the Sandstorm ledge as in the mines nearer Goldfield. The microscope shows the hard silicified material to consist of finely granular quartz, which in some places contains microscopic disseminated crystals of pyrite. Much alunite, however, occurs in the altered rhyolite near the Sandstorm and Kendall mines, especially in some of the Morena rhyolite, which is cut in the bottom of the Kendall mine. It is not always easy to say whether this alunitic material should be called ledge or country rock.

The ore bodies of the Sandstorm consist entirely of oxidized material. The deepest ore found up to the end of 1905 was at 80 feet. This shows a little pyrite under the microscope, although the gold itself is associated with limonite and kaolin. Practically all the stoping had been done at depths of less than 50 feet. The pay shoots are irregularly distributed through the ledge zone and are usually associated with zones of transverse fissuring. The best defined of these fissures runs east and west and on the whole is nearly vertical, although the dip is not uniform. It crosses the Sandstorm lode 30 or 40 feet north of the No. 6 shaft and is apparently of later origin than the metamorphism which produced the ledge. It varies from a few inches to 3 feet in width and is filled with triturated material. Some of the fragments have been rounded to pebbles by movement along the fissure. Some ore occurs in the fissure, but the principal masses extend out from it into the ledge matter. As a rule these bunches are very irregular in form, but most of them appear to rest upon an uneven although generally nearly horizontal floor of hard silicified rhyolite. This floor is apparently barren and exhibits no particular mineralization, although it, like most of the unoxidized ledge matter, contains a little very finely disseminated pyrite. There is apparently no gradation from the rich oxidized ore into this hard underlying material. Some of the pay shoots extend from this floor up to the surface as irregular pipes or chimneys; others rest upon it as flat-lying masses and are overlain by barren or low-grade ledge matter.

As already mentioned, all the ore thus far found in the Sandstorm mine is oxidized. It consists usually of a rather soft earthy mixture of kaolinite, quartz, limonite, and free gold, the latter in some of the richest lumps of ore constituting a considerable part of the mass, through which it is disseminated in small particles. Singly these are barely visible with the naked eye, but their abundance in some cases gives a yellow tint to the ore. Crystals of barite are fairly common. They are generally implanted upon the surfaces of the hard silicified rhyolite and project into the softer and richer material of the ore, which fills crevices in the rhyolite or envelops loose fragments of that rock. Some of the ore contains pearly scales of bismite, indicative of the former presence of bismuthinite.

Some of the oxidized ore shows slight copper stains, and Mr. C. D. Wilkinson reports that he has seen a little chalcopyrite in the main cross fissure. It is probable that some famatinite, or possibly goldfieldite, accompanied the bismuthinite in the sulphide ore, as in the mines near Goldfield. The best ore shipped from the Sandstorm prior to 1906 is said to have carried about $\$ 4,600$ (230 ounces) in gold to the ton.

It is probable that the Sandstorm ore bodies were originally masses of sulphide ore with very nearly their present shape-that is, they were comparatively small, rich bunches surrounded by ledge matter and having no direct downward continuation. The original ore presumably contained pyrite, free gold, bismuthinite, and some cupriferous sulphur-bearing mineral. Oxidation of the known ore bodies has been practically complete, and in the course of that oxidation there has probably been some secondary concentration of the gold. 


\section{KENDALL MINE.}

The Kendall claim adjoins the Sandstorm on the north and, with the Argosy and Oregon claims, is the property of the Goldfield Kendall Mining Company. The principal workings are on the Kendall claim and on the same ledge as those of the Sandstorm. The mine was first worked by lessees, but was being operated by the company in 1905 . The total production to the end of that year was about $\$ 100,000$. Little work has been done on the Kendall of late years, and the following description applies to the mine as it was in 1905.

The main shaft of the Kendall mine is vertical, and at the end of 1905 was about 200 feet deep, with levels at 60 and 100 feet. Sinking was then in progress. Above the 60 -foot level are some small tunnels and some irregular stopes and drifts. All the stoping at the time of visit had been done between the 60 -foot level and the surface.

The Kendall shaft is sunk in Sandstorm rhyolite, which, as shown in Plate II, here forms a narrow strip between an area of Kendall tuff on the west and the Milltown andesite on the

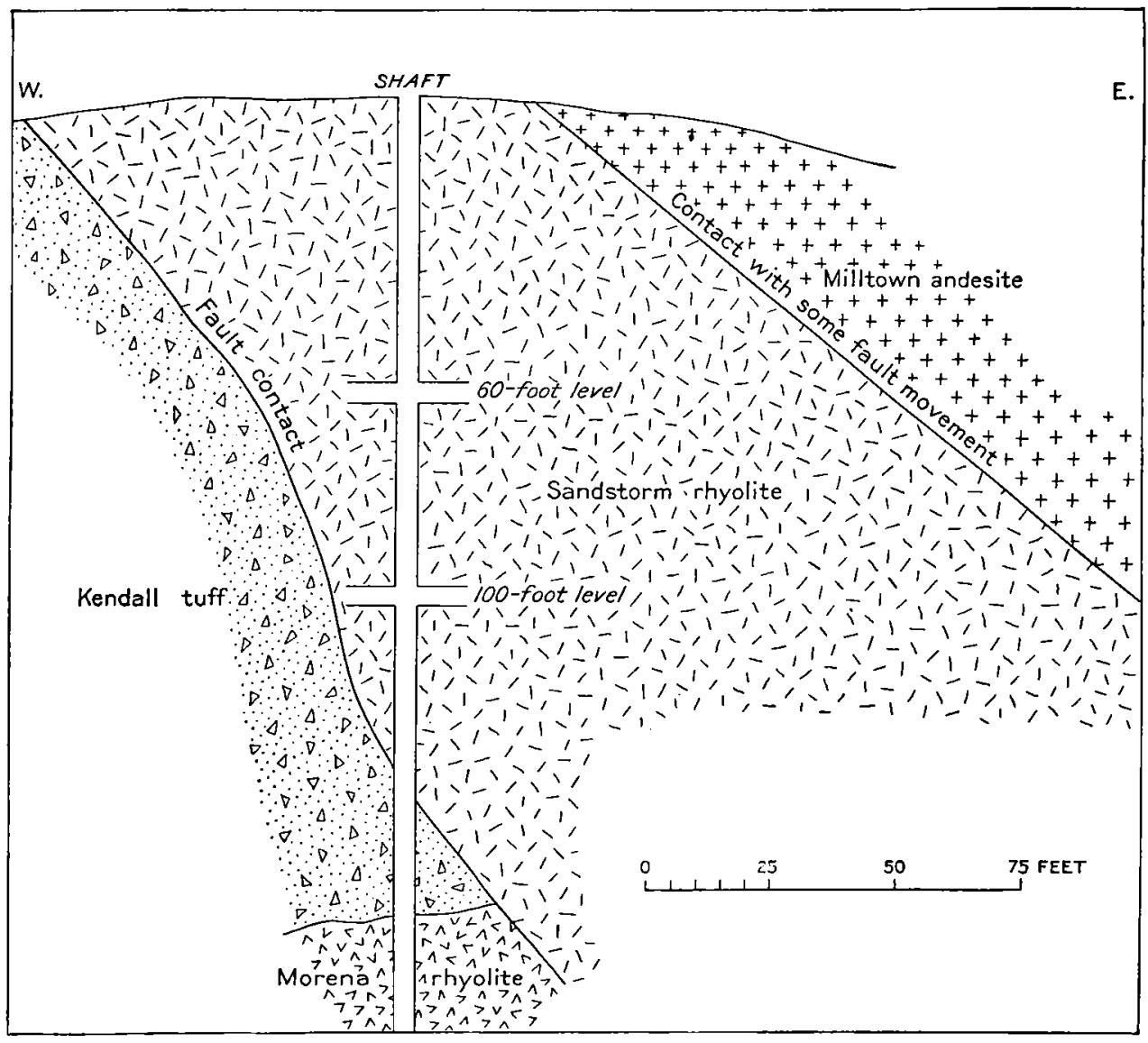

FIGURE 29.-Section through the Kendali mine.

east. At a depth of about 135 feet the shaft passed into this tuff and continued in it for about 20 feet. It then passed into rhyolite of the intrusive Morena type, and continued in this rock to the bottom. The exact thickness of the tuff where it is penetrated by the shaft is not measurable, as the lagging of the shaft conceals the contacts. The general relation of these rocks is shown in section in figure 29 .

The tuff, as exposed at the surface, appears to pass beneath the Sandstorm rhyolite on the north, west, and south, but to be cut off on the east by a fault. (See Pl. II.) This fault is well exposed on the 60 -foot level, about 27 feet west of the shaft. There is not much brecciation of either rock, but the plane of movement is marked by a distinct gouge. The fault plane at this place dips about $40^{\circ} \mathrm{E}$. It truncates the flow banding of the rhyolite, which dips about 
$25^{\circ} \mathrm{W}$. The tuff probably rests upon Morena rhyolite about 150 feet below the surface. This rhyolite is doubtless intrusive into the tuff, but the contact has not been exposed except in the shaft.

On the 100-foot level a crosscut has been driven east through the Sandstorm rhyolite into the andesite, as shown in figure 29. The contact lies about 135 feet east of the shaft on this level, and appears to be the result of faulting. The andesite is soft and altered and is either' tuffaceous or has been brecciated by movement. The faulting is probably local and is thought to represent minor displacement along a contact which originally was a rhyolitic surface over which the andesite flowed.

This same plane of movement, which dips about $35^{\circ} \mathrm{E}$., is exposed in a tunnel just north of the main Kendall shaft. Near the mouth of this tunnel a shaft goes down through about 95 feet of andesite to the same contact. This shaft was not in good condition in 1905, but the dump indicated the presence of soft gougelike material at the base of the andesite and showed considerable pyritization of this rock in its lower part.

The Kendall ledge is the same as that of the Sandstorm mine. It is an indefinitely bounded zone of silicification in the effusive rhyolite. It was doubtful at the time of visit whether the ledge could be recognized at all below the point where the shaft enters tuff. The rhyolite in the bottom of the shaft contained much alunite, but this kind of alteration is so widespread in the Morena rhyolite as to be practically useless as a means of distinguishing typical ledge matter from country rock.

At the time of visit, near the end of 1905 , no ore had been found below the 60 -foot level. Considerable rich ore was found by lessees at the surface, pockets of soft auriferous material having been gouged out from the hard, low-grade, siliceous part of the croppings. Subsequently ore was found, much as in the Sandstorm, in the form of small irregular bunches very erratically distributed through the ledge. The dependence of these rich bunches, however, upon transverse fissures was clearly shown, these fissures, which are neither regular nor persistent, having generally northwest-southeast trends.

The ore is entirely oxidized and no sulphide ore has yet been discovered beneath it. It is usually a soft mixture of kaolinite, quartz, limonite, and native gold, with abundant barite in crystals up to an inch or more in length. As in the Sandstorm mine, the barite crystals are usually implanted on silicified rhyolite with their free ends embedded in kaolinite or kaolinitic ore. No alunite has been noted in the Kendall ore, although this mineral is abundant in the bottom of the shaft.

\section{CONQUEROR MINE.}

The Conqueror or Tonopah Club mine embraces the Tonopah Club and Bonanza claims, owned by the Conqueror Mining Company. The principal workings lie about half a mile eastnortheast of the Kendall mine. Ore to the value of a few thousand dollars was obtained near the surface in 1904 and 1905, but the property has not since been an important producer. No work was in progress in 1908.

The principal workings (1905) are an incline about 100 feet in length run on an angle of $20^{\circ}$ to $25^{\circ}$, and a vertical shaft about 50 feet in depth, with a crosscut from the bottom. All the stoping has been within 10 or 15 feet of the surface.

The geologic relations at the Conqueror mine are more complex than in most of the mines in the district. At the surface is exposed an oval area of Morena rhyolite. This is intrusive into Sandstorm rhyolite, which here has a most deceptive similitude to a gray shale. Just east of the mine openings and dividing Sandstorm rhyolite on the west from andesite on the east is the line of the Columbia Mountain fault. This fault dips to the east at a low angle (see fig. 3) and is followed by the inclined shaft previously mentioned. A well-marked zone of silicification or ledge, having a course of a few degrees east of north, traverses the oval area of Morena rhyolite. The ore has been found, not in this ledge, but between its southern end and the andesite to the east. 
The mine workings show shaly Sandstorm rhyolite irregularly intruded by Morena rhyolite. All the ore thus far found was in the shaly masses of the older effusive rhyolite. The Columbia Mountain fault, as shown by the incline shaft, contains much-crushed shaly rhyolite, much of it reduced to a tough, claylike gouge. This soft material is full of small crystals of pyrite and is said to afford assay values up to $\$ 12$ per ton.

\section{ADAMS MINE.}

The Adams mine, which, like the Conqueror mine, has furnished a little ore from surface workings, closely resembles the latter in geologic relations. It is situated rather less than half a mile east of the Sandstorm. The country rock is Sandstorm rhyolite, which is underlain and irregularly intruded by Morena rhyolite, which comes to the surface just south of the mine, as shown in Plate II. The Adams, like the Conqueror, is close to the Columbia Mountain fault, but the workings had not extended to the andesite in 1905 . The effusive or Sandstorm rhyolite is much disturbed and altered, but exhibits comparatively little mineralization. None of the irregular workings had attained a depth of 100 feet in 1905 . In 1908 the mine was idle and was not again examined.

\section{KEWANAS MINE.}

The Kewanas mine is situated about $1 \frac{1}{4}$ miles northeast of the center of Goldfield and three-eighths of a mile south of the Nevada-California Power Company's transformer station. The country rock near the surface is dacite. The workings comprise an inclined shaft ${ }^{a}$ which goes down to the east for a distance of 500 feet at an angle of $45^{\circ}$. There are levels at 100,200 , 400 , and 500 feet from the collar.

The rock of the mine is generally much altered, partly to ledge matter, but more extensively to soft decomposed material which soon caves when a drift is abandoned, and which, as a rule, is difficult to identify petrographically. At the 200-foot level the shaft is in decomposed andesite or andesitic tuff, but the general country rock in the drifts which extend north and south for a total distance of about 250 feet is dacite. The relation between the two rocks is nowhere clearly shown. On the 400-foot level the main country rock is soft altered latite, but here and there in the level, which explores the ground for a distance of about 400 feet from north to south and 300 feet from east to west, are ill-defined masses of fine-grained decomposed andesite, and in a few places some dacite. The 500-foot level is chiefly in latite, which is either silicified to ledge matter carrying some pyrite or else is in a soft, gougelike condition.

The conditions for geologic study in this mine render it impossible to determine the structural relations of the much-altered rocks therein exposed. Probably the observed masses of andesite and dacite are in part dikes in the latite. The soft, risturbed character of the ground, moreover, suggests the possibility of considerable faulting, which can not be worked out from present exposures. As noted on page 53, some of the shafts just north of the Kewanas go through dacite into andesite breccia cf considerable thickness. Evidently the Milltown andesite underlying the dacite in this vicinity is not uniform in character, and this adds to the difficulty of interpreting what may be seen underground.

The Kewanas mine has shipped no ore and is essentially a prospect.

\section{GOLDFIELD MERGER MINES COMPANY'S MINES.}

\section{INTRODTCTION.}

In June, 1908, the St. Ives, Velvet, Gold Horn, and Potlatch mining companies consolidated their buildings under the title of the Goldfield Merger Mines Company, capitalized at $\$ 5,000,000$. At the time of consolidation the St. Ives and Velvet mines had small productions to their credit, mainly from the workings of lessees. Recently the company has sunk a new shaft from which to explore its ground. 
ST. IVES MINE.

The St. Ives mine is situated a little more than a mile east-northeast of Goldfield, and half a mile north of Milltown. The property was worked by lessees in 1904, and the results of their operations are summarized in the following statement, which is of interest as illustrating the conditions under which ore was marketed in the early days of the camp.

Operations in St. Ives mine, $190 ;.$

\begin{tabular}{|c|c|}
\hline Gross weight of ore shipped........ & 49. 34 \\
\hline Net weight of ore shipped..... & 47.87 \\
\hline 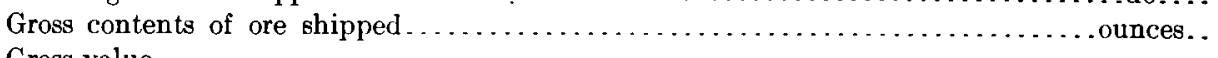 & 535.7 \\
\hline 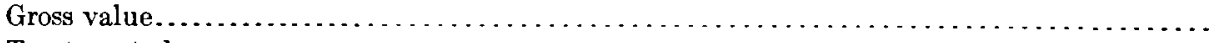 & $\$ 10,683.22$ \\
\hline Treatment charges.................. & \\
\hline Loss in smelting, $2 \frac{1}{2}$ per cent . . . . . . & \\
\hline Freight. . . . . . . . . . . . . . & \\
\hline Agent's charges...... & \\
\hline 6.00 & \\
\hline Exchange on draft.. & \\
\hline & 1,661. 79 \\
\hline Tota & $9,021.43$ \\
\hline 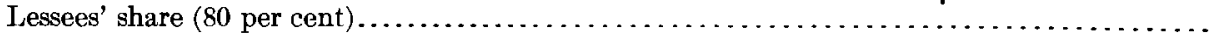 & $7,217.15$ \\
\hline ompany's & $1,804.2$ \\
\hline
\end{tabular}

The gross value of the ore per ton was $\$ 223.14$ and the net value $\$ 150.74$.

In February, 1905, the first lease expired, and the company began operations on its own account. The ore shipped by lessees was stoped between the 100-foot level and the surface, most of it coming from near the 50-foot level.

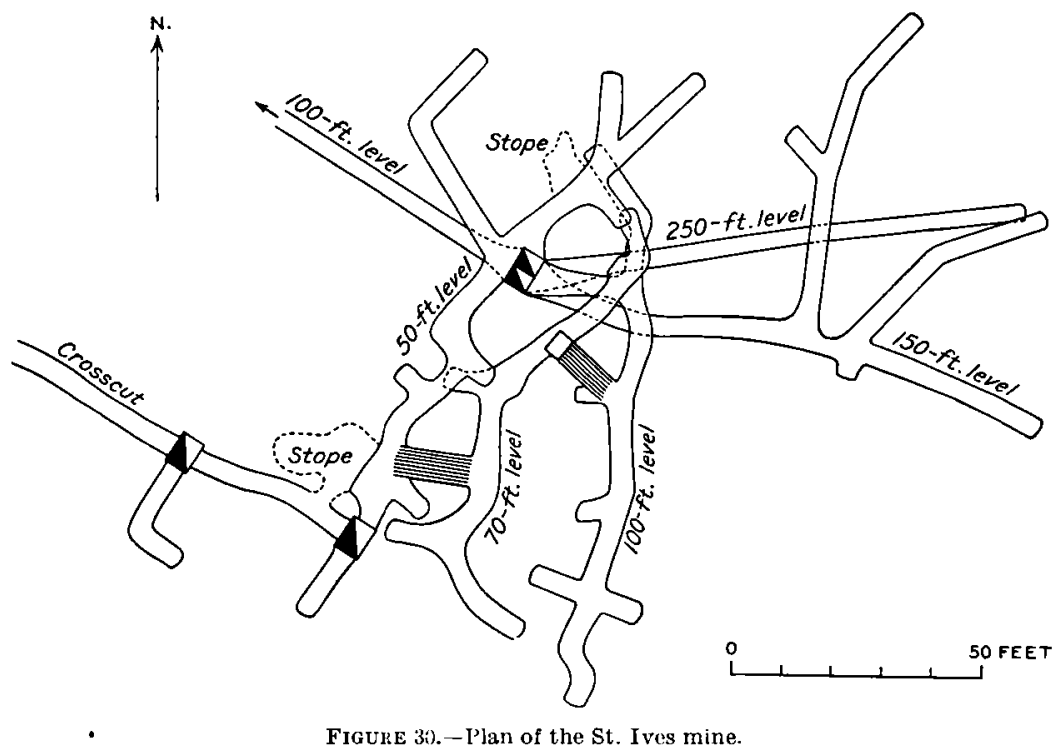

When visited late in 1905 , the workings comprised a vertical shaft 250 feet deep, with levels at 50 , 100,150 , and 250 feet. These are shown in plan in figure 30. No work was in progress in 1908 and the mine was not revisited.

The St. Ives ledge, which is in dacite, outcrops boldly, forming the crest of a small north-south ridge, as may be seen from Plate II. It has many branches and is part of a complex chain of ledges extending southeastward past Milltown to the Gold Bar mine. The main ledge at the St.

Ives mine strikes north-northeast, but the shaft is sunk at a point near which branches run out to the east-northeast and to the northwest, as shown on Plate II. Most of the 50-foot level (fig. 30) is in ledge matter, all more or less rusty from oxidation. The general trend of the siliceous zone on this level is northeast. The 70 -foot and 100 -foot levels are also almost wholly in oxidized ledge matter. The 70-foot shows nearly the same strike as the 50 -foot, but on the 100-foot level the trend of the ledge becomes almost due north and south. In other words, the dip of the ledge in the southern part of the workings is about $45^{\circ}$, while in the northern part it is nearly vertical. On the 150 -foot level, which is below the limit of oxidation, the ledge is 
very obscure. Beginning at a point about 30 feet east of the shaft the dacite for a distance of 50 feet shows irregular bunches and streaks of partially silicified material alternating with soft pyritized and alunitized dacite. In some places the dacite has been shattered and contains considerable pyrite and alunite, such material having the characteristics of unoxidized ledge matter. On the 250-foot level the ledge is still more obscure. A crosscut east from the shaft was about 100 feet in length at the time of visit. This showed soft pyritized alunitized dacite, with slight silicification along some of the fissures. The highest value obtained by assay from any of the material on this level did not exceed $\$ 5$ a ton. On the whole the St. Ires mine illustrates well the fact of a decrease in silicification with increase in depth.

The ore bodies stoped in the St. Ives mine were mainly near the 50 -foot level and were oxidized. They were irregular in outline and of small size. The largest body (see fig. 30) was about 50 feet south of the main shaft. It extended about 20 feet, on the dip, above the 50 -foot level and for a short distance down the winze to the 70 -foot level.

CODD LEASE.

The Codd lease is on the St. Ives ground and is worked through a shaft 500 feet deep, situated a short distance west of the St. Ives shaft. The upper levels are in dacite, but somewhere between 350 and 400 feet in depth the shaft goes into latite. Oxidized ore of a gross value of about $\$ 11,000$ was mined in 1907 from small irregular pay shoots in the dacite above the 50-foot level. The ore trends nearly north and south and dips west. The total length of the stopes is about 100 feet. As in the St. Ives proper, the deeper levels have not proved encouraging.

VELVET MINE.

In 1904 a bunch of oxidized ore found practically at the surface yielded lessees about $\$ 10,000$. Since then a number of shafts have been sunk near the original discovery, about half a mile northeast of Goldfield. Two of these, the Alta shaft, 418 feet deep, and the ChicagoVelvet shaft, 526 feet deep, were in operation in 1908. The geologic features of these workings are referred to on page 81 . They are not in ore.

\section{JUMBO-EXTENSION MINING COMPANY'S GOLD WEDGE CLAIM.}

The Gold Wedge, as may be seen from Plate IX, is a fractional claim lying on the northeast side of the Mohawk No. 2 claim. On it is a line of lessees' shafts, which from north to south are the Jumbo Annex, Higginson, Mohawk Ledge, Frances-Mohawk, and MohawkJumbo shafts. At the time of second visit to the district, in 1908, these workings were all closed by injunction and were not examined. The dumps showed that all the shafts at that time were wholly in the dacite. Lease blocks in the Goldfield district are bounded by vertical planes, and consequently the lessees on the northern part of the Gold Wedge are confined within narrow limits. In the Mohawk-Jumbo workings, however, at the south end of the claim, large stopes have been opened on the same pay shoots that are stoped at higher levels in the Mohawk mine. (See Pl. IX.) This shaft at last report was 685 feet deep, making it one of the deepest in the district. The settlement finally reached between the Goldfield Consolidated Mines Company and the Jumbo Extension Company over the Gold Wedge claim is described on page 23 .

\section{COMBINATION FRACTION MINES.}

The Combination Fraction Mining Company owns a nearly square fractional claim between the ends of the Mohawk No. 2 and Florence claims, and northeast of the Combination mine. In it are 5 sets of workings. In the south corner is the company's shaft, with extensive exploratory levels down to 431 feet in depth. (See Pl. IX.) These workings were closed in 1908 and were not studied. They are probably all in dacite and the ground is said to be generally soft and disturbed. No ore has been found. In the northwest corner of the claim is the Burns

$79145-N_{0} .66-09-16$ 
shaft. The ground here also is soft and the drifts soon close. Northeast of the Burns shaft is the Loftus-Davis lease shaft. From this stopes were opened on the Mohawk ledge in 1906 and 1907. This shaft had been dismantled in 1908, although it was possible to enter the stopes from the Mohawk workings. The 531-foot level (Pl. IX) is reported to follow a nearly vertical fault which is supposed to cut and displace the Mohawk ledge. This level could not be reached in 1908. The displacement is certainly not great, as a short distance north the ledge has been found generally continuous down to the 600-foot level of the Mohawk.

East of the Loftus-Davis shaft is the Oddlie shaft, originally sunk by lessees, but now being operated by the company. Its depth is 612 feet. It was sunk without any lateral exploration above the bottom level, with the expectation that the Mohawk ledge would be cut at a depth of about 600 feet. Subsequent work in the Mohawk mine shows that this expectation was justified, but the lessees failed to find ore. A part only of the 612-foot level was accessible in 1908. It is apparently mostly in latite, the contact, which locally at least seems to be a fault with steep dip to the east, being a few feet west of the shaft. The rock in the vicinity of the contact is soft and decomposed. A part of the latite on this level is distinctly a pyroclastic rock.

The 427-foot level shows a north-south dacite ledge with easterly dip. The width of this had not been determined at the time of visit.

The principal work in progress in 1908 was on the 285 -foot level, where ore in dacite, very similar in character to some of the lower-grade Hayes-Monnette ore, had been opened in two places. Dacite is the only rock on this level. Too little work had been accomplished at the time of visit to reveal the size or shape of the ore body, which is probably an irregular mass in the hanging wall of the main Mohawk ledge.

About 250 feet southeast of the Oddie shaft is the shaft of the Little Florence Leasing Company. At the time of visit no ore had been found in these workings, which are in dacite.

\section{ATLANTA GROUP.}

The Atlanta group includes the Atlanta Union, Black Bear, and Bismark claims and lies directly east of the Florence-Goldfield Mining Company's ground. The Atlanta Company has done comparatively little development, but the property has been most persistently explored by lessees, with very little encouragement. Among the shafts on this ground, most of them ranging from 300 to 500 feet in depth, are the Jumbo ledge, Blake, Maloney, Chedd, Lucky Swede, Century, Imperial, Atlanta-Cherokee, and Garrison. The lateral development from most of these shafts is small.

\section{GOLD BAR AND VICTOR MINES.}

The Gold Bar and Victor mines of the C. O. D. Consolidated Mining Company lie southeast of the Atlanta group. (See Pl. X.) The main company shaft is the Gold Bar, 300 feet deep. About 400 feet east-southeast of this is the Victor shaft, operated by lessees, and about the same distance in the opposite direction is the C. O. D. shaft, no longer in use. These three shafts are connected by the 200 -foot Gold Bar level, as shown in figure 31 .

The country rock in the upper level is the Milltown andesite, but the 300 -foot level and a large part of the 200-foot level east of the shaft are apparently in latite, although the rock is too much altered for satisfactory identification. Dacite appears at several points on the 200foot level, probably as intrusive tongues in the latite and andesite. In spite of the prevailing alteration this intrusive character of the dacite is well shown at one place on the south side of the main west drift of the 200 -foot level. Both rocks are soft and greatly altered, but the original irregular contact does not appear to have been disturbed.

A large part of the workings are in ledge matter. While this is largely altered andesite and partly latite, there is a rather close association between ledge matter and dacite. The latter penetrated in ragged protrusions into the older rocks, and the subsequent silicification and mineralization have taken place chiefly in the vicinity of these intruded masses. 
Shipments aggregating about $\$ 25,000$ in gross value have been made from time to time from a chain of very irregular bunches of ore extending eastward from near the Gold Bar shaft down to the 200-foot (250-foot Victor) level near the Victor shaft, and some ore was produced from a body of oxidized ore near the surface at the C. O. D. shaft. The unoxidized ore is characterized by an abundance of a dark-gray brittle mineral, which resembles the famatinite of the Florence and other mines near Goldfield. Like that mineral, it contains copper, sulphur, and antimony, and forms crusts around partly rounded fragments of silicified andesite or dacite. It has not the reddish tint of the famatinite, however, and unlike that mineral elsewhere in the district is not associated with particularly rich ore. It is possibly enargite. As pointed out on page 117, the distinction between enargite and famatinite is impossible without quantitative chemical analysis of pure material or the presence of satisfactory crystal form.

The Kansas City lease, northwest of the C. O. D. shaft, is not in ore and was not examined.

North of the Gold Bar shaft is the shaft of the Gold Bar Leasing Company, 475 feet deep at the time of visit, but not in ore. The country rock is all Milltown andesite. The workings

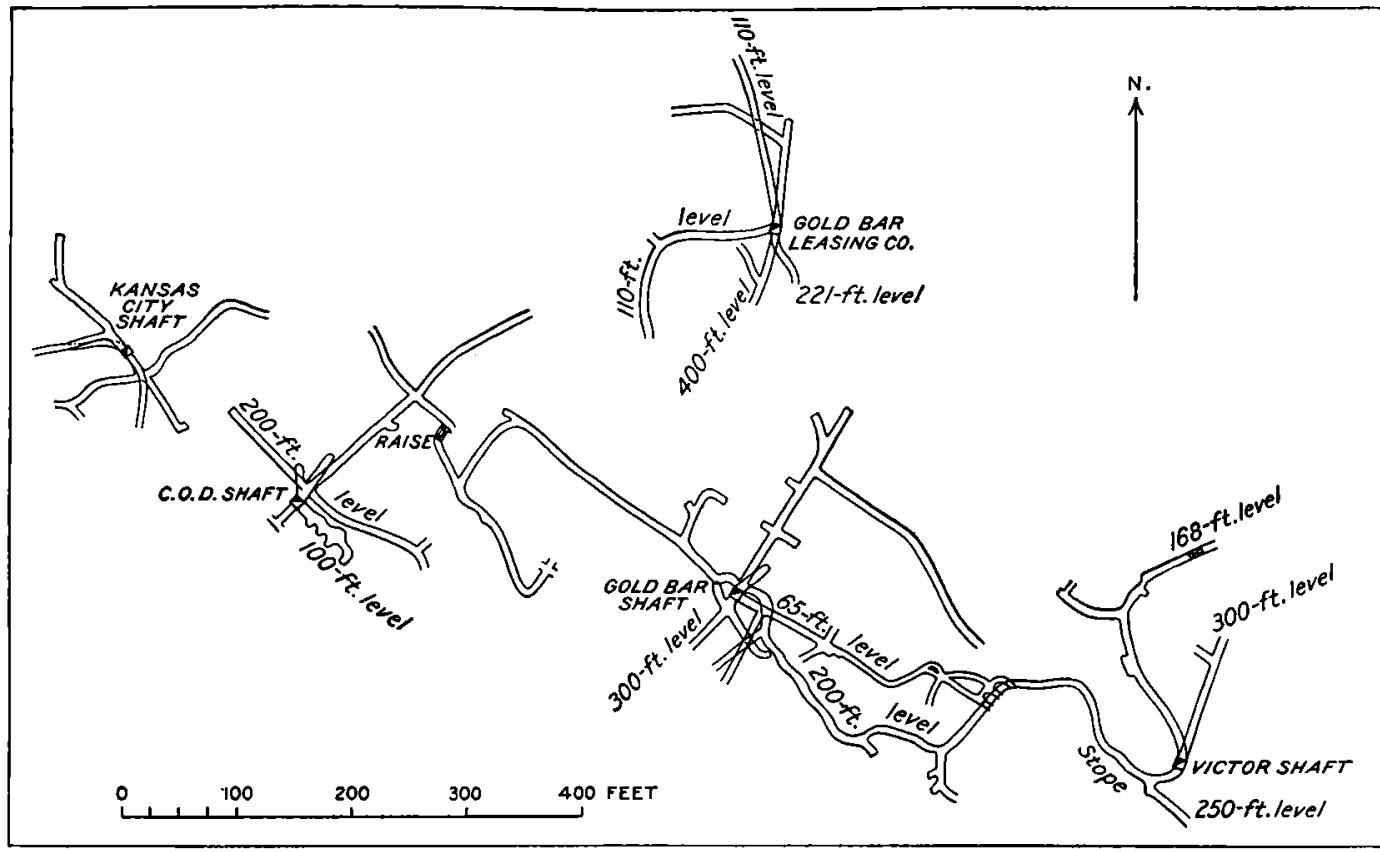

Figure 31.-Plan of the Gold Bar and Victor mines.

show irregular masses of ledge matter with abundant pyrite, partly disseminated and partly as crumbling stringers. The best assay obtained prior to the time of visit was $\$ 1.80$.

\section{BLUE BULL MINE.}

The Blue Bull Mining Company owns about 7 claims, lying in a compact group about 13 miles east of Goldfield. On the Blue Bull claim, which is the northeast member of the group, the company has sunk a shaft 110 feet deep, and has crosscut from the bottom of this for about 400 feet, under some bold lerge outcrops which crown the hill just east of the shaft. The dacite penetrated by this crosscut is cut by two sets of conjugate fissures with a common northeast strike. One set dips northwest at various angles up to $60^{\circ}$; the other dips southeast at rather lower angles. The fissures with northwest dip are generally the stronger, and considerable silicification has taken place along them. The great east-west ledge which outcrops on the ridge east of the shaft (see Pl. II) had not been satisfactorily exposed in the crosscut at the time of visit. It appears to correspond to a series of east-west fissures, concerning which the mine workings as yet afford very little information. This ledge has been crosscut by a tunnel 
near the crest of the ridge, where it proved to be about 25 feet wide. A small bunch of ore was found in shattered kaolinized dacite, about 50 feet from the surface, on the south side of the siliceous ledge, but the Blue Bull mine has never made any shipments. This shaft had been abandoned in 1908, and a new shaft, which was not visited, had been sunk about 800 feet south of the old one.

On the Hat claim, which is at the south end of the Blue Bull group, lessees at the end of 1905 had taken out a little oxidized ore from workings about 50 feet in depth. Additional work has since been done on this lease, but the shaft, like others in the vicinity, was closed at the time of second visit. The country rock here is the Milltown andesite, and the ore as seen in 1905 occurred in a prominent ledge containing abundant red oxide of iron. The character of the ore is described on page 124 .

\section{SIMMERONE MINE.}

The Simmerone is situated about 2 miles east of Goldfield, near the eastern border of the central dacite area. The mine was not producing in 1905, although a small bunch of rich ore had previously been stoped from near the surface, yielding about $\$ 5,000$ gross.

The mine in 1905 had a vertical shaft 50 feet deep and a $44^{\circ}$ incline about 110 feet in length. The country rock, which is dacite, is traversed by many fissures, which in general strike north and dip $45^{\circ} \mathrm{W}$. These give the rock a pronounced sheeted structure, and along some of them considerable silicification has taken place.

The body of ore stoped was found in the incline and extended to a depth of 60 feet. It was an irregular pipe of small horizontal section. The ore is a firm fine-grained material, much of which is pink or light red, irregularly streaked with gray. This material is chiefly alunite, mixed with kaolinite and iron oxide. The gold is distributed unevenly in small hackly particles through the impure alunite.

Since the first visit a new shaft has been sunk, which goes through the clacite into the latite. The shaft was not in operation in 1908 and no information regarding it could be obtained.

\section{LONE STAR GROUP.}

The Lone Star mine is about 2 miles east of Goldfield, just north of the ridge on which are the Blue Bull, Simmerone, and Commonwealth workings. The total gross production to the end of 1905 was approximately $\$ 10,000$, from ore mined by lessees who expended about $\$ 15,000$ on the property. So far as known there has been no subsequent output.

The Lone Star ledge, shown in Plate XIV, $B$, outcrops boldly, the exposed part consisting of strongly silicified dacite sheeted by closely spaced north-south fissures. This zone of sheeting and silicification is at least 50 feet wide at the surface. The ledge strikes a few degrees east of north and dips $60^{\circ} \mathrm{E}$.

An inclined shaft has been sunk by lessees on the foot-wall side of the ledge and levels run at 80,150 , and 220 feet below the surface. The principal ore body was followed from the 80-foot level to a point about 20 feet below the 150 -foot level. The maximum stope length of the shoot was 20 feet and the greatest width of ore 5 feet. The shoot was accordingly of pipe form. The ore all showed some oxidation and apparently consisted of iron-stained alunite, with probably some kaolinite, carrying native gold. A specimen taken from the bottom of a winze below the 150-foot level, at the point where the ore shoot ends, is a rather sandy aggregate in which the constituents are chiefly rough, doubly-terminated, microscopic crystals of quartz. The average value of the ore shipped, according to the lessees, was $\$ 290$ a ton.

Alunite is abundant in the Lone Star ledge and in some places forms soft, snow-white or faintly pink masses, with practically no impurities.

The holdings of the Lone Star Mining Company cover an extensive area and embrace about 16 claims. The principal company workings are on the Patrick claim, west of the lessee workings just described. The shaft is only 100 feet deep, but the drifts and crosscuts at this depth are unusually extensive. They have revealed no ore. The rock is generally much altered and shows considerable disturbance. The bottom of the shaft is just in latite, the 
contact with the overlying dacite as seen in the 100 -foot station being nearly horizontal. Elsewhere in the workings dacite appears to cut both latite and andesite, but the information afforded by the exposures is nowhere definite. The general relations of the rocks are similar to those observed in the Kewanas workings, although the thickness of the dacite is much less at the Lone Star shaft.

\section{COMMONWEALTH MINE.}

For the past three or four years lessees have been shipping small lots of ore from superficial workings on the north slope of the ridge east of the Blue Bull and Simmerone mines. This locality, as may be seen from Plate II, is near the eastern edge of the main dacite sheet, and with the exception of the Diamondfield mines is the farthest point east at which any important quantity of ore has been found in this ditrict. The ore thus far mined is all oxidized and occurs in the usual irregular masses in dacitic ledge matter. Below the tunnels from which the ore has been stoped the Commonwealth shaft has been sunk to a depth of 400 feet. The shaft apparently goes into latite somewhere above the 100-foot level, but the exact depth of the change could not be ascertained, owing to the close lagging of the shaft. The shaft was not in operation in 1908, and the water stood at the 300 -foot station. So far as could be ascertained no ore was found in these workings.

\section{PORTLAND MINE.}

The Portland mine is situated about a mile east-southeast of the center of Goldfield and a little less than half a mile south of the Florence mine. It has never shipped any ore. The principal development in 1905 was on the bottom level, 250 feet below the surface. Since then a level has been run at a depth of 400 feet, but none of the lateral work was visible in 1908 owing to the caving of the soft heavy ground. An attempt to put down a diamonddrill hole below this level was abandoned before the bottom of the latite had been reached.

The geologic features in this mine are especially interesting. As may be seen in Plate II, the Portland shaft is sunk through a small lobe of the Siebert formation, which apparently rests on andesite. It is not known at what depth the shaft passed out of the Siebert sediments, but it was probably very close to the surface. From the collar of the shaft to the 250foot level there was no point at which the rocks could be satisfactorily examined in 1905 . From the bottom of the shaft a crosscut has been driven for about 350 feet to the east. From all that was previously known of the structure of this part of the district it was to be expected that the rock in this crosscut would be andesite. It consists, however, of amygdaloidal olivine basalt flows with basaltic tuffs. In general these are soft and much altered and contain much disseminated pyrite. The depth at which these rocks occur appears to rule out any attempt to correlate them with the quartz basalt exposed south of Goldfield or with the later olivine basalt capping Myers Mountain. The most probable hypothesis is that they represent local basaltic eruptions within or immediately preceding the andesite period.

The dump of the mine shows that at some point between the 250-foot and 400-foot levels the shaft went into latite and continued in this rock to the bottom. As a whole the rock of the Portland mine is soft, much of it being little firmer than mud.

The Portland was for some years the only. deep shaft south of Florence Hill. Recently a number of prospecting shafts, some of which exceed it in depth, have been sunk in its vicinity. These all go through andesite into latite at a depth of about 300 feet.

\section{OTHER PROSPECTS.}

The White Rock, Silver Pick, and numerous other companies owning claims in the vicinity of Goldfield have prospected their ground fully as extensively or even more so than some of those mentioned in the preceding descriptions. To describe in detail all these workings would add to the bulk of this report without increasing its interest or usefulness. Such geological information as is furnished by these various shafts has been incorporated in earlier chapters. 


\section{CHAPTER XXI.}

\section{DETAILED DESCRIPTIONS OF MINES OF THE DIAMONDFIELD GROUP. DIAMONDFIELD-BLACK BUTTE CONSOLIDATED MINES.}

The Quartzite and Black Butte mines, with workings mainly on the north side of Black Butte, were consolidated as the Diamondfield-Black Butte Consolidated Mines in 1905. Prior to that a considerable body of ore had been stoped by lessees, mainly from the original Quartzite ground.

A plan of the combined workings is shown in figure 32. The Quartzite shaft is about 200 feet deep, with four levels 50 feet apart. The Black Butte shaft is 150 feet deep, with three

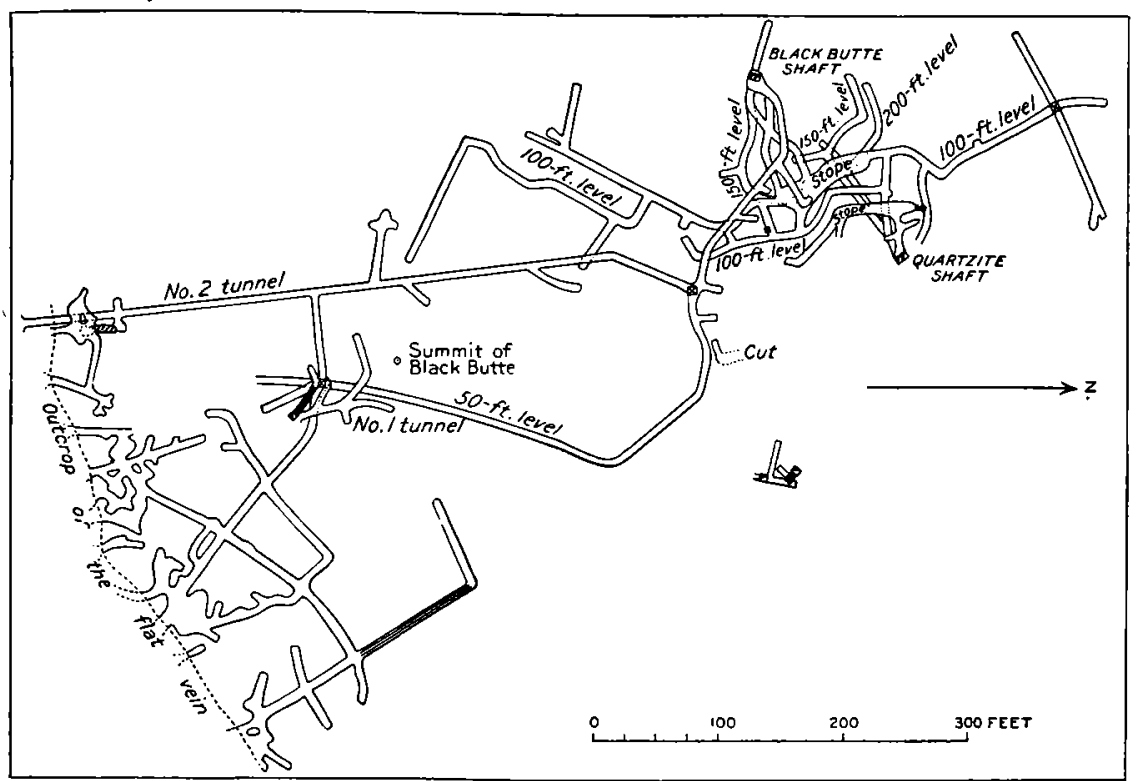

Figure 32.-Plan of the workings of the Black Butte mine. levels, which are about 10 feet below the corresponding Quartzite levels. A tunnel $\mathbf{5 4 5}$ feet in length penetrates Black Butte from the south and connects through a 25-foot winze with the 50-foot level of the Black Butte workings. East of the portal of this tunnel is a ehain of nearly horizontal stopes on a flat vein.

The general country rock of the mine is andesite, which is cut by a few ill-defined masses of dacite. Both rocks are in most places pyritized and rather soft,

containing much gypsum in gouge seams and in all the joints and crevices. Fissuring in nearly horizontal planes is a notable feature of the country rock and has resulted in the formation of sheets of brecciated and more or less silicified material. The massive ledge which caps Black Butte (see Pl. III, $B$ ) is clearly a remnant of such a sheet, since the tunnel passes directly under it. Similar but smaller silicified sheets are exposed in the tunnel, and, as may be seen from figure 14 , these may be very irregular. In some places the horizontal fissuring has produced a sheeted instead of a brecciated structure. Such in the main is the flat vein stoped along the south side of the butte. As a rule, most of these horizontal ledges contain a little ore, but it is very bunchy and erratic in its occurrence. The ledges themselves, moreover, are apparently not very persistent.

The ore body stoped by the lessees on the north side of the butte was a very irregular but generally lenticular mass, with north-south trend and a dip to the west, the lens being nearly on edge. Its maximum stope length was about 100 feet and its greatest width about 25 feet. In its widest part the ore was divided longitudinally by a slab of waste or low-grade ore. The extreme vertical range of the ore was about 100 feet, its bottom limit being near the 100 -foot level. It became poorer and narrower close to the surface. On the north the ore ended against 
a seam of gouge. At the bottom it graded into soft barren andesite. All of the ore appears to have been partly oxidized, the bottom of the pay shoot coinciding roughly with the lower limit of oxidation. The best part of the ore was between the 50-foot and 100-foot levels.

The ore, as shown by the little left in the stope, was a much-shattered mass of andesite, in which all the smaller fragments and part of the larger ones had been replaced by cryptocrystalline quartz carrying pyrite and famatinite. Doubtless native gold and probably a telluride of gold were present in the richer ore prior to the oxidation. The greenish-yellow ferric tellurite, emmonsite or durdenite, is said to have served as an indication of good ore. Alunite is abundant, both as a secondary constituent of the altered fragments of andesite and as a filling in crevices and vugs in the sulphide ore. Within the generally silicified material of the pay shoot near the bottom of the ore are some masses of andesite which have been changed to soft, crumbling aggregates, consisting chiefly of alunite and pyrite.

Practically all of the material available for examination in 1905 was sulphide ore, which in this mine has proved of low grade, rarely carrying over $\$ 15$ a ton. Whether the partly oxidized ore taken out by lessees owed its greater richness to secondary concentration or whether the sulphides from which the extracted ore was derived were originally richer than those remaining, it is impossible to say. The relations are suggestive of secondary enrichment during oxidation, but bunches of unusually rich unoxidized ore are in this district so common as to throw the burden of proof upon the enrichment hypothesis.

The boundary between the ore and the country rock appears in this deposit to have been unusually definite and in many places is marked by a seam of gouge. Similar seams were sometimes found within the ore.

All attempts to find a downward continuation of the rich ore shoot have proved futile, although, as shown in figure 32 , two levels have been driven directly under the old stope. They show altered pyritized country rock. Exploration in depth has revealed only a few small podlike masses of ore separated by curved seams of gouge from the surrounding soft andesite. Other ore bodies, however, occur in Black Butte, as shown by the discovery of rich ore at the surface, on the south slope, in December, 1905. This was in one of the numerous nearly horizontal fissure zones, and at the time of visit, shortly after its discovery, the ore body had been followed into the hill for a distance of 20 to 30 feet. This ore, which was from 18 inches to 2 feet in thickness, showed native gold of unusually rusty appearance, associated with a greenishyellow ferric tellurite and cryptocrystalline quartz in a nearly white, alunitized rock, which appears to have been originally dacite. (See Pl. II.) The gold resembles, more than does most of the native metal in the district, the gold derived from tellurides in the Cripple Creek district, and without much doubt existed in part as a telluride prior to oxidation. Small brighter specks within the dull gold probably represent original inclusions of native metal in the telluride.

When visited again in 1908 this ore body had been practically stoped out, although some lessees were still stripping the sides of the stopes. The deposit proved to be nearly horizontal near the surface of the hill, along which it has been stoped for a distance of about 300 feet. The ore was followed into the hill for a maximum distance of nearly 100 feet. The dip in this direction became steeper and the ore gave out. The better part of the body occupied a nearly horizontal zone of sheeting in dacite, the latter rock, as shown in Plate II, extending as an intrusive tongue into the andesite of Black Butte. The width or thickness of the sheeted zone amounts in some places to several feet, but the average thickness of the ore is between 6 and 10 inches. This blanket ledge is cut by a few faults, with throws up to 8 feet. No sulphide ore was found.

\section{GOLDFIELD-BELMONT MINE.}

The Goldfield-Belmont mine lies half a mile northwest of the summit of Black Butte, in ground formerly owned by the Vernal Mining Company. The Vernal workings, from which lessees took some ore in the early days of the district, are about 750 feet north of the present Goldfield-Belmont shaft. Very little ore had been shipped from the new workings up to the end of 1905. At the time of second visit in 1908 all work had been abandoned. 
A general plan of the development of the mine is shown in figure 33. There is a main vertical shaft with levels at 62 and 150 feet below the surface. There are also some shallow shafts and irregular drifts above the 62 -foot level. Whether the workings were carried deeper after 1905 is not known.

The country rock of the mine is a fine-grained andesite which is considerably altered and is usually soft. The ledge is a broad zone of partly sheeted and partly irregularly fissured and shattered rock of not very prominent outcrop. The strike is approximately north-south and the general dip about $40^{\circ} \mathrm{W}$. There are no definite walls to the ledge as a whole, although an approximate hanging wall is defined by a zone in which the andesite is very soft and is in some places sheared to the consistency of gouge.

Such ore as has been found was between the 62 -foot level and the surface. On that level, on the foot-wall side of the ledge, is a vein of soft, sugary, white quartz carrying small quantities of famatinite, gold telluride, and pyrite. Within this soft material are fragments of quartz and a silicified rhyolite. Much of the firm quartz in this part of the ledge has a porous texture and appears to be in part pseudomorphous after, or to have incrusted, some mineral which has been carried away in solution. Some of the vein material has a green tint, due to the presence

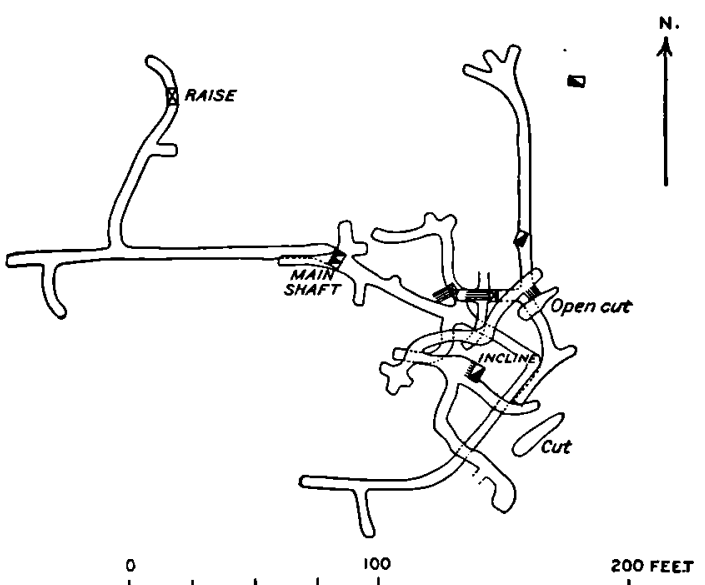

FIGURE 33.-Plan of the workings of the Goldfield-Belmont mine. of scales of sericite. On the 150 -foot level the ledge, about 40 feet in greatest width, is a zone of irregular white stringers in finetextured, partly silicified andesite. The general structure, unlike that of other deposits

$\Delta$ seen in the Goldfield district, might be characterized as a stringer lode. The irregular stringers or veinlets fill fissures up to 4 inches in width. The vein material is a fine-grained mixture of quartz and kaolinite, grading in some places from soft kaolinite to nearly pure hard quartz. Pyrite, the only sulphide found on the 150-foot level, occurs in the veinlets and in the altered andesite. Many of the small vugs in the veinlets contain gypsum, some of which is intergrown with pyrite.

The ledge material as seen on the 150-foot level shows at least two periods of fissuring and veining, which are distinguishable on structural grounds, although not by the nature of their products.

No ore had been found on the 150-foot level to the end of 1905. The chief features of scientific interest in the mine are (1) the occurrence of distinct fissure fillings; (2) the unusual character of the vein material, much of which is a porcelain-like aggregate of quartz and kaolinite; and (3) the occurrence of gypsum with pyrite below the belt of oxidation.

The sugar quartz of the upper level was doubtless originally a mass of stringers carrying quartz and kaolinite. With the removal of some of the kaolinite and perhaps other constituents the resulting porous mass was crushed to its present condition. Alunite has not been seen in the few thin sections studied, but is probably not entirely absent from the altered andesitic country rock.

\section{DAISY MINE.}

The Goldfield Daisy Mining Syndicate owns the three Daisy claims along the crest of McMahon Ridge, north of Diamondfield. A general plan and a longitudinal projection of the workings are shown in figure 34 . In all, the property had produced about $\$ 60,000$ gross up to July, 1908.

The country rock of the Daisy is the Milltown andesite. Four general ledges are recognized, namely, the North, Middle, South, and Fault "veins." The general courses of these are shown in figure 34. They are not continuous, at least in outcrop, but are marked by bunches of ledge matter along zones of fissuring. The so-called Fault vein strikes northeast and dips $55^{\circ} \mathrm{NW}$. It is probably the same as the Belmont ledge. Most of the ore hitherto shipped from 
역

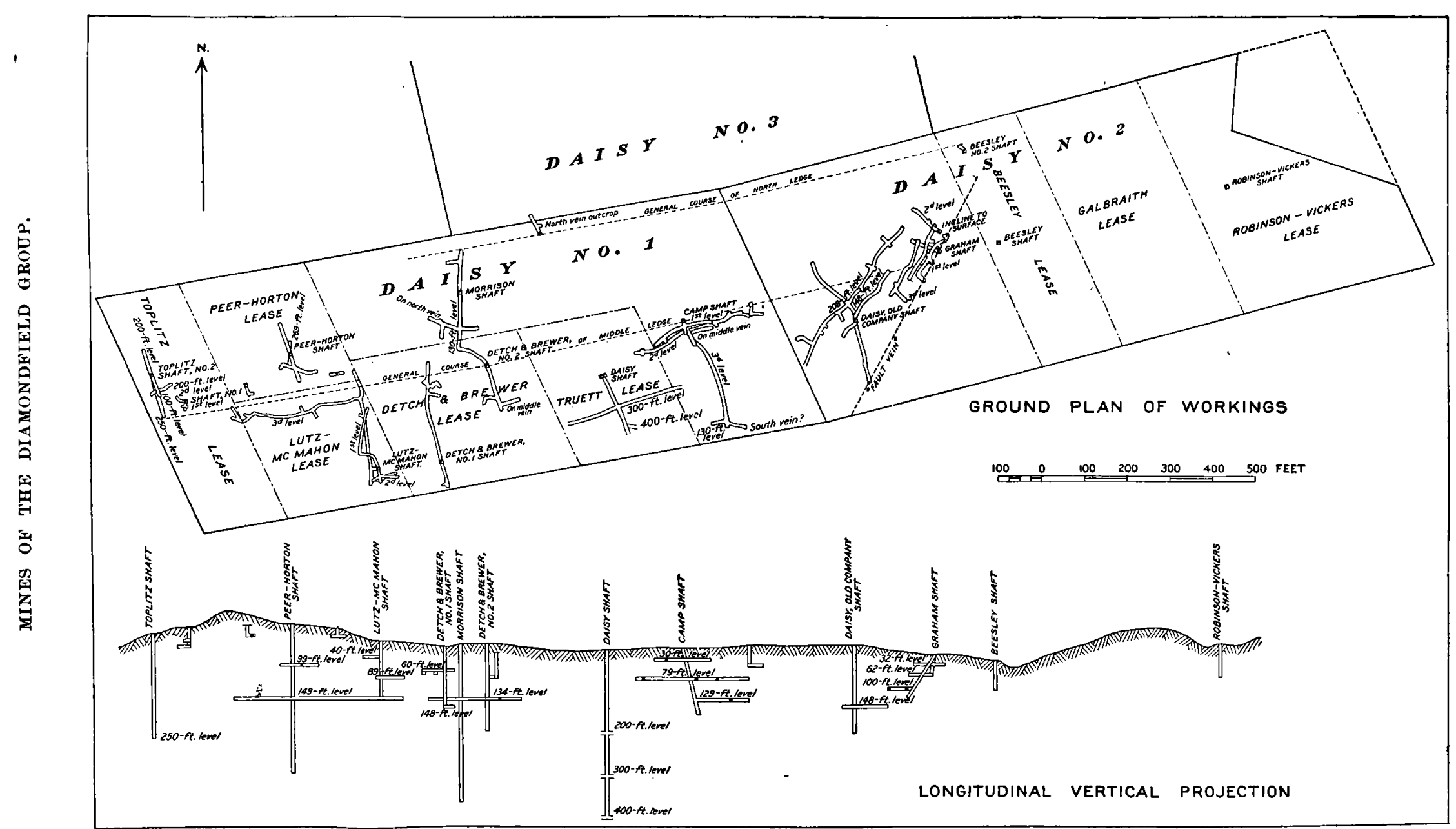

FIGURE 34,-Plan and longitudinal projection of the workings on the I)aisy group. 
the Daisy has been oxidized material from this "Fault vein." According to Mr. C. W. Geddes, the superintendent, the ore from this pay shoot averaged about 5 ounces of gold and 3 ounces of silver to the ton. No work was in progress on this ledge in 1908, and the old Daisy shaft was not in a condition to give safe access to the levels.

West of the old shaft the main work on the Daisy No. 1 claim has been on the Middle ledge, which is fairly distinct at the surface up to the highest point on the ridge. Here all the andesite between the courses of the two ledges is intensely silicified and at the surface forms a single broad mass of ledge matter. The main Daisy shaft (originally the Truett lease shaft) was 400 feet deep at the time of visit, in $\mathrm{July}, 1908$, with crosscuts running south to the Middle ledge on the 300-foot and 400-foot levels. This lies about 80 feet south of the shaft on the 300-foot level and dips about $65^{\circ} \mathrm{S}$. It is a broad soft zone of crushed andesite, showing much less silicification than the typical ledges in the dacite near Goldfield. The material apparently is not heavily mineralized, pyrite being the only sulphide seen. According to Mr. Geddes the average value of this shoot for a width of 5 feet is $\$ 50$ per ton. The pay shoot on the 400 -foot level is of the same general character. On both levels the soft ore-bearing zone is apparently on the foot-wall side of the main ledge, or zone of most intense silicification. A crosscut was being run at the time of visit to cut the North ledge on the 400-foot level.

The country rock of the 300-foot and 400-foot levels is an andesitic breccia, part of the Milltown andesite volcanic complex.

West of the company workings, on the Daisy No. 1 claim, the Morrison and Toplitz leases were being worked in 1908 . The Morrison shaft at that time was 370 feet deep, with a crosscut from the bottom 225 feet to the south. The rock exposed in this crosscut is altered and pyritized andesite and andesitic breccia, containing streaks and bunches of oxidized ledge matter but no ore.

The Toplitz shaft, about 700 feet west of the Morrison, was down 250 feet. A streak of good oxidized ore up to a foot in width was being stoped near the 200 -foot level. This was a mere streak in a great oxidized siliceous ledge fully 100 feet wide. The ore showed free gold, cerargyrite, and specks of an undecomposed gray telluride.

\section{JUMBO EXTENSION (GOLD COIN) MINE.}

The Gold Coin claim of the Jumbo Extension Mining Company's ground, on the south slope of McMahon Ridge, and south of the Daisy mine, was being worked by lessees in 1905 . At the time of visit, in November, the shaft was 150 feet deep with 3 levels. It is sunk on a lodelike, nearly east-west ledge from 2 to 3 feet in width, which is probably the "South vein" of the Daisy. Down to the 100-foot level the ledge dips $75^{\circ} \mathrm{N}$; but south of that level the dip is apparently in the other direction, although too little work had been done on the 150-foot level to establish the position of the ledge. The country rock is andesite.

Most of the ore shipped prior to 1906 was partly or wholly oxidized and came from small stopes above the 100-foot level. It consists of cryptocrystalline quartz, formed by replacement of andesite, associated with limonite. Within the quartz are specks of a dark-gray telluride of gold, associated with native gold and microscopic crystals of alunite. In the limonitic part of the ore are native gold and cerargyrite associated with a yellow-green ferric tellurite. Some of the ore contains an unusually large proportion of silver, assay certificates in the possession of the lessees showing in one case 48.2 ounces of gold and 88.1 ounces of silver per ton; in another case 814.65 ounces of gold and 579.85 ounces of silver. Presumably, therefore, the dark telluride is argentiferous as well as auriferous, for most of the unoxidized ore contains no other mineral likely to yield much silver, although a few specks of what appeared to be famatinite were noted above the 100 -foot level. The 150 -foot level, as developed at the end of 1905 , showed practically no ledge matter and no ore.

No work was in progress in 1908. 
TRIANGLE MINE.

The Triangle workings are immediately northwest of the Gold Coin, and appear to be on the same ledge. The shaft at the end of 1905 was 100 feet deep with 3 levels. The strike of the ledge in the Triangle workings is $\mathrm{N} .50^{\circ} \mathrm{W}$. The dip is northeast and, although variable, approximates to $75^{\circ}$. The country rock is andesite.

The ledge is a well-defined plate of silicified andesite generally from 1 to 2 feet in width or thickness. A little oxidized ore has been shipped from the 40 -foot and 70 -foot levels, but the ledge as exposed on the 100-foot level in 1905 contained only low-grade pyritic material, none of which, in all probability, was worth more than $\$ 30$ a ton.

No work was in progress in 1908.

\section{GREAT BEND MINE.}

On the Great Bend claim, which adjoins the Daisy No. 1 on the west, the principal work in progress in 1908 was on the Loftus \& Davis lease, on the westward continuation of the Daisy ledge zone. An inclined shaft had been sunk 300 feet on the ledge at a $65^{\circ}$ angle, and some good ore has been stoped from very soft pay shoots resembling that of the Daisy. The ore consists of tiny stringers and bunches of quartz in alunitized andesite, the whole being as a rule soft enough to pick. Most of the ore has come from the hanging-wall side of the ledge, but some bunches have been found next to the foot wall. The best ore shows small crystals of pyrite and sphalerite, with specks of a telluride in a nearly white, shattered, alunitic matrix which can be crumbled between the fingers. Firm masses of flinty ledge matter, such as are common in the mines near Goldfield, do not occur, apparently, in the Daisy and Great Bend ores, which are prevailingly soft structureless masses and have evidently undergone comparatively recent crushing.

A new vertical shaft was being sunk just south of the incline in the summer of 1908 . 



\section{INDEX.}

\begin{tabular}{|c|c|}
\hline $\begin{array}{c}\text { A. } \\
\text { cknowledgments to those aiding } \ldots \ldots \ldots \ldots \ldots\end{array}$ & Bismuthinite, occurrence and character of. \\
\hline dams mine, description of . . . & 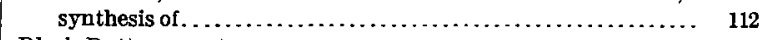 \\
\hline askite, age of $\ldots \ldots \ldots \ldots \ldots \ldots$ & 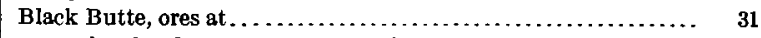 \\
\hline character and distribution of. & rocks of and near. $\ldots \ldots \ldots \ldots . .16,33,43,45,48,56,60,70-71,73,151-152$ \\
\hline geology of ................... & 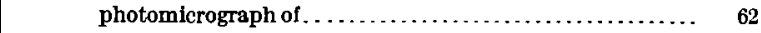 \\
\hline intrusion of . . . . . . . . . . & view of $\ldots \ldots \ldots \ldots \ldots \ldots$ \\
\hline petrography of.. & Black Butte mine, description of...... \\
\hline 34,46 & ledge in $\ldots \ldots \ldots \ldots \ldots \ldots \ldots$ \\
\hline lbite, & section of, figure showing... \\
\hline 143 & 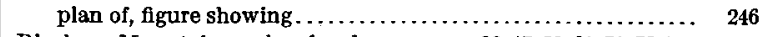 \\
\hline 143 & Blackcap Mountain, rocks of and near $\ldots . .30,47,53,61,71,72,73,74,151$ \\
\hline Iterati & 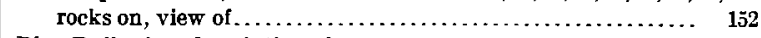 \\
\hline 108 & Blue Bull mine, description of ............. \\
\hline lunite, associs & 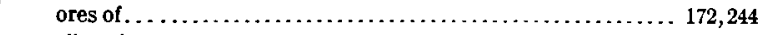 \\
\hline .. 132-133, 189, 199, 201 & silver in......... \\
\hline $30,38,132,191-192,195$ & Bonanzas, oec \\
\hline .. $108,129-133,167$ & ombination mill devised by .................. 143 \\
\hline …..... 199 & 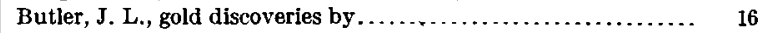 \\
\hline (n) & 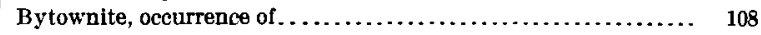 \\
\hline (n. & \\
\hline …........ 177 & \\
\hline$\ldots \ldots \ldots .178,184$ & er of \\
\hline 176 & 126 \\
\hline mphit & $\cdots$ \\
\hline e of ............ & .......... \\
\hline ndesit & 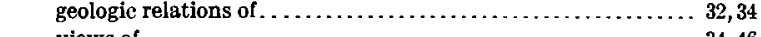 \\
\hline alter & $\ldots \ldots \ldots \ldots \ldots, 34,46$ \\
\hline 178 & 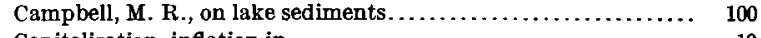 \\
\hline 65 & $\ldots \ldots \ldots \ldots \ldots \ldots, \quad 19$ \\
\hline 102-104 & $\ldots \ldots \ldots \ldots, 108,119-120$ \\
\hline 65 & r of $\ldots \ldots \ldots \ldots \ldots \ldots 108,129,171$ \\
\hline$\ldots 151,156$ & aracter of $\ldots \ldots \ldots \ldots \ldots \ldots, 108,113,166$ \\
\hline$\ldots 31,163$ & desite, character and distribution of . . . . . . . . . . $28-29,64$ \\
\hline$\ldots \ldots 156$ & hy of $\ldots \ldots \ldots \ldots \ldots \ldots \ldots \ldots \ldots \ldots, 64,65$ \\
\hline See & $\ldots \ldots \ldots, 61,61$ \\
\hline 126 & $\ldots 108$ \\
\hline 108 & $\ldots \ldots \ldots \ldots \ldots \ldots 108,113$ \\
\hline aalyses by... & ription of ............... \\
\hline 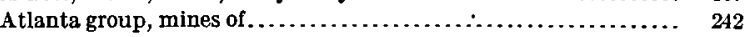 & f. \\
\hline 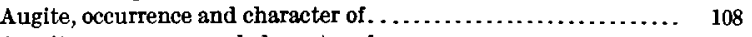 & mine $\ldots \ldots \ldots \ldots \ldots \ldots \ldots \ldots \ldots, 167,171$ \\
\hline zurite, occurrence and character of............................ & $\begin{array}{l}\text { rence of chalcopyrite } \ldots \ldots \ldots \ldots \ldots \ldots \ldots \ldots \ldots \ldots \ldots .113,166 \\
\text { ocks near } \ldots \ldots \ldots \ldots \ldots \ldots \ldots \ldots \ldots .38,39,41,42,43,44,55,58,151 \\
\ldots \ldots \ldots \ldots \ldots \ldots \ldots \ldots \ldots \ldots \ldots \ldots \ldots \ldots \ldots \ldots \ldots\end{array}$ \\
\hline$\therefore \quad 190$ & Iountain, gold on..$\ldots \ldots \ldots \ldots \ldots \ldots \ldots \ldots \ldots \ldots \ldots \ldots \ldots \ldots \ldots$ \\
\hline . & $\begin{array}{r}\text { rocks of } \ldots \ldots \ldots \ldots \ldots \ldots \\
\quad \text { views of } \ldots \ldots \ldots \ldots \ldots \ldots\end{array}$ \\
\hline (1) & (1, \\
\hline .. 86 & iption of. ...... \\
\hline (1) & . $1 . \ldots \ldots$ \\
\hline $\begin{array}{r}\text { Banner Mountain, rocks of and near........................ } \\
28,33,38-39,43,44,76-77,88,152,163\end{array}$ & 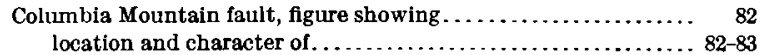 \\
\hline & $\cdots \cdots 201$ \\
\hline $08,127-128$ & $\ldots \ldots \ldots 90,91$ \\
\hline$\ldots \quad 194$ & ....2 241-242 \\
\hline$\ldots \ldots \ldots \ldots \ldots$ & $\ldots \ldots \ldots 143-145$ \\
\hline$\ldots \ldots \ldots \ldots \ldots$ & ine, geology of . . . . . . . . . . . . \\
\hline evada rocks... & glory hole in..$\ldots \ldots \ldots \ldots \ldots \ldots \ldots \ldots \ldots \ldots \ldots$ \\
\hline$\ldots 24-26$ & view of $\ldots \ldots \ldots \ldots \ldots \ldots \ldots \ldots \ldots \ldots \ldots \ldots$ \\
\hline racter of . .... & history of... \\
\hline 14 & 17 \\
\hline & \\
\hline $\begin{array}{lr}\ldots \ldots \ldots \ldots \ldots \ldots 108,121-123 \\
\ldots \ldots \ldots \ldots \ldots \ldots \ldots . \quad 123\end{array}$ & .... 211-213 \\
\hline
\end{tabular}


F'age.

Combination mine, ores of ............. 31,170,171,172-173,214-216 ores of, photomicrographs of.................... I64,168 treatment of $\ldots \ldots \ldots \ldots \ldots \ldots \ldots \ldots .143-145$ pay shoots in ............................. 159,213-214

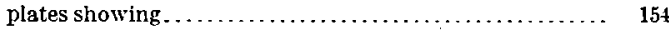
production of................................... 210 rocks in ...................................... $58-59$ section of, plate showing . . . . . . . . . . . . . . water supply of . . . . . . . . . . . . . . . . . . . . . . . . .

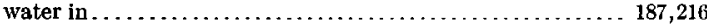

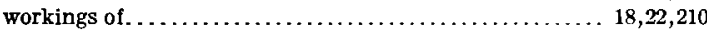
plate showing.......................................

Common wealth mine, description of . . . . . . . . . . . . . . . . . .

Comstock lode, production from ....................... 16

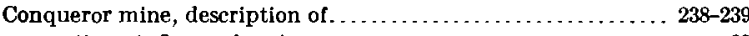

section at, figure showing . . . . . . . . . . . . . . . . . . . .

Consolidated Red Top lease, description of ................. 224

Constabulary, organization of . . . . . . . . . . . . . . . . . . 21

Copper, occurrence of ............................. 108,111

Correlation, discussion of ............................ 91-101

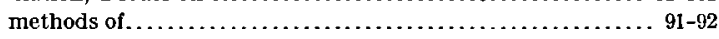

Country rock, effect of, on pay shoots.................... 1 1i3

Cretaceous time, events in........................... 87

Cuprite. sulphur near.......................... 109-110,175

D.

Dacite, alteration of. . . . . . . . . . alteration of, photomicrograph showing............... 178 results of, analyses of . . . . . . . description of.......................... 176-182 diagram showing ............................... 181 analyses of.

$55,56,64,94,179,181$

assays of $\ldots \ldots \ldots \ldots \ldots \ldots \ldots \ldots \ldots \ldots \ldots \ldots \ldots \ldots \ldots \ldots \ldots \ldots \ldots$
character and distribution of $\ldots \ldots \ldots \ldots \ldots \ldots \ldots \ldots$
$54-55,79-81$

correlation of ....................................... 94-95

distribution of, map showing ............

geology of ...................................... $58-61$

inclusions in $\ldots \ldots \ldots \ldots \ldots \ldots \ldots \ldots \ldots \ldots \ldots \ldots \ldots \ldots \ldots \ldots \ldots \ldots \ldots \ldots \ldots \ldots, 207$

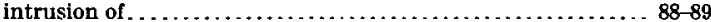

ledges in $\ldots \ldots \ldots \ldots \ldots \ldots \ldots \ldots \ldots \ldots \ldots \ldots \ldots \ldots \ldots, 151,155-156$

ores in .................................... 31, 159, 163

analyses of $\ldots \ldots \ldots \ldots \ldots \ldots \ldots \ldots \ldots \ldots \ldots \ldots \ldots \ldots \ldots \ldots \ldots \ldots, 167$

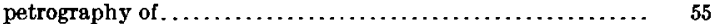

relations of $\ldots \ldots \ldots \ldots \ldots \ldots \ldots \ldots \ldots \ldots \ldots \ldots \ldots \ldots 63-64,79-81$

veins in, photomicrographs showing................. 156

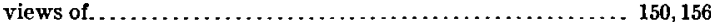

Dacite vitrophyre, analyses of . .....................61, 64,94 character and distribution of ....................... $61,81-82$ correlation of . . . . . . . . . . . . . . . .

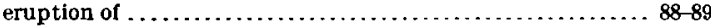

ledges in . . . . . . . . .

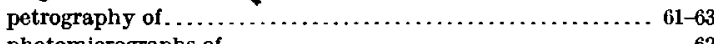

photomicrographs of.............

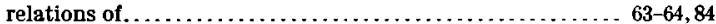

Daisy mine, description of . . . . . . . . . . . . . . . . . discovery of $\ldots \ldots \ldots \ldots \ldots \ldots \ldots \ldots \ldots \ldots \ldots \ldots \ldots, 22$

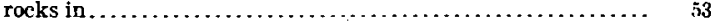

workings of $\ldots \ldots \ldots \ldots \ldots \ldots \ldots \ldots \ldots \ldots \ldots \ldots \ldots \ldots \ldots, 137,248$

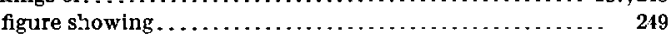

Dall, W. H., fossils determined by ...................... 102

Datums, description of . . . . . . . . . . . . . . . . . . . . . . 92

Deposition, stages of . . . . . . . . . . . . See also Ores.

Depth, relation of, to ores. ....................... 173-174, 200

Depth, original, of ore deposits................... 174-175, 193

Deville, St. Clair, experiments of.

Deville and Leblanc, on volcanic gases. . . . . . . . . . . . .

Diamondfield, rocks at and near. $. \ldots \ldots \ldots \ldots .43,45,47,48,53,56,78,152$

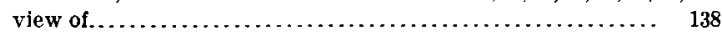

Diamondfield group, mines of . . . . .

mines of, descriptions of......................... 246-251

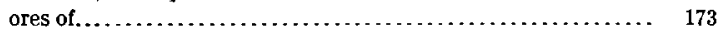

silver in ......................................... 166, 171

Diamond Peak, altitude of ............................... 15

rocks of ..............................

Diaspore, occurrence and character of ................. 108, 124-125
Dikes, andesites, character and distribution of.............. Page.

Domical, use of word........................... 27

Durdenite, occurrence and character of .................... 108, 17

E.

Edgar \& Carr, analysis hy . . . . . . . . . . . . . . . . . . . . . 220

Eldorado limestone, occurrence and character of................ $86-87$

Electric power, use and cost of. ......................... 142

Emmons, W. H., on Mira Mountain ...................... 7

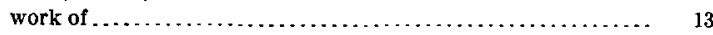

Emmonsite, occurrence and character of . . . . . . . . . .

Enargite, analyses of . . . . . . . . . . . . . . . . . . . . . . . . . occurrence and character of . . . . . . . . . . . . . . . . . . . . . 108,117-118

Engineers' lease, description of . . . . . . . . . . . . . . . ores in . . . . . . . . . . . . . . . .

Enstatite, occurrence and character of .................... 108

Epidote, occurrence and character of . ................. 108, 126-127

Erosion, amount of . . . . . . . . .

differences in..................................... 16

results of................................... $27,89,8$

Eruptive sequence, description of . . . . . . . . . . . . . . . .

Esmeralda formation, age of.......................... 102 character and distribution of $\ldots \ldots \ldots \ldots \ldots \ldots \ldots \ldots \ldots, 97$

Espina l)reccia, character and distribution of ............. 28, 30,69

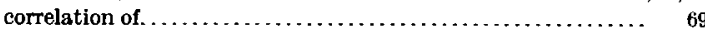

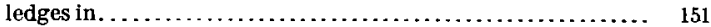

Espina Hill , rocks on . . . . . . . . . . . . . . . .

F.

amatinite, analyses of. ........................... 118-119 occurrence and character of . . . . . . . . . . . . . . . . . . . .

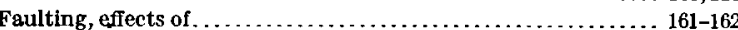
occurrence and character of . . . . . . . . . . . . . . . . 83-85, 161-162 relation of , to ores............................ 196, 201 Field work, nature of . . . . . . .

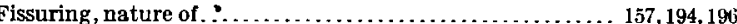
relation of, to pay shoots ........................... 160-161

Five Friends lease, description of . . . . . . . . . . . . . . . . . . . . workings of, figures showing ....................... 223

Florence-Goldfield Kining Co., mines of, description of. . ...... 225-234

Florence Hill, vie $; ;$ from ............................. $\quad 136$

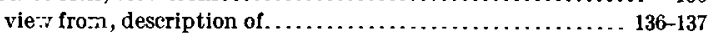

view of . . . . . . description of ............................... 135-136

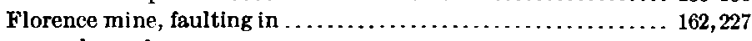
geology of . . . . . .

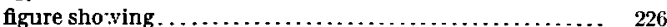

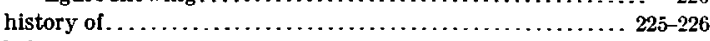

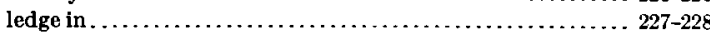
section of, figure showing . . . . . . . . . . . . . . . . . . . . . 152

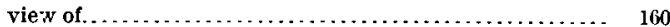
mill of . . . . ores of . .......................... 31, 166i, 170,225, 229-230 photomicrographs of . ............ pay shoots in ............................ 159, 228-229 section of figure showing . . . . . . . . . . . . . . . . . . .

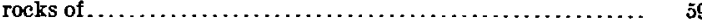
stope in, view of . . . . . . . . . . . . . water in..............................................

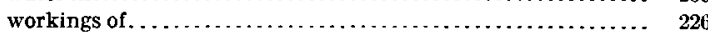
plate showing . . . .

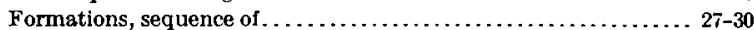

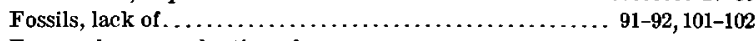
Frances lease, production of . . . . . . . . . . . . . . . . . . . . .

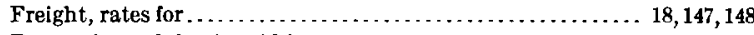
Fumaroles, sulphuric acid in ........................ 189

G.

Galena, occurrence and character of ................ 108, 112, 166 Garrey, G. II., work of . ........................... 13,113

Geikie, A., on fumarole gases......................... 190

Geographic names, application of ........................... $\quad 26$

Geologic history, outline of ........................... $86-91$

Geologic maps of district...................... 32, Pocket. Geologic names, derivation of .......................... $\quad 26$ 
Page.

Gold, occurrence and character of .................. 108, 110-111 production of . .

Gold Bar mine, description of $\ldots \ldots \ldots \ldots \ldots . .242-243$ ores of . . . . . . plan of, figure showing. rocks of.

Told Bar Fraction mine, shait sinking at, cost of .............. 142

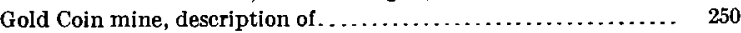

Goldfield, history of. .................................... 16

location of

location of, map showing.

view of.

$$
\text { description of. }
$$
171-172,248 plan of, figure showing ............................ 248

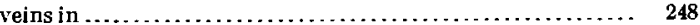
photomicrographs showing..................... 156

Goldfield Cl Mill Co., mill of......................... 146

Goldfield Consolidated Mine Co., mines of, descriptions of..... 202-224 ore treatment plan of................................ 147 organization of..... plant of.

Goldfield dome, formation of $\ldots \ldots \ldots \ldots \ldots \ldots \ldots \ldots \ldots \ldots, 76,84-85$ structure of . . . . . . . . . . . . . .

Goldfield group, mines of .............................. 135

Goldfield Hills, rocks of . . . . . . . . . . . . . . .

Goldfieldite, analyses of. . . . . . . . . . . . . . . . . . occurrence and character of...................... 108,116-117

Goldfield Merger Mines Co., mines of, descriptions of. ........ 239-241 organization of. . . . . . . . . . . . .

Gold Sovereign Mine, rocks of...

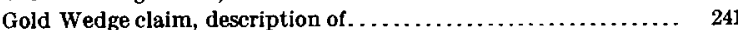
workings of, plates showing........................ 206

Gouge, formation of . . . . . . . . . . . . . .

Granite. See Alaskite.

Great Bend mine, description of.

Grènawalt, J. E., mill designed by.

Gypsum, occurrence and character of.

$$
\text { II. }
$$

Hague, Arnold, on lake sediments..................... 96

Hague, Amold, and Iddings, J. P., on Nevada rocks.

Halotrichite, occurrence and character of . ............. 108, 129, 17

Hayes-Monnette lease, ores of. production of. stope in. .

$$
\text { view of. }
$$

Hazel-Goldfield lease, description of

Hematite, flgure showing. . occurrence and character of ..................... 108, 123-124

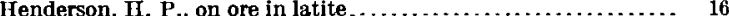
on sphalerite...

Highgrading, prevalence of...

IIill, R. T., on alunite rocks.

Hillebrand, W. F., work of . . .

Historical geology, outline of. . . . . . . . . . . . . . . . . . . . . . . $86-91$

Hornblende, occurrence and character of.................. 108

Hornblende-biotite andesite, analyses of .................. 52 petrography of . . . . . . . . . . . . . . . .

Hornblende-pyroxene andesite, analyses of . . . . . . . . . . 50,51 petrography of . . . . . . . . . . . . . .

Humboldt group, correlation of. . . . . . . . . . . . . . . . . . 104-105

IIypersthene, occurrence and character of . . . . . . . . . . .

$$
\text { I. }
$$

Iddings, J. P., on plagioclase

Iddings, J. P., and IIague, Arnold, on Nevada rocks

Igneous rocks, classiflcation of.. . .

See also Prelacustrine rocks.

Indian Springs, water from

$$
\mathbf{J}
$$

January mine, geology of . . . . . . . . . . . . . . .

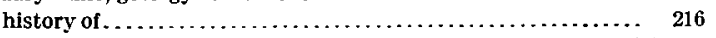
ledge of $\ldots \ldots \ldots \ldots \ldots \ldots \ldots \ldots \ldots \ldots \ldots \ldots \ldots \ldots \ldots \ldots \ldots \ldots \ldots \ldots \ldots \ldots \ldots \ldots, 217-218$
I'age. . ores of, photomicrographs of ............................. 164, 168 pay shoots in .................................. 218-219

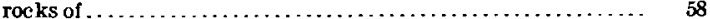
section of, plate showing $\ldots \ldots \ldots \ldots \ldots \ldots \ldots \ldots \ldots \ldots \ldots \ldots, \quad 152$

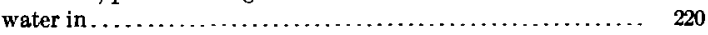

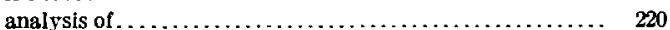

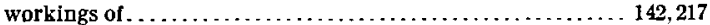
plate showing $\ldots \ldots \ldots \ldots \ldots \ldots \ldots \ldots \ldots \ldots \ldots \ldots \ldots .152,210$ Jarosite, occurrence and character of . . . . . . . . . . . Jasperoid, description of . ........................... 32 Jumbo Extension Mining Co.'s mines, descriptions of . ....... 241, 250 Jumbo mine, history of . . . . . . . . . . . . . . .

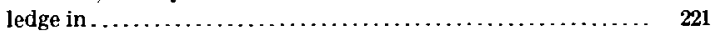

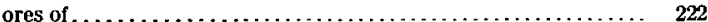

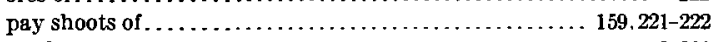

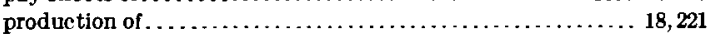
veins in, photomicrographs showing ................. 156 workings of . . . . . . . . . . . .

K.

Kalinite, occurrence and character of................... 108

Kaolinite, association of, with alunite . .................... 192 occurrence and character of ................... 108, 127, 167

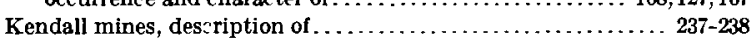
ores of .................................. 170,171,238

rocks in ............................ 41-42, 46,237

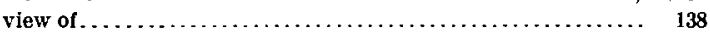

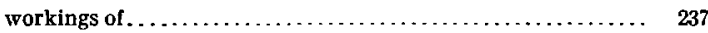

figure showing.

Kendall Mountain, rocks near..................44,44, 47, 53, 151

Kendall tuff, character and distribution of ............. 28-29,41-43,78 eruption of $\ldots \ldots \ldots \ldots \ldots \ldots \ldots \ldots \ldots \ldots \ldots \ldots \ldots \ldots, \quad 8$ relations of $. \ldots \ldots \ldots \ldots \ldots \ldots \ldots \ldots \ldots \ldots \ldots \ldots \ldots \ldots, 8,84$

Kewanas mine, description of . . . . . . . . . . . 239

King, Clarence, on age of Nevada ranges................... 35 on Great Basin rocks . . . . . . . . . on lavas .................................... 102-103 on Pahute lake sediments ................... 95-96, 100, 101 on Tertiary climate .............................. 106

King, L. M., analysis by ............................ 167 Knowlton, F. H., fossils determined by ................... 102

Labor, troubles with .......................... 18, 19, 20-22 Labradorite, occurrence and character of . ................ 109

Lacustrine sediments, age of . ........................... 104 character and distribution of $\ldots \ldots \ldots \ldots \ldots \ldots \ldots . . . \ldots, 66-69,100-101$ correlation of . . . . . . . . . . . . .

Lahontan, Lake, climate of ........................... 107

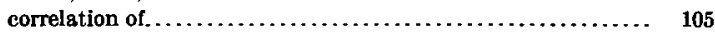

Lake beds, datum marked by .......................... 92 deposition of ....................................... 89

Laguna mine, development of....................... 18, 20

Lake, Tertiary, character of. $\ldots \ldots \ldots \ldots \ldots \ldots \ldots \ldots \ldots \ldots \ldots, \quad 89$

Latite, alteration of ................................. 182

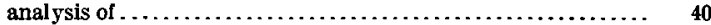
character and distribution of $\ldots \ldots \ldots \ldots \ldots \ldots \ldots \ldots \ldots . . \ldots 38,39,78$ correlation of. $\ldots \ldots \ldots \ldots \ldots \ldots \ldots \ldots \ldots \ldots \ldots \ldots \ldots, \quad 92$ eruption of $\ldots \ldots \ldots \ldots \ldots \ldots \ldots \ldots \ldots \ldots \ldots \ldots \ldots \ldots \ldots, \quad 8$

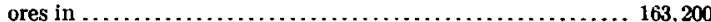
petrography of . . . . . . . . . . . . . relation of ledges to.............................. 155

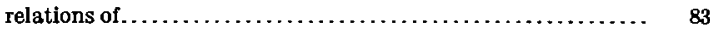

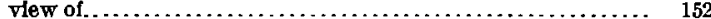

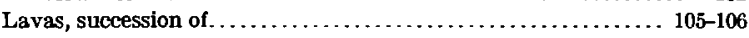
succession of, figure showing........................... 106

Lease blocks, map showing............................. 136

Leasing, practice of .................................... 17

Leblanc and Deville, on volcanic gases . . . . . . . . . . . . . 186, 189

Ledges, composition of ............................... 155-157

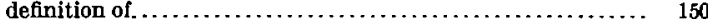

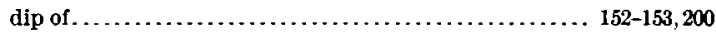
distribution................................... 150-152, 201 plate showing........................... 151, pocket. pay shoots in .............................. 150,158,200

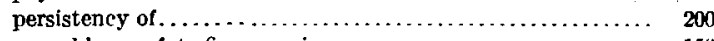
resemblance of, to fissure veins....................... 15i 
Page.

Ledges, shape of.................................... 153-155 shape of, figures showing .............................. 152-154

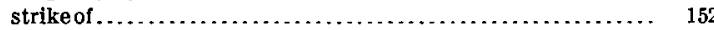
structure of ....................................... 155-157 photomicrographs showing ......................... 156 type of....

Lida, water from . .............................. 142-143

Limonite, occurrence and character of...................... 109, 125-126

Lincoln, F. C., on fumarole gases....................... 189-190

Lindgren, W., on lake sediments.......................96, 101 on occurrence of anhydrite........................... 191

Literature, review of.................................... 24-26

Lithology, correlation by .

Litigation, avoidance of ................................

Little Florence lease, description of ............................. ores of ........................................ 170,233 pay shoots of ................................. 159, 233 production of........................................ 22, 233 workings of .......................................... 142, 233

Location of district $\ldots \ldots \ldots \ldots \ldots \ldots \ldots \ldots \ldots \ldots \ldots \ldots \ldots \ldots, 14$ map showing.................................... 15

Lone Star group, description of .......................... 244-245

Louderback, G. D., on erosion ............................. $\quad 88$

on lake sediments .

M.

McMahon Ridge, rocks of .............................

Magma, water in ................................... 198-199

Magmatic water, nature of ........................... 190

Magnetite, occurrence and character of ..................... 109

Malachite, occurrence and character of .................... 109

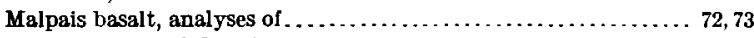
character and distribution of ......................... 28.30 .72 correlation of ...................................... 105 extension of ....................................... 90 petrography of ....................................... $72-74$

Malpais Mesa, rocks of ............................. 71,72 rocks of, photomicrograph of .......................... seepage from ...................................... 188

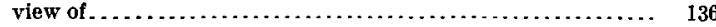
description of.

Manhattan district, boom in

Map of district...

Map, geologic, of district

(ar.

Marsh, William, gold discovered by $\ldots \ldots \ldots \ldots \ldots \ldots \ldots \ldots \ldots, 17$

Massicot, occurrence and character of. .................... 109, 123

Manzelius, Robert, work of ............................. 63

Meda Pass, rocks in and near ...................... 65, 67, 70,175

Meda rhyolite, character and distribution of............... 28-29,65 intrusion of .......................................... 89 petrography of ..................................... 65

Melanterite, occurrence and character of............. 109, 128-129, 171

Metamorphism, cause of .................................. 27

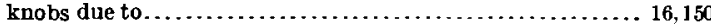
view of $\ldots \ldots \ldots \ldots \ldots \ldots \ldots \ldots \ldots \ldots \ldots \ldots \ldots \ldots \ldots, 150$ processes of ............................................. 176, 186

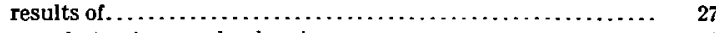
photomicrographs showing .......................... 178

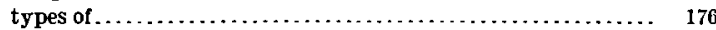

Mills, construction of . ................................... 145 ore treatment in $\ldots \ldots \ldots \ldots \ldots \ldots \ldots \ldots \ldots \ldots \ldots \ldots \ldots \ldots \ldots \ldots \ldots \ldots, 144$

Milltown, rocks near ................................. 151

Milltown andesite, character and distribution of......... 28-29, 47,79 correlation of........................................ 93-94

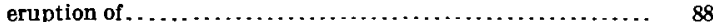
ores in $\ldots \ldots \ldots \ldots \ldots \ldots \ldots \ldots \ldots \ldots \ldots \ldots \ldots \ldots \ldots \ldots \ldots \ldots \ldots \ldots \ldots \ldots, 152,163$ petrography of ...................................... $47-53$ view of............................................ 150 See also Andesite.

Mineralogy of district .............................. 108-134

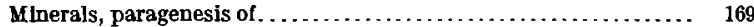

Mines, detailed descriptions of . . . . . . . . . . distribution of . .................................. 135-144 shafts of, depths of ................................... 141-142 list of . . . . . . . . water in ....................................... 187-188 character of.............................................. 188
Mines, workings of, plate showing. ....................... Page. Mining, costs of . .......................................... 141-142

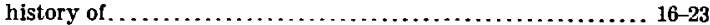

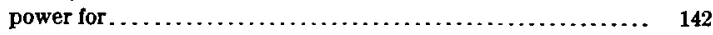

Mira basalt, character and distribution of ............... 28-29,66, 69 petrography of .......................................

Mira Mountain, rocks of ..........................69, 69,175

Mohawk mine, development of. ........................ 18,20,22 faulting in ......................................... 161

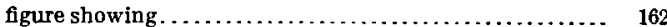
geology of .................................... 206-207 latite under, relation of ledges to ........................ 155 leases on, production of ............................. 20

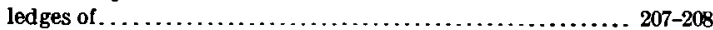
sections of, figures showing ....................... 153,206 mining costs in ................................... 141 ores of ..................... 18, 167, 169, 172-174, 200, 208-209 analyses of .................................... 167 pay shoots in ...................................... 208-209 plan of, figures showing .............................. 206 production of .................................. 204. 205

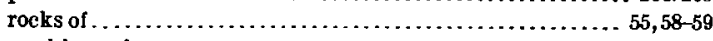
workings of ......................

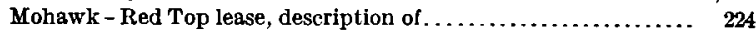
plan of, figure showing ............................... 224 Montezuma, location of ..................................... 14

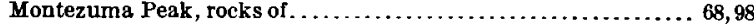
Morena rhyolite, character and distribution of ........... 28-29, 46,78 correlation of ..................................... 93 intrusion of ...................................... 88

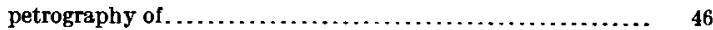

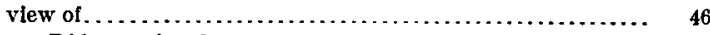

Morena Ridge, rocks of. ....................................... 29,46

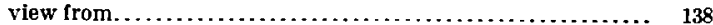
description of ................................ 137

Morris, H. C., on occurrence of sulphur...................... 109 Muscovite, occurrence and character of ................... 109, 12

Mushett lease, description of . ......................... 223-224 ores of ....................................... 165,170, 173,223 plan of, figure showing .............................. 223 Myers Mountain, rocks of and near........ 30, 53, 61, 65,66, 67, 72, 73, 84

\section{N.}

National Museum, Goldfield rocks in ...................... $1^{4}$ Nevada, bibliography of .................................... 24-25 columnar section of, figure showing ..................... 91

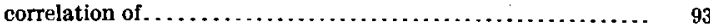
mining in ........................................ 16 Nevada Goldfields Reduction Co., mill of ....................... 145 Nomenclature, determination of......................... $\quad 26$

\section{o.}

Oligoclase, oceurrence of................................. 109 Olivine, occurrence and character of....................... 109 Open shop, maintenance of . .............................. 22 Ore deposition, solutions in $\ldots \ldots \ldots \ldots \ldots \ldots \ldots \ldots \ldots \ldots \ldots \ldots \ldots \ldots \ldots \ldots \ldots \ldots \ldots \ldots \ldots \ldots \ldots \ldots \ldots \ldots \ldots$
Ores, age of $\ldots \ldots \ldots \ldots \ldots \ldots \ldots \ldots \ldots \ldots$ alunite and, association of................. 30, 132-133, 189, 199, 201 areal variations in .............................. 172-173,201 character of ....................................... 30-31 climate and, relations of ......................... 197 deposition of . . . . . . . . . . . . . deposits of, genesis of ................................... 189-200 depth and, relation of ........................... 173-174, 200 minerals in .......................................... 30-31 original depth of.................................. 174-175 paragenesis of .............................. 169-170, 195-196 photomicrographs of .............................. 168 relation of, to country rock............................ 163 shipment of ..................................... 143,146 structures of, plates showing....................... 164,166 tenor of ........................................ 17, 171-172 treatment of . . .......................................... 143-149

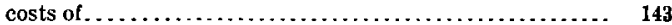
figure showing................................... 144 See also Pay shoots; Sulphide ores; Oxidized ores. 
Page.

Orthoclase, occurrence and character of . . . . . . . . . .

Oxidation, depth of solfatarism and, results of ........................ 193-195

Oxidized ores, character of . . . . . . . . . . . . . . . . . . . . 31, 170-171 minerals in. See also Ores.

\section{P.}

Pahute Lake, age of. datum marked by. situation and extent of

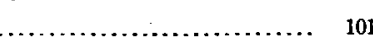
ologic evidence, scantiness of . . . . . . . . . . . . 91-92,101-102 Paleozoic time, events in ............................ 86-88 Palmer, Chase, on goldfieldite......................... 116-117 work of....

Paragenesis, discussion of . . . . . . . . . . . . . . . . . . . . 169-170, 195-196 Patrick claim, workings on .......................... 244-245 Patrick lease, production of ............................. 17

Pay shoots, distribution of . ............................ 158 relation of to country rock......................... 163 to depth . . . . . . .

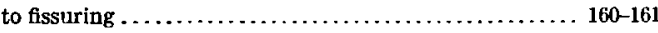

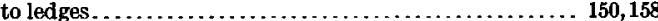

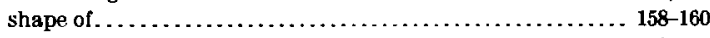
plate showing..................................... 152, similarity of, to barren matter.. See also Ores.

Petzite, occurrence and character of. .

Pocahontas well, flow of.

Polybasite, occurrence of

Population, data on.

Portland mine, description of.

rocks of....

Postlacustring rocks, charact

Postlacustrine time, events in ......................... $89-91$

Power, kinds and costs of . . . . . . . . . . . . . . . . . . . . . .

Pozo Canyon, rocks in .......................... 29,66, 70, 85

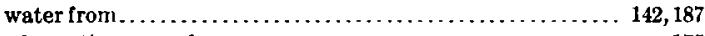

P'ozo formation, age of . ............................... 175 character and distribution of . . . . . . . . . . . . . . . . .

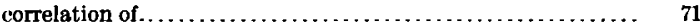
deposition of. .

Preble Mountain, altitude of rocks of and near...

$29,30,47,56,58,60,63,151,152$ photomicrograph of. . .

Prelacustrine rocks, correlation of . . . . . . . . description of . . . . . . . . . . .

Prelacustrine time, events in. . . . . . . . . . . . . . . . . . . . . . 88-89

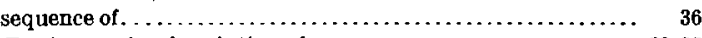

Pre-Tertiary rocks, description of. . . . . . . . . . . . . . .

Production, data on............................. 23-24, 145

Propylitic rocks, character of ........................ 176

Prospect Mountain limestone, occurrence and character of....... 86-87

Proustite, occurrence of ............................. 109, 116

Pyrite, assay of. occurrence and character of....................... 109,113-114 oxidation of, sulphuric acid from .................... 191-193

Pyroxene, occurrence and character of. petrography of ..................................

\section{Q.}

Quartz, alteration of rocks to. phenocrysts of figure showing. $109,120-121,166-16$

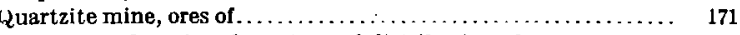

Quaternary deposits, character and distribution of ........... 75

\section{R.}

Rabbit Spring, rocks at. water from.

correlation of.

deposition of. . .

Railways, access by.

Red King claim, discovery on.

Red Top mine, development of

$$
79145-\text { No. } 66-09-17
$$

Red Top mine, discovery of ........

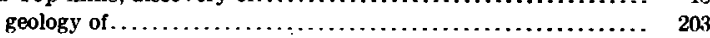

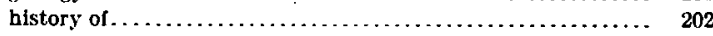

ledge in . ................................... 203-204

mining costs in $\ldots \ldots \ldots \ldots \ldots \ldots \ldots \ldots \ldots \ldots \ldots \ldots \ldots, 141$

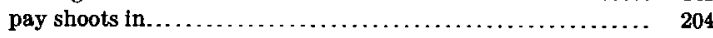

plan and section of, plate showing ................... 202

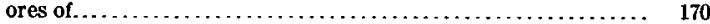

photomicrograph of .............................. 164

workings of $\ldots \ldots \ldots \ldots \ldots \ldots \ldots \ldots \ldots \ldots \ldots \ldots \ldots \ldots \ldots, \quad 202$

Reilly lease, description of............................. 230-232 ores of.................................. 171, 172,231-232 pay shoot of.............................. 159, 231 section of, figure showing ............................ 154

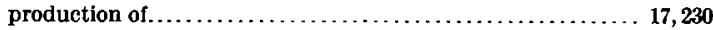

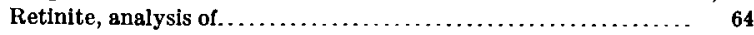

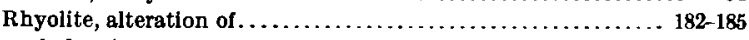
ledges in ....................................... 156-157

ores in....................................... 163

See also Meda rhyolite; Sandstone rhyolite; Morena rhyolite; Spearhead rhyolite; Vindicator rhyolite.

Rhyolite, altered, analyses of $\ldots \ldots \ldots \ldots \ldots \ldots \ldots \ldots \ldots \ldots \ldots$ photomicrograph showing.............................. 184

Rickard, T. A., on mills .......................................... 143-146 on highgrading . . . . . . . . . . . . . . . .

Rocks, sequence of . .......................... 27-30

Rogers Syndicate lease, deseription of . . . . . . . . . . . . . . . ores of $\ldots \ldots \ldots \ldots \ldots \ldots \ldots \ldots \ldots \ldots \ldots \ldots \ldots \ldots, 170, \mathbf{1 7 3 3 , 2 3 3 , 2 3 4}$

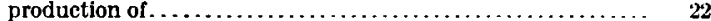
rocks of $\ldots \ldots \ldots \ldots \ldots \ldots \ldots \ldots \ldots \ldots \ldots \ldots \ldots \ldots \ldots, 59,223-234$ Rutile, occurrence and character of .................... 109, 124

\section{s.}

St. lves mine, description of......................... 240-241 plan of, figure showing ............................ 240

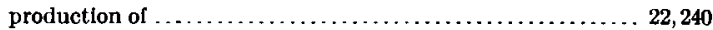

Sampling, cost of ........................................... 149

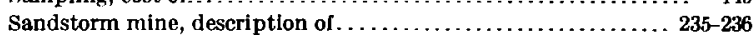

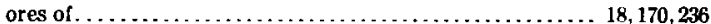

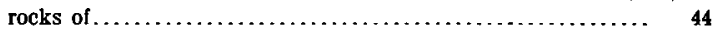

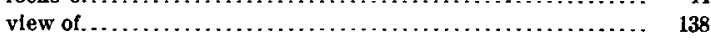
workings of . . . . . . . . . . . Sandstorm rhyolite, character and distribution of . .... 28, 43-44,77-78 correlation of ....................................... 93

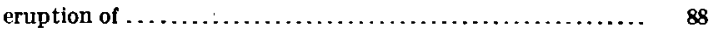
petrography of....................................... 44-46 Sanidine, occurrence and character of ..................... 126 Scapolite, occurrence and character of ........................... 109 Schalier, W. T., on bismite........................ 122-123 work of ............................. 14,111, 115, 131,133 Secondary enrichment, inadequacy of ................ 191-193,195 Sections, geologic, plate showing . . . . . . . . 76 Sericite, occurrence and character of.................. 127,167 Serpentine, occurrence and character of .................. 109 Sharwood, W. J., on minerals ......................... 110,116 Sheeted structure, occurrence of . . . . . . . . . . . . . . . . . 156

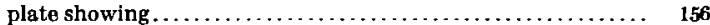
Shoshone Iake, existence of ............................. 104-105 Siebert formation, character and distrihution of . . $28,66,68,84,89,97,175$ Siebert tuff, correlation of . . . . . . . . .

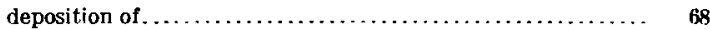
lithology of . . . . . . . relations of $\ldots \ldots \ldots \ldots \ldots \ldots \ldots \ldots \ldots \ldots \ldots \ldots \ldots \ldots \ldots, \quad 84$

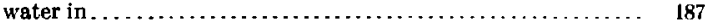

Silver, occurrence of ............................ 31, 166, 171-172 production of .................................... 23 Simmerone mine, description of ........................ 244 Sinclair, W. J., fossils determined by................... 96,101 Smelting, costs of . . . . . . . . . . . . . . . . . . . . . . . . . . 148-149 Smith, D. T., on lake sediments ........................... 96 Solfatarism, oxidation and, results of................... 193-195 Solutions, ore-depositing, character of. . ... . . . . . . . . 185-186, 191-197 source of .................................... 197-198 Spearhead Point, rocks of ............................... 67,70 Spearhead rhyolite, character and distribution of.......... 28,30,71 correlation of...................................... 105 
Spearhead rhyolite, extension of . ................... Page. use of for building..............

Sphalerite, occurrence and character of Springs, sulphuric acid in . . . . . . . . . . . . . . . . . . . 191 Spurr, J. E., correlation by ....................... 92,94, 105 on beds at Furnace Creek. . . . . . . . . . . . . . . . . . . . . . 99-100

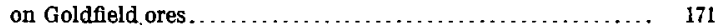
on lake sediments $\ldots \ldots \ldots \ldots \ldots \ldots \ldots \ldots \ldots \ldots \ldots \ldots .96-97,102,105$ on lava sequence............................... 105-106 on Nevada rocks. ........ 92-95,97, 102,103 on pre-Cambrian rocks ............................. 86

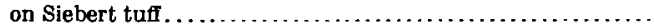

on Tonopah rocks.

on Tonopah underground temperatur work of.

Stealing, prevalence of $\ldots \ldots \ldots \ldots \ldots .18$

Steiger, George, analyses by................... 50, 52, 56, 61,63,73 work of...

timler, Harry, gold discovered by.

Stokes, H. N., on marrasite.

Strotiuraphy, columm outline of .......................................... 27-30 Structure, description of . ......................... 27,7(i-85

Sullivan, E. C., analysis by ........................... 41

Sulphide ores, character of . . . . . . . . . . . . . . . . . $30-31,165-169$ minerals in...

See also Ores.

Sulphur, occurrence and character of..................... 109

Sulphuric acid, source of . . .............................. 189-195

Sweeney lease, production of ............................. 17

$\mathrm{T}$.

Talc, so-called, nature of ........................... 167 Tellurides, occurrence and character of........... 109,110,115-116,166 Tellurides, occurrence and character of . . . . . . . . . $109,110,115-116,166$
Tellurite, occurrence and character of $\ldots \ldots \ldots \ldots \ldots \ldots \ldots 109,123,171$ Tennantite, composition of $\ldots \ldots \ldots \ldots \ldots \ldots \ldots \ldots \ldots \ldots \ldots \ldots, 118$

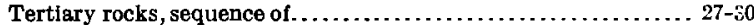
subdivision of . . . . . . . .

Tertlary time, climate in........................... 106-107

events in . . . . . . . . . . . . . . . . . . . . . . .

Tetrahedrite, composition of ......................... 118

Texas, sulphuric acid in springs in ........................ 191

Titanite, occurrence and character of..........

Tognoni Springs, rocks near.......... 45,53,54,55,57,58,60,65,81,152

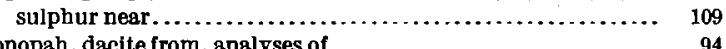

Tonopah, dacite from, analyses of .................... 94 discoveries at....................................... 16

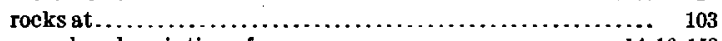

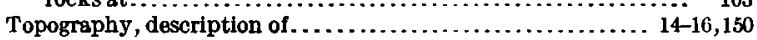

Triangle mine, description of $\quad$ Page. Truckee group, character and distribution of ............... 251 correlation of . . . . .

Tuff, petrography ol. . . . . . . . . . .

Turner, H. $\mathbf{W}$., on Esmeralda formation ................... 9

t.

Unconformity, datum marked by $\ldots \ldots \ldots \ldots \ldots \ldots \ldots \ldots \ldots \ldots, g 2$

United States Government, investigation by ................ 21

V.

Van Hise, C. R., on fumarole gases . . . . . . . . . . . . .

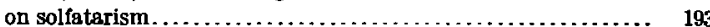

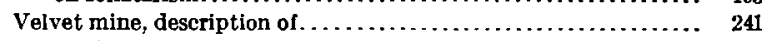
production of $\ldots \ldots \ldots \ldots \ldots \ldots \ldots \ldots \ldots \ldots \ldots \ldots \ldots \ldots \ldots . .22,241$

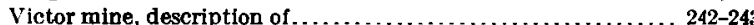

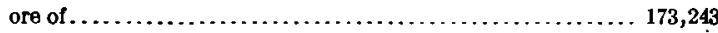

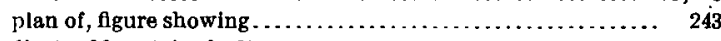

Vindicator Mountain, faults near ...................... 84 rocks of . . . . . . . . . 27-34, 38-39, 43-48, 72, 74, 76-77, 88, 152, 176, 182

Vindicator rhyolite, alunitization of, photomicrograph showing. 178, 184 character and distribution of ................... 28, 37-38, 76-77 correlation of ......................

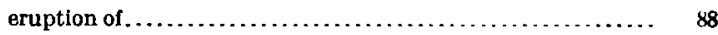
petrography of . . . . . . . . . . . .

Vogt, J. H. L., on alunite......................... 132-133

Volcanic ash, quarry in . . . . . . . . . . .

Volcanic rocks, photomicrographs of ........................... 62

Volcanism, disappearance of.......................... 198-199

relation of, to mineralizing solutions................... 197

Volcanoes, prevalence of, in lacustrine epoch ............... 89

Von Schulz \& Low, analyses by .......................... 169

W.

Wages, scale of................................. 18-19, 21 Washington, H. S., on derivation of pyroxene andesites........ 48

Water, supply of......................................... 142-143

Water, magmatic, nature of............................ 190

Water, meteoric, relation of, to mineral solutions............. 197-198

Water, underground, character of ...................... 188

depth of.............................................. 187

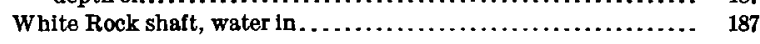

$\mathbf{Y}$.

Yellow Tiger mine, rocks of . . . . . . . . . . . . . .

Z

Zircon, occurrence of . . . . . . . . .

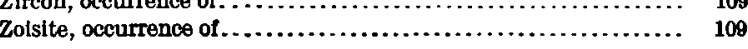

